\title{
PROPAGANDA AND PERSUASION IN THE COLD WAR: \\ THE CANADIAN SOVIET FRIENDSHIP SOCIETY, 1949-1960
}

\author{
by \\ Jennifer Anderson, B.A., M.A. \\ A thesis submitted to the Faculty of Graduate Studies \\ in partial fulfillment of the requirements for the \\ degree of Doctor of Philosophy
}

\author{
Department of History \\ Carleton University \\ Ottawa, Canada \\ 1 August 2008
}

(C)2008, Jennifer Anderson 


$\begin{array}{ll}\begin{array}{l}\text { Library and } \\ \text { Archives Canada }\end{array} & \begin{array}{l}\text { Bibliothèque et } \\ \text { Archives Canada }\end{array} \\ \begin{array}{l}\text { Published Heritage } \\ \text { Branch }\end{array} & \begin{array}{l}\text { Direction du } \\ \text { Patrimoine de l'édition }\end{array} \\ \begin{array}{l}\text { 395 Wellington Street } \\ \text { Ottawa ON K1A ON4 } \\ \text { Canada }\end{array} & \begin{array}{l}\text { 395, rue Wellington } \\ \text { Ottawa ON K1A 0N4 } \\ \text { Canada }\end{array}\end{array}$

Your file Votre référence ISBN: 978-0-494-43885-5

Our file Notre référence

ISBN: 978-0-494-43885-5

NOTICE:

The author has granted a nonexclusive license allowing Library and Archives Canada to reproduce, publish, archive, preserve, conserve, communicate to the public by telecommunication or on the Internet, loan, distribute and sell theses worldwide, for commercial or noncommercial purposes, in microform, paper, electronic and/or any other formats.

The author retains copyright ownership and moral rights in this thesis. Neither the thesis nor substantial extracts from it may be printed or otherwise reproduced without the author's permission.
AVIS:

L'auteur a accordé une licence non exclusive permettant à la Bibliothèque et Archives Canada de reproduire, publier, archiver, sauvegarder, conserver, transmettre au public par télécommunication ou par l'Internet, prêter, distribuer et vendre des thèses partout dans le monde, à des fins commerciales ou autres, sur support microforme, papier, électronique et/ou autres formats.

L'auteur conserve la propriété du droit d'auteur et des droits moraux qui protège cette thèse. $\mathrm{Ni}$ la thèse ni des extraits substantiels de celle-ci ne doivent être imprimés ou autrement reproduits sans son autorisation.
In compliance with the Canadian

Privacy Act some supporting forms may have been removed from this thesis.

While these forms may be included in the document page count, their removal does not represent any loss of content from the thesis.
Conformément à la loi canadienne sur la protection de la vie privée, quelques formulaires secondaires ont été enlevés de cette thèse.

Bien que ces formulaires aient inclus dans la pagination, il n'y aura aucun contenu manquant.

\section{Canada}




\begin{abstract}
During the early Cold War, thousands of Canadians attended events organized by the Canadian Soviet Friendship Society (CSFS), and subscribed to its publications. Although scholarship on Cold War Canada and the Communist Party of Canada (CPC) has grown, the CSFS led by Dyson Carter from 1949-1960, has received relatively little attention from historians. Moreover, few historians have noted the important role played by the Soviet All-Union Society for Cultural Relations with Foreign Countries (VOKS) in encouraging and supporting the Canadian left. This project looks at the CSFS as a blend of social and political activism, where gender, class, ethnicity, linked communities and ideology had significance. It deals with an example of foreign influence in Canada, as the elaborate pro-Soviet performances staged by the CSFS were part of a larger perception management campaign orchestrated from Moscow.

This dissertation is based on archival sources previously unavailable to researchers. In addition, oral history interviews with key players have been used to reveal personal narratives and interpretations of the early Cold War. This combination allows historians an unprecedented view of how some Canadians saw their world, and how they, in turn, were seen by other Canadians and the Soviet authorities. Between 1949 and 1960, the Canadian Soviet Friendship Society aimed its message at an audience of "progressive" leftists in North America, hoping to convince others that the USSR was indeed the epitome of an egalitarian and enlightened State. Attempting to soften, define and redirect the antagonistic narratives of the day, the CSFS story is one of propaganda and persuasion in Cold War Canada.
\end{abstract}




\section{ACKNOWLEDGEMENTS}

It is hard for me to remember a time when I was not fascinated with the Soviet Union. It all started in a library. One book on the Russian Revolution led to another, which led to investigations of Soviet and Russian culture, international relations, and Cold War antipathies. All of my final high school projects dealt in some way with the USSR and North American perceptions of it, facilitated in no small way by the mass of information that was made public in those heady Gorbachev days. By the time I had made it to university, the USSR was no more, and my plans to study Russian, history and journalism were to get me over there so that I could mitigate my book-ish learning with real experiences. The plans changed, and immediately following the completion of a Master's degree in Central/East European and Russian-Area Studies, I found a job in Kyiv, Ukraine. What was meant to be a summer internship turned into a five-year hiatus in Ukraine, where I lived in Kyiv and Kharkiv, traveled throughout the region, met and married my husband, and spent the best of a part of a year with my oldest son. Although by that point some of the harsher Soviet realities had been removed, and as foreigners we lived in privileged conditions, the economic and social aspects of life in the former USSR were a part of my everyday experience and, as such, made a big impression on me.

So, if on one level I can understand the motivation some Canadian Soviet Friendship Society members had in joining a group that allowed them to visit the USSR, on another level I cannot ignore the fact their message was part of a larger Soviet Potemkin village. Negotiating these two levels of understanding, and balancing an appreciation for idealism with a realistic and healthy dose of skepticism has been the 
theme of ongoing conversations with my supervisors, friends, acquaintances, and family members throughout this project.

Academics are fortunate in that they can periodically publicly acknowledge and express gratitude to those who have guided, assisted and inspired them. I would like to particularly thank my thesis supervisors, J.L. Black and Duncan McDowall, for their helpful suggestions, patience, and encouragement. I am grateful to Prof. Black also for arranging to have copies of the rich VOKS documents brought to Canada. Insightful comments from other Carleton University History Department faculty and staff have also been much appreciated. Thanks to the organizers and participants of the Frank Underhill Graduate Student Colloquium (2004-2008), where many of my ideas were first tested. I wish to thank the Centre for Research on Canadian-Russian Relations (now at the University Partnership Centre, Georgian College, Barrie), the Department of History, and the Faculty of Graduate Studies at Carleton University for providing funding that allowed me to travel to conduct interviews elsewhere in Canada, and to conferences in Saskatoon, Michigan and Ljubljana, Slovenia.

Several of the chapters in this thesis have benefited greatly from the comments and suggestions offered me by the members of the Canadian Historical Association and the Canadian Association of Slavists, particularly those gathered at the Learneds in Saskatoon in May 2007. I would also like to thank Wendy Mitchison and the anonymous readers who commented on a previous version of chapter four, which appeared in the Journal of the CHA (vol. 18, no. 1, 2007).

I have been very fortunate in having worked with - and been mentored by Rhonda L. Hinther (curator, Museum of Civilization) and Janice Cavell (historian, 
Foreign Affairs Canada). I am most grateful to them for the experiences they offered me, as well as useful tips, helpful suggestions, and general encouragement. Myron Momryk, who says he has retired from Library and Archives Canada, remains nonetheless available to researchers. There is no better authority than he on the archival resources dealing with the Canadian left and ethnic groups. Larissa Stavroff, John Boyd and Faith Johnston, who have all known the inside of progressive circles through their own work, have been extremely helpful to me throughout this project. Larissa even took me on a tour of "progressive Toronto," which helped me put this story into the context of the inter-relationships between progressive groups and individual lives. Larissa and John both read and commented on earlier versions of chapter six, and provided me with important documents. Thanks to Ted Baxter for the CSFS photo and promotional material. I also wish to thank Glenna Roberts, Serge Cipko, and Vernon Turner, who have offered me important background information and insights. Leonard Stern, Citizen editor, unwittingly offered me the title I was looking for, when he responded to my email about the fact that a Canadian version of the American-Soviet Friendship Society did, indeed, exist.

I would like to thank the archivists and resource staff at Library and Archives Canada, the Osler Library (McGill University) the Thomas Fisher Rare Book Library (University of Toronto) and Special Collections and Archives (Carleton University). Marion Fry, archivist at the Gravenhurst Public Library took me on a tour of Gravenhurst, and sent me copies of documents I would not otherwise have found. I would also like to thank the Access to Information and Privacy personnel who advised me first on how to quickly (and most inexpensively) apply for the restricted documents I 
needed, and then provided the material, and answered my questions all with efficiency. Thanks also to the anonymous librarians who stock books that inspire young people to study history, at whatever level. It is amazing how far a book can take you!

I owe a great deal to the individuals who agreed, on more than one occasion, to speak to me about their experiences in the CSFS, and their knowledge of its leadership, contacts, membership and activities. Enormous thanks to John Boyd, Michael Lucas, Sally Nielsen, Irja Paul, Marie Rempel, Irene Kuusela, Leslie Hunt, Koozma J. Tarasoff and Ted Baxter. I have greatly appreciated their generosity in sharing their ideas and experiences with me. Although they may not all agree with my conclusions, I hope they can appreciate my point of view.

Finally, I wish to thank my closest friends, neighbours, and family for the support they have given me throughout the time I have been working on this project. They have been there when I needed them most: for companionship, for courage, advice or a new perspective, for a hand with the kids or with making dinner -- it was always just in time. It is great to be part of such a supportive network and community.

My sons, Benjamin and Jeremy, were in diapers when this project began, but from their birth they have literally been breathing the former USSR in the air. How many Canadian babies have a picture of themselves in front of the Kremlin, or have travelled in the Crimea? We "gulyali" in Molodozhnyi [Youth] Park, ironically a former cemetery, with the other local Kharkiv mothers and babies. While we lived there, a monument was erected in the park to the victims of Chernobyl. Despite the option having been available, Benjamin was not born in Ukraine. Asked about whether I should give birth in Kharkiv, a doctor there told me: "If all goes well, you could give birth under a bridge and it would 
be fine. But if anything went wrong, we would not have the equipment or wherewithall to help you." Women's and men's lives and those of their children have been deeply affected by the ill effects of Soviet rule, and they have not yet recovered. It is with deepest respect and friendship that I dedicate this thesis to my closest Ukrainian friends: Anya, Galya, Tanya, Viola and Victor. My children have visited the former USSR; they raised theirs there. Their strength inspires me.

My special thanks to Lee - as he knows only too well, I couldn't possibly have done this without him. 


\section{TABLE OF CONTENTS}

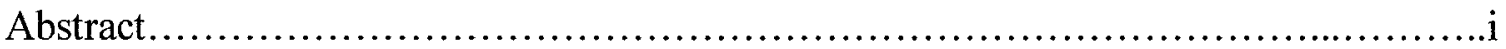

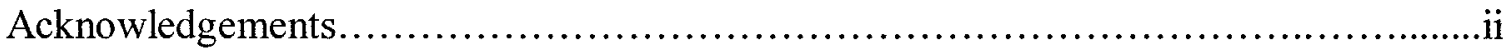

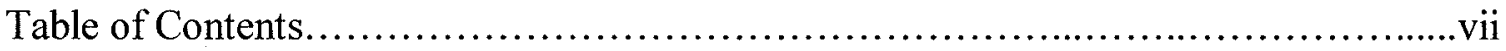

List of Acronyms...............................................................

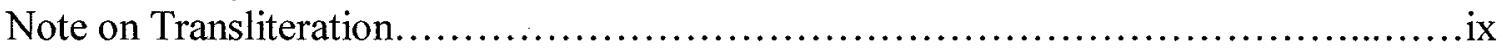

Chapter 1. Introducing the Canadian Soviet Friendship Society, 1949-1960..........1

Chapter 2. Setting the Stage: The Soviet Friendship Phenomenon, 1917-1949.......12

Chapter 3. Grappling with the Historiography and Versions of the 'Truth':

Writing a History of the Canadian Soviet Friendship Society............63

Chapter 4. The Pro-Soviet Message in Words and Images: Dyson Carter and the CSFS Literature and Photographs......................................97

Chapter 5. Institutionalizing Friendship: The Vse-soiuznoe obshchestvo kul'turnoi

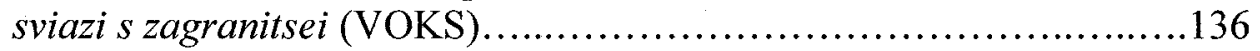

Chapter 6. Polishing the Soviet Image: The CSFS and the 'Progressive, Ethnic

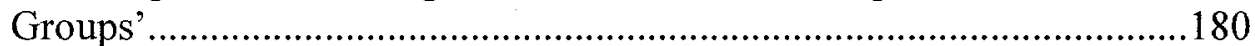

Chapter 7. The 'Pink Tea Circuit' or 'Dreams of Equality?' Women and the CSFS...............................................234

Chapter 8. Culture as Political Persuasion: Performing Soviet Friendship............269

Chapter 9. Epilogue and Conclusion......................................... 310

Appendix I. Methodology and Biography. Talking Back: Interviewing Canadian-Soviet Friends: Their Life and Times.........................3325

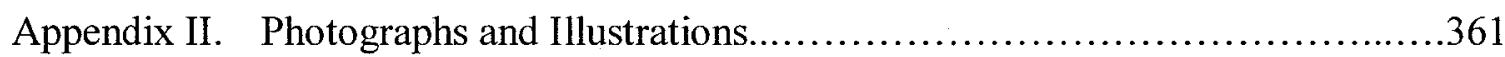

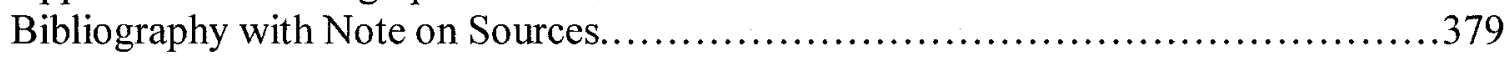




\section{LIST OF ACRONYMS}

\begin{tabular}{|c|c|}
\hline AUUC & Association of United Ukrainian Canadians \\
\hline Cominform & Communist Information Bureau (1947-1946) \\
\hline Comintern & Communist International (1919-1943) \\
\hline $\mathrm{CPC}$ & Communist Party of Canada \\
\hline CPSU & Communist Party of the Soviet Union \\
\hline \multirow[t]{3}{*}{ CRCR } & Centre for Research on Canadian-Russian Relations, University \\
\hline & Partnership Centre, Georgian College, Barrie [formerly of Carleton \\
\hline & University] \\
\hline CSFS & Canadian Soviet Friendship Society \\
\hline DEA & Department of External Affairs (Canada) \\
\hline FOC & Finnish Organization of Canada \\
\hline FRC & Federation of Russian Canadians \\
\hline FSU & Friends of the Soviet Union (pre-1939) \\
\hline \multirow[t]{2}{*}{ GARF } & State Archives of the Russian Federation [Gosudarstvennyi arkhiv \\
\hline & Rossiiskoi Federatsii] \\
\hline Glavlit & $\begin{array}{l}\text { [Main] Administration for the Protection of Military and State Secrets in } \\
\text { the Press ["Main" was added in 1953, but the acronym was used from } \\
1922 \text { until 1991] under the USSR Council of Ministers }\end{array}$ \\
\hline ID & International Department, Central Committee of the CPSU \\
\hline \multirow[t]{3}{*}{ KGB } & Committee for State Security [Komitet gosudarstvennoi bezopasnosti] \\
\hline & (USSR, 1954-1991, successor to NKGB (People's Commissariat for State \\
\hline & Security) /MGB (Ministry of State Security) \\
\hline LAC & Library and Archives Canada, Ottawa \\
\hline LPP & Labor-Progressive Party (name used by CPC, 1943-1959) \\
\hline MID & Ministry of Foreign Affairs, USSR \\
\hline NC-CSF & National Committee for Canadian-Soviet Friendship (wartime group) \\
\hline RCMP & Royal Canadian Mounted Police \\
\hline RNWMP & $\begin{array}{l}\text { Royal North-West Mounted Police ["Royal" was added in 1905, and the } \\
\text { name of the force was changed to the RCMP in 1920] }\end{array}$ \\
\hline Sovinform & Soviet Information Bureau, under the Soviet Ministry of Foreign Affairs \\
\hline \multirow[t]{2}{*}{ SSOD } & Union of Soviet Societies for Friendship and Cultural Relations with \\
\hline & $\begin{array}{l}\text { Foreign Countries [Soyuz sovetskyi obshchestva druzhbi i kul'turnoi sviazi } \\
\text { s zagranitsei, renamed from VOKS, February 1958-1992] (USSR) }\end{array}$ \\
\hline UJPO & United Jewish People's Order \\
\hline USSR & Union of Socialist Soviet Republics \\
\hline VOKS & $\begin{array}{l}\text { All-Union Society for Cultural Relations with Foreign Countries } \\
\text { [Vse-soiuznoe obshchestvo kul'turnoi sviazi s zagranitsei] (USSR) }\end{array}$ \\
\hline
\end{tabular}




\section{NOTE ON TRANSLITERATION}

Many of the documents in the VOKS collection are in Russian, and the translations used here have been done by the author. In transliterating Russian and Ukrainian names, the main text will reflect the spelling most closely related to standard transliteration. For instance, reference is made throughout the dissertation to Vladimir Burdin, even though at times his name was spelled "Bourdine" by officials at the Canadian Department of External Affairs as well as by Dyson Carter. In the case of titles, it should be noted that the second word of a title of a Ukrainian- or Russianlanguage publication does not contain a capital letter, and this pattern has been followed in English. Therefore, the reader will see the newspaper Ukrainske slovo spelled in this manner. When Ukrainian towns are mentioned in the text, most of the time they are referred to by their Russian spelling, as this was the commonly accepted practice at the time. However, particularly in the chapter dealing with progressive ethnic groups, the contemporary Ukrainian spelling of the cities has been mentioned. Therefore, the reader may notice the city of Kaniv spelled as it is in Ukrainian, or as "Kanev," which was the usual form during Soviet times. 


\title{
Chapter One \\ INTRODUCING THE CANADIAN SOVIET FRIENDSHIP SOCIETY $(1949-1960)^{1}$
}

\author{
Members of the Canadian Soviet Friendship Society (CSFS) were fellow
}

travelers. $^{2}$ They were Soviet sympathizers, attracted to socialism, who saw in the USSR

an example of social principles that they wished to see applied in the Canadian context.

They were associated with, but not always members of, the Canadian Communist Party

(CPC). At the height of the Cold War during the 1950s, CSFS members continued to admire the USSR

when such admiration was unpopular, and actively campaigned for more "friendly" Canadian policies

towards the Soviet Union. It seems that a large number of non-CPC "progressives" 3 found in the cause

of "friendship" an activist role. The Soviets encouraged them, and even provided the necessary material

and funding for many of their projects.

\footnotetext{
${ }^{1}$ For an in-depth look at the biographical backgrounds of CSFS leaders and their successors, as well as the methodological issues arising from the use of oral history techniques in conjunction with documentary evidence, please refer to "Appendix I. Talking Back: Interviewing Canadian-Soviet Friends: Their Life and Times."

${ }^{2}$ Throughout this thesis I will be using the concept of "fellow-traveller" described by David Caute to signify individuals who were not necessarily Communists, but who were enamoured with the Soviet socialist experiment. Their imaginations were, as Caute suggests, "captivated" by "the primitive aspects of Russia and later China... but only in so far as dramatic underdevelopment provided a tabula rasa for planned construction and rational experimentation." They did not always join Communist parties because their "disillusionment with Western society is less radical, less total, less uncompromising" than those who become Party members. They were admirers of Enlightenment values articulated by the Soviets and others, but also have some remaining respect for the same values in the Western context, according to Caute. This idea is not dissimilar from James C. Scott's concept of the "high modernist" who has a faith in scientific rationalism, and wishes to see it embodied by the state, or the term "progressive" used by many of the activists themselves.. David Caute, The Fellow-Travellers: Intellectual Friends of Communism (New Haven, CT: Yale University Press, 1988, revised edition), p. 3-10; James C. Scott, Seeing Like a State: How Certain Schemes to Improve the Human Condition Have Failed (New Haven, CT: Yale University Press, 1998).

${ }^{3}$ This is the term the Soviets used in describing fellow-travellers. I discovered that my interviewees preferred the word "progressive" over "Communist" and even "fellow-traveller" to describe themselves, particularly when they were not members of the Communist Party of Canada, and despite the fact that their political views at times aligned with the CPC policy. The term applies to individuals whose leftist notions led them to become involved in left-wing organizations or subscribe to left-wing publications of all types. In some cases, the word "progressive" can be used interchangeably with "fellow-traveller." In this they are following, perhaps unconsciously, the contention made in 1952 by CPC member and literary critic Margaret Fairley that Canada's "progressive culture" is defined as the "energetic expression of our life of social struggle, directed to positive, creative, fruitful ends." (Fairley, "Our Cultural Heritage," New Frontiers 1 (Winter 1952), p. 1-7). Drawing on Fairley's definition, it is also the term chosen by James Doyle for his book, Progressive Heritage: The Evolution of a Politically Radical Literary Tradition in Canada (Waterloo: Wilfrid Laurier University Press, 2002).
} 
The CSFS was led by Dyson Carter, a Sovietophile and member of the Communist Party who spent most of his career promoting the USSR to North Americans. He served as President of the Canadian Soviet Friendship Society (CSFS) from 19491960, edited the CSFS newsletter News-Facts about the USSR from 1950 to 1956, and published the popular pro-Soviet magazine Northern Neighbors from 1956 until 1989. His work was supported from Moscow by the All-Union Society for Friendship with Foreign Countries [Vse-soiznoe obshchestvo kul'turnoi sviazi s zagranitsei] (VOKS), and by the Communist Party of Canada, and his writing had wide appeal among the Canadian left. Based on recently released archival material from Russia and Canada, as well as oral history, this story of propaganda ${ }^{4}$ and persuasion in Cold War Canada offers a new perspective on the history of the Canadian left. It is also a significant adjunct to the history of Soviet foreign policy-making. Because the CSFS and the VOKS connection have been invisible to historians of Canada, this dissertation represents an important step towards filling a large gap in the historiography.

Founded in 1949 by Dyson Carter and Dorise Nielsen, the CSFS was clearly meant to provide an alternative, positive, view of the USSR, just a few years after the defection of Igor Gouzenko signaled the beginning of Cold War tensions in Canada. Concerned by the negative press, the Soviets saw in the CSFS a way to improve Canadian opinion of the USSR, but after the events of 1956 damaged the Soviet image enough for leading Communists worldwide to leave the movement, the CSFS and its Moscow-based parent organization were reorganized. In the intervening years, CSFS

\footnotetext{
${ }^{4}$ Propaganda, in the Soviet sense, as articulated by V.I. Lenin, was related to the dissemination of agitational information and ideas to small groups, with an effort to persuade them towards a particular viewpoint. See for instance, Barry Crowe, The Concise Dictionairy of Soviet Terminology, Institutions and Abbreviations (Oxford: Pergamon Press, 1969), p. 117.
} 
members were presented as 'average' Canadians seeking more 'truthful' and balanced reports of life in the USSR, and they disseminated material from the Soviet Union in publications and at public events.

In 1953 a secret RCMP report identified the Canadian Soviet Friendship Society as a Communist-front organization. This, it undoubtedly was. The links between the CSFS and the CPC-LPP have been confirmed by documentary and oral history evidence. The CSFS mission was twofold, said the RCMP report: first, the Society served as a "clearing-house" for invitations to the USSR and Soviet propaganda; second, it attempted to persuade many "innocent" Canadians to view Soviet-style communism favourably. It is clear that the CSFS was indeed engaged in propaganda and persuasion, acting as a proxy for the Communist Party of Canada, and as an attractive forum for leftists interested in Soviet culture, everyday life, scientific and socio-political innovation, and international relations. The RCMP worried that in a "stressful" situation (i.e. war) Canadians influenced by the CSFS message might support the wrong side. Certainly, the CSFS contact at the Soviet Embassy in Ottawa was working in connection with the KGB, and individual CSFS members have been accused in the Mitrokhin Archive of having been involved in espionage activities. Most likely rank-and-file members were not aware of such nefarious dealings. Today, former CSFS members remember the avenue to meaningful activism they found in countering the prevailing rhetoric about the USSR as the enemy. Rather than potential enemies within Canada's borders, these individuals saw themselves as having attempted to 'warm' Cold War international relations.

The CSFS was in constant liaison with VOKS, the All-Union Society for Cultural Relations with Foreign Countries, a Soviet organization responsible for public relations 
abroad, monitored by the Soviet Ministry of Foreign Affairs and the International Department of the Communist Party of the Soviet Union Central Committee. The CSFS also worked in close partnership with the Communist Party of Canada (called the LaborProgressive Party from 1943-1959) and the 'progressive, ethnic' groups which associated with it.

The CSFS attempted to attract readers, participants and delegates to the USSR from amongst "progressive" Canadians, many of whom had lived through the Depression, and had come to admire the USSR as a symbol of socialism in practice. A good number of these individuals were also members of the left-wing Association of United Ukrainian Canadians (AUUC), United Jewish People's Order, or the LaborProgressive Party, itself. The CSFS was never a large group: in 1951 there were roughly 50 people listed as members of the National Council for Canadian-Soviet Friendship, most of whom were in Ontario. ${ }^{5}$ There were five executive officers: the President was Dyson Carter, Major Romeo T. Lafond was listed as the Vice-President for French Canada, and Dewar Ferguson as his English-Canadian counter-part, William Tweedale was the treasurer, and Dorise Nielsen the executive secretary. Four years later, Carter claimed the CSFS had 400 members, and in 1957, 800. Although membership was relatively small, the readership of the CSFS publications grew substantially with the years. In 1950 News-Facts had four paid subscriptions, and in 1989 Dyson Carter claimed that his magazine, Northern Neighbors, was sent to 10, 000 subscribers in 81

\footnotetext{
${ }^{5}$ The list includes 29 names under the "Ontario" subtitle, six in Saskatchewan, five in British Columbia, only three in Quebec, two each in Alberta and Nova Scotia, one each in Manitoba, New Brunswick and Newfoundland, and no members listed for Prince Edward Island. (VOKS 6:1:36:23, "National Council of the C-S.F.S.," dated 1951.) Names on this list include those of prominent members of other left-wing organizations, including Emil and Fagel Gartner, John Wier, Harry Colegate, Mary Kardash and Mary Popoff. John Boyd, whose name appears on this list, has said that he was never, in fact, a CSFS member. (John Boyd, comments on manuscript by Jennifer Anderson, April 2008)
} 
different countries. The link between subscribers and members was close. In 1952, Dorise Nielsen said that every subscriber was automatically a member of the CSFS. In her "Report on Organization," Nielsen broke down the numbers of attendees at CSFS events by province, concluding that "some 10,000 Canadians have heard an account of Soviet life." She lamented the fact that although in the Maritimes "we have many readers of News-Facts, as yet we have no functioning committees," and pointed to the limited success in Quebec, explaining that in that province "... very real difficulties exist, caused by the Duplessis government and its Padlock Law." ${ }^{6}$ Still, she noted, a Quebec CSFS committee had been established, and members were both Anglophone and Francophone. ${ }^{7}$ The claim to represent 'alternative' news about the USSR did have an appeal.

Groups calling themselves "friends" of the USSR could be found in Canada from 1921, when a branch of the American Friends of Soviet Russia was founded in Toronto. These groups went variously by the names "Aid Russia campaign", "Friends of the Soviet Union", the "Canadian-Soviet Friendship Society", and the "Canada-USSR Association." From 1941, when the USSR was invaded by Nazi Germany, the National Council for Canadian-Soviet Friendship received widespread popular support, and some of the country's leading figures, including Prime Minister Mackenzie King, were known to attend events and contribute to the cause of "friendship" with the Soviet allies. But

\footnotetext{
${ }^{6}$ VOKS 6:1:36:53-54, Dorise Nielsen, "Report on Organization," at CSFS Convention, 26 January 1952. She noted that 4500 people had been reached in British Columbia, 900-1000 in Alberta, 200 in Saskatchewan, 7000 in Manitoba, and approx. 4500 in Ontario. The Padlock Law (or "La loi du cadenas" in French) in effect under the leadership of Quebec Premier Maurice Duplessis was so called because it allowed for owners to be locked out of their property if material that promoted communism was found there. The material was confiscated, and individuals could serve time in jail. It was actually called the "Act to protect the Province Against Communistic Propaganda," and was struck down by the Supreme Court in 1957. Jacques Rouillard, Le syndicalisme quebecois : Deux siecles d'histoire (Montréal: Editions Boréal, 2004), p. 68.

${ }^{7}$ Besides Major Lafond, R. McCutcheon and Irving Meyers are listed as members in Quebec. Oddly, Louis Kon is not listed as a member on this list, although he was clearly active in Montreal on behalf of the CSFS.
} 
after the defection of cipher clerk Igor Gouzenko from the Soviet embassy in Ottawa became public in 1946, friendship with the USSR fell out of style. That year, Sir Ellsworth Flavelle, head of the friendship society in Toronto, complained that "radical elements" were trying to take over the cause. In 1946, the RCMP reported that few members of the progressive groups in Canada were accepting invitations to visit the USSR, and concluded that this reticence was directly related to the investigation of individuals identified as communist spies by Gouzenko.

The story of the CSFS is framed by the Gouzenko defection, and the disillusionment affecting the LPP membership after the revelations made public by Nikita Khrushchev in 1956, the Soviet invasion of Hungary, and the international disputes during the Suez Crisis, occurring the same year. The CSFS appears to have been part of Soviet perception management at a time when even its most faithful supporters in Canada were having doubts about the wisdom of supporting the USSR. In 1945, the LPP claimed to be at the height of its membership with 20,000 members, but immediately following the Gouzenko revelations, hundreds left the Party, and many of those who remained questioned their decision to do so. ${ }^{8}$ Disillusionment over the links between the LPP and the CPSU compounded earlier feelings of resentment amongst the Party members and fellow-travellers in regards to the Nazi-Soviet Pact of 1939, and the flip-flop the CPC had been forced to perform when it came to support for World War II. After 1946, Soviet

\footnotetext{
${ }^{8}$ Ivan Avakumovic, The Communist Party in Canada: A History (Toronto: McClelland and Stewart, Ltd., 1975), p. 175.
} 
authorities posted in Canada no longer recommended reaching out to the wider Canadian public via the LPP. ${ }^{9}$

The CSFS was meant to shore up the confidence progressives had had in the Soviet experiment and, as a front organization, to bolster support for policies advanced by the CPC-LPP in a neutral, apparently nonpartisan, forum. Canadian-Soviet "friends" were part of an elaborate mise-en-scène presenting an unfailingly positive view of the USSR to fellow Canadians. But 1956 changed the dynamic once more. Disenchantment caused many Canadian leftists to cut ties with the progressive groups. The membership of the LPP was decimated, ${ }^{10}$ and the CSFS also lost members. As Merrily Weisbord has suggested, "until 1956 the nature of this relationship [between the CPSU and the LPP] would remain obscured by an almost mythological belief in Soviet communism." ${ }^{\prime 11}$ For some LPP members and fellow-travellers, it was not until Khrushchev's denunciation of Stalin's policies that they realized the full import of the revelations made public by Gouzenko a decade earlier. The Soviet response was to change its strategy. Almost immediately after 1956 the CSFS was reorganized, a new journal was introduced, and the same was done in Moscow for its parent organization, VOKS.

This dissertation focuses on the intervening years, from the founding of the CSFS in 1949 until its reorganization in 1960. In the early 1940s, Dyson Carter, well-known progressive writer, and a member of the Communist Party since 1931, wrote to Louis Kon, who had headed the Friends of the Soviet Union in Montreal before the war, asking

\footnotetext{
${ }^{9}$ On this, see especially J.L. Black, "Soviet Tactics and Targets in Canada Before and After the Gouzenko Defection," in Black and Martin Rudner, eds., The Gouzenko Affair: Canada and the Beginnings of Cold War Counter-Espionage (Manotick: Penumbra Press, 2006), p. 108-129.

${ }^{10}$ Avakumovic, The Communist Party in Canada, p. 232-234.

${ }^{11}$ Merrily Weisbord, The Strangest Dream: Canadian Communists, the Spy Trials, and the Cold War (Montreal: Vehicule Press, 1994), p. 177.
} 
for a contact at the Soviet Embassy. Kon advised Carter that the moment was ripe to reorganize the friendship society. After the Gouzenko defection, most of the high profile supporters of wartime Canadian-Soviet friendship withdrew their support, and when Dyson Carter was suggested as head of the new organization, the Soviets were enthusiastic. In late 1949, Carter together with a handful of other Canadians, including Dorise Nielsen, former MP from North Battleford, Saskatchewan, and Communist Party executive member, officially launched the CSFS. Events hosted by the Society were aimed at attracting a broad spectrum of left-leaning Canadians, and were always couched in the language of peace and friendship with our "northern neighbours."

For forty years Carter published pro-Soviet magazines (first News-Facts, and after 1956, Northern Neighbors), as well as other collections and monographs, by re-writing and building on articles sent to him by Soviet press agencies, taking every policy turn in step with the official Moscow line. For example, discussion of Khrushchev's 1956 "secret speech" distancing the CPSU from Stalin appeared in Carter's publication for the first time in the 1980s when Gorbachev's glasnost allowed discussion of that theme in the USSR. The invasions of Hungary in 1956 and Czechoslovakia in 1968 were presented from the Soviet (i.e. "liberation") point of view and, especially in the 1980s the magazine had a strong anti-American slant. Traditional "left" issues like women's rights, claims that Jews and other ethnic/national groups in the USSR were free, environmental protection, and natural health remedies were given considerable space in the magazine, but always with a strong positive spin on the USSR's advanced social policies.

But history is not memory, and from today's perspective readers will recognize the tragic irony of these claims. Several of the key CSFS players today question their 
earlier admiration of the USSR. Dyson Carter eventually recognized the message did not correspond with reality, but not until Mikhail Gorbachev's policy of glasnost had made speaking openly about Soviet "falsifications" possible. In 1990, Carter wrote that he had spent 40 years producing "bullshit." 12 This gives the story a tone of dystopia and disappointment, although at one time the USSR was a symbol of hope for many CSFS readers and members.

There is no doubt that Carter's publications were at root Soviet propaganda, coming to Canadian readers, not from across the Arctic, but from Ontario (first Toronto, and, from 1956-89, Gravenhurst). Carter was paid by the Soviets in in-kind support and benefits to serve as their propagandist, and even after a falling-out with the CPC leadership insiders say that no one "could touch him" because of this Soviet backing. He frequently travelled to the USSR and the Soviet embassy in Ottawa as a guest of honour. His prestige in the USSR notwithstanding, the Communist Party of Canada replaced Carter as head of the Friendship Society in 1960, and renamed the group the CanadaUSSR Association - a name calculated to give the impression that it was politically nonpartisan, and more business-like in its importing of Soviet cultural products. But the basic mission of the organization remained the same.

Did the CSFS have a significant impact on Canadian public opinion or CanadianSoviet diplomatic relations? Probably not. And yet, the close sustained surveillance of its membership by the RCMP, and the constant efforts of the Department of External Affairs to position itself vis-à-vis Soviet claims to "friendship," suggest that Canadian authorities took the CSFS and VOKS seriously. Despite the fact that some have described antiCommunism in Canada as "just as bad" as the infamous investigations by Senator Joseph

${ }^{12}$ Letter from Dyson Carter to John Boyd, 28 February 1990, in John Boyd's personal collection. 
McCarthy in the United States, ${ }^{13}$ the existence of the CSFS suggests otherwise. The CSFS executive distributed its publications and copious correspondence by post in Canada, and also in the United States. Although the RCMP intercepted and monitored some of this correspondence, it does not seem to have curtailed the CSFS' use of the postal system. Carter and other CSFS members traveled frequently to the USSR, and did not have their passports withdrawn, as American pro-Soviet performer Paul Robeson did, for instance. ${ }^{14}$ However, several CSFS members did have trouble traveling to the United States, and felt that their employers were influenced by the RCMP visits paid to their workplaces. Probably, their names were on the so-called "blacklist" shared with U.S. authorities. They may have sought shelter from anti-Communist public opinion in the officially non-Party CSFS, and after 1956, not unlike those who left the LPP at that time, may have found opportunities to be politically active in the CCF-NDP, the New Left, ${ }^{15}$ and in some cases, other groups like the Canada-USSR Association and leftist ethnic groups.

Until now, the Canadian Soviet Friendship Society, and indeed most of the Communist-front organizations in Canada, have received very little attention from historians, probably because the sources have not been available. An examination of the CSFS during the early Cold War offers historians a fascinating glimpse of the ideological tensions in Canada, and the ways in which some fellow-travellers responded. The CSFS made a serious attempt to change the prevailing negative view of the USSR, apparent in

\footnotetext{
${ }^{13}$ On this, see particularly the comparisons made in the National Film Board of Canada film "The UnCanadians" directed by Len Scher, 1996. The film makes this comparison more directly than Scher's book, The Un-Canadians: True Stories of the Blacklist Era (Toronto: Lester Publishing Ltd., 1992).

${ }_{14}^{14}$ On Robeson, see especially Laurel Sefton MacDowell, "Paul Robeson in Canada: A Border Story," Labour/Le Travail, no. 51, Spring 2003: 31 pars., accessed 2 June 2008, $<$ www.historycooperative.org/journals/11t/51/macdowell.html $>$.

${ }^{15}$ On former LPP members' activism post-1956, see Avakumovic, The Communist Party in Canada, p. 233-235.
} 
mainstream press and political statements in Canada during those years. Moscow provided support in quantity and quality, and CSFS efforts were monitored by high level officials in the USSR. Producing propaganda which appealed largely to left-leaning Canadians who already admired the USSR, the group did not sway the vast majority of Canadians to view the Soviet Union as politically neutral "friends." However, their attempts at persuasion were consistently in the public eye, and their calls for cultural and information exchanges did appeal to many Canadians, for whom Russia had long been an object of fascination. Explicating the relationship between the CSFS, the CPC-LPP and VOKS adds to our understanding of how individual Canadians contributed and responded to the rhetoric of Cold War international relations.

What follows, then, is an analysis of the context in which the postwar CSFS developed, and of the historiography upon which this study rests, with detailed information about the sources used. For an in-depth look at the biographical background of the key players in Canadian-Soviet friendship organizations, 1949-1991, as well as a discussion of the methodological issues related to bringing oral history techniques to this project, please see Appendix I. This discussion is physically separated from the rest of the thesis to mark the importance of its counter-narrative and the relevance of the biographical and ideological background motivating the main CSFS leaders. Chapter Five deals specifically with the Soviet perspective on and support for the CSFS and other "friendship" groups. Then the reader will find several empirically-based case studies, looking at the role of the CSFS in producing a persuasive, pro-Soviet message in Canada, relating with other pro-Soviet groups, highlighting the role of women in its activism, and finally, dealing with culture as a literal performance of Canadian-Soviet Friendship. 


\section{Chapter Two \\ SETTING THE STAGE: THE SOVIET FRIENDSHIP PHENOMENON, 1917-1949}

From the earliest days of the Bolshevik revolution there were Canadians who saw the USSR as a symbol of socialism in action. For some Canadians, the Bolshevik Revolution of October 1917 appeared to herald a new era in political affairs and international relations: an example to the world of socialism in power. For others, the symbol was of a different sort: a Red Scare in Canada was heightened when in 1919 a general strike gripped Winnipeg. ${ }^{16}$ Organizers of the strike were suspected of Soviet sympathies, and some may have indeed seen the USSR in a favourable light. Still others advocated engagement with the Soviet Union: political recognition and increased trade with the USSR was seen by these Canadians as the practical approach to international affairs. Russians and Canadians had been fascinated with one another for generations, and the Bolshevik Revolution of 1917 heightened considerably the political and ideological aspects of these mutual observations. ${ }^{17}$ The period was marked by the founding of numerous "aid to Russia" groups, amongst which were some founded by Canadian admirers of the USSR, which promoted both friendship and to a limited extent, political links with the Soviets.

From 1917 through the 1920s the plight of the "Russians" made headlines in Canada, as the Bolshevik government fought a Civil War, and the people were affected by clashing ideological and nationalist campaigns, attempts to consolidate or resist the

\footnotetext{
${ }^{16}$ On Canadian fears of communism being imported together with immigrants from Eastern Europe, and the particular "fear of aliens" engendered by the Winnipeg General Strike, see Donald H. Avery, Reluctant Host: Canada's Response to Immigrant Workers, 1896-1994 (Toronto: McClelland \& Stewart, Inc., 1995), especially p. 75-79.

${ }^{17}$ J.L. Black, Canada in the Soviet Mirror: Ideology and Perception in Soviet Foreign Affairs, 1917-1991 (Ottawa: Carleton University Press, 1998).
} 
revolution, and in 1921-22, a famine on such a large scale that V.I. Lenin and Maksim

Gorky appealed for international aid. Some refugees who had escaped the revolution and war arrived in Canada in 1924, and still other Doukhobor and Russian immigrants came to this country throughout the $1920 \mathrm{~s}$. Their impressions and experiences affected the Canadian mainstream view of the USSR. ${ }^{18}$ In 1919, Canadian troops were among those who went to the aid of the White imperial forces, fighting from the eastern city of Vladivostok, in the northeast at Archangelsk and Murmansk, and in the Caucasus. From the perspective of Canadians of all political stripes, the Soviet people really did appear to be in need of international support, foreign aid and friendship. ${ }^{19}$ Groups were organized to send provisions. ${ }^{20}$ Others, like the Winnipeg Society for Technical Assistance for the Soviet Union, and the Toronto-based Progressive Russian Club, sent workers to help repair the Russian economy. ${ }^{21}$

Among the most active in working for the promotion of trade with the Russians was Colonel Herbert J. Mackie, who with Dana Wilgress had been considered as representatives to a Canadian Trade Commission in Russia, before the plan to send a

\footnotetext{
${ }^{18}$ Black, Canada in the Soviet Mirror, p. 42. Immigrants were selected based on their abilities to work in agriculture, and Russian Jews were discouraged from coming to Canada, because it was felt they would be too urban. Although some immigrants from Russia prior to 1917 had socialist sensibilities, many of those who arrived immediately following the revolution, were White Russian refugees. Their perceptions of the Bolshevik government would clash. The Doukhobor belief system was essentially pacifist, but also emphasized communal living and farming. Later, the Soviets would attempt to convince Doukhobors and other left-wing ethnic group members to return to the Soviet homeland. All of these ideological differences brought the conflict from Russia closer to home for many Canadians. On the Return to the Homeland campaign, see Glenna Roberts and Serge Cipko, One-Way Ticket: The Soviet Return-to-the-Homeland Campaign, 1955-1960 (Manotick, ON: Penumbra Press, 2008).

${ }^{19}$ Black, Canada in the Soviet Mirror, pp. 37-46, 69-70; CRCR collection, University Partnership Centre, Georgian College, Barrie, ON, copied from GARF, fond 5283, opis 3, delo 74, p. 82-85.

${ }^{20}$ These included famine relief committees run by Canadian Communist groups, and the more mainstream Canadian Committee for Russian Relief, and the Save the Children Fund, the latter of which was also headed up by Herbert Mackie. See A. Balawyder, "Canada and the Famine in Soviet Russia and the Ukraine (1921-23)," The New Review (December 1964), p. 1-10; J.L. Black, Canada in the Soviet Mirror, p. 44-46.

${ }^{21}$ Black, Canada in the Soviet Mirror, p. 44-45.
} 
commission was scrapped in the early 1920s. Mackie went on to found a group called the Society for Cultural Relations with the USSR in 1926, which boasted more than 200 members. Although Mackie was constantly in contact with the All-Union Society for Cultural Relations with Foreign Countries (VOKS) in Moscow, they distrusted him. The Soviets felt that Mackie's interest in the USSR was primarily commercial rather than political, and suggested that it would be better to find another contact in Canada. ${ }^{22}$

In the 1920s, left-leaning Canadians considered it important not only to support the troubled "Soviet" people, but also the Bolshevik government. Workers worldwide were attracted to the idea of the New Economic Policy with which the Bolshevik government was experimenting, although they had little information as to what was happening "on the ground" in the USSR. Campaigns for "friendship" with the USSR allowed Soviet supporters to present an apparently non-political façade, to channel leftist sympathies towards admiration of the USSR while providing some distance from the more 'political' Communist Party of Canada (CPC). Except for the wartime society, the leaders in Canada were most certainly CPC members, while rank and file members and subscribers were probably fellow-travellers. They worked to promote cultural ties and understanding, and may have admired most the social circumstances claimed by the USSR. Officially, they recognized the political differences between Canada and the USSR, and did not seek to imitate the Soviet system. The cultural exchanges of performances and literature gave the impression that the Society was only cultural, but archival documents show that this image was produced intentionally.

\footnotetext{
${ }^{22}$ GARF, fonds 5283 , opis 3 , delo 74, p. 82-85, report prepared by I. Amdur, head, VOKS British Countries Division, 30 December 1930.
} 
The Royal Canadian Mounted Police reported retrospectively in the 1950s that the first Soviet friendship organizations arrived in Canada in 1921, when a branch of the American Friends of Soviet Russia was founded in Toronto. An undated RCMP report entitled "Brief: The Canadian Soviet Friendship Society" said that

The fall of 1921 saw the formation of the 'Canadian Friends of Soviet Russia', as a branch of the Friends of Soviet Russia in the United States. By 1939, this Canadian section, never having gathered any significant support, had dwindled in strength to the point where only one small group remained, that at Montreal under the leadership of Louis Kon. The American organization was formed August $7^{\text {th }}, 1921$, in New York City, with one of its main purposes the soliciting of funds and supplies for the relief of famine in Russia. In carrying out this task, a considerable quantity of pro-Soviet propaganda was circulated. ${ }^{23}$

Another organization mentioned earlier, the Society for Technical Aid to Soviet Russia, took shape in June 1921. The Mounties said that this group "was formed for the purposes of carrying out policies laid down by Soviet Russia and the Communist International," and researchers have noted that Ukrainians living in Canada could return to the USSR with the help of this organization. ${ }^{24}$ Although the Mounties reported that the Society did not attract much support during the 1930s, several activists from the Cold War period speak of their radicalization during the Depression, and the way the economic situation in Canada at that time convinced them of Soviet superiority. Certainly, the RCMP kept files on the organization through the 1930s, and reported on the wartime National Council of Soviet Friendship, as well, when being a 'friend' of the USSR gained a certain popularity.

\footnotetext{
${ }^{23}$ LAC, RG146, A200600091, RCMP "Brief: The Canadian Soviet Friendship Society," February 1951, attached to RCMP report dated April 1953, p. 126.

${ }^{24} \mathrm{LAC}$, RG146, A200600124, RCMP report "The National Council for Canadian Soviet Friendship- Origin and Growth", dated 1945 by hand in the margin, p. 179. Vadim Kukushkin also made reference to this Society and its influence in convincing Ukrainians in Canada to return to the USSR in the 1920s. Vadim Kukushkin, "Back in the USSR," Beaver, 86 (4), 2006, p. 33-36.
} 
Such organizations have an amazing resilience. To this day there are groups in Canada and the United States who support the re-establishment of the Soviet Union. These tend to trace their history to 1918 and the "Hands off Russia" campaign. They recall that the first "friends" sent funds to Soviet Russia, and lobbied Western governments not to interfere in the Russian Civil War (1917-1919), in which "White" imperial troops bolstered by some foreign units fought the "Red" Bolshevik army under Leon Trotsky's leadership. The groups, called the U.S. Friends of the Soviet People, and the International Council for Friendship and Solidarity with Soviet People (based in Toronto), celebrated the $80^{\text {th }}$ anniversary of the 1918 campaign in New York, where a banner proclaiming, "Back to the Future... Restore the Soviet Union" was featured prominently. ${ }^{25}$

Typical of this trend was Louis Kon, who dated his own involvement from 1919. Born in Moscow in 1881, he left Russia after having been involved in the 1905 revolution, ${ }^{26}$ emigrated to Canada and became a citizen in 1907 . Working for the Grand Trunk Pacific Railway as an immigration and colonization officer, he met his wife Elsa in Brussels in 1910 while attending the Universal and International Exhibition for his employer. The couple had two children, both born in Winnipeg. Irene was born in 1911, and her brother William in 1914. It is not clear what Kon was doing during the First World War, but in 1918 he returned to Russia as Secretary of the Canadian Economic Commission under the supervision of Dana Wilgress, and for whom he wrote several

\footnotetext{
${ }^{25}$ This event took place in a hall on W. $27^{\text {th }}$ Street, New York City on 24 January 1999. See Angelo D'Angelo, " $80^{\text {th }}$ Anniversary of Hands Off Russia Committee", Northstar Compass [the journal of the International Council for Friendship and Solidarity with Soviet People, editor Michael Lucas, based in Toronto], \{http://www.northstarcompass.org/usfsp/anniv.htm, accessed 6 June 2007\}. The invitation to this event also appeared in the Northstar Compass \{http://www.northstarcompass.org/usfsp/flyer98.htm, accessed 6 June 2007\}.

${ }^{26}$ Information in this paragraph comes from "Remembering Louis Kon", written by Irene Kon, 7 November 1983, Louis and Irene Kon Collection, Osler Library, McGill University, Montreal, P162, Folder 1.9.
} 
important reports. ${ }^{27}$ Upon their return to Canada in 1919, Wilgress reported Kon to the RCMP for his "Bolshevik-like" views, noting that he "contemplate[d] the trouble which can be caused... by men of the type of Mr. Kon. ${ }^{28}$ It is from this date that a RCMP file was kept on Kon, amounting essentially to a blacklisting. The reports called Kon a "Bolsheviki propagandist" who was speaking at radical immigrant meetings, and presumably drawing funds from this activity. ${ }^{29}$ In August 1919 the Civil Service Commission declared that it would "take every precaution in its power to guard against Mr. Kon's receiving any employment in the Public Service." ${ }^{30}$

Kon claimed that he was involved in organizing the Winnipeg General Strike of 1919, and his daughter, Irene, wrote that "when the strike was broken and severe reprisals [were] in store for those who had supported it, he took his wife and two small children to Montreal." ${ }^{31}$ He worked for the Canadian Electrical Association and the Montreal Light, Heat and Power Corporation, until he was offered a job by the Soviet government in 1926 to promote trade with the USSR. He was sent as a representative of the Canadian Pacific Railway to the Soviet Union in 1929 to try to sell the wider-gauged rails to the Soviet government, but once the Depression hit he found himself unemployed.

Kon served as head of the Montreal-based Friends of the Soviet Union (FSU) until the Second World War broke out, writing countless letters to the editors of local

\footnotetext{
${ }^{27} \mathrm{Kon}$ is the author of 4 of the 12 papers in the Commission's 77-page final report, published in 1919. Along with J.S. Dennis, Chairman, Kon signed the report as "Secretary." Canada, Department of Trade and Commerce, Report of the Canadian Economic Commission (Siberia) (Ottawa: Labroquerie Tache, 1919). ${ }^{28}$ Letter written by L.D. Wilgress, Canadian Trade Commissioner to Royal North-West Mounted Police, 7 May 1919, obtained through application to Access to Information and Privacy by Irene Kon, and released into the Louis and Irene Kon fonds, Osler Library, McGill University, P162, Folder 1.1.

${ }^{29}$ RNWMP reports, 22 August 1919, 30 August 1919, 9 September 1919, 5 September 1919, all found in the Louis and Irene Kon fonds, Osler Library, McGill University, P162, Folder 1.1.

${ }^{30}$ Letter from the Civil Service Commission to the Royal North-West Mounted Police, 29 August 1919, Louis and Irene Kon fonds, Osler Library, McGill University, P162, Folder 1.1.

31 "Remembering Louis Kon", written by Irene Kon, 7 November 1983, Louis and Irene Kon Collection, Osler Library, McGill University, Montreal, P162, Folder 1.9.
} 
newspapers and organizing events. One of the main attributes he brought to his work was his command of languages. At some meetings he was said to have been speaking French, at others "Jewish," and he was fluent as well in English and Russian. ${ }^{32}$ In 1935, he organized a Soviet art exhibition sponsored by the FSU in Montreal, complained that it was "the object of the [Montreal] city authorities to prevent the French Canadian workers from learning the truth about Soviet Russia," and even before the infamous "Padlock Law" was officially passed, served time in jail for having run a meeting in a hall without the necessary police permit. ${ }^{33}$ He introduced Norman Bethune to the Communist Party of Canada, ${ }^{34}$ and encouraged Dyson Carter to refound the Canadian Soviet Friendship Society after World War II. ${ }^{35}$ He remained a supporter of Josef Stalin, ${ }^{36}$ attended events at the Soviet embassy in Ottawa, and received letters from the leader of the Communist Party of Canada, Tim Buck. ${ }^{37}$ Irene Kon wrote that "throughout the thirties and until the end of his life he worked tirelessly without money, trying to educate people to the momentous changes taking place in the world." ${ }^{38}$ Kon's son, William, worked as an organizer for the Communist Party of Canada, but as a member of the Canadian forces,

${ }^{32}$ Gregory S. Kealey and Reginald Whitaker, eds., "RCMP Weekly Summary Report on Revolutionary Organizations and Agitators in Canada," no. 772, 11 September 1935; no. 778, 23 October 1935," The R.C.M.P. Security Bulletins: The Depression Years, pt. II, 1935, (St. John's Newfoundland: Canadian Committee on Labour History, 1993), p. 485, 551.

${ }^{33}$ Kealey and Whitaker, eds., "RCMP Weekly Summary Reports...," no. 759, 12 June 1935 and no. 772 , 11 September 1935," The R.C.M.P. Security Bulletins: The Depression Years, pt. II, 1935, p. 344, 485.

${ }^{34}$ Irene Kon has said that Norman Bethune did not at first accept communism, but after having lent him some books and making arrangements for him to attend a medical conference in Moscow in 1935, Bethune was persuaded to agree with Kon. Interestingly, although Frederick Banting traveled with Bethune on this trip to the USSR, Banting came back opposed to the Soviet Union. Letter from Irene Kon to Professors Yang and Chen, China, 15 June 1986, Louis and Irene Kon Collection, Osler Library, McGill University, Montreal, P162, Folder 1.5; Black, Canada in the Soviet Mirror, p. 102.

${ }^{35}$ Letter from Louis Kon to Dyson Carter, 7 November 1943, Kon Collection, Osler Library, P162, Folder 1.9 .

${ }^{36}$ Letter of sympathy from Louis Kon to the National Council, Canadian-Soviet Friendship Society, 6 March 1953, Kon Collection, Osler Library, P162, Folder 1.19.

${ }^{37}$ Letter from Tim Buck to Louis Kon on Labor-Progressive Party letterhead, 28 September 1955 wishing him to get well soon, Kon Collection, Osler Library, P162, Folder 1.9.

38 "Remembering Louis Kon", written by Irene Kon, 7 November 1983, Louis and Irene Kon Collection, Osler Library, McGill University, Montreal, P162, Folder 1.9. 
was killed overseas in $1945 .^{39}$ Irene Kon is remembered fondly by progressives in

Montreal as one of their most active members in the postwar years.

As a Communist Party front, the Friends of the Soviet Union included a good number of well-known Canadian Communists and fellow travellers. It does not appear that the political nature of the pre-war Soviet friendship movement was as scrupulously disguised as in the post-World War II friendship society. If Louis Kon was not a CPC member, he was certainly a fellow-traveller. Irene Kon wrote to him in a confessional manner in the late 1930s, promising to approach the Party soon herself about becoming a member, and he made the arrangements for CPC meetings throughout the $1930 \mathrm{~s}^{40}$ In the 1930s, an RCMP report placed several other prominent communists at Soviet friendship events in Toronto. At the National Conference of Friendship with U.S.S.R. held at the Odd Fellows' Temple on College Street in Toronto in June 1935, speakers included Sam Carr, A.A. McLeod, and Peter Hunter. ${ }^{41}$ Annie Buller and Bella Gauld were present. The Secretary of the Conference Committee, Jack Cowen, began his remarks by addressing

\footnotetext{
${ }^{39}$ Libbie Park, "Bethune as I Knew Him," in Wendell MacLeod, Libbie Park, and Stanley Ryerson, eds., Bethune: the Montreal Years: An Informal Portrait (Toronto: James Lorimer \& Company Publishers, 1978), p. 78.

${ }^{40}$ Letter from Irene Kon to Louis Kon, 9 July 1937 or 1938, Kon Collection, Osler Library, P162, Folder 1.4. Libbie Park has written that Louis Kon was "never, as far as I knew, a member of the Communist Party of Canada," but he was well-known by friends and newspaper editors for his pro-Soviet views. (Park, "Bethune as I Knew Him," MacLeod, Park, Ryerson, eds., Bethune, p. 77). According to the RCMP, Kon arranged for the Montreal Stadium to be used for a CPC meeting in 1935, and attended a CPC election rally, but more often spoke and organized events for more (at least officially) nonpartisan organizations like the Friends of the Soviet Union, the YMCA, and the a tenants league in Montreal. (Kealey and Whitaker, eds., The R.C.M.P. Security Bulletins: The Depression Years, pt. I, 1933-1934, p. 102, 146; and pt. II, 1935, p. $6,230,344,551$.

${ }^{41}$ For the programme from meetings at the 1935 conference see "Report of Proceedings, National Conference of Friendship with the USSR, June 28-29-30, 1935, Odd Fellows' Temple, Toronto, issued by Friends of the Soviet Union, Canadian Section," LAC, RCMP files, RG146, A200600091, p. 54-96. A 1965 memorandum on the RCMP file says that the 1935 FSU programme, together with material on the Young Communist League, the Canadian Youth Congress, the Civil Rights Union, Workers Unity League and fascist organizations in Canada, was seized from the Canadian Labour Defense League in 1940. (LAC, RG146, A200600091, p. 51-52.)
} 
the audience as "Comrades,"42 a choice of words that Dyson Carter would consistently avoid in favour of "Friends". Rev. C.C. Wellerman, a minister in Holland Centre, explained that "membership in the church was in itself no reason for not admiring the splendid achievements of the Soviet Union." He said "...his sympathies were with the working-class, and with the Soviet Union, which has been doing so much for the working class, and for the cause of peace. ${ }^{.43}$ The Depression of the 1930s and the social alternative that the USSR appeared to represent was an important factor here. This context was later cited by several former CSFS activists as being an important influence in their decision to become involved with the left-wing groups in Canada.

The rhetoric at the meetings in the 1930s was overtly admiring of both the cultural and social advances made in the USSR, and the political situation that made this possible. As Libbie Park, an active attendee of Friends of the Soviet Union events noted, "the FSU was a lively organization attracting Communists and non-communists curious about life in the Soviet Union. ${ }^{, 44}$ In 1935, the group organized talks given by Norman Bethune, who had just come back from the USSR, by leading CPC theorist Stanley Ryerson, and by Louis Kon's son, William, who spoke about Soviet writer Maksim Gorky, as well as the "new democracy" in the USSR. ${ }^{45}$ However, at their Congress in June 1935, it was noted that a different strategy was needed in appealing to Canadians outside the left-wing groups. For example, J.F. White said that the message needed to be pitched differently to "intellectuals, and liberals, with a small 'l', of all descriptions" than to members of the CCF, Canadian Labor Defense League, the Friends of the Soviet Union and unions.

\footnotetext{
${ }^{42}$ LAC, RG146, A200600091, p. 56.

${ }^{43}$ Ibid., p. 58.

${ }^{44}$ Park, "Bethune as I Knew Him," MacLeod, Park, Ryerson, eds., Bethune, p. 78.

${ }^{45}$ Ibid.
} 
...[I]n dealing with delegates and observers from these outside organizations, it is necessary to use a slightly different technique than in dealing with the regular inside ones. After all, we have to realize that as we make contact with larger numbers of people who have been outside the left-wing or revolutionary or even mildly socialist movement, that these people will know very much less about the U.S.S.R., and will be more or less in the kindergarten class. When we are talking to regular delegates who have been going to these meetings for years, we can use revolutionary technique, and have a regular sort of hell-fire meeting, but that sort of thing is not proper for delegates from the other organizations, who are gradually becoming interested and sympathetic towards the developments in the U.S.S.R. ${ }^{46}$

He suggested that the FSU had begun in Canada as a small group, but the fact that it now had its own journal meant that members could aspire to great things. He even dreamed of one day hosting events in Maple Leaf Gardens. ${ }^{47}$

The argument that support for the USSR meant support for peaceful coexistence was as persuasive in the interbellum period as it was during the Cold War, and it was also likely to earn its proponents a "subversive" reputation, according to the RCMP. In 1934 the RCMP reported that Kon gave a speech to the French language FSU branch in Montreal entitled "The Danger of War Against the Soviet Union," which was attended by 250 people. Beatrice Ferneyhough, who would remain active in the postwar CSFS, was physically pulled from the platform by police in Montreal where she had been speaking against the rise of Hitler and fascism in Europe. ${ }^{48}$ At the FSU Congress in 1935, White argued that the ranks of pro-Soviet Canadians could only grow, since "the Soviet Union offers the one hope of an alternative system to capitalism,"

\footnotetext{
${ }^{46}$ LAC, RG146, A200600091 p. 65.

${ }^{47}$ A rally in Maple Leaf Gardens was in fact held in 1943 on the second anniversary of the Soviet entry as an ally into World War II.

${ }^{48}$ Kealey and Whitaker, eds., "Weekly Summary Report...," no. 715, 18 July 1934, The R.C.M.P. Security Bulletins: The Depression Years, pt. I, 1933-1934, p. 146-147.

${ }^{49}$ LAC, RG146, A200600091, p. 66.
} 
and "although it is quite a long time since the Great War has finished, there are still thousands, tens of thousands, hundreds of thousands of people who remember quite clearly what war means to the working-class." ${ }^{90}$ A.A. McLeod, who later would serve as a member of the Provincial Assembly in Ontario, brought greetings to the Congress from the Canadian League Against War and Fascism, recognizing that "the Soviet Union is the greatest force for peace in the world."51

The rhetoric of the "truth" about the Soviet Union, and the universal achievements it was making, also used in the post-war period, was a feature of many of the FSU speeches. Sam Carr brought greetings from the "Communist Movement of Canada" to the FSU Congress, saying "I am certain that the gathering in this hall will again prove that there are tens of thousands of people in Canada who, though they do not agree with what they believe is Communism, admire the great deeds of the people of the U.S.S.R. and the contribution the Soviet Union is making towards a better universe...I feel confident that you will elaborate the necessary plans to further disseminate the truth about what is going on in that one-sixth of the earth, the U.S.S.R." 52 Perhaps foreshadowing Dyson Carter's emphasis on the scientific and technological achievements of the USSR, J.F. White said:

Comrades and Friends: One of the disadvantages of living as we do under a capitalist system is that nothing can be done about the weather, and it is probably due partly to the unfavorable weather that we have such a small gathering of delegates and observers here this morning. Now, in the Soviet Union, they have already begun to investigate the possibility of channeling the weather to suit themselves...as Comrade Stalin has said, 'There are no fortresses too difficult for a Bolshevik to conquer. ${ }^{, 53}$

\footnotetext{
${ }^{50}$ Ibid., p. 67.

${ }^{51}$ Ibid., p. 59.

${ }^{52}$ Ibid., p. 61.

${ }^{53}$ Ibid., p. 65.
} 
In the mid 1930s, the policy of the Comintern, laid out at its Congress in Moscow in 1935 and then adopted by all international Communist parties was to present a "united front;" that is, to co-opt all progressive, left-leaning groups and individuals into a larger forum that would be "friendly" to the USSR. The Comintern press related that CPC delegates to the USSR in the 1930s were encouraged to promote, on their return to Canada, the Friends of the Soviet Union. ${ }^{54}$ Several aspects of the 1935 Friendship convention point to development of this policy, adopted directly from the Comintern platform. Cables from Friends of the Soviet Union congresses in Sweden, Holland, France and Norway were read at the convention, and the effect was to give the Canadians a sense of being part of a larger, international movement. ${ }^{55} \mathrm{~W}$. Sydney, representing the National Committee of the F.S.U. began his speech as if at a wedding:

To-day, when we are gathered here, representatives of 75 or 80 organizations, we must understand that our role is in relation to the Soviet Union. We must understand that we have a very definite role to play and that we by showing our friendship with the Soviet Union, contribute to the success of the Soviet Union both at home and abroad. That is why it is necessary that we, to-day, re-affirm our friendship with the Soviet Union. There are representatives here from various organizations; some are as yet not clear on the aims and objects of the Friends of the Soviet Union. We will try, during this Conference and Convention to clarify what we stand for, and by doing this, we feel certain that we will draw them into our ranks, and greatly extend the ranks of those friends of the Soviet Union in Canada. We must be clear that our object here must be of the broadest possible nature, that we must not in any way do anything that will narrow our sphere of activities. We will not be doing the Soviet Union any good by trying to duplicate the work of other organizations. We have certain functions to perform." ${ }^{\text {S6 }}$ These functions involved spreading the good news of the USSR. That is to say, telling Canadians about Soviet achievements, Soviet policies 'in the interest of the working class."

\footnotetext{
${ }^{54}$ J.L. Black, Canada in the Soviet Mirror, p. 102-104.

${ }^{55}$ LAC, RG146, A200600091, p. 68.

${ }^{56}$ LAC, RG146, A200600091, p. 78.
} 
"We have to bring the truth to them, and have them realize what the Soviet Union is doing," Sydney concluded. ${ }^{57}$

The duty of the FSU was also to respond to attacks against the USSR from the bourgeoisie, according to Sydney, because these attacks "weaken not only the Soviet Union, but they weaken the working-class the world over." "As a result of this Conference, we want to see greatly added strength to the Friends of the Soviet Union, whether as members or as affiliates," said Sydney. "We want to see ever larger sections of the Canadian people rally to support the work that the workers and farmers are doing in the Soviet Union, and to answer every slander and attack against it." exactly the kind of language used by Dyson Carter in News-Facts and Northern Neighbors, as well as in the book he published with Charlotte Carter, We Saw Socialism. The emphasis was always on promoting the USSR in the most positive light, and countering critiques of the Soviet Union by presenting "facts" and personal testimonies to the contrary.

In celebrating their success, the friendship magazine, Soviet Russia To-Day, published in Canada since August 1933, was held up as an example. ${ }^{59}$ Its circulation was said to have increased from the original 3000 to 8000 in two years. This magazine may have been a Canadian version of the publication by the same title published by the New York-based FSU from February 1932 until January 1951. In its first issue, the editors noted that it was published by the "Canadian section of the F.S.U." and it carried greetings from the U.S. and British sections of the same organization. ${ }^{60}$ The last issue

\footnotetext{
${ }^{57}$ Ibid..

58 Ibid.

59 LAC, RG146, A200600091, "Conference Resolution on the Journal "Soviet Russia To-Day," p. 95.

${ }^{60}$ Soviet Russia Today, August 1933, vol. 1, no. 1, p. 15.
} 
appears to have been published in January 1936, carrying an article written by Aleksei Stakhanov, the young Soviet miner known as the inspiration for the Stakhanovite movement in the USSR. ${ }^{61}$ Articles purporting to reveal "The Truth About the Soviet Union," ${ }^{62}$ and the large photographs of Soviet people and technological might, suggest that the magazine was an example for Dyson Carter, who later spent his career publishing this type of pro-Soviet literature. The 1935 conference resolved that Soviet Russia Today “...has been an important instrument in spreading knowledge about the Soviet Union to a wide reading public. This magazine also constantly reflects in its columns, organizational activities of the Friends of the Soviet Union." ${ }^{, 63}$ In 1933 the magazine was 10 cents an issue, but in 1936 the price had been reduced to only 5 cents. No direct information was given on where the financing for this magazine came from, although trouble overcoming financial difficulties was discussed.

At the congress, J. Cowan, National Secretary of the Friends of the Soviet Union denied that funding for the FSU came from Moscow, while suggesting at the same time that Soviet financial investment would be justifiable:

Our enemies have reiterated that our financing is done on 'Moscow Gold.' I make so bold as to express my opinion that if it were true, it would be no crime, as the Soviet Union has as much and more right to finance movements in her favor in other countries as have all other countries of the world who maintain propaganda agents of all kinds, including lobbyists, trade representatives, spies, and others to further their own interests in every country. I say, therefore, if it were true that the Soviet Union finances our work, I would see no crime in it. The fact of the matter is however, not only that is it a lie deliberately spread by our enemies for their own purpose, but that on the other hand, the sections of the F.S.U. throughout the world finance the maintenance of its International headquarters in Amsterdam, Holland, by means of annual Levy

\footnotetext{
${ }^{61}$ Alexei Stakhanov, "How We Work," Soviet Russia Today, Jan. 1936, vol. 3, no. 27, p. 3, 13.

62 "The Truth About the Soviet Union," Soviet Russia Todoy, Aug. 1933, vol. 1, no. 1, p. 16.

${ }^{63}$ Ibid., p. 95.
} 
Stamps, and that not one penny either directly or indirectly has come into our funds from other than the working-class and friends in Canada.

Cowan complained that photos, pamphlets, notes and books had been confiscated by the Royal North-West Mounted Police, and provincial police visits were intimidating members $^{64}$ and hall owners into not allowing FSU events to be hosted. ${ }^{65}$ The 1935 "Conference Resolution on the Friends of the Soviet Union" concluded saying that "In spite of the unfriendly and often hostile attitude on the part of the Canadian Government and of certain powerful industrial and financial interests, this Conference records a growing feeling of friendship among the people of Canada for the people and government of the Soviet Union." 66

Being a "friend" of the USSR may have allowed members to combine political idealism with a sense of active participation on the world stage. For instance, in 1936 Louis Kon wrote a letter to Josef Stalin, asking for photographs of him for the FSU office in Montreal. The letter is striking in its naïve suggestion that Stalin was approachable: "we are addressing you, of course, as the symbol of realism and ideal of human life as understood and lived by those whose we are so proud to call ourselves- Friends of the Soviet Union." ${ }^{67}$ During the Depression, being a "friend" of the USSR was not considered to be particularly radical, and idealistic Canadians found the Soviet experiment to be a provocative example of possible solutions to economic problems they saw on their own doorsteps. ${ }^{68}$

\footnotetext{
${ }^{64}$ Ibid., p. 92. The force's name was changed to the Royal Canadian Mounted Police (RCMP) in 1920.

${ }^{65}$ Ibid., p. 93

${ }^{66}$ Ibid., p. 94.

${ }^{67}$ Black, Canada in the Soviet Mirror, p. 104.

${ }^{68}$ On the attraction of reading groups concerned with the USSR and concern over the Depression, see for example, Duncan McDowall, "The Trial and Tribulations of Miss Agatha Chapman: Statistics in a Cold War Climate," Queen's Quarterly, 114/3 (Fall 2007), p. 357-369.
} 
But the signing of the non-aggression pact between Stalin and Hitler in 1939 threw the Communist International and progressive groups worldwide into disarray. For years their message had been that the USSR represented the only alternative to fascism, and yet now Moscow had declared its neutrality if war broke out between the Allies and Nazi Germany. It was a hard pill for many communists to swallow, but within a period of a few weeks the Canadian Communist Party instructed its members on how to respond. Mostly this meant opposing the war - blaming it on imperialism sponsored by the United Kingdom and France. ${ }^{69}$ Kon stopped organizing Friendship events in 1939, and no more is said of the groups in Montreal or Toronto until the Soviet Union entered the war following Hitler's invasion in 1941. This was an extremely difficult time for communists and Soviet-sympathizers in Canada, accused of being traitors for not supporting the war against Nazi Germany. The RCMP reported in 1945 that the Friends of the Soviet Union had been diminishing before the pact was signed, noting that FSU numbers "had dwindled considerably to small groups in Montreal and Toronto" by 1937 and 1938. By 1939 just the group in Montreal under Louis Kon was left, and by 1940 even that group had dissipated. ${ }^{70}$

However, once the USSR entered the war, Soviet Friendship became broadly palatable as it had never been before. In Canada, mass support for Soviet friendship was noted to be enthusiastically accepted by 1942 , and in this climate the membership of the Communist Party lists were also bolstered. ${ }^{71}$ A BBC documentary film produced in 1980

\footnotetext{
${ }^{69}$ The Communist Party of Canada (CPC), banned in 1941, called itself the Labor-Progressive Party (LPP) from 1941-1959.

${ }^{70} \mathrm{LAC}, \mathrm{RG146}$, A200600124, RCMP brief "National Council for Canadian Soviet Friendship- Origin and Growth," handwritten date in margin 8 February 1945, p. 179.

${ }^{71}$ Joan Beaumont, Comrades in Arms: British Aid to Russia, 1941-1945 (London: Davis-Poynter, 1980), p. 97.
} 
and aired on TVO in Canada illustrates to what extent the swing of "friendship" with the Soviet Union was a result of international events and the changing interpretation of these in the West between the $1930 \mathrm{~s}$ and the $1950 \mathrm{~s} .^{72}$ In the late 1930s, the British mainstream media was "either hostile or puzzled" towards the USSR, wondering which side of the coming war the Soviets would choose. ${ }^{73}$ When the USSR signed the non-aggression pact with Nazi Germany and soon after invaded Finland, the British newscasts depicted the USSR as a totalitarian regime on a par with National Socialism. After the Nazis invaded the Soviet Union in June 1941, the tone of official British reports changed almost immediately. As the documentary suggests, keeping the Nazis busy on the Eastern front was in the interest of the Western Allies, and so the Aid to Russia campaign had practical justification. Suddenly it was possible to send planes, ammunition, supplies and extend the hand of friendship to the USSR and its people. In return, the British accepted Soviet cultural artifacts, including most importantly for the war effort, Soviet film footage of the Red Army in battle, taking German prisoners, and the Soviet war industry. In this climate, the British left-wing intellectuals "recovered their poise" after the difficult situation they had found themselves in from 1939-1941, and overtly positive views of the USSR were once more articulated in public. There even developed a kind of friendly cooperation between left-wing groups and the British Foreign Office in promoting friendship with the USSR by organizing large events, and sending greetings to the Red Army and the Soviet families and workers on the homefront. However, even as Winston Churchill smiled for the cameras in his meeting with Josef Stalin in 1942, he apparently began to worry that the British public was not restrained enough in its admiration for the

72 "Mindbenders: Propaganda with Facts: Our Soviet Friends," British Broadcasting Corporation, 1980. ${ }^{73} \mathrm{Ibid}$. 
Soviet Union. As the film summary reads, “.... a balance was sought between placating the Russians and giving too much ammunition to British leftists. ${ }^{.74}$ By 1943 the Ministry of Information made sure that the organizers of large-scale Soviet friendship parades and events were drawn from the conservative establishment, focused on wartime partnership, not political admiration. ${ }^{75}$ Once the war was over, and the Soviet Union became increasingly prickly in the United Nations, the Korean War was begun with the USSR supporting the North, and issues of Berlin were causing friction, the British news industry went back to depicting the USSR in broadly negative terms. ${ }^{76}$

This tendency can be seen also in the Canadian experience. Starting in 1941 nongovernmental, often voluntary, groups across Canada began to organize to send aid to "Russia," and lobby for the opening of a second front in Europe to help the Soviets. The RCMP was still convinced that some of these small organizations were put together by communists of long-standing. One of these groups, called the "Information Bureau, Soviet Union at Peace and War" formed in Montreal with a "membership comprised [of] many of those formerly connected with the Friends of the Soviet Union," apparently joined the Labor-Progressive Party in 1944. ${ }^{77}$ The Russian Medical Aid Committee, also set up in Montreal in 1941 was sponsored by "persons close to the Communist movement," but also attracted "prominent citizens in Montreal" to their events. ${ }^{78}$ In December 1941 former American ambassador to the USSR and the White House-

\footnotetext{
74 "Mindbenders: Propaganda with Facts: Our Soviet Friends," British Broadcasting Corporation, 1980. ${ }^{75}$ A celebratory parade in honour of the Red Army's $25^{\text {th }}$ anniversary in 1943 was apparently part of the Ministry of Information policy, termed "Sealing Thunder," designed to show the USSR that Britain was a "good Ally" but to do so within the confines of a wartime relationship. Ibid. ${ }^{76}$ Ibid.

${ }^{77}$ LAC, RG146, A200600124, "The National Council for Canadian Soviet Friendship- Origin and Growth", dated 1945 by hand in the margin, p. 179-190. This RCMP report also appears in Gregory S. Kealey and Reginald Whitaker, eds., R.C.M.P. Security Bulletins: The War Series, pt. 2, 1942-1945 (St. John's Newfoundland: Canadian Committee on Labour History, 1993), p. 251-259.

${ }^{78}$ Ibid.
} 
supported spokesman for the war effort, Joseph H. Davies, spoke at one of their events, and the money raised was donated to the Canadian Red Cross with instructions to use it towards medical supplies for the USSR. In March 1942 the group sponsored a talk by American communist, Anna Louise Strong, founder in the 1920s of the English language Soviet newspaper for foreign audiences, Moscow News. The RCMP reported that a separate Montreal-based organization called the Association of Canadian Citizens of Russian Origin also set up in 1941 had 5000 people at its first event in July of that year, $75 \%$ of whom were "communist sympathizers," but that it "ceased to exist" sometime in $1942 .^{79}$ These groups may have been merging into others. A fourth group, originally called the Society for the Study of Modern Russia and largely made up of university professors, was organized in March of 1943, later changed its name to the Canada Russia Society, and became the Montreal branch of the National Council for Canadian Soviet Friendship later that year. ${ }^{80}$

Gregory S. Kealey and Reginald Whitaker have commented that the RCMP “...were sometimes not very careful about painting people Red or Pink who were association with such alleged fronts. For instance, their discussion of the National Council for Canadian-Soviet Friendship contains names of many persons who were probably never influenced by Communism at all." ${ }^{81}$ While this is true, it is also worth noting the degree to which Communists and fellow-travellers did see a forum for expression of political and fraternal sympathies with the USSR in the NC-CSF and the postwar organization headed by Dyson Carter. Probably most of the organizers were

\footnotetext{
${ }^{79}$ LAC, RG146, RCMP report, A200600124, "The National Council for Canadian Soviet FriendshipOrigin and Growth", dated 1945 by hand in the margin, p. 179-190.

${ }^{80} \mathrm{Ibid}$.

${ }^{81}$ Kealey and Whitaker, eds., "Introduction," The R.C.M.P. Security Bulletins: The War Series, pt. 2, 19421945 , p. 18.
} 
communists, while others may have simply been attracted by the message and the chance to make a contribution, however small, to the war effort. Fraternal, good neighbourly relations were in style while the Soviets were with the Allies.

In 1942, Dyson Carter, whose writing was already well-known in progressive circles, wrote to Louis Kon in Montreal to thank him for material Kon had sent, and for his compliments on Carter's recent pro-Soviet book, Russia's Secret Weapon (1942). ${ }^{82}$ Carter said that he was receiving material from the Soviet embassy in Washington D.C., and asked Kon for a connection at the Ottawa embassy. He also requested a recommendation on Friends of the Soviet Union letterhead, which Carter said "would be very helpful." ${ }^{83}$ This may have been Carter's first initiative in Soviet friendship events, and he would remain involved with the wartime group until he himself became head of the post-war National Council. But his interest in things Soviet did not set him apart from many Canadians at that time. Throughout the war the Canadian Wartime Information Board used Soviet films, and discussed the use of Canadian culture as a means of promoting the Canadian contributions to the war effort to the Soviets. ${ }^{84}$ Louis Kon was among those who approached the Wartime Information Board about publishing Canadian material in the Soviet publication, International Literature. ${ }^{85}$ This focus on wartime use of culture also meant that the Canadian ambassador Dana Wilgress, on

\footnotetext{
${ }^{82}$ Letter from Dyson Carter to Louis Kon, 28 November 1942, Kon Collection, Osler Library, P162, Folder 1.19 .

${ }^{83} \mathrm{Ibid}$.

${ }^{84}$ LAC, RG25, file 2727-V-40, volumes 2923, 4186, 2923, references passim.

${ }^{85}$ Ibid., part 1, vol. 2923, Malcolm Ross to N.A. Robertson, 13 July 1943.
} 
behalf of the Canadian people, donated a collection of Canadian art to the city of Leningrad via VOKS in Moscow. ${ }^{86}$

In 1943, a large rally was held to mark the founding of a special Council sponsoring Soviet friendship, supported by elite politicians and businessman in Canada. ${ }^{87}$ The RCMP reported that "[o]n June 22 2 , 1943 , the National Council for Canadian Soviet Friendship ${ }^{88}$ was formed in Toronto. The first public function was under the chairmanship of Prime Minister Mackenzie King and many prominent Canadians participated. This was the second anniversary of the attack on the USSR by Nazi Germany. The main purpose of the new organization was to dispel misunderstanding and distrust of the Soviet Union, in an effort to strengthen the military alliance. It was significant to note that the affairs of the newly-formed council were conducted from the offices of Vestnik, organ of the Federation of Russian Canadians. ${ }^{89}$ The RCMP did not believe that the National Council had a "connection with any of its predecessors," nor did they feel that it was sponsored by the CPC, but they did note that "the Communist Party is very interested in its activities and has several members and sympathizers listed as patrons. ${ }^{, 90}$ An undated leaflet from the Canadian Soviet Friendship Society and NewsFacts told a similar story, but with a different spin: "The National Council for CanadianSoviet Friendship was formed in June 1943, at a rally of 17, 000 people in Toronto, with the late Hon. W. Mackenzie King as Chairman, and hundreds of prominent citizens and

\footnotetext{
${ }^{86}$ LAC, RG25, file 2727-V-40.2, vol. 2923, letter D. Wilgress to Secretary of State for External Affairs, 16 October 1944, with attached speeches made at VOKS, 13 October 1944. The art was donated to Leningrad in honour of its defence under Nazi siege, and some dealt directly with this theme.

${ }^{87}$ Joan Beaumont has noted that in Britain thousands of ordinary citizens were also turning out for rallies and contributing financially to support the USSR in the war. Beaumont, Comrades in Arms, 97-99.

${ }^{88}$ The public support this organization had during the war was most likely a key reason that post-1949 the Canadian-Soviet Friendship Society chose to keep the National Council moniker for its first few years. ${ }^{89}$ LAC, RG146, A200600124, RCMP report, 7 August 1943, p. 26.

${ }^{90}$ LAC, RG146, RCMP report, A200600124, "The National Council for Canadian Soviet FriendshipOrigin and Growth", dated 1945 by hand in the margin, p. 179-190.
} 
organizations taking part. For years the Council was made up mainly of prominent business men, professional people and others of high prestige. Much valuable work was done in publicizing facts about the USSR's war effort as Canada's ally."91

The list of the wartime National Executive of the Council for Canadian-Soviet Friendship contained the names, addresses and phone numbers of 80 Canadians, and is followed by a list of the members of the Arts, Science, Education, Agricultural and Labour committees. ${ }^{92}$ The National Executive included John David Eaton of the Thomas Eaton Company, L.W. Brockington of the Canadian Broadcasting Corporation, also serving at the Ottawa branch of the United Kingdom Information Office, Dr. Wilder Penfield, renowned Montreal-based neurosurgeon, and "renegade lawyer" J.L. Cohen. ${ }^{93}$ Also listed were the heads of two universities, Dr. Carleton Stanley, president of Dalhousie, and Dr. G.P. Gilmour, Chancellor of McMaster, as well as professors from the University of New Brunswick, University of Western Ontario, Laval University, Queen's University, and the University of Alberta . Dr. Barker Fairley of the English Department at the University of Toronto, and his wife Margaret Fairley, well-known for her work as a leftist literary critic, were on the executive. The mayor of Windsor, an alderman from Regina, Dorothy Burr Thompson, archeologist at the Royal Ontario Museum, and Canadian poet E.J. Pratt were members. Leo Malania of the Department of External Affairs was listed, as was I. Malania, secretary of the Federation of Russian Canadians. Mrs. Rae Luckock, M.P.P. and president of the Housewives' Consumers' League and

\footnotetext{
${ }^{91}$ A CSFS and News-Facts leaflet, undated but probably from 1950, found in the RCMP collection, from "Questions People Ask about the Canadian-Soviet Friendship Society" in RCMP files. A200600091, p. 53. Emphasis in the original

${ }_{92}$ The reporting officer wrote that the "exact year [of the list was] unknown, but probably 1943." LAC, RG146, A200600097, RCMP report, Toronto Special Section, 10 January 1951, p. 97.

${ }^{93}$ Reference here to the Toronto Marxist lawyer who defended members of the Communist party and other leftists before the courts in the 1930s and 1940s. Laurel Sefton MacDowell, Renegade Lawyer: The Life of J.L. Cohen (Toronto: University of Toronto Press, 2001).
} 
Margaret Gould, associated with the CPC and an editorial writer at the Toronto Daily

Star, were also listed. David Shugar, who was noted as a "research physicist" from

Ottawa, was on the executive. Shugar would later be detained by the RCMP after the

Gouzenko defection, and although he was eventually acquitted in court, he did end up losing his job at the Department of Health and Welfare. Sir Ellsworth Flavelle, ${ }^{94}$ Max Chic, and R.H. Davis, all of whom served as head of the National Council at various times until 1947, were predictably on the Executive in 1943. Several people involved with workers' and adult education, as well as cultural and festival groups were amongst the members. Sergei Koudriavtzev, First Secretary of the Soviet Embassy in Ottawa, was also on the executive. ${ }^{95}$

The famous Canadian composer and musician, Sir Ernest Macmillan, as well as Group of Seven artists A.Y. Jackson and Lawren Harris, were on the Soviet Friendship Council's Arts Committee. Fellow committee members John Grierson, ${ }^{96}$ Nat Taylor, ${ }^{97}$ Andrew Allan of the C.B.C. ${ }^{98}$ and Herbert Allen of Columbia Pictures ${ }^{99}$ were particularly interested in films. Barker Fairley was also on the Arts Committee. ${ }^{100}$ The

\footnotetext{
${ }^{94}$ The RCMP noted that until June 1944 Flavelle was chair of the National Council of the Civil Liberties Association, which had supported the lifting of the ban on the CPC-LPP, and the return of property confiscated from the left-wing Ukrainian Labour Farmer Temple Association. This apparently made the RCMP suspicious of Flavelle. Kealey and Whitaker, eds., R.C.M.P. Security Bulletins: The War Series, pt. 2, 1942-1945, p. 255.

${ }^{95}$ LAC, RG146, A200600097, list "National Executive", attached to RCMP report, Toronto Special Section, 10 January 1951, 99-101.

${ }^{96}$ John Grierson, who has been called the "father of the documentary film," was at this time still serving as the first film commissioner of the National Film Board.

${ }^{97}$ Nat. Taylor, Canadian film mogul, was the first in the world to open a multiplex cinema in 1957. The cinema was the Elgin, in Ottawa.

${ }^{98}$ Allan had just recently moved to Toronto to serve as head of radio drama at the main office of the Canadian Broadcasting Corporation.

${ }^{99}$ The Allen family had the controlling interest in the Hollywood production company, Columbia Pictures. Herbert Allen's address is listed c/o Columbia Pictures, Hermant Building, Toronto, which is the same address given by Nat. Taylor.

${ }^{100}$ LAC, RG146, A200600097, List “Arts Committee," attached to RCMP report, Toronto Special Section, 10 January 1951, p. 102. Next to the names of some members of the committee is the handwritten word "films," denoting their particular interest.
} 
Science Committee had 17 members, 13 of whom were professors at Canadian universities. Dr. H.B. Speakman, director of the Ontario Research Foundation, was chairman of the Science Committee, and David Shugar was also listed as a member. ${ }^{101}$ The Education Committee was chaired by Dr. J.A. Long of the College of Education in Toronto, and its 18 members included the president of the University of British Columbia, Norman A. Mackenzie, and provincial ministers of education from Ontario, Quebec, Saskatchewan and New Brunswick. Members of municipal boards of education, teachers and teacher councils, and home and school councils were represented on this committee. ${ }^{102}$ The National Agriculture committee was chaired by V.S. Mulburn of the Ontario Federation of Agriculture, and members included representatives of the federal Department of Agriculture, as well as provincial agricultural federations. There was representation from the Ontario Milk Control Board, as well as the Ontario Whole Milk Producers League, the Ottawa Experimental Farm, the Saskatchewan Co-op, tobacco farmers in Simcoe, Ontario, and journalists who specialized in agricultural matters. ${ }^{103}$

With almost 60 members, the Labour Committee was by far the largest of all the Soviet Friendship Council committees, and included in its membership were many who were openly associated with the Canadian left. Among these individuals were J.L. Cohen, A.A. MacLeod, Communist M.P.P., Bruce Magnusson of Port Arthur, and Pearl Wedro of Toronto, all of whom were LPP members. Most of those listed included their union affiliations. Some of these individuals would remain involved in the Canadian

\footnotetext{
${ }^{101}$ LAC, RG146, A200600097, List “Science Committee," attached to RCMP report, Toronto Special Section, 10 January 1951, p. 103.

${ }^{102}$ LAC, RG146, A200600097, List "Educational Committee," attached to RCMP report, Toronto Special Section, 10 January 1951, p. 104.

${ }^{103}$ LAC, RG146, A200600097, List "National Agricultural Committee," attached to RCMP report, Toronto Special Section, 10 January 1951, p. 106.
} 
Soviet Friendship Society under Dyson Carter's leadership. For instance, Dewar

Ferguson, of the Canadian Seaman's Union, would appear on the letterhead of the postwar Soviet Friendship Society as an executive member. Bruce Magnusson was head of the Trade Union delegation sent by the CSFS to the USSR in the early $1950 \mathrm{~s}$, and Pearl Wedro later subscribed to the CSFS publications. ${ }^{104}$ This was a fact that particularly interested the RCMP in 1951, and in submitting these lists to his superior in Ottawa, the Toronto Special Section inspector wrote, "Although the documents refer to the activities of the Council in 1943, 1944 and 1945, they are being submitted to augment our file and attention is drawn to the fact that the names of several persons who are at present prominent in subversive activities are mentioned therein." 105

In November 1943, the Council hosted a thanksgiving rally in Maple Leaf Gardens. Introducing the rally, L.K. Brockington of the United Kingdom Information Office in Ottawa said,

This great building, like many little homes which are to-night joined with it in sympathy and experience, echoes with the noble harmony of thanksgiving which has just ended. And if the Maple Leaf Gardens and the room in which you hear these words echo with the sound of that thanksgiving, it is because for many months, sometimes dark, always grim, always glorious, many hundreds of thousands of British and Canadian hearts have also been filled with thankfulness- thankfulness for the men and women of the Soviet Republics. To mark that thankfulness and to try to translate it into something real and enduring, in the spirit of Canadian-Soviet friendship and in the name of the society dedicated to that high purpose, it is my duty to bring before you who listen a proposal to draw two pioneer northern peoples closer together in neighbourly and kindly company. ${ }^{106}$

\footnotetext{
${ }^{104}$ LAC, RG146, A200600097, List "National Labor Committee Elected at 1943 Congress of CanadianSoviet Friendship," attached to RCMP report, Toronto Special Section, 10 January 1951, p. 107. ${ }^{105}$ LAC, RG146, A200600097, RCMP report, Toronto Special Section, 10 January 1951, p. 97.

${ }^{106}$ LAC, RG146, A200600097, "Abstracts of Addresses delivered at Congress for Canadian-Soviet Friendship, November 12, 13 and 14, 1943, Toronto," "Address by Leonard W. Brockington at Maple Leaf Gardens, Sunday Nov. 14, 1943," p. 170.
} 
Brockington spoke poetically, saying that the names of Soviet cities like Stalingrad, Leningrad, Kharkov, Rostov and Kiev, that had fought back the Nazis "will ring through the ages like Thermopylae and Marathon, Lapanto, Trafalgar, Waterloo, Vimy Ridge and El Alamein." "107 He called on Canadians to do as their British brothers and sisters had done- adopt Soviet cities, send much needed provisions to the Soviets, and be ready to exchange information, experience and services with them. Edgar Snow, a Canadian journalist who had visited the wartorn USSR, urged his audience "to hammer out" a partnership with the USSR "on the broad anvil of honest democratic discussion" because the "Soviet peoples want our friendship and our co-operation," and they have earned it with their wartime sacrifices. ${ }^{108}$

The cause of Soviet friendship can be seen, therefore, to have enjoyed its widest popularity and legitimacy during the Second World War, while the USSR was one of the Allies. The Red Scare of 1919 forgotten and the ideological battles of the Cold War not yet envisioned, the Soviets were admired and their political system tolerated, or perhaps simply ignored. The fellow-travellers within the organization did not stand out greatly from the other members, although the RCMP continued to track them. After 1945 the left-leaning members stayed within the group, attempting to bolster its support as the mainstream social and political elites reconsidered their affiliation. The war years were, therefore, something of a golden age for the Canadian-Soviet friends in the chilly political climate of the decade following the end of the war.

\footnotetext{
107 Ibid., 172. The Russian spelling of the Ukrainian cities (ie. "Kharkov" not "Kharkiv") were used in this report, and at the time, in most Soviet references.

${ }^{108}$ LAC, RG146, A200600097, "Abstracts of Addresses delivered at Congress for Canadian-Soviet Friendship, November 12, 13 and 14, 1943, Toronto," "Address by Edgar Snow, Maple Leaf Gardens, Sunday, November 14, 1943,"p. 182.
} 
In 1943, Louis Kon wrote to Dyson Carter to congratulate him on his admiring biography of Joseph Stalin, Stalin's Life. The Canadian Tribune, newspaper of the Labor-Progressive Party, had given it a poor review, and Carter had written to the editor to complain. The Tribune apologized, saying that "Mr. Carter is doing invaluable work to explain the USSR and the social advantages modern science can bring to Canada, and we urge the readers of our paper to give him all their support. The Tribune review erred on the side of sectarianism, as Mr. Carter says, and we apologize for any harm we have done him or his publishers." ${ }^{109}$ In his letter of congratulation, Kon suggested the Friendship Society be refounded. He argued that a less overt political strategy was needed "if we are to cease just to talk to ourselves," suggesting that a new organization be modeled after his own work to bring together "a group of likeminded persons...coastto-coast...arranged in the larger centres with a real benefit to Canada." ${ }^{110}$ He asked Carter to meet him in Montreal to discuss this idea.

Meanwhile, the minutes from a National Executive meeting in January 1944 show that the Council was meeting with success in its campaign to increase contact between Soviet and Canadian citizens. The Science Committee had been corresponding with Soviet scientists, the Labour Committee was urging Canadian unions to contact their Soviet counterparts directly, and Soviet and Canadian cities were being twinned. To facilitate this communication the Educational Committee had contacted all Canadian university language departments to ask them to promote the study of the Russian

\footnotetext{
109 "We Apologize to Dyson Carter", Letter to the editor of the Canadian Tribune by Dyson Carter, and "Ed. Note", Kon Collection, Osler Library, P162, Folder 1.19.

${ }^{110}$ Letter from Louis Kon to Dyson Carter, 7 November 1943, Kon Collection, Osler Library, P162, Folder 1.19 .
} 
language. ${ }^{111}$ Under the subtitle "Armed Forces," it was noted in the minutes that "various army contacts are enthusiastic about the use of the Council's services. Two poster exhibits are now on display at Camp Borden, Military District \#1 recruiting officer has made use of poster exhibits.[sic] The Army's Ontario Educational Services, and the Canadian Legion Educational Director for the armed forces have requested material. The Army Recreation Director, Captain Eisenhardt is arranging for a Red Army Sports exhibit to tour Canadian army centers." ${ }^{112}$ However, the Council seemed to be having financial difficulties. In January Sir Ellsworth Flavelle complained that money was being spent before it was raised, ${ }^{113}$ and at the next meeting in February it was announced that "Sir Ellsworth regrets that he can no longer be responsible for further financing of the Council. All outstanding accounts to date will be taken care of. This was not to be construed as any lack of interest or support of the Council by Sir Ellsworth." ${ }^{\prime 14}$ The Canadian Congress of Labour had apparently pledged \$1000 and a few hundred dollars had been sent by individual unions to fund the Council's activities. It was decided that big industrialists and agricultural groups like the wheat pools could be approached for further funding. ${ }^{115}$ Although listed as members, most of the 'big names' did not appear to attend the Council's meetings.

The August 1944 issue of the Council Bulletin announced the dates of the next Congress, and congratulated local branches on their efforts to promote the cause of Soviet

\footnotetext{
${ }^{11}$ LAC, RG146, A200600097, "National Council for Canadian-Soviet Friendship, Proceedings of National Executive Meeting, Thursday, January 6, 1944, 4:30-6:00 p.m.," attached to RCMP report, Toronto Special Section, 10 January 1951, p. 109-111.

${ }^{112}$ Ibid., p. 110.

${ }^{113}$ Ibid., p. 109-111.

${ }^{114}$ LAC, RG146, A200600097, "Minutes of the National Council for Canadian-Soviet Friendship Executive Meeting- Friday, February 18, 1944 in the Conference Room of the Star Bld., 80 King St. W., Toronto," attached to RCMP report, Toronto Special Section, 10 January 1951, p. 113.

${ }^{115}$ Ibid., p. 113-114.
} 
friendship. ${ }^{116}$ In particular, Vancouver came in for praise for the "Odessa Week" sponsored by Vancouver mayor and the local Soviet Friendship Council, where pledges were made to help rebuild and restore Odessa. Fifteen thousand people attended an aidOdessa concert in Stanley Park, and media helped publicize the campaign. ${ }^{117}$ Regina was said to be carrying out a similar campaign to help the Soviet city Kursk, and the telegram sent from Stalino thanking the Mayor and citizens of Glace Bay for 'adopting' them was quoted in full. The Bulletin also quoted a telegram sent from VOKS, Moscow's AllUnion Society for Cultural Relations with Foreign Countries, urging Canadian authors to correspond with Soviet writers like Boris Pasternak, Alexei Tolstoy, Ilya Ehrenburg and Mikhail Sholokhov. "Fruitful cooperation between writers [from] our two countries who are using their art as weapons against Nazism- common enemy of progressive humanitywill serve to promote friendship and closer contact between Canadian and Soviet culture and to increase [the] mutual understanding of our two peoples," the telegram said. ${ }^{118}$ The Agricultural committee decided that a delegation to the USSR was needed, and cabled the Canadian ambassador to the USSR, Dana Wilgress, to ask for more information on the Soviet agricultural situation. ${ }^{119}$

In October 1944, it looked like the Second Annual Congress for Canadian-Soviet Friendship might not go ahead as planned. Sir Ellsworth Flavelle had been absent from a series of meetings for "ill health", and he resigned in late October. ${ }^{120}$ In addition, Dr.

\footnotetext{
${ }^{116}$ Council Bulletin, vol. 1, no. 8, August 1944, published by the National Council for Canadian-Soviet Friendship, in LAC, RG146, A200600097, p. 118-122.

${ }^{117}$ Ibid., p. 119.

${ }^{118}$ Council Bulletin, vol. 1, no. 8, August 1944, published by the National Council for Canadian-Soviet Friendship, in LAC, RG146, A200600097, p. 121.

${ }^{119}$ LAC, RG146, A200600097, "Meeting of Agricultural Committee, National Council for CanadianSoviet Friendship," 10 August 1944, at the King Edward Hotel, Toronto, p. 124.

${ }^{120} \mathrm{LAC}, \mathrm{RG} 146$, A200600097, "Meeting of the Agricultural Committee, National Council for CanadianSoviet Friendship, held at 409 Huron Street, Toronto, Oct. 30, 1944", p. 128.
} 
Malcolm Ross, Canadian literary critic with the National Film Board at that time, was to make the arrangements for the Congress, but had "been recalled to Ottawa" and the executive had to replace him. ${ }^{121}$ These changes were said to have caused "a certain amount of confusion" in the Council office. Mrs. H.B. Spaulding, who was said to be "representing the national office," was the person charged with "explain[ing] a few of the difficulties..."122 What she did not admit, but seems clearly to have been happening, was that the less politically-committed Soviet "friends" were dropping out of public association with the Council.

The invitations sent out to Council branches and "friendly organizations"123 in October 1944 nevertheless included a page-long list of patrons. Nine lieutenantgovernors, Prime Minister Mackenzie King, six provincial premiers, and prominent Canadians like Samuel Bronfman, Dr. Charles Best, artist Arthur Lismer, actor Raymond Massey were among those listed as patrons. Dyson Carter and Dorise Nielsen were also on the list. ${ }^{124}$ Other problems notwithstanding, the Congress was held at the Royal York Hotel in Toronto in November 1944. Mr. R.H. Davis, president of the Atlas Steel Company, was listed as National President on the programme. Davis would remain involved with the Society during Dyson Carter's tenure in the post-war years, when he initiated the Artkino exchange of films. After the playing of "God Save the King" and the Soviet national anthem, Davis presented Soviet ambassador G. Zarubin with a

\footnotetext{
${ }^{121}$ Ibid., p. 128; also LAC, RG146, A200600097, "Minutes of the National Executive Meeting, held on Monday, October 2, 1944," p. 131-134.

${ }^{122}$ Ibid., p. 128.

${ }^{123}$ LAC, RG146, A200600097, Minutes of the meeting “Congress Committee- August 24, 1944," p. 143.

${ }^{124}$ LAC, RG146, A200600097, "Dear Friends" letter accompanying invitation to the Second Annual Congress for Canadian-Soviet Friendship, 27 October 1944, signed by Margaret Cooke, Congress Manager, and attached list "Patrons,"p. 146-147.
} 
combined map of Canada and the USSR, showing twinned cities. ${ }^{125}$ A series of panel discussions on art, agriculture, education, labour, science and medicine, and trade and commerce included presentations by professors at Canadian universities, a representative of the Ontario Agricultural College, the Central Experimental Farm in Ottawa, the Canadian Congress of Labour, the Ontario Research Foundation, and the federal Department of Trade and Commerce. ${ }^{126}$ A representative of VOKS gave a report entitled "The U.S.S.R. Academy of Sciences", and the first secretary of the Soviet embassy in Ottawa, Sergei Koudriavtzev presented a paper on "Leo Tolstoy and Traditions of Russian Literature." Dyson Carter was in the audience. ${ }^{127}$

The emphasis throughout was on Canadian-Soviet cooperation during and after the war, and the benefits this would bring to the populations of both countries. Just recently, Raymond Arthur Davies had published a book entitled Canada and Russia: Neighbors and Friends, detailing a history of Canadian-Soviet friendship. The book was published in Toronto by the Communist Party's publication house, Progress Books, and the use of the words "neighbor" and "friend" to describe the relationship between Canada and the USSR was significant. ${ }^{128}$ After 1946, these words were accepted within the progressive communities as signs of belonging, and by the RCMP as a signal of "subversion." A paper given at the congress by the Washington representative of the United Electrical, Radio and Machine Workers of America was titled "The Significance of our Friendship with the Soviet Union to Full Employment after the War," other talks

125 "Programme, Second Annual Congress for Canadian-Soviet Friendship, Friday, Saturday \& Sunday, Nov. 17, 18, 19, 1944", article in press "Friendship Congress Film Warns Against Soft Peace" copied from the private collection by Larissa Stavroff, Toronto, ON.

${ }^{126}$ Ibid.

${ }^{127}$ LAC, RG146, A200600124, RCMP report, Intelligence Branch, Toronto, dated 21 November 1944, p. 201-202.

${ }^{128}$ R.H. Davies, Canada and Russia: Neighbors and Friends (Toronto: Progress Books, 1944). 
focused on the importance of cooperation in science, trade and medicine. Sunday evening the film "Wallace in Siberia" was shown, detailing American Vice-President Henry A. Wallace's trip to the USSR, ${ }^{129}$ and at 9 p.m. a victory rally was held at Maple Leaf Gardens. The programme was sponsored by unions, the progressive Serbian organization, the Niagara Falls branch of the Canadian-Soviet Friendship Council, and other progressive groups and individuals. The T. Eaton Company published a full-page advertisement on the front of the programme asking people to give blood "to keep a flicker of life alive in a Canadian boy..."130 The emphasis was still very much on showing unified support for the Allies.

The Congress received good coverage in the Toronto papers, ${ }^{131}$ and one article reprinted the text of the speech given by Edgar Snow, military journalist, at the Thanksgiving Service for Russian Victories held at Maple Leaf Gardens. Above the text was a photograph of Edgar Snow, Colonel Nikolai Zabotin, who the Toronto Star called a "Red Army hero,",132 and the Soviet chargé d'affaires, Gregori Tonkin. ${ }^{133}$ Photographs of the main speakers appeared in the paper, as did the statements coming out of the

\footnotetext{
${ }^{129}$ Wallace favoured trade with the USSR, and resigned from Truman's cabinet in 1946 over disagreements on the development of the Cold War military apparatus. He ran unsuccessfully for President as a Progressive Party candidate in 1948. (Wallace House Foundation, "The Wallace Family," http://www.wallace.org/wallacefamily.html, accessed 5 June 2007).

130 "Programme, Second Annual Congress for Canadian-Soviet Friendship, Friday, Saturday \& Sunday, Nov. 17, 18, 19, 1944", copied from the private collection by Larissa Stavroff, Toronto, ON.

${ }^{131}$ See for example, the editorial "Enriching Political and Social Life" in the Toronto Star on 20 November 1944 , p. 6, which said that the Congress "has performed a signal public service" in bringing news of the USSR to Canada. The Nazi invasion of the USSR had been thwarted. "Thus the rest of the world will gain the benefit of the vast and humanitarian experiments of the Soviet Union, which has celebrated its $27^{\text {th }}$ anniversary this month, and will be able voluntarily to profit from its achievements and its high social purposes without having to ward off attempts by Russia itself to force its political institutions and system on other lands. The world as a whole, its political and social life, will be enriched by the Russian accomplishments."

${ }^{132} \mathrm{Ibid}$. Col. Zabotin was recalled to Moscow after the Igor Gouzenko revelations came to light in 1946 , identifying Zabotin as the main contact for Canadians who passed sensitive information to the Soviet embassy.

133 "War Correspondent with Russian Friends," "Russia Saved Mankind at Stalingrad- Snow", Globe and Mail, November 1944 (no precise date noted), from the private collection of clippings held by Larissa Stavroff, Toronto, ON.
} 
congress, calling for more Russian to be taught at Canadian schools, exchanges and courses to be taught on Soviet agriculture, and emulation of Soviet anti-discrimination policies. ${ }^{134}$ Poet E.J. Pratt, a member of the Canadian-Soviet Friendship Council, read a poem he had composed entitled "A Victory Message and Pledge of Friendship from the Canadian People to the U.S.S.R." Privately, early in 1946, Pratt wrote that "[g]ood neighbourliness and mutual trust and decency are all we have left."135

Ironically, perhaps, considering the summer of 1945 brought celebrations of Allied victory and a "Friendship for Russia Week" sponsored by Toronto's mayor, ${ }^{136}$ the wartime Friendship Society was in decline by 1945 . In the eyes of many of its mainstream patrons, the Society's wartime value was now exhausted. Insiders complained that "radical elements" were trying to take it over. ${ }^{137}$ The RCMP reported that, in contrast to the early wartime rallies, the rally held at Maple Leaf Gardens in November 1945 was mostly attended by known Communists, and members of the LaborProgressive Party were at every door handing out their literature. ${ }^{138}$ Soviet "friendship" had retreated to its peacetime definition and utility. During the summer of 1945, in the political scandal dubbed the "Gestapo Affair" by the press, a police officer was accused

\footnotetext{
${ }^{134}$ Articles from the Globe and Mail entitled "Lesson Seen in Soviet Aims," "Calls U.S.S.R. Pioneer in Free Education," "Soviet Shines in Medicine", all held in private collection by Larissa Stavroff. "The Complete Letters of E.J. Pratt: A Hypertext Edition", letter E.J. Pratt to Carl Klink, 7 January 1946, and attached notes, \{http://www.trentu.ca/faculty/pratt/letters/frletters.html $\}$, viewed 21 June 2007. In this letter Pratt mentions that he had hosted Soviet Embassy personnel at his home in Toronto in 1944 and 1945, and suggested that his biography (Klink and H.W.Wells, Edwin J. Pratt: The Man and His Poetry, pub. by Ryerson, Toronto, 1947) include "a paragraph or two" about his involvement with the CanadianSoviet Friendship Council.

136 "Board of Control Approves Friendship for Russia Week," Toronto Daily Star, 19 July 1945, in RCMP files, RG146, A200600124, p. 165.

137"Let Ottawa Act, Conant Ordered, Inquiry is Told", Toronto Daily Star, 5 July 1945, p. 2. Also in Libbie and Frank Park fonds, LAC, MG31K9, vol. 8, File "Gestapo Affair, 1945". For more on this scandal and the Lebel Commission inquiry, see the Toronto Star, Globe and Mail, Toronto Telegram and other newspapers late June- July 1945. Clippings of these also found in Park fonds, LAC, MG31K9, vol. 8, File "Gestapo Affair, 1945".

${ }^{138}$ LAC, RG146, A200600124, "Memorandum to Inspector Parsons re: National Council for Canadian Soviet Friendship, Toronto, Ontario", 15 December 1945, p. 112-113.
} 
of filing secret reports on leftists to the Ontario government, the Labor-Progressive Party was accused of receiving financial support from Moscow in Bay Street stocks, and the goals of the National Council for Canadian-Soviet Friendship were questioned. Many did not want to believe these stories. The Ottawa Citizen's editorial "Groundless Story" of 6 July 1945 argued that "Self-respecting diplomatic authorities do not indulge in underground political activities...Nor is it entertained that the Russian embassy here or anywhere else would stoop to such crude practices within a friendly country." 139 Today, historical research has shown that each of these claims was anything but "groundless." The Gouzenko Affair, which broke in the press less than a year later would make the Citizen editorial seem especially naïve.

Meanwhile, the Council for Canadian-Soviet Friendship was changing. An RCMP report from 1945 lists Rev. R.H. Thomas of Deer Park United Church in Toronto as Chairman of the Toronto Council, with Mrs. H.B. Spaulding, Pearl Wedro and Mrs. Malania also involved. The RCMP points out that Wedro was prominent in the LPP, and that Mrs. Malania was married to I. Malania of the Federation of Russian Canadians. ${ }^{140}$ Margaret Spaulding and Pearl Wedro would remain active under Dyson Carter's leadership after 1949. R.H. Davis was still President of the National Council in 1945, but he was soon replaced by Max Chic. In 1945, the Toronto branch of the Friendship

\footnotetext{
139 "Groundless Story," Ottawa Citizen, 6 July 1945, clipping in Libbie and Frank Park fonds, LAC, MG31K9, vol. 8, File "Gestapo Affair, 1945".

${ }^{140}$ LAC, RG146, A200600124, "Memorandum for File Re: National Council for Canadian Soviet Friendship, Toronto, Ontario", RCMP report dated 11 October 1945, p. 154. The RCMP got this information from a letter sent out by the Toronto Council for Canadian-Soviet Friendship on 24 September 1945 advertising a Soviet film now available via the firm Artkino. This letter is attached to the RCMP report dated 11 October 1945, LAC, RG146, A200600124, p. 160.
} 
Council did away with membership fees, perhaps because there were not enough paying members, and instead solicited all names on its mailing list for donations. ${ }^{141}$

Ironically for Louis Kon, Dana Wilgress, now Canadian ambassador to the Soviet Union, spoke at the Victory rally at Maple Leaf Gardens on 3 July 1945, welcoming Ukrainian and Belarussian delegates to the San Francisco conference. ${ }^{142}$ Five thousand people were present to hear Hewlett Johnson, the "Red Dean" of Canterbury, discuss his impressions of the USSR at the Maple Leaf Gardens rally in November, although the RCMP reported that only about half of these seemed interested in the proceedings. ${ }^{143}$ The theme of the 1945 Soviet friendship congress was "The Effect on Canada's Post-War Progress of Trade and Cultural Relations with the Soviet Union," and agricultural, veteran's affairs and labour representation from Ottawa was present. However there were far fewer businessmen in attendance. The featured talk on Saturday evening was given by Dr. Raymond Boyer, on the theme of "Science and Peace."144

In 1945, Kon wrote again to Dyson Carter, "Congratulations to you and the L.P.P. for getting together on the inside." ${ }^{\prime 145}$ Most likely he was referring to Carter's public declaration that he was a Communist, made in a December issue of the Tribune, ${ }^{146}$ because Kon speaks of framing it in gold. In the same letter he writes, "Don't you agree

\footnotetext{
${ }^{141}$ LAC, RG146, A200600124, "Memorandum for Intelligence Bulletin Re: Toronto Council for CanadianSoviet Friendship", handwritten date in margin 24 October 1945, RCMP report quoting NewsLetter sent out by Toronto Council for Canadian-Soviet Friendship, p. 152.

${ }^{142}$ LAC, RG146, A200600124, "National Council for Canadian Soviet Friendship Re: Memorandum to Inspector Leopold, Ukrainian-Canadian Association, Toronto, Ontario" RCMP report dated 12 June 1945 , p. 163.

${ }^{143}$ LAC, RG146, A200600124, RCMP report, Toronto Special Secion, 26 November 1945, "C.P. Activities in National Council for Canadian-Soviet Friendship", p. 116.

${ }^{144}$ LAC, RG146, A200600124, Programme of the Congress on Canadian-Soviet Friendship, Royal York Hotel, Toronto, November 23, 24, 25, 1945, attached to RCMP report dated November 1945, p. 115. ${ }^{145}$ Letter from Louis Kon to Dyson Carter, 21 December 1945, Kon Collection, Osler Library, P162, Folder 1.19.

${ }^{146}$ Carter made this declaration in an open letter to Party leader Tim Buck, entitled "Dyson Carter Explains: Why I've Joined the LPP", published in the Tribune on 15 December 1945.
} 
with me that we are making a considerable progress in Canada on the whole? After all, there is [sic] a lot of scientists in the Scientific Workers Association who must be forward looking, if they elected as their chairman one of our fellows -- Raymond Boyer, and if the government does not dare to dismiss General Chisholm, facts that were unthinkable only a short few years ago!" ${ }^{147}$ By then Igor Gouzenko had already defected from the Soviet embassy in Ottawa, carrying papers with him that would point to Raymond Boyer's role in passing confidential information to the Soviets. Canadian mainstream attitudes to the Soviet Union were about to experience a seachange, and the Soviet authorities were to find this a major concern.

\section{Although Igor Gouzenko left the Soviet Embassy on Charlotte Street in Ottawa} for the last time on the evening of 5 September 1945, he and his family did not receive amnesty from the Canadian government until several days later. According to all accounts, ${ }^{148}$ he was not initially understood or believed when he first attempted to explain the importance of the information he held to the editor of the Ottawa Journal, and the various government officials who learned of his behaviour were not initially sure, or in

147. Letter from Louis Kon to Dyson Carter, 21 December 1945, Kon Collection, Osler Library, P162, Folder 1.19.

${ }^{148}$ See J.L. Black, Martin Rudner, eds. The Gouzenko Affair: Canada and the Beginnings of Cold War Counter-Espionage (Manotick: Penumbra Press, 2006); Amy Knight, How the Cold War Began: The Gouzenko Affair and the Hunt for Soviet Spies (Toronto: McClelland and Stewart, 2005); I.A.

Ageeva, "Kanada i nachalo kholodnoi voinyi: Delo Gouzenko v Sovetsko-Kanadskix otnoshenyax [Canada and the Start of the Cold War: The Gouzenko Affair in Soviet-Canadian Relations] in N.I. Yegorova and A.O. Chubaryan, ed., Kholodnaia Voina, 1945-1963 [The Cold War, 1945-1963] (Moscow, 2003); J.L. Black, Canada in the Soviet Mirror, p. 171-172; Merrily Weisbord, The Strangest Dream, p. 145; Reg Whitaker and Gary Marcuse, Cold War Canada: The Making of a National Insecurity State, 1945-1957 (Toronto: University of Toronto Press, 1994); Len Scher, ed., The Un-Canadians: True Stories from the Blacklist Era (Toronto: Lester Publishing Ltd., 1992); J.L. Granatstein and David Stafford, Spy Wars: Espionage and Canada from Gouzenko to Glasnost (Toronto: Key Porter Books, 1990); Larry Black, "Canada and the Soviet Union in 1945: The View from Moscow" in Greg Donaghy, ed., Uncertain Horizons: Canadians and Their World in 1945 (Ottawa: Canadian Committee for the History of the Second World War, 1996); J.L. Black and Norman Hillmer, ed., Nearly Neighbours: Canada and the Soviet Union from Cold War to Détente and Beyond (Kingston: Frye, 1988); Robert Bothwell and J.L. Granatstein, ed., The Gouzenko Transcripts: The Evidence Presented to the Kellock-Taschereau Royal Commission of 1946 (Ottawa: Deneau Publishers, 1982). 
agreement, on the action to be taken. It was only when the Gouzenkos' apartment was broken into and ransacked by several representatives from the Soviet Embassy that the RCMP took the family, who had been hiding in a neighbour's flat, to safety. Five more months were to pass before the Canadian government took any public action on Gouzenko's allegations, and even then the Royal Commission set up to investigate carried out its interrogations in secret. Six weeks' worth of documents during this crucial time are missing from all the related departmental records and personal archival collections, so there is considerable speculation among historians on how and why the government took the decisions it eventually did. This is all the more intriguing since these six weeks represent the few conspicuous gaps in William Lyon Mackenzie King's diary. Soviet archives related to Gouzenko are still closed, so Canadian scholars are not able to benefit from Russian research on the subject. ${ }^{149}$ The Canadian public became aware of the scandal in 1946, in which 13 people, including Member of Parliament Fred Rose, were accused of spying for the Soviet Union, when the headlines splashed the news. The Soviet Union, an ally in World War II, had now, seemingly overnight, again become the enemy.

The report of the Taschereau-Kellock Royal Commission ${ }^{150}$ was released as three separate interim reports throughout 1946 , and its final version was presented in June 1946. Each new revelation made headline news in Canada and abroad. Many of the people accused of being "agents" in the report had not even been to court yet, and several

\footnotetext{
${ }^{149}$ On this, see especially Hector Mackenzie, "Canada's International Relations in the Early Cold War: The Impact and Implications of the Gouzenko Affair," in Black and Rudner, eds., The Gouzenko Affair, p. 32 fn. 2.

${ }^{150}$ The Report of the Royal Commission to Investigate the Facts Relating to and the Circumstances Surrounding the Communication by Public Officials and Other Persons in Positions of Trust of Secret and Confidential Information to Agents of a Foreign Power, Commissioners Honourable Mr. Justice Robert Taschereau and Honourable Mr. Justice R.L. Kellock (Ottawa: E. Cloutier, 1946).
} 
of them were later acquitted of all charges. Nonetheless, the report's accusations proved to be indelible, and in some cases the individuals suffered job loss and insecurity for the rest of their lives. ${ }^{151}$ One of the speakers on science at the last NC-CSFS Congress, Raymond Boyer, was among those who served time in prison. Many others were caught in the ideological about-face that signaled the beginning of the Cold War in Canada. As historian Denis Smith has suggested, in this political climate "post-war Canada thus found not security but new anxiety" with "the propagandist advantage that it played upon old fears of Bolshevism to produce a new myth of good and evil to replace the wartime myth" of an international alliance. ${ }^{152}$. The NC-CSF was caught up in this change, as "friendship" with the Soviets lost its veneer of political neutrality.

The embarrassment to Moscow caused by the Gouzenko revelations, and the importance Soviet authorities placed on repairing the damaged Soviet image abroad has been well documented. ${ }^{153}$ The increased attention paid after this moment to supplying Communist front organizations in the West with the material necessary to promote "friendship" with the USSR, rather than overt political admiration, is significant. The increasing inability for the LPP to attract mainstream Canadian members meant that the VOKS representative in the Soviet embassy in Ottawa would play a greater role in

\footnotetext{
${ }^{151}$ See Merrily Weisbord, The Strangest Dream; June Callwood, Emma (Toronto: Stoddart, 1984); Len Scher, ed., The Un-Canadians, Duncan McDowall, "The Trial and Tribulations of Miss Agatha Chapman: Statistics in a Cold War Climate," Queen's Quarterly 114/3 (Fall 2007), p. 357-373.

${ }^{152}$ Denis Smith, Diplomacy of Fear: Canada and the Cold War, 1941-1948 (Toronto: University of Toronto Press, 1988), p. 5. For the similar American experience see Elaine May, Homeward Bound: American Families in the Cold War Era (New York: Basic Books, 1988) and Alan Nadel, Containment Culture: American Narratives, Postmodernism and the Atomic Age (Durham: Duke University Press, 1995).

${ }^{153}$ I.A. Ageeva, "Kanada i nachalo kholodnoi voinyi: Delo Gouzenko v Sovetsko-Kanadskix otnoshenyax [Canada and the Start of the Cold War: The Gouzenko Affair in Soviet-Canadian Relation])" in N.I. Yegorova and A.O. Chubaryan, ed., Kholodnaya Voina, 1945-1963 [The Cold War, 1945-1963] (Moscow, 2003); Black, ed., The Gouzenko Affair: Canada and the Beginnings of Cold War Counter-Espionage (2006).
} 
facilitating and coordinating Canadian-Soviet Friendship via apparently non-partisan ethnic and progressive groups. ${ }^{154}$

As the news of Gouzenko broke, the RCMP reported that few progressive Canadians were taking the Soviets up on invitations to tour the USSR, ${ }^{155}$ and suggested that this might be because of the effects of the "spy trials." ${ }^{\text {"156 }}$ A few days after the Royal Commission began its hearings, the National Executive of the Friendship Council held a meeting in Toronto to decide on its position vis-à-vis the negative publicity directed at the USSR and Canadian communists. A press statement was released on 22 February 1946 "Addressed to all branches of Council and copy to P.M.":

Our executive met today with Mrs. W.K. Fraser, Vice-President, in the chair and gave careful consideration to the statement issued last Friday by Prime Minister Mackenzie King. We were unanimous in expressing regret that the newspapers and radio commentators had failed to follow the advice of the Prime Minister to treat the whole matter with reserve and caution. The executive felt that unwarranted speculation indulged in by the press can only do grave injury to future relations between Canada and her northern neighbor [sic]. The executive urges the Council to avoid being drawn into the current wave of hysteria. In the circumstances, the

\footnotetext{
${ }^{154}$ This development, the changing role of VOKS, and the reasons Moscow felt the CSFS was able to present a more positive image of the USSR than the discredited LPP, will be discussed in detail in subsequent chapters.

${ }^{155}$ Soviet ambassador G.N. Zarubin, was reported to have extended an open invitation to groups of Canadian journalists, "businessmen, artists or churchmen" to visit the USSR. This was announced at an Ottawa victory meeting of the National Council for Canadian-Soviet Friendship, and published in the press. RCMP memorandum to Inspector Parsons, 17 November 1945, RG146, A200600105, p. 95; "May See Russia", The Ottawa Journal, n.d. 1945; "Russia Invites Canadian Visits," The Standard, 24 November 1945, clippings in RCMP files, LAC, RG146, A200600105, p. 85, 94. The LPP and National Council of CSF were apparently publicizing a possible trip for summer 1946 amongst its members and "foreign-born Canadians." Investigators across Canada were advised to stay "alert" for signs of Canadians interested in going on these tours. LAC, RG146, A200600105, RCMP "confidential" memorandum, signed by A.B. Persons, S/Inspector, Special Section, 5 December 1945, p. 92.

${ }^{156}$ Invited in 1945 to tour the USSR, members of progressive groups initially showed an enthusiastic response, and the RCMP was warning that "foreign groups" [ie. ethnic, progressive groups in Canada] may be inclined to go, but then no reports of any such visits were recorded and the observation was made that this loss of interest may be because of 'spy trials' in 1946. LAC, RG146, A200600105, RCMP report, Prince Albert, Sask., 31 May 1946, p. 11. Reports from RCMP branches saying that no interest was recorded are passim in RG146, A200600105; one report stated that interest remained high in "among the Doukhobor element." LAC, RG146, A200600105, RCMP report, Yorkton Sub Division, Kamsack detachment, 8 February 1946, p. 68.
} 
Executive feels that there is no occasion whatever to lessen the activity of the Council and that it should be continued in the normal way. 157

But business was not as usual. The National Council personnel was rapidly changing. In August 1946, Max Chic was replaced as National Director of the Council by Frank Park. ${ }^{158}$ Park, well-known as an LPP organizer and a lawyer, would later serve as editor of the Party's theoretical journal, National Affairs Monthly, and travel to the USSR and Cuba, sending back reports to Dyson Carter and the CSFS, as well as to the LPP leadership. ${ }^{159}$ Less than two years later, the NC-CSF leadership changed again. Even LPP members were dropping out of the NC-CSF, perhaps because the discredited Party made Soviet "friends" look suspicious, and vice versa. By 1948, Park wrote that he was "no longer the director of that [Friendship] organization." "160 A CSFS leaflet described the personnel change in this way: "1946-1948 most of these Council members withdrew their support (many with sincere regrets) due to anti-Soviet hysteria."161 The RCMP reported that in December 1946 "the Party had issued instructions for its members to sever their connection with the Council. Rev. Fern Sayles, prominent Party member and former leading official of the Council in Welland, alleged that the Council was spoiling the reputation of the Party, as it was built upon a high society level and most of

${ }^{157}$ LAC, RG146, A200600091, RCMP "Brief- the Canadian Soviet Friendship Society," p. 129.

${ }^{158}$ Ibid., p. 130.

${ }^{159}$ In doing research for her book on Emma Woikin, June Callwood interviewed Kay and Brough MacPherson, who were well acquainted with Frank Park, and others who were detained by the RCMP after the Gouzenko defection. The MacPhersons suggested that, since Park knew the others and had participated in many of the same study groups as those detained, Frank Park may have "escaped arrest" in those worrisome days because he was in Toronto for an extended period at that time. LAC, MG31 K24 (June Callwood fonds), vol. 20, File 20-18, "Interview with Kay and Brough MacPherson, 8 November 1982" by June Callwood.

${ }^{160}$ Frank Park, letter to the editor and rejoinder of the Toronto Telegram, 15 March 1948, in Libbie and Frank Park fonds, LAC, MG31K9, vol. 13, file 226.

${ }^{161}$ From "Questions People Ask about the Canadian-Soviet Friendship Society" in RCMP files, LAC, RG146, A200600091, p. 102. 
its leading members were capitalists. Therefore, it had been decided to break away from the Council quietly by ignoring it."162 It is more likely, however, that post-Gouzenko, the compromised LPP reflected badly on the Soviet Union, and its overt support made it impossible for the NC-CSF to claim any political neutrality at all.

By this time, the Canadian government, and particularly the Under-Secretary of State for External Affairs, Lester B. Pearson, was also drawing back from involvement with the National Council for Canadian-Soviet Friendship. What had been seen as expediently attractive in wartime, was now tinged with ideological danger. Although the NC-CSF continued to correspond with Pearson, and he was sent their publications, ${ }^{163}$ External Affairs officials saw the President of the National Council, Leslie Roberts, as a "misguided fellow traveller," and attempted to persuade him to be more critical about the USSR and the Soviet message he was receiving. ${ }^{164}$ Pearson had also been warned that the establishment figures who had supported wartime Soviet Friendship groups in the United States and in Canada were no longer doing so. In fact, an advisor told Pearson that the Canadian organization appeared to be "a more or less Communist front organization

\footnotetext{
${ }^{162}$ LAC, RG146, A200600091, RCMP "Brief- the Canadian Soviet Friendship Society," p. 130.

${ }^{163}$ In February 1947 the National Council for Canadian-Soviet Friendship issued a newsletter entitled Northern Neighbours, which specifically outlined its "post-war aims." This newsletter was sent to Pearson, and on an attached memo he asked "Who are these people?" (LAC, RG25, A200700336, p. 99-107, copies of Northern Neighbours newsletter dated 15 February 1947, addressed to Pearson and A.D. P. Heeney, Clerk of the Privy Council, and Memorandum from Heeney to Pearson, 25 February 1947, with Pearson's marginal note.) The title of this publication would later be taken up by Dyson Carter, when he replaced the CSFS newsletter News-Facts (1950-1956), with a magazine dealing with similar issues, called Northern Neighbours (published 1956-1989).

${ }^{164}$ LAC, RG25, A200700336, p. 812-828, exchanges between Pearson and Leslie Roberts and related memoranda, August-September 1947; RG25, A200700336, p. 651-673, exchanges between Department of External Affairs and Embassy in Moscow, spring 1948. Leslie Roberts was referred to as a "misguided fellow traveler but not repeat not so far as we know a member of the Communist party" in RG25, A200700336, p. 672, telegram Secretary of State for External Affairs to J.B.C. Watkins, Canadian Charge d'Affaires, Moscow, cipher no. 93, 22 April 1948.
} 
of a mild kind, which tends to attempt to put forward the Soviet case in such a way as to gain the support of Left Wingers." ${ }^{\text {165 }}$ In effect, this was indeed the case.

But the National Council did not die out entirely. A convention was held in Ottawa in April 1947, led by Barker Fairley and Clarence S. Jackson, whom the RCMP reported were "regarded as fellow travellers, at least."166 Keynote speakers included Arctic explorer, Vilhjalmur Stefansson, Vancouver journalist Kimore Philpott, and lecturer Dr. Watson Thomson, "all regarded as sympathetic to the Communist cause," according to the RCMP. ${ }^{167}$ In January 1948 Mary Jennison, National Secretary for the Council, argued that the Council needed to put forward a program to counter the negative publicity the USSR was currently getting in the Western press. This program, she said, "would be an attempt to turn the tide of Soviet-baiting, not for the sake of the Soviet Union which is quite able to take care of itself, but for the sake of Canada and the safeguarding of Canadian families from the horrors of another war." 168 The link between pro-Soviet groups in Canada and the theme of peace would become more important in the next few years.

The National Council continued to maintain that the USSR was worthy of admiration. Echoing official Soviet responses, the media coverage of Igor Gouzenko's allegations was depicted by the National Council as anti-Soviet slander. Gouzenko's autobiography, which came out in 1948, set the tone for many of the earliest analyses of his defection, and reflected the conclusions of the Royal Commission report, but from the

${ }^{165}$ LAC, RG25, A200700336, p. 97-98, "Memorandum for Mr. Pearson," prepared by G.G. Crean, 27 February 1947, referring to an earlier memo by H. Wrong, dated 27 November 1946.

${ }^{166}$ LAC, RG 146, A200600091, RCMP "Brief- the Canadian Soviet Friendship Society," p. 130.

${ }^{167}$ Ibid., p. 130-131. On Stefansson's activism in Communist front organizations, see Henry F. Srebrnik, “The Radical 'Second Life' of Vilhjalmur Stefansson," Arctic, vol. 51, no. 1 (March 1998), p. 58-60, accessed 3 June 2008, <http://pubs.aina.ucalgary.ca/arctic/Arctic51-1-58.pdf $>$

${ }^{168}$ LAC, RG146, A200600091, RCMP "Brief- the Canadian Soviet Friendship Society," p. 131. 
perspective of Sovietophiles, it was bad news. This Was My Choice ${ }^{169}$ was the first book to deal with the defection and its consequences. Detailing his disaffection with the Soviet Union and the reasons leading up to his decision to defect, Gouzenko concluded that if he "had obediently packed up and gone to Moscow instead of to the Royal Canadian Mounted Police, Soviet agent Fred Rose would probably still be seated among the law makers of Canada and be reporting state secrets to the Soviet Union!"170 Published while Sam Carr was still underground and before he was convicted in 1949, Gouzenko detailed how several of the accused Canadians, including Carr, came to be spies, used false passports, recruited other agents, and led study groups. Gouzenko affirmed that he was motivated only by the highest ideals, and that he "had no thought, in making my break, of any financial returns to be derived from it...The greatest gain is the one I feel deep down inside: that I did my duty toward the millions enslaved and voiceless in Russia today."171 Showing how others have appreciated his courage, he quoted letters from abroad thanking him for exposing the Soviet Union for what it was, Mackenzie King's statement that Gouzenko "accomplished a historic act", and the Commission's comment about his sincerity and the "great public service" he had performed. Gouzenko modestly wrote that "I think it is promising that such a small cog as myself in the vast Soviet machine could have done so much." ${ }^{172}$ But, the NC-CSF did not like Gouzenko, and echoing Moscow, claimed his "truths" were lies.

\footnotetext{
${ }^{169}$ Igor Gouzenko, This Was My Choice: Gouzenko's Story (Toronto, 1948). It has been argued that this book was ghost-written by Andy O'Brien since, O'Brien says, "they wanted to jazz it up." (see John Sawatsky, Gouzenko: The Untold Story (Toronto, 1984), 99. Gouzenko also wrote a Governor General Award-winning novel entitled Fall of a Titan in 1953, and Svetlana Gouzenko published Before Igor: Memories of my Soviet Youth in 1960.

${ }^{170}$ Gouzenko, This Was My Choice, p. 285.

${ }_{171}$ Ibid., p. 321.

172 Ibid., 323.
} 
One of the Hollywood films based on Gouzenko's memoirs, "The Iron Curtain" (1948), starred Dana Andrews as Igor Gouzenko and Gene Tierney as Gouzenko's wife "Anna."173 A May 1948 meeting of the National Council for Canadian-Soviet Friendship ${ }^{174}$ in Toronto unanimously adopted a resolution condemning "this picture as deliberate war-mongering, based on distortion of facts. We protest its showing in Canada as against the basic interests of the people as an incitement of war."175 Calling on Canadians to boycott this film, the National Council said they "join[ed] hands with the American-Soviet Friendship Council and many other progressive groups in the United States in calling for the banning of this picture."176

In June 1948 the National Council published the first issue of its new bulletin entitled "These are the Facts." The "facts" put forward by the group were that world peace inevitably meant friendship and cooperation with the Soviet Union, and inviting Rev. Hewlett Johnson to speak once more in Canada about his impressions of the USSR was considered to contribute to this spirit. ${ }^{177}$

A summary of VOKS' work in Canada after 1946 noted that the NC-CSF was "hindered by the absence of leadership," the lack of significant funds, and an anti-Soviet campaign. ${ }^{178}$ R.H. Davis, the report said, had been just a figurehead who was only interested in increased trade with the USSR, and Max Chic, who had been active for years, was forced to leave in 1945. Under Frank Park the momentum could not be maintained, and the NC-CSF "activity had almost stopped by 1946," except for the

\footnotetext{
${ }^{173}$ Igor Gouzenko's wife's name was, in fact, Svetlana.

${ }^{174}$ The continued use of this name was a choice most likely made in the interest of continuing to attract broad popularity.

${ }^{175}$ LAC, RG146, A200600091, RCMP "Brief- Canadian-Soviet Friendship Society," p. 131.

${ }^{176}$ Ibid., p. 131.

${ }^{177} I$ Ibid., p. 131.

178 "Otchet o rabote VOKS v Kanade za 1946," [Report on the Work of VOKS in Canada in 1946], VOKS, CW2, File 2, RGASPI, 5.
} 
Vancouver branch, where a "deep sympathy" for the Soviet Union remained. The VOKS report concluded by saying that letters continued to come into the Embassy from interested Canadians, proving that there was still value in maintaining a VOKS presence in Ottawa. ${ }^{179}$

The overlap in membership in the wartime society between establishment figures and progressive activists was important because it proved that a common cause - that is, the war effort -- would attract a large number of people to the movement. The post-1949 National Council attempted to bring popular support back to Soviet friendship in emphasizing peace and cultural exchanges, but the leadership was not ultimately successful at this. The new group also imitated some earlier rhetoric and techniques, calling on its members to send greetings to the Soviets, emphasizing the Soviet success in social and economic planning, and generally arguing for positive news about the USSR. The difference is that after 1949 most of the elite sponsorship had fallen away, and the audience for most of these messages was the left-wing societies that had long admired the Soviet Union.

In February 1949 the RCMP Headquarters in Ottawa delivered a letter by hand to Lester B. Pearson, by then Minister of External Affairs, responding to his request for information on the National Council for Canadian Soviet Friendship. The RCMP assured him that this organization "is at present inactive. It has not formally gone out of existence but certain of its functions have been taken over by the Provisional Peace Committee..." ${ }^{180}$ An RCMP report filed in February showed that the financial affairs of

\footnotetext{
${ }^{179} \mathrm{Ibid}$.

${ }^{180}$ LAC, RG146, A200600096, RCMP report, "Extract Re: National Council for Canadian Soviet Friendship," dated 28 February 1949, marked "By Hand" and "Secret", p. 133. Pearson's letter does not appear in this file, but the RCMP response begins: "with reference to your letter of February 1, 1949, and
} 
the National Council and the Peace Council were linked, ${ }^{181}$ and later in 1949 Dr. James Endicott, head of the Canadian peace movement, was listed as "conducting" the Friendship Society. ${ }^{182}$ In April 1949, a report sent to the RCMP Commissioner stated, "It is interesting to note that the National Council of Canadian Soviet Friendship is apparently still active."183 However, the inspector pointed out that "there appears to be little doubt that unless financial assistance is received the National Council... will be forced to cease activities in the near future. ${ }^{9184}$

Accompanying his letter were the minutes from a Council executive meeting held 26 February 1949 at secretary Mary Jennison's Hamilton home. Mrs. M.H. Spaulding chaired the meeting, and others attending were Elizabeth Brown, Barker Fairley, Mrs. Rae Luckock, Mr. MacInnes, Stanley Ryerson, Mr. Mertunen, Mr. Sundqvist and Mary Jennison. Plans for upcoming activities were discussed; in particular the possible visit to Canada of Soviet composer Dmitri Shostakovich. The executive decided to ask members to donate more than usual, since the Council had only $\$ 156$ in the bank, and owed money for bill payments and the payment of a loan recently received. ${ }^{185}$ It looked to be on the verge of bankruptcy. However, rather than being absorbed or dying out, the Friendship Society was about to be rejuvenated.

your request in paragraph two for information concerning current developments in the National Council for Canadian Soviet Friendship."

${ }^{181}$ LAC, RG146, A200600096, RCMP report, detachment Toronto Special Section, 15 February 1949, p. $135-136$.

${ }^{182}$ LAC, RG146, A200600096, Extract dated 18 November 1949, RCMP Toronto division from the Lithuanian newspaper, Laudis Balsas (The People's Voice) of 11 November 1949, p. 107. The article said, "The Society for Canadian-Soviet Friendship, conducted by Dr. Endicott, asked the Canadian government to resume friendly relations with the Soviet Union. The Society also demands the recognition of the new government of China and to begin trade with it." [emphasis in the RCMP original].

${ }^{183}$ LAC, RG146, A200600096, RCMP report "Re: National Council for Canadian Soviet FriendshipCanada General," dated 4 April 1949, p. 129.

${ }^{184}$ Ibid.

${ }^{185}$ LAC, RG146, A200600096, RCMP report, Hamilton detachment, 28 March 1949, p. 127-128. 
On 7 November 1949, the $32^{\text {nd }}$ anniversary of the Bolshevik revolution, the Canadian Tribune nostalgically published a large photograph of the 1943 rally in Maple Leaf Gardens, founding of the wartime National Council for Canadian-Soviet Friendship. Below the photo ran the caption,

Many will recall this thrilling scene as over 17, 000 Canadians jammed Toronto's Maple Leaf Gardens to pay tribute to the people of the Soviet Union and its Red Army which at that time was alone in action against the Hitler armies...W.L. Mackenzie King, then premier and Liberal party leader also spoke. He is the man who the moment victory was won over the Nazis joined Washington in a vile betrayal by launching a 'cold war' against our Soviet ally, a 'war' the St. Laurent government has intensified. The Tribune joins the National Council of Canadian-Soviet Friendship and all democratic Canadians in calling for a return to days when Canada proudly acclaimed the Soviet Union and her peoples, allies and friends. ${ }^{186}$

Under the photograph was an article inviting "all Canadians of good will" to a conference on 26 November 1949 at the Prince George Hotel in Toronto. Press releases were sent out from the National Council office, ${ }^{187}$ the announcement was advertised in the English-language and 'ethnic' left papers, ${ }^{188}$ and RCMP detachments in large cities across Canada were instructed to find out who was attending. ${ }^{189}$ The RCMP in Toronto reported that "It would appear that the Party will make a determined effort to revitalize this front organization on the theme of trade with the U.S.S.R. and friendly cooperation, thereby ensuring peace." ${ }^{190}$ That observation proved to be correct.

\footnotetext{
186، Trade, Friendship with USSR is Call," Canadian Tribune, 7 November 1949, front page. Also found in RG146, A200600096, p. 115.

${ }^{187}$ The press releases are dated 11 and 17 November 1949. LAC, RG146, A200600096, p. 96-97.

${ }^{188}$ The announcement appeared in Ludove Zvesti, Ukrainian Life, Canadian Jewish Weekly, Pacific Tribune, and Novo Vreme. See LAC, RG146, A200600096, p. 50, 105, 109, 110, 115.

${ }^{189}$ See LAC, RG146, A200600096, p. 108 where RCMP officers commanding are informed of the conference on 26 November 1949 in Toronto, and are asked to send all relevant information. Responses are passim in LAC, RG 146, 200600096, mostly reporting that no locals were known to be attending. In the end, most attendees were from Toronto.

${ }^{190}$ LAC, RG146, A200600096, RCMP report from the Toronto Special Branch, 9 November 1949, p. 112.
} 
At 2:30 p.m. on 26 November 1949 the meeting got underway. Dyson Carter gave an empassioned speech, arguing that it was high time for a renewed Friendship Society: "Ladies and Gentlmen [sic]...GONE ARE THE DAYS, FOREVER, when we have to APOLOGIZE for friendship with the Land of Socialism! Never again do we have to go, hat-in-hand, to people in high places, and ask them: 'Please won't you allow your name to be used for the sake of friendship...important names will make people think the Russians are important!'... What we have to do NOW, is go to the Canadian people with the truth..."191 In leaving behind the wartime, elite-driven Friendship Society, Carter pointed to the ways "people in high places" had betrayed the trust of Canadians, and urged his audience to take the cause directly to the "Canadian people": most particularly the workers, farmers and youth. He blamed Canada for "whipping up" the Cold War: "In recent years Canada has taking [sic] the LEADING part in trying to DESTROY world-wide friendship with the great Socialist land, the USSR... Canada, with the notorious Spy Trials, OPENED the post-war campaign of hatred and hysteria against the S.U..."192 According to Carter, Canada had so much to learn from the USSR in science, medicine, culture, economic and Northern affairs. That is why, he said, Canadians should take the cause of friendship into their own hands, so that "Canada COULD be the KEY nation in leading the great and small powers of the world towards a new spirit of international agreement and friendship."193

Following his speech, Carter was elected president of the new National Council of Canadian Soviet Friendship. Apparently, he was the only candidate. Mary Jennison

\footnotetext{
${ }^{191}$ LAC, RG146, A200600096, from Dyson Carter's notes, "Speech for C.S.F. Meeting Nov 2649 ", p. 81 94. Throughout, Carter's notes to himself show the highly choreographed enthusiasm in the speech (ie. "PAUSE, AND SOFTLY!", "EMPHASIS", "SLOW"). Capital letters used for emphasis in the original. ${ }_{193}^{192}$ LAC, RG146, 200600096, Dyson Carter's notes, "Speech for C.S.F. Meeting Nov 26 49”, p. 82, 83. ${ }^{193}$ Ibid., p. 83.
} 
resigned as secretary of the Council to become secretary of the Canadian Peace Congress, ${ }^{194}$ replaced by William Tweedale of Toronto. Of the 60 people in attendance, Mrs. Rae Luckock, Stanley Ryerson, Margaret Spaulding, Nora Rodd, John Weir, and Gregorii Okulevich, were amongst those who paid the $\$ 1$ membership fees. ${ }^{195}$ Vladimir Burdin, First Secretary at the Soviet Embassy in Ottawa and representative of the AllUnion Society for Cultural Relations with Foreign Countries (VOKS) spoke about culture in the USSR, and a Soviet film called "Sports Parade" was shown. The meeting was glowingly reviewed in the left press. The Ukrainian Canadian, for instance, argued that Canadians would welcome the Society's initiatives because they were becoming fed up with the Cold War rhetoric against the USSR, and "public pressure must mount to secure a change. ${ }^{196}$

The CSFS leaflet claiming that the prominent members had been forced to withdraw their support "due to anti-Soviet hysteria," pledged that the new Council elected in November 1949 would continue their work. The National Council renamed the organization the Canadian Soviet Friendship Society, and called a convention for 1952, where it approved a new constitution. ${ }^{197}$ Although the links to the wartime society were played up, the CSFS was essentially a new organization, founded less on wartime friendship with the USSR than the determination to maintain friendly relations with a country most Canadians now saw as a threat. Carter explained that the membership fee

\footnotetext{
194 Jennison was listed as national secretary for the Canadian Peace Congress, 10 July 1950, "World Peace Congress," Canadian Tribune, in RCMP report dated also 10 July 1950, LAC, RG146, A200600096, p. 200.

${ }^{195}$ LAC, RG146, A200600096, p. 44, 61-79.

196 “'End Cold War Madness' Canadians Want Amity," The Ukrainian Canadian, 1 December 1949, found in LAC, RG146, A200600096, p. 55. Reports also appeared in the Vestnik, Canadian Tribune and Canadian Jewish Weekly. See LAC, RG146, A200600096, p. 49, 53-54.

${ }^{197}$ From CSFS publication "Questions People Ask about the Canadian-Soviet Friendship Society" in LAC, RG146, A200600091, p. 53.
} 
was $\$ 2$ a year, and members would get News-Facts and the VOKS Bulletin. He wrote that the CSFS was looking for branches to be founded, and would supply branches with exhibitions, films, and ideas: this “...will make your committee a highly popular center for all who want inspiring, entertaining, informative meetings and social gatherings." In response to its self-formulated question "Is there a Friendship Society in the USSR?" the CSFS answered potential members that "there is 'VOKS', the All-Union Society for Cultural Relations with Foreign Countries. Our Society exchanges publications with VOKS, and also sends Canadian books, magazines, cultural articles, music, etc. We hope to greatly increase this exchange." This hope was shared by VOKS and other authorities in Moscow.

In 1946, VOKS had concluded that the National Council for Canadian-Soviet Friendship was down but not out. According to VOKS reports, it was in need of reformulating and strengthening. In 1949, when Dyson Carter came forward to head up the new Society, VOKS got what it was asking for. It is clear from the documentary evidence, that in writing to the Soviet embassy in Ottawa, and in asking for a recommendation from Louis Kon, Carter had volunteered in the early 1940s to play a more substantial role in promoting the USSR in Canada. The decision to lead the CSFS would have been taken in conjunction with the LPP, for whom Carter was working at the time. Dorise Nielsen's reassignment to the CSFS as executive secretary from the LPP main office was naturally also a Party decision. ${ }^{198}$ The realities of the day meant that the LPP would have discussed and received approval for this strategy from authorities in Moscow, where Carter's reputation as a pro-Soviet propagandist had certainly earned him

${ }^{198}$ On Nielsen's reaction to this reassignment, see Johnston, A Great Restlessness, p. 225-227. 
praise. ${ }^{199}$ A similar pattern of CPC-Soviet planning would be followed in 1960 when Carter was replaced as the head of the Society by Les Hunt. ${ }^{200}$

In November 1949, the new friendship society had more impetus than its lackluster predecessor could by then muster, and it came with renewed strength to fight anti-Soviet 'slander.' The combination of Dyson Carter's personal talent and energy, together with renewed backing from the CPC-LPP and VOKS, made the new CSFS a much more pernicious group in the eyes of the RCMP than the groups that had come before, but it never regained the popular support that the wartime society had garnered. Ultimately it did not reach beyond the stalwart left-wing supporters that had for years looked to the USSR as a positive role model in the world, and after 1956, even this group was diminished. The legacy of the CSFS includes its consistent attempts to soften Canadian antipathies towards the USSR, its promotion of exchanges between the Cold War combatants, and its views on Soviet social experimentation. In Carter and the CSFS, the Soviets found willing and energetic partners in promoting a positive image of the Soviet Union in the post-Gouzenko, postwar, chilly international climate.

The Canadian Soviet Friendship Society has for too long been ignored by historians. The next chapter will give an overview of the related historiography, suggesting where this project makes a contribution.

\footnotetext{
${ }^{199}$ VOKS: 5:3:31:206-211, Biography and Itinerary of Dyson Carter Trip to USSR, April 1950; VOKS 6:41:5-8, K. Perevoschikov, Review of Carter's 1943 biography of Josef Stalin, 13 April 1953.

${ }^{200}$ LAC, RG146, A200700336, RCMP Research Section report, "The Canada-USSR Association," 27 March 1963, p. 835-837; Les Hunt, interview with author, 2 January 2007, Hanover, ON.
} 


\title{
Chapter Three \\ GRAPPLING WITH THE HISTORIOGRAPHY AND VERSIONS OF THE 'TRUTH': WRITING A HISTORY OF THE CANADIAN SOVIET FRIENDSHIP SOCIETY, 1949-1960
}

\author{
"We wrote [this book] because we believe Canadians want to \\ know the truth, the real facts about the Soviet Union as it is today." \\ Charlotte and Dyson Carter, We Saw Socialism (Toronto, 1951), 10.
"This is the truth. And you can be absolutely sure that the truth will win out."
Dyson Carter, "About this Book" in Libbie and Frank Park, Moscow- as Two Canadians Saw It (Toronto, 1951), 12.

In her biography of Canadian communist leader Jeanne Corbin, Andrée

Lévesque wrote: "Since 1956 and even more since 1989, the history of Communism cannot be presented as once it was." ${ }^{201}$ Knowing what we know today about the USSR, historians "...are forced to ask how it was that people who were neither cruel nor corrupt could belong to such a movement for so long." 202 Today, we have unprecedented access to sources, kept meticulously by both the Soviet authorities and the Canadian RCMP, on leftists in Canada. Today, we have the benefit of hearing activists speak out about their political commitment, and in some cases, critique their past involvement. And today, we can give context to the way historians have depicted Canadian communists, fellowtravellers, Soviet embassy personnel, and RCMP surveillance officers. We must also ask hard questions about the truth of the claims promoted in Canada by the Canadian Soviet Friendship Society and other pro-Soviet organizations during the Cold War.

The Cold War was, to a certain extent, a virtual war, fought between opponents who used the rhetoric of the "truth" as a weapon. The Cold War was suffused by

\footnotetext{
${ }^{201}$ Andrée Lévesque, Red Travellers: Jeanne Corbin \& Her Comrades. Originally published as Scenes de la vie en rouge: l'epoque de Jeanne Corbin, 1906-1944, transl. by Yvonne M. Klein. (Montreal \& Kingston: McGill-Queen's Press, 2006), p. 178.

${ }^{202}$ Ibid.
} 
powerfully emotional claims of superiority that today are generally recognized as

propaganda and persuasion. In striving to define their ideological approach as the most "truthful," players on all sides laboured hard to legitimize their beliefs and actions. Typically, books published on ways in which the Soviet Union had attempted to influence the West using information campaigns have titles like New Lies for $\mathrm{Old}^{203}$ and The Assault on the West ${ }^{204}$, the latter of which contains chapters entitled "The Propaganda Barrage" and "Agitation by Facts." Particularly after Igor Gouzenko's defection in Ottawa in 1945, the Soviet press argued that Canadians were being targeted by an orchestrated anti-Soviet propaganda campaign. ${ }^{205}$ As David Caute has pointed out, besides being a "traditional political military confrontation between empires," the Cold War was "an ideological and cultural contest on a global scale and without historical precedent., ${ }^{206}$ The history of the Canadian Soviet Friendship Society, and its relationship with the Soviet organization, VOKS, should thus be seen as part of this larger ideological/cultural conflict.

Archives, their use and their accessibility have been at the centre of debate over the historiography of the post-war period in North America. Historians have criticized each other for the ways in which documents have been interpreted to build narratives that are somehow not fully "truthful." Many archives have been closed to inquiry to protect the "truth." Consider, for example, In Denial: Historians, Communists \& Espionage by

${ }^{203}$ Anatoliy Golitsyn, New Lies for Old: The Communist Strategy of Deception and Disinformation (New York: Dodd, Mead, 1984).

${ }^{204}$ Ian Greig, The Assault on the West (Surrey, England: Foreign Affairs Publishing, 1968).

${ }^{205}$ See especially J.L. Black, "Soviet Tactics and Targets in Canada Before and After the Gouzenko Defection" in Black and Rudner, eds., The Gouzenko Affair, p. 108-129; Black, Canada in the Soviet Mirror (1998).

${ }^{206}$ David Caute, The Dancer Defects: The Struggle for Cultural Supremacy During the Cold War (Oxford: Oxford University Press, 2003), p. 1. Caute has argued persuasively for an understanding of culture as political and ideological expressions during the Cold War, and identifies the Soviet organization VOKS (the All-Union Society for Friendship with Foreign Countries) as coordinating many of these encounters. He also mentions that VOKS was known to be "supporting and subsidizing pro-Soviet foreign friendship socieities... involving a degree of 'interference' in the domestic affairs of Western countries which the Russians themselves would not have accepted." (page 29) 
John Earl Haynes and Harvey Klehr, a diatribe against American historians who have studied post-war politics, especially the Communist Party of the United States. The authors charge that this research

continues to be exempt from the standards of scholarly accuracy applied to other fields. Scholarly reference books contain distortions and lies about Soviet espionage that go unchallenged and the conventional wisdom of the academic world continues to accept pro-communist disinformation ploys as authentic. Elementary standards of proof and logic are ignored and political commitment is allowed to trump factual accuracy. ${ }^{207}$

From another perspective, Ellen Schrecker has edited a volume entitled Cold War

Triumphalism: The Misuse of History After the Fall of Communism, which accuses a different group of historians of mythologizing the American "victory" in the Cold War. ${ }^{208}$ The Soviets raised the notion of "bourgeois falsification of history" to near-doctrinal level, mostly directed at Western historians, especially after the end of World War II. ${ }^{209}$ Canadian historians have been arguing for some time about whether the RCMP surveillance of leftists was warranted, about the related issues of civil liberties, and to what degree the Gouzenko defection affected the Canadian security apparatus. ${ }^{210}$ Any

\footnotetext{
${ }^{207}$ John Earl Haynes and Harvey Klehr, In Denial: Historians, Communism \& Espionage (San Francisco: Encounter Books, 2003), 232.

${ }^{208}$ Ellen Schrecker, ed., Cold War Triumphalism: The Misuse of History After the Fall of Communism. (New York: The New Press, 2004).

${ }^{209}$ Consider for instance, B.E. Shtein, Burzhuaznye fal'sifikatory istorii (1919-1939), (Moscow: ANSSSR, 1951); V.T. Pashuto, et al., Protiv fal'sifikatsii istorii nashei rodiny (Moscow: Znanie, 1961). There was also a Soviet diatribe against Western historians published in English: Falsifiers of History (Moscow: Foreign Languages Publishing House, 1948), which was a response to a collection of documents published by the American State Department, entitled Nazi-Soviet Relations, 1939-1941 (Washington, 1948). Falsifiers of History was published in Pravda as "Fal'sifikatory istorii (Istoricheskaya spravka)" 10-17 February 1948. For more on this, see V. Piazzi, "The War of Documents: The Publication of the NaziSoviet Pact in 1948," in The History of International Relations in Central Europe and Eastern Europe: Study Traditions and Research Perspectives (Romania: Commission of History of International Relations, Babes-Bolyai University, 1995), p. 117-131; Geoffrey Roberts, "Stalin, the Pact with Nazi Germany, and the Origins of Postwar Soviet Diplomatic Historiography," Journal of Cold War History, vol. 4, no. 4 (Fall 2002), p. 93-103.

${ }^{210}$ Larry Hannant has shown that the RCMP was paying particular attention to "reds" long before Gouzenko defected, and even before the outbreak of World War II found Canadian Communists on the "wrong side." Larry Hannant, The Infernal Machine: Investigating the Loyalty of Canada's Citizens
} 
history of the Cold War that relies on previously inaccessible sources, therefore has the potential to generate enormous political and historiographic revision.

The stakes in these arguments were raised as archival collections from the former Soviet Union become more accessible to Western scholars. There is no doubt that these developments are exciting for historians, long limited in their access to sources available for study in the USSR. Academics like John Lewis Gaddis went so far as to declare that, on the basis of this new archival information, "we now know" how ideology affected Cold War politics, and he refuted some of his own earlier conclusions. ${ }^{211}$ Melvyn Leffler, who has reviewed Gaddis' book, argues that we must consider ideology beyond the highest power echelons, or we contribute simply to creating a new version of an old master narrative. He argues that "we now do know that ideas, beliefs, culture and ideology count, but that we have to continue to study the average person, not only high politics." ${ }^{212}$ Historians can not properly understand the CSFS with its Moscow backing if ideology on all levels is not given significant consideration. At the same time, historical theory has focused on how archival documents are conceptualized and used by historians. ${ }^{213}$ As Canadian historian Nancy Partner famously quipped, "Archives contain

(Toronto: University of Toronto Press, 1995). See also Richard Cavell, Love, Hate and Fear in Canada's Cold War (Toronto: University of Toronto Press, 2004); Reg Whitaker and Steve Hewitt, Canada and the Cold War (Toronto: James Lorimer \& Co., 2003); Steve Hewitt, Spying 101: The RCMP's Secret Activities at Canadian Universities (Toronto: University of Toronto Press, 2002); Reg Whitaker and Gary Marcuse, Cold War Canada: the Making of a National Insecurity State, 1945-1957 (Toronto: University of Toronto Press, 1994); Reg Whitaker, Double Standard: The Secret History of Canadian Immigration (Toronto: Lester and Orpen Dennys, 1987); John Sawatsky, Men in the Shadows: The Shocking Truth about the RCMP Security Service (Toronto: Doubleday, 1980).

${ }^{211}$ John Lewis Gaddis, We Now Know: Rethinking Cold War History (New York: Oxford University Press, 1997).

${ }^{212}$ Melvyn P. Leffler, "The Cold War: What Do 'We Now Know'?" in The American Historical Review (vol. 104, no. 2, April 1999), p. 523. (This is a review of John Lewis Gaddis, We Now Know: Rethinking Cold War History (1997).

${ }^{213} \mathrm{I}$ am particularly interested in the ideas on narrative and how historians use the language in Hans Kellner, Language and Historical Representation: Getting the Story Crooked (Madison, Wisc.: University of Wisonsin Press, 1989), and Ian McKay, Rebels, Reds, Radicals: Rethinking Canada's Left History 
many interesting things, but Truth is not among them."214 Previously restricted

documents will not provide all the answers, but, surely archives can bring us closer to the truth.

In reference to his own work in Uzbekistan, Jeff Sahadeo has noted that the opening of archives which were formerly off-limits to scholars is exciting, arousing "a sense...that 'the truth' about the nature of previous, repressive regimes could be told," "[y]et the excitement over the archives' richness risks fetishizing them" and an overreliance on archives "leaves black holes" in the narrative. ${ }^{215}$ Sahadeo's response has been to urge his colleagues to "read 'against the grain' of the documents, conscious of Verne Harris's argument that information can be distorted by, among other factors, the agendas or mentalities of those who recorded and stored information."216 Rather than making absolute truth claims based on documentary evidence, good historians use the archives to modestly suggest more truthful -- more nuanced -- narratives, until new evidence is available. Oral history narratives added to the mix would also serve to complicate archival-based research.

(Toronto: Between the Lines, 2005). Also consider Michel Foucault, Power/Knowledge: Selected Interviews and Other Writings, 1972-1977 edited and trans. by Colin Gordon (Brighton: Harvester Press, 1980); Jacques Derrida, Mal d'Archive trans. as Archive Fever: a Freudian Impression (Chicago: Chicago University Press, 1996); Carolyn Steedman, Dust: The Archive and Cultural History (New Brunswick, N.J.: Rutgers University Press, 2002); Antoinette Burton, Dwelling in the Archive: Women Writing House, Home, and History in Late Colonial India (New York: Oxford University Press, 2003); Antoinette Burton, ed., Archive Stories: Facts, Fictions and the Writing of History (Durham and London: Duke University Press, 2005).

${ }^{214}$ Nancy F. Partner, "Making Up Lost Time: Writing on the Writing of History," Speculum, vol. 61, no. 1 (Jan. 1986), 111.

${ }^{215}$ Jeff Sahadeo, "'Without the Past There Is No Future': Archives, History, and Authority in Uzbekistan" in Burton, Archive Stories, p. 46.

${ }^{216}$ Ibid., 56. Sahadeo makes reference here to Verne Harris, "The Archival Sliver: A Perspective on the Construction of Social Memory in Archives and the Transition from Apartheid to Democracy" and Ann Laura Stoler, "Colonial Archives and the Arts of Governance: On the Content in the Form" in Hamilton, Harris, Taylor, Pickover, Reid and Saleh, eds., Refiguring the Archive (Dordrecht: 2002), pp. 135-136 and 91-92, respectively. 
This theoretical discussion is significant in relation to this research project, dealing with the Canadian Soviet Friendship Society (CSFS). This project is crucially based on archival research and oral interviews. Lists of CSFS members' names, and documents related to the funding of activities are among those found in the VOKS collection, copied from the Russian State Archives, as well as in the files of the Royal Canadian Mounted Police and the Canadian Department of External Affairs. Being on a list, and being contacted for interviews, would be enough to inspire fear in some individuals on the left, reminiscent of their experiences during the Cold War. ${ }^{217}$ In fact, some individuals preferred not to be interviewed, and others commented on their worries about the possible reprecusions of "telling their story." Information in the documents was gathered for the specific purposes of those organizations, and did not always correlate with the individual's interest. In the case of the RCMP documents, there were gaping holes where Access to Information and Privacy apparently would not allow the information released to the public. The Soviet papers used provided names, addresses and lists where Canadian Access to Information personnel may have blacked them out. Increasingly this researcher became aware of the highly sensitive and complex nature of the documents being used. In the eyes of some, one could be accused of tampering with the "truth," and my interviewees and contacts all wanted to know which version of the truth this thesis was going to tell. Individuals involved wanted the story told, but from their own perspective. In many ways, they were talking back to the documents, and speaking even to the gaps in the documents. The researcher was frequently asked about

\footnotetext{
${ }^{217}$ There have been a number of books that touch on this situation in Canada, but in particular consider Len Scher, ed., The Un-Canadians: True Stories from the Blacklist Era (1992); Merrily Weisbord, The Strangest Dream: Canadian Communists, The Spy Trials, and the Cold War (1994).
} 
her own motivation in doing this study, and explained numerous times that the goal was to understand what it meant to be involved with a Soviet friendship society.

Others who have worked with RCMP documents have described similar gaps and frustrations. In particular, in reference to his own RCMP dossier to which he was not privy on his first application to Access to Information and Privacy, Greg Kealey has suggested that "what we need is openness not secrecy, both about the past and about the present. ${ }^{, 218}$ Furthermore, Kealey has said that the passage of the Access to Information Act in 1980 would not only facilitate the work of historians, but also allow for healthy, democratic debate about the role of the secret police in Canadian society. This project is a contribution to that debate. And as Steve Hewitt and Larry Hannant have suggested is necessary, this research has been carried out with an awareness of the ideological suppositions that were behind much of the RCMP surveillance of "subversives." Ideology is an important consideration in this project, and perception is everything. ${ }^{219}$ The RCMP documents, as well as those coming from other Canadian governmental departments and the Soviet VOKS archive, are neither neutral nor infallible.

And yet, together these sources corroborate basic assumptions made by the RCMP at the time: the CSFS was a Communist front organization, its leaders were Communist Party members, Dyson Carter provided the Soviets with a lot of (publicly known) information on Canada and Canadians, and widely published the Soviet version of current events. In using these documents, and in looking for alternative sources, this project has been about attempting to understand what effect ideological suppositions and perceptions had on an individual's choice to be active in a Communist front group during

\footnotetext{
${ }^{218}$ Gregory S. Kealey, "Presidential Address: The Empire Strikes Back: The Nineteenth-Century Origins of the Canadian Secret Service," Journal of the Canadian Historical Association, vol. 10, 1999, p. 3-18: p. 6. ${ }^{219}$ Hewitt, Spying 101, p. 4-17, 26; Hannat, The Infernal Machine (1995).
} 
the Cold War. As the Soviets discovered when Mikhail Gorbachev launched the glasnost policy, access to information is powerful: it can change narrative patterns. The narrative pattern of some revisionist historiography, which has tended to suggest the RCMP's assumptions about left-wing groups in Canada were outrageously wrong, has not been upheld by this research project.

Research for this project revealed other unexpected gaps and missed opportunities. It is odd that despite publishing numerous English-language books and a magazine that ran for several decades, ${ }^{220}$ the founding president of the Canadian Soviet Friendship Society, Dyson Carter, has escaped the attention of historians. His work undoubtedly had an impact on discussions in Canadian leftist circles, yet among Canadian historians his name is virtually unknown. ${ }^{221}$ When historian J.L. Black uncovered documents attesting to the importance of the Canadian Soviet Friendship Society and its president to the Soviets, Dyson Carter's name made a brief splash in the Canadian media. Black appeared on the CBC programme "As it Happens" on 14 April

${ }^{220}$ For forty years Dyson Carter published the pro-Soviet magazines News-Facts (1950-1956) and Northern Neighbours (1956-1989), and the books he wrote (often together with his wife, Charlotte Breckman Carter) include Stalin's Life: At Last the True Story (Winnipeg, 1943); Russia's Secret Weapon (London, 1943); Tomorrow is With Us (Toronto, 1950); We Saw Socialism (Toronto, 1951-1952); Science of Health and Long Life in the U.S.S.R. (Sydney, 1956); Cancer, Smoking, Heart-Disease, Drinking in Our Two World Systems Today (Toronto, 1957); The Big Brainwash (Toronto, 1958); Future of Freedom (Gravenhurst, 1961); Worker Power: Dare We Win? (Toronto, 1970).

221 Neighbours" in Black and Hillmer, ed., Nearly Neighbours, p. 6, 7. Black made frequent reference to Carter's role in changing/constructing images of the USSR in Canada in the Soviet Mirror (Ottawa, 1998). Historian Andrée Lévesque referred to the influence of Dyson Carter's writings on Canadian militant Jeanne Corbin in Red Travellers, p.168; Norman Penner hinted at his influence in supporting the publication of Tim Buck's memoirs in Canadian Communism: The Stalin Years and Beyond (Toronto, 1988), 265. An interview with Dyson Carter appeared in the Moscow English-language newspaper, The New Times, 41 (October 1983), p. 27, and his writings appeared in several journals and newspapers in the USSR. The Canadian-Soviet Friendship Society (CSFS) later changed its name to the Canada-USSR Association, at which time it was headed up by Les Hunt, and then by Michael Lucas. 
2004 to talk about Dyson Carter, and he was interviewed for a story carried by CanWest

News on 15 April 2004. In the article, journalist Randy Boswell reported that

as leader of a "friendship society" aimed at strengthening ties between Canada and the U.S.S.R., Mr. Carter was treated like a visiting head of state during a trip to Moscow and was viewed by Joseph Stalin's regime as a perfect propaganda pipeline -- more important to the Communist cause than the party's leader in Canada, Tim Buck. ${ }^{222}$

References to the Society and its members sprinkled throughout secondary literature on

the Canadian left and "progressive movements" provide clues to the background and identity of some of the society members, but leave the researcher to piece together the details, much as a quilter will sew together disparate swatches of cloth.

There has yet to be an in-depth academic study of Soviet friendship societies in Canada post-Gouzenko, and there is little written about Canadian fellow-travellers, generally. Although the literature related to Igor Gouzenko's defection, the so-called "spy trials" and what came to be known as the "Gouzenko Affair" provides context to this project, ${ }^{223}$ there are few allusions to how the USSR responded in the following years,

${ }^{222}$ Randy Boswell, "Documents show writer was Soviets' great hope in Canada: Dyson Carter led a Soviet friendship society during the Cold War, and apparently outranked the leader of Canada's Communist party, Randy Boswell reports", The Ottawa Citizen, Wed., 14 April 2004.

${ }^{223}$ Igor Gouzenko, This Was My Choice: Gouzenko's Story (Toronto: J.M. Dent and Sons, 1948). This book may have been ghost-written by journalist Andy O'Brien. (See John Sawatsky, Gouzenko: The Untold Story (Toronto: Macmillan of Canada, 1984), 99.; The Report of the Royal Commission to Investigate the Facts Relating to and the Circumstances Surrounding the Communication by Public Officials and Other Persons in Positions of Trust of Secret and Confidential Information to Agents of a Foreign Power, Commissioners Honourable Mr. Justice Robert Taschereau and Honourable Mr. Justice R.L. Kellock (Ottawa, 27 June 1946). Robert Bothwell and J.L. Granatstein, ed., The Gouzenko Transcripts: The Evidence Presented to the Kellock-Taschereau Royal Commission of 1946 (Ottawa: Deneau Publishers, 1982); June Callwood, Emma (Toronto: Stoddart, 1984); I.A. Aggeeva, "Kanada I nachalo kholodnoi voinyi: Delo Gouzenko v Sovetsko-Kanadskikh otnosheniyax" in N.I. Yegorova and A.O. Chubaryan, ed., The Cold War, 1945-1963: Historical Retrospective (Moscow, 2003); Amy Knight, How the Cold War Began: The Gouzenko Affair and the Hunt for Soviet Spies (Toronto: McClelland \& Stewart, 2005); Black and Rudner, eds., The Gouzenko Affair: Canada and the Beginnings of Cold War Counter-Espionage (Manotick: Penumbra Press, 2006); Duncan McDowall, "The Trials and Tribulations of Miss Agatha Chapman: Statistics in a Cold War Climate," Queen's Quarterly, 114/3 (Fall 2007), p. 357369. 
or how the Canadian left attempted to recover. When news leaked out that Soviet cipher clerk Igor Gouzenko had defected in Ottawa in 1945, carrying with him documents proving Canadian citizens had been passing sensitive information to the Soviet Union, the public was shocked. The Soviet Union no longer appeared to be the ally it had been during the Second World War. As a direct result of the revelations, the Communist Party of Canada and other organizations on the left were immediately discredited. Distrust of their motives and intentions, already in evidence, reached a fever pitch, echoing in a muted form the McCarthy hysteria which would later erupt in the United States. ${ }^{224}$ The international crisis that would later be referred to as the Cold War had begun.

Reference has been made in the Mitrokhin archive to how the KGB lost its contacts in Canada following the Affair, ${ }^{225}$ and the special importance Canada represented for Soviet foreign policy because of its geographical and cultural proximity to the United States. ${ }^{226}$ This would seem to confirm J.L. Granatstein's view that Canadians are used to thinking of themselves as a small nation of relatively little importance in global affairs. The history of the Cold War, however, gives the lie to this too-easy generalization. First, geography unquestionably made Canada important. Then...the Canadian government and people were deeply committed to the democratic cause and the necessity to contain Soviet expansionism. ${ }^{227}$

\footnotetext{
${ }^{224}$ In reference to the exposure of American communists and leftists by Senator Joseph McCarthy and the House on Un-American Activities, and the resulting panic in the 1950s. See Denis Smith, Diplomacy of Fear: Canada and the Cold War, 1941-1948 (Toronto: University of Toronto Press, 1988).

${ }^{225}$ When KGB archivist Vasili Mitrokhin left Moscow for Britain in 1992, he took with him notes on documents, alleging to KGB operations internationally over the previous 30 years. These were published as Christopher Andrew and Vasili Mitrokhin, The Mitrokhin Archive: The KGB in Europe and the West (New York: Penguin Press, 1999).

${ }^{226}$ Ibid., p. 473.

${ }^{227}$ J.L. Granatstein, Introduction to Robert Bothwell, The Big Chill, p. ix.
} 
Mitrokhin also accused Vladimir Pavlovich Burdin, the First Secretary and VOKS representative at the Soviet Embassy, of being a KGB agent. ${ }^{228}$ Very little has been written on Burdin, VOKS and the link in Canada to groups like the CSFS. In fact, the documentary evidence hints at other responsibilities carried out by Burdin, and most likely his successor, Alexei Tovstogan, but it was via oral history that this relationship was made most clear. John Boyd suggested that it was well-known in inner circles that both Burdin and Tovstogan were KGB representatives based at the Soviet Embassy in Ottawa. ${ }^{229}$ Clearly, VOKS was attempting to gain information from average Canadians and also to convince them of the veracity of the Soviet version of international affairs. The CSFS was an integral part of this propaganda and persuasion, and yet because certain sources were not previously accessible, this story is broached here for the first time.

From their correspondence and reports of their activities, it is plain that CSFS members believed themselves to be committed to ideals of social, political and economic equality, and were actively promoting Soviet ideas abroad; that is, ideas that were known to be contradicted by practices in the USSR. Canada was situated, geographically and culturally, between the United States and Great Britain, and even after World War II Soviet ideologues still predicted the capitalist, imperialist powers would eventually take

\footnotetext{
${ }^{228}$ Andrew and Mitrokhin, The Mitrokhin Archive, p. 181, 220, 227-228, 532. This will be discussed further in the chapter on the Moscow-based All-Union Society for Friendship with Foreign Countries (VOKS).

229 John Boyd, who was an active member of the CPC and the AUUC until 1968, was familiar with many of the CSFS activists, and was in a good position to have inside knowledge on the links between the CSFS, the CPC-LPP, and the Soviet Embassy in Ottawa. Boyd, comments on Jennifer Anderson's manuscript draft, April, 2008. This would seem to contradict Aleksei P. Makarov's observation that KGB officers in the Embassy did not handle important files. Burdin and Tovstogan were known to the Canadian Department of External Affairs personnel, as well as pro-Soviet individuals in Canada. Aleksei P. Makarov, "Living with the KGB and GRU: A 'Clean' Diplomat Recalls his Experiences Inside Soviet Embassies," in Black and Rudner, eds., The Gouzenko Affair, p. 151-189. On the other hand, the individual described as "Vladimir Borodin," and said to have been the initial KGB contact for Canadian spy Hugh Hambleton, seems to confirm Mitrokhin's allegations. See Leo Heaps, Hugh Hambleton, Spy: Thirty Years with the KGB (Toronto: Methuen, 1983), p. 44-55.
} 
up arms against one another. As one historian has written, "Whenever the foreign-policy elite in the Soviet Union took up a position on the United States or Britain, they found Canada bobbing up in front of them." ${ }^{230}$ Canada was important to the Soviets. If the Soviets needed friends in Canada after the Gouzenko allegations made politically-active Canadian communists taboo, it is natural that the friendship society was taken up as a viable, and maybe only, alternative. ${ }^{231}$ Yet, these "friends" lived and worked in an environment that was frequently hostile to Soviet or Communist sympathizers. Attendees at public rallies were keenly aware that they were making a political statement. How and why did they make the choices to speak publicly about Soviet successes, to visit the Soviet Union, and to receive Soviet publications? What motivated a Canadian to become a Soviet sympathizer?

Whatever else they were, CSFS members were believers. Historian Merrily Weisbord has provided the most encompassing picture of how Igor Gouzenko's allegations, the subsequent Royal Commission's investigations, and criminal trials affected the dream held dear by the Canadian left. ${ }^{232}$ The "Strangest Dream" Weisbord uses in her title, is a reference to the popular culture of the day, ${ }^{233}$ and frames admiration of the USSR and the Canadian left in terms of ideology. It was a dream, a belief that a better world was possible, that motivated the individuals described by Weisbord to make the decisions they did. Weisbord's own parents were involved in the movement, and it is

\footnotetext{
${ }^{230}$ J.L. Black, Canada in the Soviet Mirror, p. 336.

${ }^{231}$ On this see Black, "Soviet Tactics and Targets in Canada Before and After the Gouzenko Defection," Black and Rudner, eds., The Gouzenko Affair, p. 108-129. See also VOKS Series 1, Section 6, File 55, page 128-129.

${ }^{232}$ Merrily Weisbord, The Strangest Dream: Canadian Communists, The Spy Trials, and the Cold War (Montreal, 1983, 1994). A similarly personal experience with communism is described by James Laxer in Red Diaper Baby: A Boyhood in the Age of McCarthyism (Douglas and McIntyre, 2004).

${ }^{233}$ The reference is to the peace song entitled "The Strangest Dream," written by Ed McCurdy and performed by Pete Seeger, copyrighted by Folkways Records \& Service Corp., 1956. The song has been covered by John Denver and others. The lyrics are reproduced in Weisbord, The Strangest Dream, p. v.
} 
perhaps this fact that leads her to empathize with the subjects of her book. Although she mostly writes about members of the Communist Party of Canada (CPC), she does describe individuals who would have been known to those on the left who remained out of politics. Of particular significance to this study is her discussion of how Louis Kon and his daughter Irene came to be involved in the communist movement. Louis Kon was one of the most active members of the Soviet friendship society, and is frequently featured in the VOKS documents. The Kons claim they were instrumental in getting Dr. Norman Bethune involved in the cause. Weisbord explained that Irene Kon, like Bethune, artist Fred Taylor, and other well-known Canadian communists dreamed "a utopian dream that flew in the face of the evidence around her, a tenacious belief that mankind was potentially warm, cultured, beautiful. ${ }^{, 234}$ They believed it was possible to build a better world, and they decided that the Soviet Union was proof of this.

In reference to the era of McCarthyism in the United States, American journalist Edward R. Murrow said "we must not confuse dissent with disloyalty." 235 It has been mentioned that Vladimir Burdin, the First Secretary and VOKS representative at the Soviet embassy in Ottawa, through whom most of the CSFS requests and correspondence were channeled in the early 1950s, was accused by Vasili Mitrokhin in the well-known Mitrokhin archive of being an operator for the KGB. ${ }^{236}$ Mitrokhin also alleged that a member of the CSFS passed passports through Burdin to be used by illegals in Canada and the United States. ${ }^{237}$ Via VOKS the CSFS was indirectly funded and closely

\footnotetext{
${ }^{234} \mathrm{Ibid} ., 70$.

${ }^{235}$ Edward R. Murrow, "A Report on Senator Joseph R. McCarthy," See it Now (CBS-TV, 9 March 1954), transcript available at [http://www.honors.umd.edu/HONR269J/archive/Murrow540309.html, accessed 2 May 2006].

${ }^{236}$ Andrew and Mitrokhin, The Mitrokhin Archive, 181, 220, 227-228, 532.

${ }^{237}$ Ibid., 532.
} 
monitored by Soviet authorities. ${ }^{238}$ In dealing with interpretations of "truth" this project grapples with how "dissent" and "disloyalty" were understood by individuals involved in the CSFS. There are also important questions to be asked about the Soviet interest in the CSFS. $^{239}$

Despite the fact that the charges of espionage were rarely proven, Canadian leftists were often still shunned, ${ }^{240}$ and aspersions of disloyalty were cast on members of the CSFS. The times were such that communists and other progressives were fearful that allegations would lead to loss of employment or worse. This fear and the "ideological prejudice of the early Cold War" may explain why, until now, former CSFS members have not spoken publicly about their involvement, and about the links with the Communist Party of Canada. ${ }^{241}$ There have been some notable studies that help dispel the Cold War image that communists were straw-men, and give some insight as to how people could find themselves accused of having passed sensitive information. But this must be balanced against the very real security issues represented by Soviet attempts to repair its image in North America. Historians J.L. Granatstein and David Stafford have said that not only did Gouzenko's information warrant serious investigation, but some Canadian spy rings escaped detection. ${ }^{242}$ It is clear that the information passed to the

\footnotetext{
${ }^{238}$ See Black, "Soviet Tactics and Targets in Canada Before and After the Gouzenko Defection," in Black and Rudner, eds., The Gouzenko, p. 108-129.

${ }^{239}$ Of particular pertinence here is J.L. Black, Canada in the Soviet Mirror (Ottawa, 1998).

${ }^{240}$ See Weisbord, The Strangest Dream; Callwood, Emma; Scher, ed., The Un-Canadians: True Stories from the Blacklist Era (Toronto, 1992).

${ }^{241}$ Marcel Fournier, "Fred Rose: Notes pour une biographie" in Robert Comeau et Bernard Dionne, Le droit de se taire: Histoire des communistes au Quebec, de la Premiere Guerre mondiale a la Revolution tranquille (Outremont, QC, 1989), 296; Callwood, Emma (Toronto, 1984) ; Scher, ed., The Un-Canadians (Toronto, 1992); Mark Kristmanson, Plateaus of Freedom: Nationality, Culture and State Security in Canada, 1940-1960 (Don Mills, 2003); Joyce Nelson, The Colonized Eye: Rethinking the Grierson Legend (Toronto, 1988). The quotation in this sentence is from Duncan McDowall, "The Trial and Tribulations of Miss Agatha Chapman: Statistics in a Cold War Climate," Queen's Quarterly, 114/3 (Fall 2007), p. 373. ${ }^{242}$ J.L. Granatstein and David Stafford, Spy Wars: Espionage and Canada from Gouzenko to Glasnost (Toronto, 1990), 63.
} 
USSR by CSFS leaders, while not representing our usual conceptions of 'cloak-anddagger' spying, was deemed useful by Soviet authorities.

A decade after the Gouzenko Affair, the Canadian left-wingers received another shock. Above all, the left saw the USSR as an apostle of peace, an example of religious and ethnic egalitarianism, but for many, 1956 changed all that. For Soviet sympathizers, bitterness was added to fear ${ }^{243}$ when Nikita Khrushchev's February 1956 secret speech denouncing Stalin was made public, and a crisis occurred in the international communist movement. Leftists were presented with a choice: accept the fact that mistakes had been made and carry on, or admit to disillusionment and leave the movement. Weisbord describes why this choice was so heart-rending:

The mythology of communism had always been inextricably bound up with the Soviet Union, the prime example of a communist state. No one had desired or dared to think it less than perfect. ${ }^{244}$

The Soviets also invaded Hungary in 1956, and Poland was threatened. Many leftists made a choice after this to leave the leftist movement. The way events of 1956 affected Canadian fellow-travellers and Soviet-sponsored organizations in Canada needs to be studied further. Most of the current literature concentrates on confirmed members of the Communist Party of Canada.

How did fellow-travellers find sanctuary in the ideological storm? There is a gap here in the Canadian historiography. ${ }^{245}$ How did CSFS members overcome this dilemma

\footnotetext{
${ }^{243}$ See especially Weisbord's "Afterword", "Update on Pseudonyms Used in the Book", and "Response from Readers to the First Edition", The Strangest Dream., 224-244.

${ }^{244}$ Ibid., 215.

${ }^{245}$ For instance, there is no Canadian study comparable to David Caute's work on fellow-travellers in the United States, Britain and Western Europe: The Fellow-Travellers: Intellectual Friends of Communism (New Haven, CT: Yale University Press, 1988); revised edition of The Fellow Travellers: A Postscript to the Enlightenment (London: Weidenfeld and Nicholson, Ltd., 1973), or Julia L. Mickenberg's Learning
} 
and rationalize these choices? Reference is made in the VOKS documents to a decline in attendance at CSFS events and to the removal of an executive member who did not take the proper (i.e. Soviet) stance on these issues, ${ }^{246}$ but the Society did not die out and Carter continued to publish a pro-Soviet magazine. Immediately after 1956, several changes were made to the CSFS and the magazine itself, the Carters relocated, and more emphasis was placed on appealing to a broad base of 'progressive' supporters in Canada.

Eventually Carter was replaced, and the Communist Party of Canada renamed the CSFS, on the suggestion of authorities in Moscow. Formed after the Gouzenko revelations of 1946 and reorganized after the events of 1956, the CSFS was one facet of a larger Sovietinspired perception management strategy.

This study strives to combine a perspective on Soviet history with approaches used to study the history of the Canadian left. Of late, Canadian history has witnessed an emergence of a small library of scholarship on the Cold War left in Canada. For instance, recently an important biography of communist activist Dorise Nielsen was published. Her role in launching the CSFS in 1949 on behalf of the Labor-Progressive Party, and tensions between Nielsen and Dyson Carter over who should be the leader is contextualized in this biography. ${ }^{247}$ Books by James Laxer and Andrée Lévesque have noted the importance that Dyson Carter and his writing represented for Canadian leftists. ${ }^{248}$ Autobiographical studies of radical childhoods in North America, and how

from the Left: Children's Literature, the Cold War, and Radical Politics in the United States (Oxford: Oxford University Press, 2006).

${ }^{246}$ See VOKS Section 1, Series 6, File 49 (pages 264-267), File 55 (pages 150-151).

${ }^{247}$ Faith Johnston, A Great Restlessness: The Life and Politics of Dorise Nielsen (Winnipeg, 2006).

${ }^{248}$ Laxer notes that his father, LPP organizer, Robert Laxer had a kind of 'faith' in the USSR, and saw Dyson Carter as "Canada's greatest novelist." James Laxer: Red Diaper Baby: A Boyhood in the Age of McCarthyism (Vancouver, 2004), p. 25. Andrée Lévesque has noted that Quebec communist Jeanne Corbin, was captivated by Dyson Carter's writings, and that the CSFS president and publicist "offered hope to his many and faithful readers." Lévesque, Red Travellers, p. 168. 
parents have attempted to raise their children differently according to their ideological interpretations of world events, also provide valuable insights. ${ }^{249}$

Memoirs published by activists on the Canadian left are useful for their detail. They give information on how the Soviet Union was viewed, and the motivation for their community involvement. They make reference to the importance of The Canadian Tribune, the peace movement, Soviet links with unions, and Canadian leftist leaders, all of which are regularly featured in the VOKS documents. From these works a picture emerges of leftist intellectuals in Canada as a tight-knit group, which on occasion provoked infighting, but also promoted close friendships. ${ }^{250}$ They were active at the grassroots level of society, and they frequently make reference to their friends, enemies and comrades. References to names, cross-matched with the VOKS documents can give clues as to the background and activities of members of the CSFS. Sometimes these biographies and memoirs give a more colourful and personal version of the times than can be found elsewhere. For example, labour activist Jack Scott's memoirs make direct reference to the effect of the Gouzenko Affair on the Canadian left:

The middle class elements that had flocked into the Party during the war years, they just cut and ran. Disappeared. Working-class elements may

\footnotetext{
${ }^{249}$ On growing up in radical homes in Canada and the United States during the Cold War, see Weisbord, The Strangest Dream; Kim Chernin, In My Mother's House: A Daughter's Story (New York: HarperCollins, 1983, 1994); Paul C. Mishler, Raising Reds: The Young Pioneers, Radical Summer Camps, and Communist Political Culture in the United States (New York: Columbia University Press, 1999); James Laxer, Red Diaper Baby (2004); Johnston, A Great Restlessness (2006); Mickenberg, Learning from the Left (2006); Rhonda L. Hinther, "Sincerest Revolutionary Greetings': Progressive Ukrainians in Canada, 1918-1991." Hamilton: McMastern University, unpublished PhD thesis, 2005.

${ }^{250}$ See especially Weisbord's The Strangest Dream (1994). Also Catherine Vance, Not by Gods But By People: The Story of Bella Hall Gauld (Toronto: Progress Books, 1968); Cy Gonick, A Very Red Life: The Story of Bill Walsh (St. John's, Nfld.: Canadian Committee on Labour History, 2001); Louise Watson, She Never Was Afraid: The Biography of Annie Buller (Toronto: Progress Books, 1976); Peter Hunter, Which Side Are You On Boys... Canadian Life on the Left (Toronto: Lugus Productions, 1988); Maurice Rush, We Have a Glowing Dream: Recollections of working-class and people's struggles in B.C., 1935-1995 (Vancouver: Centre for Socialist Education, 1996); Stephen Endicott, James G. Endicott: Rebel Out of China (Toronto: University of Toronto Press, 1980).
} 
have stuck around. They might have raised hell about the policies that were being pursued and that seemed wrong. But the middle class types weren't about to chance it. They had too much to lose. Who's to blame them. You're gonna save what you can from the goddamn wreckage and you certainly weren't willing to confront going to jail. ${ }^{251}$

This gives some insight into why the more mainstream "friends" of the USSR became increasingly more important to the Soviet ideologues than the Communist Party of Canada. Unfortunately, many of these biographies fall into the genre of popular history, and often do not include an index or footnotes, thereby making them difficult to verify in an academic sense. For the most part, the CSFS itself remains invisible in these studies.

Official biographies and autobiographies of the CPC leaders are especially limited in usefulness. ${ }^{252}$ Alfred Dewhurst, member of Central Executive Committee of CPC and a CSFS activist, wrote the introduction to a collection of William Kashtan's writings, but nowhere is his own CSFS activism noted. ${ }^{253}$ The CPC publications are instructive more as to the changing Party line, than in their detail. An exception is Tim Buck's 1977 deathbed memoir, Yours in the Struggle ${ }^{254}$, based on taped interviews for $\mathrm{CBC}$, and published under protest by the CPC. ${ }^{255}$ In this book Buck dared to admit he had been wrong on several occasions, and even went so far as to question the infallibility of the leadership in the Soviet Union. He made no mention of the CSFS. Similarly, studies of

\footnotetext{
${ }^{251}$ Bryan D. Palmer, ed., A Communist Life: Jack Scott and the Canadian Workers Movement, 1927-1985 (St. John's, Nfld: Committee on Canadian Labour History, 1988), 77.

${ }^{252}$ Consider the numerous published writings of Tim Buck, as well as: Leslie Morris, The Story of Tim Buck's Party, 1922-1939 (Toronto: New Era, n.d.); Oscar Ryan, Tim Buck: A Conscience for Canada (Toronto: Progress Books, 1975); William Kashtan, Toward Socialism: Selected Writings, 1966-1976 (Toronto: Progress Books, 1976). Tim Buck was General Secretary of the CPC until 1962, replaced by Leslie Morris, who was replaced by William Kashtan in 1964.

${ }^{253}$ Kashtan, Toward Socialism (1976).

${ }^{254}$ William Beeching and Dr. Phyllis Clarke, ed., Yours in the Struggle: Reminiscences of Tim Buck (Toronto: N.C. Press, 1977).

${ }^{255}$ On the "furore" in the CPC, the disciplining of those involved, and why Yours in the Struggle was considered to be so scandalous, see Palmer, ed., A Communist Life, 245. The publication of the book was apparently supported by Dyson Carter, which would be significant considering the readership he had in leftist circles. See Norman Penner, Canadian Communism: The Stalin Years and Beyond (Toronto: Methuen, 1988), 265.
} 
Canadian communism are interesting for background information and their

historiographical approaches, but provide little or no concrete information on the Soviet

friendship society. ${ }^{256}$ This fact would lend credence to the theory that the two bodies

were purposely insulated from each other, at least to the public eye. It also suggests a

need for further research on fellow-travellers in Canada.

The tangled web of gender and ethnicity has been shown to be influential in

understanding radical groups in Canada and, although at times familiar names arise, no

one has dealt specifically with women's activists in the CSFS yet. It has been noted

elsewhere that despite lip-service paid to women's rights, the Communist Party of

Canada and its supported organizations did not usually place any serious emphasis on

achieving this ideal. ${ }^{257}$ Therefore, despite a few prominent examples, the vast majority of

women active on the Canadian left framed their activism in traditionally domestic terms,

and worked as help-mates to their husbands and male leaders. This study will take

\footnotetext{
${ }^{256}$ For example see: CCF-er M.J. Coldwell's Left Turn, Canada (New York: Duell, Sloan and Pearce, 1945); Avakumovic, The Communist Party in Canada: A History (Toronto, 1973); former CPC member Norman Penner's The Canadian Left: A Critical Analysis (Scarborough: Prentice-Hall of Canada, 1977); Ian Angus' Canadian Bolsheviks: The Early Years of the Communist Party of Canada (Montreal:

Vanguard, 1981); Norman Penner, Canadian Communism; and the Party's own self-history, Canada's Party of Socialism: History of the Communist Party of Canada, 1921-1976 (Toronto: Progress, 1982).

${ }^{257}$ Faith Johnston, A Great Restlessness: The Life and Politics of Dorise Nielsen (Winnipeg: University of Manitoba Press, 2006); Julie Guard, Canadian Citizens or Dangerous Foreign Women? Canada's Radical Consumer Movement, 1947-1950," in Marlene Epp, Franca Iacovetta, Frances Swyripa, eds., Sisters or Strangers? Immigrant, Ethnic, and Racialized Women in Canadian History (Toronto: University of Toronto Press, 2004), p. 161-189; Levesque, Red Travellers (Montreal, Kingston, 2006); Joy Parr, ed. A Diversity of Women: Ontario, 1945-1980 (Toronto: University of Toronto Press, 1995); Frances Swyripa, Wedded to the Cause: Ukrainian-Canadian Women and Ethnic Identity, 1891-1991 (Toronto: University of Toronto Press, 1993); Varpu Lindstrom, Defiant Sisters: A Social History of Finnish Immigrant Women in Canada (Toronto: Multicultural History Society of Ontario, 1992); Joan Sangster, Dreams of Equality: Women on the Canadian Left, 1920-1950 (Toronto: McClelland and Stewart, 1989); Louise Watson, She Never Was Afraid; Catherine Vance, Not by Gods but By People; Rhonda L. Hinther, "'Sincerest Revolutionary Greetings': Progressive Ukrainians in Canada, 1918-1991." Hamilton: McMastern University, unpublished PhD thesis, 2005; Stacey Zembrzycki, "Memory, Identity, and the Challenge of Community Among Ukrainians in the Sudbury Region, 1901-1939." Ottawa: Carleton University, unpublished $\mathrm{PhD}$ thesis, 2007.
} 
seriously women's activism in the CSFS, and pay specific attention to the role women played in presenting a polished image of the USSR to their fellow Canadians.

Historiographically, focusing on ethnicity yields somewhat fuller results. Secondary literature on the Russian, Ukrainian, Jewish and Finnish communities in Canada and their politics has been valuable in identifying individuals mentioned in primary documents, but no direct reference is ever made in these books to the CSFS or the material supplied by VOKS. The ethnic progressive organizations were closely tied to the work being carried out by the Communist Party of Canada, as well as the CSFS. The VOKS documents are full of references to material shared, cooperation or conflict between these ethnic leftist groups and the CSFS. The readership of several CSFS publications was itself drawn from these "progressive, ethnic" communities, and inevitably cooperation was required when Soviet delegations visited Canada. In this context, perception and image-construction is once more highlighted. ${ }^{258}$ In terms of Soviet attempts to persuade ethnic groups in Canada to sympathize with the Soviet Union, Nikita Khrushchev's "Return to the Homeland" project is of particular interest. This was a campaign to encourage Ukrainian-Canadians to return to live in the USSR, and, for some, it was considered persuasive enough for them to leave Canada for their

\footnotetext{
${ }^{258}$ Frances Swyripa, Wedded to the Cause. On the discrimination faced by many immigrants to Canada from Eastern Europe, and their radicalism include: Donald Avery, 'Dangerous Foreigners': European Immigrant Workers and Labour Radicalism in Canada, 1896-1932 (Toronto: McClelland and Stewart, 1979) and its revised version Reluctant Host: Canada's Response to Immigrant Workers, 1896-1994 (Toronto: McClelland and Stewart, 1995); as well as Barbara Roberts, Whence They Came: Deportation from Canada, 1900-1935 (Ottawa: University of Ottawa Press, 1998). The book written by Executive Secretary of the Federation of Russian Canadians (FRC), Grigorii Okulevich, was sent to Moscow by VOKS soon after its publication. Russkie v Kanade: Istoriya Russkikh Raboche-Fermerskikh Klubov imeni M. Gorkovo (1930-1940) I Federatsii Russkikh Kanadtsev (1941-1952) (Toronto: Federation of Russian Canadians, 1952).
} 
ancestral homeland. Unfortunately, they were not allowed to return to Canada when they changed their minds about the soundness of the decision. ${ }^{259}$

Both Peter Krawchuk and John Kolasky came from the Ukrainian-Canadian community, and were originally associated with the Ukrainian left. The difference between them is that Peter Krawchuk never publicly recanted on his political allegiances, while John Kolasky suffered a crisis of conscience after time spent in Soviet Ukraine, and subsequently wrote pointed critiques of his former comrades. Because of his association with members of the left, Peter Krawchuk's memoir Our History ${ }^{260}$ is full of references to individuals who were active in the AUUC and the CSFS, and whose names appear frequently in VOKS documents. On the other hand, John Kolasky's monograph ${ }^{261}$ and his collection of documents ${ }^{262}$ on the Ukrainian left show the bitterness of the debates and the individuals involved. Kolasky provides a particularly strong critique of how the USSR was emulated and obeyed unquestionably in leftist circles. Background is given on individuals and agencies whose activism overlapped with the CSFS, like John Boyd/Boychuk, Tim Buck, P. Prokopchak, W. Harasym, P. Krawchuk, Mary Kardash, William Kashtan, John Weir, Matthew Shatulsky, George Solomon, Globe Tours, S. Ziniuk, Eugene Dolny and the Shevchenko Ensemble. Kolasky also points to the decline of Ukrainian communism after Gouzenko's defection. ${ }^{263}$

\footnotetext{
${ }^{259}$ Serge Cipko and Glenna Roberts (and Peter Roberts), One Way Ticket: The Soviet Return to the Homeland Campaign, 1955-1960 (Manotick: Penumbra Press, 2008); Peter Roberts and Serge Cipko, "Canada and the Khrushchev Government's 'Return to the Homeland' Campaign," Occasional Paper no. 8 (Centre for Research on Canadian-Russian Relations, Carleton University, November 2000).

${ }^{260}$ Peter Krawchuk, Our History: The Ukrainian Labour-Farmer Temple Movement in Canada, 19071991 (Toronto: Lugus Publications, 1996).

${ }^{261}$ John Kolasky, The Shattered Illusion: The History of Ukrainian Pro-Communist Organizations in Canada (Toronto: P.M.A. Books, 1979).

${ }^{262}$ John Kolasky, ed., Prophets and Proletarians: Documents on the History of the Rise and Decline of Ukrainian Communism in Canada (Edmonton: Canadian Institute of Ukrainian Studies Press, 1990).

${ }^{263}$ Ibid., 445.
} 
Further ethnic group involvement with the CSFS surfaces elsewhere in the historiography. VOKS frequently mentioned "progressive" organizations within the Lithuanian, Estonian, Jewish, Latvian, Belorussian and Finnish communities in Canada, so the related secondary sources have been instructive. The cultural activities that were frequently central to a community's activism also provided links between different ethnic groups on the Canadian left. Establishing these links and 'performing' Soviet friendship was often about affirming political, cultural and ethnic identities in Canada. ${ }^{264}$ York University professor Varpu Lindstrom has published two studies on Finns in Canada, showing the motivations of Finnish immigrants, especially women, in joining leftist political organizations in Canada, their ideals and disillusionment in Canada, and the reasons the USSR seemed attractive to their needs. ${ }^{265}$ She also worked as the historical adviser for the NFB film "Letters from Karelia",266 which is a more visual depiction of these themes, built around the story of Aate Pikanen, who returned from Canada to Soviet Karelia, and was eventually executed by the Finns for spying on behalf of the Soviets. ${ }^{267}$

\footnotetext{
${ }^{264}$ The links between ethnic groups on the radical left and the issues of identity, community and culture, have been the subject of recent studies. See, Ester Reiter, "Secular Yiddishkait: Left Politics, Culture, and Community," Labour/Le Travail, Spring 2002, http://www.historycooperative.org/journals/1lt/49/05reiter.html, (10 Jun. 2008); Benita Wolters-Fredlund, "'We Shall Go Forward with our Songs into the Fight for Better Life:' Identity and Musical Meaning in the History of the Toronto Jewish Folk Choir, 1925-1959" (Toronto: University of Toronto, unpublished PhD thesis, 2005); Rhonda L. Hinther, "'Sincerest Revolutionary Greetings': Progressive Ukrainians in Canada, 1918-1991." (Hamilton: McMaster University, unpublished PhD thesis, 2005); Stacey Zembrzycki, "Memory, Identity, and the Challenge of Community Among Ukrainians in the Sudbury Region, 19011939." (Ottawa: Carleton University, unpublished PhD thesis, 2007).

${ }^{265}$ Varpu Lindstrom-Best, The Finns in Canada (Ottawa: Canadian Historical Association, 1985); Varpu Lindstrom, Defiant Sisters: A Social History of Finnish Immigrant Women in Canada (Toronto: Multicultural History Society of Ontario, 1992).

${ }^{266}$ National Film Board of Canada, Letters from Karelia, Directed by Kelly Saxberg, produced by Joe MacDonald, 2005.

${ }^{267}$ John Sadouski has written a book on Belorussians in Canada, but it does not contribute any information on Soviet friendship societies, or leftist groups within the Belorussian diaspora. John Sadouski, A History of the Byelorussians in Canada (Belleville: Mika Pub., 1981). The Baltic diaspora in Canada has not been the subject of a book length study, although historian Modris Eksteins has offered a moving testimony to the confused ethnic and national identities in the Latvian homeland. Modris Eksteins, Walking Since Daybreak (Toronto: Key Porter Books, 1999).
} 
The ideological considerations that informed these decisions may have been similar to those made by Finnish individuals in northern Ontario who attended CSFS events.

The negative image of European Communists in Canada was an important consideration in Moscow's decision to make the CSFS the primary purveyor of Soviet literature after the Gouzenko Affair. Individuals with Anglophone names were specifically chosen to head the CSFS, which saw its role as one of liaison between the ethnic groups and more mainstream Canadians. Certainly, the Soviet view that Canadian Slavic organizations were fiercely anti-Soviet, shaped political practices. Julie Guard has written about how the communist Housewives Consumers' Association made sure that leaders had Anglophone names, so that the cause would get better play in the Canadian press. ${ }^{268}$ She has also noted the negative attention their overlapping leftist memberships earned the Housewives from the RCMP. ${ }^{269}$

None of the studies discussed up to this point have taken Russian and Soviet perceptions of Canada into consideration. ${ }^{270}$ Here is another challenge to the present research. Particularly important is to consider the role of individuals and organizations in constructing and interpreting images during the Cold War. Images, and the persuasive impact they had, were central to Cold War rivalries. This is what Dyson Carter and the CSFS were all about. The friendship society was very much about constructing and

\footnotetext{
${ }^{268}$ Guard, "Canadian Citizens or Dangerous Foreign Women? Canada's Radical Consumer Movement, 1947-1950," in Epp, Iacovetta, Swyripa, eds., Sisters or Strangers? (Toronto, 2004), p. 161-189.

${ }^{269}$ Julie Guard, "Women Worth Watching: Radical Housewives in Cold War Canada," in Gary Kinsman, Dieter K. Buse, and Mercedes Steedman, eds., Whose National Security? Canadian State Surveillance and the Creation of Enemies (Toronto: Between the Lines, 2000), p. 72-88.

${ }^{270}$ On this, see Black and Hillmer, ed., Nearly Neighbours (Kingston, 1989); Black, "Canada and the Soviet Union in 1945: The View From Moscow" in Greg Donaghy, ed., Uncertain Horizons: Canadians and their World in 1945 (Canadian Committee for the History of the Second World War, 1996); Black, Canada in the Soviet Mirror (Ottawa, 1998).
} 
changing perceptions. ${ }^{271}$ The sources of information that informed the images of the enemy published in Canada and the USSR were not always accurate. ${ }^{272}$

What were the motives of the Soviet authorities in supporting a friendship society in Canada? Here, again, ideology must not be dismissed. ${ }^{273}$ Secondary sources to be considered must include historian Vladimir O. Pechatnov's working paper in which he confirms, based on newly released archival documents, ${ }^{274}$ that the Soviet leadership held a "firm belief in an "inevitable Anglo-American contradiction." 275 In the past, Western historians have been skeptical about the importance of ideology in Soviet foreign policy, but Pechatnov's paper proves that the belief in Lenin's theory that capitalism leads inevitably to war between imperialist powers remained unshaken even on the eve of the Cold War. ${ }^{276}$ Historian J.L. Black has suggested that Andrei Zhdanov, Josef Stalin's ideology guru, was among those who believed the Gouzenko affair was symptomatic of an organized anti-Soviet campaign in North America and a prelude to a British-American conflict. $^{277}$

\footnotetext{
${ }^{272} \mathrm{Black}$, Canada in the Soviet Mirror, 338.

${ }^{273}$ For background on Soviet ideology in this period see the following two very important books: Werner G. Hahn, Postwar Soviet Politics: The Fall of Zhdanov and the Defeat of Moderation, 1946-1947 (Ithaca, N.Y.: Cornell University Press, 1982); Gavriel D. Ra'anan, International Policy Formation in the USSR: Factional 'Debates' during the Zhdanovschina (Hamden, Connecticut: Archon Books, 1983).

${ }^{274}$ These documents were memos written in 1946 by the three most prominent Soviet diplomats of the day: Ivan M. Maisky, Maxim M. Litvinov and Andrei A. Gromyko.

${ }^{275} \mathrm{Th}$ is was the idea that an inherent rivalry existed between the United States and Britain which, some predicted could provoke a global crisis. Vladimir O. Pechatnov, "The Big Three After World War II: New Documents on Soviet Thinking about Post War Relations with the United States and Great Britain", Cold War International History Project, The Woodrow Wilson Centre (Working Paper no. 13, July 1995), 18. Italics in the original.

${ }^{276}$ Lenin believed that imperialism was an extreme version of capitalism which, because of its aggressive character, was the cause of war. See V.I. Lenin, Imperialism, the Highest State of Capitalism (1916) in Selected Works (New York, 1967).

${ }^{277}$ Black, "Soviet Tactics and Targets in Canada Before and After the Gouzenko Defection" in Black and Rudner, eds., The Gouzenko Affair, p. 108, 111.
} 
Between 1946 and 1947 debates of great ideological importance were taking place in the USSR, and their conclusions must have been important to foreign-policy planners. For example, it is clear from the transcript of the 1947 debate over prominent Soviet political economist Eugene Varga's book, Changes in the Economy of Capitalism Resulting From the Second World War, that Soviet experts were very reticent to question Stalin's interpretation of Lenin's theories. ${ }^{278}$ In a speech given to the Academy of Sciences of the USSR in 1946, Soviet historian G.F. Aleksandrov argued that what passed for freedom of the press in the United States and Britain actually perverted and corrupted democracy, and that Soviet democracy was more fully developed. ${ }^{279}$ Grigorii Fedorovich Aleksandrov was the head of Agitprop (Agitation and Propaganda), and was one of Stalin's premier idealogues. The CSFS, too, had stated clearly in its mandate the need to supplement Western reporting on the Soviet Union, and VOKS clearly supported this aim. If an Anglo-American conflict was to lead to the destruction of capitalism, could the role of the Canadian Soviet Friendship Society have been to prepare the intellectual foundation for a communist Canada? If a fair and accurate assessment of the role of the CSFS is to be given, Soviet motives in supporting the society must be taken into consideration.

So it was that this research came back to the issue of access to sources, and the theoretical issues connected to using them. Hoping to be invited to see documents on the CSFS still held in private collections, a trip to Toronto was made in September 2005 to meet the delegates to the World Congress for Friendship and Solidarity with the Soviet

\footnotetext{
278 "Soviet Views on the Post-War Economy: An Official Critique of Eugene Varga's 'Changes in the Economy of Capitalism Resulting from the Second World War"', $[1947]$ translated by Leo Gruliow and published by Public Affairs Press (Washington, 1948).

${ }^{279}$ G.F. Aleksandrov, "The Pattern of Soviet Democracy", (originally "O sovetskoy demokratii", speech delivered in 1946) translated by Leo Gruliow and published by Public Affairs Press (Washington, 1948).
} 
People, a group who advocate the re-establishment of the Soviet Union. Some of the most active members of this group knew Dyson Carter and other members of the CSFS. While explaining my project, one delegate insisted the truth be told. Other delegates questioned the possibility of a non-communist "objective observer." Could any historian immersed in their own research interests, really pretend to be completely "objective"? And to what extent would any "truth" eventually told be seen as such? What was made very clear was that although these people may have defined the "truth" differently from "mainstream" society, they nonetheless believed wholeheartedly in the value of their interpretation(s). Constructions and perceptions of the "truth" were not tangential, but central, to this story. As important as the archival sources were to this project, it was essential that they not only be read critically and sensitively, ${ }^{280}$ but also that oral history be considered as an important counter-point to any "story" that emerged from the documents.

In trying to approach a truthful version of the past, one must appreciate that those who had belonged to the CSFS subscribed to a different vision of the Cold War than most present-day historians. Their perspective generally meant appreciation for Josef Stalin, not as a murderer, but as a builder of the Soviet state; as Marxists they saw the Canadian authorities as representatives of a class, naturally repressing the rights of the Canadian working class. They chose to avoid buying into the commercialized idea about what made a person successful in the West, and they preferred to read about alternative political, social and philosophical approaches, particularly those emanating from the USSR. Franz Ankersmit's idea that theory functions as a belvedere -- that is, it is a "way

\footnotetext{
${ }^{280}$ On how historians should read "crookedly" or with an eye to the way archives presuppose the historical narrative, see Kellner, Language and Historical Representation, esp. p. 10 and McKay, Rebels, Reds, Radicals, 130-132.
} 
of seeing" that is dependent on "where you stand"281 makes sense in this connection.

This idea worked in relation to the CSFS research project because it incorporated the act of "seeing" with the positioning. It allowed a researcher from outside progressive circles to say of those studied that they saw things in this way because they stood here at this time in this place, looking in this direction. It also allowed some distance between them and the researcher.

Acknowledging that the researcher did not stand in the same place as the research subjects, allows for the recognition that one might look in the same direction and not see what they saw. For example, they lived through the Depression and the Second World War, they saw the rise of the Soviet Union as a possible model for social and political policies that appeared to be failing in the West. This researcher did not. She was able to travel, study and work relatively freely in countries of the former Soviet Union, and read widely of literature written in that part of the world, all with very little restriction. ${ }^{282}$ Furthermore, the researcher did not have an investment in any particular 'dream' that needed defending based on the realities in a particular part of the world. In considering theoretical approaches to research as a "belevedere," it is therefore possible for a researcher to position herself at a distance from beliefs to which she does not adhere, and also be able to consider that not all CSFS members ever located themselves in exactly the same place as Dyson Carter, for example. This theoretical position allows an historian to

\footnotetext{
${ }^{281}$ F.R. Ankersmit, Narrative Logic: A Semantic Analysis of the Historian's Language (The Hague: Martinus Nijhoff Publishers, 1983), p. 223. Also in his article "The Dilemma of Contemporary AngloSaxon Philosophy of History," History and Theory, vol. 25, no. 4 (Dec. 1986), 19.

${ }^{282}$ Growing up at the end of the Cold War, my knowledge of the Soviet Union was influenced by the masses of information that became public under Mikhail Gorbachev's policy of glasnost. I can understand absolutely the fascination that the Soviet Union represented for many CSFS members, as I too have spent years studying that part of the world, and its culture, politics, and society. I obtained a Combined Honours degree in History and Russian (language and literature) (1995), went on to get a Masters in Russian and East European Area Studies (1997), and lived for five years in Ukraine (1997-2002).
} 
take perception seriously, while at the same time suggesting that judgments based on perception can, in fact, be seen later to have been mistaken. The Soviet Union was never the idealized place it was made out to be by CSFS activists, and yet, in projecting their hopes for change onto the USSR, these Canadians articulated their desire for change at home.

In taking these themes into account, this project contributes to the recent historiography which has argued that our understanding of Canadian Cold War history is to a large degree shaped by discourses on what it meant to be "normal" in the context of the society of the time. For several years now, academics have been engaged in "retelling" Cold War history, emphasizing the use of newly divulged Soviet and Canadian sources, asking questions which take the cultural and ideological contexts of the period more seriously, and writing against what they argue has become a "master narrative."283 This growing literature has challenged the distinction between political and social history, showing that Cold War rhetoric shaped North American culture in the 1950s. Coming out of cultural studies, scholars have analyzed trends in popular culture, and pointed to the political aspect of the trends. ${ }^{284}$ The authors emphasize a rethinking of what it has meant to be a "radical" in the United States and Canada, with an explication of how individuals challenged the prevailing discourse of "normalcy." 285 Ian McKay has

\footnotetext{
${ }^{283}$ See the review of John Lewis Gaddis, We Now Know: Rethinking Cold War History (Oxford, 1997) by Melvyn P. Leffler called "The Cold War: What Do 'We Now Know'?" in The American Historical Review (vol. 104, no. 2, April 1999), p. 501-524.

${ }^{284}$ Stephen J. Whitfield, The Culture of the Cold War (Baltimore: Johns Hopkins University Press, 1991); Alan Nadel, Containment: American Narratives, Postmodernism, and the Atomic Age (Durham: Duke University Press, 1995); Joel Foreman, ed., The Other Fifties: Interrogating Midcentury American Icons (Urbana: University of Illinois Press, 1997).

${ }^{285}$ Elaine Tyler May, Homeward Bound: American Families in the Cold War Era (New York: Basic Books, 1988); Denis Smith, Diplomacy of Fear (1988); Wini Breines, Young, White, and Miserable: Growing Up Female in the Fifties (Chicago: University of Chicago Press, 1992); Alan Nadel, Containment Culture; Mary Louise Adams, The Trouble with Normal: Postwar Youth and the Making of
} 
argued that rather than "calling each leftism up before the Bar of History and deciding whether its partisans should be praised or damned" the historian's task is to try to understand "how each worked as a system of thought and structure of activism for the people involved in it" as "a kind of experiment in "living otherwise." ${ }^{286}$ But one obvious problem with this literature has been its tendency to downplay the very real Soviet presence in the Cold War, treating mainly the domestic aspects of the period's culture and politics.

Studying the "friends" of the USSR in Canada, therefore, means taking perception and ideology seriously, and accounting for issues of immigration and ethnic history, social history, political history, international relations and gender. This research aims at getting inside the skin of a Cold War organization at all levels of its existence. The CSFS message articulated by its leaders, and the fact that this message was ideologicallydriven, is important, but so too is the grass-roots motivation of rank-and-file members for joining and subscribing. Nostalgia for an ancestral homeland, and entertainment value may have made CSFS events and publications attractive. But members also found the CSFS message appealing because they believed in freedom for women and the working class, and saw the USSR as a symbol of socialism in action. Members believed these two phenomena were synonymous, although today we know they were not. Hence, we can recognize that perception was more significant than the Soviet reality, and it was only

Heterosexuality (Toronto: University of Toronto Press, 1997); Valerie Joyce Korinek, Roughing it in the Suburbs: Reading Chatelaine Magazine in the Fifties and Sixties (Toronto: University of Toronto Press, 2000); Lizabeth Cohen, A Consumer's Republic: The Politics of Mass Consumption in Postwar America (New York, Toronto: Knopf, 2003); Caren Irr, The Suburb of Dissent: Cultural Politics in the United States and Canada during the 1930s (Durham and London: Duke University Press, 1998); Joanne Meyerowitz, ed., Not June Cleaver: Women and Gender in Postwar America, 1945-1960 (Philadelphia: Temple University Press, 1994); Joy Parr, ed., A Diversity of Women: Ontario, 1945-1980 (Toronto, 1995); Richard Cavell, ed., Love, Hate and Fear in Canada's Cold War (Toronto: University of Toronto Press, 2004).

${ }^{286}$ Ian McKay, Rebels, Reds, Radicals, p. 130, 35. 
once the gap between its official image and the actual situation in the USSR became too wide to bridge that many CSFS members left the organization.

It is the oral history facet of this work that has most complicated the narrative of this project. Julie Cruikshank's discussion of the 'stories' told in oral interviews with Canadian native peoples has underscored the possibilities these interviews present historians. ${ }^{287}$ Like many academics exploring oral history for the first time, the initial thought was that the interviews would help to 'fill in the blanks' in dry documents, add colour, but not fundamentally change the study itself. But, one often finds that the stories that came out of the interviews were related hardly at all to the assumptions brought to the interviews. In fact, in most cases the interviewee allowed little time to pose questions -- they had their own ideas -- their own version of the "truth -- about what they considered needed to be known, and were not shy about telling the researcher what it was.

Prepared by Cruikshank and others to allow this to happen, the researcher followed the lead of the interviewee. This latitude added much to the interview. For instance, one issue brought up in the interviews was related to the role of women in the CSFS. On several occasions the interviewees were asked whether women's role in the Society was special in some way, or if they interacted differently with their children because of their involvement in the Society. The first time this question was asked to Michael Lucas, head of the Council for Solidarity with the Soviet People, currently existing in Toronto. Lucas' wife, Helen, had been involved in the Soviet Friendship organization from the early 1970s as secretary and treasurer. When asked about this,

${ }^{287}$ Julie Cruikshank, The Social Life of Stories: Narrative and Knowledge in the Yukon Territory (Vancouver: UBC Press, 1998); (with Angela Sidney, Kitty Smith and Annie Ned), Life Lived Like a Story: Life Stories of Three Yukon Native Elders (Lincoln: University of Nebraska Press, 1990). 
Lucas was clearly not expecting such a question. ${ }^{288}$ Background reading leads one to expect that women on the left were somehow different from their neighbours. But instead, Lucas went to some lengths to describe his wife as similar to other mothers and other wives, insisting even that she was 'normal'. This experience was repeated, even when the interviewee was a woman. ${ }^{289}$ Clearly, each of the interviewees wanted to assure the researcher that the women in the movement were 'normal'- they had been battling against perceptions of 'abnormality' from the earliest days.

This approach applied also to the raising of children. When Dyson Carter's successor, Les Hunt, was asked whether he and his wife had raised their children differently because of their political beliefs he said "No, we did it better." ${ }^{, 290}$ Asked how this was done, he said that they had made sure each of their children owned a house in order to protect them from the evils of capitalism. That was not expected. The researcher had been expecting reference to special political-awareness camps, Sunday schools, and other activities to train young leftists. From the historiographic reading, one would not expect an economically-determined approach to raising children, but rather a socially nurturing one. But yet this is where the significance lay. It is not surprising that a Marxist, particularly one who as a Barnardo boy during the Depression years, had seen his fair share of homelessness, would see the ownership of a house as a protection against the negative effects of capitalism.

\footnotetext{
${ }^{288}$ Michael Lucas, interview with author, 2 August 2006, Toronto.

${ }^{289}$ Sally (Thelma) Nielsen, interview with author, 28 November 2006, near Lakefield, Ontario; Irja Paul (and Irene Kuusela and Marie Rempel), 27 November 2006, Bracebridge, Ontario.

${ }^{290}$ Leslie Hunt, interview with author, 2 January 2007, Hanover, Ontario.
} 


\section{Drawing on work done by Julie Guard on the Housewives Consumers'} Association, ${ }^{291}$ as well as by Franca Iacovetta on the ways Canadian "gatekeepers" attempted to assimilate newcomers and anyone else perceived to be different, ${ }^{292}$ we can better understand how CSFS members negotiated their (self-) identities. Being normal, which essentially meant being white, Anglo-Saxon and behaving according to certain prescribed behavioural patterns, ${ }^{293}$ was the image purposely cultivated in the left-wing groups to give added respectability and therefore attractability to the movement. The CSFS had done this all along. And if this meant subverting beliefs in women's rights to the higher priorities of the cause, as Frances Swyripa has described was the case on the Ukrainian left, ${ }^{294}$ or if it meant changing names or allowing those with Anglo-Saxon names to take the leadership, that was all worth it. It was the oral history component that highlighted this aspect of the study. Reading the historiography and then consulting the documents alone would not have revealed this theme, because it was not until the interviewees were allowed to tell their own stories in their own ways, that the issue or 'normality' came into focus. When Michael Lucas was asked whether members admired the USSR for its social or political policies, he responded, "what's the difference?" Essentially, the interviewees were telling the researcher that their involvement with the CSFS was informed by their ideological approach and understanding of the world, influenced as well by class, gender and ethnic considerations. The biographical and

\footnotetext{
${ }^{291}$ Guard, "Canadian Citizens or Dangerous Foreign Women? Canada's Radical Consumer Movement, 1947-1950," in Epp, Iacovetta, Swyripa, eds., Sisters or Strangers?, p. 161-189.

${ }^{292}$ Franca Iacovetta, Gatekeepers: Reshaping Immigrant Lives in Cold War Canada (Toronto: Between the Lines, 2006.

${ }^{293}$ The pathbreaking work on radicalism in Canada and ethnicity is Donald Avery, Reluctant Host: Canada's Response to Immigrant Workers, 1896-1994 (Toronto, 1995). On Canadian responses to immigrants in Cold War Canada, see also Franca Iacovetta, Gatekeepers: Reshaping Immigrant Lives in Cold War Canada (Toronto: Between the Lines, 2006).

${ }^{294}$ Swyripa, Wedded to the Cause; Sangster, Dreams of Equality; Johnston, A Great Restlessness.
} 
methodological chapter that deals most specifically with the oral history evidence has therefore been placed in an appendix to this dissertation; not because it should be read after the rest, but because it offers a parallel, and in some cases, contradictory, narrative. Canadian historian Robert Bothwell has pointed out that the Cold War is recent history, and much is still not known. Writing in 1997, Bothwell wrote that "much remains secret in the hands of governments that have an interest in obscuring or protecting past errors. But secrets sometimes have the effect of obscuring the obvious. ${ }^{.295}$ In this context it is also useful to reflect on an observation made the same year by Gregory A. Johnson: "the real problem with ....all treatments of the Cold War, is that the analysis is one-sided" because Western historians did not have access to Soviet sources. Johnson argued that as archives open up and dialogue increases, historians will be able to judge if the "actors of the time had it right or wrong" and "whether left historiography will find itself a winner or a loser in what ironically will be a post-Cold War battle. ${ }^{, 296}$

Today, with the end of tensions and the opening of archives, historians can more readily address these questions. A decade since the Cold War ended, people who were involved are themselves coming forward, willing to be interviewed and to discuss their perception of the USSR, and what was, and was not, "obvious." Work done in the fields of immigrant and gender history allows us to expand on what has, until recently, been a traditional political history approach to this subject. The CSFS worked to persuade Canadians that the USSR was a friendly, peaceful neighbour, and Canadians who joined the CSFS or subscribed to their journals did so because they found an appeal in the

\footnotetext{
${ }^{295}$ Robert Bothwell, The Big Chill: Canada and the Cold War (Toronto, 1998), 108.

${ }^{296}$ Gregory A. Johnson, review of Cold War Canada in the Canadian Historical Review (vol. 78, no. 1, March 1997), p. 139-141.
} 
message. This is a complex, multi-faceted story of political persuasion and propaganda in Cold War Canada. It deals with a real attempt by the Soviet authorities to influence Canadians to view the USSR sympathetically. It deals with the close link between the Communist Party of Canada, "front" organizations like the Canadian Soviet Friendship Society, and the Moscow authorities. And it deals with the slippery business of "truth" and discourse about individuals' perception of -- and their effect on -- international relations. As Andrée Lévesque has suggested, today we must present this history differently, and it is time these stories were told. 


\title{
Chapter Four \\ THE PRO-SOVIET MESSAGE IN WORDS AND IMAGES: DYSON CARTER AND THE CSFS LITERATURE AND PHOTOGRAPHS
}

\author{
For forty years Dyson Carter, ${ }^{297}$ a Canadian admirer of the Soviet Union,
}

produced literature that mixed a radical political message with articles on Soviet science

and medical advances. This literature, which Carter claimed was sent to thousands of

subscribers internationally, ${ }^{298}$ maintained the Soviet political line from the first issue of

News-Facts in 1950, to the last issue of Northern Neighbors in 1989, and promised

readers an up-beat alternative view to what Carter considered to be "Western

propaganda." Arguing that Western government authorities were censoring or twisting

information provided to their citizens, Carter claimed to be a beacon in the night,

allowing his readers an inside view of the enlightened and altruistic Soviet experiment.

Carter combined text and photographs to produce this message. As president of the

Canadian Soviet Friendship Society (CSFS) from 1949 to 1960 , he organized events that

disseminated the pro-Soviet message orally and in photograph and film exhibitions.

Using Soviet sources, Carter produced what was essentially Soviet propaganda, ${ }^{299}$

\footnotetext{
${ }^{297}$ For an unpublished biography of Dyson Carter, see Mary Eleanor Barber Watson, "Study of Dyson Carter's Life and Works" (Ottawa: Carleton University, Undergraduate paper, 1974). His role in promoting the USSR and socialism has been touched upon in J.L. Black and Norman Hillmer, "Canada and the Soviet Union as Neighbours," in Nearly Neighbours: Canada and the Soviet Union from Cold War to Détente and Beyond, eds. J.L. Black and Norman Hillmer (Kingston, Ont.: Frye, 1989), 6, 7; J.L. Black, Canada in the Soviet Mirror: Ideology and Perception in Soviet Foreign Affairs, 1917-1991 (Ottawa: Carleton University Press, 1998); J.L. Black, "Soviet Tactics and Targets in Canada Before and After the Gouzenko Defection," in The Gouzenko Affair: Canada and the Beginnings of Cold War Counter-

Espionage, eds. J.L. Black and Martin Rudner (Manotick, Ontario: Penumbra Press, 2006), 108-29; James Doyle, Progressive Heritage: The Evolution of a Politically Radical Literary Tradition in Canada (Waterloo, Ont.: Wilfred Laurier University Press, 2002); and Faith Johnston, A Great Restlessness: The Life and Politics of Dorise Nielsen (Winnipeg: University of Manitoba Press, 2006).

${ }^{298}$ This claim appeared on the banner of Northern Neighbors. See also Gravenhurst News (6 December 1985).

${ }^{299}$ Literature on Soviet propaganda in the West has at times been polemical and defensive, but there have also been more balanced attempts to understand the role of ideology and perception in creating political propaganda. The word "propaganda" in Russian is not pejorative and is derived, as it is in English, from the verb to propagate or to diffuse information. In this sense, it was close to the Soviet understanding of
} 
ironically emanating not from across the Arctic, but from Ontario. This message was carried in images and perceptions of the North, to which Canadians readily were drawn. Carter's attempted to persuade progressives that the USSR represented the realization of their ideals of gender, class, and ethnic equality, and scientific and technological superiority.

The history of the CSFS and Dyson Carter's role as a promoter of the Soviet Union is linked to the history of the Canadian left, ${ }^{300}$ but adds a new perspective to the historiography. Carter was a member of the Communist Party of Canada from the $1930 \mathrm{~s},{ }^{301}$ as were several of the other core CSFS organizers and members, but the rankand-file CSFS membership and readership was mostly drawn from the non-Party left.

\footnotetext{
"political education," thus the Bolshevik acronym "Agitprop" (Agitation and Propaganda). Consider, for instance, Ian Greig, The Assault on the West (Peterham: Foreign Affairs Publishing, 1968); Mark W. Hopkins, Mass Media in the Soviet Union (New York: Pegasus, 1970); Anatoliy Golitsyn, New Lies for Old: The Communist Strategy of Deception and Disinformation (New York: Dodd and Mead, 1984); Jean Delmas and Jean Kessler, eds., Renseignement et propagande pendant la guerre froide, 1947-1953 (Bruxelles: Editions complexe, 1999); Black, Canada in the Soviet Mirror; David Caute, The Dancer (Toronto: Progress Books, 1968); Ivan Avakumovic, The Communist Party in Canada: A History (Toronto: McClelland and Stewart, 1973); Louise Watson, She Never Was Afraid: The Biography of Annie Buller (Toronto: Progress Books, 1976); Norman Penner, The Canadian Left: A Critical Analysis (Scarborough, Ont.: Prentice Hall of Canada, 1977); Stephen Endicott, James G. Endicott: Rebel Out of China (Toronto: University of Toronto Press, 1980); Ian Angus, Canadian Bolsheviks: The Early Years of the Communist Party of Canada (Montreal: Vanguard, 1981); Merrily Weisbord, The Strangest Dream: Canadian Communists, The Spy Trials, and the Cold War (Montréal: Véhicule, 1983, 1994); Peter Hunter, Which Side Are You On Boys ... Canadian Life on the Left (Toronto: Lugus, 1988); Bryan D. Palmer, ed., A Communist Life: Jack Scott and the Canadian Workers Movement, 1927-1985 (St. John's, Nfld.: Committee on Canadian Labour History, 1988); Norman Penner, Canadian Communism: The Stalin Years and Beyond (Toronto: Methuen, 1988); Joan Sangster, Dreams of Equality: Women on the Canadian Left, 1920-1950 (Toronto: McClelland and Stewart, 1989); Andrée Lévesque, Scènes de la vie en rouge: L'Époque de Jeanne Corbin, 1906-1944 (Montréal: Éditions de remue-ménage, 1999); Maurice Rush, We Have a Glowing Dream: Recollections of working-class and people's struggles in B.C., 1935-1995 (Vancouver: Center for Socialist Education, 1996); Cy Gonick, A Very Red Life: The Story of Bill Walsh (St. John's, Nfld.: Canadian Committee on Labour History, 2001); Julie Guard, "Canadian Citizens or Dangerous Foreign Women? Canada's Radical Consumer Movement, 1947-1950," in Sisters or Strangers? Immigrant, Ethnic, and Racialized Women in Canadian History, eds. Marlene Epp, Franca Iacovetta, and Frances Swyripa (Toronto: University of Toronto Press, 2004), 161-89; Faith Johnston, $A$ Great Restlessness (Winnipeg: University of Manitoba Press, 2006).

${ }^{301}$ John Boyd, private collection (hereafter Boyd collection), Dyson Carter to John Boyd, 28 February 1990.
} 
Very little has been written on fellow travellers in Canada. ${ }^{302}$ This story hints at the radical aspirations and goals of some Canadians during the Cold War; individuals who may have appeared quite "normal,"303 but who "lived otherwise"304 and interpreted Cold War international relations differently than their neighbours. Ironically, it is the demise of the USSR that makes it possible to tell this story today. "Telling the truth about the Soviet Union" was the constant theme of the literature, speeches, and cultural exchanges sponsored by the CSFS. Through their own publications, and in distributing Soviet magazines published specifically for foreign readers, the CSFS challenged the discourse of "truth" which characterized Cold War

302 On fellow-travellers in the United States, Britain, and Western Europe, David Caute has published The Fellow-Travellers: Intellectual Friends of Communism (New Haven, CT: Yale University Press, 1988); revised edition of The Fellow Travellers: A Postscript to the Enlightenment (London: Weidenfeld and Nicholson, Ltd., 1973). Julia L. Mickenberg's Learning from the Left: Children's Literature, the Cold War, and Radical Politics in the United States (Oxford: Oxford University Press, 2006) is also useful in this connection.

${ }^{303}$ A growing literature has challenged the distinction between political and social history, showing that Cold War rhetoric shaped North American culture in the 1950s. Coming out of cultural studies, this scholarship has analyzed trends in popular culture, and pointed to the way these trends were influenced by political considerations. This work has, in turn, led to a rethinking of what it has meant to be a "radical" in the United States and Canada. Implicit in this work is an explication of how individuals challenged the prevailing discourse of "normalcy" and the significance of ideology. See the review of John Lewis Gaddis" We Now Know: Rethinking Cold War History (New York: Oxford University Press, 1997) by Melvyn P. Leffler, "The Cold War: What Do 'We Now Know'?" The American Historical Review 104, no. 2 (April 1999): 501-24; Stephen J. Whitfield, The Culture of the Cold War (Baltimore: Johns Hopkins University Press, 1991); Joel Foreman, ed., The Other Fifties: Interrogating Midcentury American Icons (Urbana: University of Illinois Press, 1997); Elaine Tyler May, Homeward Bound: American Families in the Cold War Era (New York: Basic Books, 1988); Denis Smith, Diplomacy of Fear: Canada and the Cold War, 1941-1948 (Toronto: University of Toronto Press, 1988); Wini Breines, Young, White, and Miserable: Growing Up Female in the Fifties (Chicago: University of Chicago Press, 1992); Alan Nadel, Containment Culture: American Narratives, Postmodernism and the Atomic Age (Durham: Duke University Press, 1995); Mary Louise Adams, The Trouble with Normal: Postwar Youth and the Making of Heterosexuality (Toronto: University of Toronto Press, 1997); Valerie Joyce Korinek, Roughing it in the Suburbs: Reading Chatelaine Magazine in the Fifties and Sixties (Toronto: University of Toronto Press, 2000); Lizabeth Cohen, $A$ Consumer's Republic: The Politics of Mass Consumption in Postwar America (New York: Knopf, 2003); Caren Irr, The Suburb of Dissent: Cultural Politics in the United States and Canada during the 1930s (Durham, NC: Duke University Press, 1998); Joanne Meyerowitz, ed., Not June Cleaver: Women and Gender in Postwar America, 1945-1960 (Philadelphia: Temple University Press, 1994); Joy Parr, ed., A Diversity of Women: Ontario, 1945-1980 (Toronto: University of Toronto Press, 1995); Caute, The Dancer Defects; Richard Cavell, ed., Love, Hate and Fear in Canada's Cold War (Toronto: University of Toronto Press, 2004).

${ }^{304}$ Ian McKay, Rebels, Reds, Radicals: Rethinking Canada's Left History (Toronto: Between the Lines, 2005), 35. 
rhetoric in mainstream Canadian society. Upon their return from tours of the Soviet Union, members took part in cross-Canada speaking engagements organized by the CSFS, arguing that the prevalent Western view of the Soviet Union as sinister and backward was false. These arguments were built using the language of the progress and enlightenment, and the USSR was held up by foreign admirers as the only state willing and able to construct a truly "progressive" society. ${ }^{305}$ The cost of this project was not up for consideration. CSFS members were "high modernists" - a term used by James C. Scott in Seeing Like a State ${ }^{306}$ to denote a "faith" in the possibility that scientific rationalism can cure all social ills, and in admiration of highly rational, scientific state planning done in the name of egalitarianism. CSFS members visited Soviet hospitals, sanatoriums, prisons, factories, collective farms, and schools, and everywhere admired the order and egalitarianism they saw. They were interested in how "average" people lived and in the workings of "everyday socialism" in the Soviet Union. ${ }^{307}$ They were interested in how Soviet women were treated. They were interested in peace. They never appeared to notice that much of what they saw was purposely prepared for them, as Potemkin villages. Instead, they reported back on their observations, emphasizing that, like scientific observers, they were witnesses and could attest to the truth in these social experiments. The CSFS newspaper News-Facts and Dyson Carter's Northern Neighbors magazine published information on old age and health in the USSR, innovations in the

\footnotetext{
${ }^{305}$ On the link between fellow-travellers and the language and ideals of the Enlightenment, as well as the way the USSR was seen to embody these ideals, see Caute, The Fellow-Travellers, especially 250-66.

${ }^{306}$ James C. Scott, Seeing Like a State: How Certain Schemes to Improve the Human Condition Hove Failed (New Haven, CT: Yale University Press, 1998). Scott argued that "high modernism" was a "faith" or "ideology" based on the idea that scientific and technological progress could be used by a state to create an improved social order and to champion nature (see 4-6).

${ }^{307}$ Adapted from the term "everyday Stalinism" used by Sheila Fitzpatrick in Everydoy Stalinism: Ordinary Life in Extraordinary Times: Soviet Russia in the 1930s (New York: Oxford University Press, 1999).
} 
treatment of cancer, sport and physical culture, greetings from Moscow schools, and Soviet innovations and inventions. The CSFS thus appeared as a projector of social idealism, acted out through "friendship" with the Soviet Union.

How do we understand this techno-utopian view of the future, and the Soviet Union's prominent place in it? It might help to know that Dyson Carter himself was something of a science-miracle boy. Raised by Salvation Army parents in a home for the rehabilitation of juvenile delinquents, no amount of prayer was able to help young Dyson overcome the condition of osteogenesis imperfecta, with which he was afflicted. A rare bone disorder which meant that the slightest impact or pressure could break his bones, Carter did not walk until he was 14 and only after he accidentally took a super-dose of vitamin D. Doctors were just learning that vitamin D aided in the absorption of calcium, and could be useful in curing rickets and other bone disorders. In 1932, Carter earned a master's degree in chemistry from the University of Manitoba, and his articles on popular science and engineering were published in mainstream journals through the 1930s and $1940 \mathrm{~s}^{308}$ Carter was convinced that a cure for many common ailments and diseases was just around the corner, but although he had full confidence in scientists, he worried that because of press bias, citizens of North America might not be informed of Soviet scientific advances in a timely fashion. Carter's wife Charlotte ${ }^{309}$ died of cancer in 1972 , and this may have played a role in his publication of numerous articles on research and treatments for cancer, at home and especially in the USSR. Publishing this material,

\footnotetext{
${ }^{308}$ Doyle, Progressive Heritage, 174-79; Dyson Carter, This Story Fierce and Tender (Gravenhurst, Ont.: Northern Book House, 1986).

${ }^{309}$ Unfortunately we know very little about Charlotte Carter. Charlotte and Dyson Carter's son Breck was not available for oral interviews. Some additional comments on Charlotte Carter's role in the CSFS and as Dyson's partner will be discussed in the chapter on the role of women in the CSFS.
} 
knowledge apparently "hidden" by the Western powers-that-be from their denizens, ${ }^{310}$ became his raison d' être. Rejecting the religious evangelism of his parents, Carter took up secular evangelism. His was a belief in the ability of science, and Soviet science in particular, to solve society's problems. ${ }^{311}$

It is important to understand the symbolic significance the USSR held for many Canadian leftists at this time. As Merrily Weisbord and James Laxer have suggested, in looking to the Soviet Union, Canadian communists and sympathizers were seeking a concrete example of how their beliefs could be implemented, and at times were willing to close their eyes to unflattering evidence of Soviet reality in order to maintain this ideal. ${ }^{312}$ Progressive Canadians with ethnic roots in Eastern Europe saw the Soviet Union as embracing and promoting the cultures of the various peoples and republics. ${ }^{313}$ It is likely that individual members were constantly negotiating a compromise between their ideals and the practical realization of them, in Canada and abroad. In oral interviews, former

${ }^{310}$ A discussion of the concept of "rejected knowledge" prevalent in radical literature can be found in Michael Barkun, A Culture of Conspiracy: Apocalyptic Visions in Contemporary America (Berkeley, Los Angeles, London: University of California Press, 2003), 23-4.

${ }^{311}$ For more on Carter's upbringing in a Salvation Army home, and his parents outreach activities, please see Appendix I.

${ }^{312}$ See Weisbord, The Strangest Dream. A similarly personal experience with communism is described by James Laxer in Red Diaper Baby: A Boyhood in the Age of McCarthyism (Vancouver, Toronto: Douglas and Mclntyre, 2004). In the American context, Kim Chernin describes how and why communists and Soviet sympathizers admired the USSR, and the ways narrative is constantly reformulated by the storyteller, the reader, and the circumstance. Kim Chernin, In My Mother's House: A Daughter's Story (New York: Harper Collins, 1983, 1994).

${ }^{313}$ See, for instance, Frances Swyripa, Wedded to the Cause: Ukrainian-Canadian Women and Ethnic Identity, 1891-1991 (Toronto: University of Toronto Press, 1993); Varpu Lindstrom-Best, The Finns in Canada (Ottawa: Canadian Historical Association, 1985); Varpu Lindstrom, Defiant Sisters: A Social History of Finnish Immigrant Women in Canada (Toronto: Multicultural History Society of Ontario, 1992). The path breaking work on radicalism in Canada and ethnicity is Donald Avery, Reluctant Host: Canada's Response to Immigrant Workers, 1896-1994 (Toronto: McClelland and Stewart, 1995), which is a re-working and expansion of his earlier "Dangerous Foreigners": European Immigrant Workers and Labour Radicalism in Canada, 1896-1932 (Toronto: McClelland and Stewart, 1979). On Canadian responses to immigrants in Cold War Canada, see also Franca Iacovetta, Gatekeepers: Reshaping Immigrant Lives in Cold War Canada (Toronto: Between the Lines, 2006). On the way leaders with Anglo-Saxon names were chosen to head up the radical consumer's movement in the late 1940s, in order to avoid being seen as "communist," see Guard, "Canadian Citizens or Dangerous Foreign Women?" 161-89. 
Friendship Society activists speak about the need of researchers to understand that the Depression was a terrible time in Canada, and that the Communist Party was the only group standing up for the working person. References to philosophical similarities between Christianity and communism are also frequent, and several of those involved explain that they came to the movement through the United Church or other Social Gospel-based groups. The Soviet Union appeared to these people as the only nation in the world that had successfully established a system that did not exploit the lower classes, and for this it was admired. When through the years, evidence from Moscow showed the USSR to be less than ideal, some members left the Party, the Friendship Society, and the movement, while others hung on. These decisions were not taken lightly, and many experienced disillusionment, anger and even a sense of betrayal in the process. ${ }^{314}$

What many CSFS members and readers may not have known is that despite the seeming altruism of his activism, Dyson Carter made a living as a propagandist for the USSR. He received materials from the Soviet Union via the All-Union Society for Friendship and Cultural Relations with Foreign Countries (VOKS) and its successor, the Canada-USSR Society, and he took every policy turn in step with Moscow. His income consisted of the subscription payments, generous donations sent by his readership, as well as payment for books purchased from him, all of which he had received at no cost from Moscow. ${ }^{315}$ In addition, his second wife, Sally Nielsen, remembers that the Soviet

\footnotetext{
314 John Boyd, interview with author, 2 August 2006, Toronto, Ont.; John Boyd, "A Noble Cause Betrayed ... But Hope Lives On: Pages from a Political Life," originally published as Canadian Institute of Ukrainian Studies Report, no. 64, 1999; Socialist History Project, $<$ http://www.socialisthistory.ca/Remember/Reminiscences/Boyd/B1.htm> (viewed 25 August 2007); Sally (Thelma) Nielsen, interview by author, 28 November 2006, near Lakefield, ON.; Leslie Hunt, interview by author, 2 January 2007 , Hanover, ON.

${ }^{315}$ There are references to products and books shipped to Carter for sale throughout the VOKS collection. Carter wrote frequently to VOKS asking for material on particular subjects for publication. A report sent from the Soviet Information Bureau representative in Canada in 1954 specified the number of articles and
} 
embassy staff themselves periodically brought him cash bonuses, and that he received some financial support from the Communist Party of Canada. ${ }^{316}$ With these funds he invested in Bay Street stocks and bought real estate. When he sold the warehouse he used for his journal and bookhouse, he apparently turned a profit on the deal. He lived out his life in a comfortable home in Gravenhurst, Ontario. But there is no doubt that Dyson Carter believed sincerely in the USSR and its brand of socialism. Sally Nielsen, daughter of one of the original CSFS leaders, Dorise Nielsen, had known Dyson for many years before she married him in 1980 and has said that he was greatly disappointed with Mikhail Gorbachev's reforms, but "quickly changed his tune in order to keep his job."317

The Soviets were pleased when Dyson Carter was chosen as president of the Canadian-Soviet Friendship Society in 1949, praising him as a propagandist of longstanding. ${ }^{318}$ In 1952, an article about Carter in the Soviet magazine Ogonyok called the picture of the USSR given by Dyson and Charlotte Carter in We Saw Socialism "correct." "319 Ogonyok gave a favourable review of Dyson Carter's latest book, The

partial articles the office had supplied that year to the progressive press in Canada, including News-Facts. Centre for Research on Canadian-Russian Relations, Georgian College, Barrie, Ont., VOKS collection (hereafter VOKS), Series 6, Section 3, File 97, 36-47, V. Kachanov, Deputy Director of the Soviet Information Bureau in Canada, Top Secret report of the Mission of the Soviet Information Bureau in Canada in 1954. Documents originally in Russian have been translated by the author.

${ }^{316}$ Sally (Thelma) Nielsen, interview by author, 28 November 2006, near Lakefield, ON; also John Boyd, interview by author, 2 August 2006, Toronto. The RCMP confirmed in 1960 that the Communist Party of Canada would carry on subsidizing Carter's publication of Northern Neighbors magazine because it was popular and considered "useful." (LAC, RG25, A200700336, RCMP Research Section report, "The Canada-USSR Association," 27 March 1963, p. 834-845.) John Boyd has commented that the Party tried to convince the Soviet Embassy to distance themselves from Carter after 1960, but the Embassy personnel maintained in close contact with him for the same reasons. (John Boyd, comments on manuscript by Jennifer Anderson, April 2008.)

${ }^{317}$ Sally (Thelma) Nielsen interview.

${ }^{318}$ VOKS, 5:3:31:202, "Kharakteristika Prezidenta Obshestvo Kanado-Sovetskoi druzhbi Daisona Cartera" ["Biography of the President of the Canadian-Soviet Friendship Society, Dyson Carter"], 1950.

${ }_{319}$ Library and Archives Canada (hereafter LAC), RG1 46, A200600101, 124, RCMP translation of G. Vladimirov and D. Erde, "Exposed Provocation," Ogonyok, no. 37 (September 1952), dated 27 September 1952; VOKS, 6:1:41:5-8, K. Perevoschikov, Review of Carter's 1943 biography of Josef Stalin, 13 April 1953. Perevoschikov said that in the biography of Stalin, Carter "correctly" describes Stalin's activities and events in the USSR. 
Future is With Us (translated as The Future is Ours), and compared one of his characters to the mother figure in Maxim Gorky's Mother (high praise from the Soviets) for her exclamation that the radical pamphlets she printed were "pure truth! Like the holy scriptures!" ${ }^{320}$ The review pointed to the popularity of Carter's books in left-wing American circles, and noted that the action in the novel could be taking place in Canada or the United States. The Soviets clearly saw Carter and the CSFS as a kind of information bridge to American, as well as Canadian, audiences, and American readers of his publications often wrote to Carter. ${ }^{321}$

Carter was already relatively well-known in Canada during the Second World War as a science writer, and for his descriptions of the Soviet Union as an ally. For instance, his Sea of Destiny, published in 1940, warned that Canada's undefended North could leave it open to Nazi invasion, and Russia's Secret Weapon (1943) suggested that the power of the USSR was its ethos of positivism in the promotion of science and universal well-being. ${ }^{322}$ For the Soviets, it did not hurt that Carter also wrote an admiring biography of Josef Stalin, ${ }^{323}$ and in 1945 he published an account of why he became a member of the Labor Progressive Party. ${ }^{324}$ Other books Carter published, sometimes coauthored with Charlotte Carter, included comparisons of the medical care and health of Canadians and Soviets, stories about the difficult living conditions for Canadian miners

\footnotetext{
${ }^{320}$ LAC, RG146, A200600101, RCMP translation of Vladimirov and Erde, "Exposed Provocation," 125.

${ }^{321}$ Letters from American readers can be found in the VOKS collection, as well as in the Dyson Carter fonds at LAC (MG31-D182).

${ }^{322}$ Dyson Carter, Sea of Destiny: the Story of Hudson Bay-our Undefended Back Door (New York: Greenberg, 1940); Dyson Carter, Russia's Secret Weapon (London: Hooper, 1943); and see also Doyle's commentary on Carter's literary work in Progressive Heritage, 105-6, 174-9, 224-30, 258-62.

${ }^{323}$ Dyson Carter, Stalin's Life: At Last the True Story (Winnipeg: Contemporary Publishers, 1943).

${ }^{324}$ This declaration was published as Dyson Carter, "Dyson Carter Explains: Why I've Joined the LPP," Canadian Tribune (15 December 1945); but Carter said elsewhere that he had been a Party member since 1931. Carter and John Boyd were in the same closed Party group in Winnipeg at that time. Boyd collection, Dyson Carter to John Boyd, 28 February 1990; John Boyd interview.
} 
and their families, and the discrimination affecting poor Americans, and UkrainianCanadians and Blacks on the Canadian prairies. ${ }^{325}$

The style and themes of his writing led many on the Canadian left to find in Carter's work a reflection of their own ideals. For instance, Robert (Mendel) Laxer, an organizer with the Labor Progressive Party, called Carter "Canada's best writer." ${ }^{\text {"326 }}$ It appears as well that Carter's combination of scientific and technologically-oriented articles had particular appeal to the subscribers of News-Facts, and later Northern Neighbors. When towards the end of the 1950s, the Canadian Communist Party put a new person in charge of the Friendship Society and renamed the group the Canada-USSR Association, Carter continued to publish Northern Neighbors. ${ }^{327}$

The Friendship Society based its perceptions of the Soviet Union on a very Thucydidean notion that "being there" and "seeing the facts for oneself," combined with a special talent for seeing through "Western propaganda," provided their members with a healthy perspective on Cold War politics. This perspective was presented as the basis for true knowledge about the Soviet reality, a knowledge that could and should be passed on to other Canadians. For example, in its draft constitution of January 1952, the CSFS's

\footnotetext{
${ }^{325}$ Other published books by Dyson Carter include Men, Machines and Microbes (Winnipeg: Contemporary Publishers, 1942); Night of Flame (New York, 1942;. London: Chapman, 1946); Atomic Dollars (Winnipeg: Frontier Books, 1946); Sin and Science (New York: Heck-Cattell 1946); Fatherless Sons (Toronto: Progress Books, 1955); (with Charlotte Carter), Science of Health and Long Life in the U.S.S.R. (Sydney: Current Book Distrib., 1956); (with Charlotte Carter), Cancer, Smoking, Heart-Disease, Drinking in Our Two World Systems Today (Toronto: Northern Book House, 1957); The Big Brainwash (Toronto: Northern Book House, 1958); Future of Freedom (Gravenhurst, Ont.: Northern Book House, 1961); Worker Power: Dare We Win? (Gravenhurst, Ont.: Northern Book House, 1970); and his semiautobiography, This Story Fierce and Tender (Gravenhurst, Ont.: Northern Book House, 1986). An interview with Dyson Carter appeared in the Moscow English-language newspaper, The New Times, 41 (October 1983), 27. His article on new treatments for heart disease, "How Not to be Afraid of your Heart," was published in New Liberty, vol. 29, August 1952, p. 22-23, 62-63, but no mention was made of the USSR or the CSFS. For a listing of Carter's publications in the USSR, showing that he was published there almost every year between 1956 and 1983, see J.L. Black, Soviet Perception of Canada, vol. I (Ottawa: Carleton University, 1987), p. 231.

${ }^{326}$ Laxer, Red Diaper Baby, p. 25.

${ }^{327}$ Leslie Hunt interview; John Boyd interview.
} 
aim was proclaimed to be: "develop friendship between the peoples of Canada and the peoples of the Soviet Union," which would

be realized by bringing to the Canadian peoples, in every possible way:

a) Information about all aspects of life in the Soviet Union today;

b) The truth that the Soviet peoples and their Government want peace and friendship with all countries;

c) Facts concerning the great advantage Canada can gain by economic, cultural and scientific exchange and co-operation between our country and the Soviet Union. ${ }^{328}$

This aim was to be accomplished using the CSFS journal News-Facts as "the chief means for building the Society and achieving its aims. ${ }^{.329}$ Leading members of the CSFS repeatedly argued that any suggestion that the Society served Moscow's interest was the result of anti-Soviet sentiments that had taken root in Canada since the beginning of the Cold War. Rather than appealing exclusively to convinced communists in Canada, the CSFS emphasized that its membership included Canadians of all political stripes, those who simply wished to see a warmer international climate. For instance, in his "President's Speech," given at the first CSFS conference in 1952, Dyson Carter said:

no doubt there will be efforts, by those whose aim is to promote hatred, not friendship, efforts to make people think the Friendship Society has aims which are not made public in our constitution. For example: some people will say the aim of the Friendship Society is to bring about Socialism in Canada, to do away with the capitalist system in our country. This is not true .... True, the Friendship Society does include people who would like to see Socialism in Canada. But the majority of Friendship supporters are people who believe in the economic and political system we have in Canada, the capitalist system. ${ }^{330}$

Probably Carter was exaggerating these claims to some extent. The idea of "friendship" with the USSR had broader appeal between 1941 and 1945, while the Soviet Union was

\footnotetext{
${ }^{328}$ VOKS, 6:1:36:19, "Canadian-Soviet Friendship Society, Draft Constitution", January 1952, 1951-1952.

${ }^{329}$ Ibid.

${ }^{330}$ VOKS, 6:1:36:60, “President's Speech, January 27, 1952," Carter's emphasis, 1951-1952.
} 
an ally, but after the defection of Igor Gouzenko, a cipher clerk at the Soviet Embassy in

Ottawa in late 1945, prominent "friends of the USSR" had become skeptical about such

claims. In adopting the rhetoric of earlier times, Carter probably hoped to convince those

on the non-Party left that they were in good company. As it was, the CSFS gained most

of its positive press from the established left-leaning papers. ${ }^{331}$

Still, the "truth" argument was one that Carter frequently used. He argued that

"the Canadian people want the truth, the facts. The job ahead is to get the truth, the facts, into their hands! ... What is the greatest, most inspiring truth brought forward at this convention? - that friendship with the Soviet Union is a means to preserving world peace." 332 Frequently referring to negative reports on the USSR as "slander," the CSFS worked to produce information that would disprove claims it saw as "untruthful." For example, Dyson Carter wrote:

... a flood of fantastic anti-Soviet slanders [have been] poured on the Canadian people for so long. Truth has been virtually excommunicated from the press. But the love of truth and reason is deeply engrained in Canadian [sic] character, founded as it is upon intermingling of French and British democratic traditions and the freedom-loving spirit of millions of immigrant European

\footnotetext{
${ }^{331}$ During World War II, the National Council of Canadian-Soviet Friendship enjoyed broad mass support and many prominent Canadians were honorary members, including Prime Minister Mackenzie King. However, soon after Igor Gouzenko defected from the Soviet Embassy in the fall of 1945, an event which most historians agree signalled the beginning of the Cold War in Canada, the National Council membership dropped off sharply, and in February 1949 the Royal Canadian Mounted Police told Under-Secretary of State for External Affairs, Lester B. Pearson, that it was "inactive." VOKS suggested that the Council's trouble was "absence of leadership," lack of funds, and an anti-Soviet campaign. In November 1949 the National Council was reorganized, under the leadership of Dyson Carter, who claimed that Council members who "withdrew their support" had done so "(many with sincere regrets) due to anti-Soviet hysteria." See Amy Knight, How the Cold War Began: The Gouzenko Affair and the Hunt for Soviet Spies (Toronto: McClelland and Stewart, 2005); LAC, RG146, A200600096, 133, RCMP report "Extract Re: National Council for Canadian Soviet Friendship," 28 February 1949; VOKS, CW2, file 2, 5, "Otchet o rabote VOKS v Kanade za 1946" [Report on the Work of VOKS in Canada in 1946]; LAC, RG146, A200600091, 53, from "Questions People Ask about the Canadian-Soviet Friendship Society," a "NewFacts" leaflet, n.d., but probably from late 1952.

${ }^{332}$ VOKS, 6:1:36:65-6.
} 
workers and peasants. Today the Canadian people are becoming sharply curious about life in the Socialist world. ${ }^{333}$

Education was seen to be the best way to combat this "slander," as it brought

enlightenment. Carter argued:

... the main features of anti-Soviet opinion in Canada today are utter stupidity and gross ignorance. People with such weaknesses of thought in time become hungry for truth .... Over and above all facts about the Soviet Union there stands the profoundly impressive truth that the land of Socialism is the most faithful, most determined, most powerful guardian of peace for all peoples. This truth, without a doubt, is wearing away the foundations of anti-Soviet propaganda. ${ }^{334}$

The CSFS emphasized this theme in all its publications, and the distribution figures were celebrated as proof that the truth was spreading. The tone of reports to VOKS in Moscow were enthusiastic, and sales figures for We Saw Socialism were put forward as proof that that the Canadian public was increasingly sympathetic to the USSR. In October 1951, Carter claimed that the first 4000 copies of the book had completely sold out, and another 4,000 copies were being printed. ${ }^{335}$ Similarly, Carter proclaimed that the CSFS bulletin News-Facts, which had for a mission statement "Canada's Authoritative Information Service," was increasing its circulation in the United States and in Canada "continues to be popular"; and the distribution of "Anti-Slander 'Photo-Facts" cards ("little bullets of truth" ${ }^{336}$ ) were spreading positive information about the Soviet Union. ${ }^{337}$ Photography played an important role in the message produced by Dyson Carter and the CSFS. In the USSR, creating images of the progress and technological advance

\footnotetext{
${ }^{333}$ VOKS, 6:1:32:165, draft of article for New Times on Canadian-Soviet Friendship Month entitled "A Demonstration of Friendship" by Dyson Carter, 1951.

334 Ibid., p. 166.

335 VOKS, 6:1:32:1, letter from Dyson Carter to V.S. Bogatyrev (Head, Dept. of British Countries, VOKS), October 1951, p. 34 .

${ }^{336}$ VOKS, 6:1:36:29, "The President's Recommendations to the Convention," n.d., 1951-1952.

337 Ibid.
} 
of socialism was the task the photographer performed for the state. The CSFS used this technique, and photos received from the USSR, to educate Canadian audiences to the Soviet reality. "Photo-Facts," published by the CSFS in 1951, came in a set of 12 cards, with photos of the Soviet Union on one side and Soviet factoids on the other. CSFS printed 4,000 sets of these cards and had their branches across Canada distribute them. Carter had hit on the idea of publishing photo-cards in 1951, and argued that "tens of thousands more" needed to be sent out. ${ }^{338}$ For instance, one card showed a worker smiling at the camera, and under the photo was the phrase "Freedom for the Working Man." On the back were three categories: "The Papers Say: Soviet workers have to work where they're told to, their wages are low and working conditions are bad." Then under the title "The Photos Shows" were the words, "This machinist of Soviet Latvia, U. Masulis, has been elected member of his country's Supreme Parliament." Under the subtitle, "The Facts Are," several comparisons between Soviet and American workers were made. Holders of the card were encouraged to write to News-Facts for a subscription, so they could have "proof" of these facts. Each card finished with the phrase, "Let's get to know our neighbors - we can live in peace!"339 Other cards dealt with "Freedom from Rising Prices," "Freedom from War Propaganda," and "Freedom from Farm Debts." Writing to VOKS, Carter suggested sending sets of these cards to other Soviet friendship societies, such as those in Australia and New Zealand, and, if needed, he was willing have more printed, presumably for a fee. In April 1952, an article on the cards ran in the Toronto Telegram, calling them "straight, undiluted Communist

\footnotetext{
${ }^{338}$ LAC, RG146, A200600091, from "Questions People Ask about the Canadian-Soviet Friendship Society," p. 53.

${ }^{339}$ The "Photo-Facts" cards are copied in LAC, RG146, A200600101, p. 11-12, 95-102.
} 
propaganda" that was ultimately unconvincing. ${ }^{340}$ John Yaremko, Ontario MPP, made fun of the cards, which he had received unsolicited in his mail, when he spoke at the annual meeting of the Women's Progressive Conservative Association in February 1952. ${ }^{341}$ But Carter called the cards "a new development in fighting against anti-Soviet slanders." "342 Members were encouraged to buy "Photo-Facts" to distribute to friends and to leave them in public places where other Canadians could find them.

Similarly, in their book We Saw Socialism, the Carters put images to the text describing their highly orchestrated trip to the USSR. ${ }^{343}$ The text is arranged around thematically-oriented photographs, which are large and usually include one of the Carters in the shot. The message clearly is: here is the evidence that the Carters were there and that they investigated the truth about the USSR. Captions under the photographs included: "Mr. and Mrs. Carter saw hundreds of apartments like these," "Mr. and Mrs. Carter shopped in splendid stores like these," "[T]he Carters saw mass-production of these big welding generators," "[T]he Carters witnessed this Victory Day Anniversary scene," and "Charlotte Carter was deeply impressed by the cleanliness and care provided for workers' children."344 The shopping photograph appeared in the chapter "Paradise or Poverty?" subtitled "Here's What We Saw."345

\footnotetext{
${ }^{340}$ Allan Kent and Clem Shields, "Red Menace Real if War with Russ or Slump Comes," Toronto Telegram (1 April 1952).

341 "Communist Posters Shown to Women's PC Association," Globe and Mail (20 February 1952), p. 8. ${ }^{342}$ VOKS, 6:1:32:51, letter from Dyson Carter to Bogatyrev, 10 October 1951. If the CSFS gained from the distribution of the cards, it was mostly in terms of publicity. The financial statements from 1951 indicate that only $\$ 100$ were made on the sale of the cards. LAC, MG28-V-154, vol. 25, file 11, CSFS Income Statement, 1 November 1950-1 November 1951.

${ }^{343}$ VOKS, 5:3:31:206-211, Biography and Itinerary of Dyson Carter trip to USSR, April 1950.

${ }^{344}$ Charlotte and Dyson Carter, We Saw Socialism. (Toronto: Canadian-Soviet Friendship Society, 1951), p. $25,65,59,368,225$.

${ }^{345}$ Ibid., p. $62-5$.
} 
Nineteen fifty saw the first News-Facts publication, which was a small folded newsletter that contained snippets of interesting (and always positive) facts about the Soviet Union. Sixty-eight issues of News-Facts were published between 1950 and September 1956. Dorise Nielsen, as co-founder and executive secretary of the CSFS, said in a November 1950 promotional address that by becoming a subscriber, individuals would automatically become members of the Canadian-Soviet Friendship Society. The RCMP reported her as having said, "All that is necessary to become a member is to subscribe to the Society's publication which is edited by Dyson Carter. ${ }^{\$ 346}$ Written in what has been described as the "U.S. News and World Report" style that Dyson Carter always used in his publications, ${ }^{347}$ they were snappy, concise, and enthusiastic reports on Soviet medical and scientific advances. In addition to articles that praised all things Soviet, Dyson Carter used these pages to respond to critiques of the USSR. Armed with "facts" and "the truth about the USSR", he urged readers to engage friends and neighbours in discussion, to write to political leaders advocating trade with the USSR, and argued that the mainstream domestic newspapers must be read with skepticism. The first issue included greetings to J.V. Stalin on his $70^{\text {th }}$ birthday, declaring that "history is not changed by falsehood, and history records forever the truth that the Canadian people owe to you immeasurable gratitude for your leadership in the historic battles of Moscow, Leningrad and Stalingrad." 348 In 1956, reports and photographs of people born in the USSR, who had been relocated as "displaced persons" to Western Europe and North

\footnotetext{
${ }^{346}$ LAC, RG146, A200600114, RCMP Special Section report, 9 November 1950, re: an event that took place at the Winnipeg PlayHouse Theatre on 5 November 1950, p. 210.

${ }^{347}$ John Boyd interview.

${ }^{348}$ News-Facts, no. 1 (5 January 1950), p. 4.
} 
America, and subsequently "returned to the homeland" were published. ${ }^{349}$ The overall impressions readers got from News-Facts have been described in this way:

A subscription fee of one dollar would cover twelve issues, mailed in a plain brown envelope. When they opened their plain brown envelopes, subscribers could read about the latest wonders of Soviet science: "famed Soviet scientist finds way to double production of sheep ... daring new airplane flies with no fuel." They could be assured that they were in good company: that in Britain, Vivien Leigh, Laurence Olivier, and Arthur Rank were members of the British-Soviet Friendship Society. And they could have some of those hard questions answered. Why, for example, had the Soviet Union refused to allow the UN to investigate charges of slave labour camps? No, answered Carter, the Soviets had not refused, they had proposed a commission to investigate prisons in all countries. ${ }^{350}$

By 1953, a page or two of photographs appeared monthly, and the quantity and size of the photographs steadily grew. Initially, Carter wrote to VOKS asking for photos "showing different sides of life of the Soviet people" to be used in News-Facts; ${ }^{351}$ but, increasingly, he began to request photographs of specific subjects. In the April-May 1953 edition, the captions to photographs of Soviet development and smiling faces read, "These new, exclusive News-Facts photographs show life inside the Soviet Union today. News-Facts welcomes readers' suggestions for topics to be shown in future photo pages. ${ }^{352}$ On the same page under the headline "Canadian Trade Unionists on Visit to U.S.S.R.," photographs of the smiling delegates were shown touring. The names of the delegates were printed in the captions, thus attesting to the truth of the image, and in the location was noted in terse phrases: "Arrival in Moscow, Aug. '52, Tom Applegarth of Toronto receives welcoming bouquet"; "Up From the Coal Mine, K. Hladiy, C. Leech"; “On Moscow's Metro. K. Hladiy, J. Goldman, J. Hines, B. Magnuson, C. Leech, J.

\footnotetext{
${ }^{349}$ News Facts, no. 62 (February 1956), p. 3; no. 65 (June 1956), p. 7.

350 Johnston, A Great Restlessness, 226-7.

${ }^{351}$ VOKS, 6:1:50:29, letter from Yakovlev to Pozdeev, 17 December 1955.

${ }^{352}$ News-Facts, no. 36 (April-May 1953), p. 7.
} 
Leech." ${ }^{353}$ In February 1954, a line at the bottom of a page said, "The News-Facts camera takes you visiting; a Soviet hockey game with 80,000 in attendance; opening of Moscow's new university; and a New Year party in the Kremlin," alerting readers to the exciting photos inside. The pictures of the opening of Moscow State University present a spectacular skyscraper of knowledge and classrooms packed with studious proletarian youths. The enormity of the building and its modern architecture are impressive, and readers were informed that "in all there are 27 academic and 10 subsidiary buildings, 148 auditoriums, over 1,000 laboratories, and a 1,200,000-volume library." ${ }^{, 354}$ In April 1955, under the headline "Just Arrived in Canada: They Saw for Themselves: Seven Canadians in the Soviet Union," another delegation, including R.L. Patriquin, Morris Biderman, and Louis Kon are shown in conversation with citizens of the "worker's state. ${ }^{.355}$ In its photographs, News-Facts showed the Soviet truth and showed Canadians as the witnesses.

After returning from visits to the USSR, CSFS delegates toured regions of Canada speaking about their experiences. The location and number of people attending each of these meetings was duly recorded and reported to VOKS. The Royal Canadian Mounted Police also paid close attention to the numbers of attendees at each of these functions. After their return from the USSR in May 1951, Jacob Penner is recorded as having spoken to 500 people in Toronto and 600 in Winnipeg; Mr. and Mrs. Gartner to 500 people in Toronto, 800 more in Toronto at a later date, as well as smaller groups of musicians and artists, university people, housewives, Jewish adults and children at a United Jewish Peoples Order meeting and summer camp; Frederick Taylor and Jeannette

\footnotetext{
353 Ibid.

${ }^{354}$ News-Facts, no. 43 (February 1954), 7, 10.

${ }^{355}$ News-Facts, no. 55 (April-May 1955), 8.
} 
Pratte, restricted from speaking to public meetings by "conditions in ... [the] province of Quebec," were reported to have spoken at five or six small, private meetings each. ${ }^{356}$

Dorise Nielsen argued that in terms of delegations sent to the USSR:

the most important thing ... is NOT how big they are, nor HOW MANY we send ... it is that every member is prepared to give of their time and energy in telling the truth about the Soviet Union to Canadians when they return. Even if this means personal sacrifice, it becomes the most important thing about any member of a delegation, that they are prepared to defeat the Big Lie, and give of their best effort to help maintain peace and friendship [sic] with the Soviet people. ${ }^{357}$

Nielsen quoted from the journals of the Italian-Soviet Society, which had written, "Today the centre of our struggle for peace, and the future of our nation is the struggle against anti-Soviet propaganda"; and from the Iceland-Soviet Society, where a member had pledged to "... work persistently and honestly, everywhere, and all the time, to strengthen world peace, to defend the truth that comes to us from the great land of Russia." Nielsen asked members of the Canadian-Soviet Friendship Society to take heed of these words in their own work and to appreciate the "profound truth" contained therein. ${ }^{359}$

Photograph exhibitions sent by VOKS for exhibition by the CSFS were named "Vacation below Moscow," "A Day at a Kolkhoz," "Science and Religion," and a slide show entitled "Along the Halls of the Museum of the History of Religion and Atheism" was sent in $1957 .{ }^{360}$ Once sent, VOKS remained very interested in getting feedback on the way the photographs and films were being used. VOKS asked to know not only where, when, and who saw these materials, but if the progressive groups had any

\footnotetext{
${ }^{356}$ VOKS, 6:1:32:74-75, "Report on Activities of Society Delegation to USSR," May 1951 (20 July 1951).

${ }^{357}$ VOKS, 6:1:36:57, "Report on Organization," January 26, 1952, Nielsen's emphasis, 1951-1952.

${ }^{358}$ Ibid., p. 58.

${ }^{359}$ Ibid.

${ }^{360}$ VOKS, 55:186-188, letter from G. Ioanisyan to A. Tovstogan, 29 October 1957.
} 
comments or wishes to express to the organizers of these exhibits for future reference. Films also fit the bill of objectively showing Soviet realities to Canadians. In 1953, the RCMP reported that Dorise Nielsen, former MP and co-founder of the CSFS, toured Saskatchewan “... to organize cultural groups throughout the province, and to make arrangements for the screening of Soviet movies." At her talk in Kamsack, "The Leading Soviet Athletes in Training" was shown, and in Winnipeg "Construction Sites of Moscow," "Republic of Kazakhstan," and "Girl at the Circus" were shown. ${ }^{361}$

Films and photo exhibits were often used to supplement other activities, such as handicraft sales or lectures. At one showing a room meant to hold 250 people was so full that some people were refused entry. The VOKS representative in Ottawa reported to his Moscow office that the audience responded to the film and Carter's speech "very warmly." Carter had pointed out to VOKS that this report "shows once more that the Canadian public is interested in the life of the Soviet people, willingly attends suitable events and the Society (CSFS), because of this ready cooperative desire, is able to find the necessary audience amongst Canadians. ${ }^{, 362}$ But at times the Russian language used in the Soviet films offended the Canadian audience, many of whom were of Ukrainian background. A letter sent to VOKS in December 1956 requested that films sent in Ukrainian and Latvian languages to Canada have English subtitles (not Russian), because the clients are members of the Canadian progressive organizations, specifically listed as "Russians, Ukrainians, Latvians, etc.," and the Russian subtitles are displeasing and even used by Ukrainian-Canadian nationalists in anti-Soviet propaganda about the

\footnotetext{
${ }^{361}$ LAC, RG146, A200600091, RCMP report, "The Canadian Soviet Friendship Society, February 1951 to March 1953. Addendum to Brief Ending February 1951," 15 April 1953, p. 113-44.

${ }^{362}$ VOKS, 6:1:49:74, letter from A. Tovstogan to Kulakovskaya, 9 March 1956.
} 
Russification of the USSR. ${ }^{363}$ In forwarding this letter to the Ukrainian cultural organization, the request was made that action be taken "in alleviating the uncomfortable situation for Ukrainian-Canadian progressive organizations." 364

Films and photographs also represented a budgetary consideration for the CSFS, though the amounts were rather small. In 1952, the CSFS finances listed "films" as accounting for $\$ 269.75$ in income, while in 1953 income "receipts from films" came to $\$ 123.00$; "receipts from records," $\$ 30.00$; "receipts from exhibition," $\$ 662.50$; "Sale of donated picture," $102.50 .{ }^{365}$ Probably, more than financial return, the films and photographs sent from the USSR were meant to draw larger audiences to CSFS events.

In October 1951, Dyson Carter reported to VOKS that 35 percent of new subscribers to News-Facts were residents of the United States. ${ }^{366}$ By 1956, with the subscription to News-Facts, readers were entitled to receive Moscow News, ${ }^{367}$ and many also subscribed to the VOKS Bulletin, which was a Soviet magazine prepared especially for a foreign audience, and available in English, French, and other languages. International events in 1956, which included the Suez Crisis, the Soviet invasion of Hungary, and Nikita Khrushchev's famous speech denouncing Josef Stalin's personality cult, damaged the Soviet image abroad. Most likely as a response to the resulting crisis in leftist circles worldwide, both VOKS and the CSFS produced a new journal shortly afterward. In January 1957, VOKS changed the name of its magazine to Culture and Life, and the VOKS representative in Ottawa was told that his task was to "popularize the journal ... and use links to Canadian intelligentsia and the progressive organizations of

\footnotetext{
${ }^{363}$ VOKS, 6:1:55:27-8, letter from Tovstogan to Abramov, Sovexportfilm, 11 December 1956.

${ }^{364}$ VOKS, 6:1:55:29, letter from Ioanisyan to K.Z. Litvin (UkrOKS), 9 January 1956.

${ }^{365}$ VOKS, 6:1:50:116, 1952 finances; 6:1:50:117, 1953 finances.

${ }^{366}$ VOKS, 6:1:32: 32-37, letter from Dyson Carter to Bogatyrev, 1 October 1951.

${ }^{367}$ VOKS, 6:1:49:150-153, letter from A. Vertogradov to A. Tovstogan, 17 April 1956.
} 
the Russian and Ukrainian diaspora" to do so, while the CSFS was also asked to "propagandize" the journal. ${ }^{368}$ Carter advertised the opportunity of subscribing to other Soviet magazines on sport, women, literature, and photography, and lists of addresses in the VOKS files shows that many did.

In December 1956, the first issue of Northern Neighbors appeared, replacing News-Facts, which stopped publishing in October 1956. Subscribers were automatically changed over to the new magazine, ${ }^{369}$ which was much fuller, with bigger pictures, and more like main-stream magazines. Northern Neighbors did not call itself a CSFS publication, and instead was published by the Northern Neighbors Publishing Company, which was Dyson Carter's own initiative. A few years later, when the Carters moved from Toronto to the more northerly town of Gravenhurst, Carter gave up his presidency of the CSFS to devote his time entirely to the magazine and bookhouse work. The Party apparently felt Carter needed help, so Leslie Hunt was asked to take over the Society, soon after renamed the Canada-USSR Association, and Carter kept on with his work on Northern Neighbors. ${ }^{370}$

The initial price of the new magazine was $\$ 1$ for 10 issues, and even in 1989 it was still affordable at $\$ 10$ for 10 issues. The first issue featured an interview with Soviet ballerina Galina Ulanova, photographs of the International Seminar on the Equality of

\footnotetext{
${ }^{368}$ VOKS, 6:1:49:217, letter from A.S. Tovstogan from Yakovlev, 16 October 1956.

${ }^{369}$ Northern Neighbors (December 1956), title page.

${ }^{370}$ Leslie Hunt interview. 1956 was a water-shed for many communists and fellow-travellers. Nikita Khrushchev's so-called "secret speech" to the $20^{\text {th }}$ Party Congress in Moscow, officially distancing the CPSU from the legacy of Josef Stalin, plus the Suez affair and the invasion of Hungary created a crisis in the international communist movement. Charlotte Carter commented on the fact that the Congress had "made the idea of Canadian-Soviet friendship 'unpopular' in Canada." VOKS, 6:55:150-153, letter from A. Tovstogan to G. Ioanisyan, 31 May 1957. An executive member of the CSFS was "freed from his duties" because of his "incorrect behaviour" following the $20^{\text {th }}$ Party Congress. VOKS, 6:49:264-7, letter from A. Tovstogan to A. Vertogradov, 20 September 1956. The need to issue a new magazine was probably an attempt to respond to this crisis. For more on the response in Canadian leftist circles, see Weisbord, The Strangest Dream.
} 
Rights of Women in the USSR, and photos of the CCF Delegation and Canadian lumbermen visiting the USSR. The page on the lumbermen was headlined "Northern Neighbors in Real Life."371 Articles dealt with experiments in wind and solar power, women's rights, and the way the Soviet Union provided daycare and opportunities for women outside the home, freedom of religion, human rights and disabled rights, and how the USSR tackled environmental problems. But the wonder of science, and Soviet science above all, remained a popular theme. For example, in one of its first issues Northern Neighbors showed how "Man's Conquest of Nature is Taming Siberia," with the help of guest farm workers from across the USSR. ${ }^{372}$ Carter published a page on "Science and Our Future" in the February 1957 issue, that promised that once "the Cold War [was] out of the way" a "Climate Alteration Authority of the three northern neighbor countries: USA-Canada-USSR" could be set up to "revolutionize our winters" using atomic power. ${ }^{373}$ The same issue featured photographs of massive machines in Soviet construction and industrial projects under the headline "Big Jobs for Heavy Industry."374 Frequently, articles on Soviet medicine appeared, dealing with how science could conquer cancer, but also recommending alternative medicine, such as ginseng. Throughout, the idea that Canadians had gone to the USSR and "seen the truth for themselves" was prominent.

The magazine also carried a heavy political message. Until its last issue in 1989, it followed the Soviet line closely — from the events of 1956 in Hungary to the advent of glasnost under Gorbachev. Northern Neighbors presented more in-depth political content

\footnotetext{
${ }^{371}$ Northern Neighbours (December 1956), 5, 12, 13. The Canadian spelling of "Neighbours" was used in its first issue only, after which the magazine was called Northern Neighbors.

372 Ibid., p. 13.

${ }^{373}$ Ibid., (February 1957), p. 3.

${ }^{374}$ Ibid., p. 12-13.
} 
than News-Facts. In January 1957, the magazine ran a large article called "Our Readers Ask: What do Soviet People Really Say About Hungary," which essentially outlined the Soviet position on the 1956 Hungarian revolution. ${ }^{375}$ Readers were told that the facts of the situation, "rarely noted here," [ie. in the North American mainstream press] were that the Hungarian "rebels" had established a "Reign of Terror," and the Soviet Army had entered the country to prevent the establishment of a fascist state there. ${ }^{376}$ Reading Northern Neighbors today, a consistent pattern of about-turns is evident as it followed the line from Moscow. Nikita Khrushchev's famous "secret speech" to the Twentieth Party Congress in 1956 is not mentioned in the magazine's pages until 1989, ${ }^{377}$ although, from 1957 on, Stalin's legacy was referred to as "mixed" — the product of a "personality cult." An explanation for why the Soviets put down the Czech "rebellion" in 1968 is provided, ${ }^{378}$ and as the Cold War heated up in the 1980s, so did the Northern Neighbors rhetoric; articles defending the Soviet invasion of Afghanistan appeared in $1980,{ }^{379}$ and opinion pages protesting the boycott of the 1980 Moscow Games followed. ${ }^{380}$ Articles purporting that the Soviets were winning the space race appeared throughout the $1980 \mathrm{~s},{ }^{381}$ and Gorbachev's photo and speeches were prominently featured after 1985 . In 1986-1987, the effects of Chernobyl were downplayed, ${ }^{382}$ and by 1989 perestroika and glasnost were providing the main themes. ${ }^{383}$

\footnotetext{
375 lbid., (January 1957), p. 7.

376 Ihid.

377 lbid., (May-June 1989), p. 4-5.

${ }^{378}$ Ibid., (March 1957), p. 16; (February 1980), p. 11; "Student Rebels - Czech Liberals," Ibid., (September 1968), p. 3.

${ }^{379}$ Ibid., (February 1980), p. 4-5, and special supplement; Ibid., (March 1980), p. 6; Ibid., (October 1980), p. 13; and cover story in November 1986 issue as Soviets left Afghanistan in "friendship."

${ }_{380}$ Ibid., (March 1980), p. 4, 17.

${ }^{381}$ For example, see Ibid., (November 1982).

${ }^{382}$ For example, see "Real "Chernobyl' Disaster Was in West," Ibid., (June 1986), p. 4; "How Many Will Die from Chernobyl?" Ibid., (January 1987), p. 3. In the last article is the claim that “... no informed
} 
Science offered the solutions to technological and industrial dilemmas, Carter argued, and machines brought nature under man's control. Many of these articles carried gendered assumptions. In "Big Jobs for Heavy Industry" ${ }^{\text {"384 }}$ the power of mechanical tools was heavily masculinized. Although women were shown to be the partners of Soviet men in bringing the caprice of Mother Nature under control, femininity was not sacrificed. Unisex clothing was eschewed in the USSR, Carter told his readers, and women delighted equally in physical work and traditional feminine pursuits such as dancing, teaching, cooking, and child-rearing.

The North featured prominently in this pro-Soviet message. Soviet sovereignty in the North, and the technological tools needed to defend it, were the implicit themes of many of Carter's articles, whether or not the story was explicitly about northern cities or ice-breakers. (This approach was similar to the way outer space was portrayed in Northern Neighbors.) The Northern theme was a clever move by Carter to appeal to Canadians. The Cold War caused issues of the North to resonate with much greater meaning in Canada than it had previously. ${ }^{385}$ The D.E.W. line, the fear of bombers coming over the North Pole from the USSR, and Prime Minister John Diefenbaker's "Northern Vision" emphasized the link between Canadian sovereignty and the Arctic. Carter's message played on these issues, with a pro-Soviet tune. The USSR was a good friend to Canada, ran the message, and Canadians would do well to expand friendly

scientist ... can state that this fall out will in any significant way change the future cancer death rate." (Emphasis in the original.)

${ }^{383}$ See, especially, the final issue of Northern Neighbors (December 1989).

${ }^{384}$ Ibid., (February 1957), p. 12-13.

${ }^{385}$ There has been a good deal of work in Canadian historiography dealing with the links between Canadian (self-) identity and the North. See, for instance, Janice Cavell, "The Second Frontier: The North in English-Canadian Historical Writing," Canadian Historical Review 83, no. 3 (September 2002): p. 364389; Kerry Abel and Ken S. Coates, eds., Northern Visions: New Perspectives on the North in Canadian History (Peterborough, Ont.: Broadview Press, 2001). Soviet writers, like A. Cherkassov, had made the Northern link a theme for years. 
relations with their northern neighbours, in order to learn from them. On the inside of the cover of the first issue of Northern Neighbors an image of the North was presented to represent its mission — a flat map of Canada and the Soviet Union, appearing side-byside (1956). By 1957, the image depicted the Arctic from above, as if the viewer were looking down on the globe, with the Canadian North on the left and the Soviet on the right. In 1958, a similar image included a series of human figures holding hands, stretching across the Arctic Ocean from Canada to the Soviet Union. The image was eventually dropped altogether from the inside cover, but the rhetoric of Northern linkages remained. Stories about Soviet ice-breakers and skiers reaching the North Pole hinted heavily at Soviet sovereignty in the Arctic. ${ }^{386}$

Carter apparently held a modernist view of what we now call global warming. As a scientist and a utopian, he had a strong belief in the possibility of science to improve the everyday lives of people, using techniques that could seem fantastic. In addition to the article on how to "revolutionize our winters" using atomic power, Carter frequently referred to Soviet advances in meteorology. In October 1962, in an article entitled "When will Scientists Change the Weather?" Carter informed his readers:

Soviet scientists believe [melting the Arctic ice] would have big beneficial effects, and the undesirable effects could be offset by other deliberate actions. Such as: spray the Atlantic Ocean with chemicals to speed up evaporation, and prevent Europe-Soviet drought. Achieve the same end by mounting great solar mirrors on special sputniks, above the Ocean. By the way: both in China and in USSR they are right now trying out a weather-change of immense beneficial possibilities. By spraying cheap carbon-black on high mountain glaciers, vast quantities of solar heat are absorbed (instead of reflected) this melts whole rivers of ice, and

\footnotetext{
${ }^{386}$ An article on the Soviet atomic ice-breaker Lenin appeared in Northern Neighbors (July-August 1961), 19; "How to Ski to the Pole," Ibid., (February 1980), p. 20.
} 
opens the way to turning some of Asia's worst and biggest deserts into real Gardens of Eden. ${ }^{387}$

By January 1980, Carter had changed his tune. Under the headline "Ice Work," Carter wrote that the "world is just becoming aware of the fact that our planet's ice is vital to our future. In USSR most elaborate research goes on in many areas." Next to the text were pictures showing male scientists taking measurements. Under one photo of snowmobiles, a plane, and an ice tractor, the caption read, "Soviet people make greater use of ice than we do. Here they are studying new methods of making landing strips for aircraft. USSR has world's largest fleet of Arctic planes, and nowadays they are increasingly used to carry heavy freight to polar construction sites." On the next page Carter asked, "What's so fascinating about ICE?" and answered: "When you burn down a jungle it will re-grow in a couple of years. Damage permafrost, and you've ruined the land for a century, maybe forever. Avoiding that tragedy is the goal of hundreds of Soviet researchers. Their aim is no less than preserving one-quarter of our entire planet." ${ }^{388}$ Never one to miss an opportunity to criticize the United States, Carter wrote in March 1980 in "Which way is our Weather going?" that "[y]ou'd think, from reports we get in our media, that USA scientists have 'weather theory' pretty well wrapped up. Not so. Recent astonishing discoveries by Soviet researchers show that the Ocean's ice plays a dominant role in weather." Arguing that the world needed cooperation on weather studies, he wrote, "This is the kind of joint world-wide research which the man

\footnotetext{
${ }^{387}$ Ibid., (October 1962), p. 8.

${ }^{388}$ Ibid., (January 1980), p. 20, 21.
} 
in the White House is now wiping out. And it may well be that USA needs this most of all. Science for peace, not for profits in bloodshed." 389

Setting the tone in the earliest issues of Northern Neighbors, Carter maintained a commentary on how Soviets had tamed and domesticated the wild environment of the North, making it fit for human habitation. ${ }^{390}$ This rhetoric appears tragically ironic today, knowing as we do that Soviet attempts to tame the environment led to extraordinary destruction and suffering. The article entitled "Man's Conquest of Nature is Taming Siberia," in which Carter argued that the wilderness of the North was being domesticated by the Soviet state, mentioned earlier in this paper, was not unique. ${ }^{391}$ In June 1960, Carter wrote, "Siberia Has a Winning combination - Resources for Electric Power, Metallurgy, Chemicals, Agriculture," and by using numerous statistics on the amount of timber, coal, metal, and power generated, as well as the population increase, Carter explained how machinery and planning allow the economic development and exploitation of Siberia. ${ }^{392}$ In October 1960, he made precise comparisons between the Soviet and Canadian experiences: "Mirny, far up near the Arctic Circle is on a parallel with much of Canada that is considered uninhabitable in any big way. Yet look what planners there are doing." He bragged that Mirny had a "hospital, nurseries, kindergartens, schools, movies and clubs, swimming pools, stadiums, centres for skiing and ice-boating," as well as shopping opportunities. Engineers had built a reservoir on a nearby river to supply the town with water, and efficient and low-cost heating techniques were used, and all this

\footnotetext{
${ }^{389}$ Ibid., (March 1980), p. 10.

${ }^{390}$ It is worth noting here the work by Ken Coates and William Morrison on how winter, technology, and ideas about national exceptionalism in Canada are also linked. They point out that newcomers to the North often had the attitude that rather than adapt to winter, the North should be "conquered." Ken S. Coates and William R. Morrison, "Winter and the Shaping of Northern History: Reflections from the Canadian North," in Northern Visions, eds. Abel and Coates, p. 23-35.

${ }^{391}$ Northern Neighbors (December 1956), p. 13.

${ }^{392}$ Ibid., (June 1960), p. 18-19.
} 
amounted to only positive affects on the environment. "Trees?" asked Carter, "A Soviet town just isn't a town without trees. So Experts had to find a way to make them grow in the climate of Yakutia." 393 In February 1962 Carter claimed, "The Roar of Industry is the Music of a New Era for the 29 Million People Who Make their Homes in Siberia." ${ }^{\text {394 }}$ Significantly, he ignored the Soviet indifference to the environment, which was always sacrificed to industry and production. In comparing how government policies affected the lives of the peoples of the North, Carter argued that "[w]e can be proud of Canadian Eskimos and Indians $[s i c]$ who have achieved professional or trades standing despite government policies. But how much more fortunate are their Soviet counterparts who are not hand picked — but whose whole populations are encouraged and given every opportunity to sweep forward to a full life." $" 395$ The North was well-populated, therefore Soviet sovereignty there was secure, Carter seemed to say.

Carter argued that the Soviet Northern peoples were better off, more personally developed and happier, than the Inuit of Canada. Special emphasis was placed on the medical facilities and schools made available to the Northern peoples by the "generous" Soviet state, and pictures and text often functioned in a before/after relationship, suggesting how the lives of Soviet people had improved since 1917. Articles were accompanied by pictures of smiling people in northern settings, usually dressed in furs, with signs of progress, such as like schools and other institutions and industry in the background.

\footnotetext{
393 "New Siberian Town has no Chimneys," Ibid., (October 1960), p. 16.

${ }^{394}$ Ibid., (February 1962), p. 14.

395 "Arctic Socialism: Full Education, Full Employment Among Rights of Northern Peoples," Ibid., (May 1962), p. 12-13. (Emphasis in the original.)
} 
In September 1962, under the headline "A Doomed People Lives Again," photographs of members of the Nivkhi tribe showed them to be modern yet still able to practice their traditions. One photo in particular, of a man named Chuner Taxami dressed in a suit, was accompanied by the caption, "Chuner Taxami, (left) of the Nivkhi nationality, a Master of Historical Sciences, recalls: 'My fellow-tribesmen huddled in windowless yourtas and dug-out shelters.' Today the Nivkhi have sound, well-equipped homes. Above, a village kindergarten and nursery. ${ }^{1396}$ A few months later, in December 1962, an article, which asked rhetorically, 'Soviet 'People of the Deer' - Can They Prosper in the Arctic?" argued that "32 years of Socialist Evenkia Gave Evenks New Life, New Jobs: They are hunters and reindeer breeders, but also doctors, teachers, writers." Under one photo of a man in traditional dress holding a reindeer was the caption, "Vasili Uvachan, Evenki author, has not forgotten how to handle his reindeer team. He travels widely in the taiga (the arctic forest). ${ }^{397}$ In a 1981 article called "North Country Boom," Carter arranged photos of female schoolchildren in classrooms next to adults dressed in furs to show progress made and traditions preserved. ${ }^{398}$ The message seemed to be that the Soviet state allowed for progress without usurping the traditional gendered way of life.

Another Northern theme that ran through the magazine was the idea that involvement in winter pursuits meant Soviet people were like their Canadian neighbours. Not surprisingly, this often meant hockey. While noting that ice-hockey was a rather new sport in the USSR, the message of the importance of hockey as a language of friendship

\footnotetext{
${ }^{396}$ Ibid., (September 1962), p. 17.

${ }^{397}$ Ibid., (December 1962), p. 14-15.

398 "North Country Boom," Ibid., (February 1981), p. 14-15.
} 
was frequent. $^{399}$ Still, the competitive spirit was always present in Carter's writing. For example, following the Summit series in September 1972, Carter ran an opinion piece under the headline "Truth of the Month: The Russians Didn't Beat Us in Hockey," in which he argued that "Soviet sportsmen took up hockey only 25 years ago" and "the best system plays the best hockey." That was to say, the National Hockey League style of hockey was too violent, Soviet players were more sportsmanlike, and clearly played for the love of the game, rather than the money. ${ }^{400}$ Conveniently, no mention was made of the extraordinary perks to which Soviet hockey players were entitled. Carter probably saw himself as combating the congratulatory rhetoric which pervaded the Canadian press. As the website "1972 SummitSeries.com" observes of the winning Canadian goal, "... millions of Canadians danced and hugged in a scene that was reminiscent of the celebrations at the end of World War II. Never has a single sporting moment meant so much to so many Canadians..." Carter, on the other hand, argued that many Canadians were fed up with the bad behaviour their players demonstrated on the ice, and that the main lesson to be learned from the summit was this, not victory.

Carter used perceptions of the North to persuade Canadian readers, many of whom already admired the Soviet Union, that the USSR was an advanced nation, and friendly relations were possible and desirable. Strangely, what could be considered real and specific advances in Northern cooperation, such as the protocols of Canada-USSR cooperation in the North signed in 1984, and Mikhail Gorbachev's Murmansk speech in October $1987,{ }^{401}$ earned no coverage at all in the magazine. Instead it was the general

\footnotetext{
${ }^{399}$ For example, see "World-Wide Hockey," Ibid., (January 1958), p. 12-13.

${ }^{400}$ Ibid., (October 1972), p. 4.

${ }^{401}$ For discussion of these developments, see the special edition of Northern Perspectives, 16, no. 4 (JulyAugust 1988), published by the Canadian Arctic Resources Committee
} 
message that the North linked Canada to the Soviet Union that predominated; that by building bridges of cooperation and goodwill, Canadians could learn from Soviet superiority in the North.

By the late 1980 s, it became difficult to maintain this argument. As Aileen Espiritu has shown, with the advent of glasnost, Soviet indigenous people spoke out against the "concealed racism" to which they had been subjected, and which had lead to cultural decline, environmental damage, and high rates of tuberculosis, poverty, and infant mortality in the Soviet North. Espiritu concludes that the official line was "... not congruent with the realities experienced and lived by the indigenous peoples of the Russian North and Siberia." ${ }^{402}$ The use of massive machinery throughout the USSR to "tame Nature" wreaked havoc with the environment, and technological innovations did not live up to Carter's claims of a "citizen's paradise." The image Carter created, and readers had hoped for and believed in, was grotesquely out-of-sync with the everyday lived experiences of Soviet peoples, especially in the North.

From the archival collections at Library and Archives Canada, we can see how Dyson Carter put together his later issues of Northern Neighbors. Included among the files in the Dyson Carter fonds are pages of news releases published in English summarizing articles from the Soviet press. There are also thick packets of Soviet press agency photos showing smiling Soviet people and enormous machines at work on

$<$ http://www.carc.org/pubs/vl6no4/index.html $>$, (viewed 23 April 2007). From this edition, Dan Hayward's "Gorbachev's Murmansk Initiative: New Prospects for Arms Control in the Arctic?"; Carl Macmillan's "Joint Ventures in Arctic Resource Development"; and J.L. Black's "The Soviet Perspective on Canada's North: An Overview of the Literature, 1947-1988" are particularly useful in this connection. Also, Walter Slipchenko, "Co-operation in Arctic Science," Northern Perspectives, 15, no. 2 (May-June 1987), published by the Canadian Arctic Resources Committee <http://www.carc.org/pubs/v15no2/6.htm> (viewed 29 April 2007).

${ }^{402}$ Aileen Espiritu, "Whither the Northern Natives in Russian History?" in Northern Visions, eds. Abel and Coates, p. 170-1. 
building Soviet socialism. Also included are clippings taken from Western newspapers, underlined and annotated in Carter's red pen, showing how he spliced together scientific reports in the West that coincided with recent reports on Soviet accomplishments. From the VOKS files, we can see that Carter wrote constantly to officials in the USSR, asking for further information on particular themes in order to respond to readers' queries, and to publish on these themes in Northern Neighbors. The Soviet authorities took his letters quite seriously and responded quickly. Customs forms show that the material sent to Carter included all kinds of books and publications which he used as incentives for subscribers, as well as photos and opinion pieces which he could publish. Carter did not usually cite his sources, and readers did not always know that Carter rewrote material found elsewhere.

How was the message produced by Dyson Carter received by his readers? Readers' letters often featured a strong political interest, and some were clearly Stalinophiles. In 1980, an Australian reader wrote "the campaign of vilification of the USSR never lets up for a moment in our press and radio. But in the long run policies of destabilization are not going to destroy the world movement any more than bombs, napalm, etc. were able to do in VietNam. As you say, peace will win." Accompanying their \$50 donation, Signie and Henry Traeger of Chilliwack, B.C., wrote that they would "gladly send you a donation to help you spread the gospel of truth to many more people." A Toronto reader wrote to thank Carter for the article on Stalin, saying, "Thank you for

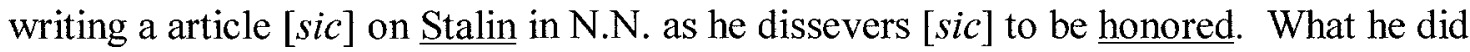
in his lifetime for his country and for the world." But another reader in Oregon did not like the article for its reference to the number of people Stalin had killed. Norman 
Haaland wrote that "this [was] without one iota of evidence. This is the cheepest [sic] form of Journilism $[s i c]$ and I want you to know I resent it deeply. It had no place to be used in the Northern Neighbors. ${ }^{403}$ In 1981, a reader in British Columbia wrote to say that he was "a Christian that believes there is more godliness and Christianity in Soviet Communism than in any Church-centred 'Christian' organization .... [In reading Scriptures] it became overwhelmingly clear to me ... that Soviet Communism would conquer the world, overthrow every imperialist power and wipe out the spirit of imperialism (in some 430 to 540 years) and usher in a reign of peace and righteousness commonly known amongst Bible scholars as the 'millenium [sic]',."404

A specialist on radicalism in the United States, political scientist Michael Barkun has noted the frequent overlap of radical political messages with information on natural health and the paranormal in right- and left-wing literature. ${ }^{405}$ Northern Neighbors, too, had its articles on garlic, not to mention onions, ginseng, and other dietary and nutritional advice. ${ }^{406}$ Although the juxtaposition of these dietary and medicinal alternatives seemed odd at first, they fit with the alternative views on social development and medical care voiced elsewhere in the publications. However, the articles on the paranormal and newageism did not fit quite so well. The first such story appeared in Northern Neighbors in

\footnotetext{
${ }^{403}$ LAC, MG31-D182, vol. 2, file 10 letter from: Alf and Kay Watt, New South Wales, Australia to Dyson Carter; vol. 1, file 2, letter from Signie and Henry Traeger, Chilliwack, B.C., to Dyson Carter; vol. 4, file 2, letter from Anna Hintsa, Toronto, to Dyson Carter; vol. 3, file 7, letter from Norman Haaland, Portland, $\mathrm{OR}$, to Dyson Carter. (Emphasis in original.)

${ }^{404}$ LAC, MG31-D182, vol. 5, file 7, letter from Paul Mann, Telegraph Creek, B.C., 13 March 1981, to Dyson Carter. The broken English apparent in many of these letters may hint at the fact that many readers were not native speakers. Indeed, from the VOKS files it is clear that members of the "ethnic progressive" organizations were amongst the most faithful subscribers.

${ }^{405}$ Barkun, A Culture of Conspiracy (Berkley, 2003).

${ }^{406}$ See for example, "Garlic Might Cure You" in Northern Neighbors, no. 304, March 1984, p. 11; "Onions Might Cure You", Ibid., (April 1985), p. 16; "Soviet Views on Eating Meat", Ibid., (May 1982), p. 16; "Try Beets for Pep", Ibid., (June-July 1980), p. 13; "What You May Not Know About Vegetables", Ibid., (September 1980), p. 19.
} 
April 1960, when Carter reported on a Soviet theory that God had been an alien. ${ }^{407}$ This story was followed up in June 1964, giving further details on Soviet research on this theme, predictably emphasizing that Westerners were not receiving news of this because of our own governments' censorship policies. ${ }^{408}$ Particularly in the early 1980 s articles on Soviet sightings and research on UFOs, Sasquatch, aliens, and other "far-out science mysteries" were frequent features of the magazine, always with the underlying premise of "stigmatized knowledge" and the assumption that Soviet scientists would eventually find the answers. ${ }^{409}$ It seems clear that these patterns fit with the observations Prof. Barkun has made in relation to radical groups in the United States, but how does one begin to understand the relationship between Dyson Carter and his readership's political orientation and their interest in the paranormal?

One clue may be in the theme of human agency which runs throughout the literature. From the earliest editions, Carter underscored the ability and the necessity of human action enabling historical change in his excerpts on history-makers. For instance, the headline above a series of human interest stories ran "People are the Makers of History" in December 1956. ${ }^{410}$ In 1984, Carter ran an article entitled "God is Waiting?" which argued that human beings are becoming divine, and that "God" then functioned as a collective "in a Communist way." 411 Again in 1985, Carter suggested that "we are 'super-beings"' in an article called "You Boss the Universe". ${ }^{412}$ Even when 'average'

\footnotetext{
407 "Was God a Man From Space?", Ibid., (April 1961), p. 21.

408 “'Gods Are Space-Men?", Ibid., (June 1964), p. 9.

${ }^{409}$ See for example, "Bermuda Triangle Exposed", Ibid., (October 1980), p. 3; "Abominable Snowman Walks Again", Ibid., (December 1980), p. 5; "Seen any UFOs Lately?", Ibid., (September 1982), p. 3; "Four Far-Out Science Mysteries", Ibid., (March 1983), p. 12; "Astonishing New Mysteries Are Upsetting Astronomers Today", Ibid., (March 1985), p.3.

410 "People are the Makers of History," Ibid., (December 1956), p. 16.

411 “"God is Waiting?", Ibid., (May 1984), p. 3.

412 "You Boss the Universe," Ibid., (June 1985), p. 7.
} 
individuals were not in a position to control their future, scientists were constantly discovering more about the world we live in, and would eventually be able to solve these dilemmas. For example, in a piece on the 'power' of numbers, Carter asked "Are numbers part of some general Law of our universe? If we discover it, how can we put it to use?"413 In his publications, Carter never seemed to waver in the universalist belief that humans could and would be able to grasp the underlying rules of life, and that this would come about when true scientific socialism was reached. ${ }^{414}$ Apparently readers appreciated this optimism, as many letters complimented Carter on just this up-beat spirit, and one writer from Mission City, British Columbia said "My husband and I do enjoy Northern Neighbours [sic] so much and feel just great when our inner-most feelings about world conditions are confirmed in N.N.",415

Periodically, Carter asked readers for comments on the photographs published, and whether they preferred them to be larger or more plentiful. Readers responded enthusiastically, arguing that more shots of the USSR were better than large ones, to better allow for visual understanding of Soviet life and people. Mrs. Olive Cooper, a reader from Waterloo, Ont., wrote Carter in February 1982 to say, "I enjoy the health articles, science and many pictures." Lynn K. Sully, a reader in White Rock, B.C., wrote September in 1981 that Northern Neighbors editors “... are to be complimented for a spiritual uplift that their writings and pictures give." However, some readers objected to photographs of military machines. Florence Petrie of Magog, Que., wrote in December

\footnotetext{
${ }^{413}$ From "Unbelievable 'power' of Numbers" in "Four Far-Out Science Mysteries," Ibid., (March 1983), p. 12.

${ }^{414}$ This theme if further elaborated in his 'autobiography' This Story Fierce and Tender (Northern Book House, Gravenhurst, 1986). In the book, a character named Dyson Carter writes a book on a man whose name is given as Elgin Morley, but who otherwise resembles very closely the real Dyson Carter. It is purported to be the first of two volumes, but the second volume apparently has not been published.

${ }^{415}$ LAC, MG31-D182, vol. 3, file 7, letter from Frank and Irene Horsford, Mission City, British Columbia, 5 February 1980.
} 
1981: "It makes it difficult to persuade prospective new readers when there are pictures and articles indicating the armnament [sic] superiority of the USSR"; and Belly Farmer wrote suggesting the magazine show "people enjoying themselves in a natural way," since the appeal of military parades is "over except in fascist countries." Stacks of the glossy photos Carter used for his publications remain in the Dyson Carter fonds, including those of Warsaw Pact arms, which were to illustrate a feature entitled "We Must Not Fall for Any Illusions."

The last issue of Northern Neighbors appeared in December 1989. Shortly thereafter acquaintances remember that Dyson Carter said cynically that he had spent forty years producing "bull shit," this view was still the Soviet line. The State Committee on Education in the USSR cancelled elementary and high school history exams in June 1988 because, according to Izvestiia, the Soviet textbooks were nothing but "lies." ${ }^{\text {418 }}$ The decision to cancel the exams was hailed by Izvestiia as "brave" and the "honest thing to do," but readers were reminded that history itself could not be cancelled. The policy of glasnost had been producing almost daily newspaper articles about the inaccurate portrayal of the Soviet past, students had been confronting their history teachers with the gaps between these revelations and their textbooks, and a well-known history professor in the USSR, Yuri Afanasev, was heard to say, "I can give you my assurance that there is not a single page

\footnotetext{
${ }^{416}$ LAC, MG31-D182, vol. 7, file 7, letter from Mrs. Olive Cooper to Dyson Carter, February 1982; vol. 10, file 2, letter from Lynn K. Sully to Dyson Carter, 28 September 1981; vol. 6, file 12, letter from Florence Petrie to Dyson Carter, 4 December 1981; vol. 7, file 10, letter from Belly Farmer, Tofino, B.C., to Dyson Carter, March 1982. These photos are in LAC, MG31-D182, vol. 11, file 9.

${ }^{417}$ Leslie Hunt interview; John Boyd interview; J.E. Baxter, interview with author, 8 December 2006, Stratford, Ont.; Boyd collection, letter from Dyson Carter to John Boyd, 28 February 1990.

${ }^{418}$ 1. Ovchinnikova, "Na temi dnya: Ekzamen otmenen, istoriya ostaetsya!" Izvestiia, 10 June 1988, p. 1; Esther B. Fein, "Moscow Summit: Unmaking History and Debating Rights; Soviet Pupils Spared Exams While History is Rewritten," New York Times (31 May 1988); David Remnick, "Soviets Cancel History Tests over Text, Washington Post, 11 June 1988, p. A1.
} 
[in the textbook] without a falsification., ${ }^{, 419}$ It appears that Dyson Carter, too, had come to this conclusion: "I publicized so many Soviet 'achievements' that were total falsifications, that I consider my 'work' an exercise in political pathology." ${ }^{, 20}$ Carter said he had an offer to continue publishing Northern Neighbors from Moscow, but he decided it was time to give it up.

How many people read or were influenced by Northern Neighbors? In 1985, when Dyson Carter celebrated his $75^{\text {th }}$ birthday, an article in the press repeated his claim that there were 10,000 subscriptions to Northern Neighbors in 81 countries; but Carter's ex-wife has said that not all of these were paid subscriptions. ${ }^{421}$ Free subscriptions were sent to public libraries across the country, and ethnic organizations on the political left received copies. Readers were encouraged to leave used copies in public places, such as cafes and city buses, for others to read. It is difficult therefore to arrive at an exact number of readers, or judge the impact of these publications. Nonetheless, from anecdotal evidence, it appears that Dyson Carter's magazines had a large and committed readership on the Canadian left. ${ }^{422}$

Dyson Carter dedicated his career, in fact most of his life, to promoting the Soviet Union. News-Facts and Northern Neighbors represented Soviet propaganda prepared and published by Canadians for a North American audience. In his publications and

\footnotetext{
${ }^{419}$ Iurii Afanas'ev, "Perestroika i istoricheskoe znanie," Literaturnaia Rossia 8 (June 1988), quoted in Tatyana Volodina, "Teaching History in Russia After the Collapse of the USSR," The History Teacher February $2005,<$ http://www.historycooperative.org/journals/ht/38.2/volodina.html $>$ (viewed 17 January 2008), paragraph 5.

${ }^{420}$ Boyd collection, letter from Dyson Carter to John Boyd, 28 February 1990.

${ }^{421}$ Reg Watson, "Controversial pro-Soviet publisher turns 75," Gravenhurst News (6 December 1985); Sally (Thelma) Nielsen interview. The magazine was distributed in the United States, and "friends" of the USSR in other countries also received it. This international character was promoted by Carter as further proof of the popularity of the interpretations found in the magazine.

${ }^{422}$ A survey of young members of the Association of United Ukrainian Canadians in 1965 found that many of them read Northern Neighbors. LAC, MG 28-V-154, vol. 27, file 14-18, "Poll of Participants of the AUUC National Youth Conference, July 9-11, 1965, Ukrainian Camp Palermo," Toronto.
} 
through his work for the CSFS, Dyson Carter tried hard to create a version of the "truth" that complimented the USSR. Those who traveled under CSFS auspices to the USSR, and subscribed to News-Facts and Northern Neighbors, wanted to believe that the Soviet Union represented an important alternative to Western society. Today, we see that this image was highly constructed, ignoring the negative aspects of Soviet reality. However, in acting out their political views, many of the CSFS members and readers sincerely hoped that as individuals they could make a difference in Cold War international relations. Dyson Carter's efforts were important in that they provided both vehicle and data to the large cross-section of the Canadian left, and kept the Soviet "version" in circulation. From the Soviet perspective, this made Carter an important contact, as will be shown in the next chapter. 


\section{Chapter Five \\ INSTITUTIONALIZING FRIENDSHIP: THE VSE-SOIUZNOE OBSHCHESTVO KUL'TURNOI SVIAZI S ZAGRANITSEI (VOKS)}

The All-Union Society for Cultural Relations with Foreign Countries [ Vse-

soiuznoe obshchestvo kul'turnoi sviazi s zagranitsei] (VOKS) was founded in Moscow in April 1925 and served the dual function of disseminating Soviet propaganda and collecting information abroad to be used domestically. Although purportedly a voluntary, non-governmental organization, VOKS provided a direct link between international proSoviet leftist groups and the Soviet state apparatus. It was closely monitored by the Soviet Ministry of Foreign Affairs and the International Department of the Communist Party of the Soviet Union. By 1928, VOKS had links with Soviet friendship societies in twenty countries; ${ }^{423}$ by 1946 there were 60 VOKS-supported groups abroad, and a few years later these included both a large group in the United Kingdom, ${ }^{424}$ and the Canadian Soviet Friendship Society (CSFS). VOKS-linked friendship societies located in Britain, Canada, Australia and New Zealand were overseen by the British Countries division, and correspondence was coordinated via a VOKS representative in the Soviet embassies.

Once the CSFS was founded in 1949, it began to follow a pattern similar to other VOKSsupported groups: it organized Soviet Friendship Months, hosted film showings and proSoviet discussion groups, published a pro-Soviet journal, and sponsored delegations of

\footnotetext{
${ }^{423}$ Olga Davidova Kameneva, "Cultural Rapprochement: The U.S.S.R. Society for Cultural Relations with Foreign Countries," Pacific Affairs, vol. 1, no. 5 (October 1928), p. 6.

${ }^{424}$ This information comes from British sources, and it may not be exact. In 1928, the same source said that VOKS was linked to 11 friendship societies abroad, while Mme. Kameneva, head of VOKS, said there were 20 such groups. Library and Archives Canada, Records of the Department of External Affairs, RG25, vol. 7117, File 9055-40, Pt. 3.1, document appearing to have been prepared by U.K. Embassy in USSR, examined by Canadian Embassy to USSR, 21 October 1955, signed by "Soviet Section F.O.R.D" [Foreign Office Research Department].
} 
Canadians on visits to the USSR. ${ }^{425}$ Soviet friendship societies in other countries had identical programs. For instance, in 1956, the Belgian-Soviet Friendship Society, which was founded in 1929 and linked with VOKS, was following a pattern remarkably similar to that of the CSFS, as shown by a feature article written by its president for the VOKS Bulletin. $^{426}$

By the 1950s, the CSFS served as VOKS' main contact with the Canadian public, as requests, correspondence and supporting materials passed by the VOKS representative at the Ottawa embassy, Vladimir Burdin, and later Aleksei Tovstogan. The Canadian Department of External Affairs paid attention to VOKS, as can be seen by documents in the departmental fonds at Library and Archives Canada that refer to the Soviet organization and its activities. At the same time, the Royal Canadian Mounted Police were certain that VOKS was supporting the CSFS. If in the early 1950s, External Affairs was not aware that Vladimir Burdin, First Secretary at the Soviet Embassy in Ottawa, was also the VOKS representative in Canada, and that this might be a security issue, the link was made clear at least by $1963 .^{427}$ In 1958 , when VOKS was renamed the Union of

${ }^{425}$ These activities were described in 1955 by British observers as being common to all Soviet Friendship Societies in contact with VOKS. LAC, RG25, vol. 7117, 9055-40, Pt. 3.1, 21 October 1955, signed by "Soviet Section F.O.R.D."

${ }^{426}$ Fernand Jacquemotte, "Belgian-Soviet Friendship," VOKS Bulletin, September 1956, no. 9 (104), p. $32-$ 34.

${ }^{427}$ In External Affairs exchanges dealing with Burdin at the time of the ambassadorial exchange negotiations, he is invariably referred to as "Bourdine of the Soviet Embassy" or as First Secretary. Although the links between VOKS and the CSFS were known to External Affairs officials, they may not have realized that the link was in the person of Burdin himself. In 1963 the RCMP informed the UnderSecretary of State for External Affairs that the renamed Soviet organization did indeed have an individual with past experience as a KGB official placed at the Soviet Embassy in Ottawa, responsible for corresponding with the Soviet friendship society in Canada. (LAC, RG25, A200700336, RCMP Memorandum to Under-Secretary of State for External Affairs, J.J. McCardle, 2 April 1963, p. 833. As mentioned in the previous chapter, the archive published by Vasili Mitrokhin with notes on documents from the KGB collection suggests that Burdin was a KGB operator. Christopher Andrew and Vasili Mitrokhin, The Mitrokhin Archive: The KGB in Europe and the West (New York: Penguin Press, 1999), p. $181,220,227-228,532$. 
Soviet Friendship Societies and Cultural Relations with Foreign Countries (SSOD), its function remained the same. ${ }^{428}$

Olga Davidovna Kameneva, who was the sister of Leon Trotsky and the first wife of Lev Kamenev, both Old Bolsheviks and Politburo members, was one of the first VOKS chairpersons. The high political profile she brought to the organization was reflective of the significance the Soviet authorities attributed to VOKS, and its role in international relations. ${ }^{429}$ Kameneva had been active in high politics for years, associated closely with V.I. Lenin. Her activities had involved promoting culture domestically as a tool of education and enlightenment, and representing women within the CPSU. Her work at VOKS was an extension of the work she had done earlier, representing Soviet culture abroad and coordinating linkages with Westerners who admired the USSR. In 1928, she published an article in the journal Pacific Affairs explaining the function of VOKS. Noting that the USSR had been for years surrounded by hostile states, she argued that the new Soviet culture to which the Revolution had given birth deserved to be better known in the West. Particularly, she wrote that VOKS was satisfying the demands for information coming from "progressive intellectual elements in foreign countries [who had been led to] interest themselves in the question: what is it that has taken place $\mathrm{n}$ that

\footnotetext{
${ }^{428}$ See the entry for "Vsesoyuznoe obshchestvo kul'turnoi Svyazi s zagranitsei (VOKS)" in the $3^{\text {rd }}$ edition of the Bolshaya Sovetskaya Entsiklopediya (Moskva: Izdatel'stvo 'Sovestkaya Entsiklopediya,' 1971), vol. 5, p. 464. Also available in English translation, "All-Union Society for Cultural Exchange (VOKS)," Great Soviet Encyclopedia, vol. 5 (New York: Macmillan Inc., 1970). On the SSOD, see "Union of Soviet Friendship Societies and Cultural Relations with Foreign Countries," Great Soviet Encyclopedia (New York: Macmillan Incl., 1979) vol. 24, p. 637; "Public, Social and Arts Organizations," Great Soviet Encyclopedia (New York: Macmillan Inc., 1979), vol. 31, p. 538.

${ }^{429}$ Kameneva remained in this position until 1928, concurrent with Lev Kamenev and Leon Trotsky's fall out of favour. She was executed on Stalin's orders in 1941, a few years after her two sons and ex-husband were also executed.
} 
mysterious country which used to be known as the "Russian Empire.",430 After

describing the function of the various sections of VOKS, underscoring the volume of

information sent abroad, including the distribution of 14000 copies of Soviet books per

month to foreigners in 1928 , she concluded with a simple statement that "at present there

are 20 societies for cultural relations with U.S.S.R. in various countries." ${ }^{431}$ And interest abroad was growing.

Like other Soviet cultural organizations, VOKS masqueraded as a voluntary association. In fact, the Soviet interpretation of artistic figures as 'servants of the state' meant that if individual writers and performers wanted to be published and accepted, they cooperated when asked to do so. At home, for instance, the Soviet Writers' Union served as a clearing agency for all literature. Although the VOKS leadership was elected by its larger membership, and was represented abroad as a non-governmental organization, the fact that it reported directly to the Ministry of Foreign Affairs and the International Department of the Communist Party of the Soviet Union, meant that it clearly was not truly independent. ${ }^{432}$ At the same time, it was not officially part of any government

\footnotetext{
${ }^{430}$ Kameneva, "Cultural Rapprochement: The U.S.S.R. Society for Cultural Relations with Foreign Countries," Pacific Affairs, vol. 1, no. 5 (October 1928), p. 6.

${ }^{431}$ Ibid., p. 7, 8.

${ }^{432}$ This is made clear by reports on the work of VOKS, the Canadian Communist Party (called the Labor Progressive Party from 1943-1959), and other Soviet interests in Canada, forwarded to the Ministry and to the ID. Copies of these from the Russian State Archives are now part of the VOKS collection, Centre for Research on Canadian-Russian Relations, University Partnership Centre, Georgian College, Barrie, Ontario. For instance, see "Otchet o rabote VOKS v Kanade za 1946 god" [Report on the Work of VOKS in Canada in 1946], VOKS collection, Cold War Documents, from the Russian State Archives of Social and Political History, Moscow, File 2, no. 6; V. Loginov sent to the Soviet Ministry of Foreign Affairs and N. Slavin, deputy director of European Section, International Department, Communist Party of the Soviet Union, report on the LPP, April 1955, VOKS, Series 6, Section 3, File 98, p. 5-20. See also J.L. Black, "Soviet Tactics and Targets in Canada Before and After the Gouzenko Defection," in J.L. Black and Martin Rudner, eds., The Gouzenko Affair: Canada and the Beginnings of Cold War Counter-Espionage (Proceedings of conference on Gouzenko Affair, held at Library and Archives Canada, April 2004, Canada/Russia Series no. 8, Penumbra Press, 2006), p. 108-129.
} 
department. ${ }^{433}$ A document prepared by the British mission to the USSR in 1955, which was seen by Canadian diplomats there and by the Department of External Affairs, suggested that VOKS was "undoubtedly heavily sponsored and controlled by the Soviet Government and the CPSU," with "its main activity up to the present [being] Soviet ideological and cultural propaganda abroad through the medium of foreign delegations to the USSR and various societies. ${ }^{434}$ The report quoted the most recent edition of the Great Soviet Encyclopedia which defined VOKS' role as "acquainting the Soviet Society with the achievements of the culture of foreign countries and the popularization of the culture of the peoples of the USSR abroad, contributing thereby to the development and strengthening of friendship and mutual understanding between the peoples of the USSR and the peoples of other countries. ${ }^{435}$ The encyclopedia definition remained unchanged in its $3^{\text {rd }}$ edition, published in $1971 .^{436}$

The British remarked upon the rapid growth of VOKS in the immediate post-war years, as the organization expanded its contacts abroad and opened more offices within the Soviet republics. In 1946 VOKS opened branches in the capitals of Soviet Georgia and Ukraine, and in 1954-1955 in the Armenian, Belorussian, Uzbek, Kazak and Azerbaijani republics. Monitoring the references to VOKS in the Soviet press allowed the British to conclude that there was also an increase in visits by foreign delegations to the USSR sponsored by the organization. In 1950, VOKS claimed to have sponsored 32 delegations to the Soviet Union; in 1951 this number had risen to 41 and included 23 individuals; in 1952 VOKS said it had sponsored 47 delegations and 13 individual visits;

\footnotetext{
${ }^{433}$ LAC, RG25, vol. 7117, 9055-40, Pt. 3.1, 21 October 1955.

${ }^{434}$ Ibid.

${ }^{435}$ LAC, RG25, vol. 7117, 9055-40, Pt. 3.1, 21 October 1955.

436 "Vsesoyuznoe obshchestvo kul'turnoi svyazi s zagranitsei (VOKS)" in the $3^{\text {rd }}$ edition of the Bolshaya Sovetskaya Entsiklopediya (Moskva: Izdatel'stvo 'Sovestkaya Entsiklopediya,' 1971), vol. 5, p. 464.
} 
and in 1953, 53 groups and 42 individual visitors. The British report noted that "the figures show a pronounced upward trend." In general, the British concluded that VOKS' "main activities seem to be the reception of foreign delegations and propaganda to attract national émigrés abroad." ${ }^{437}$ The highest number of foreign delegations visiting the USSR was reported in 1956, coming just before negative international reactions to the Soviet invasion of Hungary in the fall of that year. ${ }^{438}$ Western countries, including Canada, had been in the process of negotiating cultural exchanges with the USSR at that time, but the plans were cancelled or suspended after these events, as a direct result of events in Hungary. ${ }^{439}$ Soon afterwards VOKS was reorganized and renamed. ${ }^{440}$

The involvement of Soviet organizations in the policy, planning and monitoring of foreign leftist groups, especially Communist parties abroad, was not new. From the 1920s, the Communist International (Comintern), and later the International Department of the Central Committee of the Communist Party of the Soviet Union (CPSU) had coordinated policy between foreign Communist Parties. From its formation in 1943 until

${ }^{437}$ LAC, RG25, vol. 7117, file 9055-40, Pt. 3.1, 21 October 1955.

${ }^{438}$ Ibid., Pt. 3.2, Memorandum from the Canadian Embassy in the USSR, n.d. 1957, "USSR Establishes New Cultural Relations Committee," marked "Canadian Eyes Only- Secret".

${ }^{439}$ For the suspension of these planned agreements, and the reconsideration of this suspension, see "Memorandum from Under-Secretary of State for External Affairs [Jules Léger] to Secretary of State for External Affairs [L.B. Pearson]," 20 December 1956, "Exchange of Visits with the Soviet Union," marked Secret, no. 518, DEA/12230-40; and "Memorandum from Under-Secretary of State for External Affairs to Secretary of State for External Affairs," 17 April 1957, "Exchange of Visits with the U.S.S.R. and the Satellites," no. 519, DEA/12230-40 in Greg Donaghy, ed., Documents on Canadian External Relations, vol. 23, 1956-1957, Part II (Foreign Affairs and International Trade Canada, 2002).

${ }^{440}$ Not to be confused with VOKS, which was officially a non-governmental organization, on 21 May 1957 a State Committee for Cultural Relations with Foreign Countries was established, led by former deputy director of Pravda, Yury Zhukhov, reporting to the Soviet Ministry of Culture. Canadian diplomats argued that the establishment of this committee, which preceded the reorganization of VOKS, and subsequently the CSFS in Canada, was "the most recent indication of Moscow's desire to break out of the isolation imposed by its actions in Hungary and the Suez Crisis. The USSR has been conducting a vigorous campaign to restore contacts at all levels with the West." LAC, RG25, vol. 7117, file 9055-40, Pt. 3.2, Memorandum from the Canadian Embassy in the USSR, n.d. 1957, "USSR Establishes New Cultural Relations Committee." This campaign may also have been related to a desire to signal change, as a result of the XXth Party Congress which took place in 1956, and in which Nikita Khrushchev made a break with the past actions of Josef Stalin. The reorganization of VOKS in 1958 and the CSFS in 1960 will be further discussed below. 
the late $1980 \mathrm{~s}$, the International Department was the most important Soviet organization dealing with foreign affairs. It monitored all incoming information gathered by the Departments of Foreign Affairs and Defence, and the KGB, and drew up policy papers for the Soviet leaders. ${ }^{441}$ It operated mostly in secret, and had the same director, Boris Ponomarov, from 1955 until $1986 .{ }^{442}$ It helped set up the Communist Information Bureau (Cominform) in 1947 to ensure that Communist parties in Europe followed the 'correct' Soviet ideological path, ${ }^{443}$ but the International Department took over responsibility for liaison with all Communist parties and Communist front groups abroad, and published the World Marxist Review and the New Times. ${ }^{44}$ It was also responsible for the Soviet news service, TASS, the Soviet Information Bureau (Sovinformburo) which worked abroad to distribute Soviet news with the desired perspective to foreign audiences, and VOKS.

The importance of VOKS to the authorities in the USSR is hard to gauge, precisely because the inner system in the Kremlin relied so heavily on secrecy. Nevertheless, the fact that many VOKS reports from Canada, among them information directly from and about the CSFS, were stamped "sekretno" [secret] or "ves'ma

\footnotetext{
${ }^{441}$ Mark Kramer, "The Role of the CPSU International Department in Soviet Foreign Relations and National Security Policy," Soviet Studies, vol. 42, No. 3 (July 1990), 429-446, (see esp. p. 429-430). ${ }^{442}$ Black, Canada in the Soviet Mirror, p. 295.

${ }^{443}$ Herbert Romerstein, "History of the ID," in Foreign Service Institute, U.S. Department of State, Center for the Study of Foreign Affairs, The International Department of the CC CPSU Under Dobrynin, (Washington, 1989), p. 111-138. See also J.L. Black, "Introduction" to Jennifer Anderson, David Hood, Lindsay Kent, eds., The Canadian Soviet Friendship Society: Useful Liaison, Harmless Dupe, or Source of Subversion? Documents from Russia Held at CRCR: Annotated with Name Index, 1945-1957 (Centre for Research on Canadian-Russian Relations, Bibliographic Series No. 17/Occasional Paper No. 11, Carleton University, Ottawa, October 2005.) This last reference is the finding aid to the VOKS collection, currently held at the Centre for Research on Canadian-Russian Relations at Georgian College, Barrie, Ontario. The collection contains copies of files from the British Countries division of VOKS, which are kept at the Russian State Archives.

${ }^{444}$ Kramer, "The Role of the CPSU International Department in Soviet Foreign Relations and National Security Policy," Soviet Studies, vol. 42, No. 3 (July 1990), p. 429-430. Dyson Carter had articles and interviews appear in both these publications.
} 
sekretno" [top secret] and copied directly to high-level personnel like Andrei Vyshinsky, Vyacheslav Molotov and Boris Ponomarev, speaks volumes. The authority wielded by agencies run by these individuals had absolutely no counterpart in Canada. The chiefs were hand-picked for their posts by Josef Stalin, and ranked the highest in the land in terms of authority, second only to him. Vyshinsky and Molotov ran the Ministry of Foreign Affairs, the most important department of the Soviet government. Molotov was the minister until 1949, when Vyshinsky took over the post. Vyshinsky had been Stalin's main trouble-shooter abroad. They both sat on the Politburo of the CPSU's Central Committee, the most powerful committee in the country, even though it was not mentioned in the Soviet constitution.

Boris N. Ponomarev had a different sort of power as the classic back-roomer. A member of the CPSU's Central Committee Secretariat, he ranked higher than either Vyshinsky or Molotov within the Party itself. As head of the semi-secret International Department for an astonishingly long period, he was the unchallenged interpreter of Marxism-Leninism for almost the entire post-war period. The fact that Vyshinsky's successor as foreign minister, Andrei Gromyko, held office for nearly as long as Ponomarev (1957-1985) ensured that these foreign specialists held what to all intents and purposes was a monopoly of authority within a power monopoly in the USSR. Their interest in the CSFS, therefore, was no small matter.

How did all of this affect Canada? In 1954, for instance, the Sovinformburo bragged that it had arranged for the publication of 378 excerpts from Soviet official documents in sympathetic Canadian "progressive" journals, ${ }^{445}$ and distributed more than

\footnotetext{
445 "Progressive" here is used in the sense of "left-wing, pro-Soviet." Progressive is the term chosen by these groups themselves to describe their political views. The connections between the CSFS and the
} 
7,000 photographs dealing with 1,251 Soviet themes. In all, the Sovinformburo report claimed "in 1954 it had performed a great service providing the progressive Canadian press with honest information about our foreign policy and the Soviet way of life." $" 446$ The mandate of VOKS was to promote a positive image of the USSR abroad, but it involved itself less with official Communist parties than with the non-party leftist cultural and social groups in other countries. Its officers gathered information from its contacts, and possibly cultivated friendships with the view to gaining more useful contacts in the future. In Canada, VOKS maintained close contacts with the pro-Soviet Federation of Russian Canadians (FRC), Association of United Ukrainian Canadians (AUUC), other East European 'progressive' groups, and especially the Canadian-Soviet Friendship Society (CSFS). While the Sovinformburo provided these groups with material to condense or re-write in their journals, ${ }^{447}$ VOKS ordered the subscriptions they needed, arranged for material and objects to be delivered for sale and exhibition in Canada, and corresponded with individual members of progressive groups and the general public. From the VOKS archive, large parts of which are copied and held at the Centre for Research on Canadian-Russian Relations in Barrie, Ontario, it is clear that the VOKS representative in Canada was sending information to the International Department of the

\footnotetext{
"progressive, ethnic groups" associated with the Communist Party of Canada will be elaborated upon in the next chapter.

${ }^{446}$ VOKS 6:3:97:36-47, V. Kachanov, Deputy Director of the Soviet Information Bureau in Canada, Top Secret report of the Mision of the Soviet Information Bureau in Canada in 1954.

${ }^{447}$ The Sovinformburo reported in 1954 materials it distributed were published in the Canadian Tribune and the Pacific Tribune [newspapers of the Labour-Progressive Party], Vestnik [Messenger, FRC newspaper], Ukrainske zhyttia' [Ukrainian Life], Ukrainske slovo [Ukrainian Word], Ukrainian Canadian [AUUC newspapers], Vapaus [Freedom, Finnish progressive newspaper], Kanadai Magyar Munkas [The Worker, Hungarian progressive newspaper], Laudis Balsas [Latvian progressive newspaper], Novo Vreme [New Time, Bulgarian-Macedonian], Ludovy Zvesti [People's News, Slovenian] Chempion [Albanian], Vochenblatt [United Jewish People's Order newspaper], Kronika Tygodniowa [Weekly Chronicle, Polish], and News-Facts [CSFS newsletter]. Kachanov suggested ways to improve the distribution of this material. Kachanov, Report of the Mission of the Sovinformburo in Canada in 1954, VOKS 6:3:97:37-47.
} 
CPSU, and the Soviet Ministry of Foreign Affairs. Authorities in Canada were also paying close attention. ${ }^{448}$

But if VOKS had existed as early as the 1920s, how can its sudden growth immediately following the Second World War be explained? It appears that the increased importance placed on VOKS' work was related to changes in Soviet ideological concerns following the war. An emphasis on encouraging renewed ideological commitment within Soviet society, and especially the Party, was led by Andrei Zhdanov, head of the International Department before he died in $1948 .{ }^{449}$ Zhdanov, who had also been in charge of Propaganda and Agitation (Agitprop) for the CPSU, launched a purge of Soviet writers in 1946 that made demonstrated ideological commitment a prerequisite to publication. $^{450}$

A series of international incidents that occurred about the same time were interpreted as damaging the Soviet image abroad. Research has established that Cold War perception at times affected international relations. ${ }^{451}$ It has been argued that the American invitation to extend the Marshall Plan to Eastern Europe, and even to the

\footnotetext{
${ }^{448}$ Evidence of this can be found in the documents relating to VOKS and the CSFS released under the Access to Information and Privacy Act, as well as to exchanges within the Dept. of External Affairs, and between External Affairs and the RCMP, found in Library and Archives Canada, RG25.

${ }^{449}$ On this see J.L. Black, Canada in the Soviet Mirror: Ideology and Perception in Soviet Foreign Affairs, 1917-1991 (Ottawa: Carleton University Press, 1998), p. 179-180.

${ }^{450}$ Black, Canada in the Soviet Mirror, p. 180.

${ }^{451}$ See Black and Rudner, eds., The Gouzenko Affair: Canada and the Beginnings of Cold War CounterEspionage (Manotick: Penumbra Press, 2006); I.A. Ageeva, "Kanada i nachalo kholodnoi voinyi: Delo Gouzenko v Sovetsko-Kanadskix otnoshenyax" [Canada and the Start of the Cold War: The Gouzenko Affair in Soviet-Canadian Relations] in N.I. Yegorova and A.O. Chubaryan, ed., Kholodnaya Voina, 19451963 [The Cold War, 1945-1963] (Moscow, 2003); J.L. Black, Canada in the Soviet Mirror: Ideology and Perception in Soviet Foreign Affairs, 1917-1991 (Ottawa, 1998), 171-172; Merrily Weisbord, The Strangest Dream: Canadian Communists, the Spy Trials, and the Cold War (Montreal, 1983, 1994), 145; Reg Whitaker and Gary Marcuse, Cold War Canada: The Making of a National Insecurity State, 19451957 (Toronto, 1994); Len Scher, ed., The Un-Canadians: True Stories from the Blacklist Era (Toronto, 1992); Larry Black, "Canada and the Soviet Union in 1945: The View from Moscow" in Greg Donaghy, ed., Uncertain Horizons: Canadians and Their World in 1945 (Canadian Committee for the History of the Second World War, 1996); J.L. Black and Norman Hillmer, ed., Nearly Neighbours: Canada and the Soviet Union from Cold War to Détente and Beyond (Kingston, 1989).
} 
Soviet Union, caused the Soviets some alarm, as Moscow feared this was a Trojan horse. ${ }^{452}$ After the defection of Igor Gouzenko from the Soviet embassy in Ottawa became public in 1946, the Soviets complained constantly of heightening anti-Soviet campaigns in the West. In the next decade, other high-profile Soviet defections periodically made news, including most famously the defection of Vladimir Petrov in Australia in 1954. Like the Gouzenko defection, the Petrov case became known as an "Affair" and its political implications had ripple effects internationally. ${ }^{453}$ Although Western commentators have labelled the incidents the "Gouzenko" and "Petrov" affairs, in the Soviet Union, the defection in Canada became known as the "King Affair" because of the perceived involvement of Prime Minister Mackenzie King in causing an exaggerated increase in anti-Soviet public opinion, inconsistent with the consequences of Igor Gouzenko's actual revelations. ${ }^{454}$ As one historian of the USSR has written, "by 1947 it would no longer be possible to print anything in the USSR about a foreign country without conveying at the same time a clear political, social or economic message. ${ }^{455}$ This message invariably fit with the renewed importance placed on themes espoused in Vladimir Lenin's Imperialism: The Highest State of Capitalism (1916). ${ }^{456}$

Canada was important to the Soviets not only because it was in Ottawa that the Gouzenko Affair exploded into the headlines, but also because the Soviets believed that

\footnotetext{
${ }^{452}$ See, for example, discussions of Soviet insecurity in Vojtech Mastny, The Cold War and Soviet Insecurity: The Stalin Years (New York: Oxford University Press, 1996); Vladislav Zubok and Constantine Pleshakov, Inside the Kremlin's Cold War: From Stalin to Khrushchev (Cambridge, Mass.: Harvard University Press, 1996).

${ }^{453}$ See especially Robert Mann, The Petrov Affair: Politics and Espionage (Sydney and New York: Pergamon, 1987); Aleksei P. Makarov, "Living with the KGB and GRU: A 'Clean' Diplomat Recalls his Experiences Inside Soviet Embassies," in Black and Rudner, eds., The Gouzenko Affair, p. 158-160.

${ }^{454}$ I.A. Ageeva, "Kanada i nachalo kholodnoi voinyi: Delo Gouzenko v Sovetsko-Kanadskix otnoshenyax (Canada and the Start of the Cold War: The Gouzenko Affair in Soviet-Canadian Relations)" in N.I. Yegorova and A.O. Chubaryan, ed., The Cold War, 1945-1963: Historical Retrospective (Moscow, 2003). ${ }^{455}$ Black, Canada in the Soviet Mirror, 180.

${ }^{456}$ Ibid., 180-181; V.I. Lenin, Imperialism: the Highest Form of Capitalism (published in translation by the Communist Party of Britain, London, 1924).
} 
Canada had great geo-political importance. Because it was a northern hemispheric neighbour, which was also a neighbour and partner to the United States, and with historical ties to the other "great imperial power," Britain, the Soviet authorities paid very close attention to Canadian public opinion. Convinced the West was ganging up on the USSR, and could provoke a Third World War directed against Moscow, ${ }^{457}$ and aware that their country was weakened by the Second World War, and not prepared for another world conflict, Soviet leaders attempted diplomatic damage control. This strategy as applied to Soviet influence in Canada appears to have manifested itself in efforts to gather information on Canadian attitudes to the USSR, and thereby attempt to influence the larger North American public against another war.

After the Gouzenko revelations, which resulted in the arrest of, among others, Fred Rose, Member of Parliament and Labor Progressive Party member, the LaborProgressive Party (LPP) suffered considerable loss of legitimacy, and its leaders went underground. A VOKS report in 1946 complained that "Canada is among the most active leaders of the post World War II new reaction against the Soviet Union. The year 1946 was marked by the activation of anti-Soviet groups that organized a special legal process against the only parliamentary deputy who is a member of the Labor-Progressive Party...for the purpose of spreading lies and slanders against the Soviet Union. ${ }^{458}$ The cultural attaché at the Soviet Embassy in Ottawa, N.D. Belokhvostikov, was particularly

\footnotetext{
${ }^{457}$ Vladimir O. Pechatnov, "The Big Three After World War II: New Documents on Soviet Thinking about Post War Relations with the United States and Great Britain", Cold War International History Project, The Woodrow Wilson Centre (Working Paper no. 13, July 1995); G.F. Aleksandrov, "The Pattern of Soviet Democracy", (originally "O sovetskoy demokratii", speech delivered in 1946) translated by Leo Gruliow and published by Public Affairs Press (Washington, 1948).

${ }^{458}$ VOKS 6:3:98:5-20, V. Loginov, Advisor, Soviet Embassy in Ottawa, "Short Report on the $5^{\text {th }}$ Congress of the Labor Progressive Party of Canada and its Post-Congress Work with the Masses," 19 March 1955. In 1961 Loginov was expelled from Canada for having attempted to pay for information from Canadians whose friendship he had cultivated. Department of External Affairs, Canadian Weekly Bulletin, 20 December 1961, p. 5.
} 
upset by the way Igor Gouzenko portrayed him and other Soviet officials in Gouzenko's 1948 book about the defection, This Was My Choice, and sent V.M. Molotov, Soviet Foreign Minister, the book, his own complaints, and a copy of a book by Canadian Leslie Roberts, entitled Home from the Cold Wars, which received good Soviet reviews. ${ }^{459}$ Leslie Roberts was at that time National President of the National Council of Canadian-Soviet Friendship, but if the Soviets hoped that this group could keep relations friendly, they were wrong. The wartime National Council had received widespread Canadian support during the war, including that of Prime Minister Mackenzie King, but after the Gouzenko defection, the high profile members left. Other individuals involved in the National Council out of idealist concern for an Ally felt persecuted by the new Cold War climate in Canada that made such associations seem disloyal. ${ }^{460}$ By 1947 Lester B. Pearson, Canadian Secretary of State for External Affairs, was attempting to distance the Canadian government from this group, and had been advised that a large number of prominent members no longer supported it, that it had increasingly taken an uncritical stance towards Soviet policy, and that the same developments were taking place in the United States. ${ }^{461}$ In 1948 when Leslie Roberts was invited by VOKS to visit

\footnotetext{
${ }^{459}$ VOKS 7:2:6, Letter from Belokhvostikov to Molotov, USSR, Minister of Foreign Affairs, 21 October 1948. The Roberts book was criticized in a review in the LPP newspaper, The Canadian Tribune, for not being pro-Soviet enough. Frank Williams, "Confusion, Contradiction, Mar Roberts' Reportage of 'Cold War,' Canadian Tribune, 8 November 1948, clipped on the Department of External Affairs files, LAC, RG25, A200700336, p. 628-629. In 1954 Roberts published an article criticizing McCarthy-like attitudes in Canada: "McCarthyism - it's spreading in Canada- Now," New Liberty, vol. 31, May 1954, p. 15-17, 7883.

${ }^{460}$ Duncan McDowall has written about the unfortunate effects this climate had on the career of national statistician, Agatha Chapman, who had been active in the wartime National Council for Canadian-Soviet Friendship. McDowall, "The Trial and Tribulations of Miss Agatha Chapman: Statistics in a Cold War Climate," Queen's Quarterly, 114/3 (Fall 2007), p. 357-373. On how Canadian Communists experienced this change see especially Merilly Weisbord, The Strangest Dream $(1983,1994)$.

${ }^{461}$ See LAC, RG25, A200700336, Mackenzie King's approved response from Pearson to Leslie Roberts' letter, 26 August 1947 and 8 August 1947; Memorandum to the Secretary of State for External Affairs from Escott Reid, 26 August 1947; and letters from Leslie Roberts, pp. 4-30. Roberts had been sending memoranda on Canadian-Soviet postwar relations to Pearson, Mackenzie King and Louis St. Laurent.
} 
the USSR, he accepted, but his treatment in Moscow suggests that from the Soviet authorities' point of view, he was out of favour.

The Roberts visit created a flurry of correspondence between the Canadian embassy in Moscow and Ottawa tracking his activities. The Secretary of State telegrammed Moscow saying, "Since Leslie Roberts seems to be a misguided fellow traveler but not repeat not so far as we know a member of the Communist party, anything that you could do to educate him would be well worth the effort in view of the wide public his articles are likely to reach." ${ }^{462}$ From Moscow, John Holmes responded that although VOKS was "looking after him," he was "not being treated as a particularly distinguished visitor," and had become skeptical of the storyline he was receiving from his Soviet hosts. ${ }^{463}$ Holmes was congratulated on his approach by Escott Reid, ${ }^{464}$ who wrote "it is not likely that the visit will result in any radical change in Mr. Roberts" views, but it may, I hope, lead him to a more realistic and critical approach." ${ }^{465}$ In London, Roberts had lunch with G. Zarubin, who had been Soviet ambassador to Canada until 1946, but did not show up for his appointment with the Canadian chargé d'affaires in Prague. ${ }^{466}$ The doubts and questions Roberts expressed about the Soviet project, as well as declining membership in the wartime National Council of Canadian-Soviet Friendship, helped convince VOKS the group needed reorganization. A VOKS report on

${ }^{462}$ LAC, RG25, A200700336, telegram no. 93 to Canadian Chargé d'Affaires, Moscow from Pearson, 22 April 1948, p. 672.

${ }^{463}$ RG25, A200700336, letter to L.B. Pearson from John Holmes, 28 April 1948, p. 667-671.

${ }^{464}$ Reid was at this time Assistant Under-Secretary of State for External Affairs.

${ }^{465}$ RG25, A200700336, letter to John Holmes from Escott Reid, Under-Secretary of State for External Affairs, 11 May 1948, 657.

${ }^{466}$ RG25, A200700336, letter to L.B. Pearson from John Holmes, 28 April 1948; letter to John Holmes (copied to Norman Robertson and Lester B. Pearson) from R.M. Macdonnell, chargé d'affaires, Prague, 13 May 1948 , p. 656, 667-671. 
the National Council at that time said that it was "hindered by the absence of leadership," the larger anti-Soviet campaign, and lack of funds. ${ }^{467}$

We know that VOKS maintained contacts with "friendly" groups in Canada during the 1920 s and $1930 \mathrm{~s},{ }^{468}$ but previously it had been the Communist Party of Canada that had most publicly expressed pro-Soviet views. However, Soviet 'imagepolishing' via Communist parties abroad could not work in post-Gouzenko Canada. The Labor-Progressive Party was largely discredited, and with so many of its leaders affected by the arrests and trials, it could not be looked to by the Soviets for support. A secret report prepared by V. Loginov, Counsellor at the Soviet Embassy in Ottawa in 1955 and forwarded via MID to the Central Committee of the CPSU, suggested that the Soviet authorities continued to be disappointed in the work of the Canadian Communists a decade after the defection. Loginov pointed to the Party's weaknesses, and its inability to make any serious inroads in the unions, farmers' movements, or amongst the Canadian intelligentsia. ${ }^{469}$ In addition, Loginov criticized the fact that more than half of the LPP membership was composed of "immigrants," and the majority of these were UkrainianCanadians. Despite this, the nationalist Ukrainians in Canada still produced stronger propaganda and influenced a larger percentage of Ukrainian-Canadians than the Communists, he said. ${ }^{470}$ According to Loginov, the Party was clearly not in a position to

\footnotetext{
${ }^{467}$ VOKS, Cold War Documents, Section 2, File 2, no. 5, "Otchet o rabote VOKS v Kanade za 1946," [Report on the Work of VOKS in Canada from 1946], n.d., but appears to have been written in 1949. ${ }_{468}$ As mentioned in Chapter one, VOKS had maintained contact with Colonel Herbert Mackie, head of the Society for Cultural Relations with the USSR in the late 1920s, as well as the Friends of the Soviet Union, in the 1930s.

${ }^{469}$ VOKS 6:3:98:5-20, V. Loginov, Counsellor, Soviet Embassy in Ottawa, "Short Report on the $5^{\text {th }}$ Congress of the Labor Progressive Party of Canada and Its Post-Congress Work with the Masses", 19 March 1955.

${ }^{470}$ Ibid.
} 
reach out to mainstream Canadian society, and thereby to improve the image of the Soviet Union as socialist state.

From the Soviet perspective, an alternative organization that could have real appeal to a broader Canadian audience, promoting Soviet friendship as a non-political avenue to closer relations, was needed. In 1949, a reshuffling of the wartime National Council, which retained its name and most of its pro-Soviet members, but became a front organization for the Labor-Progressive Party, resulted in much more enthusiastic VOKS reports. This reorganization put the already well-known Soviet sympathizer, Dyson Carter, in charge of the Friendship Society, and may have corresponded with the arrival of Vladimir Burdin as the VOKS representative at the Soviet Embassy. ${ }^{471}$ A VOKS biography of Dyson Carter written in 1950 praised the LPP's choice of president of the Soviet Friendship Society, particularly because he was a propagandist for the Soviet system, a member of the Communist Party, and a "friend of the Soviet Union." 472 At first, Carter and other active members corresponded directly with VOKS headquarters from the CSFS office in Toronto or from their homes, but from 1951, perhaps due to the increasing volume of mail, the VOKS representative in Ottawa asked that all further contact be directed via his office. ${ }^{473}$ The representative, in turn, relayed the messages to the VOKS headquarters, which passed them to the government departments

\footnotetext{
${ }^{471}$ The first letter in the VOKS collection that refers to Burdin by name is dated December 1950, and Burdin was present at the meeting in November 1949 where Carter was elected as President of the CSFS. Before this, requests from Canadians were addressed to N.D. Belokhvostikov, Soviet attaché. VOKS 6:35:25, 27, 28-29; LAC, RG146, A200600096, p. 49, 53-54. But another document places Burdin in Canada earlier in 1949. VOKS 6:40:34-37

${ }^{472}$ VOKS 6:31:206-11, dated April 1950. The biography says that Dyson Carter is a member of the "kommunisticheskoi partii," even though at that time, the Communist Party of Canada was using the name, Labor Progressive Party.

${ }^{473}$ VOKS 6:33:111, Vladimir Burdin to N.M. Gorshkov, 11 November 1951. Burdin had been in Canada for some time before this date, however. The VOKS records show correspondence dealing with the fact that his four year-old son, Sergei, had been killed in a car accident in Montreal in 1949. [VOKS 6:40:3437]. It is not known what Burdin was doing in Montreal at that time.
} 
or ministries in Moscow, as deemed necessary. Dyson Carter felt it was important to differentiate between VOKS and the Soviet government more generally. In 1955, when a telegram signed "the Soviet government" was sent by VOKS headquarters to congratulate the CSFS on hosting Soviet Friendship Month, Carter wrote to VOKS to ask them, in the interest of avoiding "confusion" in Canadian minds, to avoid signing the cables in this way. ${ }^{474}$ And yet the connection between VOKS and Soviet governing bodies was clear. When Carter wrote in 1956 to complain about a Soviet review of one of his books, his letter was forwarded to the Central Committee of the CPSU, and when another was published in 1957, two copies were forwarded by VOKS to the Ministry of Foreign Affairs. ${ }^{475}$ The VOKS representatives may have been 'clean' diplomats, but it is clear that they were in highly trusted positions. Aleksei P. Makarov, who for years worked within the Soviet embassy in Ottawa has described the degree to which all Soviet diplomats' activities were closely monitored by KGB staff, who doubled as embassy personnel. ${ }^{476}$ The sensitive nature of their jobs meant that they and their Canadian contacts were under constant surveillance from both Soviet and Canadian security forces. In seeking out sympathetic individuals and distributing and gathering information, the VOKS representatives warranted watching.

Vladimir Pavlovich Burdin, who was also the First Secretary at the Soviet embassy, served as the VOKS representative in Ottawa from December 1950 until June

\footnotetext{
${ }^{474}$ VOKS 6:53:12, Carter to Perevoschikov, chief British Countries Division, VOKS, Moscow, 5 December 1955.

${ }^{475}$ VOKS 6:53:29-34a, VOKS to Central Committee of CPSU, n.d., 1956; VOKS 6:55:122, A. Tovstogan to G. Ioanisyan, 20 June 1957.

${ }^{476}$ Makarov, "Living with the KGB and GRU: A 'Clean' Diplomat Recalls his Experiences Inside Soviet Embassies," in Black and Rudner, eds., The Gouzenko Affair, p. 150-189.
} 
1955. ${ }^{477}$ John Holmes, who was Assistant Under-Secretary of External Affairs for

Canada at that time, described Burdin as a "slick operator,",478 and Jules Léger, also of the Department of External Affairs, once thought him "cocky," ${ }^{479}$ but both Canadians noted that in 1953 Burdin suddenly became much more charming. He was involved in lobbying to have ambassadors re-appointed in Moscow and Ottawa, replacing the chargés d'affaires who had been in place since the scandal over the Gouzenko defection. ${ }^{480}$ In discussing ambassadorial appointments, Burdin had behaved so cordially that Léger was led to believe Burdin had either taken him "for a ride," or had "made a deliberate attempt to create an atmosphere favourable to discussing common problems. Or both." Holmes too, wondered whether his initial impressions of Burdin had been mistaken, and whether Canadian chargé d'affaires Robert Ford's belief that Burdin was in fact sincere was more correct. Holmes noted that Burdin had always seemed to have a "privileged position" at the Soviet embassy, and wondered if this was because of his character or his job. ${ }^{481}$ Holmes wondered also whether these changes were related to the recent death of Josef

\footnotetext{
${ }^{477}$ The first letter in the VOKS collection that refers to Burdin by name is dated December 1950. Before this, requests from Canadians were addressed to N.D. Belokhvostikov, Soviet attaché. VOKS $6: 35: 25,27$, 28-29.

${ }^{478}$ John Holmes, "Memorandum by Assistant Under-Secretary of State for External Affairs," 29 September 1953, "Discussion with Mr. Bourdine of the Soviet Embassy," Documents on Canadian External Relations (Ottawa: Foreign Affairs and International Trade Canada), ed., Donald Barry, vol. 19 (1953), p. 1011. ${ }^{479}$ Jules Léger, "Memorandum by Assistant Under-Secretary of State for External Affairs," 23 June 1953, marked "Secret", DCER, vol. 19, p. 1006.

${ }^{480}$ The USSR suggested Dmitri Sergeyvich Chuvakhin as Soviet ambassador to Canada in August 1953. Canada reciprocated in December 1953 by suggesting John Watkins as Canadian ambassador to the USSR, and the Soviets agreed in January 1954. The diplomatic rupture over the Gouzenko Affair in 1946 had meant that the Soviet ambassador to Canada, G. Zarubin, did not return to Ottawa, and External Affairs transferred the Canadian ambassador to the USSR, L.D. Wilgress, to Switzerland and did not replace him. From 1946 to 1953 the embassies in each country were run by charges d'affaires. In 1953 these were R.A.D. Ford in Moscow and L. Teplov in Ottawa. See correspondence, DCER, vol. 19, p. 1007, 1009, 1012, 1014; Hector Mackenzie, "Canada's International Relations in the Early Cold War: The Impact and Implications of the Gouzenko Affair," in J.L. Black and Martin Rudner, eds., The Gouzenko Affair: Canada and the Beginnings of Cold War Counter-Espionage (Ottawa: Penumbra Press, 2006), p. 25.

${ }^{481}$ John Holmes, "Memorandum by Assistant Under-Secretary of State for External Affairs," 29 September 1953, "Discussion with Mr. Bourdine of the Soviet Embassy," DCER, ed., Donald Barry, vol. 19 (1953), p. 1011.
} 
Stalin, a topic which Burdin broached, saying that the USSR had since been making concessions which were not being recognized or reciprocated by the United States. "It may of course be that recent trends in Moscow have given Mr. Bourdine [sic] a little more confidence in his license to speak if not freely at least more flexibly," wrote Holmes. ${ }^{482}$ Today it is clear that Burdin's privileged position was related to the complete trust the Soviet authorities had in him, suggesting that he had the backing of influential Soviet authorities.

Burdin worked both sides of the ocean: in 1952 while on leave in Moscow, he met several times with Robert Ford, introducing the Canadian diplomat to Soviet "friends." Ford realized at the time that Burdin had been requested by his superiors to set such contacts up, but argued that it might be worthwhile for the Canadians to maintain these "friendships" with Soviet cultural figures for their own purposes. ${ }^{483}$ Apart from his official job as First Secretary at the Soviet Embassy, and his less well-known position as VOKS representative in Canada, Burdin may well have had other tasks. He was accused by the KGB archivist Vasili Mitrokhin, in the well-known Mitrokhin Archive of being an operator for the $\mathrm{KGB}^{484}$

Throughout his tenure at the embassy in Ottawa, Burdin was active in corresponding with the CSFS and other Canadian progressive groups, and accompanying

\footnotetext{
${ }^{482}$ Holmes, "Memorandum by Assistant Under-Secretary of State for External Affairs," 29 September 1953, "Discussion with Mr. Bourdine of the Soviet Embassy," DCER, ed., Donald Barry, vol. 19 (1953), p. 1011.

${ }^{483}$ LAC, RG25, vol. 8225, File 2.2, R.A.D. Ford to External Affairs, "Meetings with Vladimir Bourdine," 12 November 1952.

${ }^{484}$ Andrew and Mitrokhin, The Mitrokhin Archive, 181, 220, 227-228, 532. John Boyd, as a long-time member of the Communist Party of Canada, acquaintance of Dyson Carter, and active in other CPCsupported groups had inside knowledge, has agreed that Burdin and his successor Alexei Tovstogan were known to be with the KGB. John Boyd, comments on Jennifer Anderson's manuscript draft, April, 2008. As mentioned earlier, Mitrokhin also alleged that a member of the CSFS passed passports through Burdin to be used by illegals in Canada and the United States
} 
Soviet chargé d'affaires, L.F. Teplov, and later ambassador Dmitri Chuvakhin, ${ }^{485}$ to proSoviet events. Ted Baxter, National Secretary for the CSFS, remembers meeting Burdin and his wife together with the Chuvakhins at a CSFS Friendship evening held at the Royal York Hotel in Toronto in $1954 .{ }^{486}$ Burdin clearly saw himself as a cultural representative in Canada, and he requested and received from VOKS materials to support him personally in this role. All sorts of "typical" Soviet objects, including a gramophone and music records, busts and small statues of Soviet figures, ashtrays, and vodka were sent from Moscow to Ottawa for Burdin's needs in entertaining. ${ }^{487}$ In 1954 VOKS headquarters promised to arrange for Burdin's own writing to be published in Soviet journals, as he was an "official representative and cultural actor" in his own right. ${ }^{488}$

On the personal side, Burdin's four year-old son, Sergei, was killed in a car accident in Montreal in 1949. In the spring of 1952, Burdin had to negotiate with VOKS headquarters to have the ashes accepted into a crematorium in Moscow. ${ }^{489}$ When meeting Ford later that year, Burdin's wife showed the Canadian pictures of her two sons, whom she said had been born in Canada. ${ }^{490}$ When Burdin was replaced by Alexei Tovstogan in June 1955, he headed to India, where he appeared in a film about Nikita Khrushchev and Nikolai Bulganin's visit to India in $1956 .{ }^{491}$

\footnotetext{
${ }^{485}$ VOKS 6:47:18-19, V. Burdin to K.A. Perevoschikov, 10 August 1954.

${ }^{486}$ Interview with J.E. (Ted) Baxter, 8 December 2006, Stratford, ON. A photograph from Ted Baxter's personal collection shows Mr. and Mrs. Baxter in the company of Mr. and Mrs. Burdin and Ambassador and Mrs. Chuvakhin. Also in the picture is Paul Pauk, a CSFS executive member. The caption lists Vladimir Burdin as "cultural attaché at the Soviet embassy."

${ }^{487}$ VOKS 6:47:143-144, V. Burdin to V.S. Bogatyrev, February 1953; and V. Bogatyrev to V.G. Yakovlev (Deputy Chief, VOKS), 30 March 1953.

${ }^{488}$ VOKS 6:47:157, K. Perevoschikov to V. Burdin, 3 April 1954.

${ }^{489}$ VOKS 6:40:34-37, N.M. Gorshkov (VOKS administration) to A.V. Antisishkin (director, Moscow crematorium), 5 April 1952; V. Burdin to A. Denisov (Chief, British Countries Division, VOKS), 12 April 1952; Perevoschikov to Burdin, 21 May 1952.

${ }^{490}$ LAC, RG25, vol. 8225, File 2.2, Ford to External Affairs, 12 November 1952.

${ }^{491}$ In February 1955 Bulganin became Soviet Premier, and Khrushchev was at that time First Secretary of the Communist Party of the Soviet Union. In 1958 Khrushchev became leader of both Party and State.
} 
Tovstogan, too, ordered vodka, wine, tins of crabmeat, caviar, cigarettes, and other "representative products" from VOKS headquarters to be used as gifts and decoration in his apartment. ${ }^{492}$ Particularly after the fire that ravaged the Soviet Embassy on New Year's Day 1956, Tovstogan wrote VOKS headquarters to ask for his radioreceiver to be replaced. ${ }^{493}$ When attending CSFS events, Tovstogan was referred to as the "Second Secretary" at the Soviet Embassy in Ottawa, although in his letters to VOKS in Moscow he called himself the "VOKS Representative in Canada." In November 1958, the RCMP reported that Tovstogan was not a very effective speaker. Apparently, he "read a 22-page speech in very poor English," "made up entirely of statistics." The RCMP observer found it was "hard enough to follow as given, but the fact that it was read too fast and into a very poor public address system left most of the audience more annoyed than informed." ${ }^{, 494}$ An RCMP report dedicated completely to analyzing the background of Alexei Tovstogan, dated 18 November 1958, was unfortunately completely blacked out by the Access to Information and Privacy staff, and therefore the

VOKS 6:53:114, D. Carter to Svetlana Kolmakova (Secretary, British Countries Dept., VOKS), 6 June 1956. John Boyd has said that Burdin was serving in this capacity also in India as Khrushchev's translator and guard. John Boyd, comments on Jennifer Anderson's manuscript draft, April, 2008.

${ }^{492}$ VOKS 6:55:120-121, 144, 175, A. Tovstogan to G. Ioanisyan, 17 May 1957; A. Tovstogan to G.M. Kalishyan, 18 June 1957, A. Tovstogan to G. Ioanisyan, 29 October 1957.

${ }^{493}$ VOKS 6:49:32, A. Tovstogan to V.G. Yakovlev, 10 January 1956. This fire which raged out of control despite the efforts of Embassy staff to put it out themselves, resulted in a conflict with Ottawa Mayor Charlotte Whitton, who insisted the Soviet personnel allow Ottawa firefighters to enter the building. Once staff felt that as much as possible was saved from the flames, the firefighters were allowed in, but it was necessary to demolish and rebuild the building. (Harold Kalman and John Roaf, Exploring Ottawa: An Architectural Guide to the Nation's Capital (Toronto: University of Toronto Press, 1983), 72. This naturally made headlines across Canada. See for instance, "Embassy in Ottawa Burned as Russians Impede Firemen: Documents Taken Out by Carload," Globe and Mail, 2 January 1956, p. 1; Harvey Hickey, "Russians Fought Blaze Alone as Firemen Kept Out for $2 \frac{1}{2}$ Hours," Globe and Mail, 3 January 1956, p. 7. ${ }^{494}$ LAC, RG146, A200600114, Winnipeg Security and Intelligence Section report, F.S. Spalding, Supt., 19 November 1958, p. 289-299. The RCMP also recorded an audio version of the proceedings, and reported that on the stage with Tovstogan were Chester King, head of the local CSFS branch, Mary Kardash, and other CSFS members. Approximately 450 people were in attendance. 
details were unavailable to this researcher. ${ }^{495}$ Like Burdin, Tovstogan maintained contacts with the progressive groups in Canada, frequently forwarding their letters and requests to the branches of VOKS in Belorussia, Ukraine, Leningrad, Uzbekistan and elsewhere, or to the particular departments concerned.

What kind of correspondence was forwarded to other VOKS departments? Because of his interests in health and science, a considerable amount of material from Dyson Carter was forwarded to the VOKS Medical Section, and this department responded with answers to Carter's questions and requests. The Medical Section sent the requests and received responses from Soviet doctors. Requests for books or magazines were sent to the VOKS Book Exchange department, and subscriptions were sent to the Department of Printing and Information. A musical score composed by a Canadian, Sam Dolan, an English language poem praising the Soviet Union, and requests for accordion music were sent to the Soviet Culture Section. ${ }^{496}$ Other letters were forwarded to the Soviet Ministry of Culture, Ministry of Health, Soviet Academy of Sciences, Writers' Union, Sovexportfilm, who in turn arranged to have the letter answered by individual athletes, musicians, academics and specialists. In Moscow, letters from the Canadian VOKS representative passed through the office of V.S. Bogatyrev, Chief of the British Countries Department, or his deputy, Konstantin Perevoschikov. After 1954, it was A. Vertogradov who served as chief of the department, with Inna Kulakovskaya as his deputy. Kulakovskaya went to work for the new VOKS journal, Culture and Life in

\footnotetext{
${ }^{495}$ LAC, RG146, A200600114, p. 290-291. Only the title and date is visible on this document. It was signed by Supt. F.S. Spalding on 24 November 1958 at Winnipeg.

${ }_{496}$ VOKS 6:34:40, Bogatyrev to Yu. M. Brusnichkin (Head, Soviet Culture Section, VOKS), 7 April 1952; VOKS 6:40:7-8, Bogatyrev to Brusnichkin, 5-6 June 1952; VOKS 6:38:129, 135, PerevoschikovBrusnichkin-Bogatyrev, April-June 1952. These materials and requests were largely sent to VOKS by Dyson Carter.
} 
1957, and G. Ioanisyan, who had previously been head of the VOKS Balkan Countries department, took over from Vertogradov. Responses to Burdin and Tovstogan came frequently from one of the acting chiefs or deputy chiefs of this same department. Very infrequently letters to the Ottawa VOKS representative came from V. Yakovlev, the deputy head of the entire VOKS organization, or his superior, A. Denisov. Unlike in the Soviet Ministry of Culture, where the United States portfolio was grouped together with Commonwealth nations in the Department of Countries of America and England, VOKS had a separate department for the Americas. Issues dealing with Canada were dealt with by the British Countries division, but when American readers of the CSFS journal were discussed, the correspondence was directed to K.A. Chugonov, chief of the American Department. $^{497}$

The main outward interest of the VOKS representatives was in Canadian culture and particularly where Canadian cultural interests intersected with Soviet ideological approaches. Some of this correspondence may have appeared mundane, but VOKS left nothing to chance. In a system where secrecy was pervasive, all information was treated as sensitive, and represented a valuable political currency. This was manifested in an enormous correspondence with leftist cultural groups in Canada, especially the Federation of Russian Canadians, the Association of United Ukrainian Canadians, the United Jewish Peoples' Order, the Lithuanian and Yugoslav progressive groups, and others. ${ }^{498}$ Shipments of goods, music, films and photographs, but most especially books,

${ }^{497}$ VOKS 6:38:134 Perevoschikov to K.A. Chugunov, 3 May 1952; VOKS 6:49:46, I. Kulakovskaya to Chugunov, 8 March 1956; VOKS 6:40:153-154, memos forwarding letter from American citizen Jan. M. MacDonald (noting he had tried to become a Soviet citizen in 1945-1946), 30 December 1951. This correspondence dealt with Americans subscribing to Soviet magazines, or asking for information on the USSR.

${ }^{498}$ A separate chapter on this interaction follows. 
were arranged through the VOKS office for these groups. Requests were made for films to be in Ukrainian or Latvian with English subtitles, so as to avoid irritating the Canadian ethnic groups' sensitivities to the Russian tongue. ${ }^{499}$ Authors of the books sent were approved by the Soviet authorities. VOKS sent the CSFS books that were more generally known abroad as classical Russian literature, or new Soviet writers, including Leo Tolstoy, Aleksei Tolstoy, Mikhail Sholokhov, Alexander Herzen, Fyodor Dostoevsky, Nikolai Berensky, and of course, before 1956, volumes of Josef Stalin's own work. The proceeds gained by the sale of these items appear to have been left in the CSFS coffers, and the shipment was made at no charge to the Society. In response to a request from a Finnish member of the LPP, VOKS sent 15 sets of Stalin's Collected Works in Finnish to Canada. ${ }^{500}$ VOKS also made sure that any Canadian writers whose work was published in the USSR would then have boxes of their books to distribute at home. For instance, when the leader of the Canadian Communist Party, Tim Buck, had his book 30 Years of the Communist Movement in Canada published in Russian, 100 copies were sent for distribution in Canada. ${ }^{501}$

In the early 1950 s, the work done by the VOKS representative appeared to be rather passive. Generally, he passed along requests and interesting material to his superiors, but he did not go out of his way to solicit such material. Much of the correspondence between Ottawa and Moscow consisted of lists of materials being sent to Canada, and requests for information on how these materials were being used. In

\footnotetext{
${ }^{499}$ VOKS 6:55:27-29, A. Tovstogan to Abramov (Sovexportfilm), 11 December 1956; VOKS 6:55:27-29, G. Ioanisyan to K.Z. Litvin (UkrOKS [VOKS branch in Ukrainian SSR]), 9 January 1957.

${ }_{500}$ VOKS 6:54:2-3, A.T. Hill to Chesnokov, 1 January 1956, sending New Year's greetings and request; G. Chesnokov's reply, 31 January 1956.

${ }^{501}$ VOKS 6:47:98, K. Perevoschikov to N.K. Shenko, (Head of Book Exchange Dept., VOKS), 10 August 1954.
} 
addition, Burdin fielded questions on a wide variety of themes, passing them on to headquarters for more detailed replies. Most of the correspondence came from members of progressive groups. For instance, in 1954, Burdin passed along a letter from Beatrice Ferneyhough, a well-known progressive activist in British Columbia, asking for a Soviet opinion on her master's thesis about Machiavellianism in Shakespeare. ${ }^{502}$ Similarly, VOKS arranged to send a CSFS member, Alfred Dewhurst, for a therapeutic rest at a Soviet sanatorium. ${ }^{503}$ Progressive Jews in Toronto asked to set up a book exchange, and donated Canadian books to the Lenin Library in Moscow. ${ }^{504}$ The Federation of Russian Canadians addressed Burdin with a request for a periodic update on the Alekhinsky chess tournament in 1956, and VOKS complied. ${ }^{505}$ Fel Dorland of the CSFS asked VOKS to arrange a letter exchange between schoolchildren in Vancouver and those in Minsk. The request was granted and a list of Pioneers willing to write to Vancouver children was forwarded. ${ }^{506}$ Leslie Morris, Labor Progressive Party executive member and editor of the LPP's newspaper, The Canadian Tribune, asked for 20 copies of the collected works of Peretz Markish, a Soviet-Jewish writer who praised the Soviet Union, "to be used

\footnotetext{
${ }^{502}$ The correspondence between Ferneyhough, Burdin,VOKS headquarters and Dr. R.M. Samarin of the Institute of World Literature, Academy of Sciences is in VOKS 6::47:4-6, 53-54, 167, 168-170; 50:108-11. Ferneyhough was a VOKS Bulletin subscriber. VOKS 6:47:34.

${ }^{503}$ VOKS 6:55:19, 94-95, L.Starikov (VOKS) to G.N. Besedin, 26September 1956, and Dewhurst's thank you, referenced in A. Tovstogan to Vertogradov, 24 August 1956.

${ }_{504}$ Correspondence between Mr. Burney at the Victory Bookshop, a store known to stock "progressive" literature in Montreal, D. Rome, the director of the Jewish Public Library in Montreal, and VOKS, February-August 1956. VOKS 6:54:21-23, 53, 54, 67-69, 85-90.

${ }^{505}$ The FRC's request was sent to VOKS headquarters is in VOKS 6:55:60-62, A. Tovstogan to I.M. Kulakovskaya, 3 December 1956; which was forwarded (VOKS 6:55:13) by Kulakovskaya to A.S. Chikin (International Sport Ties, Committee on Phys. Cult. And Sport, Council of Ministers, USSR), 28 January 1957.

${ }^{506}$ Fel Dorland was a CSFS delegate to the USSR in 1953, and it was she who passed Beatrice Ferneyhough's MA thesis to VOKS for evaluation. (VOKS 6:47:167). Correspondence between Fel Dorland and VOKS on the theme of children's letter exchange during the spring of 1954: VOKS 6:47:4-6, $10-13,60,161$.
} 
amongst prominent Jews in Canada." ${ }^{507}$ The Association of United Ukrainian Canadians requested $\$ 600$ to fund a film about the July 1956 All-Canadian Festival of Ukrainian Music, Song and Dance, which the AUUC hoped to show at the Youth Festival in Moscow in 1958, was forwarded to VOKS for consideration. ${ }^{508}$ Photographs of the Winnipeg festival, and news of the Canadian progressive youth's preparation for the Moscow festival were included. Burdin must have been asked in early 1953 to survey Canadian progressives as to the success of the VOKS Bulletin, because both Dyson Carter and Avrom Yanovsky suggested improvements for the magazine. Their advice was sent to VOKS headquarters. ${ }^{509}$ Canadians sympathetic to the Soviet cause generally found their needs for cultural and ideological reinforcement promptly and generously satisfied by Moscow and VOKS, through the medium of the CSFS.

VOKS treated just as seriously correspondence from the wider Canadian public. The fact that these requests are still on file, copied and/or translated in archives, demonstrate the importance once attached to them. All information had value, every letter was placed in a file, answers were recorded, lists of names compiled, follow-ups were made when the opportunity seemed appropriate. Not knowing whom to address, many of these people wrote directly to Premier Nikolai Bulganin. Bulganin's office forwarded them to VOKS. Otherwise, they wrote to the Soviet Embassy in Ottawa, and Burdin and Tovstogan handled the correspondence. In 1950, VOKS prepared a list of 12 Canadians and the questions they had asked in the past year. The questions included requests for penpals, souvenirs from the USSR, stamps and coins, medical and scientific

\footnotetext{
${ }^{507}$ VOKS 6:55:183, A. Tovstogan to G. Ioanisyan, 25 September 1957.

${ }^{508}$ VOKS 6:55:41-43, P. Strunnikov (Temporary Charge d'Affaires, Soviet Embassy in Ottawa) to S.K. Romanovsky (Preparatory Committee for Worldwide Festival of Youth and Students), 4 February 1957. ${ }^{509}$ VOKS 6:44:37-41, 42-49, D. Carter, March 1953; A. Yanovsky, 31 March 1953.
} 
advice and general information. ${ }^{510}$ A Toronto artist, G. Kingsford, wrote via the Soviet Embassy for information on a Dutch painting which was hanging in the Leningrad

Hermitage Museum. The Soviet ambassador, Chuvakhin, suggested VOKS forward Kingsford's letter together with the sketch he had done of the work to the Leningrad VOKS branch. Kingsford got his answer in March 1955, and sent a thank-you note. ${ }^{511}$ In 1955 an horticulturalist from Duncan, British Columbia, N.A. English, sent seeds for the "Cascara Tree" to Moscow, and in return was sent some seeds from the Academy of Sciences Main Botanical Garden. ${ }^{512}$ In April 1956, Raymond Arthur Davies, a left-wing book dealer in Toronto and author of a book on Canada and Russia, ${ }^{513}$ asked for information on archival material about Canada in the Soviet archives. VOKS responded that they did not deal with archival matters, but forwarded the request to several archives. Eventually it was the Ministry of Foreign Affairs that answered Davies, listing several holdings related to Canada. ${ }^{514}$ In October 1956, a representative of the World University Service of Canada wrote Premier Bulganin to ask for a display of Uzbek hats for one of their events. VOKS handled the request and sent the hats in January $1957 .^{515}$ Teachers frequently requested information to supplement their class curricula, and students

\footnotetext{
${ }^{510}$ On penpals see VOKS 6:54:138-140; 57:28-30, 33-36, 44-46, 58-59; on requests for coins and stamps, see VOKS 6:54:51-52, 59, 128-129; 57:40-42; on requests for photos, postcards and other souvenirs see VOKS 6:55:24, 118-119, on requests for science and medical information (not including Carter's), VOKS 6:54:43-50; 55:68-69, 57:60-62.

${ }^{511}$ For correspondence between G. Kingsford, Chuvakhin, VOKS Moscow and S.T. Golubovich (Acting Head, Leningrad branch of VOKS), November 1954-May 1955, see VOKS 6:48:155-156, 159-161, 192196.

${ }^{512}$ For correspondence between N.A. English, VOKS, and N.V. Tsitsin (Director of Main Botanical Gardens, Academy of Sciences, USSR), November-December 1956, VOKS 6:48:7-10, 28, 34-35, 38-39, $40,42$.

${ }^{513}$ Raymond Arthur Davies, Canada and Russia: Neighbors and Friends (Toronto: Progress Books, 1944). He also wrote (with Andrew J. Steiger) Soviet Asia: Democracy's First Line of Defense (New York: Dial Press, 1942); This is Our Land: Ukrainian Canadians Against Hitler (Toronto: Progress Books, 1943). ${ }^{514}$ This exchange between R.A. Davies, VOKS, and the Ministry of Foreign Affairs of the USSR, April 1956, VOKS 6:54:112-118.

${ }^{515}$ The correspondence between E.W. Mulaney and Jane Banfield of the World University Service of Canada and VOKS is found in VOKS 6:57:2-4, 37.
} 
sometimes wrote for class projects. ${ }^{516}$ Someone asked about mushroom-picking in the USSR, and others wanted to know more about the Soviet chess champions. ${ }^{517}$ Burdin translated the chess tournament between Canadian chess champion Frank Anderson and Igor Bondarevsky in 1954 by cable, and also sent clippings of the Canadian coverage to VOKS headquarters. ${ }^{518}$ A Canadian asked for information on Soviet nursery school designs, another asked about cinema design, and a man calling himself a "proletarian scientist" sent VOKS a book called the Mysteries of the Cosmos. VOKS may not have responded to all correspondence. ${ }^{519}$

VOKS also received letters of thanks and personal correspondence from Canadians who had visited the USSR, or who were interested in the USSR. Dyson Carter cabled VOKS to make announcements about important CSFS events, like the performance of a Shostakovich oratorio in $1951 .{ }^{520}$ VOKS sent telegrams of congratulations to Dyson Carter and the CSFS to be read at CSFS events. For example, in 1952 VOKS cabled the participants in the CSFS Friendship Month wishing them success and international peace. ${ }^{521}$ After their visit to the USSR in 1951, Fagel and Emil Gartner, Jeanette Brunelle, artists Frederick Taylor and Jacob Penner each wrote glowing thank you notes to VOKS. ${ }^{522}$ The tone of these letters was very friendly, and clearly personal ties had been established during the visit. Several members of the Cooperative Commonwealth Federation (CCF) who visited the Soviet Union in 1956 wrote thank you

\footnotetext{
${ }^{516}$ These requests are throughout the collection.

${ }^{517}$ VOKS 6:51:51-52, K. Sidora to VOKS, July 1955; VOKS 6:47:49, K. Perevoschikov to A.S. Chikin, 22 October 1954, forwarding letter from B. Freedman (editor of journal Chess Life).

${ }^{518}$ VOKS 6:47:114, V. Burdin to V.S. Bogatyrev, 25 March 1954.

${ }^{519}$ VOKS 6:51:118, 35:30-31, 32-33, 14-16, M.R. Colby to VOKS, 1954, Mr. W. Schacter to VOKS, 2 February 1951, reply 13 April 1951, Samuel Gibson, 29 December 1950.

${ }_{520}$ VOKS 6:32:153, D. Carter cable to K. Perevoschikov and A. Denisov.

${ }^{521}$ VOKS 6:34:1-3, Cable to Carter from N.M. Gorshkov, n.d. 1952.

${ }^{522}$ Written in May 1951 these letters and other testimonials prepared by the delegates about their experiences appear in VOKS 6:32:130-151.
} 
letters to VOKS on their return. ${ }^{523}$ Harold Bronson, a CCF member from Lethbridge, Alberta, claimed that his photographs of the USSR were causing a stir in Canada, and boasted of his struggle with the "monopoly big business daily newspaper" in Edmonton. VOKS responded, asking for clippings of the Canadian press opinions on the CCF visit. The former CCF Member of Parliament, William Irvine, wrote VOKS on Alberta CCF executive letterhead, mentioning that his "speeches in the Soviet Union created quite a furor in the capitalist press..." A month later, VOKS wrote to suggest Irvine write an article for the Soviet magazine, New Times, ${ }^{524}$ and in 1960 he was chosen honourary chairman of the CSFS' successor, the Canada-USSR Association. ${ }^{525}$ Another CCF delegate, Otto Wobick, praised socialism over capitalism in his thank you letter, and VOKS responded, asking him to send material on farming practices in Canada. ${ }^{526}$ The interest VOKS took in the CCF members was maintained.

Chatty, personal letters were sent to VOKS personnel by CSFS member R.T. Lafond in $1957,{ }^{527}$ and Dyson Carter frequently addressed his correspondents by first name, asking after their spouses and children. The Cysz family in Edmonton wrote

${ }^{523}$ VOKS 6:54:74-83, B.F. Tanner, Harold Bronson, Dorothy Johnson, and William Irvine letters to VOKS and responses, August-September 1956. Irvine published a book on his impressions of the USSR, entitled Live or Die with Russia (Edmonton: s.n., 1958), in the introduction to which the USSR was hailed as "a great laboratory of social experimentation." Alexander Calhoun, "Foreword" to Irvine, Live or Die with Russia, p. 3. The book was translated and published in Moscow as Zhit' vmeste s Rossiyei [Live with Russia] (transl. V.V. Isakovich) (Moscow: Inostrannoi izdatel'stvo literature, 1958).

${ }^{524}$ VOKS 6:54:74-83. New Times was overseen by the International Department of the Central Committee of the Communist Party of the Soviet Union.

${ }_{525}$ LAC, RG25, A200700336, RCMP Research Section report, "The Canada-USSR Association," 27 March 1963, p. 834-845.

${ }^{526}$ Correspondence between Otto Wobick and VOKS, December 1956-February 1957 in VOKS 6:57:1419.

${ }^{527}$ VOKS 6:57:5-7, 58:52, R.T. Lafond to "Helen" [Korolkova], February 1957, and her reply 28 Feb. 1957, and Lafond to Perevoschikov, 19 April 1954. 
"Long Live Great Rus" in Russian on their New Year's card to VOKS in $1957 .{ }^{528}$ When

Louis Kon fell ill, his friend Louise Harvey wrote VOKS to let them know. VOKS

responded with a get-well letter, and informed Kon about his financial holdings in the USSR. $^{529}$ On Kon's death in October 1956, Tovstogan informed headquarters. ${ }^{530}$ This correspondence was personal, but it was also official. In 1951, when the USSR celebrated its $34^{\text {th }}$ anniversary, Dyson Carter sent a letter of congratulations to A. Denisov at VOKS. ${ }^{531}$ On the death of Andrei Vishinsky, famous as the chief prosecutor (or the "hanging judge") during the show trials of the Stalin period, and also the Soviet representative to the United Nations, Dyson Carter sent condolences to Denisov at VOKS. $^{532}$

Very occasionally VOKS dealt in official government information. The VOKS representative in Ottawa routinely forwarded the Canadian Department of External Affairs bulletins to Moscow, and also sent shipping guides for the Accounting Department, presumably so the costs of sending packages could be calculated. In 1957 , the Fisheries Research Board of Canada requested and exchange of information of fisheries. W. E. Ricker explained that the Canadians had been sending material for some years to the USSR, and would like to receive some in return. ${ }^{533}$

The VOKS representatives in Ottawa and the Moscow headquarters also put the CSFS in contact with other Soviet Friendship Societies abroad, and informed them of the Canadian-Soviet Friendship evenings hosted in Moscow. For example, Carter's 1951

${ }^{528}$ VOKS 6:57:20, Cysz family New Year's greeting, 10 January 1957. Dorothy Johnson, who had recently visited the USSR with the CCF delegation, also sent a New Year's card to VOKS. VOKS 6:57:13-13a, Dwight and Dorothy Johnson, 2 February 1957.

${ }_{529}$ VOKS 6:51:26-27, Louise Harvey to VOKS, 12 October 1955, Chesnokov to Kon, 13 November 1955.

${ }^{530}$ VOKS 6:55:2, A. Tovstogan to I. Kulakovskaya, 11 December 1956.

${ }^{531}$ VOKS 6:32:59, Carter to Denisov, 4 October 1951.

${ }_{532}$ VOKS 6:58:23, Carter to Denisov, 24 November 1954.

${ }^{533}$ VOKS 6:57:64-65, W.E. Ricker letter, 14 June 1957. 
letter to the Sino-Soviet Friendship Society was directed via VOKS. ${ }^{534}$ Because of the political situation in the United States, many American progressives received the CSFS journal and other mailings, and corresponded with Dyson Carter. In 1952, Carter forwarded VOKS a glowing letter to "Dear, dear Joseph Stalin" from a "rank and file U.S. citizen," praising socialism, as well as a poem written in English by an American CSFS member, which included the odd phrase, given the USSR's official atheism, "God Bless the Soviets. ${ }^{~} 535$

VOKS representatives in Ottawa also sent material to headquarters related to Canadian culture, society and politics. Often these packages included newspaper clippings and magazine articles, the Canadian Who's $W h o^{536}$ or biographical descriptions of Canadian figures, and books published that showed the USSR in a favourable light. ${ }^{537}$ Gregori Okulevich's book Russkye v Kanade (Russians in Canada) was sent to VOKS in 1957. In addition, any letters from CSFS readers or members who spoke in favour of Soviet policies in Hungary and elsewhere, and material like Dyson Carter's information on housing in Canada, which described homes as status symbols, were forwarded to interested parties in the USSR. ${ }^{538}$ A package of brochures, probably anti-communist, written in German and Ukrainian was sent by VOKS to the Institute of Marx-Engels-

\footnotetext{
${ }^{534}$ VOKS 6:32:161-162.

${ }^{535}$ Correspondence between A. Denisov, Bogatyrev, Pskrebyshev, Yu. M. Brusnichkin (head, Soviet Culture Section, VOKS) and I. Riggs (an American CSFS member), April-June 1952, VOKS 6:40:3-5, 7-8. The poem appears to have been written by Riggs.

${ }^{536}$ VOKS 6:55:138, A. Tovstogan to G. Ioanisyan, 11 July 1957.

${ }^{537}$ Including books by Dyson Carter, passim in the VOKS collection. VOKS 6:55:21, 103-104, 204. Carter frequently forwarded plays and novels which he thought would interest VOKS. These will be discussed further in the chapter on the CSFS and culture.

${ }^{538}$ VOKS 6:55:63-65, 70-77, A. Tovstogan to A. Vertogradov, 1 February 1957; A. Tovstogan to G. Ioanisyan, 22 February 1957.
} 
Lenin-Stalin in Moscow. ${ }^{539}$ Inna Kulakovskaya wrote to editors of mainstream Canadian magazines, asking if they would be interested in a magazine exchange. The editors of Canadian Art, Liberty, Phoenix, Canadian Forum, and Maclean's agreed to exchanges, and VOKS Book Exchange Department made it happen. ${ }^{540}$ All such activity ramped up particularly in 1956, when the VOKS representative reported to his superiors on the difficulties exhibiting Soviet photographs and declining attendance at Soviet friendship events caused by the $20^{\text {th }}$ Party Congress announcements in February. After this, Aleksei Tovstogan displayed much more initiative in seeking interviews and securing exchanges.

After Khrushchev's famous "Secret Speech" denouncing Stalin in 1956 became public in the West ${ }^{541}$ and the Soviet invasion of Hungary in the autumn of the same year, the pro-Soviet communist movement suffered an enormous attrition worldwide. In Canada, not only did great numbers of long-time Communist Party members disassociate themselves from their former comrades, but the purportedly more mainstream CSFS also suffered. One of the most important CSFS administrators, Jim Leech, was "freed from his duties" due to his "incorrect behaviour" following the $20^{\text {th }}$ Party Congress, ${ }^{542}$ and another, Ted Baxter, admits that after 1956 police intimidation and fear became too much to bear, and he left the movement. ${ }^{543}$ Ted Baxter's subscription to the VOKS Bulletin was

\footnotetext{
${ }^{539}$ VOKS 6:39:180, 189. K. Perevoschikov to A.V. Tushunov (Director of the Institute of Marx-EngelsLenin-Stalin), 7 December 1953. One brochure dealt with a speech given by J.V. Stalin in 1935 at Lviv (Lvov), Ukrainian SSR, and came from the AUUC. Others dealt with resolutions of the Comintern Congress, also held in 1935 in Lviv.

${ }^{540}$ Correspondence between Kulakovskaya and these journals, as well as her letters to the editors who did not answer in VOKS 6:54:103-110, 134-137, 144-146; 57:7-12.

${ }^{541}$ Khrushchev's declarations were not made fully public in the USSR until Mikhail Gorbachev's glasnost allowed for its complete release.

${ }^{542}$ VOKS 6:49:264-267, A. Tovstogan to A. Vertogradov, 20 September 1956. Probably "incorrect behaviour" meant that Leech became disillusioned with the USSR over the revelations and change of policy.

${ }_{543}$ Interview with J.E. (Ted) Baxter, 8 December 2006, Stratford, ON.
} 
cancelled in August $1956 .{ }^{544}$ Charlotte Carter's comments that the $20^{\text {th }}$ Party Congress had made the idea of Soviet friendship unpopular in Canada were duly reported by Tovstogan to the VOKS headquarters. ${ }^{545}$ Apparently, it was not only Canadian-Soviet friendship that suffered: in the summer of 1957 when more issues of the VOKS magazine were requested for Canada, the head of the VOKS Book Exchange department was instructed to take the copies the supply earmarked for the New Zealand Society for Closer Relations with the USSR. ${ }^{546}$

The Soviet response was again to reshuffle and reorganize, as had been done after the Gouzenko defection. The timing corresponded with the automatic changeover from the VOKS Bulletin, the in-house magazine for foreign readers, to the more lively and colourful Culture and Life, which from January 1957 was sent to all Bulletin readers. CSFS members had written for the Bulletin, ${ }^{547}$ and Dyson Carter had periodically sent VOKS comments and suggestions for the publication. In November 1956, Carter was asked to promote the new magazine, and to give VOKS a list of Canadians who should receive a free subscription. ${ }^{548}$ Probably it was not a coincidence that the first issue of Northern Neighbors appeared in December 1956. Dyson Carter continued to organize tours and promote Soviet literature through the journal's pages.

Increasingly, probably as a result of the suspension of high-level Soviet and Canadian discussions of cultural exchanges in late 1956, the VOKS representative at the Soviet Embassy began to travel in Canada, interviewing individuals about the possibility

\footnotetext{
${ }^{544}$ VOKS 6:49:232-237, A. Tovstogan to A. Vertogradov, 17 August 1956.

${ }^{545}$ VOKS 6:55:150-151, A. Tovstogan to G. Ioanisyan, 31 May 1957.

546 VOKS 6:55:145, G. Ioanisyan to N.K. Shenko, (chief, Book Exchange dept., VOKS), August 1957.

${ }^{547}$ See Kate Bader, "Let us Be Friends!" VOKS Bulletin, 2(91) 1955; Louis Kon, "A Letter from Moscow," VOKS Bulletin, 3(92) 1955. Library and Archives Canada has sporadic issues of the VOKS Bulletin in its collection, and a fairly complete run of Culture and Life from 1985-1990. LAC is currently unable to locate issues of Culture and Life from 1957 to 1984.

${ }^{548}$ VOKS 6:53:11, I. Kulakovskaya to D. Carter, 17 November 1956.
} 
of organizing tours of Soviet performing artists. Alexei Tovstogan's notes on these interviews were sent to the VOKS headquarters in Moscow. For instance, in March 1957 Tovstogan visited Walter Homburger, who was the director of International Artists, representing pianist Glenn Gould, soprano Lois Marshall, conductor Jack Bowdrie and other Canadian performance artists. They discussed Glenn Gould's upcoming European tour, which would include a visit to the USSR. ${ }^{549}$ Glenn Gould was the first Canadian performer to visit the Soviet Union, where he had a large fan base, and this was Gould's first trip to Europe. Homburger said that naturally Gould was slightly nervous, but that preparations were on schedule. Tovstogan then proceeded to ask Homburger about the possibility of organizing a tour of Soviet artists to Canada, and Homburger responded positively, saying a few concert performers, or a ballet troupe would be feasible. Tovstogan concluded his report by saying that he personally felt that Homburger had the experience and capability to organize such a tour. ${ }^{550}$

In April 1957, Jules Léger suggested to Lester B. Pearson, Minister of External Affairs, that "the time has come for us to reconsider our present policy" towards cultural exchanges with the USSR ${ }^{551} \mathrm{He}$ mentioned that the Soviets had been pressing "for a resumption of those exchanges which were planned before the events in Hungary," and in response to Canadian hesitation had "now taken the line that they will have to make alternative plans if they cannot count on us for an early decision." Rather than allow this to happen, Léger suggested that a strictly non-political performing tour that would

\footnotetext{
${ }^{549}$ VOKS 6:55:199-202, Tovstogan, "Notes on Interview with Director of Canadian Firm 'International Artists', Walter Homburger," 28 March 1957.

${ }^{550}$ VOKS 6:55:199-202.

551 "Memorandum from Under-Secretary of State for External Affairs to Secretary of State for External Affairs," 17 April 1957, "Exchange of Visits with the U.S.S.R. and the Satellites," no. 519, DEA/12230-40 in Greg Donaghy, ed., Documents on Canadian External Relations, vol. 23, 1956-1957, Part II (Foreign Affairs and International Trade Canada, 2002).
} 
interest Canadians, perhaps of a ballet troupe, provided that the Soviets negotiated all details with External Affairs first, may be in order. ${ }^{552}$ In June 1957, the Assistant UnderSecretary of State, John Holmes, renewed the suggestion that the negotiations be revived. ${ }^{553}$ In early 1958 , the Canadian government promised the Soviets that it would discuss further exchange programs, but a federal election caused some delays. Ambassador Chuvakhin was told in February 1958 that "pressure from the Soviet side on these matters during the pre-election period would be embarrassing," but once re-elected the cabinet agreed. ${ }^{554}$ The Soviet Embassy in Canada was informed of the Canadian proposals for high-level exchanges in August 1958..$^{555}$

In the meantime, Tovstogan continued sounding out Canadian impresarios on the theme of exchanges. In July 1957, he interviewed impressario Nicholas Koudriavtsev, president of Canadian Concerts and Artists, about a Soviet performing art group to Canada. ${ }^{556}$ Koudriavtsev also agreed in principle that having a Soviet group visit Canada after they had finished their tour of the United States was possible. He noted that there was a "weak cultural market in Canada" and his company could only guarantee six or seven concerts of Soviet artists in eastern Canada. He suggested, then, that it would be best to arrange a tour of North America in cooperation with American companies.

\footnotetext{
${ }^{552}$ Ibid. On the other hand, Léger noted that the Soviets had yet to place an order for Canadian wheat in 1957.

553 "Memorandum from Assistant Under-Secretary of State for External Affairs to Acting Secretary of State for External Affairs," 6 June 1957, "Exchange of Visits with Communist Countries," no. 500, DEA/1223040, Michael Stevenson, ed., Documents on Canadian External Relations, vol. 25, 1957-1958, (Foreign Affairs and International Trade Canada, 2005). Pearson was away from Ottawa at this time, campaigning for the election, which took place on 10 June 1957.

554 "Memorandum from Assistant Under-Secretary of State for External Affairs to Under-Secretary of State for External Affairs," 7 February 1958, no. 501, DEA/12230-40; "Extract from Cabinet Conclusions," 19 June 1958, no. 503, DCER, volume 25. Sydney Smith was Minister of External Affairs at this time. ${ }_{555}$ External Affairs note no. 35, dated 19 August 1958, attached to "Memorandum from Under-Secretary of State for External Affairs [Jules Léger] to Secretary of State for External Affairs," 22 August 1958, no. 504, DEA/12230-40, DCER, volume 25 .

${ }^{556}$ VOKS 6:55:153-157, Tovstogan, "Notes on Interview with President of the Company, 'Canadian Concerts and Artists,' N.F. Koudriavtsev.
} 
Koudriavtsev further suggested that a group of 50-60 artists might consider participating in Montreal's annual festival of music and dance, or perhaps the Stratford Music Festival. On the financial side, Koudriavtsev noted that he had good connections at the Canadian Department of External Affairs, and especially with Deputy Minister Jules Léger, and it would be necessary to make sure visas were issued before contracts were signed. ${ }^{557}$

Not surprisingly, given Koudriavtsev's recommendation, Tovstogan visited Louis A. Applebaum in October 1957 to discuss the possibility of Soviet participation in the Stratford Music Festival. ${ }^{558}$ Applebaum was one of the initiators of the festival in 1954, noted Tovstogan, and spoke at length about organizing a music seminar where internationally renowned musicians would mix with newer talents. He suggested to Tovstogan that some Soviet musicians might attend that seminar, and promised to let the Soviet embassy know when the plans were better formed. In December Ambassador Chuvakhin wrote to Yury Zhukhov, head of the State Committee for Cultural Relations with Foreign Countries, officially suggesting that Soviet music groups be sent to participate in the music festivals in Montreal, Stratford, and British Columbia in 1958. Chuvakhin added that Sydney Smith, Canadian Secretary of State for External Affairs, had said publicly that greater cultural exchanges between the USSR and Canada were needed. 559

In October 1957, Tovstogan also sent a letter to V.A. Bony at the Soviet Ministry of Culture giving details about the upcoming visit of Canadian conductor Jack Bowdrie

\footnotetext{
${ }^{557}$ VOKS 6:55:153-157.

${ }^{558}$ VOKS 6:55:209-214, Tovstogan, "Notes on the Interview with Canadian Composer L.A. Applebaum, 22 October 1957," notes dated 12 November 1957.

${ }^{559}$ VOKS 6:55:216-218, Chuvakhin to G.A. Zhukov, 13 December 1957.
} 
to Moscow. ${ }^{560}$ Bowdrie would be arriving from Brussels and Paris, and Tovstogan reported that he had agreed to do six concerts as the director of Soviet symphony orchestras in November and December 1957. Tovstogan also sent along information about Lois Marshall's visit to the USSR in $1958 .{ }^{561}$

The damage done to its international image by the events of 1956 meant that the Soviet authorities were looking for ways to respond, just as they had 10 years earlier. It has been suggested that changes in the way the International Department of the CPSU Central Committee (ID) functioned after this time were directly related to post-1956 perception management. ${ }^{562}$ In the spring of 1957, the ID was relieved of its supervision of ruling Communist parties abroad, and this task was handed over to a new Central Committee department, the Department for Liaison with Communist and Workers' Parties of Socialist Countries. ${ }^{563}$ The new State Committee for Friendship established in 1957 could very possibly have been to replace the ID in its responsibility for the foreign Communist-front friendship groups. Also at this time the Return to the Homeland project was initiated, appealing directly to individuals abroad who had roots in the Soviet territories to return "home." 564

By the end of the 1950s, the State Committee for Cultural Relations with Foreign Countries dealt with high-level exchanges agreed to between the Soviet government and governments abroad, and was also "commonly recognized and tacitly admitted" to be in

${ }^{560}$ VOKS 6:55:170-172, A. Tovstogan to V.A. Bony, 29 October 1957.

${ }^{561}$ VOKS 6:55:186-188, A. Tovstogan to G. Ioanisyan, 29 October 1957.

${ }^{562}$ Kramer, "The Role of the CPSU International Department in Soviet Foreign Relations and National Security Policy," Soviet Studies, vol. 42, No. 3 (July 1990), p. 430.

${ }_{563}^{563}$ Ibid.

${ }^{564}$ Glenna Roberts and Serge Cipko (with Peter Roberts), One Way Ticket: The Soviet Return to the Homeland Campaign 1955-1960 (Manotick: Penumbra Press, 2008). See also Serge Cipko and Peter M. Roberts, Canada and the Khrushchev Government's "Return to the Homeland" Campaign (Centre for Research on Canadian-Russian Relations, Carleton University, Ottawa, November 2000. Occasional Paper no. 8). 
charge of VOKS. ${ }^{565} \mathrm{~A}$ memorandum prepared by the Canadian Embassy in Moscow in 1957 explained that the recent establishment of this State Committee, which was linked to the USSR Council of Ministers, was the "most recent indication of Moscow's desire to break out of the isolation imposed by its actions in Hungary and the Suez Crisis. The USSR has been conducting a vigorous campaign to restore contacts at all levels with the West. ${ }^{, 66}$ At the head of the committee was G.A. (Yuri) Zhukhov, former deputy editor of Pravda, and a man the Canadian mission described as "a skilled propagandist," who had "acted on many occasions as an unofficial spokesman for the Soviet government." Therefore, the establishment of the State Committee signaled the beginning of the changes to VOKS and its sponsored groups.

In February 1958, VOKS was dissolved and a new organization mandated to deal with friendship abroad was set up in Moscow. This new institution was called the Union of Soviet Societies for Friendship and Cultural Relations with Foreign Countries, known by its Russian acronym, SSOD. Despite the new moniker, the head of VOKS, N.V. Popova, carried on in the post of president for the SSOD, two of her deputies kept the position of vice-chairmen in the new organization, the same building was used as a headquarters, and the SSOD continued to publish the journal Culture and Life. ${ }^{568} \mathrm{~A}$ memorandum prepared by the European Division of the Canadian Department of

\footnotetext{
${ }^{565}$ LAC, RG25, vol. 3704, file 5496-40 part 2, "New Organization to Control 'Friendship"”, April 1958, memorandum attached to Memo from Defence Liaison (2) to Information Liaison, External Affairs, 15 January 1959.

${ }^{566}$ LAC, RG25, vol. 7117, file 9055-40, Pt. 3.2, Memorandum from the Canadian Embassy in the USSR, n.d. 1957, "USSR Establishes New Cultural Relations Committee," marked "Canadian Eyes Only- Secret". The establishment of the State Committee was announced in Sovetskaya Kultura on 21 May 1957. LAC, RG25, vol. 7117, file 9055-40, Pt. 3.2, Letter from David M. Johnson [Canadian Ambassador] to UnderSecretary of State for External Affairs, 23 May 1957. ${ }^{567}$ Ibid.

${ }^{568}$ LAC, RG25, A200700336, memorandum entitled "New Organization to Control 'Friendship,"” April 1958, p. 510-511.
} 
External Affairs in April 1958 declared: "It is in fact clear that the new union is merely VOKS under another name." 569 The Canadian memorandum also clearly identified this change as part of the Soviet appeal for greater cultural exchange, by which they meant not "the abolition of their censorship, radio jamming and restrictions on the import of books and newspapers but the stepping up of such cultural activities as the exchange of ballet companies." Apparently, foreign governments had complained to authorities in Moscow about VOKS' sponsorship of unofficial Communist-led groups in their countries, and Mme Popova "admitted that some of VOKS' past activities have embarrassed the Soviet Government and prejudiced its relations with other countries..." ${ }^{570}$ In renaming the organization the Union of Soviet Societies, the impression was given that these groups were themselves non-governmental organizations within Soviet society, and could therefore negotiate freely with other unofficial nongovernmental groups like them abroad. The definition of its mandate did not change in the Soviet encyclopedia, nor in the speech given by its "new" president in February 1957. In 1959, the Canadian Department of External Affairs discussed the fact that the VOKS headquarters had been known to have within it a KGB office, and expressed concern that a corresponding individual working directly for the KGB often held a position within the friendship societies abroad. ${ }^{571}$ Indeed, it appeared that certain types of information forwarded to VOKS were probably prepared with KGB interests in mind. ${ }^{572}$ The

\footnotetext{
${ }^{569} \mathrm{Ibid}$.

${ }^{570}$ Ibid.

${ }^{571}$ LAC, RG25, A200700336, Memorandum from Defence Liaison (2) to Information Division, External Affairs, 15 January 1959, p. 494-495.

572 On the overlap of diplomatic duties and KGB interests see Aleksei P. Makarov, "Living with the KGB and GRU: A 'Clean' Diplomat Recalls his Experiences Inside Soviet Embassies," in Black and Rudner, eds., The Gouzenko Affair, p. 151-189.
} 
Defence Liaison Division of External Affairs suggested that this overlap of intelligence with friendship would continue under the SSOD..$^{573}$

The Canadian Department of External Affairs and its Embassy in Moscow followed these developments closely and skeptically, particularly in the SSOD's organization of special friendship evenings that were linked to Western countries. In February 1959, a memorandum from Canadian Ambassador to Moscow, David Johnson, to Ottawa noted that the SSOD had established groups in Moscow that specialized in the promotion of culture and friendship with France and Italy, and anticipated that SSOD would soon approach the Canadian Embassy with a proposal for a Moscow-based Canadian friendship group. ${ }^{574} \mathrm{He}$ also indicated the reactions of American, British and German diplomats in Moscow to the activities of the SSOD. ${ }^{575}$ The North Atlantic Treaty Organization in Paris was also pondering the line to be taken in relation to this group. Ottawa advised its representatives to NATO that "if the Canadian ambassador is invited to attend or to be represented at an inaugural meeting of any Soviet-Canadian Friendship Society, he should make it clear to VOKS [SSOD] that the Canadian-Soviet Friendship Society, as it is at present constituted, is unrepresentative and unrespected and would not repeat not enjoy the cooperation of the Canadian government in any effort to play any role in cultural exchanges between Canada and the USSR." 576

\footnotetext{
${ }^{573}$ This information had become available after the Australian Royal Commission on Espionage of 1955. LAC, RG25, A200700336, Memorandum from Defence Liaison (2), External Affairs to Information Division, External Affairs, 15 January 1959, p. 494-495.

${ }^{574}$ These names are confusing. VOKS had a British Countries Division which corresponded with the CSFS in Canada until 1957, after which the SSOD established a Moscow-based USSR-Canada Society, and after 1960, the CSFS became the Canada-USSR Association, with its main office in Toronto.

${ }^{575}$ LAC, RG25, A200700336, letter from the Canadian Ambassador in Moscow, Daniel Johnson, to the Under-Secretary of State for External Affairs, letter no. 275, 27 February 1958, p. 519-521.

${ }^{576}$ LAC, RG25, A200700336, telegram Ottawa to NATO Paris, 328/518, 15 February 1958, copied to Moscow, p. 535.
} 
The SSOD established a Moscow-based USSR-Canada Society on 28 December 1959, and it was announced in Pravda the next day. ${ }^{577}$ The first president of the USSRCanada Society was Soviet actor Mikhail I. Tsarev, who had once visited Canada, and the General-Secretary was Igor A. Tikhomirov of the SSOD, who later went to work for the State Committee on Cultural Relations with Foreign Countries. ${ }^{578}$ In 1962 D.M. Zabrodin, who had previously arranged teachers' exchanges between Canada and the USSR for the Union of Education, Higher Education and Scientific Workers, took over from Tikhomirov. ${ }^{579}$ The Canadian ambassador to the USSR, David M. Johnson, was instructed by External Affairs to send junior representatives to the inaugural meeting, but not to attend himself. External Affairs explained that this was because the new Moscow group was intent on propagandizing the Soviet Union in Canada, had used Canadian visitors to do this, and maintained contact with sympathetic groups in Canada, "possibly through the Soviet embassy." Still, External Affairs concluded that the Society could be useful to Canadian diplomats in the USSR if treated carefully, so it was not in their interest to 'cold-shoulder' the group, as long as the USSR-Canada Society did not make any specific mention of supported groups in Canada. ${ }^{580}$ The SSOD was informed of

${ }^{577}$ LAC RG25, A200700336, letter from the David M. Johnson, Canadian Ambassador to USSR to UnderSecretary of State for External Affairs, Ottawa, 29 December 1959, with translated excerpt from Pravda article "To Strengthen Soviet-Canadian Friendship" attached, p. 451-455; LAC, RG25, A200700336, RCMP Research Section report, "The Canada-USSR Association," 27 March 1963, p. 834-845.

${ }^{578}$ The inaugural meeting was held on 28 December 1959 at the "House of Friendship" in Moscow. LAC, RG25, A200700336, Letter from the David M. Johnson, Canadian Ambassador to USSR to UnderSecretary of State for External Affairs, Ottawa, letter no. 1425, 29 December 1959, p. 451-455; LAC, RG25, A200700336, "Letter from Moscow to the Under-Secretary of State for External Affairs, Ottawa," no. 415,15 May 1962 , p. $850-851$.

${ }^{579}$ Ibid.

${ }^{580}$ LAC, RG25, A200700336, letter from M. Cadieux, the Under-Secretary of State for External Affairs, Ottawa to the Canadian Embassy, Moscow, no. S34, 20 January 1960, p. 442-443. 
these conditions, and appears to have respected the Canadian Embassy's views in this connection. $^{581}$

Given the expressed distrust of the Canadian-based CSFS, as well as the changes in VOKS/SSOD, it is not surprising that the CSFS was dissolved and reformed in 19591960. The Royal Canadian Mounted Police reported that in the spring of 1959, Tim Buck, leader of the Labor Progressive Party traveled from Canada to Moscow for discussions about establishing a new Soviet-Canadian friendship link. Apparently he was urged by "Soviet officials" to find a new leader from within the Canadian party, and to reestablish the Society soon after its Moscow link was formed. In late 1959, the recently renamed Communist Party of Canada decided to change the name of the CSFS to the Canada-USSR Association, and in March 1960 Leslie Hunt was chosen to head up the new group. ${ }^{582}$ The Association was officially launched in December 1960 at the King Edward Hotel in Toronto. ${ }^{583}$ Although the Canada-USSR Association would publish its own newsletter, Dyson Carter was encouraged to continue publication of Northern Neighbors. ${ }^{584}$ Carter continued to be a frequent guest at the Soviet Embassy in Ottawa, and his relationship with Embassy and Moscow-based officials remained close. ${ }^{585}$ The Association cooperated and corresponded with the Moscow-based Society via the Soviet

${ }^{581}$ RG25, vol. 3704, file 5496-40, part 2, Letter from the David M. Johnson, Canadian Ambassador to USSR to Under-Secretary of State for External Affairs, Ottawa, letter no. 1425, 29 December 1959, p. 451455.

${ }^{582}$ LAC, RG25, A200700336, RCMP Research Section report, "The Canada-USSR Association," 27 March 1963, p. 834-845.; Leslie Hunt, interview with author, 2 January 2007, Hanover, ON.

${ }^{583}$ LAC, RG25, A200700336, RCMP Research Section report, "The Canada-USSR Association," 27 March 1963, p. 834-845.

${ }^{584}$ J.E. (Ted) Baxter, interview with author, 8 December 2006, Stratford, ON; John Boyd, interview with author, 2 August 2006, Toronto, ON; LAC, RG25, A200700336, RCMP Research Section report, "The Canada-USSR Association," 27 March 1963, p. 834-845; LAC, RG25, A200700336, "Letter from Moscow to the Under-Secretary of State for External Affairs, Ottawa," no. 415, 15 May 1962, p. 850-851.

${ }^{585}$ John Boyd, a Party insider, has said that the Communist Party of Canada tried to convince the Soviets to distance themselves from Carter, but that it was unsuccessful in this. Carter and his prolific, pro-Soviet writing were just too valuable to the Soviet cause. John Boyd, comments on manuscript written by Jennifer Anderson, April 2008. 
Embassy in Ottawa. In 1962, the RCMP confirmed that a Soviet official at the embassy of the USSR in Ottawa, responsible for liaising with the new Canadian group and for dealing with cultural affairs, had previously been with the USSR-Canada Society in Moscow and "had been firmly identified as a K.G.B. careerist officer" with previous foreign experience in that field. ${ }^{586}$ The work of Soviet image-spinning in Canada carried on as before. ${ }^{587}$

In a society that placed great importance on managing contacts with Westerners, VOKS had a special significance. The weight placed on its activities is clear from the high-profile individuals who headed the organization, but also in the people selected as representatives in Ottawa. Burdin and Tovstogan, if not actually KGB officers, benefited from enormous official Soviet trust, and were given cover that was unusual even in Soviet embassies, where many of the diplomats held such dual positions. The KGB would have been keeping very close track of their activities. The RCMP and the Department of External Affairs were correct in their concern about the security risks this represented to Canadians. As an authoritative and sympathetic contact, Dyson Carter and perhaps some of the other CSFS activists were providing information the Soviets craved, and in turn their own demands were also satisfied. In 1956 Carter, for instance, asked VOKS to send him a special camera that took miniature photographs: "I have long wanted to send certain 'micro-film' copies of letters, etc., to VOKS," he wrote. ${ }^{588}$ Whether Carter received this camera is uncertain.

\footnotetext{
${ }^{586}$ LAC, RG25, A200700336, letter delivered by hand from J.R.W. Bordeleau, Assistant Commissioner, Director, Security and Intelligence, RCMP to Mr. J.J. McCardle, Under-Secretary for External Affairs, 2 April 1963, p. 833. Access to Information and Privacy officers have deleted the name of this Soviet official and his position at the Soviet Embassy in Ottawa.

${ }^{587}$ Details on the activities and make-up of the Canada-USSR Association will be given in the epilogue.

${ }^{588}$ VOKS $55: 99$, Carter letter.
} 
What is clear is that Canadian historians have for too long overlooked the importance of VOKS in negotiating both high and grass-roots cultural exchanges, and as actors in international relations, just as 'ordinary' Canadians may have overlooked the sensitive nature of their contacts with VOKS. The promotion of Soviet culture abroad and the establishment of contacts with sympathetic individuals was the main goal of the VOKS representatives in Ottawa. The message they underwrote was disseminated by the progressive groups in Canada, with the CSFS leading the way. Understanding how the Soviet image was polished by pro-Soviet Canadians during the Cold War using information and opportunities provided by VOKS, and analyzing the reasons this image had so much appeal on the Canadian left, will be the focus of the next chapter. 


\section{Chapter Six \\ POLISHING THE SOVIET IMAGE: THE CANADIAN SOVIET FRIENDSHIP SOCIETY AND THE 'PROGRESSIVE ETHNIC GROUPS'}

The post-war CSFS, operating in the political climate of the early Cold War, used "friendship" to appeal to Canadians who may have been put off by more politically overt declarations of admiration for the Soviets. This was an extension of the Popular Front appeal undertaken by Communist parties and communist-front groups during the war, by which they reached out to more mainstream groups, and, together with peace and price activism, formed an important part of the radical agenda in Canada after World War II. While superficially appearing as a non-partisan group, political messages were never far below the surface of most CSFS-organized events and publications. The links between the radical left-wing communities in Canada have been touched upon by other researchers, but in the CSFS we see that this interconnectedness was intentional. ${ }^{589}$ In fact, this aspect was probably one of the CSFS' most attractive features for members. In this linked community, the USSR was a symbol of progressivism, and a short-hand for political and social group identity. For Soviet sympathizers and fellow travellers, being part of a larger community was also comforting, as mainstream Canadian public opinion would have been critical of their views and their activism.

Judging from documents recently copied from the VOKS archives, as well as RCMP files which have now been released, the CSFS saw its mission to work as a liaison with ethnic groups, while at the same time attempting to recruit members from the Anglophone middle-class into the progressive movement. Indeed, the archives are full of

\footnotetext{
${ }^{589}$ On this, Ester Reiter's work on the Jewish radical left in Toronto has been most useful. Reiter, "Secular Yiddishkait: Left Politics, Culture and Community," Labour/Le Travail, Spring 2002,

$<\mathrm{http}: / /$ www.historycooperative.org/journals/llt/49/05reiter.html> (10 Jun. 2008).
} 
references to material shared, and the cooperation or conflict that existed between the socalled "ethnic" leftist groups and the CSFS. While there have been several very good historical studies of radicalism within particular ethnic groups in Canada, as well as ethnic participation with the LPP/CPC, relatively little work has been done on the interethnic relationships between the apparently 'non-ethnic' CSFS and other 'progressive, ethnic' groups. ${ }^{590}$ Understanding how the self-described 'pan-Canadian,' AngloSaxon $^{591}$-led CSFS interrelated with radical ethnic groups in Canada can tell us more about what it meant to be radical in Canada during the early Cold War.

Before 1945, the task of attracting ethnic and more "Canadian" members to the communist movement may have been carried out largely within the Party. The so-called "language groups" had always been more popular than the main body of the CPC, and they raised more money, as well. Members of these "mass organizations" were divided over the political policies the Comintern wished them to adopt and the linguistic and cultural matters they felt to be at least equally important. In 1929, the Comintern decreed that the language groups would no longer be considered officially part of the $\mathrm{CPC}$, but

\footnotetext{
${ }^{590}$ One particular exception is the work done by Julie Guard on the interaction of Anglo-Saxons with ethnic members of the Housewives' Consumers Association, and the use of Anglo-Saxon names to attract more mainstream Canadians to the cause. Julie Guard, "Canadian Citizens or Dangerous Foreign Women? Canada's Radical Consumer Movement, 1947-1950" in Marlene Epp, Franca lacovetta, Frances Swyripa, Sisters or Strangers? Immigrant, Ethnic, and Racialized Women in Canadian History (Toronto, 2004), p. 161-189. These links are also mentioned in Ester Reiter, "Secular Yiddishkait: Left Politics, Culture, and Community," Labour/Le Travail, Spring 2002

$<\mathrm{http} / / /$ www.historycooperative.org/journals/llt/49/05reiter.html> (10 Jun. 2008). See also Frances Swyripa, Wedded to the Cause: Ukrainian-Canadian Women and Ethnic Identity, 1891-1991 (Toronto, 1993); Varpu Lindstrom-Best, The Finns in Canada (Ottawa, 1985); Varpu Lindstrom, Defiant Sisters: A Social History of Finnish Immigrant Women in Canada (Toronto, 1992).

${ }^{591}$ In using this term, I am following my sources. Despite the fact that this term is unwieldly, and possibly inaccurate, "Anglo-Saxon" is used here to refer to Anglophone Canadians of white, Protestant, middleclass, British ancestry. Some of the sources suggested that these people were more "Canadian" than individuals who had Ukrainian, Russian, or other "ethnic" last names.
} 
"were to be recruiting grounds for party membership." CPC was to be the main link between Canadian Communists and the USSR. But after the Gouzenko revelations in 1946, the LPP suffered considerable loss of legitimacy. A decade later the Soviets were still not impressed with the work of the Canadian party. A secret report prepared by V. Loginov, Counsellor at the Soviet Embassy, in 1955 specified that the problem was that more than half of the LPP membership was composed of "immigrants" and the majority of these were Ukrainian-Canadians. ${ }^{593}$ Despite this, Loginov argued, the nationalist Ukrainians in Canada still produced stronger propaganda and influenced a larger percentage of Ukrainian-Canadians than the Communists. ${ }^{594}$ This was disappointing for the Soviets, because they wanted to influence mainstream Canadian public opinion, and catering mainly to "immigrants", and doing even that poorly, was not considered by them to be a sign of success. The Soviets were concerned as well that too many Ukrainians in the Party would lead to "bourgeois-nationalist tendencies," or admiration of the Ukrainian nation rather than the USSR. Marketing Soviet-Canadian friendship to "non-ethnic" Canadians was a strategy supported by VOKS, especially via the CSFS. In reaching out to the general Canadian population, that

\footnotetext{
${ }^{592}$ Reither, "Secular Yiddishkait," Labour/Le Travail, Spring 2002, $<\mathrm{http} / / /$ www.historycooperative.org/journals/lt/49/05reiter.html> (10 Jun. 2008), paragraph 14; Norman Penner, Canadian Communism: The Stalin Years and Beyond (Toronto: Methuen, 1988), p. 273-274; Peter Krawchuk, Our History: The Ukrainian Labour-Farmer Movement in Canada, 1907-1991 (Toronto: Lugus Publications, 1996), p. 154-185.

${ }_{593}$ VOKS, 6:3:98:5-20, V. Loginov, Counsellor, Soviet Embassy in Ottawa, "Short Report on the $5^{\text {th }}$ Congress of the Labor Progressive Party of Canada and Its Post-Congress Work with the Masses", 19 March 1955. Another Loginov, A.F. Loginov, military attaché at the Soviet Embassy, was expelled from Canada in 1961 for attempting to pay Canadians for information. (Department of External Affairs, Canadian Weekly Bulletin, 20 December 1961, p. 5.) John Boyd, an active LPP organizer until 1968, has also written about "the LPP's inability to effectively reach Anglo-Saxon Canadians." John Boyd, "A Noble Cause Betrayed...But Hope Lives On: Pages from a Political Life," originally published as Canadian Institute of Ukrainian Studies Report, no. 64, 1999; Socialist History Project, $\{$ http://www.socialisthistory.ca/Remember/Reminiscences/Boyd/B1.htm $\}$, accessed 25 August 2007. ${ }^{594}$ VOKS, $6: 3: 98: 5-20$.
} 
is to say, Anglophone ${ }^{595}$ and middle-class, VOKS hoped to make admiration of the USSR and its politics more broadly palatable.

The CSFS was an important element in this strategy, because its leadership was Anglo-Saxon or had chosen English-sounding names, and it claimed to be promoting Soviet "friendship" in a way that appealed to middle-class peace activists, artists, teachers and others who did not self-identify as Communists. For example, John Boyd, a LPP member of Ukrainian origin, who was active in the left-wing ethnic communities in the early 1950s, was originally known by the surname Boychuk, but was asked by the leadership of the Communist Party to change his name so that he would have greater influence in wider Canadian society. ${ }^{596}$ Boyd has argued that the Canadian Communist Party skillfully managed the organizations it supported, such as the Friendship Society, the Canadian Slav Committee, and various peace groups, to create the illusion of independent, nonpartisan progressivism. Dyson Carter was among the best at this, Boyd says, because he was seen by outsiders to be suitably "Canadian." The ethnic composition represented a disadvantage to the Party, according to Boyd. Particularly he mentioned that the ethnic composition gave the Party "a foreign rather than a Canadian image," and this may have contributed to the difficulty the Party had in retaining AngloSaxon members. Many Ukrainian and Jewish Party members changed their names at the request of the Party leadership. Among these were John Weir (Vyviursky) who was the Moscow correspondent for the Canadian Tribune, and later editor of the Ukrainian

\footnotetext{
${ }^{595}$ The leadership of the CSFS was English-speaking and the correspondence with authorities in Moscow was maintained almost exclusively in English, even with members from Quebec, until the 1960s when a "Canada-URSS" Society was founded in Montreal.

${ }^{596}$ Interview with John Boyd, 2 August 2006, Toronto, ON. Boyd has said that he was never a member of the CSFS, but Carter claimed him to be a National Council executive member in 1951. (VOKS 36:22-23) Boyd was secretary of the Canadian Slav Committee in the late 1940s and 1950s.
} 
Canadian, and Robert Laxer (also known as Robert Owen, and whose real name was Mendel or Menachem) -- an LPP executive who once called Dyson Carter "Canada's greatest novelist." ${ }^{, 597}$ Although the cultural events offered by the CSFS attracted Canadians who had immigrated from Eastern Europe and who often had developed socialist ideals, the leaders were invariably chosen for their clear, unaccented speech and Anglo-Saxon names. ${ }^{598}$

The RCMP had been remarking upon the ethnic make-up of the Soviet friendship groups for years. When Louis Kon promoted the Friends of the Soviet Union at a YMCA meeting in 1934, the RCMP reported that there were "a goodly number of Anglo-Saxons" in attendance, probably worried that the contagion of pro-Soviet communism could spread to wider Canadian society. ${ }^{599}$ Later, at a meeting of the Society for the Study of Russia in May 1943, the RCMP reported that "a feature of the meeting as observed by members attending was the unusually large percentage of Anglo-Saxons present. ${ }^{, 600}$ Membership of this Society overlapped largely with the National Council for CanadianSoviet Friendship, minus the prominent politicians and businessmen. ${ }^{601}$ A month later, at

\footnotetext{
${ }^{597}$ Interview with John Boyd, 2 August 2006, Toronto, ON. John Boyd, "A Noble Cause Betrayed," Socialist History Project; James Laxer, Red Diaper Baby: A Boyhood in the Age of McCarthyism (Toronto, 2004), p. 25, 54. Other CPC-LPP supporters who changed their names were Fred Rose (Alfred Rosenberg), Sam and Bill Walsh (Saul and Mo Wolofsky), Louis Kon (Koniatski).

${ }^{598}$ On how this was also attempted in the Housewives' Consumers Association, see Guard, "Canadian Citizens or Dangerous Foreign Women? Canada's Radical Consumer Movement, 1947-1950" in Epp, Iacovetta, Swyripa, Sisters or Strangers? p. 161-189.

${ }^{599}$ Kealey and Whitaker, eds., "Weekly Summary Report on Revolutionary Organizations and Agitators in Canada," no. 712, 27 June 1934, The R.C.M.P. Security Bulletins: The Depression Years, pt. I, 1933-1934, p. 102.

${ }^{600} \mathrm{LAC}$, RG146, A200600124, RCMP Intelligence Branch, Toronto, report on the Society for the Study of Russia, Toronto, Ont., 31 May 1943, p. 96.

${ }^{601}$ Besides Gartner, R.A. Davies and Margaret Gould attended events run by both these organizations. The Montreal-based group led by Louis Kon in the 1930s called itself the Friends of the Soviet Union, and Kon became more involved again with the CSFS under Dyson Carter. In November 1949 at the founding meeting for the new CSFS, Dyson Carter said "Ladies and Gentlmen [sic]...GONE ARE THE DAYS, FOREVER, when we have to APOLOGIZE for friendship with the Land of Socialism! Never again do we have to go, hat-in-hand, to people in high places, and ask them: 'Please won't you allow your name to be used for the sake of friendship... important names will make people think the Russians are important!"”
} 
a National Council rally for the Soviet troops, the RCMP reported that "at least 80 per cent of the persons present were of foreign extraction and it was noted that many wellknown members of the C.P. of C. and the foreign mass language organizations occupied reserved seats in a block of the blue seats on the east side of the Gardens." ${ }^{602}$ The same report noted that the United Nations choir which performed at the rally was made up of the choirs of the AUUC, FRC and the Jewish Labor League, conducted by Emil Gartner. ${ }^{603}$ Gartner, a member of the League, and later the United Jewish People's Order, continued to be active in the CSFS under Dyson Carter as well, and traveled to the USSR with a CSFS-sponsored trip in 1951. In 1953, remarking on the steadily increasing CSFS activity, the RCMP worried that by acting as a communist-front organization, and a "clearing house" for Soviet materials, the CSFS was "bringing to the fringe of communism groups of people across the Dominion, many of them innocent, who may, in turn, become sympathetic to communist ideology." ${ }^{\text {"604 }}$ The RCMP knew at that time that the LPP was raising funds to send CSFS delegates on Soviet tours, but may not have known the extent of the support received from VOKS. ${ }^{605}$ Dyson Carter would have taken the RCMP concern as a sign that he was meeting his objectives. Responding to an article in the Financial Post in January 1952, Carter expressed glee in the journalist's consternation over what he called the "friendship front" used by the Canadian leftists, and

(LAC, RG146, A200600096, p. 81-94, Dyson Carter's notes, "Speech for C.S.F. Meeting Nov 26 49"). (Throughout, Carter's notes to himself show the highly choreographed enthusiasm in the speech (ie. "PAUSE, AND SOFTLY!", "EMPHASIS", "SLOW"). Capital letters used for emphasis in the original. ${ }^{602}$ LAC, RG146, A200600124, RCMP Intelligence Branch, Toronto, 25 June 1943, "Re: Rally- Maple Leaf Gardens, Toronto, Ont. June $22^{\text {nd }} .1943$," p. 49.

${ }^{603}$ LAC, RG146, A200600124, p. 49.

${ }^{604}$ LAC, RG146, A200600091, RCMP report "The Canadian Soviet Friendship Society, February 1951 to March 1953. Addendum to Brief Ending February 1951", 15 April 1953, p. 116.

${ }^{605}$ LAC, RG146, A200600091, p113, 116. 
boasted that CSFS strategies "have played no small part in changing public opinion in Canada."

Sponsoring events, distributing photographs and films, and organizing trips to the USSR, were among the means by which the CSFS attempted to improve the image of the Soviet Union in Canada. The organization publicized widely the Return to the Homeland campaign launched by Nikita Khrushchev in the 1950s, hoping to persuade ethnic Ukrainians, Finns, Balts, Jews, Hungarians and other East Europeans that returning to the USSR to live, or at least to visit, would be a positive experience. Key events sponsored by the CSFS included a Canadian-Soviet Friendship Month arranged in November each year, timed to correspond with the anniversary of the Bolshevik Revolution. In addition, through his articles and correspondence Carter promoted Canadian progressive writers, artists and activists, and became well known in the USSR as a leading Canadian writer. ${ }^{607}$

Sharing human and financial resources among left-wing groups in Canada was an effective way for a marginal movement to maximize its assets. It was also natural, in that members of these organizations knew each other personally, frequently attended events organized by other groups, intermarried, and lived and worked in the same geographical

\footnotetext{
${ }^{606}$ Ronald Williams, "Reds at Work on 'Friendship': Now Start Photo Propaganda Deluge," Financial Post, 5 January 1952, LAC, RG146, A200600099, p. 114; LAC, RG146, A200600100, Dyson Carter, "President's Speech, January 25, 1952", p. 67-76; also in VOKS 6:1:36:43-52.

${ }^{607}$ In 1954 a Canadian journalist posted to Moscow, G.W. Boss, went to see A. Denisov, chief of VOKS, at the VOKS headquarters. One point he made to Denisov was that there were in fact other contemporary Canadian writers besides Dyson Carter, and he asked whether there were any plans to publish them in the USSR. Denisov's notes on this interview were forwarded to M.A. Suslov, of the International Department of the Communist Party of the Soviet Union. VOKS 6:1:45:99-105, G.W. Boss to K. Perevoschikov, with questions for upcoming interview with Denisov, 24 February 1954; VOKS 6:3:96:19-21, A. Denisov to M.A. Suslov, 3 March 1954.
} 
areas. $^{608}$ Indeed, social and political networking was an important way for these

individuals to express and act on their beliefs, while at the same time lobbying for better

work conditions, and sheltering themselves from the scathing criticism Soviet

sympathizers received in mainstream Canadian society. Indeed, in this milieu the USSR

itself was a symbolic short-hand for progressive hopes and dreams. In interactions with

outside groups, those left-wingers who could claim a more "acceptable" name or accent

could represent the movement, and thereby improve its public face. ${ }^{609}$ Studying the

interaction between the CSFS and the 'progressive, ethnic' groups will provide us with

some insight into the effectiveness of the CSFS campaigns to make the Soviet Union look

attractive to Canadians, as well as into the experiences of left-wing radicals in Canada. ${ }^{610}$

\section{Shared Space, Materials and Finances}

As an organization set up by the Communist Party of Canada, ${ }^{611}$ the CSFS personnel and

readership overlapped with that of the "language groups, ${ }^{, 612}$ and they used left-wing

\footnotetext{
${ }^{608}$ This interaction, which deserves more study, has been commented upon by Ester Reiter in "Secular Yiddishkait," Labour/Le Travail, Spring 2002,

$<$ http://www.historycooperative.org/journals/llt/49/05reiter.html $>$ (10 Jun. 2008).

${ }^{609}$ In oral interviews, former CSFS members and acquaintances frequently referred to this inside/outside relationship, particularly in arranging events. At times, it may have been in response to nastier circumstances. Ester Reiter has noted that in 1925 when the Jewish Labour League wanted to buy land from the Canadian National Railway to be used for Camp Kindervelt, a "Ukrainian sympathizer" had to be asked to front the sale, because the CNR would not sell to Jews. Ester Reiter in "Secular Yiddishkait," Labour/Le Travail, Spring 2002, <http://www.historycooperative.org/journals/lt/49/05reiter.html> (10 Jun. 2008), paragraph 28.

${ }^{610}$ On admiration of the USSR in ethnic groups on the Canadian left, see Frances Swyripa, Wedded to the Cause: Ukrainian-Canadian Women and Ethnic Identity, 1891-1991 (Toronto, 1993); Varpu LindstromBest, The Finns in Canada (Ottawa, 1985); Varpu Lindstrom, Defiant Sisters: A Social History of Finnish Immigrant Women in Canada (Toronto, 1992), but especially the film Letters from Karelia; Ester Reiter, "Secular Yiddishkait," Labour/Le Travail, Spring 2002,

$<$ http://www.historycooperative.org/journals/llt/49/05reiter.html> (10 Jun. 2008). For admiration of the USSR by the Communist Party of Canada, see Merrily Weisbord's The Strangest Dream (Montreal, 1983, 1994); Laxer, Red Diaper Baby: A Boyhood in the Age of McCarthyism (Toronto, 2004).

${ }^{611}$ For an interesting discussion on how Dorise Nielsen and Dyson Carter were asked by the Party to travel across Canada to do damage control to the image of communism following the Gouzenko revelations of 1946, and their work to reorganize the CSFS, see Faith Johnston, A Great Restlessness: The Life and Politics of Dorise Nielsen (Winnipeg, 2006), p. 197, 225-231.
} 
ethnic group halls across Canada for their own meetings. RCMP investigators reading the ethnic press reported to their superiors on CSFS-related events hosted in these premises. Touring the Western provinces in 1950 to raise awareness of the CSFS, Dorise Nielsen spoke at the Doukhobor Dome in Verigin on 30 November 1950, and at the leftwing Ukrainian Hall in Wynyard, Saskatchewan on 28 November. $^{613}$ In January 1951, CSFS meetings were held at the Ukrainian Labour Temples in Niagara Falls and Welland; ${ }^{614}$ in March 1953 the CSFS exhibited Soviet photographs and sponsored a talk by Dyson Carter in the Niagara Falls Hungarian Hall. ${ }^{615}$ In November 1955 a CSFS event was held in the United Jewish People's Order's hall in Toronto. ${ }^{616}$ In October 1951, the RCMP reported that a "CSF-League evening was to take place at the Hungarian Hall in Niagara Falls, with Emil Gartner, his wife Fagel Gartner, Archie Hamilton, Alek Tichnovich and Dorise Nielsen (co-founder of the CSFS) speaking on their recent trip to USSR. ${ }^{.617}$ In January 1953, performances of the United Jewish Peoples Order choir, directed by Emil Gartner, ${ }^{618}$ and the AUUC choir, directed by Eugene Dolny, followed speeches given by Dyson Carter and Dorise Neilsen, of the Friendship Society ${ }^{619}$ In

\footnotetext{
${ }^{612}$ There are numerous examples of personnel being asked to serve on committees for the 'language' groups, the LPP, and the CSFS. This includes Nadia Savich, asked in 1955 by the National Executive of the Federation of Russian Canadians, to represent the FRC in the CSFS. LAC, RG146, A200600104, "Minutes of proceedings N. 25 of the meeting of the National Executive of the FRC of September 27, 1955," p. 30. ${ }^{613}$ LAC, RG146, A200600097, RCMP report from Yorkton Special Branch, 21 December 1950, p. 20. ${ }^{614}$ LAC, RG146, A200600117, RCMP Headquarters, report of information in Ludove Zvesti (Slovak for People's News), 20-1-51, report dated also 20-1-51, p. 11.

${ }^{615}$ From the Sudbury Finnish-language newspaper Vapaus, 21 March 1953, no. 34, vol. XXXVI, p. 8.

${ }^{616}$ VOKS, 6:1:49:17, letter from Tovstogan to Kulakovskaya, 26 Nov. 1955.

${ }^{617}$ LAC, RG146, A200600117, "RCMP report, 19-10-51 source Ukrainian Life 18-10-51", p. 10.

${ }^{618}$ On the Jewish left generally, and on its links with other leftist ethnic groups in Canada see Ester Reiter, "Secular Yiddishkait: Left Politics, Culture, and Community," Labour/Le Travail, Spring 2002 $<\mathrm{http} / / /$ www.historycooperative.org/journals/lt/49/05reiter.html $>$ (10 Jun. 2008). For more on the Jewish Folk Choir's mission and appeal, see Benita Wolters-Fredlund, "We Shall Go Forward with our Songs into the Fight for Better Life:' Identity and Musical Meaning in the History of the Toronto Jewish Folk Choir, 1925-1959" (Toronto: University of Toronto, unpublished PhD thesis, 2005).

${ }^{619}$ LAC, RG146, A200600091, RCMP report "The Canadian Soviet Friendship Society, February 1951 to March 1953. Addendum to Brief Ending February 1951", dated 15 April 1953, p. 115.
} 
1954, the Russian Canadian newspaper, Vestnik, reported that over 500 people attended a CSFS film screening in Grand Forks, B.C., and the majority of these were Doukhobors and Ukrainians. ${ }^{620}$ In a 1955 letter to his Moscow chief, the VOKS representative in Ottawa, A. Tovstogan, reported that the "National committee of CSFS organized and ran 20 Nov. this year a meeting of the Toronto branch of the CSFS dedicated to Canadian Soviet friendship. This meeting took place in one of the big halls belonging to the progressive organization Jewish People's Order. ${ }^{, 621}$ Tovstogan also reported that Carter's speech, "Towards the further strengthening of Canadian-Soviet Friendship" was well received, and was at times "interrupted by applause" ${ }^{622}$ In the USSR, this was high praise.

But in addition to sharing space, the CSFS also shared information materials with the progressive, ethnic groups. In terms of material sent from the USSR, the keystone between the CSFS and these groups was the VOKS representative at the Soviet embassy in Ottawa. At first this was Burdin, who was replaced in the mid-1950s by Tovstogan. The VOKS representative collected letters and other material to send to the VOKS headquarters in Moscow, together with reports on the activities of progressives in Canada, and other newsworthy items. In 1953, Burdin forwarded to VOKS headquarters an "illegal" brochure that he had received from the AUUC, apparently printed in Lviv in 1935-1936. ${ }^{623}$ He would also receive packages from Moscow, and distribute the

\footnotetext{
${ }^{620}$ M.I. Gritzak, "Meeting of Canadian Soviet Friendship in Grand Forks," Vestnik, 27 February 1954, RCMP summary in LAC, RG146, A200600121, p. 20.

${ }^{621}$ VOKS, 6:1:49:17, letter from Tovstogan to Kulakovskaya, 26 Nov. 1955.

${ }^{622}$ Ibid.

${ }^{623}$ No other details on this brochure are given, but considering the date of printing, it may have dealt with issues of Ukrainian nationhood and identity. VOKS, 6:1:39:188-189, letter from Burdin to Bogatyrev, 25 June 1953.
} 
materials. $^{624}$ Frequently correspondence included information and packages from the VOKS republic branches in the Ukrainian and Belorussian capitals. This material was usually destined for the AUUC and FRC.

In May 1956, the Ottawa VOKS representative was informed that the Latvian Soviet Socialist Republic had founded a VOKS-affiliated Society For Cultural Ties Abroad, and the Moscow headquarters asked "whether in Canada there exists some kind of progressive organization of Latvian emigrants. If it exists let us know whether it is worth it in your opinion to establish a link and send a short report on it. In the report it is desirable to show the make-up of the organization and its leadership," what activities it planned, and what material was needed. ${ }^{625}$ However, the Latvian group was told that "Comrade Tovstogan answered that in Canada for the moment that kind of progressive cultural-enlightening organization amongst emigrants from Latvia does not exist. There does exist amongst that emigration an organization which is nationalistic and diffuses sharp anti-Soviet propaganda." ${ }^{, 626}$

Sometimes the progressive groups in Canada sent requests via the VOKS representative in Ottawa for particular materials from the USSR. For instance, the director of the Federation of Russian Canadians' choir, Alex Tichnovich, requested a song collection be sent, ${ }^{627}$ and in October 1956 Tovstogan wrote that "the leadership of the Federation of Russian Canadians wrote to VOKS with the request to send to its address, if possible, two copies of the spravochnik [guide book] by administrative division of the Ukrainian SSR and the Belorussian SSR. These spravochniks are quite

\footnotetext{
${ }^{624}$ VOKS 6:1:49:272, letter from Tovstogan to Kulakovskaya, 12 Oct. 1956.

${ }^{625}$ VOKS, 6:1:49:115, letter from Vertogradov to Tovstogan, 12 May 1956.

${ }^{626}$ VOKS, 6:1:49:181, letter to Rimyans from Kulakovskaya 19 Sept. 1956.

${ }^{627}$ VOKS, 6:1:49:125-127, Tovstogan to Kulakovskaya, 7 April 1956. Tichnovich's name had been anglicized from Tsekhanovich.
} 
necessary to the federation, as Russian Canadians often come to the FRC requesting help in finding the address and place of birth according to the new administrative divisions. ${ }^{, 628}$ The AUUC choir director, Eugene Dolny, asked for Lithuanian and Latvian folk music to be sent via VOKS in $1956 .{ }^{629}$

Packing slips and other correspondence from Moscow note for whom and what groups the materials were destined. From these documents we can see that many hundreds of books were sent to the CSFS via VOKS, and a good number of books were also sent to the AUUC, FRC, and others on request. Usually there were multiple copies, and from the last pages of News-Facts and, later Northern Neighbors it can be seen that these items were for sale. Titles included the works of Lenin, Stalin, Marx and other theoreticians of the system, as well as classical Russian and Ukrainian literature, and Soviet works. Many of the books sent to the CSFS were on topics related to scientific discoveries and health. After the XXth Party Congress in 1956, the VOKS representative received 350 copies of a collection of resolutions from the congress in English to be distributed in Canada, but not a copy of Khrushchev's speech. ${ }^{630}$ One order form filled out by CSFS secretary, Jim Leech, for books from the Soviet book distributor Mezhdunarodnaya Kniga included 100 copies of certain books, with never fewer than 25 copies of any book in English, or five in French. No mention was made of the CSFS paying for these. ${ }^{631}$

\footnotetext{
${ }^{628}$ Spravochnik is the Russian word for guide or reference book. In this case, they probably meant a type of address book. VOKS, 6:1:49:272, Tovstogan to Kulakovskaya, 12 October 1956.

${ }^{629}$ The choirs of the AUUC and FRC would frequently sing folk songs from other East European traditions, particularly if they knew that these ethnic groups were represented in the audience. VOKS, 6:1:49:227, letter to P.I. Valeskeln (Chairman, Latvian OKS) from Kulakovskaya, 3 July 1956; VOKS, 6:1:49:228, letter to P.I. Ratomskis (Lithuanian OKS) from Kulakovskaya, 3 July 1956.

${ }^{630}$ VOKS, 6:1:49:59, letter from Vertogradov to Tovstogan 13 April 1956.

${ }^{631}$ VOKS, 6:1:49:210-212, dated 18 June 1956.
} 
Invoices for the customs and excise officials listed books sent from VOKS to the CSFS and showed the value of each book listed in rubles, but the price to be paid by the receiver is listed as "free." allow for the dissemination of Soviet literature in Canada, while from the CSFS perspective it represented an important financial income. The books and other materials were advertised in the bulletins of the ethnic groups, and in their annual picnic souvenir programs. ${ }^{633}$ This probably also allowed both groups to avoid customs duties and other taxes. Eventually the volume of this book-selling business increased to such an extent that a bookhouse entitled Northern Bookhouse was opened in Gravenhurst under Charlotte Carter's name. When first initiated in the CSFS budget as "Sales of other literature" in 1952 , that income came to $\$ 1,879.80$, but by 1953 the amount had already doubled, ringing in at $\$ 3,005.97 .{ }^{634}$ When Carter sold the bookhouse premises in the late 1980 s, he received $\$ 99,000$, which probably represented a profit considering he had bought it for just $\$ 20,000$. $^{635}$

Although the VOKS representative in Ottawa sent books and other material directly to the AUUC, the FRC and sometimes to the Lithuanian progressive organization, at other times material was sent to the CSFS to forward. For example, in

\footnotetext{
${ }^{632}$ VOKS, 6:1:53:19-25, dated 3 March 1956; 53:81, dated 23 May 1956.

${ }^{633}$ Examples of these can be found in the Robert S. Kenny collection, Thomas Fisher Rare Book Library, University of Toronto.

${ }^{634}$ VOKS 6:1:50:116, "Canadian Soviet Friendship Society, Receipts and Payments-13 months to December 31 1952"; VOKS 6:1:50:117, "Canadian Soviet Friendship Society, Receipts and Paymentsyear to December 31 1953". These are among the few documents reporting the CSFS income. Dyson Carter's second wife, Sally Nielsen, has said that thousands of dollars were kept in the house, and periodically the CPC leadership would come to ask Dyson for a share. She has said that booksale business accounted for a large share of this income, and Dyson Carter also received cash from Soviet Embassy officials who visited their home in Gravenhurst. (Sally (Thelma) Nielsen, interview by author, 28 November 2006, near Lakefield, ON.)

${ }^{635}$ Sally (Thelma) Nielsen, interview by author, 28 November 2006, near Lakefield, ON. Certainly real estate costs and taxes would have eaten up some of the profit.
} 
December 1955 Carter wrote to VOKS requesting material for Armenian progressives, who did not have access to literature elsewhere. Carter wrote

At this time we have a request to make. For the first time, we have succeeded in having a meeting with Canadian-Armenians. It was a fine meeting, and we hope to have more. The people want us to try to get Armenian literature from the Armenian SSR. Will you do your best to get us some literature? I am writing directly to Armenian VOKS, so they will know that at long last we have started some work among the Armenian people here. ${ }^{636}$

VOKS headquarters passed this message on to its branch in the Armenian SSR ${ }^{637}$ but received a reply to the effect that they had already sent books and a list of further literature available directly to Dyson Carter ${ }^{638}$ In 1953, Carter asked for material in Finnish, ${ }^{639}$ and in March 1956 the CSFS requested literature in Lithuanian. ${ }^{640}$ Later, however, this proved unnecessary, perhaps because Carter was able to put those who had requested the literature in contact with the Lithuanian progressive organization. In April 1956, Tovstogan wrote his superiors to say that "the number of periodicals sent by you to the address of the Lithuanian progressive organization is sufficient, and subscribing the CSFS to the same editions is not worthwhile. As regards sending artistic literature in Lithuanian to the CSFS, that will not be necessary." ${ }^{641}$

From time to time, VOKS requested particular kinds of information, needed for use in the USSR. For example, in January 1956 a request came for the AUUC, FRC, CSFS and other organizations to send to VOKS any newspapers, brochures, books or other material on the effects of the October Revolution on Canadian political life, for

\footnotetext{
${ }^{636}$ VOKS, 6:1:53:12 letter from Dyson Carter to Perevoschikov 5 Dec. 1955.

${ }^{637}$ VOKS, 6:1:53:13, letter from I. Kulakovskaya to Astvatsaturyan 26 Jan. 1956.

${ }^{638}$ VOKS, 6:1:53:14, letter from Astvatsaturyan to Kulakovskaya, 3 Feb. 1956.

${ }^{639}$ This request was forwarded by VOKS in Moscow to the Karelo-Finnish SSR. VOKS, 6:1:44:79-81; 8990; 96-97, letter from Carter to Bogatyrev, 1 March 1953; N. Gorshkov (VOKS) to I.I. Tsvetkov, 16 April 1953; Carter to Bogatyrev, 12 June 1953.

${ }^{640}$ VOKS, 6:1:49:47, letter from Smilge to Yakovlev, 6 March 1956.

${ }^{641}$ VOKS, 6:1:49:125, letter from Tovstogan to Kulakovskaya, 7 April 1956.
} 
possible display in the Museum of the Revolution, Moscow. ${ }^{642}$ In addition, VOKS frequently asked Tovstogan to provide information on how the materials being sent from Moscow to the progressive groups were being used. ${ }^{643}$

Files on the Canadian left kept by the Royal Canadian Mounted Police show the cooperation between the CSFS and other groups meant shared space and materials, as well as shared financial support. An RCMP report from November 1957 notes that a CSFS meeting was held at the AUUC hall in Calgary, Alberta to celebrate the $40^{\text {th }}$ anniversary of the October Revolution, and 60 people were in attendance. ${ }^{644}$ Several speakers spoke enthusiastically about conditions in the USSR, particularly Ukraine, and funds were raised for the Labor Progressive Party. The reporting officer wrote that "in making an appeal for funds [unnamed person] pointed out that the only political organization that is fighting for the working man with the tradition of Lennin [sic] and Marx in the background is the Labor Progressive Party, who have the interest of the working man at heart at all times." He also noted that the CSFS had sponsored the event "in order to deceive the public with the hope that a much larger group would attend. This meeting was actually under the sponsorship of the Labor Progressive Party and the profit derived from same was turned over to the Labor Progressive Party." ${ }^{645}$ The CSFS did try to appeal to a broad Canadian audience, but most consistently its readership and financial support came from the LPP and the "language groups."

\footnotetext{
${ }^{642}$ VOKS, 6:1:49:28, letter from Kulakovskaya to Tovstogan, 26 Jan. 1956.

${ }^{643}$ VOKS, 6:1:49:52, letter from Vertogradov to Tovstogan, 23 March 1956.

${ }^{644}$ LAC, RG146, A200600091, RCMP Security and Intelligence Section report, Calgary, Alberta, 20 November 1957, p. 7.

${ }^{645}$ LAC, RG146, A200600091, RCMP Security and Intelligence Section report, Calgary, Alberta, 20 November 1957, p. 9.
} 
Funds were routinely raised by the various progressive ethnic groups to be donated to the Canadian Soviet Friendship Society. In one instance, Vestnik published a thank-you note from the CSFS addressed to "all organizations and persons who aided the Society in organizing the trip of the Trade Union delegation to the Soviet Union." Various groups on the Canadian left had raised $\$ 1,301.82$ for this CSFS- sponsored trade delegation which toured the USSR in $1952 .^{646}$ In 1951, John Weir, editor of the Ukrainian Canadian initiated a campaign to raise money for the CSFS, and the Federation of Russian Canadians also made donations. ${ }^{647}$ Carter appealed directly to local clubs of the Federation of Russian Canadians, asking them to read his letters aloud at meetings, to subscribe to at least one copy of his publication for their club, and to contribute financially to the cause of Soviet friendship. ${ }^{648}$

Ticket sales also represented financial income for the CSFS. The CSFS sponsored concerts, film-screenings and photograph exhibitions, and often entry was for ticket-holders only. The Society worked hard to convince progressive Canadians, especially Jews, that there was no anti-Semitism in the USSR. ${ }^{649}$ An important part of this persuasion was the sponsorship of Rev. Hewlett Johnson, the "Red Dean of Canterbury" on his tour of Canada in February 1953. The RCMP reported that the tour was to counter information given by the anti-communist Canadian Jewish Congress about

646 "Account of Bruce Magnusson's trip to the Soviet Union", Vestnik, vol. XXX, No. 1153-1154, 31 December 1952, in LAC, RG146, A200600102, RCMP report 5 January 1953, p. 77.

647 "'If people know truth about us- no more war' Stalingrad woman," Canadian Tribune, n.d., in LAC, RG146, A200600105, p. 129; LAC, RG146, A200600103, "Circular Letter N. 2," from the National Executive of the FRC, signed by J. Kurban, secretary, Toronto, 27 November 1953, p. 86.

${ }^{648}$ LAC, RG146, A200600096, Letter from Dyson Carter to "Dear Friends of the Federation of Russian Canadians," 24 March 1950, p. 234-235.

${ }^{649}$ After Khrushchev's speech in 1956 documenting Soviet abuses under Josef Stalin, including systemic anti-Semitism, many Jews left the LPP and Party-associated groups. Hints of this situation had been appearing earlier in the 1950s, however, and the LPP-supported clubs had been working for some time on damage control. The CSFS was no exception, and articles in its journal celebrated the Soviet treatment of Jews. Khrushchev's and others' revelations of the real injustice caused deep disillusionment for many leftists. 
official state anti-Semitism in the USSR. At the University of Western Ontario, the Dean was heckled when he gave a whitewashed version of the Soviet treatment of minority and religious groups, and he avoided speaking on this issue for the rest of his visit. ${ }^{650}$ The CSFS literature played the Dean's tour as "tear[ing] down the 'velvet curtain' of silence," and spun the negative reception the Dean received in London, Ontario, as a case of stifling freedom of speech. ${ }^{651}$ His appearance in Toronto at Massey Hall was sold out, and more careful attention was paid at the door to allow only ticket-holders to enter. Although it was a CSFS-sponsored event, attendees included members of the UJPO, Jewish individuals from the LPP and larger public. Plainly, the CSFS saw itself as a linch-pin between a larger progressive community, and that of the ethnic groups, "Canadianizing" the message.

It is unclear who paid Carter's salary, but he definitely received some money from the LPP. When he left the CSFS at the end of the 1950s, John Boyd said Carter continued to receive support from the LPP because his newspaper, Northern Neighbors, was so popular, including in the United States. ${ }^{652}$ This view fits with the RCMP's notes. In a 1963 report, the RCMP mentioned that the LPP had agreed to continue to subsidize Carter's work because Northern Neighbors was "useful." ${ }^{.653}$ Much later, Carter's second wife, Sally Nielsen, recalled Party executives asked Carter for a cut of the money he was making in the bookhouse, ${ }^{654}$ and Soviet Embassy personnel brought him cash

\footnotetext{
${ }^{650}$ LAC, RG146, A200600091, RCMP report "The Canadian Soviet Friendship Society, February 1951 to March 1953. Addendum to Brief Ending February 1951”, dated 15 April 1953, p. 115.

${ }^{651}$ News-Facts, no. 35, March 1953, p. 1.

${ }^{652}$ Interview with John Boyd, 2 August 2006, Toronto, ON.

${ }^{653}$ LAC, RG25, A200700336, RCMP Research Section report, "The Canada-USSR Association," 27 March 1963, p. 834-845.

${ }^{654}$ Interview with Sally (Thelma) Nielsen, 28 November 2006, near Lakefield, ON.
} 
payments. ${ }^{655}$ This direct financing may have begun while Carter was in charge of the

CSFS, but it is certain that Carter received in-kind financial backing from the Soviets as early as 1951 by way of books and other objects for sale. ${ }^{656}$ When his books and other writings were published in the USSR, Carter was entitled to royalty payments. ${ }^{657}$ Under Carter's leadership, the CSFS was capable of competent coordination, shrewd financial planning, and effective persuasion. Carter was, in effect, an ideological entrepreneur.

This is why the Soviet authorities valued his contributions so much that, even after 1960, he maintained close contact with individuals in Moscow and the Soviet Embassy in Ottawa.

\section{Exhibitions, Sales and Soviet Friendship Month}

The CSFS also requested items to be sent from the Soviet Union for exhibition and sale.

The sale of these items was noted on the annual financial reports sent back to VOKS.

The volume of this material represented important Soviet in-kind financial backing for

Carter. A three-page list stamped with the date 10 April 1956 and entitled "List of

Artistic Handicrafts and Sewn Items Sent to the Embassy of the USSR in Canada for the

CSFS" contained close to 90 tablecloths of different sizes and designs, paper-maché

${ }^{655}$ Interview with Sally (Thelma) Nielsen, 28 November 2006, near Lakefield, ON. John Boyd does not believe that the money came from Moscow, but argues instead that the Canadian Party had clever ways of financing its supported organizations. He pointed out that the RCMP and the Bank of Commerce knew about these strategies all along. (Interview with John Boyd (né Boychuk), 2 August 2006, Toronto.)

${ }^{656}$ Much of this came as books and saleable objects as discussed early and in the next section.

${ }^{657}$ A letter from Carter to Tovstogan dated 18 Feb. 1957, thanking Tovstogan and Soviet ambassador D.S. Chuvakhin for their help in making sure that $\$ 3086.09$ royalty fees for Carter's Tomorrow is With Us were received by Carter from "Goslitigat Ukrainy" seems to suggest that Carter was not always able to get his payment. (VOKS, 6:1:55:107) The Soviets always took interest in Carter's books published in Canada, and he usually forwarded them via VOKS to the Writer's Union and others in the USSR. In 1956 when Carter complained about a Soviet review of his book Fatherless Sons, his letter was forwarded to the Central Committee of the Communist Party of Canada. (VOKS, 6:1:53:28-36) VOKS headquarters informed the Ottawa representative that this book was to be published in the USSR in 1957. (VOKS, 6:1:49:55) In 1957 two copies of Charlotte and Dyson Carter's book Cancer, Smoking, Heart Disease and Alcohol in Two World Systems were sent to the Soviet Ministry of Foreign Affairs (VOKS, 6:1:55:122). In February 1957 VOKS discussed the fact that their Science of Health and Long Life in the USSR was published in Australia, and reviewed in the Soviet press. (VOKS, 6:1:55:63-65). 
boxes decorated with images from Russian fairytales, ashtrays, teacups and glasses. ${ }^{658}$

Carter explained the motivation for this request in this way:

We have also been asked (because of the great success of the Slav Handicrafts Exhibit) if it would be possible for us to obtain something of a similar nature; perhaps a small collection of industrial-production consumer goods. We believe that the majority of Canadians still do not know that Soviet consumers can buy a wide range of highest-quality goods, such as photographic equipment, cosmetic articles, etc. ${ }^{659}$

The material arrived in the summer, amounting to four boxes of handicrafts, and

Tovstogan noted that it was forwarded on to the CSFS for exhibition in fall of 1956.

Shipping costs were covered by VOKS. ${ }^{660}$

But the CSFS did not always reap the financial rewards of the exhibit. To have its exhibit reach mainstream audiences, the CSFS tried to have it hosted by even more "neutral" groups. In 1955, the CSFS organized a series of exhibitions of Soviet children's paintings in Montreal art galleries. Owing to the "difficult situation in Quebec," which was related to the Duplessis government's Padlock Law and discouragement of leftist group meetings, the CSFS could not take public recognition for these exhibitions. Instead, Carter asked Louis Kon to make the arrangements privately ${ }^{661}$ Following what proved to be a success, Carter suggested to VOKS that an exhibition of Soviet dolls be set up. ${ }^{662}$ He argued that "in view of the big success of the Soviet Children's Paintings (which you know have been seen by many thousands of

\footnotetext{
${ }^{658}$ VOKS, 6:1:49:61-63, dated 10 April 1956.

${ }^{659}$ VOKS, 6:1:50:71-72, letter from Carter to Bourdine, 12 Jan. 1955.

${ }^{660}$ VOKS, 6:1:49:173, letter from Tovstogan to Vertogradov, 13 August 1956.

${ }^{661}$ VOKS, 6:1:50: 81, letter from Carter to Perevoschikov, 22 March 1955. There is also reference to this in the Louis and Irene Kon fonds at the Osler Library, McGill University, Montreal. Kon had previously organized Soviet art exhibitions for the pre-war Friends of the Soviet Union. Kealey and Whitaker, eds., "RCMP Weekly Summary Reports...," no. 759, 12 June 1935 and no. 772, 11 September 1935," The R.C.M.P. Security Bulletins: The Depression Years, pt. II, 1935, p. 344.

${ }^{662}$ VOKS, 6:1:50:49, letter from Yakovlev to Petrushev, Chief of Tsentropromsovet, 28 July 1955.
} 
Canadians, in many centers)" a doll exhibit should be sent. Carter pointed out that such displays were "very popular in Canada, and draw wide audiences, not only of the general public and school children, but also intellectuals, artists, teachers, etc." Drawing an audience from the wider Canadian society, and being able to offer this exhibit for nonpolitical groups to show was an important consideration. ${ }^{663}$ Carter was disappointed because the exhibit could not be prepared in time for Soviet Friendship Month, ${ }^{664}$ but he continued to organize this type of event, which fit well with a genuine interest amongst Canadians in ethnic handicrafts.

This promotion was never more apparent than during Friendship Month. The CSFS began in 1951 to organize an annual Soviet Friendship Month every February, changed to November in 1954 to coincide with the anniversary of the October Revolution. ${ }^{665}$ The Friendship Month provided an umbrella for activities in CSFS branches across the country, uniting the localized, often small, groups in a larger program. The activities were publicized in the CSFS publications, and specific letters sent to readers and members were meant to build excitement and it was hoped the Society coffers, leading up to November. Events such as these were often organized in cooperation with the local progressive ethnic group branches, and members were encouraged to plan with the local AUUC, FRC, "and all other organizations that support our aims. ${ }^{9666}$ For instance, in November 1954, Yugoslav, Macedonian and Ukrainian groups in Toronto jointly sponsored the screening of a film about a recent visit of Canadians to the USSR, Dyson Carter spoke to the Finnish Organization of Canada

\footnotetext{
${ }^{663}$ VOKS, 6:1:50:47-48, Carter to Perevoschikov, 3 July 1955.

${ }^{664}$ VOKS, 6:1:50:50, letter from Goryachkin to Yakovlev, 11 Aug. 1955.

${ }^{665}$ LAC, RG146, A200600091, letter from Ted Baxter to CSFS branches, 1954, n.d., p. 25.

${ }^{666}$ LAC, RG146, A200600091, letter from Ted Baxter to CSFS branches, 29 September 1954, p. 23.
} 
(FOC) about the need for a trade mission to the USSR, Ted Baxter spoke on the same subject at the Carpatho-Russian Hall, and the Federation of Russian-Canadians held a film-meeting. ${ }^{667}$ All these events were organized under the auspices of Soviet Friendship Month.

Progressive Canadians received news and encouragement to attend these events from numerous sources. The CSFS advised all branches to make their activities known via the progressive press, including the Canadian Tribune, the Ukrainian Canadian, the FRC journal, Vestnik, the Finnish newspaper, Vapaus and the Polish Weekly Chronicle. ${ }^{668}$ In 1953, the Labor-Progressive Party sent a missive to its national membership encouraging them to support the Friendship Month activities, ${ }^{669}$ and in announcing the final concert of the 1954 Friendship Month in Vancouver, the local LPP branch wrote, "members are asked to fully support this event." Russian Canadians reminded all its members that they were obliged to cooperate with allSlav committees, as well as the Canadian-Soviet Friendship Society, "whose aim is to throw a correct light on the life of the peoples of the Soviet Union..." FRC members were asked to attend Friendship Month activities, "but also to aid the Society morally and materially."671 In January 1953, the editor of Ukrainske slovo (Ukrainian Word) urged readers to remember to honour "the late Matthew Shatulsky...mark the "month of Slavic

${ }^{667}$ A list of these Soviet Friendship Month events was published in the Canadian Tribune, 9 November 1954, LAC, RG146, A200600104, p. 100; also published in Vestnik, 3 November 1954, Jedinstvo (Unity), 2 November 1954, Laudis Balsas (The People's Voice), 29 October 1954, summaries in RCMP files, LAC, RG146, A200600104, p. 107, 108, 110.

${ }^{668}$ LAC, RG146, A200600091, memo from Ted Baxter, CSFS Secretary, to "All Society Branches on Publicity", 19 October 1954, p. 16.

${ }^{669}$ VOKS, 6:1:45:123-124, letter from LPP, 19 November 1953.

${ }^{670}$ LAC, RG146, A200600103, "Club Letter" signed by Vancouver City Secretary, Maurice Rush, dated 23 February 1954, recorded in RCMP Vancouver Sub Division, Special Branch memo, dated 4 March 1954, "RE: Labor Progressive Party- British Columbia," p. 241.

${ }^{671}$ LAC, RG146, A200600103, "Circular Letter N. 2," from the National Executive of the FRC, signed by J. Kurban, secretary, Toronto, 27 November 1953, p. 86. 
unity and friendship," and Canadian-Soviet Friendship Month, "held under the auspices of the Canadian-Soviet Friendship Society."

Carter and his assistants began early in the year to send specific requests to VOKS for materials to be used during Friendship Month. Sometimes requests were made for items to be exhibited and sold, including Soviet books, photographs, traditional handicrafts and household items, and frequently requests were made for films to be shown at these exhibitions. For example, in October of 1955 Dyson Carter wrote directly to VOKS in Moscow, saying

On behalf of our National Council I wish to thank VOKS very warmly for the wonderful displays, of photographs and works of art, etc., which we have just received. This material has arrived in excellent condition. It has come just in time for Friendship Month, and we shall do our best to make full use of it. ${ }^{673}$

In the following January, Carter wrote VOKS to say that the $\$ 530$ raised by the sale of Soviet "household goods" in November had been welcome: "This income played a very important part in keeping the Society alive during November and December." ${ }^{, 674}$ Carter earlier had requested VOKS send household goods, to show Canadians that Soviet people did in fact have a comparably high standard of living, a theme that perhaps foreshadowed the famous "kitchen debate" between Nikita Khrushchev and Richard Nixon in 1959. He had suggested that household goods would be a good investment -- both in terms of image-improvement for the USSR, and financially for the CSFS. ${ }^{675}$ In the same letter, Carter suggested to VOKS that Soviet-made accordions might sell well in Canada. He asked whether it would be possible to send one, to test the market, and wrote, "If it

\footnotetext{
${ }^{672}$ Ukrainske slovo (Ukrainian Word), editorial "Fulfill these tasks in January", vol. XI, No. 1 (522), 7 January 1953, p. 10, LAC, RG146, A200600102, RCMP summary dated 9 January 1953, p. 71.

${ }^{673}$ VOKS, 6:1:49:24, letter from Carter to Perevozchikov [sic], 15 Oct. 1955.

${ }^{674}$ VOKS, 6:1:53:27, letter from Carter to Kulakovskaya, 3 Jan. 1956.

${ }^{675}$ VOKS, 6:1:50:71-72, letter from Carter to Burdin, 12 Jan. 1955.
} 
proved saleable, we might be able to arrange for someone here to import Soviet accordions on a commercial basis, for our Society or independently; and the Society would benefit, financially. ${ }^{, 676}$ It appears that VOKS did not take Carter up on this suggestion.

One of the activities organized by Carter during Friendship Month was the collection of greetings to be sent to the Soviet Union, on behalf of Canadian individuals and groups. Ahead of November 1955, a form was sent out by CSFS to 350 organizations, ${ }^{677}$ and was printed in News-Facts, addressed to "Secretaries of organizations, and Chairmen of meetings!... Help to make friends for Canada, in the Soviet Union! In Friendship Month, be one of the thousands who will send greetings to the Soviet people!" ${ }^{678}$ Above the form, instructions were given on how to fill it in, and what groups or places in the USSR might be appropriate destinations for greetings. Readers were encouraged to enclose a photograph or postcard, "as a souvenir", if they wished. And above all, wrote Carter, remember to send the form back to News-Facts and the CSFS, both located at 753 Bathurst St. in Toronto, to be sure your greeting will be forwarded on to the USSR. ${ }^{679}$ At the top of the form, News-Facts readers were given the bonus of a Soviet stamp, with the following caption: "Here you see a real Soviet postage stamp. We suggest you keep this souvenir of Friendship Month. If you decide to visit the Soviet Union (as thousands of Canadians soon will) you might use this stamp to mail a letter back home!",680

\footnotetext{
${ }^{676}$ Ibid.

${ }^{677}$ VOKS, 6:1:49:6, letter from A. Tovstogan to Kulakovskaya, 26 Nov. 1955, 49:6. The greeting form is found in the VOKS collection, 49:22.

${ }^{679}$ VOKS, 6:1:49:22, 23. The form destined for groups listed the CSFS' name above the Bathurst address, and the one that was printed in News-Facts, used the journal's name, with the same address.

${ }^{680}$ VOKS, 6:1:49:22, emphasis in the original.
} 
After the 1955 Friendship Month meeting, Tovstogan reported that "greetings to the Soviet peoples from Canadians living in Toronto" were approved. "Analagous greetings will be approved at all meetings sent from various Canadian cities linked to Canadian-Soviet Friendship Month. At the end of the month, all greetings will be sent to VOKS." ${ }^{\circ 81}$ The list of groups that were sending greetings, sent by Carter to VOKS in December 1955 included AUUC branches in Point Douglas, Moose Jaw, Winnipeg, Transcona, Port Arthur and elsewhere writing to towns in the Ukrainian SSR; FRC branches across the country writing to towns in the Russian and Belorussian republics; UJPO branches writing to the Birobidjan Autonomous Region; and branches of the FOC sending greetings to the Karelo-Finnish SSR. CSFS branches in Hamilton, Vancouver, Winnipeg and Welland, Ontario wrote to cities across the USSR. An LPP club in Vancouver wrote via the CSFS to the denizens of Vladivostok. ${ }^{682}$

Here we can see Carter and the CSFS serving as a liaison between the progressive ethnic groups, and attempting to present this initiative as a pan-Canadian hand of friendship extended to the peoples of the Soviet Union. He was careful to explain to VOKS that replies to these greetings should be sent to the CSFS, and not directly to the organization that had sponsored them: "I would like to stress that any responses you can get for us, to these greetings, from the various places greeted, would arouse much interest among Friendship Society supporters in Canada, and we would see that the responses were given maximum publicity throughout the entire progressive movement. ${ }^{.683}$

In January 1956, Carter sent VOKS another long list of greetings, this time from individuals in Canada and the United States. He repeated that "All replies should be

\footnotetext{
${ }^{681}$ VOKS, 6:1:49:17, letter from Tovstogan to Kulakovskaya, 26 Nov. 1955.

${ }^{682}$ VOKS, 6:1:53:42-44, Carter to Kulakovskaya, 28 Dec. 1955.

${ }^{683}$ Ibid.
} 
addressed to our Society; although, of course, each reply should be directed to the person or persons who sent the particular message. We plan to publish as many of the replies as possible." ${ }^{\circ 84}$ The list includes more than 130 individual greetings from the United States and Canada. The full names of those in Canada sending the greetings are listed, and those names appear to be of Anglo-Saxon origin, as well as Ukrainian, Russian and of other ethnic backgrounds. At times, anonymity was preserved by listing the individuals as "friends in Stenen, Sask" or "friends in San Francisco, Calif. USA," and so on. In fact, individual greetings sent from the United States named the sender by initials only. Destinations included particular towns or factories in Ukraine, Moscow, Stalingrad, Azerbaijan, Odessa, Sochi and elsewhere in the USSR. In February 1956, Carter sent a further list of greetings that included messages from Jim Leech and Ted Baxter, both assistants to Carter who would leave the CSFS later that same year as a direct result of the XXth Party Congress. ${ }^{685}$

Groups and individuals in the Soviet Union responded to the greetings collected by the CSFS, and these replies were sent via VOKS back to the CSFS. For example, in April 1956, the VOKS representative in Ottawa received copies of the replies from the Kazakh Society for Cultural Ties Abroad, and the Stalingrad Committee for the Defense of Peace. ${ }^{686}$ In May 1956, the reply from the middle schools in Moscow was sent. ${ }^{687}$ In June 1956, workers from the Ternopil region in Ukraine sent return greetings to the Winnipeg branch of the AUUC, written in Ukrainian, wishing the peoples of the world

\footnotetext{
${ }^{684}$ VOKS, 6:1:53:45-52 Carter to Kulakovskaya, 2 Jan. 1956, emphasis in the original.

${ }^{685}$ VOKS, 6:1:49:88, dated February 1956.

${ }^{686}$ VOKS, 6:1:49:5, letter from A. Vertogradov to A.S. Tovstogan, 3 April 1956.

${ }^{687}$ VOKS, 6:1:49:117, letter from A. Vertogradov to A.S. Tovstogan, 12 May 1956.
} 
peace. ${ }^{688}$ The responding message to the AUUC in Moose Jaw, Saskatchewan from the Kostelnyky village in Ternopil region, also sent in June 1956, ended with the wish, "May 1956 bring heightened friendship between our peoples ${ }^{\prime \prime 689}$ In each case VOKS noted that the original of the letters had been sent directly to the CSFS. The CSFS published these letters and made much of forwarding them on.

These greeting campaigns were not restricted to Friendship Month, though. Probably encouraged by the success of the 1955 campaign, Carter organized another one the next year. In March 1956, the CSFS collected messages for a telegram to be sent to the Bratsk Hydroelectric Station. When the names were all collected, the telegram was to be sent to VOKS in Moscow, with the request to forward it on to Bratsk. ${ }^{690}$ In a letter to the CSFS members, Carter asked them to send in the attached card plus 25 cents to congratulate and greet the Bratsk Hydroelectric Plant construction workers: "Men and women have left comfortable homes all over the U.S.S.R., to carry out this remarkable job of peaceful construction. And some of your fellow-members of the Society want to greet them, to send them a word of encouragement and friendship from Canada...And remember: The people at Bratsk are 'the finest' ${ }^{,{ }^{691}}$ It is difficult to judge the effect of these greetings. Most likely they did not persuade anyone to change their minds about the USSR, but the CSFS did offer those who were already sympathetic to the Soviet Union a chance to express their wishes. In the greetings we can see the CSFS as a medium for individuals who wished to offer alternative views on Cold War international affairs.

\footnotetext{
${ }^{688}$ VOKS, 6:1:53:87-89 forwarding letter Kiz to Kulakovskaya, 22 June 1956, and "Greetings to the AUUC in Winnipeg, Manitoba, Canada".

${ }^{689}$ VOKS, 6:1:53:90.

${ }^{690}$ VOKS, 6:1:49:126, letter from A. Tovstogan to Kulakovskaya, 7 April 1956.

${ }^{691}$ VOKS, 6:1:49:127b, letter from Carter to CSFS members, dated 29 Feb. 1956, emphasis in the original.
} 
Many of these Canadians may not have been aware of the degree to which this exercise was orchestrated by Carter and by VOKS in the Soviet Union.

The CSFS participated in other events organized by progressive groups. For example, in November 1955 the Canadian Peace Congress organized a meeting of 1725 delegates at Massey Hall in Toronto, among whom were CSFS representatives, as well as well-known peace activists like James D. Endicott and Rev. D.S. Kendy, women's rights activist Mrs. Rae Lucock, labor leaders, members of the CCF and the Labor-Progressive Party, and John Boyd, Secretary of the Canadian Slav Committee. This meeting, and the presence of individuals sympathetic to the Soviet Union and to the progressive movement in Canada, was duly reported on by the VOKS representative in Ottawa. ${ }^{692}$ Dyson Carter also advertised his magazine and the bookhouse in souvenir brochures issued by the AUUC and other progressive groups at special events, labor picnics and anniversaries. ${ }^{693}$

Photographs and films were a valuable part of the CSFS mission. Seen as accurate, objective reflections of reality, pictures seemed to fulfill Carter's proclaimed goal "to tell the truth about the USSR." Carter began to use photos in News-Facts within the first few years of publication, and from then on the photo-pages multiplied, photograph exhibits became part of the CSFS repertoire, and delegates fresh from touring the USSR showed their own pictures. Curious Canadians who might not otherwise have attended CSFS events were attracted by the opportunity to see behind the Iron Curtain "for themselves" via the photos. Some might have viewed these photos with nostalgia for their ancestral homes. Most of the photographs came directly from Moscow via VOKS,

${ }^{692}$ VOKS documents, letter from A. Tovstogan to Kulakovskaya, 26 Nov. 1955, 49:5-6. ${ }^{693}$ Numerous examples of these brochures, and the Carter advertisements, can be found in the Robert S. Kenny collection, MS Collection 179, Thomas Fisher Rare Book Library, University of Toronto, box 62. 
but after 1961 some came from the Novosti Press Agency Office in Ottawa. ${ }^{694}$ Carter asked for photos "showing different sides of life of the Soviet people" to be used in News-Facts. ${ }^{695}$ Of course, any Canadians who visited the USSR, especially those on CSFS-sponsored trips, were encouraged to take many photos and to send them and a report on their visit to Carter. These photos made it into CSFS publications, and were shown at their speaking engagements upon return.

Photograph exhibitions had names like "Vacation below Moscow", "A Day at a Kolkhoz", "Science and Religion", and a slide-show entitled "Along the Halls of the Museum of the History of Religion and Atheism" was sent in $1957 .{ }^{696}$ Once sent, VOKS remained very interested in getting feedback on the way the photographs and films were being used. For example, after noting in March 1956 that "on D. Carter's request we are sending 28 photographs of Soviet sportsmen and 13 photographs of artists of the theatre, ballet and cinema," the VOKS official in Moscow noted. "In 1955," he continued, "VOKS sent to Canada 4 photo exhibits: "Soviet Uzbekistan" "At the Soviet textile makers"; "VSKhV" [the All-Soviet Agricultural Exhibition in Moscow]; "Sport in the USSR" and a large quantity of other photoillustrative material. We ask you to tell us before 1 May of this year about the use of these materials by CSFS, AUUC, FRC and other organizations." ${ }^{\prime 697}$ VOKS asked to know not only where, when and who saw these materials, but if the progressive groups had any comments or wishes to express to the organizers of these exhibits for future reference.

\footnotetext{
694 The Novosti Press Agency Office photograph archives are located in the Special Collections, at Carleton University.

${ }^{695}$ VOKS, 6:1:50:29, letter from Yakovlev to Pozdeev, 17 Dec. 1955.

${ }^{696}$ VOKS, 6:1:55:186-188, letter from G. Ioanisyan to A. Tovstogan, 29 Oct. 1957.

${ }^{697}$ VOKS, 6:1:49:52, Vertogradov to Tovstogan, 25 March 1956.
} 
Besides still photos, moving-picture films were often used to supplement other activities, like handicraft sales or lectures. Most importantly, they were a way for the CSFS to show Canadian audiences the Soviet Union "as it actually was." This fit well with the Marxist-Leninist notion that art was meant to " picture life as it is." "698 As proof of the usefulness of films, Tovstogan wrote to his chief that there had been a showing of the Soviet film "Sources of Life" at which Carter had also given a speech on "The Problems of Long-Life", and which the CSFS had advertised through the local Toronto press. Tovstogan reported, "In the words of D. Carter, this event was successful and showed that [these events] attracted not only the progressive circles. The opposite [sic], by far the majority of the audience was made up of those far from the progressive movement, but interested in the achievements and life of the Soviet Union." ${ }^{699}$ Apparently for this event there was standing-room only in a hall meant for 250 people, and some had to be turned away. Tovstogan wrote that the audience responded to the film and Carter's speech "very warmly". Repeating Carter's words, Tovstogan argued that this "shows once more that the Canadian public is interested in the life of the Soviet people, willingly attends suitable events and the Society (CSFS), because of this ready cooperative desire, is able to find the necessary audience amongst Canadians." 700

\footnotetext{
${ }^{698}$ Hanno Hardt, In the Company of Media: Cultural Constructions of Communication, 1920s-1930s (Boulder Colorado: Westview Press, 200), p. 38. This quotation is from Leon Trotsky, but although Carter would have agreed with the notion, he would never have acknowledged Trotsky for having made the comment. Trotsky had been declared an "enemy of the people" by Stalin in the late 1920s, exiled, and assassinated in 1940. He was never rehabilitated. Carter followed the official Soviet line unfailingly in all his publications.

${ }^{699}$ Most likely the attendees were not, as Carter claimed, "far from the progressive movement," but rather individuals who were not Party members, but nonetheless left-leaning. The CSFS-sponsored films were a drawing card for those who may not normally have attended a Labor-Progressive Party event, but who had some sympathies for and curiosity about life in the USSR. It is this nonpartisan veneer, and its ability to reach out to the non-Party left, that made the CSFS so useful to both the LPP and the Soviets, themselves. ${ }^{700}$ VOKS, 6:1:49:74, letter from A. Tovstogan to Kulakovskaya, 9 March 1956.
} 
Sometime in 1955, a firm called New World Films was set up in Toronto to show and sell Soviet films in Canada. The founding members of New World Films were in fact CSFS members, as a letter from 1956 detailing how Sovexportfilm would send between 10 and 15 films noted the destination to be New World Films and the CSFS, suggests. ${ }^{701}$ The list of films, both in English and French, included "Romeo and Juliette", "VSKhV", "Ostrov Sakhalin", "A Portrayal of the Art of China", "Peter I", "State Hermitage", and "Vietnam". 702 In March 1956, Tovstogan received a list of " $16 \mathrm{~mm}$ films produced in the USSR and available to the CSFS". ${ }^{703}$ VOKS asked that this list be sent to the CSFS for its use and to "Artkino", a CSFS club, and "New World Films".

However, there is no doubt that, even if these events were meant to attract more mainstream (read "Anglo-Saxon") Canadians into the progressive movement, many of those who purchased photographs and films and attended the screenings were members of the ethnic progressive groups. A letter written by Tovstogan on behalf of New World Films in December 1956 requested that films sent in Ukrainian and Latvian languages to Canada have English subtitles (not Russian), because the clients, members of the Canadian progressive organizations specifically listed as "Russians, Ukrainians, Latvians, etc.", found the Russian subtitles displeasing. Furthermore, he suggested the films' subtitles allowed Ukrainian-Canadian nationalists to publish anti-Soviet propaganda about the Russification of the USSR. ${ }^{704}$ In forwarding this letter on to the Ukrainian cultural organization, the request was made that action be taken "in alleviating the

\footnotetext{
${ }^{701}$ VOKS, 6:1:49:116, Vertogradov to Tovstogan, 12 May 1956.

${ }^{702}$ VOKS, 6:1:49:117-120, lists of films in French and English, colour and black and white.

${ }^{703}$ VOKS, 6:1:49:74a-75, Kulakovskaya to Tovstogan, 5 March 1956.

${ }^{704}$ VOKS, 6:1:55:27-28, Tovstogan to Abramov, Sovexportfilm, 11 Dec. 1956.
} 
uncomfortable situation for Ukrainian-Canadian progressive organizations."705 The political message was ever-present at these events, but probably some also attended out of the desire to socialize with friends, and converse in their native language. For instance, one November evening in 1955 several 80-year old Armenian-Canadian women attended a CSFS showing of the film "Soviet Armenia" at the Armenian Hall in Brantford. These women had come to Canada 40 or more years earlier. Kate Bader, a recent CSFS delegate, spoke about her impressions of the USSR. ${ }^{706}$ For some of the women in the audience the motivation to attend might have been as much about nostalgia and entertainment as politics, but in this ethnically interlinked leftist commuity, social and political networking overlapped.

Films and photographs represented a budgetary consideration for the CSFS, but the amounts seem rather small. In 1952, the CSFS finances listed "films" as accounting for $\$ 269.75$; and in 1953 "receipts from films" came to $\$ 123.00$; "receipts from records," $\$ 30.00$; "receipts from exhibition," $\$ 662.50$; "Sale of donated picture," 102.50 . $^{707}$ Probably, more than amounting to a financial income per se, the films and photographs were a drawing card for both subscribers to the publications, and audiences at the events. Even when the CSFS did not host the showings themselves, the income raised by selling tickets was given to the CSFS. One example of this taking place was in Sudbury, where the "Red" Finnish organization ordered Soviet films from the CSFS, showed them during Friendship Month, and gave the proceeds to the CSFS. ${ }^{708}$

\footnotetext{
${ }^{705}$ VOKS, 6:1:55:29, loanisyan to K.Z. Litvin (UkrOKS), 9 Jan. 1956.

${ }^{706}$ Ukrainske zhittia, 12 January 1956, summarized by the RCMP, LAC, RG146, A200600104, p. 17.

${ }^{707}$ VOKS, 1952 finances 6:1:50:116;1953:6:1:50:117.

${ }^{708}$ LAC, RG146, A200600103, RCMP review (dated 24 February 1953) of Vapaus, no. 22, vol. XXXVI, 21 February 1953, p. 251.
} 
Support for most of the CSFS events was drawn from other organizations on the Canadian left. Carter's claim to be attracting mainstream Canadians to his events was the way in which he justified the existence of the CSFS: its nonpolitical appeal was an important counterweight to the more political nature of the Labor-Progressive Party. The apparently Anglo-Saxon make-up of the CSFS made it appear more ethnically "mainstream" than the ethnic groups associated with the LPP. Indeed, many people may have attended for reasons other than to hear pro-Soviet declarations, but it appears that the most consistent participants were, in fact, individuals who were members of other Canadian leftist groups.

\section{News-Facts, Northern Neighbors and other Publications ${ }^{709}$}

One of the most tangible ways the CSFS was active in making the USSR attractive was in endorsing Nikita Khrushchev's 'Return to the Homeland' project. As Glenna Roberts and Serge Cipko have argued, this sophisticated campaign was deliberately promoted among the refugees who left the USSR after World War II, some of whom were convinced to emigrate back to the Soviet Union. Unfortunately, many of these individuals later regretted their decision, but only a small number were able to leave the USSR. ${ }^{710}$ As an

\footnotetext{
${ }^{709}$ News-Facts was published from 1950-1956, and Northern Neighbors from December 1956-1989. Although News-Facts was the official journal of the CSFS, Northern Neighbors was not. Dyson Carter's magazines and many of his books, although published by the CSFS or Northern Neighbours, were printed by Eveready Printers, Toronto. This continued to be the case after he had moved to Gravenhurst in 1957. Eveready were the printers used most often by the LPP/CPC, and many of the employees were in fact LPP members. Interview with Sally (Thelma) Nielsen, 28 November 2006, near Lakefield, ON; John Boyd, “A Noble Cause Betrayed," Socialist History Project.

${ }^{710}$ Glenna Roberts and Serge Cipko, One Way Ticket: TheSoviet Return to the Homeland Campaign 19551960 (Manotick: Penumbra Press, 2008). See also Serge Cipko and Peter M. Roberts, Canada and the Khrushchev Government's "Return to the Homeland" Campaign (Centre for Research on CanadianRussian Relations, Carleton University, Ottawa, November 2000. Occasional Paper no. 8). Serge Cipko has also studied the campaign in relation to the Ukrainian diaspora in Argentina. Some Finnish-Canadians had earlier been encouraged to return to the Karelo-Finnish Soviet Socialist Republic, and this movement was also generally tragic for those concerned. See especially Varpu Lindstrom's work and the National Film Board-produced film (directed by Kelly Saxberg) Letters from Karelia, which she consulted on. On propaganda used to convince Canadians to return to the USSR, and their subsequent desire to return to
} 
editor, Carter featured stories that supported the Soviet efforts to entice some Canadians to return to their ancestral "homeland." In March 1956, News-Facts reproduced stories of former citizens of the Soviet Union, who had now returned to their homeland. Under the headline “Thousands of Soviet 'DP's' Return to Find Sympathy, Friendship and Jobs", Carter recounted five individual stories of those who had responded to the "general 'amnesty' offered by the USSR." ${ }^{\text {711 }}$ For example, the experience of Arkady Berishvili, who had worked for a German intelligence agency, "repented, took advantage of the Soviet Union's pardon offer, and returned home. He has completed his college education, is a Master of Architecture, and now lectures in university." Carter also cites Andrei Mikhailichenko's experience, quoting him as saying that "' Any returning Soviet citizen...who wants to work honestly, will find good work, and sympathy and friendship.",712 In June 1956, Carter published photographs of repatriates getting off ships in a Soviet harbour, all smiling and welcomed with open arms. ${ }^{713}$ None of these individuals appears to be coming from Canada. In contrast to the CSFS view, the Return to the Homeland campaign was ultimately a failure, which caused trauma in the lives of Canadians convinced to go back. The fact that the CSFS helped lure Canadian families back to the USSR, where their Canadian passports were taken and destroyed, highlights the negative side of the pro-Soviet apologia.

Apart from these articles written specifically on the Return to the Homeland initiative, those who were considering such a move would have found plenty of

Canada, see also Memoranda exchanged between the Department of External Affairs, the Prime Minister and the Canadian Embassy in Moscow in 1960, Documents on Canadian External Affairs, (Ottawa: Foreign Affairs and International Trade Canada) ed. Janice Cavell, vol. 27 (1960), Chapter VI, Section C Repatriation, (Ottawa, 2007) p. 1009-1013.

${ }^{711}$ News-Facts, March 1956, no. 63, p. 3.

${ }^{712}$ Ibid.

${ }^{713}$ Ibid., June 1956 , no. 65 , p. 7. 
encouragement in the pages of Carter's publication. For example, Frank Park, who had been director of the Friendship organization during the Second World War, wrote an article entitled "How to Get a Place to Live" in the Soviet Union, published in March 1950. His wife and partner, Libbie Park, wrote an article in the same edition, which was headlined "Canadian Social Worker Visits Moscow... Gets First-Hand Information: 'I was Inside Soviet Hospitals." ",714

Photographs invariably emphasized the happiness of the Soviet people, and the progress made since the Bolshevik Revolution of $1917 .^{715}$ When he first used photos in the April-May 1953 edition of News-Facts, the captions to photographs of Soviet development and smiling faces read, "These new, exclusive News-Facts photographs show life inside the Soviet Union today. News-Facts welcomes readers' suggestions for topics to be shown in future photo pages." ${ }^{, 716}$ Carter handed out copies of News-Facts at other progressive group meetings, solicited subscriptions from them, and advertised in their newspapers. One advertisement included the promise that any canvasser who found two new subscribers for News-Facts, would receive a free map of the Soviet Union. ${ }^{717}$ In December 1956, News-Facts readers were automatically switched over to the new publication, Northern Neighbors, in which Carter continued to write about the advances made in Soviet science and society.

\footnotetext{
${ }^{714}$ Ibid., March 1950, no. 3 .

${ }^{715}$ In Northern Neighbors Carter developed a technique using captions and photographs to suggest a before/after narrative about the USSR. This was most striking when Carter wrote on the situation for natives in the Soviet north. Showing photographs of smiling people in traditional native dress, with signs of progress such as schools or factories in the background, Carter suggested in the caption that none of this was possible before 1917. The gendered and racialized stereotypes are obvious and offensive, especially considering the way this kind of propaganda disguised the very difficult conditions experienced by natives during the Soviet period. See for instance, Northern Neighbors, "Peoples of the North Transformed," January 1978, p. 6.

${ }_{716}^{71}$ News-Facts, April-May 1953, no. 36.

${ }^{717}$ LAC, RG146, A200600102, p. 72, RCMP summary of a Hungarian-language newspaper (title blacked out, but probably Kanadai Magyar Munkas (Canadian Hungarian Worker), vol. XXIV, no. 26, 8 January 1953 , p. 10.
} 
Carter tried to make Canadian-Soviet friendship appear as non-political admiration of everyday socialism. Introducing Moscow- As Two Canadians Saw It by Libbie and Frank Park, Carter wrote, "What is the purpose of the Canadian-Soviet Friendship Society? Why do we bring you this book? There's nothing to keep secret. Our aim is to help the Canadian people and the Soviet people to understand each other.,"718 Also published in 1951, Dyson and Charlotte Carter's account of their visit to the USSR, We Saw Socialism, presented a more in-depth view of everyday life in the Soviet Union, with an overwhelmingly positive spin. On the Ukrainian SSR, the Carters wrote,

Is the Ukrainian Soviet Socialist Republic a free nation, or are its 40 million people 'enslaved' by the Russians, and seeking 'independence'? This was a matter we looked into carefully during out trip. We observed, we asked questions everywhere. And this is what we two 'Anglo-Saxons' say: anyone who actually goes to the Ukraine and lives there, in the cities and out in the countryside, as we did, will discover two warm, passionate 'loves' in the hearts of all the people there. First comes their love for their Socialist Ukraine. With it, inseparable, is their love for all the other Soviet Republics, above all for the Russian people... ${ }^{719}$

The AUUC and other groups promoted and purchased Carter's publications. M. Korol of the Association of United Ukrainian Canadians sent a letter to all "Englishspeaking branch executives" in November 1951 praising the Carters' book. ${ }^{720}$ Both the Parks' book and their own were published by the Canadian-Soviet Friendship Society, using the publishers of the LPP, Eveready Printers. In 1957, the readers of the progressive newspaper, The Ukrainian Canadian, ordered 1000 copies of Charlotte and Dyson Carter's book, Cancer, Smoking, Heart Disease, Alcohol, which compared the

\footnotetext{
${ }^{718}$ Dyson Carter, "About this Book, in Libbie and Frank Park, Moscow- As Two Canadians Saw It (Toronto, March 1951), p. 10.

${ }_{719}$ Charlotte and Dyson Carter, We Saw Socialism, Part One (Toronto, 1951), p. 100.

${ }^{720}$ VOKS, 6:1:35:2, letter from M. Korol, 10 November 1951.
} 
health situation in capitalist and socialist countries. ${ }^{721}$ The overall tone of these publications, and those published by Northern Neighbors later to explain the Soviet perspective on the situations in Czechoslovakia and China, ${ }^{722}$ was to assure Canadian readers that the Soviet Union was a peaceful, advanced friend whom we should emulate.

Carter also worked hard to counteract any negative publicity he saw given the USSR in other publications. When an employee of the Massey-Harris plant, Harry Colegate, distributed CSFS leaflets at the entrance to the plant, explaining he was off to see the USSR for himself, and asking his fellow workers if they had any particular questions they would like him to find out about, the incident made it into the Globe and Mail. An article presented Harry Colegate as one seeking the truth about the USSR, and his co-worker, Nicholas Prychodko, as a counter-witness in possession of true knowledge about Soviet life. ${ }^{723}$ Prychodko wrote to the editor, arguing that visitors to the Soviet Union were exposed to propaganda tours over which they "enthused" when they returned, and so asked them 15 pointed questions about what was "true" for Soviet workers. At the end of the letter he identified his own group as the anti-Soviet Ukrainian Association of Victims of Russian Communist Terrorism, and asked "in whose interests does the Canadian Soviet Friendship Society operate, Canadian or Russian?"724

Prychodko presented himself as someone who could see through the policy of misinformation presented by the Soviet authorities. The Carters mocked witnesses who

\footnotetext{
${ }^{721}$ VOKS, 6:1:55:123-125, letter from A. Tovstogan to G. Ioanisyan, 4 June 1957.

722 Whatever Happened in Czechoslovakia (Gravenhurst, 1968) and Whatever Happened in China? (Gravenhurst, 1969) were both prepared and published by the Northern Neighbors magazine, of which Dyson Carter was editor.

${ }_{723}$ Ralph Hyman, "What's Behind the Curtain? One Fled, Knows; One Sails to Learn," Globe and Mail, 5 September 1951, p. 15.

${ }^{724}$ N. Prychodko, letter to editor of Globe and Mail, "Questions of Victims Challenge the Iron Curtain", Globe and Mail, (8 September 1951), p. 6. Clipping also in Library and Archives Canada, RG 146-3, 94A-00198, p. 79.
} 
argued against their more idealistic view of Soviet reality. In putting quotation marks around Prychodko's self-identification as a "living witness", and arguing that his description of life in Soviet labor camps was exaggerated, the Carters implied that he was a liar intent on self-promotion, that the Globe and Mail was biased since it published his story but not the Carters' rebuttal, and, finally, they argued that their perspective was more scientifically and logically sensible. ${ }^{725}$ We can only assume that, at that time, Carter believed what he was saying, ignoring the opinion of an eye-witness to the negative Soviet realities.

Apart from his own publications, Carter also worked to encourage Canadian progressives to subscribe to Soviet publications. For example, he announced in NewsFacts that any reader who joined the CSFS would be able to receive the VOKS Bulletin magazine for 50 cents a year. ${ }^{726}$ During the 1954 Soviet Friendship Month a free subscription to the VOKS Bulletin was given to paid-up members and new members of the CSFS. ${ }^{727}$ Lists of new VOKS Bulletin subscribers were regularly sent by the CSFS to VOKS in Moscow. One pleased reader, and an activist in Montreal leftist circles, Louise Harvey, wrote that the VOKS Bulletin was "a source of joy and comfort...in times when reaction seems to be firm in the saddle., ${ }^{.728}$ When VOKS first launched the Bulletin, Dyson Carter was among the first people solicited for constructive criticism, ${ }^{729}$ and when VOKS stopped publishing the Bulletin to publish Culture and Life instead, the CSFS was

\footnotetext{
${ }^{725}$ C. and D. Carter, We Saw Socialism., 271-273. This section is subtitled "'But I Was There!" ${ }^{726}$ News-Facts, Dec. 1955-January 1956, no. 61, p. 16.

${ }^{727}$ LAC, RG146, A200600104, p. 26 "Society offering sub to members," Pacific Tribune, 25 November 1955; LAC, RG146, A200600104, p. 35-36, CSFS Circular letter signed by Dyson Carter, 19 October 1955. CSFS yearly membership cost 50 cents.

${ }^{728}$ VOKS, 6:1:57:60, Louise Harvey to VOKS, 1 April 1957.

${ }^{729}$ VOKS, 6:1:39:23, Yakovlev to Burdin, 23 February 1953.
} 
asked to "propagandize the journal along their channels." "730 Lists of individuals interested in receiving the new journal were duly sent along. ${ }^{731}$

There were perks to being a CSFS member/subscriber. Carter had noted in 1954, writing to VOKS, that "As you probably know, our Society receives a number of copies of the periodicals: Soviet Union, Soviet Woman, Soviet Literature, News, New Times. We have received these for a long time, without any invoices, and we distribute them for free." ${ }^{, 732}$ In 1955, CSFS members were offered a course-book in the Russian language for $\$ 1$, or they could receive the course plus a year's subscription to News-Facts for $\$ 1.25 .^{733}$ VOKS handled the shipping of the Russian language textbook. Carter also came up with an idea to increase Canadian subscriptions to the Soviet English-language paper, Moscow News. A letter from Tovstogan to the VOKS main office in Moscow in January 1956 noted new subscriptions to the Moscow News for individuals associated with the CSFS, some of whom were also members of "ethnic, progressive" groups. ${ }^{734}$ But just a few months later, VOKS wrote to say that not enough Canadian subscriptions to Moscow News were being found. In fact, VOKS headquarters wrote that there was a strong need to increase the subscription to the English version of the Moscow News, and to be sure that it was "distributed widely" in Canada. ${ }^{735}$ In April 1956, Tovstogan responded saying that Dyson Carter had suggested Moscow News subscriptions be linked to News-Facts,

\footnotetext{
${ }^{730}$ VOKS, 6:1:49:217, Yakovlev to Tovstogan, 16 Oct. 1956.

${ }^{731}$ See, for example, VOKS, 6:1:55:55, 56-59.

${ }^{732}$ VOKS, 6:1:50:84, letter from Carter to Perevozchikov [sic], 17 Aug. 1954.

${ }^{733}$ News-Facts advertisement, "At Last! You can learn the Russian language," dated 27 March 1955, RG146, vol. 3349, Pt. 20, p. 50.

${ }^{734}$ VOKS, 6:1:49:37-38, letter from Tovstogan to Kulakovskaya, 10 Jan. 1956.

${ }^{735}$ VOKS, 6:1:49:49, letter from Yakovlev to Tovstogan, 5 March 1956.
} 
and by June 1956 the decision to do this had been made in Moscow. News-Facts subscribers would receive a discount on a subscription to Moscow News. ${ }^{736}$

In addition to being translated in the USSR and appearing in Soviet newspapers, Carter's own writing was frequently featured in the Canadian progressive ethnic press. For instance, in February 1954 an article written by Carter arguing that there was growing interest in the USSR in Canada, and that joining the CSFS was one way they could satisfy their curiosity, was carried in both the Ukrainian Canadian and the Hungarian Kanadai Magyar Munkas (Canadian Hungarian Worker). In the Ukrainian paper the headline was "Trade, Jobs, Peace in Friendship with USSR", and in the Hungarian newspaper the article appeared under the statement that "Millions are awakening to the fact that friendship with the Soviet is for our own sake, for Canada." In both cases Dyson Carter's byline was "President, Canadian-Soviet Friendship Society." ${ }^{, 737}$ The photograph captions suggested to readers that Soviet-Hungarian friendship had a long history, as did Ukrainian-Russian cooperation within the USSR, and the usual pictures of the Lenin Mausoleum on Red Square, and ballet stars also appeared with the article. ${ }^{738}$ Carter claimed that "Already big sections of our population are beginning to see a great, historic truth. Friendly relations between Canada and our neighbour to the north are what we Canadians urgently need to make sure of a peaceful, prosperous, independent future of our country. ${ }^{, 739} \mathrm{He}$ urged all Canadians to read the CSFS publications, to get the "eye-witness story" published by the CSFS, a brochure

\footnotetext{
${ }^{736}$ VOKS, 6:1:49:157, letter from Kulikov, Deputy Director of Publication at Moscow News, to Starikov, VOKS, 15 June 1956; 6:1:49:165, Kulakovskaya to Tovstogan, 19 June 1956.

${ }^{737}$ Dyson Carter, "Millions are awakening to the fact that friendship with the Soviet is for our own sake, for Canada," Kanadai Magyar Munkas, 18 February 1954; Carter, "Trade, Jobs, Peace in Friendship with USSR," Ukrainian Canadian, 15 February 1954; both articles in LAC, RG146, A200600103, p. 5-10. ${ }^{738}$ Ibid.

${ }^{739}$ Ibid.
} 
entitled Canadians Visit our Northern Neighbours, to listen to radio broadcasts from Moscow, and attend CSFS events. "...It's our responsibility to see that we and all our friends show the people of Canada, and the people of the Soviet Union, just where we stand," he argued. ${ }^{740}$ Carter's pro-Stalin stance which, not coincidentally, was still the official Soviet position at that time, was made especially clear in the caption to a photograph of a statue of Sergei Kirov, now known to have been assassinated by Josef Stalin's agents. Carter claimed that Kirov was "killed by agents of foreign imperialists."

CSFS branches placed ads in the left-wing press looking for volunteers to host Friendship Month activities in their homes, CSFS publications were reviewed in the leftwing press, and the times, dates and frequencies of Soviet radio programs were published there. ${ }^{72}$ Biographies of Dyson and Charlotte Carter were run in newspapers like the Canadian Jewish Weekly, promoting the couple as "a Canadian man and his wife" who admired the USSR and were admired by Soviet people. ${ }^{743}$ An essential part of this message was that the Carters had been to the USSR, proven by the picture of them in front of Moscow State University, and they encouraged other Canadians to see the Soviet Union for themselves.

The effectiveness of Carter's publications and his attempts to persuade readers to view the Soviet Union in a more positive light is, of course, difficult to measure. However, the fact that so many of the non-Party left were subscribers to his magazine,

\footnotetext{
${ }^{740}$ Ibid.

${ }^{741}$ Ibid., p. 5. Claiming that Kirov had been murdered by a foreign agent allowed Josef Stalin the necessary justification to arrest and execute hundreds of Party members in the Purges of the 1930s.

${ }_{742}$ See for instance, clippings from the Pacific Tribune, Canadian Jewish Weekly, the Ukrainian Canadian, Kanadai Magyar Munkas (Canadian Hungarian Worker) in LAC, RG146, A200600103, p. 11, 20, 23, 33.

${ }^{743}$ Bobbie Marsden, "A Name to Remember," Canadian Jewish Weekly, n.d., RG146, A200600103, p. 21.
} 
the abiding support he received from both the Communist Party of Canada and the Soviet authorities after he left the Canadian-Soviet Friendship Society in 1960, and the supportive letters he received from readers, seems to point towards a limited success, at least as a message aimed at those who already sympathized with the USSR. More than any other left-leaning magazine, members of the various progressive ethnic groups in Canada appear to have found in Carter a writer of appealing, non-ethnically specific, proSoviet essays and articles. His vision of the USSR as a hopeful yet realistic progressive society was attractive to Canadians who shared the dream.

Visiting the USSR

The ultimate dream for many Soviet sympathizers, not to mention other curious Canadians, was to see the USSR for themselves. The CSFS offered Canadian progressives the regular opportunity of subsidized trips to the USSR. Analysts of the Soviet reaction to the Gouzenko affair have concluded that the idea of sending select Canadians to the USSR, so that they "could deliver the "truth' about the Soviet Union" to their fellow Canadians had been in the works since 1946, and "would soon be the new Soviet approach" to perception management. ${ }^{744}$ A short trip with a return date in a few weeks was a tempting option for members of progressive groups interested in the Soviet Union, and the talks given by returnees drew large audiences. It was especially tempting in that most of the expense was covered by VOKS. Only the airfare needed to be paid by the delegates, and this money was raised locally by the LPP and the ethnic progressive groups. ${ }^{745}$ Dyson and Charlotte Carter went first in 1950, and then again in 1953.

\footnotetext{
${ }^{744}$ J.L. Black, "Soviet Tactics and Targets in Canada Before and After the Gouzenko Defection," in Black and Rudner, The Gouzenko Affair, p. 109.

${ }^{745}$ See for instance the record of a "collection card issued to raise funds to send X on a trip to the Soviet Union under the auspices of the Canadian Soviet Friendship Society", issued by the British Columbia
} 
Subsequently, Carter was a frequent visitor to the USSR. The Carters used their experiences to write their book We Saw Socialism, and also to proclaim in other publications that their view of the USSR was sure to be truthful because they had been there, and seen it for themselves. The trip provided material on which the Carters based their two-volume celebratory book, as well as articles in New Times, the Englishlanguage Soviet newspaper for foreign readers. They may not have been aware that even the questions they posed were sent in advance of their visits to various Soviet organizations. ${ }^{746}$

After their return in 1950, Carter began to organize follow-up tours for other individuals. In Carter's letters to VOKS suggesting possible delegates, we can see him attempting to reach out to the wider progressive community, to reward those who had been active, and to encourage others to contribute on their return. The main requirement was always that the delegates would participate actively in speaking tours on behalf of the CSFS once they returned. Their lectures were often accompanied by exhibitions of their own photographs, or photos and films sent by VOKS. The number of public lectures given by each delegate, the venue, and the approximate number of people in attendance was information sent in reports back to VOKS. VOKS also maintained contact with delegates after the trip, and effusive letters of friendship remain in the VOKS archival collection.

branch of the LPP, recorded by the RCMP in a memo from the Vancouver Sub-Division, Vancouver Special Branch, 9 November 1953, LAC, RG146, A200600103, p. 95. This delegate's name has been erased from the document by ATIP. He/she was the secretary of the British Columbia CSFS branch. ${ }^{746}$ The biography and itinerary of the trip is in VOKS 6:31:206-211. See also Black, "Soviet Tactics and Targets in Canada Before and After the Gouzenko Defection," in Black and Rudner, The Gouzenko Affair, p. 117. 
So who went on these trips? Frank and Libbie Park's trip in December 1949 gave them the material to write Moscow- as Two Canadians Saw It. ${ }^{77}$ Their travel file reveals that they attended a large list of cultural events, including Bolshoi Ballet performances, and were invited to an official gala in Moscow celebrating Stalin's $70^{\text {th }}$ birthday. The invitation came directly from Soviet Foreign Minister Andrei Vyshinsky's office. ${ }^{748}$ It is not clear why the Parks were rewarded with such a high-level invitation, but it is a sign of the Soviet authorities' recognition of the importance of the visit.

While other delegates may not have received their invitation from such a highranking indivividual, they nonetheless established good contacts with VOKS personnel in Moscow. This would not have happened if those higher in the power echelon did not make the arrangements. In May 1951, a delegation of Canadian "cultural workers" went to the USSR to investigate Carter's claims of Soviet cultural superiority for themselves. The delegation, composed of Winnipeg alderman Jacob Penner, Emil and Fanny Gartner, musicians active in the Jewish progressive movement, artist Frederick Taylor, and Jeannette Brunelle-Pratte, were reported by TASS to have "acquainted themselves with cultural, educational and scientific institutions in Kiev, [and] made a trip to the town of Kaniv, where they visited the grave and the museum of the great Ukrainian poet, Taras Shevchenko." 749 The Soviet Monitor wrote that "conductor Emil Gartner particularly stressed the high level of musical culture in the land of the Soviets and the perfect organization of musical education in schools for children." ${ }^{, 750}$ On their return, the

\footnotetext{
${ }^{747} \mathrm{Ibid} ., 118$

${ }^{748}$ Frank and Libbie Park Trip to USSR File, CRCR, University Partnership Centre, Georgian College, Barrie.

${ }^{749}$ LAC, RG146, A200600098, p. 29, "Canadian Delegation in the Ukraine," datelined "Kiev (Tass).

${ }^{750}$ LAC, RG146, A200600098, p. 30, from the Soviet Monitor, 19 May 1951.
} 
delegates spoke to groups in Canada, emphasizing the quality and accessibility of cultural education in the USSR. ${ }^{751}$

In 1952, the CSFS sponsored a delegation of trade unionists and workers. On her return from the USSR, a talk to be given by one trade delegate, Mrs. Katherine (Kay) Hladiy, who was employed in the Toronto needle trade industry, was advertised directly to needle-trade workers in Point Douglas. The ad noted that she had "made it a point to visit a number of Needle Trades Shops- Cloaks, Garment, Fur, Shoe, etc.," and the questions she would deal with in her presentation were listed. ${ }^{752}$ It was signed by the Needle Trades Committee of the Canadian-Soviet Friendship Society. Other labour activists, like Bruce Magnuson, were also on the trip.

In September 1953, a delegation of seven CSFS members including Rosalind McCutcheon (Montreal), Leo Clavir (Toronto), Florence Dorland (Vancouver), Paul Pauk (Toronto) Margaret Spaulding (Toronto), Eleanor Ashworth (Edmonton) and (Major) R.T. Lafond (Quebec) visited the USSR. The essays they wrote later were published by the CSFS as a 32-page booklet called Canadians Visit Our Northern Neighbours: Picture Report of a Trip to the Soviet Union. For 25 cents, readers could get this booklet which included enthusiastic reports on all things Soviet, along with pictures of the highlights. On the last page, the News-Facts Toronto address was noted with the bold-faced title "Did you enjoy reading this report? Every month, 'News-Facts' contains information like this." ${ }^{.753}$ Below are the words "Not just articles- not just pictures - but

\footnotetext{
${ }^{751}$ LAC, RG146, A200600098, p. 37-38, RCMP report, dated 2 June 1951.

${ }^{752}$ This meeting took place in the Point Douglas Labor Temple, 7 December 1953. LAC, RG146, A200600114, p. 19, circular letter, signed "Needle Trades Committee of the Canadian-Soviet Friendship Society.

${ }^{753}$ Canadian-Soviet Friendship Society, Canadians Visit Our Northern Neighbours, no publication date [1954], inside of back cover.
} 
FILMS!" advertising three Soviet films available for rental. ${ }^{754}$ And on the back cover there is a photograph of Charlotte and Dyson Carter sitting on a picturesque terrace, which from the personal letter that follows turns out to be "the new city of Stalingrad." Here the Carters ask for funds to contribute to their efforts to pass on the information they received during their visits to the USSR, since "by helping to bring truthful information to the Canadian people, you'll be a builder of real friendship between our country and our northern neighbor [sic]. ${ }^{755}$ Documents in the VOKS collection show that particularly during February 1954, Soviet Friendship Month, the CSFS encouraged its branches to actively distribute this booklet. ${ }^{756}$ Predictably, speaking engagements also took place that month. ${ }^{757}$

In 1954, the CSFS sponsored a delegation of Canadian "artists" to go to the USSR, including the famous Group of Seven painter, Frederick Varley. ${ }^{758}$ At the same time, a group of Soviet performers came to Canada, and were toured around the country by John Boyd. The tour was sponsored by the CSFS, and the Canadian left-wing groups supported the concerts. Sophia Golovkina and Leonid Zhdanov, ballet dancers, Leonid Kogan, violinist, Elizaveta Chavdar, soprano, Arturs Frindbergs, tenor, and pianist Pavel Serebryakov, were welcomed by Dyson Carter as they arrived in Toronto. ${ }^{759}$ The concerts were popular -- 3000 were in attendance at the first concert in Massey Hall, and

\footnotetext{
${ }^{754}$ Ibid.

${ }^{755}$ Canadian-Soviet Friendship Society, Canadians Visit Our Northern Neighbours, back cover.

${ }^{756}$ VOKS, 6:1:42:21, 23, 27, 93, 110 letters and memos written by Ted Baxter, CSFS National Secretary until 1956.

${ }^{757}$ VOKS, 6:1:42: 20, 25, 79, 81, 103 various announcements and publicity for speaking engagements by 1953 delegates.

${ }^{758}$ Montreal Gazette, 10 April 1954, LAC, RG146, A200600093, p. 18, 20, 23, 33. The departure of the Toronto artists was reported in Lotta Dempsey's article "Leave Next Week: three Toronto Artists Plan Tour of Russia," Toronto Globe and Mail, 1 April 1954, LAC, RG146, A200600093, p. 50; "What's Going On in Red Culture Takes Six Canadians to Moscow," Montreal Gazette, 10 April 1954, LAC, RG146, A200600093, p. 22.

${ }^{759}$ V. Nekrasov, "Around the World: Soviet Artists in Canada", News, 10 May 1954, LAC, RG146, A200600095, p.18-19.
} 
7000 people crowded into Varsity Arena to hear them at the end of their tour. More than 4000 were reported to have attended the concert in Winnipeg, over 1000 in Sudbury, and 2, 500 people were said to be at the concert in Ottawa at the Capitol Theatre. ${ }^{760}$ At one performance in Toronto the RCMP reported "there were numerous known local communists in attendance..." ${ }^{761}$ The schedule of their concerts was printed in Ukrainske slovo, and other left-wing publications, with information about where to buy tickets. ${ }^{762}$ Interviewed by the Tribune, John Boyd said that the audiences everywhere were large, and the advertisements taken out by anti-communist Ukrainian groups did little to deflate the enthusiasm of the crowds. ${ }^{763}$

In February-March 1955, the CSFS delegation was comprised of Morris Biderman from the UJPO in Toronto; Louis Kon from Montreal; Mrs. Anna Sochasky, AUUC member in Vancouver; K. Rankin, CSFS member from Vancouver; Kate Bader from Toronto; R. Patriquen from Saskatchewan; and Dorothy Johnson from Manitoba. On her return, Anna Sochasky wrote a letter to VOKS addressed to "Dear Soviet Friends," describing the Ukrainian-Canadian left:

As a Canadian I want to tell you how some of us spend our spare time in the evenings in Canada. I belong to a club called the Society of United Ukrainian Canadians. Across the whole of Canada we have 125 such clubs, some larger, some smaller. There are about 115 Ukrainian halls that belong to us. The workers have built them with their own money. I will tell you about such a club in Vancouver British Columbia. We have a separate men's club and a separate women's club. We have about 80 women in our club. There is also a large youth club. We have private teachers that teach our children the Ukrainian language in the evening. Ukrainian dancing is also tought [sic]. We have about 150 children

\footnotetext{
760 "All Canada acclaims triumphant Soviet artists," Canadian Tribune, 10 May 1954, RG 145, A200600095, p. 28.

${ }^{761}$ RCMP report, Toronto Special branch, 10 May 1954, LAC, RG146, A200600095, p. 22.

${ }^{762}$ Ukrainske slovo, 21 April 1954, p. 1, 3, in LAC, RG146, A200600114, p. 12.

763 "They Fell in Love with Canada," Canadian Tribune, RG146, vol. 3350, Supp. 5, Pt. 3, n.d., p. 48-49.
} 
that dance. We have a youth mandolin orchestra, and a mixed choir of young and old of 50 people. We give concerts in our hall with these groups once a month. Every Sunday we have a Soviet film showing. Three hundred people can be seated in our hall. Our women's club has a sewing circle, and we embroider Ukrainian shirts, aprons, and other articles. Our members take an active part in peace campaigns. ${ }^{764}$

Sochasky's letter reflects the gendered realities of the progressive movement, ${ }^{765}$ reflected also in the "eye-witness" stories brought back by delegates. A common pattern for CSFS events, especially under the leadership of Dyson Carter, was for women to speak about the everyday concerns of Soviet people, particularly concerns seen to affect women and children.

These talks backed up the message carried in the CSFS publications that it was because of the socialist state that Soviet women were able to handle the 'double burden' of work outside of the home and child-rearing. From these speeches there appeared to be no contradiction in Soviet women's increasing autonomy, and even preeminence, in the work force, and their continuing traditional roles in the family. Production-line factories and common kitchens helped ease the burden for women, it was claimed. There is real pathos in reading these reports today. Research has now shown that despite Soviet claims to the contrary, the position of women in the USSR was nowhere near egalitarian. After leaving work they often had to stand in long line-ups to purchase essentials for the family, goods were not always readily available, housing was cramped and several generations lived in small apartments, the divorce rate and rate of single-motherhood

\footnotetext{
${ }^{764}$ VOKS, 6:1:50:107 Sochasky to VOKS, no date, but handwritten annotation 12 March 1955 in margins. Mrs. Sochasky's name was variously transliterated in the VOKS documents also as Suchasky, Suchaski, Sokhatsky and Sokhatsky, but each time she was listed as Mrs. Anna/Anne ... from Vancouver, CSFS delegate, VOKS Bulletin reader, AUUC and/or CSFS member.

${ }^{765}$ On this see especially Frances Swyripa, Wedded to the Cause: Ukrainian-Canadian Women and Ethnic Identity, I891-199I (Toronto, 1993).
} 
were high, access to birth control and abortion difficult, pay was not equal, and neither was political representation. In fact, it was considered that "feminism" had been coopted by the State, and the problem solved, while women continued to experience gender and sex discrimination in their everyday lives. Perhaps their declarations can be better understood in relation to their idealistic hopes for their own lives, rather than accurate reflections of what they had seen in the USSR. Speaking before audiences after their return, Sochasky and Kay Rankin described the good bread made in "modern bakeries," chicken or meat eaten at every meal in cafeterias, and other idealized impressions of the USSR. $^{766}$ Their remarks were published in the Nelson Daily News. ${ }^{767}$

As with other delegations, the details of the 1955 delegates' presentations on their visit were reported back to VOKS. In a letter to his boss, VOKS representative in Ottawa, Vladimir Burdin noted the dates and venue in which each candidate spoke, as well as the number of people in the audience, and what else was on offer at that meeting. Sometimes this included an FRC choir concert, the playing of Soviet records or screening of films, or special speeches given, for example, in honour of the tenth anniversary of the Warsaw uprising. ${ }^{768}$

VOKS and the CSFS had company keeping track of attendance figures; the RCMP also counted speaking engagements and the number of individuals attending. For instance, a report noted that on their return from the USSR, Ann Sochasky and Kay Rankin spoke in Natal, B.C. to an audience of 45 people, where funds were raised for the local FRC branch. Mrs. Sochasky was said to have spoken poorly, and Mrs. Rankin was

\footnotetext{
${ }^{766}$ LAC, RG146, A200600092, RCMP report from the Special Branch, Nelson, B.C., 4 April 1955, p. 11.

${ }^{767}$ LAC, RG146, A200600092, Nelson Daily News, "Soviet Life Described Here," 31 March 1955.

${ }^{768}$ VOKS, 6:1:48:135, letter from Burdin to Perevoschikov, 25 May 1955.
} 
“impressive." 769 Another RCMP report from April 1955 notes that Mrs. Sochasky and Mrs. Rankin spoke on 30 March in Nelson, B.C. where there were about 85 people present, $90 \%$ of whom were Doukhobors. ${ }^{770}$ After two films were shown, the women "described conditions in the Soviet Union including modern bakeries, meals throughout the trip, and Technical Institutes and other general living conditions." ${ }^{771}$ At some meetings Mrs. Sochasky spoke in Ukrainian, and at others in English. ${ }^{772}$ The RCMP included reviews and publicity from the local press with their reports, in which the women said that there was plenty of meat to eat in the USSR, the Soviet television sets did suffer from interference, and the bread produced in modern, efficient factories was "not handled by human hands." life, an impression which, unfortunately, was far from the reality for most Soviet families, though their Canadian purveyors may not have known that.

The overlap of progressive personnel on this delegation was not coincidental -- it was an important characteristic of the CSFS. Delegates and CSFS executive members were carefully selected for their ability to interact with the diaspora groups, the LPP, and attract new members. William Teresio, executive member of the AUUC, was also on the National Council of the CSFS. ${ }^{774}$ When he died in 1954, the CSFS made this connection explicit in a eulogy sent to all CSFS branches: "His death is a grievous loss to the cause

\footnotetext{
${ }^{769}$ LAC, RG146, A200600092, RCMP report from Cranbrook Special Branch, Nelson, B.C., 13 April 1955, “Canadian-Soviet Friendship Society, Delegation to the U.S.S.R., December 1954", p. 7-8.

${ }^{770}$ LAC, RG146, A200600092, RCMP report from the Special Branch, Nelson, B.C., 4 April 1955, "Canadian-Soviet Friendship Society, Delegation to the U.S.S.R.- December 1954", p. 11.

${ }^{771}$ Ibid.

${ }_{772}^{72}$ LAC, RG146, A200600104, RCMP report dated 14 April 1955, p. 53.

${ }^{773}$ LAC, RG146, A200600092, "Soviet Life Described Here", Nelson Daily News, 31 March 1955, attached as part of the RCMP report, 4 April 1955, "Canadian-Soviet Friendship Society, Delegation to the U.S.S.R.- December 1954," p. 14.

${ }_{774}$ An RCMP report from 1950 noted emphatically that "the AUUC is a part of the CANADIAN SOVIET FRIENDSHIP SOCIETY, and that Mr. WM. TERESIO, president of the AUUC is on the executive of the CANADIAN SOVIET FRIENDSHIP SOCIETY." LAC, RG146, A200600096, RCMP report dated 6 March 1950, p. 248, emphasis in original.
} 
of Canadian-Soviet friendship, and will be deeply felt by all members of our Society." 775 Members of progressive groups were asked to help finance trips to the USSR made by local individuals, whether or not they actually belonged to the same ethnic group. For instance, a fundraiser was held at the Ukrainian Labour Temple in Moose Jaw, Saskatchewan in November 1954 to raise funds for R.L. Patriquen's trip to the USSR. A form letter was sent out to local progressives, addressed to "Dear Friend," suggesting that the remaining funds "can be secured through contributions from men and women who are aware of the need for goodwill and friendship between nations." 776 Signatures on the attached form show eight individuals gave between five and ten dollars each. Later, Carter sent out thank-you notes, published in the pages of the leftist ethnic press. Returned CSFS delegates had their stories published in the progressive press in Canada, and the RCMP in turn clipped the articles and put them on files. In one, a Jewish delegate described Soviet Jews telling him that they had all the money and comforts they needed, saying “"All Jews should feel as free as we do." 777 This just a few years before Nikita Khrushchev admitted in his speech at the XXth Party Congress that Jews had been among the most repressed minority groups under Josef Stalin.

In March 1955, Carter wrote to VOKS headquarters in Moscow to suggest a Soviet "professors" tour of Canadian universities and CSFS branches in Canada. In

\footnotetext{
${ }^{775}$ LAC, RG146, A200600091, "Memo to All Society Branches” from Ted Baxter, 15 January 1954, p. 38. William Teresio died on 6 January 1954.

${ }^{776}$ LAC, RG146, A200600092, "Dear Friend" letter and form from John Flatt, Joe Kossick, Jack Bingley, calling themselves jokingly the "Committee for 'Pat", Moose Jaw, Saskatchewan, 8 November 1954, attached to RCMP report, p. 24, 26. A postscript to this letter announced that "this month is Soviet Friendship Month."

${ }_{777}^{77}$ For instance, Morris Biderman, himself a CSFS delegate, published an article on Louis Benzvy's trip to the USSR in 1955. LAC, RG146, A200600092, Morris Biderman, "A Warm Reunion in Moscow", Vochenblatt, stamped 30 April 1955, attached to RCMP report, p. 46. For more on Biderman's activism, see his autobiography $A$ Life on the Jewish Left: An Immigrant's Experience (Toronto: Onward Publishing, 2000).
} 
regard to whether public meetings or Society events would take precedence, he wrote "Of course, what we actually do will be in the sole interest of this delegation having greatest impact and influence for Friendship. ${ }^{.778}$ He was also in the process of planning another CSFS delegation be made up of Dr. Howard Lowrie, who had been an important financial contributor to the CSFS, the Canadian artist Tom Thomson's sister, Margaret Tweedale, "a long-time worker for Friendship, [with] a wide circle of friends in CCF and Church groups," 779 and her husband William, who sat on the CSFS Administration Committee after 1956, when his views on the Hungarian events were judged by VOKS to be "correct." 780 But the events in Hungary and Poland in $1956^{781}$ threw something of a wrench into Carter's plans. In 1957, the Embassy decided not to support the visit, possibly because they were on the 'wrong side' of the policy shake-up, and the tour did not go ahead. ${ }^{782}$ VOKS did, however, organize a Soviet tour for members of the Cooperative Commonwealth Federation (CCF) in 1956, but this tour was not sponsored by the CSFS. ${ }^{783}$

\section{The CSFS in 1956}

Significant aspects of the CSFS' work changed in 1956, after news of Khrushchev's secret speech at the XXth Party Congress in February slowly reached

\footnotetext{
${ }^{778}$ VOKS, 50:52-54 Carter to Perevoschikov, 31 March 1955.

${ }^{779}$ VOKS, 49:268 Carter to Tovstogan, 12 Sept. 1956.

${ }^{780}$ VOKS, 49:264-267, letter from Tovstogan to Vertogradov, 20 September 1956; VOKS, 55:70-77, letter from Tovstogan to Ioanisyan, 22 February 1957.

${ }^{781}$ Nikita Khrushchev's so-called secret speech was given to a closed session of the Party at the XXth Party Congress on 25 February 1956. It became public only in March of that year, and has said to have been influential in giving impetus to uprisings in the Soviet satellite countries later that year. When the revolt in Hungary was put down forceably by the Soviets in November 1956 international critics of all political orientations expressed alarm at the Soviet response. Many leftists worldwide mark their disillusionment with the USSR from this moment.

${ }^{782}$ VOKS, 50:203, letter D. Chuvakhin (Soviet Ambassador to Canada) to G. Ioanisyan, 8 April 1957.

${ }^{783}$ William Irvine, Dorothy Johnson, Harold Bronson and B.F. Tanner participated on this tour, and their thank-you letters to VOKS personnel (August-September 1956) are in the VOKS archival collection. VOKS, 6:1:54:72-83.
} 
international communist groups. ${ }^{784}$ Key CSFS staff members left the Society over it, and the membership shrank. In the summer of 1956, Ted Baxter, National Secretary, cancelled his subscription to the VOKS Bulletin, and left the Society. ${ }^{785}$ In an interview, Baxter said that he became disillusioned and, given a number of visits of RCMP officers to his workplace, he feared losing his job, and putting his young family at risk. He decided to distance himself from the progressive movement at that time. ${ }^{786}$ Next to leave was Jim Leech, the Organizing Secretary, whom VOKS had congratulated for managing much of the everyday work of the CSFS and the publication of News-Facts. ${ }^{787}$ In September 1957, Tovstogan informed the VOKS head office that Leech had asked the CSFS leadership to relieve him of his duties. "Considering his request, and also his incorrect behaviour following the XXth Congress of the CPSU" the CSFS leadership agreed, Tovstogan wrote. ${ }^{788}$ In late 1956, Louis Kon died. ${ }^{789}$ In May 1957, Charlotte Carter's comments that the XXth Party Congress had "made the idea of Canadian-Soviet friendship unpopular in Canada (especially amongst the Jewish members)" were reported to VOKS in Moscow. ${ }^{790}$ Apparently only half of the CSFS executive members turned up for a meeting to discuss the CSFS plan for 1957.

\footnotetext{
${ }^{784}$ On the crisis in the Canadian LPP, and the strong feelings of disillusionment and disappointment among members, caused by the events of 1956, see Merrily Weisbord, The Strangest Dream: Canadian Communists, the Spy Trials, and the Cold War (Montreal, 1983, 1994).

${ }^{785}$ VOKS, 49:232-237, list of VOKS Bulletin subscribers and one cancellation, attached to a letter from Tovstogan to Vertogradov, 17 August 1956.

${ }^{786}$ J.E. Baxter, interview with author, 8 December 2006, Stratford, ON. Baxter said RCMP officers repeatedly visited his workplace, and spoke with his boss about his political activities.

${ }^{787}$ VOKS, 49:13, letter from Tovstogan to Kulakovskaya, 16 Dec. 1955.

${ }^{788}$ VOKS, 49:264 letter from Tovstogan to Vertogradov, 20 Sept. 1956.

${ }^{789}$ VOKS, 55:2, letter from Tovstogan to Kulakovskaya, 11 December 1956.

${ }^{790}$ VOKS, 55:150-151, letter from Tovstogan to Ioanisyan, 31 May 1957.
} 
A few months later, the Carters moved north from Toronto to Gravenhurst, ${ }^{791}$ taking their new journal Northern Neighbors with them. John Boyd has suggested Carter had a falling out with the Canadian Party leadership, and although "the Party tried to get the Soviet embassy to loosen its ties with Carter, the Embassy found him more of an asset than what the Party could offer." 792 The Carters remained in touch with VOKS for materials, and continued to visit the USSR from time to time. After the CPC-LPP changed the name of the CSFS to the Canada-USSR Association and put Les Hunt ${ }^{793}$ in charge, the links between the progressive ethnic groups and the more Anglo-Saxon Association remained in effect. Many of Carter's readers continued to be of Ukrainian, Russian, Finnish, Polish, and Baltic backgrounds. ${ }^{794}$

The reorganization of the CSFS after the events of 1956 shows flexibility in the persuasive strategies used by its Soviet sponsors and leaders of the Canadian left. In practice, the CSFS message was aimed mainly at those who already sympathized with Soviet Union, many of whom also attended progressive, ethnic group events, so its campaign of persuasion was made easier by the fact that most attendees were already convinced. The relative success of the CSFS initiatives can be seen in the numbers

\footnotetext{
${ }^{791}$ VOKS, 6:1:56:24-25, Carter to Kolmakova, 10 September 1957 . The move may have been due partly to Carter's health. An accident in 1957 which resulted in him spending some time in the hospital, and may have kept him from walking again, was mentioned in letters to VOKS. VOKS, 6:1:55:150-151, 161-163, letter Tovstogan to Ioanisyan, 31 May 1957; Tovstogan to Ionisyan, 13 September 1957; VOKS, 6:1:56:1819, 24-25, letter Charlotte Carter to Kolmakova, 11 June 1957; Kolmakova's reply to Charlotte Carter, 21 June 1957; letter from Dyson Carter to Kolmakova, 10 September 1957

${ }^{792}$ John Boyd (né Boychuk), interview with author, 2 August 2006, Toronto; John Boyd, comments on manuscript by Jennifer Anderson, April 2008.

${ }^{793}$ In an oral interview, Hunt explained that his English name and mannerisms helped him book speakers and make other arrangements for the Association. Leslie Hunt, interview with author, 2 January 2007, Hanover, ON.

${ }^{794}$ Although it is difficult to be certain of the statistics, the letters to the editor in the Dyson Carter fonds at Library and Archives Canada seem to suggest that many of his readers had immigrated to Canada from East/Central Europe. As previously mentioned, an AUUC survey in 1965 found that many young AUUC members enjoyed Northern Neighbors. LAC, MG 28-V-154, vol. 27, file 14-18, "Poll of Participants of the AUUC National Youth Conference, July 9-11, 1965, Ukrainian Camp Palermo," Toronto.
} 
attending events and subscribing to the journals, some of which would have been read by individuals outside of the left-wing communities. Convinced that anti-Soviet feeling was being constructed by the Western press and governments, Carter and other CSFS leaders consciously constructed an alternative image of the USSR: a warm, progressive picture.

To CSFS readers and members, the USSR represented a hope and a dream, and evidence to the contrary was either not available or ignored. There is no doubt that the CSFS membership sincerely wished to see progressive policies put into practice in Canada, and individuals also found in the CSFS a forum where they could voice their rejection of Cold War antipathies. However, the reorganization of the CSFS after 1956 suggests that the convergence of this idealism and sympathy for the USSR on the Canadian left had been seriously questioned. ${ }^{795}$

The way this dream was articulated by and for Canadian women will be discussed more particularly in the following chapter.

\footnotetext{
${ }^{795}$ Although Khrushchev's speech and the Soviet invasion of Hungary in 1956 were probably the main reasons for this change, the geographic dispersion of the left-wing communities from downtown Toronto, as well as the improved socio-economic backgrounds of second- and third-generation Canadians may also have played a role in the declining CSFS membership. Ester Reiter has suggested that these factors, together with the UJPO's 1951 expulsion from the Canadian Jewish Congress, caused the UJPO's decline. Ester Reiter, "Secular Yiddishkait: Left Politics, Culture, and Community," Labour/Le Travail, Spring 2002 $<\mathrm{http} / / / \mathrm{ww} w$.historycooperative.org/journals/llt/49/05reiter.html> (10 Jun. 2008), paragraphs 33-35.
} 


\section{Chapter Seven \\ THE 'PINK TEA CIRCUIT' OR 'DREAMS OF EQUALITY?' WOMEN AND THE CSFS}

The Financial Post published an article in 1951 under the headline "The Reds" Pink Tea Circuit: The Communist Front Fools a Lot of Women."796 Claiming that there were hidden connections between Moscow, the Labor-Progressive Party and women activists in Canada who protested expensive daycare and visited Communist countries, the article suggested that Communist-inspired protests were recognizably "belligerent, abusive in a well-organized way."797 The journalist hinted that, as a "pink tea circuit," the women were involved for superficial reasons, were not real communists, and were being manipulated by other forces. He argued that since two of the women cited, Nora Rodd of Windsor and Ethel Nielsen of Toronto, were "not known to be ...Communist party member[s]," they must have been 'duped' into their activism on behalf of leftist groups like the Canadian Congress of Women and the Canadian Soviet Friendship Society. In hindsight, the Financial Post article invites us to ponder the role of gender in the CSFS' activities.

To what extent were women in the CSFS fooled into activism? To what extent did gender impel their activism? It is clear that many of them were idealistic, and, if associated with the LPP, they chose to keep their membership discreet. Many of these women were attracted more to LPP-linked groups, such as the CSFS, than to the LPP itself, although they could probably be described as communist-sympathizers or fellowtravellers. The 'popular front' appeal of the LPP in the post-war years used methods

\footnotetext{
${ }^{796}$ Ronald Williams, "The Reds' Pink Tea Circuit: The Communist Front Fools a Lot of Women," Financial Post, 9 June 1951, transcribed in an RCMP report, LAC, RG146, A200600105, 12 June 1951, p. 109-110; and in photostat original, LAC, RG146, A200600098, p. 32. ${ }^{797}$ Ibid.
} 
tested during the 1930 s to attract socialists of all brands, and the 'woman question' was one of these avenues. Joan Sangster has explained that the Popular (or Peoples') Front was an attempt by the Communist Party of Canada to increase its membership base and its profile by appealing to progressives outside of the Party, emphasizing issues that had broad support, rather than criticizing other 'brands' of socialism and activism. For women, she noted that this policy "generated new opportunities for activism and inspired innovative organizing techniques," allowing women a more active role in the organization of campaigns against fascism and for progressive ideals. ${ }^{798}$ Studying women's roles within the CSFS and the way the Society played up rhetoric about women's equality in the USSR demonstrates that members were drawn to their activism through idealism. They were not 'duped' into activism.

Details of the support given the CSFS by VOKS were not widely known among members and subscribers. The Soviet Union was held up as a concrete example of a state where equality of the sexes had been achieved and no matter how inaccurate the message was, it was repeated in CSFS literature and speeches. The Canadian women who put a voice to this message were convinced that equality was both desirable and achievable in Canada, and they in turn convinced other women to attend CSFS-sponsored events on this basis. Rather than being 'fooled' into their activism, these women chose their roles: they thought their participation would further their own idealistic cause. In understanding this, we can better understand how the CSFS appealed to its members. At the same time, however, the perceptions promoted by the CSFS of an egalitarian and progressive environment for women in the Soviet Union were sadly mistaken, and CSFS persuasion was built on this distortion.

${ }^{798}$ Joan Sangster, Dreams of Equality: Women on the Canadian Left, 1920-1950 (Toronto, 1989), p. 124. 
In her work on Canadian women on the left, Joan Sangster identified the opportunities Popular Front strategies offered women in the 1930s and 1940s. ${ }^{799}$ The Communist Party appealed directly to progressive women outside of the Party to improve the political profile of the CPC, but most of these women were far from passive dupes. ${ }^{800}$ Encouraged to join mainstream groups so as to educate working-class housewives about political issues, Communist women found the "apolitical" nature of this task more suited to their interests than high Party positions. Some women hesitated to take up leadership roles, and instead chose tasks related to fundraising, administrative and general support, tasks that were important enough to make them the Party's "foot-soldiers", but not bring them into the limelight. This reticence was partly due to class and cultural norms about what women should do, but was also related to the material conditions of everyday life. Most of these women had domestic childcare responsibilities, and many, particularly those in the Finnish, Ukrainian and Jewish communities, were bringing in income by keeping boarders or working outside of the home. ${ }^{801}$ Limited free time meant that women did not always achieve the degree of theoretical knowledge their male counterparts considered necessary for leadership positions, although they were important actors when it came to maternalist policy campaigns, like better schools, daycare access and reproduction rights. However, the Communist Party of Canada never took feminism seriously, and class interests, and in some groups, ethnic identity, took precedence over campaigns for women's equality. ${ }^{802}$ Despite rhetoric to the contrary, deep-seated

\footnotetext{
${ }^{799}$ Ibid, p. 124-164.

${ }^{800}$ Ibid., p. $55,124$.

801 Sangster, Dreams of Equality, p. 146-153.

${ }^{802}$ The CPC-LPP defined women's oppression in society as a byproduct of capitalism, linked to the system's class-based inequalities. Therefore, nothing short of a revolution could alter women's position, and postwar campaigns led by women on the left for price controls, peace and women's rights received only "lukewarm support" from their male counterparts. This definition of feminism at times paralleled the
} 
convictions about male privilege were as prevalent in leftist groups as they were in wider Canadian society at that time, and mainstream notions of femininity and woman's place percolated into the CSFS. ${ }^{803}$

This predicament drew to some extent also on the situation in the Soviet Union. In the USSR, Vladimir Lenin and the Communist Party (CPSU) had considered the "woman question" a factional interest, and overt consideration of it was banned by the CPSU from 1921 as part of the left-wing opposition, challenging party unity. Indeed, Marxist-Leninists held that consideration of feminism as a theoretical issue separate from class interests was bourgeois. For Alexandra Kollontai, an "Old Bolshevik" most wellknown as an advocate of women's rights in the USSR, issues of women's equality were deeply connected to class inequality, and attempts to address women's rights must necessarily challenge the class-based nature of capitalism. However, as Kollontai was shunted aside from the main decision-making in the CPSU in the 1920 s, so too were women's issues gradually subjugated to the struggle for survival. Most female Bolsheviks supported Lenin's approach to Party unity, and "factionalism" was no small matter. ${ }^{804}$ Although the representation of women in political bodies was often trumpeted

women's suffrage movement, and other times criticized the women's movements for being too "bourgeois." On how women on the Ukrainian-Canadian left articulated a particular feminism, see Rhonda L. Hinther, "'Sincerest Revolutionary Greetings': Progressive Ukrainians in Canada, 1918-1991." (Hamilton: McMaster University, unpublished PhD thesis, 2005). On the issue of ethnic unity and the liberation of the ancestral homeland, as well as class interests, taking precedence over issues of women's equality with male leftist leaders, see Frances Swyripa, Wedded to the Cause: Ukrainian-Canadian Women and Ethnic Identity, 1891-1991 (Toronto, 1993); Linda Kealey, Enlisting Women for the Cause: Women, Labour, and the Left in Canada, 1890-1920 (Toronto: University of Toronto Press, 1998); Sangster, Dreams of Equality, p. 88, and passim.

${ }^{803}$ Rhonda L. Hinther, “'Sincerest Revolutionary Greetings': Progressive Ukrainians in Canada, 19181991." (Hamilton: McMaster University, unpublished $\mathrm{PhD}$ thesis, 2005).

${ }^{804}$ The CPSU resolution "On Party Unity" passed in 1921 at the Tenth Party Congress, made factions illegal, and was one of the most lasting of CPSU decisions. On this see Alexandra Kollontai, Selected Writings, with introduction and commentaries by Alix Holt (New York: W.W. Norton and Company, 1977); Adam B. Ulam, The Bolsheviks: The Intellectual and Political Triumph of Communism in Russia (New York: Macmillan Publishing Company, 1965). On another example of a woman revolutionary 
by the Soviet leadership, these numbers were based largely on quotas, and women were rarely in positions to affect decisions. The fact that "several educated and talented women [were] in the Russian socialist movement, but, like [Nadezhda] Krupskaya, they concentrated on secretarial or technical work and did not participate much in editorial boards or policy-making discussions, ${ }^{, 805}$ became more significant once Josef Stalin closed all the women's departments of the CPSU (Zhenotdel) in 1930. In the Communist Party of Canada the precedence given to class (and the energy spent arguing about ethnic issues) over questions of women's place in society was defined by Marxist-Leninist theory and the Soviet example. This was put in practice in the CPC-supported Canadian Soviet Friendship Society, where women played key organizational roles, but always as help-mates to their male counterparts.

Following the Gouzenko revelations and the debut of the Cold War, the Communist Party (or LPP) was under pressure and, watching the arrests and public hearings both in Canada and in the United States, its members were worried and fearful. Once again the Party resorted to Popular Front strategies to shore up its membership, and to boost its support within larger Canadian society. The Canadian Soviet Friendship Society was a big part of this campaign. The promotion of women to high positions never really took hold in the CSFS, despite constant lip-service to the ideals of gender equality. Still, of the 50 names listed as members of the National Council for CanadianSoviet Friendship in 1951, eleven were women, which proportionally was not

challenging this situation in the early years of the USSR, see R.C. Elwood, Inessa Armand: Revolutionary and Feminist (Cambridge: Cambridge University Press, 1992).

${ }^{805}$ Alix Holt, "Introduction," to Alexandra Kollontai, Selected Writings, p. 17. 
insignificant. ${ }^{806}$ In addition, it is clear from the documents left by the CSFS on its activities that frequently the wives of the male members of the CSFS performed important organizational tasks for the group, although they were not always listed as members.

The main leadership positions were held by men and Dorise Nielsen, who as Executive Secretary was the only woman ever in position to become a CSFS leader, was not offered the position she wanted, and stepped aside. ${ }^{807}$ And yet, as her biographer has pointed out, "Nielsen's low profile may have suited her in some ways." ${ }^{808}$ With news of the pronouncements of Joseph McCarthy in the United States, and the attempts by the RCMP to curtail radical political activities in Canada, she worried about arrest. On a personal level, she also worried about her health and that of her children. ${ }^{809}$ Charlotte Carter, who was at times listed as a simple member, and later handled the CSFS finances, often took up Dyson Carter's responsibilities when he was physically unable to do so, and yet she was never officially in the leading position. Perhaps she did not wish to be. The Northern Bookhouse, through which Carter sold Soviet books sent him by VOKS, was set up in Charlotte Carter's name in Gravenhurst in $1957 .{ }^{810}$ Helen Burpee, a

\footnotetext{
${ }^{806}$ VOKS 6:1:36:23, List of "National Council of the C-S.F.S.", 1951. The women listed here were: Dorise Nielsen, Executive Secretary, Mrs. Eleanor Ashworth, Mrs. Wilma Williams, Mrs. W. Savenoff, Mrs. Mary Kardash, Fagel Gartner, Mrs. W. Kugler, Mrs. C. Roberts, Mrs. M. Popoff, C. [Charlotte] Carter, Mrs. R. McCutcheon.

${ }^{807}$ Faith Johnston, A Great Restlessness: The Life and Politics of Dorise Nielsen (Winnipeg: University of Manitoba Press, 2006), p. 228-229, 231.

${ }^{808} \mathrm{Ibid}$, p. 228.

${ }^{809}$ Ibid, p. 228, 231.

${ }^{810}$ In the spring of 1957, Charlotte Carter took over the editorship of Northern Neighbors while Dyson was in hospital. VOKS 6:1:55:150-151, letter from A. Tovstogan to G. Ioanisyan, 31 May 1957.
} 
chartered accountant and member of the $\mathrm{CPC}$, did the end-of-year accounting for the CSFS. $^{811}$

Many other women, whose names did not appear on any event banners or letterheads actively participated in the CSFS activities. Although not often in the limelight, at the membership level these women played important roles. They attended events, subscribed to newsletters, wrote letters to the editor, went on delegations, organized fundraising campaigns and provided administrative support to the CSFS. It is difficult to accurately quantify their numbers, but anecdotally the women whose names appear in these capacities outnumber those who are listed as CSFS members or executive members, and it is therefore worth exploring how and why they were active. The reasons they chose this type of activity over more high profile leadership positions may have been similar to Dorise Nielsen's own.

In her work on the Housewives Consumers' Association, another Communistbacked group in Canada which took up the cause of price activism immediately following the war, Julie Guard has pointed to an explanation of the way radical Canadian women expressed their opinions on public policy in ways that fit with their conceptions of class, ethnicity and femininity. ${ }^{812}$ Through the Housewives' group, women were able to express their disagreement with the status quo, and voice their conception of "the state in familial terms,"

${ }^{811}$ VOKS 6:1:36:42, Receipts and Disbursements, CSFS, Nov. 1950-Nov. 1951, audit report signed by Helen Burpee; 6:1:50:115-118, Audit report, 23 Nov. 1954, signed by Helen Burpee.

${ }^{812}$ Julie Guard, "Canadian Citizens or Dangerous Foreign Women? Canada's Radical Consumer Movement, 1947-1950," in Marlene Epp, Franca Iacovetta, Frances Swyripa, eds., Sisters or Strangers? Immigrant, Ethnic, and Racialized Women in Canadian History (Toronto, 2004), p. 161-189; and Guard, "Women Worth Watching: Radical Housewives in Cold War Canada," in Gary Kinsman, Dieter K. Buse, Mercedes Steedman, eds., Whose National Security? Canadian State Surveillance and the Creation of Enemies (Toronto: Between the Lines, 2000), p. 72-88. Also Sangster, Dreams of Equality, p. 148.

${ }^{813}$ Guard, "Canadian Citizens or Dangerous Foreign Women," p. 168. 
community. Ethnicity was also a consideration. Guard notes that women with AngloSaxon names, not known to be openly associated with the Communist Party, were chosen to be speak on behalf of the Housewives' campaign to minimize the negative association many Canadians had with "foreigners" and Communism. Guard found that they were also portrayed in the press as having been 'duped' into their activism. Although "politicians and the press publicly dismissed the Housewives as a political force," because of their Communist-affiliation and the fact that they were women, their ideas did generate support, ${ }^{814}$ and an alternative, elite-driven group, the Canadian Association of Consumers, eventually took on the campaign for fairly-priced consumer goods.

The patterns of women's activism noted by Julie Guard and Joan Sangster are similar to those of women involved in the Canadian Soviet Friendship Society. There was even an overlap in personnel. Dorise Nielsen and Rae Luckock (both of whom usually signed their names with the prefix 'Mrs.') were both involved with the Housewives' Consumers' Association, as well as the CSFS. Like the Housewives, the CSFS drew its "overlapping membership" from many of the 'progressive, ethnic' groups such as the United Jewish People's Order, the Association of United Ukrainian Canadians, the Finnish Organization of Canada, and the Federation of Russian Canadians, and the CPC-LPP, itself. ${ }^{815}$ Most likely the RCMP were referring to Dorise when they reported in 1935 that "a Mrs. Neilsen" [sic] was working as an assistant at a CPC children's camp at Sylvan Lake, Alberta. ${ }^{816}$ Mary Kardash, a prominent member of

\footnotetext{
${ }^{814}$ Ibid., p. 178.

815 This could be compared to Julie Guard's discussion of the "overlapping membership" between the Housewive's Consumers' Association, the LPP, and progressive, ethnic groups. Guard, "Canadian Citizens or Dangerous Foreign Women," p. 179.

${ }^{816}$ Kealey and Whitaker, eds., "Weekly Summary Report on Revolutionary Organizations and Agitators in Canada," no. 767, 7 August 1935, The R.C.M.P. Security Bulletins: The Depression Years, pt. II, 1935, p.
} 
the AUUC, Congress of Canadian Women, and a school board trustee subscribed to CSFS literature and wrote to the USSR using CSFS channels. So did Beatrice Ferneyhough; a woman who had been pulled from the stage once in Montreal when she spoke in favour of the CPC. ${ }^{817}$ Kay Hladiy, who joined the ULFTA in 1932, and served on the executive of the AUUC for years, was a CSFS subscriber and delegate to the USSR in $1952 .{ }^{818}$ Many of the most active women in the CSFS were in fact married to executive members, and supported the organization by handling administration. It has already been noted, for example, that Charlotte Carter took over important duties when her husband was incapacitated due to illness, and also dealt with financial matters. ${ }^{819}$ Like their male counterparts, many of the women chosen as CSFS delegates and speakers had Anglo-Saxon names, which may well have been to increase the mass appeal of the message they conveyed.

From its founding in 1949, Dyson Carter played down the political aspect of the Soviet friendship movement, repeating that Canadians of all ideological and political orientations should recognize that a policy of good relations with the USSR was beneficial to Canada and Canadians. But few would miss the strong message favouring socialism that ran through all the CSFS publications and events. Women who spoke on behalf of the CSFS said that they were attracted to the group because they saw the Soviet Union as an example of fairer state treatment of women, which included institutionalized and subsidized daycare and extra-curricular education, and opportunities for women's

435. In an earlier report the RCMP had identified Dorise's husband Pete as on of the B.C. relief camp strikers marching to Ottawa. (Ibid, "Weekly Summary Report...," no. 761, 26 June 1935, p. 366).

${ }^{817}$ Kealey and Whitaker, eds., "Weekly Summary Report...," no. 715, 18 July 1934, The R.C.M.P. Security Bulletins: The Depression Years, pt. I, 1933-1934, p. 146-147.

${ }^{818}$ Peter Krawchuk, ed., Reminiscences of Courage and Hope (Stories of Ukrainian Canadian Women Pioneers) (Toronto: Kobzar Publishing Co., Ltd., 1991), p. 294.

${ }^{819}$ VOKS 6:55:150-151, letter A. Tovstogan to G. Ioanisyan, 31 May 1957. 
advancement in the workplace. In other words, they hoped that the USSR represented a state that operated in "familial terms."

Women involved in the rigidly hierarchical Labor-Progressive Party often found the experience stifling, and were frustrated by their failure to advance in the maledominated executive. ${ }^{820}$ The Friendship Society offered them a more responsive way to be active in organizing, hosting and speaking at left-wing events, while maintaining a lower profile than many of their male counterparts. Handling the secretarial and financial duties of the national CSFS, as well as the branch groups, allowed women to play essential roles. Women's perceived expertise in educating children and running the everyday matters of the home were capitalized on by the CSFS leadership, who often asked female delegates to write and speak about these issues when they returned from the USSR. A few leading women, including Dorise Nielsen, Charlotte Carter, and after the group was renamed the Canada-USSR Association, Helen Lucas, played active roles in the Society, but individual delegates also used their special position as women to articulate a message of Soviet admiration to progressive Canadians.

The use of women's issues and appeals to women as a persuasive tool in Canada was encouraged by Soviet authorities. For instance, during Canadian-Soviet Friendship Month in 1952, a letter to Canadian mothers written by the mother of one of the youngest Soviet women partisans to die in World War II, Lyubov Kosmodemyanskaya, was

\footnotetext{
${ }^{820}$ The best example of this in relation to the CSFS is Dorise Nielsen's experience, but other women involved in the CPC/LPP have commented on this, as well. See Faith Johnston, A Great Restlessness: The Life and Politics of Dorise Nielsen (Winnipeg, 2006); Joan Sangster, Dreams of Equality: Women on the Canadian Left, 1920-1950 (Toronto, 1989), esp. p. 224-238; Andrée Lévesque, Red Travellers: Jeanne Corbin \& Her Comrades. Originally published as Scènes de la vie en rouge: l'époque de Jeanne Corbin, 1906-1944, transl. by Yvonne M. Klein. (Montreal \& Kingston: McGill-Queen's Press, 2006); Louise Watson, She Never Was Afraid: The Biography of Annie Buller (Toronto, 1976), esp. p. 79-86; Catherine Vance, Not by Gods but By People: The Story of Bella Hall Gauld (Toronto, 1968), p. 61.
} 
published in The Canadian Tribune. ${ }^{821}$ This could only have been done with official Soviet encouragement, probably via the Soviet Information Bureau or VOKS. The image of a Soviet mother reaching out to Canadian mothers was palpable. She argued: "I believe that the peace won at the cost of the lives of our children, at the cost of the tears of mothers, widows and orphans, will not be violated again at the will of a handful of imperialists gone mad: we will not permit it." She quoted Josef Stalin, whom she called the "great standard-bearer of peace," and concluded by saying, "I press your hands, dear friends, the hands of the working folk of Canada. From the bottom of my heart I want this month of friendship to make still stronger the fraternal ties between our two peoples." ${ }^{822}$ This message, couched in the language of maternal feminism, touched on issues of peace and friendship, which were the raison d'être of several Canadian Party-supported groups, but also concepts that offered a larger appeal in Canadian society.

A sense of dramatic style, combined with good speaking skills, gave some women an edge on the stage, as evidenced from reports of earlier Soviet friendship meetings. For instance, in 1945 the RCMP reported that speeches given by Margaret Gould and Soviet Military Attaché Nikolai Zabotin at a National Council for Canadian-Soviet Friendship event in Toronto were humdrum, but called the guest speaker, Nila Magidoff, the "pièce de résistance. $"{ }^{\prime 23}$ The RCMP officer reported that Magidoff "is described in publicity as a Soviet writer and stylist, whatever that is. In any event, she would make a dramatic actress. She has been perfectly schooled probably both in the Soviet Union and America.

\footnotetext{
${ }^{821}$ Canadian Tribune, 4 February 1952, p. 14.

${ }^{822}$ Ibid.

${ }^{823}$ LAC, RG146, A200600124, RCMP report from Toronto C.I.B. Detachment, 26 February 1945, detailing the National Council for CSFS meeting at Royal York Hotel on 22 February 1945, p. 175. Besides Margaret Gould, Margaret Spaulding, who was an active participant in postwar CSFS, was also on the platform at this event.
} 
In a 20-minute speech, using only meager notes, she did not once make a mistake in Soviet party line or in conventional Soviet emotional appeal." He wrote further that her performance "was too perfect, but to an unsophisticated audience, very effective," and concluded that " $[w]$ hatever her ability, which may be considerable, the dramatic perfection of her performance indicated undoubted training as a propagandist." ${ }^{\text {"24 }}$ The "unsophisticated" audience of about 1, 550 was "largely Slavic," the officer reported. It was this fact, he suggested, that made Magidoff's performance so "effective," which may explain why a second RCMP report noted that her address was "not outstanding in any way. ${ }^{" 825}$ The Toronto Star noted that Magidoff had returned to speak in Toronto because of "popular request," and she would continue to tour the country. ${ }^{826}$

Dorise Nielsen, too, was known as a colourful speaker who could make a strong impression on her audience. With experience speaking in small auditoriums to local constituents, in the House of Commons, and later on behalf of the Party for peace, civil liberties and women's equality, she knew how to tweak her message to suit the audience. In 1950 in Winnipeg, Nielsen drew a crowd of more than 1000 to hear her speak about her impressions of the USSR, and the newly reconstituted CSFS. ${ }^{827}$ In Drumheller, Alberta, Nielsen spoke about how the USSR "had made great progress in conquering poverty, insufficiency and want." She "gendered" this argument in such a way as to appeal to the women in the audience, explaining that "[s]tyles in women's clothes...did not change as often in Russia as in Canada, United States or England. Materials and cuts,

\footnotetext{
${ }^{824}$ Ibid.

${ }^{825}$ Ibid., p. 174.

826 "Canadian-Soviet Friendship Honors $27^{\text {th }}$ Red Army Date," Toronto Daily Star, 23 February 1945, p. 8.

827 "Urge Canadian Gov't Trade with USSR Now," Canadian Tribune, 20 November 1950, in LAC, RG146, A200600114, p. 207.
} 
however, were serviceable and equal to other markets. ${ }^{9828}$ Nielsen had been to the USSR attending the Soviet-backed Women's International Democratic Federation conference in Moscow. In Lethbridge she told her audience that “...over 3000 women delegates representing 62 countries attended the Congress in Russia and that the Russian delegates asked that visitors from all the world come to Russia providing they were of the working class. Bank Managers and such were not welcome there. ${ }^{, 829}$ After speaking "very glowingly" of conditions in the USSR, she showed pictures of what she had seen, and her audience was informed that the CSFS was planning to send "as many delegates as possible" to the USSR, to be chosen from the Canadian working class. ${ }^{830}$ Nielsen's task on this tour was to promote the newly-founded CSFS and to gain subscribers for NewsFacts. At each event she went out of her way to credit Dyson Carter for bringing the 'truth' to Canadians, with the help of friendly diplomats in the Soviet embassy in Ottawa.

She was also ready to make excuses for the USSR if negative comments arose from the audience. In Manitoba, challenged by an elderly gentleman to explain the Soviets policy on Jews, Dorise Nielsen dodged the question: "I don't profess to know everything about Russian policy, some questions will have to be sent to Dyson Carter," she said. ${ }^{831}$ But she supplemented this response by saying that clearly the USSR couldn't let just anyone leave because then these individuals "might give an undesirable misconception of the USSR which would be exploited by the Americans or British, or even engage in the disgracefull [sic] business of spying." ${ }^{832}$ For the same reason, she

\footnotetext{
828 "Nielsen Reports on Soviet Life," The Drumheller Mail, 13 December 1950, no page noted, clipping in LAC, RG146, A200600097, p. 29

${ }_{829}^{8 A C,}$ RG146, A200600097, RCMP report, Lethbridge Special Branch, 7 December 1950, p. 31.

${ }^{830}$ LAC, RG146, A200600097, RCMP report, Drumheller Special Branch, 14 December 1950, p. 27.

${ }^{831}$ LAC, RG146, A200600114, RCMP Manitoba Special Section report on CSFS meeting held in Hebrew Sick Benefit Hall, 4 Dec. 1950, Winnipeg, report dated 8 December 1950, p. 198.

${ }^{832}$ Ibid., p. 198.
} 
said, "Russia doesn't welcome certain Canadian or American visitors." 833 The "seeing is believing' approach was typical of CSFS events, and was meant to build enthusiasm in the audience, but the CSFS only wanted individuals who would declare the positive version of the 'truth' about the Soviets.

Her flair for public speaking could backfire, however, and Nielsen was at times dismissed by male Party comrades as a "populist". Despite her best efforts to improve her knowledge of Marxist theory, the LPP continued to limit the tasks Nielsen was given to publicity and behind-the-scenes organization, rather than real leadership. ${ }^{834}$ It is hard to tell whether her lack of theoretical knowledge was the only reason she was not chosen to lead any Party-supported groups. Probably this was the official reason, but the Party's preference for male leaders, and her own choices and responsibilities were also influential. This situation reflected the broad gender patterns elsewhere in Canadian society.

In her role as CSFS Executive Secretary, Dorise Nielsen encouraged and even prodded CSFS women members to publicly articulate their experiences in the USSR. In 1952, for example, she wrote to Mrs. Carole Laurie in Vancouver, who had recently returned from a CSFS-sponsored trip to the Soviet Union, asking her to write down six typical questions she was being asked at various meetings about life in the USSR, especially from a woman's perspective. If Mrs. Laurie could not remember the questions, Nielsen advised her to make them up, along with plausible answers, and to send them "RIGHT AWAY" to the Toronto office. ${ }^{835}$ Questions and answers gathered

\footnotetext{
${ }^{833}$ Ibid., p. 199.

${ }^{834}$ Johnston, A Great Restlessness, 229.

${ }^{835}$ LAC, RG146, A200600101, Dorise Nielsen, letter to Mrs. Carole Laurie, Vancouver, 15 September 1952 , p. 129. Emphasis in the original.
} 
from recent delegates were going to be made into a pamphlet published by News-Facts, she explained.

A common pattern for CSFS events, especially under the leadership of Dyson Carter, was for women to speak about the everyday concerns of Soviet people, particularly those seen to affect women and children. In covering the "overflow meeting" in Vancouver where 300 people heard Nielsen speak, the Canadian Tribune wrote that "Questions on free health, educational services and general welfare in the U.S.S.R. come thick and fast, placed by teachers, normal school students and professional people. ${ }^{.836}$ Carter usually spoke about the scientific and technological advances being made in the USSR, and the ways this benefited the working classes, ${ }^{837}$ and other male delegates on CSFS tours later spoke according to their professional expertise. One of the first delegations the post-war CSFS sent to the USSR was composed of three men and two women: Jacob Penner, Emil Gartner, Fagel Gartner, Jeannette Pratte and Fred Taylor. Penner was well-known in Winnipeg as a Communist and an alderman; Emil Gartner directed the choir of the United Jewish People's Order, which frequently performed at CSFS and other left-wing events; Fagel Gartner was a pianist in the UJPO orchestra, Jeannette Pratte was said to be "active in consumers organizations and the peace movement, ${ }^{, 838}$ and her husband was on the executive of the Quebec provincial LPP, ${ }^{839}$

\footnotetext{
836 "Soviet Friendship Tour: Keen interest shown about life in USSR," Canadian Tribune, n.d., RG146, vol. 3349, Supp. 1, Pt. 2, p. 128.

${ }^{837}$ One example of this was at a meeting in 1951 where Dyson Carter spoke to 200 people at the Ukrainian Labor Temple in St. Catherine's, Ontario, and "covered such points as medicine, science, agriculture, mining" and their benefits for the Soviet working man. LAC, RG146, A200600105, RCMP report, Niagara Falls Detachment, 31 January 1951, p. 126.

838 "Friendship Society Sponsors Delegation of 5 to U.S.S.R.," Canadian Tribune, 30 April 1951, clipping in LAC, RG146, A200600105, p. 123.

${ }^{839}$ Ronald Williams, "The Reds' Pink Tea Circuit: The Communist Front Fools a Lot of Women," Financial Post, 9 June 1951, transcribed in an RCMP report, 12 June 1951, LAC, RG146, A200600105, 12 June 1951, p. 109-110; and in photostat original, LAC, RG146, A200600098, p. 32.
} 
and Frederick Taylor was an artist and a Communist. Nora Rodd also accompanied the group, but although she was officially noted to be representing the Canadian Congress of Women, she had frequent dealings with the CSFS and the CSFS membership. ${ }^{840}$ From Moscow the delegates sent a statement home to Canada via VOKS, rhapsodizing about what they saw. Gartner spoke about Soviet composers, Taylor about Soviet art, but both Fagel Gartner and Jeannette Pratte were quoted on the position of Soviet women:

Jeannette Pratte, a housewife, and the well-known Canadian pianist Fagel Gartner, spoke of the impressions produced on them by the position of the woman and children in the Soviet Union. The nurseries, kindergartens, schools and Young Pioneer Houses, they said are real palaces where the Soviet children receive a versatile education, culture and physical training... The difference between the education of the children in the Soviet Union and in Canada, is as great as the difference between day and night, said Jeannette Pratte. ${ }^{841}$

The Soviet Monitor published Fanny Gartner's comments that

In Ukraine we had unforgettable meetings with Soviet women employed in different branches of industry, agriculture and culture. Everywhere we witnessed happy motherhood. Soviet children are surrounded with the solicitude of the State. Marvellous medical institutions have been set up for Soviet women who, on an equal footing with men, have every opportunity to master knowledge and various specialities and to be useful members of society. The women collective farmers whom we met at the Komintern Collective Farm in the Korsun-Shevchenkovski District, seem to be the happiest women in the world. They are proud of their work and do it with joy and energy, being confident that their labour serves the cause of peace. ${ }^{842}$

There is no evidence to suggest that the Canadian visitors were aware that great care was taken by Soviet authorities to show only the best. At any rate, it is clear that the visitors

\footnotetext{
${ }^{840}$ Ibid. After her visit to the USSR, Nora Rodd sent children's literature to a teacher she had met there via the VOKS representative at the Soviet embassy of Ottawa. VOKS, 49: 150-153, 156.

841 "'Lasting Peace' Soviet goal say Canadian goodwill envoys," Canadian Tribune, 11 June 1951, in LAC, RG146, A200600105, p. 111.

${ }^{842}$ From "The Canadian Delegation in the Ukraine," Soviet Monitor, 18 May 1951, transcribed in an RCMP report, RG146, A200600098, p. 30.
} 
missed, avoided, or were isolated from the realities. Women in the former-Soviet Union would not have recognized these experiences as their own. Rather, recent research has shown that Soviet women's experiences of motherhood were anything but ideal, and certainly the "solicitude of the State" in their regard has been questioned. ${ }^{843}$

Still, the CSFS women seemed to see their home-grown ideals in practice in the distant USSR; that is, they saw what they wanted to see. The 1952 CSFS Trade Delegation told the Soviet press that they were impressed to see that "Women receive without exception good pay equal to that of men and suffer no discrimination. The social welfare and care for the health of the workers and their families are unique. ${ }^{844}$ On paper, this may have been true, but in practice skilled workers, managers, CPSU leaders and military scientists were better paid and were usually disproportionately, men. On reaching Odessa, CSFS national secretary, Jim Leech, and his wife Constance "recorded statements giving their impressions of industrial relations, welfare and construction work and of the benefits enjoyed by Soviet women. Both stressed that the Soviet people were building for peace, not war." ${ }^{845}$ The equality of women and the high standard of children's education were related directly, in this message, to the peaceful nature of

\footnotetext{
${ }^{843}$ Much has now been written on the reality gap between the USSR's promises to women and their experiences with the double burden, stress, access to birth control, daycare, high infant mortality and divorce rates. For a sampling, see Chris Corrin, ed., Superwomen and the Double Burden: Women's Experiences of Change in Central and Eastern Europe and the Former Soviet Union (Toronto: Second Story Press, 1998); Paula A. Michaels, "Motherhood, Patriotism, and Ethnicity: Soviet Kazakhstan and the 1936 Abortion Ban," Feminist Studies, vol. 27, no. 2 (Summer 2001), p. 307-333; Laurie Occhipinti, "Two Steps Back?: Anti-Feminism in Eastern Europe," Anthropology Today, vol. 12, no. 6 (December 1996), p. 13-18; Barbara Alpern Engel, "Engendering Russia's History: Women in Post-Emancipation Russia and the Soviet Union," Slavic Review, vol. 51, no. 2 (Summer 1992), p. 309-321; Ellen Carnaghan, "Political Attitudes and the Gender Gap in the USSR," Comparative Politics, vol. 22, no. 4 (July 1990), p. 293-304. ${ }^{844}$ Quoted in the Soviet newspaper Trud (Labour), 10 September 1952, from The Current Digest of the Soviet Press, 25 October 1952, in RCMP memorandum dated 30 October 1952, LAC, RG146, A200600107, p. 46.

${ }^{845}$ Radio Moscow English broadcast, 26, 27 August 1952, reported in the Monitoring Service for the British Broadcasting Corporation, "Summary of World Broadcasts, no. 343, 1 Sept. 1952, in RCMP report, 4 October 1952, LAC, RG146, A200600107, p. 127.
} 
Soviet society. They contrasted this Soviet 'peace' message with what they saw as the hawkish rhetoric in the North American press, the influence of which, they said, was apparent even in the type of toys given to children. On their return, Pearl Wedro was amongst those who gave public speeches, concluding with "an appeal for support of the Canadian-Soviet Friendship Council." ${ }^{\prime 846}$ Mary Kardash, secretary of the local CSFS, collected $\$ 78.80$ from the audience "to help defray expenses of the Trade Union delegates. ${ }^{847}$

The reports given by these Canadians in the USSR were meant for a domestic Soviet audience, showing that foreigners supported their system. Usually the reports made it back to Canada, though, appearing in the progressive press. Rosalind McCutcheon, who was a CSFS delegate to the USSR in 1953, was interviewed about her impressions on Radio Moscow, and spoke particularly about the place of women and children in Soviet society. In Uzbekistan, McCutcheon said that she had been especially impressed that the Minister of Culture and an Honoured Artist who greeted her were "two wonderful women". ${ }^{848}$ Rather than being veiled, these Muslim women were "two modern cultured women who were the equals of men". She continued, saying

Two phenomena particularly surprised me- the new Uzbek woman and the maternal care of the Soviet state for the children. I saw these remarkable women and children, warmed by nation-wide kindness, on the streets of Tashkent and Samarkand, in factories and in theatres, in an excellent kindergarten in Smarkand and the Pioneers' Palace here, in Tashkent. Concern for the children is a

\footnotetext{
${ }^{846}$ LAC, RG146, A200600114, RCMP Special Section Manitoba report on CSFS event held at the Hebrew Sick Benefit Hall, Winnipeg on 21 October 1951, report dated 26 October 1951, p. 168.

${ }_{847}$ Ibid.

${ }^{848}$ This information comes from the Monitoring Service of the British Broadcasting Service, Summary of World Broadcasts, \#456, Part I, 5 October 1953, p. 41, as quoted in an RCMP memorandum entitled "Canadian Soviet Friendship Society- Visit to Soviet Russia", 23 November 1953, LAC, RG146, A200600103, p. 89.
} 
most striking example of how your society is devoting all efforts to the welfare of the people. ${ }^{849}$

She was particularly pleased to see women in the higher echelons of Uzbek society: "To meet these women who today are deputies, scientists, honoured artists, will always be for me one of the highlights of my visit to the Soviet Union." She felt that speaking about the way women and children in the USSR were cared for by the state would encourage Canadian women in particular to become Soviet "friends." 850 In fact, the Soviet example was related specifically to Canadian homes and the children who lived within them, the delegation told a press conference it gave at the VOKS Moscow offices: "More and more Canadians are coming to realize that the struggle for friendship with our great northern neighbour is at the same time a struggle for the peace of our own homes, for our children and our country's growth and independence."

Another delegate on the same CSFS tour, Margaret Spaulding, commented that the geriatric care in the Soviet Union was much more advanced than in Canada: "After three weeks in the USSR, I feel like dropping the term 'old age' from my vocabulary altogether. It does not seem to have any of the usual meaning here at all. People in the USSR live a long time, but it is a ripe old age, full of energy, of usefulness and of happiness." This she argued was because of the "provision of pensions, the absence of

\footnotetext{
${ }^{849}$ This account appeared as "Sojourn in Uzbekistan of Delegation of Canadian-Soviet Friendship Society," in Pravda Vostoka (Truth of the East) on 26 September 1953, and is found in translation in LAC, RG146, A200600103, p. 102.

${ }^{850}$ This information comes from the Monitoring Service of the British Broadcasting Service, Summary of World Broadcasts, \#456, Part I, 5 October 1953, p. 41, as quoted in an RCMP memorandum entitled "Canadian Soviet Friendship Society- Visit to Soviet Russia", 23 November 1953, LAC, RG146, A200600103, p. 89.

${ }^{851}$ This press conference was given on 3 October 1953. Information from the BBC, Summary of World Broadcasts \#457, 9 October 1953, p. 40-41, as cited in RCMP memorandum entitled "Canadian Soviet Friendship Society- Visit to Soviet Russia", 23 November 1953, LAC, RG146, A200600103, p. 89-90.
} 
compulsory retirement and the fact that they 'are an important part of every community." $" 852$

After returning to Canada, CSFS women continued spreading the message about how fortunate Soviet women were. Whether in public speeches or in written reports sold to CSFS members and subscribers, they invariably put a positive spin on news of the condition of Soviet women. In 1950, Dorise Nielsen told an audience in The Pas, Manitoba, that children in their town "spent their time window shopping, windows that are full of toy guns...", while Soviet children read and engaged in cultural activities. ${ }^{853}$ One statement from the Trade Union delegation, included the point that "Even [Soviet] children's toys reflect the desire to teach youth the art of peaceful construction." The direct relationship between the provisions given by the state to women and children was noted:

When visiting industrial enterprises the equitable position of women produced a deep impression on us. We met many women working as directors of huge industrial enterprises, engineers and doctors. They all, without exception, receive equal pay with men for their work and have equal opportunities for promotion to more responsible work...Everywhere there are crèches and kindergartens. A woman worker can leave her children there while she is at work. Children are surrounded with attention and affection. An insignificant fee is taken for the upkeep of the child in such children's institutions. ${ }^{854}$

The trade union story was sold by the CSFS as We Were There! The delegates on the 1953 trip to the USSR wrote about their impressions as well, and the CSFS published

\footnotetext{
${ }^{852}$ Margaret Spaulding's interview was broadcast by Radio Moscow to North America on 10 October 1953. Information from Summary of World Broadcasts \#459, Part I, 16 October 1953, p. 36, as cited in RCMP memorandum entitled "Canadian Soviet Friendship Society- Visit to Soviet Russia", 23 November 1953, LAC, RG146, A200600103, p. 90.

${ }_{853}^{8}$ LAC, RG146, A200600097, RCMP report, C.I.S. Manitoba Special Section, 6 December 1950, p. 40.

854 "USSR Builds in the Name of Peace," Press Conference in Editorial Offices of Trud (Labour), 19 September 1952, LAC, RG146, A200600107, p. 132-134.
} 
these essays in a pamphlet entitled Canadians Visit Our Northern Neighbours: Picture Report of a Trip to the Soviet Union. This report was sold to CSFS members and other progressives for 25 cents. Rosalind McCutcheon's essay was called "Children Come First," and her biography listed her as being a married woman from Montreal, "bookkeeper and office worker. Mother of one child. Secretary, Montreal branch, C.S.F.S.: member of National Council, Chairman of the delegation." ${ }^{, 855}$ In her chapter McCutcheon dealt with the schooling of Soviet children, which she praised, but she also claimed that the choice of women to stay home with their children, or have them at home with a relative, was not stigmatized. ${ }^{856}$ Florence Dorland's essay called "Out of the Darkness" described how Uzbek women had been liberated since the Soviets took power. Dorland, who is described as a worker in Vancouver trades and the secretary of the Vancouver CSFS branch, wrote her essay as a letter home to her son, describing the wonderful sights of the Soviet Uzbek republic.

Most of the pictures accompanying her text show Uzbek women, and the captions under the photos depict a "before and after effect" of the Bolshevik Revolution. For instance, the captions tell us that one girl's "mother was a chattel slave" in the pre-Soviet days; that this group of women now serving in the Uzbek Supreme Soviet were once slaves; and of another woman: "Thirty years ago, a custom dictated she could eat only the leftovers on her husband's plate. ${ }^{, 557}$ Dorland was impressed by the children: "Little girl whose mother was a slave- little Uzbek girl whom life itself has brought out from behind

\footnotetext{
${ }^{855}$ CSFS, Canadians Visit Their Northern Neighbours: Picture-Report of a Trip to the Soviet Union (Toronto: News-Facts, 1953), p. 4. Thanks to J.E. Baxter for providing me with a copy of this publication. ${ }_{856}^{85 i d .,}$ p. $4-8$.

${ }^{857}$ Ibid., p. 13-14.
} 
the veil of darkness. ${ }^{.858}$ In the same publication, Margaret Spaulding wrote about the health care available to all Soviet citizens, Eleanor Ashworth about the housing conditions for Central Asian farmers, and Bob Pauk about the condition of workers, including women. Other contributors addressed the rights of minority groups in the USSR, arts, and university education. Florence Dorland concluded the pamphlet with a short piece about consumer goods available to Soviet shoppers. She said Soviet consumers were presented with only one problem: how to get the product they want before someone else buys it! Nevertheless, she claimed that the shelves were quickly restocked..$^{859}$

An all-expense-paid trip to the USSR usually came with the condition that delegates travel widely on speaking tours after their return to Canada. These were wellplanned events. Ida Kovalevich (Edith Kowalewich), who was described in Ukrainske slovo as a "young activist among the Slav progressive youth," spoke about her trip to USSR and China at a CSFS-sponsored event at the Winnipeg Playhouse Theatre on 7 November $1954{ }^{860}$ She said that as a delegate to the World Federation of Youth, she found that the Chinese and "Soviet people recognize the Canadian delegation as messengers of peace. ${ }^{, 861}$ After their trip to the USSR in 1954, Anne Sochasky and Kay Rankin described their impressions in words that would appeal to women. They spoke particularly about the quantity and quality of bread available to Soviet families at a low price. ${ }^{862}$ In the immediate post-war years, rations and pricing were issues that concerned many Canadian women, and to suggest that the USSR was producing such basic foods at

\footnotetext{
${ }_{858}^{85 i d ., \text { p. } 15 .}$

${ }^{859}$ Canadians Visit Their Northern Neighbours, p. 32.

${ }^{860}$ Vestnik, 1 December 1954, p. 6; Ukrainske slovo, 17 November 1954, p. 4.

${ }^{861}$ LAC, RG146, A200600114, RCMP Winnipeg Special Branch report, 15 November 1954, p. 6.

${ }^{862}$ LAC, RG146, A200600092, RCMP report from the Special Branch, Nelson, B.C., 4 April 1955, p. 11.
} 
reasonable prices, despite the hardships their people had endured during the war, was to give the impression that the socialist system was superior to that in Canada.

Sochasky and Rankin continued speaking tours in British Columbia through 1955 and 1956. Sochasky frequently spoke in Ukrainian, and Rankin often showed Soviet films. The RCMP took Rankin's appearances seriously enough to advise local detachments in April 1956 that "continued reports received indicate that Kay RANKIN of Vancouver is again touring British Columbia and showing Soviet films... Should the appearance of this woman become known to your Special Branch, it is suggested that some coverage be given the meetings which she will be holding..." ${ }^{963}$ In May 1956, the inspector of the Victoria RCMP Special Branch noted that "more urgent duties" had kept his officers from covering Mrs. Rankin's entire Vancouver Island tour, but mentioned that her stops had also included Cumberland, Port Alberni, Nanaimo, Duncan, Lake Cowichan and Sidney, British Columbia.. ${ }^{864}$ The RCMP interest in Kay Rankin was not new. It had been reported twenty years earlier that she toured southern Alberta publicizing the $\mathrm{CPC}$ policy for unemployment insurance, and had run as the $\mathrm{CPC}$ candidate for the Calgary School Board. ${ }^{865}$

On her return from the USSR, a report to be given by Mrs. Katherine (Kay) Hladiy, who was employed in the Toronto needle trade industry, was advertised directly to needle-trade workers in Port Douglas. The ad noted that she had "made it a point to visit a number of Needle Trades Shops- Cloaks, Garment, Fur, Shoe, etc.," and the

${ }^{863}$ LAC, RG146, A200600121, "E” Division, Special Branch, Vancouver, B.C., Inspector H.J. Spanton to RCMP Officers Commanding in Victoria, Chilliwack, Nelson, Kamloops and Prince Rupert Sub-divisions, 16 April 1956, p. 179. Emphasis in original.

${ }^{864}$ LAC, RG146, A200600121, Inspector C.F. Harvey, Victoria Sub-division to RCMP Vancouver Subdivision, 8 May 1956, p. 171.

${ }^{865}$ Kealey and Whitaker, eds., "Weekly Summary Report on Revolutionary Organizations and Agitators in Canada," no. 750, 27 March 1935; no. 774, 25 September 1935; no. 781, 13 November 1935, The R.C.M.P. Security Bulletins, The Depression Years, pt. 2, 1935, p. 193, 500, 584. 
questions she would deal with in her presentation were listed. ${ }^{866}$ It was signed by the Needle Trades Committee of the Canadian-Soviet Friendship Society. It was also noted that "while the speaker will devote considerable time to the above subjects, Mrs. Hladiy will also refer to other features of Soviet life. This is your opportunity to hear the facts from first hand information." Those who received the notice were asked to "pass this invitation along to your shop-mates." ${ }^{867}$ Yet the RCMP reported that "her main topic of discussion was the welfare of a mother and child." To wit, "in the USSR the women are on the same level as the men are and they receive the same pay. Every woman that become [sic] pregnant receives a special security from the Soviet Government. During a certain time of her pregnancy she receives one half of her wages until she is able to work again and her place in the factory is secure. After the birth of her baby she can place the child in a nursery provided by the factory and return to her same employment.",868

On the surface, these claims seem truly worth admiration, and Hladiy's enthusiasm probably stemmed from her sincere desire to see such conditions in Canada. But, whereas de jure these conditions may have existed in the USSR, de facto the lived experiences of women, and particularly mothers, was far from this idealized depiction. As journalist and social commentator Slavenka Drakulic has written, the communist system in Eastern Europe and the Soviet Union was utterly unable to satisfy the fundamental needs and wishes of women, who represented more than half of the population. ${ }^{869}$ Once Drakulic dared to stand before a conference of American leftists and

${ }^{866}$ This meeting took place in the Point Douglas Labor Temple, 7 December 1953. Circular letter, LAC, RG146, A200600114, p. 19.

${ }^{867}$ Ibid.

${ }^{868}$ LAC, RG146, A200600107, RCMP report, 9 December 1952, p. 197. The same report is in LAC, RG146, A200600114, p. 23.

${ }^{869}$ Slavenka Drakulic, How We Survived Communism and Even Laughed (New York: HarperCollins Publishers, 1993). 
made this declaration more dramatic by insisting that basic feminine hygiene products had never been available in Eastern Europe, proving that the system, and its hyperpolized claims to superiority, was in fact a failure. The conference did not believe her, and treated her as a "right-wing freak," not because they lacked knowledge of the communist system, but because they had no "experience of living under such conditions." 870 The lives of Soviet and East European women were not what leftists in North America believed - or wanted - them to be.

But in the 1950s, the Soviet image carried real weight among Canadian progressives, who turned out in large numbers to hear reports from the CSFS delegates. In Winnipeg in October 1952, Kay Hladiy spoke to an audience of 200 in the Hebrew Sick Benefit Hall on women and medical care in the USSR. She described the facilities available to Soviet workers in the factory, and said further that "the wages for men and women are equal and the state provides free nursery for working women." She liked the Youth Camp delegates visited near Leningrad, where the boys were active, disciplined, well-fed and well-supervised. She appreciated the fact that if a working man is killed on the job, "his beneficiary receives his full wages monthly. Pregnant women are not discharged, but 2 months before and after the birth they receive holidays with pay and are cared for by the state. Their pay is half their monthly salary. 2 months after the birth of the child they return to work and the child is cared for in a state nursery while the mother works." ${ }^{871}$ Concluding the meeting, Mary Kardash said that more delegations to the USSR were necessary if Canadians were to know the 'truth' about the Soviet conditions,

\footnotetext{
${ }^{870}$ Ibid., p. 124-125.

${ }^{871}$ LAC, RG146, A200600107, RCMP report, Manitoba Special Branch, 14 October 1952, RG146, p. 116. A copy of this report is also in LAC, RG146, A200600114, p. 28.
} 
including their approach to the 'woman question', and she urged the audience to read Soviet publications.

The political message was ever-present at these events, but probably many women also attended out of the desire to socialize with friends, and converse in their native languages. For instance, one November evening in 1955 several 80-year old Armenian-Canadian women attended a CSFS showing of the film "Soviet Armenia" at the Armenian Hall in Brantford. These women had come to Canada 40 years or more before. In addition to the film, Kate Bader, a recent CSFS delegate, spoke about her impressions of the USSR. ${ }^{872}$ For some of the women in the audience, the motivation to attend might have been as much about nostalgia and entertainment as the political message. And yet, in the progressive communities, all of these elements were linked.

Not every CSFS woman could afford time away from her family or job to travel to the USSR on a delegation, or was given to public speaking. Some of the tasks women performed in their local groups were more "behind the scenes." Of the four "Friendship Society Secretaries" listed for the Western provinces in 1952, three were women: Mrs. Eleanor Ashworth, Edmonton; Mrs. Wilma Williams, Saskatoon; and Mrs. Mary Kardash, Winnipeg. ${ }^{873}$ By 1953, Pearl Wedro, who had been a delegate on the Trade Union tour and had subsequently spoken in public halls on behalf of the CSFS, moved to Toronto to serve as the helm of the Toronto CSFS branch. The Toronto branch and the main CSFS office worked hand-in-hand in organizing events in the provincial capital, as

\footnotetext{
872 Ukrainske zhyttia, 12 January 1956, summarized by the RCMP, LAC, RG146, A200600104, p. 17.

${ }^{873}$ CSFS announcement of Trade Delegation, News-Facts, no. 26, May 1952. It is worth noting that in most of the publicity, the women were referred to by the prefix "Mrs." A common practice in those days, the prefix was a sign of a married woman's traditional respectability.
} 
shown by a 1953 circular signed by both Dorise Nielsen and Wedro inviting area members and subscribers to a film screening and a Dyson Carter presentation. ${ }^{874}$

Dyson Carter and Dorise Nielsen called on readers in towns where there was no CSFS branch, to consider getting together, and with help from the central office, plan local events. In 1952 Carter noted that there were News-Facts readers in Windsor, Port Arthur, Fort William, St. Catherine's, Timmins, Trail, Kimberly, Kamloops, Crows Nest, Medicine Hat, Brandon, Swift Current, The Pas, Sydney, Glace Bay, St. John's (Newfoundland)- but no CSFS branches there. Nielsen asked readers in these places to consider hosting a small event. Earlier, she had sent out a circular letter asking readers directly, "can you invite a number of friends and neighbors to someone's home and have a "Friendship" evening together? We will send you some Soviet pictures, literature, or even a Movie....875 Organizing a home meeting was an activity some women may have found easier than big meetings in a hall. For instance, Louise Harvey and Margaret Russell hosted an informal, question-and-answer discussion of Soviet life in their living room. They invited two recent delegates to the USSR to their home to tell guests "how the people live there, what kind of homes, jobs and recreation they have..." ${ }^{876}$ Casual evenings in the homes of CSFS members were part of the appeal of joining these groups and discussing Canadian-Soviet friendship.

The CSFS also encouraged its active members to attend conferences at the head office in Toronto, and to organize events afterwards to report on developments. Eleanor

\footnotetext{
${ }^{874}$ LAC, RG146, A200600103, letter from Nielsen and Wedro (signed as the chairman of the Toronto CSFS branch) to members and News-Facts readers, 25 March 1953, p. 132.

${ }^{875}$ VOKS 6:1:36:43-52, Dorise Nielsen, "Report on Organization" to the CSFS Convention, 26 January 1952; VOKS 6:1:36:25, circular letter on "News Facts" letterhead, addressed to "Dear reader," signed by Dorise Nielsen, 12 Dec. 1951.

${ }^{876}$ LAC, RG146, A200600103, "Dear Friend," invitation from Margaret Russell, 31 March 1953, p. 126.
} 
Ashworth traveled from Edmonton to the Canadian-Soviet Friendship convention in Toronto, and then spoke at a meeting in the Ukrainian Labor Temple Hall in Newcastle, Alberta in March 1952. An RCMP officer reported that she had said that in the USSR "women ...had equal rights with the men and were able to compete with them in every phase of industry and science." She compared the number of women pilots in the USSR to the fact that "in Canada not a single woman pilot [is] employed," and after reading extracts from the Constitution of the United Nations, she apparently accused Canadian newspapers of ignoring Soviet attempts to broker world peace. ${ }^{877}$

And there were other tasks that women stepped forward to do, even if they were not actually the leaders of local CSFS branches. For the Winnipeg CSFS, Mary Kardash handled correspondence, logisitics for speakers at various meetings, and did the introductions, but it was Chester King who was, in fact, chairman. ${ }^{878}$ In 1950, Kardash spoke about the good living conditions for workers in the Soviet Ukraine, mentioned that farmers had electricity in their homes, although some Canadian farmers did not yet. ${ }^{879}$ Canadians who had been convinced to 'return to the homeland' would have disagreed with her about her claim of superior Soviet living conditions. Like Eleanor Ashworth, Kardash was a delegate to the CSFS convention in Toronto in late January $1952 .{ }^{880}$ Earlier that month, she appeared on the stage in Winnipeg before an audience of about $350^{881}$ to speak about the position of women in the USSR. She shared the stage with

${ }^{877}$ LAC, RG146,A200600101, p. 106, RCMP report of Drumheller Special Branch on meeting 13 March 1952, report dated 20 March 1952.

${ }^{878}$ LAC, RG146, A200600114, p. 32.

${ }^{879}$ This meeting took place at the Federation of Russian Canadian Hall in Winnipeg on 12 November 1950. LAC, RG146, A200600114, p. 203, RCMP report dated 20 November 1950.

${ }^{880}$ LAC, RG146, A200600114, p. 37, RCMP Winnipeg Special Branch report, dated 22 January 1952.

${ }^{881}$ A Vestnik reporter claimed there were more than 500 people in attendance, but an RCMP report put the number at approximately 350 . N. Kuchinksy, "Meeting of the Society of Canadian Soviet Friendship in Winnipeg," Vestnik, 6 February 1952, p. 4, translated and summarized by the Winnipeg RCMP, LAC, 
Winnipeg alderman Jacob Penner, who argued that the "level of the Soviet democracy is much higher than in Canada," and with Nikolai Hrynchyshin, who worked for the Canadian-Ukrainian newspaper Ukrainske slovo, and who spoke on the freedom of the press in the Soviet Union. ${ }^{882}$ If Hrynchyshin knew about the role of Glavlit in censoring and controlling the Soviet press, he did not mention it. In March 1952, Kardash introduced a Soviet film at a Winnipeg CSFS meeting, and explained the purpose of the CSFS, defined in the words of an RCMP investigator as "to promote friendship with the USSR and to counteract alleged anti-Russian 'propaganda' in the Canadian press." She also solicited new members and readers. ${ }^{883}$

Much of the financial side of the CSFS work was handled by women. At the CSFS-sponsored performance of the new Shostakovich oratorio in Toronto by the Jewish Folk Choir in 1951, Mrs. Dewar Ferguson sold books and VOKS literature in the Massey Hall lobby. The RCMP reported that she and other women did this "despite the protests of Massey Hall officials," and identified them as "LPP women members." ${ }^{984}$ Mrs. Ferguson's husband, Dewar, was on the CSFS executive at the time. ${ }^{855}$ Hazel Currie, an activist in Port Arthur, handled the letter-writing and fund-raising needed to send Bruce Magnuson to the USSR on the CSFS trade delegation in 1952. Her letter, addressed to "all Labor Unions, Workers, Farmers and Citizens of Northwestern Ontario," asked for

RG146, A200600114, p. 35; LAC, RG146, A200600114, Winnipeg Special branch report, 22 January 1952, p. 37.

${ }^{882}$ This meeting was held 20 January 1952 in the Hebrew Sick Benefit Hall in Winnipeg. N. Kuchinksy, "Meeting of the Society of Canadian Soviet Friendship in Winnipeg," Vestnik, 6 February 1952, p. 4, translated and summarized by the Winnipeg RCMP, LAC, RG146, A200600114, p. 35.

${ }^{883}$ LAC, RG146, A200600114, RCMP Winnipeg Special branch report, 22 March 1952, on meeting held at the Winnipeg Ukrainian Labor Temple, 14 March 1952, p. 34.

${ }^{884}$ LAC, RG146, A200600098, RCMP report, 17 April 1951, p. 88. Referred to as "Mrs. Dewar Ferguson," we do not know her first name.

${ }^{885} \mathrm{He}$ was also a LPP member, and leader in the LPP-backed Canadian Seamen's Union. 
contributions not only towards Magnuson's travel, but also to support his family while he was away. ${ }^{886}$

Indeed, from 1949 the women closest to the Friendship Society leaders played crucial supporting roles, particularly in handling the business end of the work. Charlotte Carter was Dyson Carter's business manager, and often compensated for his absences when he was injured. Later, after they moved to Gravenhurst, the Northern Bookhouse, through which the Carters sold the books they received from VOKS, was under her name. Charlotte Carter co-authored many books with Dyson, and as a nurse and mother, her focus in these publications was often to attest to the public health standards and conditions for women and children in the USSR. After Charlotte's death in 1972, Dyson Carter set up the Charlotte Carter Memorial Fund, to which readers of Northern Neighbors could contribute. ${ }^{887}$ Irja Paul, who had been friends with the Carters for years, and later on Sally Nielsen took over some of Charlotte Carter's tasks. Both of these women lived with Dyson. They were each officially termed "executive secretary" on the editorial page of Northern Neighbors, but Irja Paul said her work dealt mostly with "looking after Dyson," whose health was deteriorating. ${ }^{888}$ Sally Nielsen has said that she did much of the banking. ${ }^{889}$ Helen Lucas, wife of Michael Lucas, who led the renamed Canada-USSR Association for years, handled the finances for the group. ${ }^{890}$

\footnotetext{
${ }^{886}$ LAC, RG146, A200600106, letter signed by Hazel Currie on CSFS letterhead, dated 17 June 1952, as part of Fort William RCMP detachment report, 21 June 1952, p. 67-68.

${ }^{887}$ Sally Nielsen said that the money in this fund was eventually donated to a local Gravenhurst charity for children. Sally (Thelma) Nielsen, interview by author, 28 November 2006, Lakefield, ON.

${ }^{888}$ Irja Paul (and Irene Kuusela and Marie Rempel), interview by author, 27 November 2006, Bracebridge, ON.

${ }^{889}$ Sally (Thelma) Nielsen, interview by author, 28 November 2006 , Lakefield, ON.

${ }^{890}$ Michael Lucas, interview by author, 27 July 2006, Toronto, ON. Today Michael Lucas is the head of the Toronto-based International Council for Friendship and Solidarity with Soviet People which advocates the re-establishment of the USSR, and Helen Lucas continues in the post of Financial Secretary.
} 
For forty years, Dyson Carter's publications, News-Facts and Northern Neighbors, carried the message that it was because of the socialist state that Soviet women were able to handle the 'double burden' of work outside of the home and childrearing. Today we know that this message was false. Soviet women struggled with their workload, and their efforts to free themselves from this predicament were actually frustrated by the official claim that the issue had long ago been solved ${ }^{891}$ But, Carter's readers were told that there was no contradiction in Soviet women's increasing autonomy, and even preeminence, in the work force, and their continuing traditional roles in the family. The undertone of all articles on youth and school systems in the USSR was that the socialist system allowed children to learn while remaining true to their traditional, gendered identities. Often, Carter transmitted this message using photographs and captions. For instance, the message that work did not interfere with nuturing mothering styles was apparent in the photograph of two adult women, one working at the day care centre, and one mother delivering her child to school. Both women are smiling and inclined towards the child, who herself appears to be pleased to spend the day at daycare. The caption reads, "Mrs. Baranova, a young nurse, brings her daughter to kindergarten in a section of Stalingrad, (Russian Republic)." ${ }^{892}$ The fact that this photograph is placed in Stalingrad is not entirely coincidental. Soviet publicity, and hence Carter's own, put a large onus on showing how Stalingrad had recovered from its devastating battle with the Nazi Army during World War II, and how life had returned to 'normal'. Describing his visit to Stalingrad, Dyson Carter wrote that what he "found in

\footnotetext{
${ }^{891}$ Natalia Roudakova and Deborah S. Ballard-Reisch, "Femininity and the Double Burden: Dialogues on the Socialization of Russian Daughters into Womanhood," www.auburn.edu/ mitrege/FLRU2520/Roudakova.pdf, (11 June 2008).

892 "Soviet Children at Study and Play...", News-Facts, no. 40, October 1953, p. 8.
} 
Stalingrad was...laughter. Along the Volga there is singing and laughing today." This, Carter argued was the best memorial to the fallen: "human joy."

In its first issue in December 1956, Northern Neighbours ${ }^{894}$ had Soviet ballerina Galina Ulanova on the cover, and inside a picture story of the International Seminar on the Equality of Rights of Women, held in Moscow. Photographs showed women from around the world smiling at one another, while touring Soviet industry and speaking at a Kremlin reception. ${ }^{895}$ Twelve years later, an article entitled "Where Else?" claimed that "All advanced countries have women who are outstanding. But in our world of Capitalism, such women are written about and interviewed as if they were inhabitants of a distant planet. In the Soviet Republics, in Socialism, no one is surprised to hear of women in high places." ${ }^{896}$ The accompanying photographs show the female Foreign Affairs Minister of Kirghizia, a dairymaid who was also a District Councillor, a Chief Justice, a symphony orchestra conductor, a teacher, and the head of a State Farm. Interestingly, considering Carter's claim, no reference was made to the lack of women in the CPSU leadership or the Politburo, where policy was made.

Mothering and professional skills went hand-in-hand, wrote Carter. An article on Soviet vaccinations of babies for smallpox shows a photograph of a woman doctor administering the shot. ${ }^{897}$ The fact that so many women in the USSR were doctors, whereas in Canada most women in the medical profession were nurses, was cited frequently to show the advanced nature of women's rights in the Soviet Union. On the

\footnotetext{
${ }^{893}$ Dyson Carter, "'A warless human race' That is what Soviet peace policy may bring for today's children," Canadian Tribune, n.d., in LAC, RG146, A200600103, p. 113-114.

${ }^{894}$ The first issue of Northern Neighbours, in December 1956, had the title spelled in the Canadian style, but from then on, the magazine title was Northern Neighbors.

${ }^{895}$ Northern Neighbours, "Women Review their Rights," December 1956, p. 5.

${ }^{896}$ Ibid., "Where Else?", July-August 1968, p. 6.

${ }^{897}$ Ibid., "Dreaded Smallpox will soon be Exterminated," May 1973, p. 13.
} 
cover of the June 1973 issue a photograph shows a mother coming home from a business

trip, kissing her children. Readers are referred to the article "Soviet women are

overtaking their men" inside, which details why women in the USSR were not seeking

liberation: they already had it, Carter claimed. ${ }^{898}$ Photographs of prominent women in

Ukraine are on the facing page, in an issue appearing just after Mother's Day in

Canada ${ }^{899}$ But, in fact, science and medicine neglected Soviet women. Carter made no

mention of the high rates of maternal deaths in childbirth and infant mortality in the

USSR. Nor did the subject of high divorce rates and the fact that abortion was the main

Soviet method of birth control warrant any mention. ${ }^{900}$

Women's "liberation" did not come at a cost to femininity, according to Carter.

In a 1974 article entitled "Why They Want NO UNISEX in Socialism," Carter claimed

that the Western Women's Liberation movement had "done much fine work" but also

"much damage by taking the unscientific position that equality means identity." 901

Instead, Carter pointed out, the Soviets felt that differentiating between the sexes is not

only healthy, but an important tool for building the future: "Sex difference created human

beings and all our magnificent cultural heritage... and will lead us into our great awaiting

future." ${ }^{902}$ In 1978, Carter wrote that "There Are No Homely Women" in the USSR. ${ }^{903}$

Advancing the views of a Moscow hairstylist on why it is essential that a woman "always

\footnotetext{
${ }^{898}$ Ibid., cover and "Soviet Women are Overtaking Their Men," June 1973, p. 7.

${ }^{899}$ Ibid., "Women's Lib in Ukraine," June 1973, p. 6.

${ }^{900}$ On the way Glavlit and Soviet statistics disguised these figures, see Barbara A. Anderson, Kalev Katus and Brian D. Silver, "Developments and Prospects for Population Statistics in Countries of the Former Soviet Union," Population Index, vol. 60, no. 1 (Spring, 1994), p. 4-20; Celestine Bohlen, "Russian Women Turning to Abortion Less Often," New York Times, 29 March 1999.

${ }^{901}$ Ibid., p. 6.

${ }^{902}$ Northern Neighbors, "There Are No Homely Women," January 1978, p. 3. This article is apparently based on an interview conducted by Yuri Ivanin with a Moscow hairstylist.

${ }^{903}$ Ibid., "Why They Want NO UNISEX in Socialism," December 1974, p. 3. Emphasis in the original.

Bold text in original removed here.
} 
look nice," Carter argues that "in Socialism all girls and women are encouraged to make themselves attractive. They don't buy the current notion [in the West] that this is 'sexism." "904 Instead, readers of Carter's publications were sold the theory that the position of Soviet women was superior to that of women in the West.

Women may not have served at the head of the CSFS, but they did take on important subordinate roles in the Society's administration and publicity. A dedicated group of women were active in branch groups, in supporting roles, and women were also the target audience for many of the CSFS public speaking events and published articles. Motivated by the message that the conditions for women were better in the USSR and under socialism than in Western capitalist countries, women on the Canadian left played an important organizational role for the CSFS. The women were not duped into their activism, because they clearly chose to participate, albeit usually in supporting roles. In local branches from Vancouver to Montreal, women were active not only in "traditional" roles of preparing food for buffet dinners, but also in soliciting funds, writing articles and speaking at meetings. Many of these people were probably hoping to redefine gender roles at a time when Canadian society seemed to put more value on women's domestic identities.

But they were duped into believing the Soviet claims. Their advocacy of a Soviet ideal that was largely false evokes pathos today. While their activism did help some progressive Canadian women to leverage their role in Canadian society giving them a sense of political engagement and agency, this engagement was part of the larger miseen-scène. All the rhetoric about women's position in society aside, their activism was not different from that of their male counterparts. The CSFS women were operating under a ${ }^{904} \mathrm{Ibid}$. 
series of false perceptions of women in the USSR, and persuading others that their version was the "truth." Soviet women did not experience anything like the projected vision the CPSU and Soviet leadership claimed they did. In defending claims that the "woman question" had been solved by the Soviets, CSFS delegates suspended their critical faculties and believed what they heard in the USSR. In transmitting this erroneous message, the CSFS contributed to the smoke-screen which hid great divisions and inequalities within the USSR. And in attempting to persuade their fellow Canadians to believe these declarations as the truth, the CSFS activists cast themselves as apologists for the Soviet Union.

Culture was an integral part of the CSFS performance, and will be explored in detail in the following chapter. 


\section{Chapter Eight \\ CULTURE AS POLITICAL PERSUASION: PERFORMING SOVIET FRIENDSHIP}

"There is no other country where art remains on such a high level as in the USSR, $" 905$ proclaimed Dyson Carter in 1951. For Carter and other progressives, culture provided the main stage on which Canadian-Soviet friendship could be enacted, and it was a political performance. The exchange of information on art, displays and sales of representative cultural artifacts, paintings and books, and CSFS-sponsored tours of the USSR and Canada by artists promoted cross-cultural friendship with overt political implications. Within the CSFS and other progressive groups, admiration of Soviet culture was a symbol of a subculture ${ }^{906}$ where members shared ideological, political and social values, and dreamed of radically changing Canadian society. Art was perceived as an international language, a language that tied Canadians of different ethnic backgrounds together, and also connected them to Soviet sympathizers in other countries. In singing, reading, attending film-showings and lectures, CSFS members lived and thought "otherwise," 907 i.e. defining their view of the world in opposition to the mainstream. For the CSFS, Soviet culture also represented an avenue to reach out to the wider Canadian public, because many Canadians were genuinely interested in Soviet cultural and artistic figures, given the storied reputation of Russian literature, art and music. High profile Soviet artists, writers, composers and performers knew that they were playing a political

\footnotetext{
${ }^{905}$ Headline of article from Ukrainske zhittia about Dyson Carter's recent speech, 14 June 1951, vol XI, p. 5, translated by RCMP in report dated 16 June 1951, LAC, RG146, A200600098, p. 20.

${ }^{906}$ Here I am influenced by Ester Reiter's contention that left-wing Jews in Toronto "formed a subculture that unified their ethnic and class identities, and was marked by values and cultural patterns in opposition to the dominant society." This was true in a different sense for most of the progressive groups in Canada, as well as for the CSFS, which tried to work as a liaison or bridge between other groups. Reiter, "Secular Yiddishkait: Left Politics, Culture and Community," Labour/Le Travail, Spring 2002, $<\mathrm{http} / / /$ www.historycooperative.org/journals/llt/49/05reiter.html $>$ (10 Jun. 2008), paragraph 19.

${ }^{907}$ Ian McKay, Rebels, Reds, Radicals: Rethinking Canada's Left History (Toronto: Between the Lines, 2005). p. 130,35. Unfortunately, McKay makes no specific reference to the CSFS.
} 
role, and were also aware that the Soviet state, particularly under Josef Stalin, "had a superlative appreciation of the propaganda potential of art." ${ }^{9908}$ VOKS actively encouraged cultural exchange in Canada via Dyson Carter, the CSFS, News-Facts, and later Northern Neighbors.

The CSFS was supported by other progressive organizations in sponsoring and promoting Soviet culture to the wider Canadian public. In 1952, the Canadian Tribune proclaimed that "Sports and culture are vital avenues for friendship among nations," and congratulated the Canadian Soviet Friendship Council "for its initiative in developing friendship with our neighbors to the north." 909 The Ukrainian Canadian enthused over a "number of exciting cultural events [sponsored by the CSFS] to celebrate the increasing desire for friendship between the Canadian and Soviet peoples." ${ }^{910}$ Soviet culture was the USSR's best propaganda tool, and one of the hardest for Canadian authorities to counter. Dyson Carter was aware of this, and promoted Soviet culture and cultural actors with all his energy and publishing ability. His message unfailingly emphasized that the social and political system that produced these artistic works should be admired. He never remarked upon the stifling restrictions and rigid dictates put on artistic development by the Soviet state, nor the periodic official criticisms of high-profile Soviet artists for their failure to live up to these dictates.

\footnotetext{
${ }^{908}$ One of the best examples of a Soviet artist with a political role thrust upon him, trapped by the vicissitudes of Soviet artistic policy, and consistently promoted as a human propaganda tool, is the composer Dmitri Shostakovich, movingly documented by his Testimony. This quotation comes from the Solomon Volkov's "Introduction" to Testimony: The Memoirs of Dmitri Shostakovich (trans. by Antonina W. Bouis) (New York: Harper \& Row Publishers, 1979), p. xxxiii.

909 "Avenues of Friendship," Canadian Tribune, January 1952, clipping in LAC, RG146, A200600099, p. 113.

910 "Boost Friendship of Canada, USSR," Ukrainian Canadian, 1 January 1952, clipping in LAC, RG146, A200600099, p. 120.
} 
In his authoritative book on cultural exchanges and propaganda during the Cold War, David Caute wrote that in addition to being a "traditional political-military confrontation," this period was characterized by "an ideological and cultural contest on a global scale and without historical precedent." ${ }^{911}$ The prize, according to Caute, was to be able to declare one's own side the legitimate inheritor of Enlightenment ideals, and so the conflictual rhetoric drew on definitions of culture, modernity, progress, "facts" and reason. ${ }^{912}$ In Canada, the identification of culture as one of the Soviet Union's greatest exports, which had considerable propaganda value, was also recognized by the RCMP and the Canadian Department of External Affairs. In the USSR, the term 'propaganda' coincided almost exactly with the Soviet concept of social and political education, and so it was exploited to the maximum. Carter sent VOKS material to Canadians prominent in cultural associations, and promoted lesser known Canadian artists whose message fit nicely with the Soviet philosophy. ${ }^{913}$ The painter Frederick Taylor, ${ }^{914}$ writers like Wilson Macdonald and Ted Allan, as well as Fagel and Emil Gartner, musicians well known in the Jewish progressive groups, were promoted by Carter at CSFS events. Carter tried to encourage VOKS to view artists who were seen as mainstream, like Frederick Philip Grove, favourably. The CSFS had the same role models as many other progressive organizations. Among the models was Paul Robeson, the black American peace activist

\footnotetext{
${ }^{911}$ David Caute, The Dancer Defects: The Struggle for Cultural Supremacy During the Cold War (Oxford: Oxford University Press, 2003), p. 1. ${ }_{912}^{913}$ Caute, The Dancer Defects, p. 3-4.

${ }^{913}$ On the publication of Canadian writers in the Soviet Union, and the criteria used to select them, see Joseph Black and J.L. Black, "Canada in the Soviet Mirror: English-language Canadian Literature in Soviet Translation," Journal of Canadian Studies, Vol. 30, No. 2, Summer 1995.

${ }^{914}$ Emil Gartner's participation in Soviet friendship activities predated Dyson Carter's presidency. He had been active on the Canadian left, as choir director for the Jewish Folk Choir, which often performed at National Council for Canadian-Soviet Friendship during the Second World War. LAC, RG146, A200600124, RCMP report, Toronto Intelligence Branch, re: a National Council for CSF event on May 4, 1944 , p. 230.
} 
and singer, who was also featured frequently in Carter's magazine, as he was in other Soviet promotional material and progressive publications. ${ }^{915}$

Culture had been an important feature of the older National Council for CanadianSoviet Friendship, and soon after it was founded in 1943, the Arts Committee included poet E.J. Pratt, painter A.Y. Jackson, writer Ted Allan, and film critic John Grierson. But the atmosphere changed, and by the $1950 \mathrm{~s}$, most of these artists no longer chose to be so actively involved. Nevertheless, the use of culture as a vehicle for Soviet friendship was stepped up, at the same time that high-level negotiations of cultural contacts were being discussed. Carter and the CSFS called for more cultural exchanges with the USSR, echoing the official Soviet emphasis on increasing cultural exchanges between the USSR and the West. In the late 1950 s, VOKS pursued a policy of encouraging Canadian impresarios to bring performers to Moscow. Jack Bowdrie, Glenn Gould and Lois Marshall took VOKS up on the invitation, and allowed their impresario, Walter Homburger, to make the arrangements for Soviet tours in 1957 and 1958 . The fact that the VOKS representative in the Soviet Embassy in Ottawa negotiated these contracts as "cultural attaché" made the ellipsis of cultural promotion and persuasion complete. The late 1950s saw a large increase in general exchanges between the USSR, under Khrushchev's leadership, and Canada, studying agricultural, forestry and other traderelated domains. The Canadian Department of External Affairs (DEA) also advocated

\footnotetext{
${ }^{915}$ As a darling of the elite educational and sports institutions of the United States, Robeson's outspoken pro-Soviet social activism earned him the accolades of Soviet authorities, and the negative attention of American State and security officials. There is a photograph of Paul Robeson voting in the USSR in the SovFoto Press Agency Collection at the MacLaren Art Centre, Barrie, Ontario, and his popularity among Canadian union members, UJPO members and others has been remarked upon elsewhere. Laurel Sefton MacDowell, "Paul Robeson in Canada: A Border Story," Labour/Le Travail, no. 51, Spring 2003: 31 pars., accessed 2 June 2008, www.historycooperative.org/journals/11t/51/macdowell.html; Reiter, "Secular Yiddishkait: Left Politics, Culture and Community," Labour/Le Travail, Spring 2002, $<$ http://www.historycooperative.org/journals/llt/49/05reiter.html> (10 Jun. 2008), paragraph 18.
} 
increased cultural exchange at this time, suggesting that this was in effect the best way to counter-act any overly positive views of the USSR. ${ }^{916}$ The DEA considered that the more often Soviets visited the West, and the more frequently Westerners saw the USSR for themselves, the harder it would be to convince foreigners that the Soviet Union was in fact a socialist ideal. The Soviets thought just the opposite. In the cultural field the international stakes were high.

When VOKS replaced the Bulletin with Culture and Life in 1957, Carter was asked to promote it in Canada, and to send a list of people who should receive free issues. On the list which the Ottawa VOKS representative sent to Moscow were Celia Franca, the director of the National Ballet School of Canada; M.P. Beique, head of the Montreal Symphony Orchestra; Walter Susskind, the conductor of the Toronto Symphony Orchestra, plus directors of the Stratford Shakespeaean Festival, directors of theatres in Montreal and Ottawa, impresarios, journalists and editors of large newspapers and scholarly journals. ${ }^{917}$ Editors of left-wing publications also received free copies. It is unclear whether all of these individuals asked to be put on VOKS' mailing list. Canadian poet Joe Wallace, who received VOKS literature, was known to admire the USSR. Since he was dealing with the USSR on cultural matters, Walter Homburger was probably pleased to have the journal. In any case, there is no record in the VOKS documents of anyone complaining about receiving it.

CSFS events were made more colourful by the addition of cultural performances, but these were always understood by performers and audience alike to be acts of political

\footnotetext{
${ }^{916}$ On this see LAC, RG25, vol. 7117, file $9055-40$ and vol. 6829 , file $2727-\mathrm{V}-40$ for analyses originating in the Department of External Affairs as well as in the Canadian Embassy in Moscow.

${ }^{917}$ VOKS 53:111, I.M. Kulakovskaya to Carter, 17 November 1956; VOKS 55:55-59, A. Tovstogan to V.G. Yakovlev, 11 December 1956 with "List of Organizations and Private Persons to Receive Journal Culture and Life.
} 
significance. Music concerts often set the stage, and were even possibly the main attraction for CSFS-organized speeches and discussions. The choir of the Federation of Russian Canadians and the Jewish Folk Choir led by Emil Gartner were frequently featured at large CSFS gatherings. Often mini-concerts were followed by lectures or discussions of life and politics in the USSR. For example, in November 1954 between 700 and 900 people attended a concert organized in honour of Friendship Month by the CSFS at the Playhouse Theatre in Winnipeg. ${ }^{918}$ The evening opened with renditions of the Canadian and Soviet national anthems. ${ }^{919}$ Choirs from local AUUC, FRC branches, as well as the United Jewish People's Order choir and the Winnipeg Folk Singers performed folk songs in several languages, as well as songs about peace. The head of the Winnipeg CSFS branch, Fred Chester King, was the Master of Ceremonies. He insisted that the success of the recent Soviet artists' delegation showed that friendship with the USSR was a popular idea in Canada. Ida Kovalevich (Edith Kowalewich) from Winnipeg spoke about her recent trip to the USSR and China. Two films shown at the event depicted a Canadian delegation visiting the USSR, and the celebration of Friendship Month in Moscow. ${ }^{920}$

The Vochenblatt (The Canadian Jewish Weekly) advertised this concert and similar events in Vancouver, Brandon and Port Arthur organized by the CSFS for Friendship Month. ${ }^{921}$ To mark Canadian-Soviet Friendship Month and the $41^{\text {st }}$

\footnotetext{
${ }^{918}$ The RCMP said there were 700 people in attendance, and Ukrainske slovo reported there being approximately 900 people there. RCMP Winnipeg Special Branch report, 15 November 1954, LAC, RG146, A200600114, p. 7; Summary of "Mark the Month of Canadian-Soviet Friendship with a Fine Concert Meeting," Ukrainske slovo, 17 November 1954, p. 4.

${ }^{919}$ RCMP Winnipeg Special Branch report, 15 November 1954, LAC, RG146, A200600114, p. 6.

${ }^{920}$ Summary of "Mark the Month of Canadian-Soviet Friendship with a Fine Concert Meeting," Ukrainske slovo, 17 November 1954, p. 4.

${ }^{921}$ Excerpt from Vochenblatt (Canadian Jewish Weekly), 28 October 1954, p. 3; and 4 November 1954, in LAC, RG146, A200600114, p. 9, 10.
} 
anniversary of the Bolshevik revolution the Winnipeg branch of the CSFS organized a concert at the Playhouse Theatre on 9 November 1958. There were 400 people in the audience, including Alexei Tovstogan, VOKS representative at the Soviet embassy in Ottawa. Tovstogan spoke on "Science and Education in the USSR," but because of his poor English and the faulty public address system, ${ }^{922}$ few people in the audience were able to understand what he said, so the text of his address was later printed in full in Ukrainske slovo. ${ }^{923}$ The women's AUUC choir, the women's FRC choir and the Winnipeg Folk Singers performed. ${ }^{924}$ By bringing in popular performers, Carter attracted and maintained the attention of individuals who were equally interested in the music, singing and socializing, and the political message the CSFS wanted to convey. As one UJPO member recalled, the cultural aspect was integral to the progressive movement in Canada: "...it was an ideology and a way of life." Another participant said "the political was cultural and the cultural was political." ${ }^{925}$

Mainstream commentators at the time noted that although peace was an important part of this rhetoric, it took the backstage to culture. A writer for the Financial Post, Ronald Williams, suggested in January 1952 that this was a new tactic used by the Canadian left to attract a broad spectrum of Canadians to view the USSR more favourably. Comparing the big names the Friendship Council had during the war with the relative little information available on the post-war financial backers, Williams

\footnotetext{
${ }^{922}$ RCMP Winnipeg Security and Intelligence Section report, 19 November 1958, LAC, RG146, A200600114, p. 289-290.

923 "Science and Education in the USSR," Ukrainske slovo, 19 November 1958, p. 4; in LAC, RG146, A200600114, p. 288.

924 "Mark the $41^{\text {st }}$ Anniversary of the USSR," Ukrainske slovo, 19 November 1958, p. 3, in LAC, RG146, A200600114, p. 287.

${ }^{925}$ Molly Myers and Pearl Blazer, as quoted by Ester Reiter in Reiter, "Secular Yiddishkait: Left Politics, Culture and Community," Labour/Le Travail, Spring 2002,

$<$ http://www.historycooperative.org/journals/llt/49/05reiter.html (10 Jun. 2008), paragraph 27 and 24.
} 
suggested that the real message the CSFS hoped to pass on was neither about Soviet achievements, nor the increased trade and cultural exchange with the USSR, but rather a consolidated attempt to counter the negative publicity the USSR had been getting since 1946. He cited comments made by Beckie Buhay, one of the top CPC leaders. Buhay's comments about "unmasking the foul Big Lie that the USSR menaces Canada and Peace..." sound remarkably similar to speeches made by Dorise Nielsen and Dyson Carter on behalf of the CSFS. ${ }^{926}$ Williams pointed to the printed "Photo-Facts" cards, which CSFS members were urged to send to Members of Parliament and leave in public spaces as "weapons of truth", and the expensive delegations to the USSR as a left-wing effort to replace the relatively unpopular peace campaign as a leftist unifier in Canada. Williams concluded that,

All this expense and trouble is taken to be an admission that the 'peace' offensive isn't going so well in Canada and that something had to be done not only outside the party, but inside as well. It is no secret that the various peace petitions have been received by many party workers with something less than wild enthusiasm. The rough time they had trying to get people to sign petitions didn't help either. The Reds hope the 'friendship front' will smooth out some of the roughest spots, and perhaps again lure some big nonCommunist names in the Communist bear trap. ${ }^{927}$

There was not much discovery here, for this is precisely what Carter and Nielsen had been saying themselves for some time. Progressive Canadians would not have denied the basic argument that cross-cultural friendship was meant to draw in more supporters from beyond the traditional Party constituencies. Carter loved the publicity Williams unwittingly gave the CSFS. In the president's speech at the January 1952

\footnotetext{
${ }^{926}$ Ronald Williams, "Reds at Work on 'Friendship': Now Start Photo Propaganda Deluge," Financial Post, 5 January 1952, LAC, RG146, A200600099, p. 114. Buhay's comments were made in the Party's journal, National Affairs Monthly.

${ }_{927}^{9}$ Ibid.
} 
Soviet Friendship Convention, Carter laughed at Williams' anger over "Photo-Facts," saying "Mr. Williams, watch your blood pressure! You're going to blow a valve. By the way, in this 'Financial Post' piece, Mr. Williams manages to come out with one piece of truth. He says: "The friendship front is going ahead like a house afire." Carter agreed that this was the case, and the CSFS and its Photo-Facts "have played no small part in changing public opinion in Canada." ${ }^{.928}$

Meanwhile, Dyson Carter continued to put forward progressive Canadians as delegates to the USSR, and sent Canadians' manuscripts and biographical information to VOKS for possible publication in Moscow. Carter believed that 'cultural workers' could, by engaging in these exchanges, use culture as a political tool to improve society. This idea fit nicely with the official Soviet view that artists were servants of the (Soviet) state, who gave their art for state use and were rewarded for doing so. Of course, Carter never acknowledged that in theory Soviet artists were to mirror the interests of a class, not the state probably because he accepted the claim that the Soviet state and the working class were synonymous. In his letters to VOKS Carter emphasized the contributions select Canadian artists had made to the labour movement over and above their artistic work. Highest praise was reserved for members of the Labor-Progressive Party. Some of the artists, such as Frederick Taylor and Avrom Yanovsky, wrote directly to VOKS themselves. Apparently blissfully unaware of the tragic circumstances under which many Soviet artists lived, Taylor assured VOKS that the artist in the USSR was in a superior position to that of artists under capitalism because of the social value and responsibilities

928 "President's Speech, January 25, 1952", VOKS 6:1:36:43-52, 1951-1952; also in LAC, RG146, A200600100, p. 67-76. 
the work entailed. ${ }^{929}$ Echoes of bitterness about the way he believed he had been treated in Canada may be heard between the lines of Taylor's letter. In his opinion, his work received little acknowledgement from the mainstream Canadian art community because he refused to leave the Labor Progressive Party. ${ }^{930}$ Yanovsky wrote to VOKS in June 1951 to introduce himself as the new chairman of the CSFS Arts Committee, noting that he had "...set myself the task of establishing to the best of my ability friendly relations and exchange of information... between art workers of our two countries." ${ }^{.931}$ Art exchanges, he argued, encouraged international 'truth-telling' and were thus an important path to peace.

Hoping to shape Canadian public opinion, Carter wrote VOKS constantly about the need to reach out to all types of Canadians, to convince them that the information about the USSR received from mainstream papers in Canada was false. Names of prominent Canadians who supported his cause, and names of people abroad who did so, were dropped as reminders that respected citizens elsewhere had already become convinced of this argument. Most of these individuals were writers, actors or artists. An article in the Pacific Tribune in 1952, for example, proclaimed that delegates' reports were causing more Canadians to be attracted to the CSFS and its cause:

A number of Canadian trade union and cultural delegations visited the Soviet Union in 1951 and brought back impressions which diverge widely from the stock cold war anti-Soviet propaganda, the Canadian people are fed daily. Thus an interest in getting at the

\footnotetext{
${ }^{929}$ VOKS 5:3:32:137-139, Taylor to VOKS, May 1951.

${ }^{930}$ Three of his paintings done during the Second World War now hang in the gallery at the Canadian War Museum, Ottawa. For more on Taylor, see the recently published biography: John Virtue, Fred Taylor: Brother in the Shadows (Montreal and Kingston: McGill-Queen's University Press, 2008). ${ }^{931}$ VOKS 5:3:32:15-18, Yanovsky to Gerasimov (President of VOKS Fine Art Section, Moscow), 3 June 1951.
} 
real truth, instead of the usual propaganda, is also a factor in the growth of friendship sentiment. ${ }^{932}$

In November 1951, a Canadian Tribune article reported that "the people of Canada are showing such an interest in learning the truth about the Soviet Union that the Canadian Soviet Friendship Society cannot keep pace with the demand."933 However, Carter is reported to have said: "“But please don't give Tribune readers the idea we are too busy to look after their orders. Tell them to step up the demand.",934

In 1952, the British-Soviet Friendship Society sent greetings to its Canadian counterpart, via a group of British artists. In addition to Hewlett Johnson, who was not an artist but the "Red" Dean of Canterbury, this group included a professor, an author, two actors and a composer. Their message to Dyson Carter read: "“Best wishes for the success of Canadian-Soviet Friendship Month, which we hope will lead to that mutual understanding and toleration on which the peace of the world depends." 935 Three years later, the LPP decided to jump on the bandwagon. At the LPP Cultural Conference, it was proclaimed that the

Canadian-Soviet Friendship Society -- have always stressed cultural relations between the peoples of the Soviet Union and Canada" and that this was a positive feature of the CSFS' work. The truth is that our Party cannot, in a full fashion, pick up and carry forward the banner of the nation unless we vigorously enter into the cultural struggle and do everything we can to encourage, cultivate and aid the work of the cultural forces of our movement and the entire labor movement. Everything that defends Canada is good! We are for the uniting of all, the encouragement of all who resist the Yankee assault...Our Party must vigorously get into the

\footnotetext{
932 "Canadian-Soviet friendship," Pacific Tribune, January 1952 (exact date indecipherable), LAC, RG146, A200600099, p. 65.

${ }^{933}$ John Stewart, "'Can't keep pace' with demand for truth about USSR- Carters," Canadian Tribune, 5 November 1951, LAC, RG146, A200600099, p. 141.

${ }_{934}^{935}$ Ibid.

935 "Eminent Britons send greetings to Canadian-Soviet Friendship parley," Pacific Tribune, January 1952 (exact date indecipherable), LAC, RG146, A200600099, p. 64.
} 
cultural battle. We must seize every opportunity to get into public debate on all cultural issues... ${ }^{936}$

In demonstrating the propaganda value in promoting Soviet culture, the CSFS had provided a model for the LPP to use. This was one its most significant contributions to the progressive movement in Canada.

Culture and the prestige that went with it were part of the message, but it was also inextricably linked to the cause of peace. The General Secretary of the British-Soviet Friendship Society, Pat Sloan, greeted candidates to the convention organized by the CSFS, saying that "'The British and Canadian peoples have everything to gain from friendly peaceful co-operation and trade with the Soviet Union and everything to lose from a new international conflict." ${ }^{\prime 937}$ The opening ceremonies at the convention were held in Bathurst United Church, where Dyson Carter spoke and the Soviet film "The Childhood of Maxim Gorki" was said to be "given its Canadian premiere." $" 938$ Each reference to cultural exchange was followed by a reference to the USSR's peaceful intentions: "How can one believe that the Soviet people are preparing for war against us when they are reading millions of copies of the works of Maxim Gorki whose every word cries out against war, against oppression and slavery?" asked Dyson Carter. ${ }^{939}$ To cite an example, during the 1952 Soviet Friendship Month, Canadians were able to receive Soviet radio programmes on short-wave radios every day. Programmes included concerts given by Dmitri Shostakovich and Sergei Prokofiev, reviews and readings of Stephen

\footnotetext{
${ }^{936}$ RCMP "Memorandum for File" and list of "Correlated Files (Incomplete list)" dated 17 October 1955, reporting on the Fourth National Cultural Conference of the Labor Progressive Party, 8-10 April 1955, LAC, RG146, A200600104, p. 37-39.

${ }^{937}$ Ibid.

${ }^{938}$ Ibid.

${ }^{939}$ Ibid.
} 
Leacock's work, and lectures on Soviet agriculture and science, ${ }^{940}$ as well as recent CSFS publications. ${ }^{941}$

If friendship and peace were linked, so too was the work of the CSFS linked to the Canadian Peace Congress. In the context of the Korean War, peace resonated. A January 1952 editorial in Vestnik stated that a "plan for an energetic campaign" would see the CSFS cooperating with the Canadian Peace Congress to promote friendship and trade with the USSR. In particular, the contention that "Canada could play a decisive role in regulating the relations between the Soviet Union and the U.S." was hauled out as a motivating factor in promoting Soviet-Canadian friendship. ${ }^{942}$ Ahead of the showing, Dyson Carter announced that in "combining as it does great Soviet film art and the story of a world-renowned Russian literary figure ...the presentation of this film symbolizes one of the functions of our society, namely the building of friendship with the Soviet people through the interchange of cultural media and the presentation to Canadians of the truth about the influences that mould Soviet thinking." "'943

In May 1951, a delegation of Canadians went to the USSR to observe this cultural superiority for themselves. The delegation, composed of Winnipeg alderman Jacob Penner, Emil and Fanny Gartner, artist Frederick Taylor, and Jeannette Brunelle-Pratte, were reported by TASS to have "acquainted themselves with cultural, educational and scientific institutions in Kiev, [and] made a trip to the town of Kanev, where they visited

\footnotetext{
940 "Radio Moscow beams series on USSR-Canada friendship," Canadian Tribune, January 1952 (exact date not noted), LAC, RG146, A200600099, p. 112.

${ }^{941}$ The CSFS publications reviewed were Frank and Libbie Park, Moscow as Two Canadians Saw It (CSFS, 1951) and Dyson and Charlotte Carter, We Saw Socialism (CSFS, 1951).

${ }_{942}$ Vestnik editorial, 5 January 1952, in RCMP report, RG146, vol. 3348, Pt. 12, p. 115.

943 "Show famous film Childhood of Gorki," Canadian Tribune, 14 January 1952, LAC, RG146, A200600099, p. 82.
} 
the grave and the museum of the great Ukrainian poet, Taras Shevchenko." ${ }^{944}$ Penner was quoted enthusiastically describing the quality of these institutions, especially the university, rebuilt after having been destroyed by the Nazis. He admired the university's equipment, as well as the machines at the Komintern Collective Farm, which they also visited. "We saw with our own eyes that the members of this collective farm lead happy, prosperous and cultured lives," he said. ${ }^{945}$ According to the delegation, this culture leant itself to peaceful living, which in turn inspired more creativity. Frederick Taylor was quoted by TASS saying, "The arts serving the people are developed in the Soviet Union as nowhere else in the world. The peaceful labour of the Soviet people, their devotion to their Motherland, their patriotism are sources of inspiration for artists, sculptors and designers." 946 The Soviet Monitor reported that Taylor said "the paintings of Soviet artists...are the most vital and life-asserting of all now produced in the world." ${ }^{947}$ It was emphasized that "conductor Emil Gartner particularly stressed the high level of musical culture in the land of the Soviets and the perfect organization of musical education in schools for children." 948 The delegation told Soviet journalists that they would take this message home to Canada: "In our speeches at meetings, and over the radio and in the press, we shall tell our fellow countrymen the truth about the Soviet Union and shall assist in consolidating Canadian-Soviet friendship." 949 The Soviet Monitor quoted Penner saying "on our return home we shall spare no effort to prevent our country from

\footnotetext{
${ }^{944}$ The Russian spelling of the city "Kanev" was used in the original source, although today it is referred to by its Ukrainian name, "Kaniv." Soviet Monitor article, "Canadian Delegation in the Ukraine," datelined "Kiev (Tass)", 18 May 1951, this appears in an RCMP report, LAC, RG146, A200600098, p. 29-30. ${ }^{945}$ Ibid. ${ }^{946}$ Ibid.

${ }^{947}$ From the Soviet Monitor, 19 May 1951, from a press conference given by the delegation at Friendship House, Moscow, RCMP report, LAC, RG146, A200600098, p. 30.

${ }_{948}$ Ibid.

${ }^{949}$ Ibid, p. 29.
} 
being involved in an aggressive war against the USSR." ${ }^{950}$ The Canadian artists' impressions were here encapsulated for Soviet domestic consumption, more than for foreign progressive audiences.

But the main purpose of the trip, according at least to Fred Taylor, was to witness the May Day celebrations as official guests atop the reviewing stand on Red Square. Presenting its foreign supporters at the event had special significance that year as the USSR now belonged to the atomic club. For Taylor, the emotional impact of being in the centre of Moscow, not far from the Soviet leadership, viewing the military hardware and rapturous crowds on parade was intense. His biographer wrote that "[d]espite the downpour, Fred later said that he could feel the power emanating from the Soviet premier [Stalin], 150 feet distant." ${ }^{951}$ In his reminiscences, Taylor enthused over the "philosophy" of culture articulated by Soviet ideological chief, Andrei Zhdanov, the clean cities, efficient public transport, and the energetic Soviet people. ${ }^{952}$ He was also impressed by the respect the Canadian delegation received from other international delegates because they were from the same country as Norman Bethune, and apparently he spoke with great effect of his personal friendship with Paul Robeson. ${ }^{953}$ This "mileage" paid off for Fred on his return to Canada, as he was put "on the party's lecture circuit," and the Financial Post called him the "darling of the Communist artistic crowd," but a few years later when his family threatened to cut off his financial backing, he quit the LPP. ${ }^{954}$

\footnotetext{
${ }^{950}$ Ibid, p. 31.

${ }^{951}$ LAC, Frederick B. Taylor fonds, MG30-D360, vol. 3, Taylor's reminiscences of his 1951 visit to the USSR. Also, Virtue, Fred Taylor, p. 150.

${ }_{952}$ LAC, Frederick B. Taylor fonds, MG30-D360, vol. 3.

${ }^{953}$ Ibid., p. 150.

${ }^{954}$ Financial Post, 9 June 1951, quoted in Ibid., p. 151-154. Fred Taylor's brother was the well-known Canadian industrialist, E.P. Taylor.
} 
On their return the Canadian delegates did their best to live up to Penner's promises to "spare no effort" in their speaking tours. The ethnic left press carried interviews with Penner, and touted his speaking tour. ${ }^{955}$ Groups interested in having one or more of the delegates speak were asked to contact the CSFS. ${ }^{956}$ On 20 May Frank and Libbie Park held a discussion of their book, Moscow As Two Canadians Saw It, followed by a performance of the United Jewish Folk Choir, led by the Gartners. The Canadian Tribune noted that "the concert will mark the first public appearance of EMIL and FAGEL Gartner following their return from a visit to the Soviet Union." ${ }^{.957}$ A few days later, the Jewish Folk Choir performed again, followed by a speech by Dyson Carter on Soviet musical developments. ${ }^{958}$

On 29 May, a CSFS meeting held in the AUUC hall in Toronto opened with Emil Gartner directing the approximately 500 people in the audience in the singing of ' $\mathrm{O}$ Canada.' Fanny Gartner played the accompaniment on the piano. Fanny Gartner was then introduced by Dyson Carter as "the beloved pianist of the famous United Jewish People's Folk Choir." She spoke about the availability of cultural education to all Soviet young people, which allowed them to pursue a career in the fine arts. ${ }^{959}$ Introduced as "almost as popular as his wife", Emil Gartner also chose to speak about the high cultural development of the Soviet people. He pointed to the 46 opera houses in Moscow, the numerous Soviet composers, and the schools and theatres that supported them, as proof that his claim was true. In particular he noted that "the theatres were always jammed

\footnotetext{
${ }^{955}$ See Ukrainske slovo, vol. IX, no. 23 (439), 6 June 1951, p. 1, translated in RCMP report, LAC, RG146, A200600098, p. 35.

${ }_{956}$ This ad appeared in the Canadian Jewish Weekly, 26 April 1951, LAC, RG146, A200600098, p. 82.

957 "What's Doing," Canadian Tribune, 21 May 1951, LAC, RG146, A200600098, p. 57, 59.

${ }^{958}$ Ibid.

${ }^{959}$ RCMP report, dated 2 June 1951, LAC, RG146, A200600098, p. 37.
} 
with people, and the people who attended these lavish performances were the common working class, since the admission price was well within the reach of all classes ( 2 rubels) [sic]. ${ }^{960}$ All of this was, in fact, true and for Canadians accustomed to the elite nature of high culture; it was a real marvel. A system that could allow its people such access to theatre appeared to be as enlightened as its citizens. Jacob Penner was the main speaker that evening, speaking for close to an hour about the living conditions for average Soviet working people, and their desire for peace. Dorise Nielsen took up the collection, raising $\$ 160$ for the CSFS, and urged the audience to ask the speakers questions. ${ }^{961}$ CSFS literature was distributed, and attendees were asked to sign a petition for peace.

An important consideration here is that the itineraries for delegations were determined by the Soviet authorities, not by the visitors, and highly organized. No random or chance encounters were permitted. The controlled nature of the Soviet repertoire, which had been vetted by the responsible state institutions, was a safe choice for foreign tourists' entertainment. At the same time, the more culture they saw, the less time there was for visitors to inspect other aspects of Soviet life. In this way, cultural visits were double performances: one stage was set up inside the theatre, while the theatre itself was part of an elaborate display put on to dazzle and impress the foreign visitors. Pokazukha, ${ }^{962}$ or the "Potemkin village" approach, is an effective technique, and the

\footnotetext{
${ }^{960}$ Ibid., p. 38. Interestingly, throughout the RCMP commented on how closely the Gartners and Penner "stuck to the Party line."

${ }^{961}$ Ibid., p. 40.

${ }^{962}$ The phenomenon of pokazukha, which comes from the Russian verb pokazat' meaning literally "to show, to display," is sometimes referred to as a "Potemkin village" in relation to the V. Potemkin's efforts to present Catherine the Great with an ideal village in Ukraine. Potemkin had false fronts put on the village buildings to present an idealized impression. For more on the usage of pokazukha in Russian slang, see Irina H. Corten, Vocabulary of Soviet Society and Culture: A Selected Guide to Russian Words, Idioms and
} 
CSFS reports were part of the show. Their post-visit speaking tours extended the performance.

On 1 June 1951, an account of Penner's impressions was published in the Winnipeg Free Press. Penner remarked upon the number of cultural events he had attended while in the USSR, and his wife "held out a handful of programmes from operas, ballets and similar events," which he had presumably brought home. ${ }^{963}$ A few weeks later the scene at a talk given by Penner in Winnipeg was not so peaceful. On 6 June a meeting where he was due to speak was cancelled because of a bomb threat in the hall. ${ }^{964}$ The case was taken to the Winnipeg city council, where Penner argued that "'a small group' had come to his meeting with the deliberate purpose of disrupting it. They were overheard 'plotting in a Main street hall' prior to the meeting..."965 He asked for groups holding meetings in the Playhouse Theatre to be authorized to prevent anyone from attending, if it was considered they would disturb the proceedings. Apparently, what the RCMP called a "security squad" of LPP members had been in the habit of patrolling the entrance to meetings to keep out those expected to break up the meeting. The RCMP said that these people were often "D.P.'s", which implied that they were of ethnic background. The authorization was denied by City Council, and the meeting was rescheduled to 18 June. A CSFS advertisement urged Winnipegers to come "hear the

Expressions of the Post-Stalin Era, 1953-1991 (Durham and London: Duke University Press, 1992), p. 107.

963 "China Blockade Means War, Says Ald. Penner," Winnipeg Free Press, 1 June 1951, LAC, RG146, A200600114, p. 192.

${ }_{964}$ Summary of report in the Winnipeg newspaper Das Yiddishe Wort (The Israelite Press), 8 June 1951, p. 1, in RCMP report, 22 June 1951, LAC, RG146, A200600098, p. 18.

965 'City Rejects Penner Move to 'Screen' Audiences, Winnipeg Free Press, 26 June 1951; RCMP letter to the Ottawa Commissioner, 27 June 1951, LAC, RG146, A200600098, p. 16. 
speech which illegal elements endeavoured to suppress." ${ }^{966}$ The left press blamed Ukrainian nationalists for the "fascist hoax," and headlined the rescheduled meeting, proving the "trick" had failed. ${ }^{967}$

In November 1951, Frederick Taylor wrote the Montreal Gazette to dispute the claim of another reader that anti-Semitism existed in the USSR. He wrote that he drew on first-hand knowledge, gained by being a member of the CSFS delegation. "I met a great many people including many Jews, among them several outstanding artists," wrote Taylor. "There is no discussion of a 'Jewish question' or anti-Semitism there. Everything which I saw and heard substantiates quite the opposite status quo referred to by Mrs. Marshall. In fact, the Constitution of the Soviet Union specifically bans antiSemitism and its laws make it a criminal offence. Two members of the Canadian delegation attended services in one of the principal synagogues in Moscow and talked to the rabbi and members of the congregation. In the Soviet Union a Jew is simply as anyone else, a person, and as all other citizens. His lot is his own making as is that of all other individuals." ${ }^{" 968}$ Taylor was whitewashing the Soviet reality for Canadian readers. Five years later, with the revelations of Khrushchev's 'secret speech,' Jewish members of the progressive movement were shocked by the degree to which they had been fooled into believing this rubbish, and many abandoned the left as a result.

In January 1952, Pearl Wedro spoke about her recent visit to the USSR at a CSFS meeting held at the Pender Auditorium in Vancouver. She "emphasized that the people

\footnotetext{
${ }^{966}$ Summary of report in the Winnipeg newspaper Das Yiddishe Wort (The Israelite Press), 15 June 1951, p. 2, in RCMP report, 22 June 1951, LAC, RG146, A200600098, p. 18.

${ }_{967}$ Ukrainske slovo, vol. IX, no. 24 (440), 13 June 1951, p. 3; Canadian Tribune, 18 June 1951, p. 2; RCMP report, LAC, RG146, A200600098, p. 21.

${ }_{968}$ Frederick B. Taylor, letter to the editor, "Alleged Anti-Semitism in the USSR," Montreal Gazette, 6 November 1951, LAC, RG146, A200600099, p. 136.
} 
of Russia are very interested in Canadian culture and working conditions." She advocated setting up student exchange programmes between the countries that would promote peace and friendly relations. ${ }^{969}$ The provincial secretary for the British Columbia branch of the CSFS, George Palmer, complained that when he had approached the Vancouver Art Gallery about exhibiting the photographs of Soviet industry and culture, displayed at this meeting, he was told that there was "not enough space available."970 Palmer was probably right in his suggestion that this was just an excuse to avoid acquiring propagandistic photos. ${ }^{971}$ It was decided that a hall should be rented in order to display these photographs to a larger public.

The rhetoric surrounding the CSFS discussions of art was not without a strong hint of Canadian national pride and self-congratulation for breaking down Cold War cultural barriers. In April 1951, a Dmitri Shostakovich oratorio was performed in Toronto in Massey Hall by the Jewish Folk Choir, directed by Emil Gartner, and sponsored by the CSFS. ${ }^{972}$ The Folk Choir appealed to its audience by including a prelude which featured French Canadian, Jewish, "Negro" and Newfoundland folk songs. At the end of the programme, a message from Dyson Carter appeared under the title "Canadian-Soviet Friendship": "Today we are very fortunate. We are the first people outside the Soviet Union to hear an inspiring work by a world-famous composer. As Canadians, let us all congratulate each other! We have drowned out the roar of hateful propaganda with a

\footnotetext{
${ }_{969}^{969}$ LAC, RG146, A200600099, RCMP Vancouver S/Div. Special Branch report, 14 January 1952, p. 88. ${ }^{970}$ Ibid.

${ }^{971}$ Interestingly, since the end of the Cold War, Soviet propaganda photos and art have made for provocative exhibitions. Consider the September 2007 exhibition of SovFoto Press Agency photos at the MacLaren Art Centre, Barrie, Ontario entitled "Broken Promises: Soviet Photography in the Age of Stalin," and "1930: The Making of "the New Man"" at the National Gallery of Canada, 6 June- 7 September 2008. 972 "Captivated by the Oratorio "The Song of the Forests," Ukrainske slovo, vol. IX, no. 16 (432), 18 April 1951 , summarized in RCMP report, LAC, RG146, A200600098, p. 87.
} 
splendid song of peace and love and life. ${ }^{.973}$ During the intermission, Dorise Nielsen read a telegram from Shostakovich, in which the Soviet composer referred to the "peaceful pursuits of the Soviet people." 974 The Quebec Special Branch of the RCMP saw the event quite differently. It reported that "it was no co-incidence that the Canadian-Soviet Friendship Society chose the time of the National Assembly of Peace to hold this concert." 975 In fact, the officer reported, "all the top LPPers were to be seen in Massey Hall as well as the music-lovers amongst the delegates to the National Assembly of Peace. All in all, it was a very successful evening for the stooges of VOKS in Canada." 976

Shostakovich's Testimony refers to the public statements credited to him, but drafted by Soviet officialdom. Close friend and confidante, Solomon Volkov, wrote that Shostakovich was obliged to make "occasional mandatory public appearances, hurriedly and with visible revulsion reading confessions or pathos-filled pronouncements he had not written. ${ }^{, 977}$ His music was periodically attacked by the Soviet authorities, as was the case in 1948 when CPSU passed a resolution condemning "formalism" in music, a meaningless term that nevertheless had serious consequences for Soviet composers. As his friends and colleagues in the artistic world were arrested, executed and silenced, Shostakovich managed to escape bodily harm, although the negative and pseudo-positive attention he received from the authorities had severe psychological effects. Obliged by Stalin to travel abroad, he complained of being a "mock celebrity." 978 Members of the

\footnotetext{
${ }^{973}$ LAC, RG146, A200600098, from the programme for the performance of "Song of the Forests" by the Jewish Folk Choir at Massey Hall, 7 April 1951, p. 97.

${ }_{974}^{97}$ LAC, RG146, A200600098, RCMP report, 17 April 1951, p. 88.

${ }^{975} \mathrm{Ibid}$.

${ }^{976}$ Ibid.

977 Volkov, ed., Testimony, p. xxxvi.

${ }^{978}$ Ibid., p. xxxviii.
} 
Canadian left-wing groups saw him as a real celebrity, and Jewish progressives in particular admired his use of Yiddish folk songs as the source for some of his work. ${ }^{979}$ Truthfully, Shostakovich took pride in his Jewish-themed compositions because they challenged, however subtly, the Soviet system's rampant anti-Semitism. His music was banned in the USSR, his life in jeopardy, yet the Soviet authorities shamelessly used Shostakovich's image abroad for their own purposes. ${ }^{980}$ One example is the congratulations heaped upon him for foreign readers of the VOKS Bulletin, reminding them nonetheless that he had "repudiated" those works the Soviet authorities had criticized. ${ }^{981}$ Undoubtedly, he would have felt the CSFS lauding of the Soviet Union and his oratorio as "humiliating" as his command performances and official Soviet pronouncements on his work. ${ }^{982}$

The CSFS programme from 1952 contained phrases attributed to Shostakovich, which were most likely exaggerations for political purposes. In writing "Song of the Forests," the programme explained, Shostakovich "was inspired by the Stalin master plan for the transformation of nature in the Soviet Union, and by the composer's love for the forests of the north." The programme quotes him saying that it was his "desire to create a poetic song of the woods in which the strong voice of man, subduing and transforming his natural environment, would ring out loudest of all." The poem written by Eugene

\footnotetext{
${ }^{979} \mathrm{Ibid}$., p. xxxvii. Shostakovich was able to speak out more openly against Soviet anti-Semitism after Khrushchev's 1956 speech launched a mild cultural "thaw" in the USSR. In 1962 he composed his Thirteenth Symphony, re-working parts of Yevgeny Yevtushenko' "Babi Yar," a poem describing the Nazi slaughter of Jews outside of Kyiv. Ibid., xxxvii, 185.

${ }_{980}$ The more attention paid his music in the West, the more fearful Shostakovich became of repressions at home. Ibid., p. 137. On the way well-known but banned poets were made to 'dance' for foreign delegations to the USSR, see Ibid., p. 202.

${ }_{981}$ I. Nestyev, "On His Fiftieth Birthday: Dmitry Shostakovich," VOKS Bulletin, September 1956, no. 9 (104), p. 17-21.

${ }_{982}$ For a discussion of why he appreciated Jewish folk music, see Shostakovich, Testimony., p. 156-157; on being 'humiliated' by Stalin's order that he attend the Cultural and Scientific Congress for World Peace in New York in 1949, despite the fact that his work was banned in the USSR, see Ibid., p. 147.
} 
Dolmatovsky to accompany the oratorio deals with the reconstruction of the USSR following the Second World War. ${ }^{983}$ Following the performance Carter sent a telegram to Shostakovich saying: "This was historic cultural event demonstrating to our people the immense benefits of free cultural exchanges between our countries...In universal language of music your oratorio and our singers spoke powerfully of glories of peace." He sent a similar cable on behalf of the CSFS to the VOKS headquarters in Moscow. ${ }^{984}$ There is no record of a reply from Shostakovich.

In January 1952, publicity carried in the Canadian Tribune and other left-wing publications by the CSFS encouraged readers of to celebrate Friendship Month by attending the 1952 CSFS convention in Toronto, "bring[ing] the family to the exhibit of Soviet displays, photos, films, etc." at the offices of the United Jewish Peoples' Order (83 Christie Street), arranging a film showing locally, joining a "listening group" to tune in to Moscow Radio, or "help[ing] build up the collection of typical Canadian art and handicrafts which the Convention will send as a gift to the Soviet people." 985 One of the Soviet radio programmes made available in Canada during the 1952 Soviet Friendship Month was the "This is Canada" pageant presented by the Canadian Youth Friendship League at the World Youth Festival in Berlin in 1951. ${ }^{986}$ The left-wing press, including the Tribune and the Canadian Jewish Weekly publicized a campaign to donate a collection of Canadian cultural artifacts to the USSR, and specified that these could be

\footnotetext{
${ }^{983}$ LAC, RG 146, A200600098, from the programme for the performance of "Song of the Forests" by the Jewish Folk Choir at Massey Hall, 7 April 1951, p. 94.

${ }^{984}$ VOKS 5:3:32:153, Carter cable to Shostakovich, 8 April 1951; VOKS 5:3:32:153, Cable to Perevoschikov and Denisov, 8 April 1951.

985 "Elect Delegates to Jan. 25 Parley: Canadian-Soviet friendship celebrations across Canada," Canadian Tribune, January 1952 (exact date indecipherable), clipping in LAC, RG146, A200600099, p. 80; "Film Masterpiece of Maxim Gorki's Childhood Features Convention's Opening," Canadian Jewish Weekly, 10 January 1952, clipping in RG146, A200600099, p. 95.

986 "On Soviet Radio "This is Canada," Chempion, 17 January 1952, RG146, vol. 3348, Pt. 12, p. 67.
} 
"[b]ooks about Canada, especially on history, politics, economics, art and literature together with distinctive Canadian handicrafts, paintings, music, photograph records or stamps..."987 Gifts were to be brought to the convention in Toronto or sent to the address of the CSFS newspaper, News-Facts.

Leonid F. Teplov, the Soviet chargé d'affaires delivered the closing address in Massey Hall at the CSFS annual convention in January 1952. Because no ranking Soviet diplomat had made a public appearance in Canada since the Gouzenko revelations in 1946, the CSFS took the address as a sign of its importance to Moscow. ${ }^{988}$ The Ottawa Journal headlined their coverage of the speech as "Top Soviet Diplomat to Canada Charges 'Big 3' Preparing War," and noted that "it was the first major address by a Soviet diplomat in this country since 1945, when the RCMP cracked a spy ring funneling top-secret information behind the Iron Curtain. ${ }^{989}$ James McCook of the Ottawa Journal elaborated, writing that "since the spy trials the Soviet representatives here have kept much to themselves...they have stayed away from gatherings where they would be expected to speak in public and have done little to develop personal friendships among Ottawa citizens. The indications of a change were seen in the visit of L.F. Teplov, USSR chargé d'affaires, in Toronto where he addressed the annual convention of the CanadianSoviet Friendship Society."

Accompanied by Vladimir Burdin, First Secretary at the Embassy and the VOKS representative in Canada, Teplov also called briefly on the mayor of Toronto. Constable

987 “Nationwide 'Friendship Month' climaxed by Jan. 26 convention," Canadian Tribune, Jan. 1952, LAC, RG146, A200600099, p. 121; Canadian Jewish Weekly, 3 January 1952, RG146, A200600099, p. 119. 988 "Says Democracies Foil Russian Peace Efforts," Toronto Globe and Mail, 28 January 1952, LAC, RG146, A200600100, p. 36.

989 “Top Soviet Diplomat to Canada Charges 'Big 3' Preparing War," Ottawa Journal, 28 January 1952, LAC, RG146, A200600100, p. 83.

990 James McCook, "Russian Embassy Door Creaks Open a Crack," Ottawa Journal, 31 January 1952, LAC, RG146, A200600100, p. 3. 
David Balfour of the Toronto Board of Control told the Toronto Telegram that he thought "they are in the city to visit the Art Gallery," but of course they had come to attend the CSFS convention. ${ }^{991}$ Before Teplov spoke to the audience of 2, 200 in Massey Hall, greetings from Soviet Friendship Societies in Britain, Czechoslovakia, Poland, the United States and from across Canada were read by Dorise Nielsen and Ross Russell, chairman of the convention. Teplov presented the CSFS with a Prokofiev oratorio "On Guard for Peace," while Emil Gartner, the director of the Jewish Folk Choir, presented Teplov with an oratorio written by Canadians Sam Doland and Louis Model. ${ }^{992}$

The entire text of Teplov's speech, in which he called the CSFS delegates "ambassadors for peace" and claimed that Britain, the U.S. and France were thwarting the Soviet peace gestures in the United Nations, was published in the Canadian Tribune. ${ }^{993}$ The RCMP made sure a copy of the text was sent to George Glazebrook, head of the Defence Liaison division at the Canadian Department of External Affairs. ${ }^{994}$ In the CSFS literature promoting the speech, Carter claimed that this exchange was purely cultural, the majority of CSFS-supporters were in favour of capitalism, and the claim that the CSFS was a communist front was an "untruth." However, people entering the hall were carefully checked, and had to be holding an invitation or known by those at the door. ${ }^{995}$ The highlights of the convention, which included speeches made by John Boyd, Dorise

\footnotetext{
991 "Russ Visit Stirs Storm Ban Receptions- Balfour," Toronto Telegram, 29 January 1952, LAC, RG146, A200600100, p. 32.

${ }_{992}$ LAC, A200600100, p. 37.

993 "Text of L.F. Teplov address," Canadian Tribune, 4 February 1952, p. 8.

${ }^{994}$ RCMP Transit Slip for Headquarters Use, dated 4 February 1952, signed by Supt. McClellan, reads "I want two [corrected to "a"] copies of Teplov's address to go to George Glazebrook at External Affairs." LAC, RG146, A200600100, p. 205. It was forwarded with memo the next day.

995 "Says Democracies Foil Russian Peace Efforts," Toronto Globe and Mail, 28 January 1952, LAC, RG146, A200600100, p. 36. The Canadian Tribune claimed that six thousand invitations were mailed out to subscribers to News-Facts, "Photo-Facts", CSFS members and associated groups. "6,000 invites out for Friendship meet," Canadian Tribune, 28 January 1952.
} 
Nielsen, and the crowds visiting the cultural exhibitions and performances were listed in the Canadian Tribune with photographs. ${ }^{996}$

In the spring of 1954, a group of Soviet concert artists visited Canada on a CSFSsponsored tour. Sophie Golovkina and Leonid Zhdanov, ballet dancers; Leonid Kogan, violinist; Elizaveta Chavdar, soprano; Arturs Frindbergs, tenor; and pianist Pavel Serebryakov, were welcomed by Dyson Carter as they arrived in Toronto. ${ }^{997}$ The concerts were popular -- 3000 were in attendance at the first concert in Massey Hall, and 7000 people crowded into Varsity Arena to hear them at the end of their tour. More than 4000 were reported to have attended the concert in Winnipeg, over 1000 in Sudbury, and 2,500 people were said to be at the concert in Ottawa at the Capitol Theatre. ${ }^{998}$ At one performance in Toronto the RCMP reported "there were numerous known local communists in attendance..."999 John Boyd was Master of Ceremonies. On behalf of the CSFS he also conducted the delegation on its cross-Canada tour, as it played in Vancouver, Edmonton, Saskatoon, Winnipeg, Fort William-Port Arthur, Sudbury, Ottawa, Hamilton, and once more in Toronto. The schedule for their concerts was printed in Ukrainske slovo and other left-wing publications, with information about where to buy tickets. ${ }^{1000}$

Both the mainstream and left-wing press carried generally enthusiastic reports of the performances and of the Soviet artists' impressions of Canada, but the tone of the articles differed. The progressive, ethnic press stressed what the Ukrainian Canadian

\footnotetext{
996 "Convention Highlights," Canadian Tribune, 4 February 1952, p. 9.

${ }^{997}$ V. Nekrasov, "Around the World: Soviet Artists in Canada," News, 10 May 1954, LAC, RG146, A200600095, p. 18-19.

998 "All Canada acclaims triumphant Soviet artists," Canadian Tribune, 10 May 1954, LAC, RG146, A200600095, p. 28.

${ }_{999}$ LAC, RG146, A200600095, p. 2, RCMP report, Toronto Special Branch, 10 May 1954.

${ }^{1000}$ Ukrainske slovo, 21 April 1954, p. 1, 3 in RG146, A200600114, p. 12.
} 
called "a Spring thaw in the icy barrier the Western cold-war diplomats have tried to set up between the Canadian and Soviet people during the past few years." ${ }^{1001}$ The unwelcoming attitude of the Duplessis "regime" was blamed for not allowing a performance in Montreal, and stress was laid on the incongruity of Western stereotypes about the Soviet people in contrast with the wonderful performances. "The Soviet cultural delegation made a tremendous impression on the Canadian people and the greetings of friendship and peace they brought with them were sincerely welcomed," wrote Rose Mickoluk for the Ukrainian Canadian. She continued,

They have taken back with them many favourable impressions of Canada and the Canadian people also. They loved the city of Vancouver, where they visited Stanley Park and the native Indians. They marveled at the beauty of Niagara Falls, as does the whole world. They were deeply moved by the warm reception of the Canadian people everywhere they went and will convey to their people the sincere desire of the Canadian people for still closer bonds of friendship between our two countries. ${ }^{1002}$

The Canadian Tribune proclaimed that the Soviet artists "Fell in Love with Canada," and it was "A Triumphant Tour." ${ }^{1003}$ Interviewed by the Tribune, John Boyd said that the audiences everywhere were large, and the advertisements taken out by the anticommunist Ukrainian groups did little to deflate the enthusiasm of the crowds. He mentioned that at one of Leonid Kogan's performances, Wilson Macdonald, whom Boyd called "one of Canada's leading poets," presented Kogan with an illuminated scroll calling him "the new king of the violin." 1004 At the end of May, Carter reported to VOKS Chief of the British Section, Konstantin Perevoschikov, that "we are still receiving

\footnotetext{
${ }^{1001}$ Rose Mickoluk, "Canada Tour Triumph for Artists from USSR," Ukrainian Canadian, 1 June 1954, LAC, RG146, A200600095, p. 45.

${ }^{1002} \mathrm{Ibid}$.

1003 "They Fell in Love with Canada", Canadian Tribune, LAC, RG146, A200600095, p. 48-49.

${ }^{1004} \mathrm{Ibid}$
} 
wonderful letters and calls about the visit of the Soviet concert artists." He promised a full report on the tour would be sent soon, and wondered whether Wilson Macdonald might be allowed to visit the USSR, to see the river Volga, about which he had written a poem. ${ }^{1005}$ It is not clear from the archives whether Macdonald got his wish.

A Montreal Gazette article was more cynical, noting the impressions given by the Soviet artists on their return to the USSR were that "Canada could be a nice enough place if Canadians would only listen to their 'progressive people' and 'throw off the yoke of that phony low-class culture from the United States that is strangling the country.",1006 The same article noted the artists had praised Canadians of East European background for "keeping alive their culture with choruses and dancing groups, and that the music of Shostakovich, Khatchaturian and other Russian composers is very popular in these circles." ${ }^{1007}$ Apparently Canadians, and especially the Winnipeg audience, had poor "concert manners": they moved about in the aisles during the performances, and were noisy. ${ }^{1008}$ In April 1955, a few articles appeared in the Canadian press reporting that Leonid Kogan had issued a statement saying that he and other artists would be pleased to welcome Canadian musicians to the USSR on a return visit. ${ }^{1009}$

In terms of the delegation's inability to find a concert hall for the Soviet performers in Quebec, the Montreal Gazette suggested that it was possibly the Quebec government who had missed the opportunity to use culture as a political tool. In an

\footnotetext{
${ }^{1005}$ VOKS 6:1:58:35, Carter to Perevoschikov, 28 May 1954.

${ }^{1006}$ Richard Kasischke, "Soviet Artists Comment on Canada," Montreal Gazette, 9 July 1954, LAC, RG146, A200600095, p. 37-38. ${ }^{1007}$ Ibid.

${ }^{1008}$ S.Roy Maley, "Russian Violinist Superb Virtuoso: Audience at Soviet Concert Most Ill-Mannered in Years," Winnipeg Tribune, 27 April 1954, LAC, RG146, A200600095, p. 37.

${ }^{1009}$ Harvey Hickey, "Special Invitation: Soviet Would Welcome Musicians from Canada," Globe and Mail, 11 April 1955, LAC, RG146, A200600104, p. 52; Frank Swanson, "Canadian musicians get invitation," Vancouver Daily Province, RG146, vol. 3349, Pt. 20, p. 54.
} 
editorial on 29 April 1954, the Gazette pointed out that some were of the opinion that rather than fearing the impact of Soviet culture on Quebec society, suggesting that "...more would be gained by showing the Party the benefits of life in Canada and sending them back to Russia as missionaries... They would have taken back to others, it is argued, word of life on this side of the Iron Curtain.." ${ }^{1010}$ The editors wondered, however, whether this would have worked, since clearly individuals chosen for a foreign delegation were trusted by the Soviet authorities, and it would be therefore probably quite difficult to persuade them to view the West favourably. Moreover, their families were still at home, 'hostages' to the system. Apparently, the idea of culture as a political lever in the Cold War was clearly not reserved to the Soviets.

The same day the Soviet concert stars arrived in Canada, a group of Canadian artists left for Moscow. This delegation included one of the painters from the Group of Seven, F.H. Varley; Eric Aldwinkle, a Toronto muralist and writer; Micheline Legendre, a Montreal puppeteer; Wilfred Lemoyne, whom Carter called a "Montreal poet and literary critic"; Pierre St. Germaine, also a journalist from Montreal; as well as Madeleine Perron-St. Germain, who was not an artist, but a Montreal social worker, formerly associated with the Red Cross. ${ }^{1011}$ The CSFS press release noted that while the Soviet artists were being hosted by the CSFS, the Canadian artists would "spend three weeks as the guests of the USSR Society for Cultural Relations with Foreign Countries," VOKS. ${ }^{1012}$ A photograph of the delegation at Dorval airport appeared in the Montreal

\footnotetext{
1010 "On and Off the Record," Montreal Gazette, 29 April 1954, LAC, RG146, A200600095, p. 87. 1011 VOKS 43:26, CSFS Press Release, April 1954. Lemoyne is said to work for the Montreal paper L'Autorite. Later that year, Margaret Fairley, editor of New Frontiers, the LPP's literary magazine, as well as contributors and CSFS members Avrom Yanovsky and J.S. Wallace, visited Rumania. (Canadian Tribune, 30 August 1954, RG146, A200600093, p. 88).

1012 VOKS 43:26, CSFS Press Release, April 1954.
} 
Gazette on 10 April $1954 .{ }^{1013}$ Except for Varley, the travelers seem young, smiling in presumed anticipation of their trip. Varley appears to be nonchalant, not looking at the camera, with his hands in the pockets of his overcoat.

The Montreal Gazette quoted Aldwinkle saying that " "this is the first time the U.S.S.R. has invited any group who are not associated in any way with their party or political ideas. ${ }^{" 1014}$ Aldwinkle also commented on the motivation the artists felt in going, saying, they wanted "'to see what's going on in the cultural field in Russia." 1015 Frederick Varley said that he was sure they would be able to travel freely and " whatever we especially want to see, they will let us see." "1016 The RCMP had doubts about this being an apolitical trip: the correspondence around the delegation was copious. ${ }^{1017}$ The Canadian Tribune claimed that a "press and radio campaign in Montreal attempting to witchhunt the delegation has... failed to intimidate most of the delegates," but noted that Fraser MacDonald, a Toronto composer employed by the Canadian Broadcasting Corporation, had changed his mind about making the trip. ${ }^{1018}$

Louis Kon made the passport arrangements for the Canadian delegation and saw them off at the airport. The Montréal Matin could not resist reporting the rumour that Kon was "un agent relevant directement de Moscou," but was sure at least that he was "une espèce d'attaché culturel officieux pour le compte de l'URSS à Montréal," who was

\footnotetext{
${ }^{1013}$ Montreal Gazette, 10 April 1954, RG146, A200600093, p. 18, 20, 23, 33. The departure of the Toronto artists was reported in Lotta Dempsey's article, "Leave Next Week: Three Toronto Artists Plan Tour of Russia," Globe and Mail, 1 April 1954, RG146, A200600093, p. 50.

1014 "What's Going On in Red Culture Takes Six Canadians to Moscow," Montreal Gazette, 10 April 1954, RG146, A200600093, p. 22.

${ }^{1015}$ Ibid.

${ }^{1016} \mathrm{Ibid}$.

${ }^{1017}$ Unfortunately the RCMP's reasoning is unknown, because despite the release of the related documents under Access to Information and Privacy, these particular reports are almost entirely blacked out.

1018 "Canadian Artists Going," Canadian Tribune, April 1954, RG146, A200600093, p. 34. MacDonald's decision not to go was also reported in "Composer Unable to Tour Russia," Globe and Mail, 6 April 1954, RG146, A200600093, p. 46.
} 
"bien connu à Montréal pour ses sympathies communistes."1019 The Matin further noted that the Secretary of State for External Affairs, Lester B. Pearson, had had no objection to the delegation making the trip. ${ }^{1020}$ In each report it was repeated that the delegation had been invited by VOKS, who would foot the bill, and sponsored by the CSFS.

A year later Kon wrote to VOKS about Varley and this delegation. With the letter, he forwarded an "account of life [sic] of F.H. Varley and reproductions of some of his paintings," where the fact that Varley had visited Moscow was mentioned. ${ }^{1021}$ In an awkward statement, Kon commented that Varley, "like others of that delegation, gained a lot from the visit to the USSR, though too intimidated and afraid to tell the truth publicly, though doing so in their own fashion in personal conversations, and like Walter Duranty, to my recollections, resent and refute the lies maliciously circulated."1022 This may have meant that Varley had refused to speak at public events after his return. It is likely that his refusal to give voice to fawning descriptions of the USSR had resulted in his censure within progressive circles. Kon explained that Varley was "unfortunately addicted to drink and an ultra-individualist," but noted that he "undoubtedly is one of our foremost painters." ${ }^{\prime 023}$ From the Soviet point of view, this was damning. An artist, no matter how talented, was not useful to the (Soviet) state if he would not defend its interests in public; nor could an artist of any kind be an "ultra-individualist" in the USSR.

\footnotetext{
1019 "Le lieutenant Boyczum leur a souhaité 'bon voyage': Quatre pelerins de '1'amitié canado-russe' sont parties hier de Dorval pour la lointaine Russie, Montréal Matin, 9 April 1954, RG146, A200600093, p. 3738. ${ }^{1020} \mathrm{Ibid}$.

${ }^{1021}$ VOKS 6:1:51:113, Kon to L.D. Kislova, 18 January 1955.

${ }^{1022}$ VOKS 6:1:51:113. Walter Duranty was a pro-Soviet journalist for the New York Times who refused to acknowledge that a famine had taken place in the USSR in 1932-1933.

${ }^{1023}$ VOKS 6:1:51:113. The word "drink" and the date Varley visited the USSR (1954) appear to have been underlined by the letter reader. The letter was forwarded to Perevoschikov [Deputy Director of the British Countries division of VOKS] and Chesnokov [head of the VOKS Medical Section].
} 
The VOKS representative at the Soviet Embassy was tasked with bringing forward Canadian writers whose work fit with Soviet literary ideals. Dyson Carter made this job easier. He took seriously not only the promotion of the exchange of cultural delegations, but also that of Canadian 'progressive' writers. Such writers were not necessarily well known to their fellow Canadians, but they were of great interest to the Soviet authorities, and often had their work published in the USSR. Carter promoted their work through CSFS events, and routinely sent reports to VOKS on their performances and publications. In 1951, he was already lobbying on behalf of Canadian playwright, Melville Taylor. ${ }^{1024}$ Certainly, any of the artists who had been delegates to the USSR and spoke publicly afterwards, remained of interest to VOKS. Officials at the Moscow VOKS headquarters corresponded with Frederick Taylor after his return to Canada, and sent him publications at his request. They also asked for material he had written, among them the article describing his tour of the USSR, which appeared in Canadian Art in December 1951. ${ }^{1025}$

In January 1954, Carter sent a long letter to the Soviet Writers' Union via Vladimir Burdin, describing the work of Frederick Philip Grove, a Canadian writer who Carter claimed wrongly had been born in Russia. ${ }^{1026}$ Carter called Grove "the leading Canadian novelist," and mentioned that he had discussed Grove's career with members of the Writers' Union the previous year. One reason Carter recommended Grove to Soviet

\footnotetext{
${ }^{1024}$ There is an exchange of correspondence between Taylor, Carter and VOKS in the summer of 1951. VOKS 6:1:32:76, 77-79, 84, 85.

${ }^{1025}$ VOKS 6:1:33:46, 55; 36:133; 38:83; 40:63. In January 1952, Dorise Nielsen reported that Taylor's seminars on Soviet art had proven popular. (VOKS 6:1:36:54, Dorise Nielsen, "Report on Organization," CSFS Convention, 26 January 1952.)

${ }^{1026}$ VOKS 6:1:47:70-71, 3 January 1954. Actually, Grove was born in Prussia in 1879, and died in Canada in 1948. His real name was Felix Paul Greve. Recent research has suggested that Grove lied about many of his experiences, including those described in his autobiography. Klaus Martens, F.P. Grove in Europe and Canada: Translated Lives (Edmonton: University of Alberta Press, 2001).
} 
experts was that the writer had come in his later life to hold anti-American views.

Similar views, Carter wrote, were held by "the Canadian people today," who understand that "the 'American ideal' is only an empty dream, an historical legend, perpetuated by their [America's] propagandists and even by 'progressives' in the USA who are fond of portraying their country as only 'diverted' from its 'ideal course' by a handful of reactionaries." 1027 The fact that Grove's book, The Master of the Mill (1944), was critical of capitalism would also have appealed to Carter. ${ }^{1028}$ In addition, Carter found it significant that the only book Grove ever translated was a biography of Sun Yat Sen, telling the story of the Chinese revolution. This letter was duly sent to VOKS headquarters and forwarded to the Union of Soviet Writers, together with Grove's autobiography, In Search of Myself, and a biography of the writer by Desmond Pacey, all of which had been sent by Carter. ${ }^{1029}$ Presumably, these were placed in the Lenin Library.

Carter was not completely submissive in his correspondence with Moscow. In March 1954 he wrote VOKS to complain about a Soviet book review that called Barker Fairley, German professor at the University of Toronto, an "exponent of fascist ideologies." ${ }^{1030}$ The review was written by Marietta Shaginyan, Soviet author of a book on Goethe, at a time when Barker Fairley was known in the West as one of the foremost experts on the German poet. Carter pointed out that the political aspersions cast rankled most because Fairley was an executive member of the CSFS, and had long been a peace

\footnotetext{
${ }^{1027}$ VOKS 47:70.

${ }^{1028}$ Carter may have modeled his own writing on Grove's. Like Grove, he used a pedantic style with stereotypically oppressive male characters controlling the female characters who sought personal liberty. ${ }^{1029}$ VOKS 47:12, Burdin to Bogatyrev, 10 February 1954; VOKS 47:69, Perevoschikov to B.N. Polevoi, head of the Foreign Commission, Union of Soviet Writers, 29 April 1954. In 1947 Grove won the Governor General's Award for In Search of Myself.

${ }^{1030}$ VOKS 47:160, Carter to Perevoschikov, 5 March 1954.
} 
activist. Proof of this, according to Carter, was the fact he was banned from entering the United States. ${ }^{1031}$ In fact, Barker Fairley's wife, Margaret, was a long-time member of the Labor-Progressive Party, writer and critic for New Frontiers. It was in 1949 when she and Barker attended the Cultural and Scientific Conference for World Peace at the Waldorf Hotel in New York that they were arrested for associating with leftists, and subsequently refused entry to the United States. Together with his letter of complaint, Carter sent VOKS Barker Fairley's well-respected book entitled Goethe's Faust. ${ }^{1032}$

Letter and book were sent to the VOKS headquarters, and later forwarded to the Writers' Union for Shaginyan, ${ }^{1033}$ but no further reply is recorded. The Writers' Union was not famous for changing its mind.

Carter wrote several times to VOKS recommending the poetry of Wilson Macdonald who, according to Carter, "personifies the tragic condition of Canadian culture: his genius has been recognized by great men in many countries, yet he is officially treated almost with silence in Canada." ${ }^{1034}$ Although Carter notes with regret that Macdonald was "not a Marxist," he wrote that he had been a "tireless supporter of peace and a friend of the Soviet Union from the days of the Intervention." ${ }^{\text {"1035 }}$ Carter almost apologized for the liberal Christian beliefs held by Macdonald, and the fact that the poet's father was a clergyman, but brushed these issues aside, saying "his father was a clergyman who abandoned the church because of its hypocrisy... in university he [Macdonald] became known as a rebel against convention [sic] ideas and hypocrisy, and

\footnotetext{
${ }^{1031}$ VOKS 47:160.

${ }^{1032}$ Barker Fairley, Goethe's Faust: Six Essays (Oxford: Clarendon Press, 1953).

${ }^{1033}$ VOKS 47:7-9, Burdin to Bogatyrev, 29 March 1954; VOKS 47:159, Perevoschikov to Polevoi, 22 April 1954.

${ }^{1034}$ VOKS 58:68-71, Carter to Denisov, March 1954.

${ }^{1035}$ VOKS 58:68-71; 58:51a.
} 
to this day he is a 'persona non grata' at most of the leading Canadian Universities...for the last 15 years or so his sharp attacks on various reactionary forces have greatly restricted his engagements." "1036 The disdain paid him by E.J. Pratt and "his breed" was evidence enough, according to Carter, that Macdonald was deserving of Soviet support. What is more, Carter wrote, as the "greatest living Canadian poet," Macdonald's poetry included none of the glorification of "sexual deviations" so prevalent in other modern poetry, and he is a "poet of healthy, normal love relationships."1037 In this case, at least, Carter's praise was enough for VOKS. Macdonald's books were immediately sent on to the Foreign Language Press in Moscow for consideration, and Macdonald received official congratulations from VOKS on his $75^{\text {th }}$ birthday in $1955 .{ }^{1038}$ In the USSR, this signaled official approval.

Apparently, Macdonald first became interested in VOKS in 1954 when he read the lecture given by the Chairman of VOKS, Professor A.I. Denisov, on Canadian culture. ${ }^{1039}$ Denisov's lecture in honour of Canadian-Soviet Friendship Month had criticized an article written by history professor Arthur Lower in New Liberty, ${ }^{1040}$ and claimed that Lower did not recognize that Canada had its own culture, independent of England and France. Lower also heard about this lecture, and was moved to write a scathing letter to Denisov. ${ }^{1041}$ Lower noted that he had no idea where Denisov had got his information, but clearly he did not know what he was talking about. Contrary to what Denisov had suggested, Lower said Stephen Leacock would not have been friendly

${ }^{1036}$ VOKS 47:37, Carter to Perevoschikov, 1 November 1954. The reference to the clergyman father is especially interesting because Carter's own father was a minister in the Salvation Army church, and so too was James Endicott, spokesperson for the Canadian Peace Congress, which was linked to the LPP. ${ }^{1037}$ VOKS 58:68-71.

${ }^{1038}$ VOKS 47:140; 48:2; 51:28-29; 58:53, 55.

${ }^{1039}$ VOKS 58:67.

${ }^{1040}$ Arthur Lower, "So This is a Free Country, Is It?" New Liberty, May 1953, vol. 3, no. 3, p. 15, 92-95.

${ }^{1041}$ VOKS 48:204-205, A.R.M. Lower to Andrei Denisov, 14 October 1954. 
towards the Soviet Union, but "was a reactionary capitalist if ever there was one."1042 Lower concluded by saying that "even your friends here will no doubt be embarrassed" by this lecture. The source of most of Denisov's comments was probably Dyson Carter and the CSFS. The VOKS headquarters sent its Ottawa representative a copy of the letter from the Canadian historian, but told Burdin that "it is not considered worthwhile to answer Lower." ${ }^{.1043}$

But Carter was not always successful in promoting Canadian writers. Collections by working-class poet Joe Wallace were sent several times to Moscow, and these were forwarded on to the Writers' Union, but in 1955 Wallace complained bitterly that the USSR was ignoring him. ${ }^{1044}$ This, despite recommendations from Carter, Wilson Macdonald and even Tim Buck, leader of the LPP. Wilson referred to his long service to the Canadian left as justification for his publication in the USSR: "Because of my writings and because of my activities in strikes, unemployed demonstrations, I was driven out of my business, lost my home, and was imprisoned for 18 months. My work in the movement extends beyond 36 years: Tim Buck refers to me as one of the founders of the Party in Canada in one of his books." ${ }^{1045}$ The VOKS files contain no reply to Wallace's letter, possibly because there was none.

In 1952, when Carter sent VOKS a radio play called "Coloured Buttons" by Ted Allan, he wrote that "all progressive people were enthusiastic about it. The importance of the play was shown by the vicious attacks on the author and the C.B.C. by certain

\footnotetext{
1042 VOKS 48:204-205.

${ }^{1043}$ VOKS 48:203, Perevoschikov to Burdin, 4 February 1955.

${ }^{1044}$ VOKS 47:7, 178; 45:21, on Wallace materials sent to VOKS; VOKS 51:75, J.S. Wallace to VOKS, 14 April 1955.

${ }^{1045}$ VOKS 51:75.
} 
reactionary elements who heard the broadcast." ${ }^{, 1046}$ Allan, Carter explained, was worthy of Soviet consideration because he was "a progressive, although his views are not known by the C.B.C." ${ }^{1047}$ A year later, when Carter recommended the book just released by Ted Allan and S. Gordon on Norman Bethune entitled The Scalpel and the Sword, the VOKS representative in Ottawa wrote his superiors to say that "Carter considers it desirable to place a reference or review of this book in a Soviet periodical." ${ }^{1048}$ In 1954, another play by Allan entitled "The Money Makers" was sent to VOKS, this time with Burdin's comment that "T. Allan himself sympathizes with the progressive movement, but out of fear he will lose his job (he is a radio commentator), it is necessary to conceal his views and therefore he does not himself participate in the progressive movement." 1049

In 1957, an active CSFS executive member in Montreal, Romeo Lafond, wrote to VOKS to recommend a play by D.S. Daniels entitled "The Witching Hour," but his efforts were unsuccessful. VOKS communicated Daniels' credentials, which included having worked for a Labor Progressive Party newspaper for years, being from a poor workers' family, and a member of the Communist-led Canadian Seamans' Union, to the Writers' Union. ${ }^{1050}$ However, the Writers' Union concluded that although playwright's profile was correct, the play itself had "serious artistic deficiencies," "1051 which meant that it failed to meet the doctrinaire requirements.

Of all the progressive authors in whom VOKS took interest, Dyson Carter himself was the most prolific. When Carter was first selected as President of the re-organized

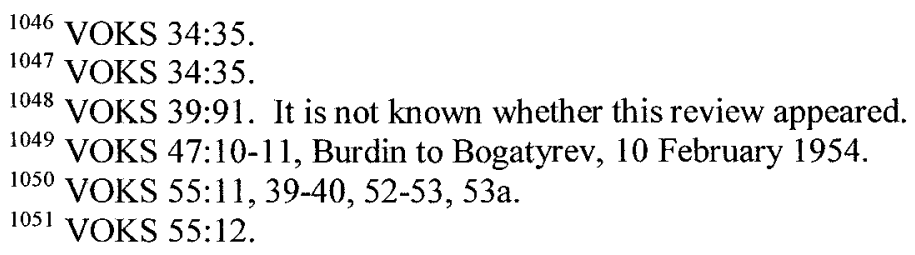


National Council for Canadian-Soviet Friendship, VOKS wrote a page-long description of his work, praising him for being "very well known as a friend of the Soviet Union." 1052 VOKS was especially pleased that in the books Carter published about the USSR since the Second World War he had argued that the Soviet socialist system was superior to other forms of government. The fact that he was a member of the Labor Progressive Party, and had written for the Canadian Tribune, was also noted and VOKS underlined the fact that it had been with the help of the LPP leadership that Carter was chosen to rejuvenate the practically defunct wartime Soviet Friendship Society. ${ }^{1053}$ In 1953, the head of the VOKS British Countries Division, Konstantin Perevoschikov, reviewed Carter's 1943 book Life of Stalin. The reviewer noted that although the book described "correctly" Stalin's actions and the historical events that took place in Russia and the Soviet Union during Stalin's lifetime, the reader could tell that Carter had not yet been to the USSR. ${ }^{1054}$ By 1950 , he had, and he would continue to visit the USSR regularly. The books he subsequently published about what he had seen in the USSR, ${ }^{1055}$ as well as articles and books on the Canadian social and economic system, made him even more popular with the Soviet authorities and the Canadian progressive groups. Copies of Carter's work were always sent to Moscow for review and possible publication there, ${ }^{1056}$

1052 VOKS 31:206-211, "Kharakteristika" [Biography] of the President of the Canadian-Soviet Friendship Society, Dyson Carter, [1950].

1053 VOKS 31:206-211.

${ }^{1054}$ VOKS 41:5-8, Perevoschikov, 13 April 1953.

1055 The description of this first trip appeared as Charlotte and Dyson Carter, We Saw Socialism (Toronto, 1951), originally published in two volumes. On the publication of this book, see VOKS 44:51-54, 65-66.

${ }^{1056} \mathrm{~A}$ complete list of Carter's publications in USSR is provided in Joseph Black and J.L. Black, "Canada in the Soviet Mirror: English-language Canadian Literature in Soviet Translation," Journal of Canadian Studies, Vol. 30, No. 2, Summer 1995; and J.L. Black, Soviet Perception of Canada, 1917-1987. An Annotated Bibliographic Guide, Parts I and II (Ottawa: Carleton University Press, 1987-91), p. 231 shows that Carter was published in the USSR almost yearly between 1956 and 1983. A selection of his publications in English include Men, Machines and Microbes (Winnipeg, 1942); Night of Flame (New York, 1942, republ. London, 1946); Atomic Dollars (Winnipeg, 1946); Sin and Science (New York, 1946); Fatherless Sons (Toronto, 1955); (with Charlotte Carter), Science of Health and Long Life in the U.S.S.R. 
and materials destined for publication in his Northern Neighbors magazine were shipped in return. Carter took great personal initiative in encouraging this, sending his books with "progressive" reviewers' comments to the VOKS representative, ${ }^{1057}$ as well as constant requests for information for his future projects. In 1957, the Soviet ambassador, Dmitri Chuvakhin, helped Carter receive payment in Canadian funds for the publication of Tomorrow is With Us in Ukrainian. The author's royalty came to $\$ 3,086.09$.

The staff at the VOKS headquarters in Moscow, as well as the VOKS representative in Ottawa, took very seriously the propagandistic opportunities they felt cultural exchanges offered. This attitude also informed the dialogue on exchanges between the Canadian Department of External Affairs and Moscow in the 1960s and 1970s. When the Soviet poet, Andrei Voznesensky visited Canada in 1971, the VOKS representative at the Soviet Embassy in Ottawa spoke of the trip as being successful in both artistic and propagandistic terms. VOKS was still well pleased with the investment they made in the CSFS and its leader, Dyson Carter; a man who was both convinced that socialism provided artists with an environment favourable to cultural development, and willing to inform Canadians of this. Carter benefited personally in receiving materials, in

(Sydney, 1956); (with Charlotte Carter), Cancer, Smoking, Heart-Disease, Drinking in Our Two World Systems Today (Toronto, 1957); The Big Brainwash (Toronto, 1958); Future of Freedom (Gravenhurst, 1961); Worker Power: Dare We Win? (Toronto, 1970); and his semi-autobiography, This Story Fierce and Tender (Gravenhurst, 1986). An interview with Dyson Carter appeared in the Moscow English-language newspaper, The New Times, 41 (October 1983), 27. He also published "How Not to Be Afraid of your Heart," New Liberty, vol. 29, August 1952, p. 22-23, 62-63, but no reference was made in this article to his work for the CSFS or of the USSR, more generally.

${ }^{1057}$ VOKS 39:105, I.V. Alekseev, 18 April 1953 on the Soviet publication of Carter's The Future is With Us and the Soviet adaptation for the theatre; VOKS 48:93, T. Moiseyenko-Velikaya to Dyson Carter, 19 September 1955, on review of Carter's Fatherless Sons to be published in Sovetskaya Literatura; VOKS 49:162, A. Tovstogan to V. Vertogradov, 29 May 1956, on the publication of Dyson and Charlotte Carter's The Science of Health and Long Life in the USSR; VOKS 55:122, A. Tovstogan to G. Ioanisyan, 20 June 1957, on release of Charlotte and Dyson Carter's Cancer, Smoking, Heart Disease and Alcohol in Two World Systems. Two copies of this last book, which argued that the Soviets were handling these ailments better than the capitalist system was, were forwarded by VOKS to the Soviet Ministry of Foreign Affairs. (VOKS 55:122). 
enjoying a large readership in the USSR, and having VOKS vouch for his political "correctness," but the relationship was mutually beneficial.

The CSFS performed an important function for VOKS, and through their interaction, VOKS could argue that a politically important void was being filled in Canada. The CSFS played its role by cooperating with the Soviet export of its own cultural geniuses, with their images and speeches re-tooled for the purpose, and also by providing the Soviets with access to Canadian artists who were in sympathy with the USSR. For the CSFS, culture represented its most effective influence over Canadian perceptions of the USSR. It was a "soft" reality better suited to persuasion than the "hard" realities of politics, and in this had real appeal in Canada. The Soviets had used this technique of "agitation and propaganda" domestically for years, and as a result many Soviet denizens had developed the habit of deciphering official "Aesopian" language and using "double-think." The Canadian fellow travelers and committed communists who were members of the CSFS did not appear to distance themselves from the often grotesquely exaggerated Soviet claims to superiority.

Canadians, of all political stripes, had for years been fascinated by Russia and its cultural products. In offering information and exchanges on ballet, literature and music, the CSFS had a real appeal in Canada. Undoubtedly, the CSFS members were sincere in their admiration and enjoyment of Soviet culture, and in their hopes that cultural exchanges would ease Cold War tensions. In many ways, they did. However, in exclaiming over the freedom of Soviet artists, the Canadians seemed to have been unaware of the fact that the officially-sanctioned content of Soviet art was much more limited than in Canada. The experiences of many famous and less-famous Soviet 
performers demonstrate the vicissitudes of the Soviet official state policy on art. ${ }^{1058}$ The gushingly enthusiastic CSFS descriptions of life in the USSR published in the Soviet press assured foreign sympathizers and the Soviet readership that Westerners thought these official claims were accurate. In this, the CSFS was merely part of the show.

${ }^{1058}$ In Soviet literature, Mikhail Bulgakov's novel, written "for the drawer" (ie. not in hopes of publication) Master and Margarita is one of the few novels that deals directly with the tragic situation for artists in the USSR. Bulgakov, Master and Margarita (New York: Grove Press, Inc., 1967). On Soviet policy vis-à-vis artists see for instance, Matthew Cullerne Brown, Art Under Stalin (Oxford: Phaidon, 1991); Brandon Taylor, Art and Literature under the Bolsheviks (Concord: Pluto Press, 1991); Regine Robin (transl. Catherine Porter), Socialist Realism: An Impossible Aesthetic (Stanford, CA: Stanford University Press, 1992); Boris Grois (transl. Charles Rougle), The Total Art of Stalinism: Avant-Garde, Aesthetic Dictatorship, and Beyond (Princeton: Princeton University Press, 1992); Priscilla Johnson, Khrushchev and the Arts: The Politics of Soviet Culture, 1962-1964 (Cambridge: M.I.T. Press, 1965). 


\section{Chapter Nine \\ EPILOGUE AND CONCLUSION}

Persuasion is largely a hidden art. The close ties between the Soviet foreign ministry, VOKS, and later, the SSOD, the Labor-Progressive Party (Communist Party of Canada), and the Canadian Soviet Friendship Society are demonstrable now, but were less clear before Soviet archives were opened to the public in the 1980s. The appeal of the CSFS was precisely in playing these connections down, and indeed, most members probably did not know the extent of Soviet and LPP support for their organization. They certainly were unaware of KGB links. Today, documents and oral history both make these links clear. As an extension of his earlier work for the CPC-LPP, Dyson Carter worked to convince Canadians that the Soviet Union was worth admiring. In addition to his own intuitive preferences and skills, he drew on all kinds of material, most of it sent to him from the USSR, other articles and ideas sent him by readers, or adapted from the mainstream North American press by Carter himself. His message was always optimistic; that is, that Canadians were gradually coming around to his way of seeing things. In larger Canadian society this was not, in fact, the case, but amongst those who self-identified as "progressive" Canadians where the USSR was a symbol of their political hopes and dreams, Carter's claims were believed, and his efforts were celebrated. The popularity of his magazine, Northern Neighbors, and the refusal of the Soviets to let him go after he was replaced as head of the Canadian Soviet Friendship Society in 1960, is proof enough of his importance to the left in Canada and as a propagandist to Moscow. Yet, for the most part, he has remained invisible to the great majority of Canadian historians. 
The unprecedented access to archival research forming the basis for this project allows us to see a continuity between Carter's CSFS and the Canada-USSR Association which replaced it in 1960. Despite the fact that the Communist Party of Canada, in consultation with authorities in Moscow, changed the leadership and renamed the organization, ${ }^{1059}$ its goals and its activities remained remarkably similar. But as it had under Carter, the success of the group depended to a large extent on the personality of the leadership, and by 1969, the Association was again faltering under Les Hunt. It appears that the Association was practically defunct between 1969 and 1972, when it was reorganized under the leadership of Michael Lucas. Later, Lucas complained that he had had to repurchase all of the necessities for the Association's work, because "what was accumulated by Leslie Hunt, had gone with very few exceptions." ${ }^{1060}$ Lucas continued to head the Association until 1991, when it was renamed once more, and Lucas still leads a Toronto-based group that advocates the re-establishment of the Soviet Union, and friendly relations with Soviet peoples.

A report in the VOKS collection written in Russian, probably intended for the Moscow main office of the SSOD, explained that the Association "Canada-USSR" was founded in 1960 in Toronto, and could, around 1974, claim 2.5 thousand members. ${ }^{1061}$ The RCMP concurred, reporting that the official launch took place at the King Edward

${ }^{1059}$ The RCMP reported that Tim Buck had discussed these changes with authorities in Moscow as early as Spring 1959, although the new Association was not officially launched until December 1960. LAC, RG25, A200700336, RCMP Research Section report, "The Canada-USSR Association," 27 March 1963, p. 834845.

${ }^{1060}$ VOKS 6:2:62:3, Michael Lucas letter to Igor Zabrodin, Chief, USSR-Canada Association, Moscow, 10 January 1973. Lucas re-established the Association at 55 Bloor Street, opening the doors on 28 June 1972. ${ }^{1061}$ VOKS 6:2:64:18-19, "Spravka o Kanadskykh obshesvakh druzhbi s SSSR", n.d. but with other documents from 1974, no author listed, probably written by SSOD representative in Soviet Embassy, Ottawa. 
Hotel in Toronto in December $1960{ }^{1062}$ The RCMP noted that William Irvine was the honorary chairman of the new group, with Les Hunt as executive secretary and Clarence Richard Claus as treasurer. The Mounties also suspected that CPC members who had previously been involved in Canadian-Soviet friendship organizations were members of the new group as well. ${ }^{1063}$ A list specifying the members of the "Canada-USSR Association, Canadian Council" included the names of Toronto bookseller Robert Kenny, Michael Lucas, Helen Lucas, John Wigdor, and Guelph herbalist, Dr. A.J. Thut. ${ }^{1064}$ A Quebec variant called the Quebec-USSR Association was led by André Maire, whom the RCMP identified as a Communist from Richelieu. ${ }^{1065}$ Initial start-up funding for the Association was to come from the $\mathrm{CPC}$, and individual members were asked for donations towards its sustainability. ${ }^{1066}$ Dr. Thut was apparently amongst its most generous financial backers. ${ }^{1067}$ Not unlike the CSFS with its links to the progressive ethnic groups supported by the Communist Party of Canada, the Association, maintained "traditional ties with progressive organizations of emigrants from Soviet republics, for instance, the Canadian Ukrainians, Russians, Carpatho-Russians." ${ }^{1068}$ Canadian Doukhobors also found attractive the Association's message of peaceful coexistence and

${ }^{1062}$ LAC, RG25, A200700336, RCMP Research Section report, "The Canada-USSR Association," 27 March 1963, p. 834-845.

1063 Ibid.

${ }^{1064}$ VOKS 6:2:65:26.

${ }^{1065}$ LAC, RG25, A200700336, RCMP Research Section report, "The Canada-USSR Association," 27 March 1963, p. 834-845.

1066 Ibid.

${ }^{1067}$ Michael Lucas, interview with author, 27 July 2006, Toronto, ON.

${ }^{1068}$ VOKS 6:2:64:18-19, "Spravka o Kanadskykh obshesvakh druzhbi s SSSR", n.d. but with other documents from 1974, no author listed, probably written by SSOD representative in Soviet Embassy, Ottawa. 
cultural exchange with the Soviet Union. ${ }^{1069}$ Members of these groups actively participated in the Association and its events.

One remarkable difference between Carter's CSFS and its successor is that from 1960 a separate francophone association existed in Quebec. It is not clear what became of the group led by André Maire, but documents from the VOKS/SSOD collection show that in 1969 a Montreal-based organization called the Societé Culturelle Québec-URSS was founded with a dentist, Adelard Paquin, described as "popular" by the authorities in Moscow, at its head. This group apparently had professionals, lawyers, doctors, journalists as members, and boasted of good ties with Montreal University and the press. Like its Toronto affiliate, the Societé organized professional meetings with Soviet individuals visiting Canada, exhibitions of Soviet art and objects, and offered Russianlanguage courses and Soviet film-showings. In the early 1970s it claimed to have 4.5 thousand members. ${ }^{1070}$ A major event planned by the Montreal group in 1973 was a large party on board the Soviet ship Aleksandr Pushkin, which was docked in the harbour. Three hundred people were guests of the Societé on board that night, and Paquin and Soviet Ambassador to Canada, B.P. Miroshinchenko, gave speeches. E. Gusarov, of the General Consulate of the USSR in Montreal, was also present. ${ }^{1071}$

As had been the case with the CSFS under Carter, Soviet friendship appeared to be a family affair, where the women played supporting, but nonetheless essential roles. In the Montreal Societé, for instance, the whole Paquin family was involved, and Adelard Paquin's female relatives organized buffets, handled secretarial work, and served on the

\footnotetext{
${ }^{1069}$ Koozma J. Tarasoff, interview with author, 27 September 2006 , Ottawa, ON.

${ }^{1070}$ VOKS 6:2:64:18-19, "Spravka o Kanadskykh obshesvakh druzhbi s SSSR", n.d. but with other documents from 1974, no author listed, probably written by SSOD representative in Soviet Embassy, Ottawa.

1071 VOKS 6:2:60:51-52, Majorov report, 27 May 1973.
} 
cinema and photograph committees. ${ }^{1072}$ In Toronto, Helen Lucas has assisted her husband, and been financial secretary of the Association for more than thirty years. But despite the fact that their goals were the same and their activities similar, relations between the Toronto- and Montreal- based groups were at times fractious. In 1973, Paquin refused absolutely to be united with Lucas' group, because he said it "would be a brake" on the Quebec Societé, but he did agree to cooperate when necessary with Toronto. ${ }^{1073}$ Paquin did not like the way the Toronto-based Association was run, and possibly for this reason, and as a nod to Quebec politics, preferred to keep the groups separate. Canada-USSR friendship was subject, it seems, to the same entrenched regional politics as most Canadian organizations.

Like its predecessor, the Association claimed to have a pan-Canadian membership. A list of the branches in the VOKS collection noted that there were active groups in Halifax, Winnipeg (led by Mary Kardash), New Brunswick, Regina, Toronto, Edmonton, Hamilton, Vancouver, London, Grand Forks (led by Doukhobor leader, John J. Verigin), Windsor, Vernon, Sudbury, Saskatoon, Brantford, Montreal, Thunder Bay, Guelph (led by herbalist A.J. Thut), and Calgary. ${ }^{1074}$ The Montreal-based Societé was listed as a partner group. Paquin complained that except for the groups in Toronto, Montreal and Vancouver, none of these Association branches were really working. ${ }^{1075}$ Koozma J. Tarasoff has nonetheless described the Ottawa branch as having been active in hosting discussion groups. ${ }^{1076}$ It is clear that organized Canadian-Soviet friendship had less appeal in the Maritimes, perhaps precisely because the CPC-LPP had never gained

\footnotetext{
1072 VOKS 6:2:65:11-14.

${ }^{1073}$ VOKS 6:2:61:40-42, Mayorov to A.N. Masko, 30 April 1973.

1074 VOKS 6:2:65:25, List, "Branches of the Canada-USSR Association Across Canada."

1075 VOKS 6:2:61:40-42, Mayorov to A.N. Masko, 30 April 1973.

${ }^{1076}$ Koozma J. Tarasoff, interview with author, 27 September 2006, Ottawa, ON.
} 
much popularity there. Lucas and Paquin remained, for all intents and purposes, the Canadian voices of Soviet friendship through the 1980s. In 1988, they published separate reports in the SSOD's journal, Culture and Life, celebrating Mikhail Gorbachev's policy of glasnost, and declaring that it was making it easier for all Canadians to admire the USSR. $^{1077}$ In tone, these articles were reminiscent of Carter's unceasingly optimistic pandering to the USSR and its leadership.

The Vancouver branch of the Canada-USSR Association was established with lawyer Harold Dean as president in 1960. George Legebokoff also took a leading interest in organizing events and writing to SSOD in Moscow. A Russian document in the VOKS collection reports that in the 1970s the Vancouver group claimed to have two thousand members, and was "engaged in active propaganda work about the achievements of the Soviet Union," and organizing Canadians to tour the USSR. The group claimed to have established good contacts within the last two years within science circles, universities and technical colleges. ${ }^{1078}$ In 1973, the Vancouver branch got the go-ahead from Moscow to begin planning a concert tour of the Vancouver Kitsilano Boys' Band to the USSR. ${ }^{1079}$

The SSOD representative in Ottawa continued to serve as a liaison for these groups in Canada and the main SSOD office in Moscow. In 1974 a document accounting for the work of the Moscow based Society "USSR-Canada" said that it engaged with "Dr.

\footnotetext{
1077 Adelard Paquin, "Truth is the way to confidence," Culture and Life, 4/1988, p. 29; Michael Lucas, "Facing the truth," Culture and Life, 12/1988, p. 32. Today, Lucas blames Gorbachev for the Soviet Union's demise. Michael Lucas, interview with author, 27 July 2006, Toronto, ON.

${ }^{1078}$ VOKS 6:2:64:18-19, "Spravka o Kanadskykh obshesvakh druzhbi s SSSR", n.d. but with other documents from 1974, no author listed, probably written by SSOD representative in Soviet Embassy, Ottawa.

${ }^{1079}$ VOKS 6:2:62:102-103, Zabrodin to Dean, 28 June 1973. The Band made the trip to Moscow in 1974, but asked about their Soviet tour, members of the band who made this trip preferred not to comment for this project. (http://www.kitsband.com/kitshist.htm, accessed, 30 April 2008).
} 
Paquin, Michael Lucas, Dyson Carter, the AUUC, the FRC, and the anti-Soviet Ukrainian population in Canada." ${ }^{1080}$ When a SSOD delegation came to Canada and the United States in October that year, various progressive groups organized their visit, with meetings arranged for the press and other individuals. ${ }^{1081}$ In April 1973, the SSOD representative in Ottawa, Valentin Mayorov, attended the Festival of Soviet Lithuania, as did the Deputy Chair of the Novosti Press Agency, A.Yu. Chekuolis. ${ }^{1082}$

Sometimes the task of liaison was more difficult than others. In May 1974, Mayorov reported a clash between Lucas' Association and the AUUC. Lucas complained that the AUUC had been trying to make all the arrangements for a visit of a Ukrainian SSR delegation to Canada in 1973. At issue was who was in charge. Mayorov had earlier reported to the SSOD office in Moscow that when the delegation came to Toronto, none of the Association leaders were available. Lucas was in the USSR, and Robert Kenny was in England, so the AUUC organized almost everything. Mayorov concluded that more accountability was needed from Lucas, ${ }^{1083}$ and later pointed out that "here, clearly, a big role is played by the personal interrelationship of Lucas with the AUUC leadership." 1084 As far as the SSOD was concerned, Mayorov was to ensure coordination between the pro-Soviet groups in Canada.

Certainly, it is clear that the SSOD maintained close personal contact with Dyson Carter after he had left the Friendship Society. This link was preserved on the express desire of authorities in Moscow. Carter's popularity among Canadian progressives, and

\footnotetext{
${ }^{1080}$ VOKS 6:2:64:6-15, "Account of work of Society USSR-Canada in 1974," this appears to be the text of a speech, perhaps made by Igor Zabrodin.

${ }^{1081}$ VOKS 6:2:64, 16-17, Zabrodin report

1082 VOKS 6:2:61:34, Mayorov to Masko, 21 April 1973. The festival took place on 20 April.

${ }^{1083}$ VOKS 6:2:61:63-65, Mayorov to AN Masko, 20 July 1973. The Ukrainian delegation was in Canada 721 June 1973

${ }^{1084}$ VOKS 6:2:65:53-54, V.N. Mayorov's interview notes with M. Lucas, 9 May 1974, interview notes dated 21 May 1974.
} 
his willingness and ability to rework Soviet news into a popular left-wing magazine was important to the Soviets, and, although Northern Neighbors was not to be a CanadaUSSR Association publication, the CPC agreed to continue to subsidize it. ${ }^{1085}$ John Boyd has suggested that Soviet support for Carter was real, and amid LPP-CPC disputes, it made him "untouchable." 1086 The relationship had tangible results for the Soviets. In spring 1973, the Novosti Press Agency office wrote to the VOKS Secretary-General in Moscow to explain that Dyson Carter, "well-known Canadian writer, publicist, and Society member," had asked readers of Northern Neighbors to collect books for Soviet youth on Canada during A.N. Kosygin's visit to Canada in autumn 1971. The Novosti representative in Ottawa suggested the SSOD take these forty sets of books collected, and distribute them to their members and associates in the USSR. ${ }^{1087}$ In 1974, Carter wrote to Zabrodin in Moscow about his idea of organizing a tour of Soviet battlefields. Carter had apparently already had a discussion in SSOD Deputy Chairman Andrei Ledovski's Moscow office about the idea. Irja Paul was with Carter in Moscow at that time. ${ }^{1088}$ Zabrodin in Moscow and Mayorov in the Ottawa Embassy routinely asked Carter about his family, and in 1973, having just recently taken up his post, Zabrodin wrote to Carter with condolences on the passing of Charlotte Carter the year before. ${ }^{1089}$ The Soviet authorities liked Carter, and ensured that the SSOD representative in Canada would continue to deal with him.

\footnotetext{
${ }^{1085}$ LAC, RG25, A200700336, RCMP Research Section report, "The Canada-USSR Association," 27 March 1963, p. 834-845.

1086 John Boyd, interview with author, 2 August 2006, Toronto, ON.

${ }^{1087}$ VOKS 6:2:61:31, G. Isachenko, APN to I.M. Zabrodin, 30 March 1973.

${ }^{1088}$ VOKS 6:2:66:252, Zabrodin to Carter, 20 Dec. 1974; VOKS 6:2:66:246, Carter to Andrei M. Ledovski, Vice-chairman, SSOD, Nov. 26, 1974.

${ }^{1089}$ VOKS 6:2:63:16, from Dyson Carter to Zabrodin, 25 May 1975; VOKS 6:2:63:15, Zabrodin to Carter June 18, 1973.
} 
Known as cultural attachés, and also at times as the First- or Second Secretary at the Soviet Embassy in Ottawa, the representatives of VOKS, and later SSOD, were most definitely also working on behalf of the KGB. In the context of the times, it could not have been any different. Working in a foreign country, performing daily tasks that required the individual to reach out to highly placed Canadian politicians and figures, as well as to contact "average" individuals, attempting at all times to encourage a more positive view of the USSR, these diplomats would necessarily have had to pass the highest degree of Soviet security, which was, of course, KGB-approved. Canadians who interacted with them may have been largely naïve in believing that such young, personable Soviet diplomats would not conform to the stereotypical view of post-war international relations, but in this, they were sadly mistaken. The interest taken by the RCMP in surveillance of Burdin and Tovstogan's contacts in Canada was certainly justifiable.

The RCMP attention to Dyson Carter was also reasonable, considering the kind of literature he was putting out. Taken separately, some of his articles appear benignly naïve, but read over long stretches, the anti-American and at times militaristic support of the USSR was really quite remarkable in its tone and content. He was successful in appealing to Canadians who were already looking for this type of radicalism, and who similarly wished to soften Western images of the USSR, to promote peace, and who admired the Soviet system. Judging from letters to the editor preserved in the Library and Archives collection, at times Carter's message fit well with the message individuals received from other pro-Soviet organizations within Canada, and at other times, readers were interested by the opportunities to contradict more mainstream views, published in 
the larger Canadian dailies. They were no doubt motivated by a sincere desire to see a different kind of international climate make headlines, and "friendship" probably made pro-Soviet political ideas more broadly palatable.

Dyson Carter was clever, and a skilled writer. In one of the earliest postwar

CSFS conventions, he bragged that

In the last 12 months, millions of Canadian men and women have learned the truth. According to the Gallup Poll early this month, 5 million Canadian adults believe the Soviet Union does not want war. A tremendous change, a complete reversal of public opinion has taken place in our country. A year ago a big majority of people felt that war was facing us. Today, a very large majority no longer believe this... ${ }^{1090}$

Besides citing a Gallup Poll to back up his claims, Carter referred to an editorial from the Globe and Mail, purposely choosing a conservative business paper to support his argument that Canadians want to see the USSR, and want to see it as a peaceful nation. ${ }^{1091}$ Carter immodestly claimed credit for these attitudes: "It is correct to say that "NEWS-FACTS" has played a part in changing public opinion in Canada."1092

The CSFS did, indeed, enlarge its membership. If, in 1949 when the CSFS was founded, there were only about sixty delegates, at the 1952 convention in Toronto Carter announced that there were 259 registered delegates, with 118 corresponding delegates from the United States, Yukon and Newfoundland, and 35 observers. ${ }^{1093}$ From a few readers in 1950, Carter could that year boast readers in every province and territory, as

\footnotetext{
${ }^{1090}$ VOKS 6:1:36:43-52, President's speech to 1952 CSFS convention, 25 January 1952.

${ }^{1091}$ Wellington Jeffers, "Finance at Large," Globe and Mail, January 4, 1952, p. 16. According to Carter, Jeffers "tries hard to distort Soviet achievements. But here is forced to say: '...I am quite sure that if competent observers could go into Russia, travel in every part of it, and see all as easily as they can on this continent, there would be much more willingness here to pay attention to Soviet bids for peace..."” ${ }^{1092}$ VOKS 6:1:36:59, President's Speech, Jan. 271952.

${ }^{1093}$ Ibid.
} 
well as in fourteen other countries, including the United States. ${ }^{1094}$ A poll in 1965 confirmed that Northern Neighbors was one of the most popular magazines amongst the youth of the Association of United Ukrainian Canadians, and anecdotal evidence suggests that progressives of all ethnic backgrounds found Carter's magazine to be inspiring.

The Mounties were correct when, in 1953, they reported that "it is clear that, as a communist front organization, the CSFS fulfill[ed] two functions in Canada. First as a clearing house for invitations for visits to the Soviet Union, and for the distribution of films, books, and propaganda literature produced in the USSR. Second, by directing or making available the cultural products of communist Russia..."1095 Probably the CSFS had some limited success also in "bringing to the fringe of communism groups of people across the Dominion...who may, in turn, become sympathetic to communist ideology, ${ }^{, 096}$ but more likely, the CSFS appealed to those who were already sympathetic to this cause. In 1963, the RCMP suggested that the Canada-USSR Association was similarly "designed to act as an instrument of the Soviet Government controlled through the apparatus of the $\mathrm{CP}$ of $\mathrm{C} . "$ Once more they were correct in their conclusion that the role of the SSOD was central, as it functioned "in part [as] a propaganda department whose purpose it [was] to encourage foreigners to think of the Soviet Union as a friendly and peace-loving country." 1097 In the context of those times, the CSFS and its successors did represent a considerable worry for the Mounties. In the end, however, the sympathy

\footnotetext{
1094 Ibid.

${ }^{1095}$ LAC, RG146, A200600091, RCMP report "The Canadian Soviet Friendship Society, February 1951 to March 1953. Addendum to Brief Ending February 1951," dated 15 April 1953, p. 116.

${ }^{1096}$ Ibid.

${ }^{1097}$ LAC, RG25, A200700336, RCMP Research Section report, "The Canada-USSR Association," 27 March 1963, p. 834-845.
} 
the Canadian-Soviet friends claimed to have generated for the USSR had few tangible consequences.

This project shows that the CSFS was sponsored and guided by the USSR for specific reasons. To appeal to a broader membership, the CSFS and its membership generally denied this link publicly, but since the Berlin Wall came down in 1989, Dyson Carter himself, and many of his associates, have admitted openly that the Soviets supported the group. Historians have largely ignored the CSFS, and, in fact, have paid far too little attention to the Communist front organizations and the role of fellowtravellers in Cold War Canada. Most likely this is because the documentation, and the will to do oral history, has been generally lacking. But documents from the collections of the RCMP, the Canadian Department of External Affairs, and the Moscow-based AllUnion Society for Friendship with Foreign Countries (VOKS, and later, SSOD) are now available for research, and some former participants have come forward to supplement the historical narrative.

Today, an historian can confirm that the RCMP was correct in labeling the CSFS a Communist front organization intent on persuasion and propaganda in Canada. Dyson Carter and his closest associates were well aware of police surveillance, and in some ways, welcomed the attention. Their literature and claims were such that they warranted observation, but they were not really dangerous. Their influence was one of persuasion, not revolution. The RCMP's concern that in the event of a Third World War these individuals may be on the wrong side $\mathrm{e}^{1098}$ did not materialize, but their assumption that the CSFS represented an extension of Soviet foreign policy-making was correct. It is, unfortunately, not possible to ascertain whether the RCMP acted on their conclusions in a 1098 Ibid. 
reasonable manner, because the documents they allowed to be released through Access to Information and Privacy are blacked out where description of action taken would have appeared. Certainly, Dyson Carter claimed he was beaten up at least once by police, Romeo T. Lafond complained the police had stolen his photographs of the USSR, ${ }^{1099}$ and others worried that the authorities were interfering in their personal affairs, but it has been impossible to prove or disprove many of these claims based on documentary evidence. However, it is clear that the intimidation the RCMP brought to principals was influential in Ted Baxter's decision to change jobs, and ultimately, to leave the CSFS. It was not, to be sure, the only influence in that decision.

The story of the CSFS and its successors adds to our knowledge of Cold War Canada, and also adds to our understanding of how some Canadians chose to negotiate their personal political beliefs. It is a story of propaganda and persuasion, of soft-power foreign influence in Canada, and individual Canadians' responses to that influence. As a mechanism for the dissemination of Soviet propaganda, the CSFS was effective among the believers in its narrow membership base, where the unwaveringly pro-Soviet message fell on sympathetic ears. In terms of persuasion, the CSFS was perhaps somewhat more effective in giving a public forum to those who would soften the hard edges of the Cold War, especially through cultural exchanges. From the Soviet perspective, it was a costeffective method of perception management, not unlike the Soviet friendship societies that were supported by Moscow in the United States, Britain, Belgium, France, New

\footnotetext{
${ }^{1099}$ VOKS 6:1:55:118-119, A. Tovstogan to G. Ioanisyan, 14 May 1957, detailing loss of photo album belonging to Romeo Lafond, who visited USSR with CSFS delegation in Sept. 1953. Lafond is described as "CSFS member and Labor-Progressive Party of Quebec provincial Committee member." Lafond suggested that the album was stolen from his car by a police agent, but it is not clear whether he meant an RCMP officer or the provincial police.
} 
Zealand, and elsewhere. ${ }^{1100}$ Apart from the VOKS representative's time, which he divided among other tasks, the cost of producing and shipping the materials, and the periodic hospitality provided to delegates, most of the work was done by Carter and other key Canadian members. Conveniently, Carter was not so naively idealistic that the twists in Soviet policy bothered him, and he took the required policy turns in 1956, 1968, and 1985 in step with the Soviet authorities. He also gladly supplied the Soviets with information he gathered; information that might otherwise have been difficult for a Soviet diplomat to garner himself. This is not to suggest that Carter had any particular access to secret information, but his prolific reports and letters show that he forwarded copious amounts of publicly-available information on Canadian living conditions, public opinion and the political situation to VOKS. Most likely the RCMP was unsure of how to handle such a character. In retrospective, the CSFS and Carter himself were never especially dangerous, but they were active agents in the Cold War interplay.

Focusing on the CSFS allows historians to recognize that its members were attempting to find a concrete example of a place where there were no gender, class and ethnic inequalities; an example that ultimately proved false, but which was, at one time, no less attractive an illusion for its falsity. The CSFS story suggests to historians the importance of not only considering class, gender, ethnicity and generation as categories of analysis, but also paying serious attention to ideology and perception. The CSFS story is also one of individuals re-evaluating their beliefs and their actions in light of another age: the Soviet Union is gone, and with it, the Cold War. Individual memories and perceptions have since changed, and we get a glimpse of these through oral history

${ }^{1100}$ The character and activities of these societies in their respective countries, the VOKS support they received, and the linkages between them, deserve further study. 
approaches. This project offers all of these stories, and for researchers aware of the power of narrative, memory and archival documents, it thus represents an important contribution to the historiography of the Canadian Cold War. 


\section{Appendix I. METHODOLOGY AND BIOGRAPHY TALKING BACK: INTERVIEWING CANADIAN-SOVIET FRIENDS: THEIR LIFE AND TIMES}

The individuals who agreed to be interviewed for this project were motivated to do so because they were offered a chance to "talk back" to the historical record. As Len Scher suggested in his oral history of Canadians who found themselves blacklisted during the Cold War, “...letting the victims speak for themselves lends an emotional quality to our picture of those times and brings the experience closer to the reader." ${ }^{1101}$ For this reason, the following discussion has been placed in an appendix, instead of as a chronological chapter. The information and the "emotional quality" that follow are relevant to the entire discussion of the CSFS, and deserve to be read in parallel to the discussion of its activities. In her exploration of the Jewish left in Toronto, Ester Reiter pointed out that the history of the UJPO has largely been forgotten because "the vision of this community is obliterated by the cruel facts that emerged about how life in the Soviet Union failed to present a more humane alternative to capitalist society." ${ }^{\prime 102}$ In other words, the dream was an illusion, and so the dreamers are forgotten. One might make this same point about the CSFS. It has not received much attention from historians. The following is an attempt to understand the motivations and desires the most active CSFS members brought to their work. When direct oral interviews were not possible, their memoirs were used, or interviews with friends and family were conducted about their involvement.

\footnotetext{
${ }^{1101}$ Len Scher, The Un-Canadians: True Stories of the Blacklist Era (Toronto: Lester Publishing, Ltd., 1992), p. 11.

1102 Reiter, "Secular Yiddishkait: Left Politics, Culture and Community," Labour/Le Travail, Spring 2002, $<\mathrm{http} / /$ www.historycooperative.org/journals/llt/49/05reiter.html $>$ (10 Jun. 2008), para. 35.
} 
In recent years historians have increasingly come to recognize the potential

offered them by oral history, but continue to be skeptical about how it works. ${ }^{103}$

Sensitivity to the importance of the kind of story told, as well as the relationship between

the interviewer and interviewee, has proven to provide an empowering experience, and an effective means of telling the stories of societies which have placed priority on oral tradition. ${ }^{104}$ Oral history can allow people who may not have chosen to write down their histories, or for whom the archives have not adequately collected material, to speak to the way their histories are told. ${ }^{1105}$ In terms of ethnic history, conducting interviews as a team has been shown to make recording these stories, in spite of language, culture and generational barriers, not only possible, but illuminating. ${ }^{1106}$ While the oral record may not always be absolutely "reliable in point of fact," it can tell us much about the meaning attached by participants to their experiences and memories of them. ${ }^{1107}$ This is particularly the case when the documentary evidence itself has a strong narrative behind the "facts." In the case of this project, the documents come mostly from the secret

\footnotetext{
${ }^{1103}$ See for instance, Gwyn Prins, "Oral History," in Peter Burke, ed., New Perspectives on Historical Writing (Pennsylvania: Pennsylvania University Press, 2004), p. 120-156; Donald Ritchie, Doing Oral History: A Practical Guide (New York: Oxford University Press, 2003). On the ability of oral history to "recover" past voices, see Franca Iacovetta, "Post-Modern Ethnography, Historical Materialism, and Decentring the (Male) Authorial Voice: A Feminist Conversation," Histoire sociale/Social History 32.64 (November 1999), p. 85-101; Joan Sangster, "Telling Our Stories: Feminist Debates and the Use of Oral History," Women's History Review 3.1 (March 1994), p. 5-28.

${ }^{1104}$ See especially Julie Cruikshank, The Social Life of Stories: Narrative and Knowledge in the Yukon Territory (Vancouver: UBC Press, 1998 "Images of Society in Klondike Gold Rush Narratives: Skookum Jim and the Discovery of Gold," Ethnohistory, 39, 1 (1992), p. 20-41; ); (in collaboration with Angela Sidney, Kitty Smith, and Annie Ned), Life Lived Like a Story: Life Stories of Three Yukon Native Elders (Lincoln: University of Nebraska Press, 1990).

1105 On this see Michael Riordon, An Unauthorized Biography of the World: Oral History on the Front Lines (Toronto: Between the Lines, 2004).

1106 Stacey Raeanna Zembrzycki, "Memory, Identity, and the Challenge of Community Among Ukrainians in the Sudbury Region, 1901-1939," PhD dissertation, Carleton University, 2007. Stacey Zembrzycki has written eloquently on the role her grandmother played for her during the interview stage as an entry into a community sub-group that was not open to her as a second-generation, non-Ukrainian speaker, and as a story-teller herself.

${ }^{1107}$ See especially Alessandro Portelli, "The Death of Luigi Trastulli: Memory and the Event," in The Death of Luigi Trastulli and Other Stories (Albany: SUNY Press, 1991), p. 1.
} 
archives of the Royal Canadian Mounted Police, who gleaned this information for surveillance purposes, and from the Soviet organization, VOKS, who had their own purposes in keeping these records. Narrative and selectivity are not used solely by those who engage in oral history.

In post-Cold War Canada, oral history has a special role. Today, people on whom police and government officials collected reports during the Cold War, and whose personal testimonies have not been fully recorded, can speak back to the documents and the narrative embedded in them. ${ }^{1108}$ In addition, some of the individuals who were personally involved in secret or semi-secret activities, can now feel free to speak openly about the past, without fear of repercussion. Documents attesting to details of these events have either been restricted or destroyed, so oral history can provide valuable information. This is a benefit to historians, as it contributes to the knowledge we have about the Cold War period, but it also complicates the task of understanding the significance of the events and interpretations of them.

Memory is notoriously fickle, especially when it comes to describing one's own life. And yet, it is in remembering, speaking and writing about our personal lives that history becomes most personal. The handful of surviving leading members of the Canadian Soviet Friendship Society and its successor, the Canada-USSR Association, are

\footnotetext{
${ }^{1108}$ Merrily Weisbord has explored this in her book on the Canadian Communist Party. Weisbord, The Strangest Dream: Canadian Communists, the Spy Trials, and the Cold War (Montreal: Vehicle Press, 1983, 1994). This spirit probably also accounts for recent autobiographies published describing childhood experiences in Communist households. James Laxer has written poignantly about the "secrets" in his household, and his struggle to rationalize his father's Stalinism in Red Diaper Baby: A Boyhood in the Age of McCarthyism (Douglas and McIntyre, 2004). In the American context, Kim Chernin describes how and why communists and Soviet sympathizers admired the USSR, and the ways narrative is constantly reformulated by the storyteller, the reader and the circumstance. Kim Chernin, In My Mother's House: A Daughter's Story (New York, 1983, 1994). Even the Royal Canadian Mounted Police are interested in hearing these stories, and reassessing the historical record. Recently an RCMP historian asked me if the CSFS members who were under police surveillance, knew that they were being tailed. Of course they did.
} 
living proof of this. Several of them are past the age of 90 , and remembering their activities and accounting for events in the 1950s and 1960s has special significance for them. In agreeing to be interviewed by an academic researcher, they have explicitly chosen to speak back to the way the story of the Canadian left has been told, attempting to influence the way it is remembered by others. They had a strong personal interest in ensuring that a 'truthful' version of the story was told, and they spoke to the kind of stereotypes held by most Canadians about Communists during the Cold War. In particular, they spoke about the symbolic significance the Soviet Union held for them on a personal level, and (re-)evaluated their admiration for the USSR from a contemporary perspective. Some want to see the USSR restored.

Several of these individuals maintain still that the USSR was at its highest point of influence and prestige under the leadership of Josef Stalin. But many have suffered disillusionment. John Boyd, who joined the Communist Party of Canada with Dyson Carter in 1931, has since 1968 come to question the link the CPC maintained with the CPSU, and feels that in this the Canadian Party erred. Each of the participants spoke about their life-long concern for the everyday lives of workers in Canada, who were vulnerable particularly when the economy failed as it had most memorably in the 1930s, and for whom the USSR seemed to represent an alternative socio-economic model. Rather than shadowy figures, they presented an image of Communists concerned about their fellow-man, however mistaken they may have been in believing that solutions to economic and social problems were found in Moscow. Each of them spoke about being part of a progressive Canadian community, where everyone one knows, whether family or friends, is a participant in events and a subscriber to left-wing publications. Movie 
nights, lectures and musical evenings were an opportunity to visit with friends in a welcoming, comfortable environment. Those individuals who left the LPP and its associated organizations after 1956, or after 1968, spoke of the sadness they felt in leaving the communities. None of the individuals who participated in the oral history component of this project question their liberal-leftist values, but some have come to question the naïveté of their own more youthful admiration of the USSR.

The interview participants were able to answer questions that otherwise may have gone unanswered, and to provide details that were not readily available from the documentary evidence. One of the first interviews conducted was with John Boyd, and he immediately explained how the Communist Party of Canada (or Labor-Progressive Party) supported its front organizations, of which the Canadian Soviet Friendship Society was one. He readily furnished copies of his personal correspondence with Dyson Carter attesting to Carter's CPC membership from 1931, and his later disillusionment with the Soviet cause. He corrected details of fact and tone in a manuscript derived from this project, as he has done voluntarily for others working on the history of the Canadian left. ${ }^{109}$ He suggested to his friend, Ted Baxter, that participating in the project was an interesting way to make a contribution, and would not, today, represent a danger. Baxter agreed. ${ }^{110}$

Speaking of events and times that were familiar to him, Boyd said factually that the VOKS contacts who provided material to many of the progressive organizations in Canada were KGB representatives, and gave details on the relationship between the LPP

\footnotetext{
${ }^{1109}$ John Boyd, comments on manuscript by Jennifer Anderson, April 2008; follow-up correspondence and conversation with Jennifer Anderson re: the CSFS. Boyd has been known to read and comment upon manuscripts dealing with the Canadian left written by other historians and researchers, as well.

${ }^{1110}$ Baxter had earlier made a contribution to Scher's The Un-Canadians, p. 219-223. In Scher's book Baxter did not speak about his involvement with the CSFS, but only his peace activism.
} 
and the Soviet Embassy that would be difficult, if not impossible, to find in any document. This did at times prove problematic. Boyd insists that he was not a member of the CSFS, and yet a list probably composed by Dyson Carter in 1951 includes his name. Ultimately, whether Carter found this claim to be convenient, or whether Boyd has possibly forgotten that he was briefly a member, the larger point is that the close relationship between all of the LPP-supported organizations in Canada, made his actual membership irrelevant. Most of these groups were working towards similar aims, and all were pro-Soviet. This brought members of each of the groups together for many different kinds of events, illustrated best by the 1954 Canadian concert tour of Soviet artists, sponsored by the CSFS. John Boyd was the Master of Ceremonies and the tour guide for this group, and as such he travelled with the Soviet performers, and made all of their arrangements for them. Much of the publicity was handled by the CSFS, and Dyson Carter was at the airport to greet the artists when they arrived in Canada. The ticketbuyers were mainly members of a wide range of ethnic progressive organizations and communities, as well as the LPP.

To tell the story of the CSFS, we need to know who the main characters were. Oral history, combined with the documentary evidence, allows the historian better access to this biographical information, but sadly it has not always been possible to locate the individuals or close relatives in order to conduct interviews. Unfortunately, one of the main actors in this story, Dyson Carter, passed away before this particular research project began, and so could not be interviewed. ${ }^{111}$ The RCMP, as well as the VOKS authorities in Moscow, collected some biographical information on the key players, although these sources, of course, recorded 'facts' that were deemed useful for their own

${ }^{1111}$ Dyson Carter died on 15 December 1996 in Gravenhurst, Ontario. He was 86 years old. 
purposes. For instance, we know that in 1952 well-known LPP activists, Dewar Ferguson and Romeo T. Lafond, were elected at the CSFS Convention as Vice-Presidents of the organization. However, we know little more than the RCMP did about why they were inclined to be so involved. Ferguson also organized for the Canadian Seamen's Union, which was supported by the LPP, and Lafond ran a camp in Quebec that the LPP Youth used for educational retreats. ${ }^{112}$ His letters to VOKS were often typed on Camp Lafond letterhead. The personal narratives of other key players have since been lost to historians, for various reasons. Although interviews with such individuals or their relatives would have added to this project, perhaps some ideas from the other interviews can be considered in terms of the motivations these individuals may have had for being involved in the CSFS.

Interviewing Dyson Carter today about his activities between 1949 and 1989 would have been most beneficial. An interview transcript does not exist, and yet, in his final years he produced a semi-autobiography which he considered to represent his own attempt to "speak back" to the story as it was being told. ${ }^{1113}$ Perhaps this written testament is more meaningful than an oral interview, in that Carter had built his career on his writing skills, and in this text he wove together his biographical details, impressions and disappointments. Carter had apparently planned to write a second biographical volume, bringing his life-story up-to-date, but if it exists at all, the manuscript has not been published, and its location is not known. Autobiography is written, of course, by

\footnotetext{
${ }^{1112}$ LAC, RG146, A200600091, RCMP report, "The Canadian Soviet Friendship Society, February 1951 to March 1953. Addendum to Brief Ending February 1951", Biographical Notes, dated 15 April 1953, p. 118120.

${ }^{1113}$ Dyson Carter, letter to John Boyd, 28 February 1990, from John Boyd's private collection.
} 
individuals who want to locate themselves in history, and must always be treated with caution, even skepticism.

Charlotte Carter died in 1972, and their son, Breck, could not be found, and may not have been interested in speaking to a researcher. But Carter's third wife, Sally Nielsen, daughter of Dorise Nielsen, who was one of the CSFS founding members, was interviewed for this project. ${ }^{1114}$ In addition, Irja Paul, who for years worked for and lived with Dyson Carter, agreed to an interview. ${ }^{115}$ John Boyd, who knew Carter from their earliest days in the CPC, spoke about the role played by Dyson Carter and the CSFS. ${ }^{1116}$ Ted Baxter, who for several years worked closely with Carter as the Secretary for the CSFS, has elaborated on his earlier memories of Cold War Canada, ${ }^{1117}$ and offered his perspective on the CSFS and his involvement in it. ${ }^{1118}$ Leslie Hunt, who took over from Carter as head of the CSFS in 1960 and who was in charge when the group was renamed the Canada-USSR Association, and Michael Lucas, who succeeded Hunt as President of the Association, have both been interviewed. ${ }^{1119}$ Irene Kon, daughter of Louis Kon, added notes in the margins of the police reports on her father. Today these notes function as a silent response to those who wrote the reports, and a message to historians using the documents. ${ }^{1120}$ In weaving together the oral testimonies and the written record, this

\footnotetext{
1114 Sally (Thelma) Nielsen, interview by author, 28 November 2006, near Lakefield, ON.

1115 Irja Paul (and Irene Kuusela and Marie Rempel), interview with author, 27 November 2006, Bracebridge, $O N$.

1116 John Boyd, interview by author, 2 August 2006, Toronto, ON; John Boyd, "A Noble Cause Betrayed... But Hope Lives On: Pages from a Political Life," originally published as Canadian Institute of Ukrainian Studies Report, no. 64, 1999; Socialist History Project, $\{$ http://www.socialisthistory.ca/Remember/Reminiscences/Boyd/B1.htm\}, accessed 25 August 2007

${ }_{117}$ Len Scher, ed., The Un-Canadians, "A Peace Activist and His Church: The Red Squad and the Divinity School," p. 219-223.

${ }_{1118}$ J.E. (Ted) Baxter, interview with author, 8 December 2006, Stratford, ON.

1119 Leslie Hunt, interview with author, 2 January 2007, Hanover, ON.

${ }^{1120}$ Irene and Louis Kon Collection (P162), Osler Library, McGill University, Montreal. This collection includes the RCMP file on Louis Kon, which his daughter Irene Kon obtained through Access to Information and Privacy, and deposited in the open collection at McGill.
} 
chapter attempts to give a voice to the participants themselves in telling the story of the CSFS. These are their stories.

Herbert Dyson Carter was born in 1910 in New Brunswick, moved to Winnipeg with his parents as a child, and died in 1996 in Gravenhurst, Ontario. In his autobiography ${ }^{1121}$ Carter explains how he came to an understanding that he was a "Red". His parents were active in the Salvation Army, and ran a reformatory school and residence in Winnipeg. Carter credits attempts by his parents to mediate between the youngsters accused of criminal activities, most of whom came from new immigrant, poor neighbourhoods, and the authorities' harsh and sometimes random reactions as providing the environment that radicalized him. He claims he was deeply influenced in seeing his parents, and especially his father, come to question whether religious faith was enough to effect real change in a society that clearly discriminated against women, non-AngloSaxons, and the poor. He explains that his respect for the Soviet Union came from a combination of socialist conviction and admiration for the scientific and technological advances made in the USSR. Later, this techno-utopian view of socialism at times set him apart from his Party peers, but he was held in high regard by Soviet authorities.

Carter was very well educated. Home-schooled and a voracious reader, he entered university years ahead of his peers, and studied science, eventually obtaining a Master's degree in chemistry and physics. ${ }^{1122}$ He was motivated by the desire to discover other cures that may be just around the corner; cures similar to the vitamin D that had

${ }^{1121}$ Dyson Carter, This Story Fierce and Tender (Gravenhurst: Northern Book House, 1986). This is an unusual autobiography because in the book Carter splits his own biographical details between two protagonists: "Dyson Carter" and "Elgin Morley". James Doyle has argued that this narrative technique allows an older Dyson Carter to reexamine his own youth. See James Doyle, Progressive Heritage: The Evolution of a Politically Radical Literary Tradition in Canada (Waterloo, 2002), p. 260.

1122 LAC, RG146, A200600091, RCMP report, "The Canadian Soviet Friendship Society, February 1951 to March 1953. Addendum to Brief Ending February 1951", Biographical Notes, dated 15 April 1953, p. 117. 
allowed him to finally leave his bed, where he had been imprisoned for years by osteogenesis imperfecta, and embark on a more independent life. His conviction that only in a socialist system could scientific discoveries have immediate impact on the lived experiences of all citizens may have been reinforced by the premature deaths of two women important to him: a first wife, around 1944 from a rare virus, and Charlotte, in 1972, from cancer. Carter also discovered another gift -- he could write with flair, yet in a way that made complex ideas accessible to the non-initiated. He used this talent for writing to flamboyantly praise scientific and technological advances, particularly those made in the USSR.

He was active for years on the left before heading the CSFS, and was known primarily as a writer with progressive views. An RCMP report written in 1953 said that Carter joined the Party in the 1946, ${ }^{1123}$ but according to Dyson Carter himself he joined the Communist Party of Canada in 1931, in the same Winnipeg group as John Boyd. ${ }^{1124}$ Carter published in Saturday Night and Maclean's, and his book Russia's Secret Weapon $^{1125}$ was noted by Canadian dailies. He was made a Fellow of the Royal Canadian Geographical Society in 1941 for his book on Canadian sovereignty in the North, entitled Sea of Destiny (1940). ${ }^{1126}$ In 1936, Carter wrote a story set in Canada for the Canadian Forum using the pseudonym "Jack Parr," 1127 but most of his fictional work was published in New Frontier, a Toronto journal that attempted to "integrat[e]

\footnotetext{
1123 Ibid., p. 117.

1124 The RCMP may have made this mistake because Carter belonged to one of the secret 'closed' Party clubs. Ibid., p. 117; Letter from Dyson Carter to John Boyd, 28 February 1990, in John Boyd's private collection; Interview with John Boyd, 2 August 2006, Toronto, ON.

1125 Dyson Carter, Russia's Secret Weapon (London, 1943).

${ }^{1126}$ Dyson Carter, Sea of Destiny: the Story of Hudson Bay, Our Undefended Back Door (New York, 1940).

1127 Jack Parr, "East Nine" in Canadian Forum (June 1936), p. xx; analyzed by James Doyle in Progressive Heritage, p. 105.
} 
Communist writing with the mainstream of Canadian culture." 1128 As a gifted orator and writer, at first his Party duties were mostly speaking and writing for the Party. In 1946, Carter moved to Toronto to work for new Communist daily, the Tribune. ${ }^{1129}$ During the summer of 1948 and 1949 he taught at the LPP Party Training School in Long Branch, Ontario. ${ }^{130}$ Well known Canadian progressive activists, like Quebec Communist Jeanne Corbin and Robert (Mendel) Laxer admired his work. A biography of Corbin notes that she was captivated by Dyson Carter's writings, and that the CSFS president and publicist "...offered hope to his many and faithful readers." $" 1131$ James Laxer has similarly described how his father, LPP organizer Mendel (Robert) Laxer, said Dyson Carter was “Canada's greatest novelist.".1132 In later years, many of Carter's books were translated into Russian and published in Moscow, and his articles were frequently featured in Soviet newspapers. $^{1133}$

Literary critic John Doyle has noted that when Dyson Carter proclaimed publicly in 1945 that he was a member of the LPP, ${ }^{1134}$ he was effectively "marking the end of his association with the mass media." "1135 Carter did, however, publish an article on heart

\footnotetext{
${ }^{1128}$ Doyle, Progressive Heritage, 104, 105.

${ }^{1129}$ Faith Johnston, $A$ Great Restlessness, p. 203.

${ }^{1130}$ LAC, RG146, A200600091, p. 117.

${ }^{1131}$ Andrée Lévesque, Red Travellers, p.168.

1132 James Laxer, Red Diaper Baby: A Boyhood in the Age of McCarthyism (Toronto, 2004), 25. Laxer's father was on the executive of the Labor Progressive Party until 1956.

${ }^{1133}$ References to his books being sent to the USSR, and their publication and review there are frequent in the VOKS documents. Carter received royalties for these Soviet published books. (VOKS 6:55:107, Carter to A. Tovstogan, 18 February 1957). A journalist for Canadian Press, G.W. Boss, once sarcastically commented to VOKS that there were other Canadian writers besides Dyson Carter, and asked whether there was any plan to publish their work in the USSR. (VOKS 6:45:99-105, Boss to Perevoschikov with responses from A. Denisov, head of VOKS, 24 February 1954). An interview with Dyson Carter appeared in the Moscow English-language newspaper, The New Times, 41 (October 1983), 27.

${ }^{1134}$ Carter did this by writing an open letter to Party leader Tim Buck, entitled "Dyson Carter Explains: Why I've Joined the LPP", published in the Tribune on 15 December 1945. (Doyle, Progressive Heritage, 224.)

${ }^{1135}$ Ibid.
} 
disease and new transplant treatments in the Toronto weekly, New Liberty, in $1952 .{ }^{1136}$ Although Carter claims that he was ostracized by the mainstream press because of his political views, ${ }^{1137}$ he no longer needed that outlet. He worked for the LPP on publicity throughout the late 1940s, until the founding of the Canadian Soviet Friendship Society at the request of the LPP in $1949 .^{1138}$ By the 1950s Carter was on the LPP National Executive. ${ }^{1139}$ In addition, the combination of his radical politics, writing talent and interest in the Soviet Union brought him to the attention of Soviet authorities, ${ }^{1140}$ who assured him an audience until he stopped publishing in 1989.

Perhaps because he was so often laid up in bed, cared for by young women who appreciated his wit, Carter learned that he had a certain charm with women. He claims in his memoirs that his first sexual experience was with an adolescent who lived in the Salvation Army shelter, and who was regularly asked by his parents to keep him company. Far from taking advantage of her, Carter describes their relationship as one involving equal, consenting individuals, if not adults, seeking pleasure. ${ }^{1141}$ At university, Carter describes himself as something of a Casanova, able to attract women with his talk of how "love" can save the world. Later he refers to certain Party insiders advising him to calm his love life down. In his autobiography, he has one of his "motherly" Party figures say of him, "Many a time I thought he was a son-of-a-bitch" because of his sexual

\footnotetext{
${ }^{1136}$ Dyson Carter, "How Not to be Afraid of your Heart," New Liberty, August 1952, p. 22-23, 62-63.

1137 Carter, This Story Fierce and Tender, inside title page, p. 537.

1138 Faith Johnston, A Great Restlessness: The Life and Politics of Dorise Nielsen (Winnipeg, 2006), p. 225-226.

${ }^{1139}$ RCMP excerpt of the Telegram, 24 March 1952, LAC, RG146, A200600101, p. 92.

${ }^{1140}$ VOKS 5:3:31:206-211, Biography and Itinerary of Dyson Carter Trip to USSR, April 1950; LAC, RG146, A200600101, translation of Vladimirov and Erde, "Exposed Provocation," Ogonyok, no. 37, September 1952, p. 125; VOKS 6:41:5-8, K. Perevoschikov, Review of Carter's 1943 biography of Josef Stalin, 13 April 1953.

${ }^{1141}$ Dyson Carter, This Story Fierce and Tender (Gravenhurst: Northern Book House, 1986), p. 46. Occuring in the book on the same day as "Elgin" receives news of the February Revolution dethroning the Russian royal family, this incident appears to be exaggerated.
} 
promiscuity. ${ }^{1142}$ Today, his former comrades remember him still variously as a "womanizer" and a man with an enormous sexual appetite, surrounded by beautiful women, or as a "horrible man."

As is the case while reading most of Carter's writing, it is difficult to sort fact from fiction. For example, it is not clear how many times Carter was married. In his memoirs, he describes his first wife, "Shirley Anne Northway," as a nurse whom he claimed to have met in Winnipeg in the mid-1930s while he was in the hospital after having been beaten up. Carter inferred that it was the police who had beaten him up for being a "red." 1143 They were married secretly because their acquaintances feared her family would not approve of Dyson, but "Shirley" died soon after from encephalitis, caught from a patient. ${ }^{1144}$ This first marriage has not been confirmed by other interviewees. There may have been another short-lived marriage after this one. In 1944, Louis Kon sent his congratulations to Dyson and "Lina," 1145 but this marriage may have been annulled. ${ }^{1146}$ Dyson (re-)married soon afterwards to Charlotte Breckham Carter, who from then on co-authored his books, and ran his publications when he was injured. ${ }^{1147}$ Many acquaintances spoke admiringly of Charlotte Carter, her patience and her willingness to put up with Dyson, who was apparently a very difficult man. In 1953, they had a son, Breck. At first it seemed that Breck did not suffer from the same

\footnotetext{
1142 Ibid., p. 541.

1143 Ibid., p. 471-473.

${ }^{1144}$ Carter, This Story Fierce and Tender., p. 472-494.

${ }^{1145}$ Letter from Louis Kon to "Dyson and Lina- Lina and Dyson," 3 April 1944, Louis and Irene Kon fonds, Osler Library, McGill University, P162, Folder 1.19. In his "autobiography" Carter appears to refer to this woman as "Eleanor." Carter, This Story So Fierce and Tender, p. 555-556.

${ }^{1146}$ Sally Nielsen, correspondence with Jennifer Anderson, 23 June 2008.

1147 In 1957 Charlotte Carter took over the editorial work for Northern Neighbors, as Dyson Carter was in hospital. VOKS 6:55:150-151, letter A. Tovstogan to G. Ioanisyan, 31 May 1957. Previously much of this work may have been done by Jim Leech and Ted Baxter, who were CSFS secretaries, but both of these men left in 1956 following the announcement of the XXth Party Congress speech by Nikita Khrushchev, and other international events of that year.
} 
condition as his father, ${ }^{1148}$ but as he aged it became apparent that he did. On one trip to Crimea, the waves crashing on the beach broke Breck's leg. ${ }^{1149}$ The Carters were perhaps typical of Party families, in that they occasionally traveled on Party business, but otherwise were able to work from home. When they were away, young Breck was often cared for by Dorise Nielsen's daughter, Sally. Later, when Breck was a young man, Sally remembers that father and son would sometimes have passionate arguments, and that Dyson was as arrogant with his son as he was with others in his life. ${ }^{1150}$

When the LPP replaced Dyson Carter as head of the CSFS with Les Hunt, Carter continued to publish Northern Neighbors. John Boyd insists that although Carter had had a falling out with the LPP leadership, the Soviet Embassy in Ottawa continued to support him financially and in other ways. ${ }^{1151}$ Boyd said that the Party had tried to convince the Soviet Embassy to let Carter go, but the Soviet authorities found him too useful to their own cause, and continued to honour him as a special guest to Embassy events. More euphemistically, Les Hunt said that the LPP had decided Carter should concentrate on publishing, and allow someone else to handle the Friendship Society. ${ }^{1152}$ Sally Nielsen, Carter's ex-wife, has said that the Embassy personnel paid him in cash for his services. ${ }^{153}$ The popularity of Northern Neighbors, with a readership that although progressive, was not always drawn directly from the LPP membership, was one reason

\footnotetext{
${ }^{1148}$ VOKS, 6:47:76, letter Dyson Carter to K. Perevoschikov, 20 October 1954; VOKS 6:50:111, letter Carter to Perevoschikov, 12 November 1954.

${ }^{1149}$ Michael Lucas, interview by author, 27 July 2006, Toronto, ON.

1150 Sally (Thelma) Nielsen, interview with author, 28 November 2006, Lakefield, ON.

1151 John Boyd, interview with author, 2 August 2006, Toronto, ON; comments on manuscript by Jennifer Anderson, April 2008.

${ }^{1152}$ Leslie Hunt, interview with author, 2 January 2007, Hanover, ON.

${ }^{1153}$ Sally (Thelma) Nielsen, interview with author, 28 November 2006, Lakefield, ON.
} 
why Carter was untouchable. ${ }^{1154}$ The move to Gravenhurst in 1957 may have been partly a result of Dyson Carter's illness. ${ }^{155}$ The Carters remained in touch with VOKS for materials, and continued to visit the USSR from time to time.

Some years after Charlotte Carter died from cancer in 1972, Irja Paul ${ }^{1156}$ was listed on the masthead of Northern Neighbors as "executive secretary." However, she said this was "just a fancy name he gave me," and her real tasks were to keep house for him and help him with administrative tasks. They were also lovers. Irja Paul and her daughter Irene Kuusela have fond memories of both Dyson and Charlotte Carter, and also recall with pleasure Irja's trips to the USSR, accompanying Dyson. They enjoyed receiving Northern Neighbors, and Irja in particular spoke about the significance of being a member of a progressive community and family circle. To be born into a progressive Finnish family in Sudbury necessarily meant that she had been familiar with Dyson Carter, and CSFS-sponsored movie nights and other such events from childhood. ${ }^{1157}$ She said that Carter had investments on the stock exchange, built with royalty payments that allowed him to charge minimal rates for the magazine subscriptions. In his memoirs, Carter also makes reference to investments on Bay Street, and how during the Depression he had learned how to play the markets.

\footnotetext{
1154 John Boyd, interview with author, 2 August 2006, Toronto, ON; A survey of young members of the Association of United Ukrainian Canadians in 1965 found that many of them read Northern Neighbors. LAC, RG3120-0-6-E, Association of United Ukrainian Canadians (AUUC) fonds, Vol. 27, file 14, 15. ${ }_{1155}$ VOKS, 6:1:56:24-25, Carter to Kolmakova, 10 September 1957; VOKS, 6:1:55:150-151, 161-163, letter Tovstogan to Ioanisyan, 31 May 1957; Tovstogan to Ionisyan, 13 September 1957; VOKS, 6:1:56:1819, 24-25, letter Charlotte Carter to Kolmakova, 11 June 1957; Kolmakova's reply to Charlotte Carter, 21 June 1957.

${ }_{1156}$ Irja Paul grew up in the Finnish community in Timmins. Her first husband, Bob Paul, had been the campaign manager and common-law partner of Dorise Nielsen for some time in the 1940s. Bob Paul had known Dyson Carter at that time, and later on he and Irja occasionally visited the Carters in Gravenhurst. (Johnston, A Great Restlessness, 47, 123, 203; Irja Paul (and Irene Kuusela and Marie Rempel), interview by author, Bracebridge, ON, 27 November 2006.

${ }^{1157}$ Irja Paul (and Irene Kuusela and Marie Rempel), interview by author, Bracebridge, ON, 27 November 2006.
} 
When his relationship with Irja Paul ended in 1980, Carter employed Sally Nielsen as his secretary, and they were married in 1981. Sally had known Dyson and his family for years, but was not sure that her mother, Dorise, who by then had passed away, would have been pleased to know she had married her friend-turned-rival. ${ }^{158}$ She recalled with sadness the tragic effects of the Depression in Canada, and speaks with pride of her mother and Dyson's efforts to find a better solution through the progressive movement. In the 1980s, Sally ran the office for Dyson, did the banking, and occasionally wrote pieces for Northern Neighbors. She remembers that Carter would periodically receive cash payments brought to Gravenhurst in briefcases when Soviet embassy personnel would visit. On these occasions, Carter always went into the office and closed the door. Once, the Soviets asked whether she would like to also become more involved in the work he was doing, she refused saying that she had enough to do in keeping house for Carter, looking after him, and managing the secretarial duties for Northern Neighbors. Some of her memories of Dyson Carter may be coloured by difficulties in their marriage. Today, Sally remembers him as an angry, stubborn man, who would simply turn off the lights to win an argument, an effective way for him, as a lip-reader, to refuse to listen. Dyson and Sally were divorced in 1988 on acrimonious terms, because according to Sally, he refused to share his unofficial income with her. ${ }^{1159}$ After Sally left, Dyson Carter's name remained alone on the editorial page of Northern Neighbors until its last issue in December 1989.

One of Dyson Carter's closest colleagues in the early days of the CSFS was Dorise Nielsen. Like Carter himself, she was gone before this project was begun, and so

\footnotetext{
1158 Sally (Thelma) Nielsen, interview with author, 28 November 2006, Lakefield, ON.

1159 Ibid.
} 
direct oral interviews with her could not be undertaken. Fortunately for the historical record, a biographer, Faith Johnston, has conducted wide-ranging interviews with her children, as well as her colleagues and friends. In addition, Dorise had been preparing a biography of sorts, and her daughters have made notes on this, and this interactive document is preserved today in the collections of Library and Archives Canada. Despite her political affiliations, Dorise's daughter, Sally, is uncomfortable calling her mother a "communist." She prefers to use the term "progressive.",

Born in 1902 in London, England, Nielsen emigrated to Canada in 1927 with a teacher exchange programme called the "Fellowship of the Maple Leaf," organized by the Church of England. ${ }^{1161}$ While teaching, and then raising a young family in Saskatchewan, Nielsen became active with farmer's movements during the Depression. The RCMP reported that she was expelled from the CCF in 1939 for her efforts to merge the party with other left-wing groups, including Communists, and say that "soon after she secretly joined the Communist Party of Canada." ${ }^{1162}$ Her biographer writes that Nielsen and her good friend and political collaborator, Bob Paul, were probably "courted by communists who recognized their ability and their legitimacy in the English-speaking community. This period of courtship may have occurred early in the 1930s, but more likely it took place in 1934 or 1935 when the communist push to unite the left began." 1163 In 1940, Nielsen was elected as an independent Member of Parliament for the North Battleford, Saskatchewan riding. In 1943 she became an executive member of the Labor-

\footnotetext{
${ }^{1160}$ Ibid.

${ }^{1161}$ LAC, RG146, A200600091, RCMP report, "The Canadian Soviet Friendship Society, February 1951 to March 1953. Addendum to Brief Ending February 1951", Biographical Notes, dated 15 April 1953, p. 121. 1162 LAC, RG146, A200600091, p. 121.

1163 Johnston, A Great Restlessness, p. 47. Irja Paul was married to Bob Paul before she became Dyson Carter's partner.
} 
Progressive Party, and in the 1945 federal election she ran on the LPP ticket. ${ }^{164}$ When she was not re-elected, she moved to Toronto to do work for the Party. That work often involved touring with Dyson Carter, promoting the Party, Party-backed campaigns, and its publications, National Affairs Monthly and the Tribune. In 1946 when the news finally hit the headlines that Igor Gouzenko had defected, naming Fred Rose and other key personnel in Ottawa as Soviet spies, Nielsen was touring the country with Dyson Carter.

Nielsen was not present in November 1949 for the founding of the CanadianSoviet Friendship Society because she was in Moscow attending a conference hosted by the Women's International Democratic Federation, another organization supported by the LPP. ${ }^{1165}$ However, on her return in January 1950 she immediately began a tour of Western Canada, together again with Dyson Carter, to drum up support for the newlyreformed Friendship Society. She was elected CSFS national secretary in $1952 .{ }^{1166}$ While Executive Secretary, she did most of the organizational and publicity work, arranging tours, visits and attempting to have new branches set up. Carter was responsible for editing News-Facts and corresponding with VOKS, but by 1953 Nielsen was complaining resentfully that Carter was "managing the organization like his own private fiefdom." 1167 In addition, she was bothered by the fact that Carter was receiving a higher salary than she was. She was disappointed by the treatment the Party gave her; using her as a spokesperson, but not giving her the plum jobs. ${ }^{1168}$ Her Party colleagues did not value her leadership potential, arguing that she was "'not theoretically

\footnotetext{
${ }^{1164}$ LAC, RG146, A200600091, p. 121.

1165 Ibid., p. 121.

1166 Ibid., p. 121.

1167 Johnston, A Great Restlessness, p. 231.

1168 Ibid., 230-231.
} 
developed," and labeling her a populist. ${ }^{169}$ Faith Johnston has noted, "in a Marxist party, populists are regarded as rather fuzzy-headed individuals." ${ }^{\prime 170}$ She resented the fact that the Party had passed her over in favour of James Endicott for leadership of the Peace movement, and in favour of Dyson Carter for the Friendship Society. In 1953, Nielsen resigned from the CSFS, and Ted Baxter took over most of her work. The Party did not offer Nielsen a better post. In 1955, she left Canada for Britain where she hoped to find a more satisfying role, and in 1957 went to China, where she lived the rest of her life doing publicity work for the Mao regime. When Dyson Carter criticized her in 1962 for her pro-Chinese, anti-Soviet views, Nielsen called him "'the highest-paid Soviet agent in Canada.""1171

Ted Baxter has said that in the summer of 1953, Stanley Ryerson, historian and leading theorist for the Labor Progressive Party, approached him and asked him to take over from Dorise Nielsen as National Secretary of the CSFS in Toronto. ${ }^{1172} \mathrm{He}$ joined the team in October 1953, and in November of that year gave a talk to a Hamilton CSFS book club about his 3 -week trip to the USSR as a Canadian youth group member. ${ }^{1173}$ Baxter said he was paid $\$ 40$ a week for his CSFS work from 1953-1956, although at one time there were not enough funds to pay him, so he split his time between the CSFS and the Canadian Peace Congress.

During his time with the CSFS, Baxter counts the reception organized for Ambassador Chuvakhin at the Royal York Hotel in Toronto the major success. In his

\footnotetext{
${ }^{1169}$ Interviews conducted by Faith Johnston with Norman Penner and William Kashtan in 1988, as cited in Johnston, A Great Restlessness, p. 229.

1170 Ibid., p. 229.

1171 Ibid., p. 262.

1172 J.E. (Ted) Baxter, interview with author, 8 December 2006, Stratford, ON. Dorise Nielsen resigned from the CSFS in the summer of 1953, in 1955 went to England for some time, and in 1957 to China. She died in 1980 in China. (Johnston, A Great Restlessness, 231-237).

${ }^{1173}$ VOKS 6:45:109-114, Ted Baxter, 6 November 1953.
} 
personal collection he has a photograph of himself with Soviet Ambassador and Mrs. Chuvakhin and First-Secretary/VOKS representative, Vladimir Burdin and his wife at the reception. Baxter said that at first the Royal York had refused to host this reception, but when Dyson Carter wrote directly to the head of Canadian National Railway and Canadian Airways, which company was hoping to get landing rights in Moscow, the CSFS received permission to host a reception for the Soviet ambassador at the exclusive hotel. Baxter also remembers the visit of Soviet performing artists in 1954 as a highlight of his work with the CSFS: "everybody agreed that this visit was really a great success," he said. ${ }^{1174}$ It was "a first step in cultural exchange between the two countries" and may have "set the stage for Glen Gould's visit to the USSR" in 1957, he added. ${ }^{1175}$ On this trip, John Boyd traveled with the artists across Canada. Boyd and Baxter had first met on their trip to China in 1952, and Baxter said that Boyd, as Secretary of the Slav Committee, and an activist in the LPP and AUUC, was a skilled spokesman and Master of Ceremonies. Baxter also visited the Soviet embassy in Ottawa with Dyson Carter every 7 November. ${ }^{1176}$

Baxter understands the mandate of the CSFS to have been "to show Canadians the Soviet Union in a positive light because there was no shortage of people showing it in a negative light," and particularly to show "the human side" of life in the USSR. ${ }^{1177} \mathrm{He}$ said they were "not suggesting Canada should have a Soviet style government," but that

\footnotetext{
1174 J.E. (Ted) Baxter, interview with author, 8 December 2006, Stratford, ON.

${ }^{1175}$ Ibid.

${ }^{1176}$ Ibid.

1177 Ibid.
} 
there should be trade, cultural exchanges, and increased contact between the two countries in order to break down Cold War tensions. ${ }^{1178}$

What motivated Baxter to become involved with the CSFS and the Canadian left in the first place? He prefers to say that he was a "fellow traveler" rather than a Communist, because he was never actually an LPP member. He was attracted to socialism because of its similarity to the Christian Social Gospel he had absorbed as a child and young man. Born in 1927 in Charlottetown, Prince Edward Island of Scots-Irish ancestry, Baxter's father was a minister with the United Church of Canada, and young Ted aspired to become a minister himself. He said that growing up they did not have very many luxuries, kept a cow and chickens, and had a garden. In the fall of 1944 he went to Mount Alison University to do a Bachelor of Arts in humanities, and he became involved in the Student Christian Movement there. He was interested in the progressive Social Gospel message of the United Church, not "fundamentalism". The Student Christian Movement sponsored discussion groups and work camps every summer. In 1947, Baxter participated in one of these in Montreal, where he was employed in a paint factory. Again in 1949, Baxter worked in Montreal, where he met activists on the Canadian left. Baxter said that he was impressed and attracted to the individuals he met through these experiences, many of whom were intellectuals, deeply interested in world events, demonstrating against sending arms to the nationalist Chinese forces led by Chaing Kaishek, for example. ${ }^{1179}$

In the summer of 1950, the National Federation of Labour Youth (the "successor" of the Young Communist League) organized a group to go to Europe. Six young people

\footnotetext{
${ }^{1178}$ Ibid.

${ }^{1179}$ Ibid.
} 
including Guy Caron (leader of the LPP) and Ted Baxter went on this trip. In France they contacted left-wing groups, and again in Italy. In Prague, there was a congress of students organized by the International Union of Students -- all were sympathetic to the USSR and the Eastern bloc. Then the group went to Poland, and eventually to the USSR where they spent three weeks visiting Moscow and surroundings and Stalingrad. They visited factories and state and collective farms, and attended ballets at the Bolshoi. Ted Baxter has a photograph album of this trip, containing the fond memories he has of this experience. He said that the people they met in the USSR "were not trying to proselytize," but the tour was well-organized. They attended a church service, and met university students.

Baxter felt the attraction of the USSR was that it had apparently been successful in improving education and medicare. On gender equality, he said that in the USSR there were more female doctors than male, at a time when things were quite different in Canada. He said that many Soviet-admirers "chose not to be aware of the negative," although 'DP's' "were talking about how terrible it was there." After Khrushchev's 1956 speech was made public most everyone realized that Josef Stalin was a paranoid personality, he said. However, he added, during the Civil War in 1919 many Western countries did send armies into the USSR, so to some degree it was natural that the USSR felt it was surrounded by enemies. Mr. Baxter understood VOKS to be exclusively a "cultural organization and we [the CSFS] were a cultural organization so it made sense for them to help us in a cultural way." He said that VOKS sent boxes of books that the 
CSFS sold, but did not send cash. He referred to Vladimir Burdin as the cultural attaché at the Soviet embassy in Ottawa. ${ }^{1180}$

In the academic year 1950-1951, Baxter was enrolled in the theology programme at McGill University, Montreal. He was late starting in the fall because he had been in Europe. He didn't finish this degree, at least partly because the "powers-that-be" in the faculty "were quite upset" about his trip to the USSR, and "thought I was going to be a troublemaker." 1181 During the year, Baxter invited a friend to talk about a visit to China at a United Church youth group meeting, and the "Red Squad" came into the church. Mr. Baxter explained that "Red Squad" referred to the Quebec provincial police officers who, dressed in plain clothes, attended peace meetings "to keep track of the "reds." 1182 Soon after, a university official called Mr. Baxter into his office, and said that the police had told them that Mr. Baxter was a communist. When Baxter asked what evidence they had of this, and commented that the university should be asking the police why they are "barging into a church young people's group," he may have been asked to leave the programme. ${ }^{183}$ In any case, Baxter realized that the church was not going to offer him the career he wanted. ${ }^{1184}$

Friends he had in the LPP helped Baxter find work. For a time he had a summer job as a program coordinator at CSFS member Major R.T. Lafond's youth camp, sponsored by the LPP, which was held at an estate in Quebec. At this camp, Baxter met

\footnotetext{
${ }^{1180}$ Ibid.

${ }^{1181} \mathrm{Ibid}$

${ }^{1182} \mathrm{Ibid}$.

${ }^{1183}$ Baxter cannot himself remember whether the decision was made by the university official, or whether he left of his own volition. (Ibid.)

${ }^{1184}$ For a discussion of the RCMP surveillance of meetings at the United Church of Canada, see Reg Whitaker and Steve Hewitt, Canada and the Cold War (Toronto, 2003); Steve Hewitt, "Sunday Morning Subversion: The Canadian Security State and Organized Religion in the Cold War," in Richard Cavell, ed., Love, Hate and Fear in Canada's Cold War (Toronto: University of Toronto Press, 2004), p. 57-74..
} 
his wife, Barbara. Later, Baxter worked for a company in Montreal that imported records, and his employer was a wealthy man who contributed financially to the LPP. And then in 1953, he joined the CSFS. The VOKS documents, as well as the records kept by the RCMP, attest to the prolific nature of his work. Baxter wrote frequently to CSFS members and subscribers, alerting them to interesting events and promotions, and coordinating these same events.

But in 1956, things changed for Ted Baxter. In reference to the events of that year, Baxter said "everything fell apart, blew apart." ${ }^{185}$ Many in the Montreal LPP left the movement, including Guy Caron, and especially the Jewish members, some of whom were Ted Baxter's friends. Baxter said, "it didn't bother me as much as others -- some felt very guilty for having involved other people. I hadn't done anything that was injurious to anyone or to Canada." 1186 But coincidentally at this time, Ted and Barbara Baxter had decided to adopt twin boys, and he thought it best for his family to distance himself from the movement. He became a high school teacher of French, first in Port Perry on Lake Scugog, then in North York. Baxter's VOKS Bulletin subscription, and presumably his subscription to the CSFS publications, was cancelled in August $1956 .{ }^{1187}$ While teaching in Port Perry, the principal once said to him that the board would not renew his contract, and that he had better resign. This principal made some reference to Herbert Norman, the Canadian diplomat who had recently committed suicide after having been accused of being a Communist, and warned Baxter that he would not want the same thing to happen to him. Baxter resigned from that school, and the family moved to North York. In North York, once the principal called Baxter to the office, where there

${ }^{1185}$ J.E. (Ted) Baxter, interview with author, 8 December 2006, Stratford, ON.

${ }^{1186}$ Ibid.

${ }^{1187}$ VOKS 6:49:232-237, list of VOKS Bulletin subscribers, August 1956. 
were two plain clothes police officers to speak to him. They asked Baxter about whether he was involved in an automobile accident, which he denied. He then went back to class, and there was no further development in this incident, but Baxter thinks they were simply identifying him. He said that perhaps the principal decided that since his politics were not affecting his work, there was no reason to do anything. But still this constant surveillance bothered him. ${ }^{1188}$

Ted Baxter did experience further effects of his "radical youth" later in life. In the late 1980s, he was not allowed on a flight to the U.S., and later was questioned when crossing the border by train. He had never had any trouble crossing the border by car. Later, he wanted to fly to visit people in Seattle, Washington, so he drove to the U.S. border and asked the border officer to tell him if he would be allowed to do so, before he bought the ticket. The border officer went into a back room, and another officer came out to speak to Baxter. He said that judging from what he had seen, he would allow Baxter to go, but another border officer might not. He advised Baxter to phone a certain number in Toronto. Baxter later did this, and was assured there was no longer a problem, and he traveled to Seattle without incident. He figures he was on an old list prohibiting him from entering the United States, and with a simple phone call, his name had been deleted from this Cold War relic. In 1986, Baxter retired from teaching, and a few years later moved to a quieter life in Stratford, Ontario. Asked about whether he thought his activities were dangerous at the time, he said that all young people do something dangerous. He said that he and his wife had not raised their children in any particular way ("did not brainwash them"). Mr. Baxter has been active in the New Democratic Party for a long time, and although noting that the Communist Party still exists he did not ${ }^{1188}$ J.E. (Ted) Baxter, interview with author, 8 December 2006, Stratford, ON. 
seem to consider it a viable political option, and he said of the NDP that "this is all we have." Asked about regrets, Mr. Baxter said only that he might have got a scholarship to do further studies.

Leslie Hunt took over the management of the CSFS successor group in 1960 . He was an electrician from Toronto who had been active in the Party for some time before. Soon after he was asked by the Party to lead the group, its name was changed to the Canada-USSR Association, to allow members to join without feeling that they necessarily had to be 'friends' of Communism. ${ }^{189}$ This was part of the Society's appeal to a broad, mainstream audience. Hunt said the point was to make the Society more like a business that imported and sold movies and slides, where people did not have "to smile all the time." He said that some people told him they were relieved that they could now participate, since they would no longer be known as Soviet "friends."

Hunt referred explicitly to his own name and manners, claiming that his British accent and Anglo-Saxon name helped him book both halls in Toronto, and speakers for Association events. One specific example Hunt gave was in booking Farley Mowat for a talk in the late $1960 \mathrm{~s}$. He said he was "able to talk to the bourgeoisie, to school teachers," and argued that this was easier for him than others in the Party because "English people have certain habits not imitated by Slavs." He noted that this had been established earlier, too, since "Dyson Carter called himself 100\% Canadian." He said

\footnotetext{
${ }^{1189}$ The RCMP believed this to have been a CPC decision, but the initiative may have come from Moscow, since Tim Buck had been there to discuss the plans. LAC, RG25, A200700336, RCMP Research Section report, "The Canada-USSR Association," 27 March 1963, p. 834-845.

${ }^{1190}$ Leslie Hunt, interview by author, 2 January 2007 , Hanover, ON.
} 
that he "made decisions and called them group decisions." He had two or three trusted people helping him, including Bert Kenny and Michael Lucas. ${ }^{1191}$

Hunt was born in 1910, the same year as Dyson Carter, and immigrated to Canada from Britain at age 10 as a "Barnardo boy." 1192 .He said that his experiences on farms around Peterborough taught him that adults were against the youth, and he became a rebel. Eventually, just as the Depression began, he ran away to Toronto. This experience radicalized him. At first he attended youth group meetings at Carleton United Church in Toronto, where he met "others like him", who later were called the "ecclesiastical politicians." Hunt remembers that "being a left-winger wasn't loony in those days," when middle-class people found themselves hungry and on the streets. He did Party work, publishing together with John Boyd, and learned the electrical trade. During World War II, Hunt was a technician responsible for radios and batteries, and later became director of army education in his unit, "but not without opposition." He said that it had been decided that soldiers should study literature and language, and he became the corporal in charge of education in current affairs. He said that he was monitored because they knew he was "red." After the war, he disapproved strongly of Churchill's 1946 Iron Curtain speech at Fulton, Missouri, where he said that Churchill proved himself to be a "mortal enemy of the USSR." He said that at that time he was fortunate he had no family, and could attach himself to anybody. At one time Hunt lived in North York on

\footnotetext{
${ }^{1191}$ Ibid.

1192 There were about 30,000 children brought to Canada from Britain between the mid-1800s and 1914 by British philanthropist and pedagogist, Dr. Thomas Barnardo. They were often called "home children," and were used as cheap labour on farms and as domestic servants. On the conditions in which the Barnardo children lived, see Gail H. Corbett, Nation Builders: Barnardo Children in Canada (Toronto: Dundurn Press, 2002). For a more admiring view of Barnardo see John Wesley Bready, Doctor Barnardo:

Physician, Pioneer, Prophet, Child Life Yesterday and Today (London: Allen and Unwin, 1932).
} 
Maple Leaf Drive, and he remembers that house as "a place for revolutionaries to come to. $" 1193$

After the war, Les Hunt married twice and had five children. Besides running his electrical business, he organized Marxist schools for the Party. He advertised his business in the souvenir brochures published by the Party and the 'progressive, ethnic' groups. He said he found it easy to make money, and shared it with the less fortunate. Asked if he raised his children differently because of his values and he said, "no, I just did it better." He said he did not systematically teach them his values, that he doesn't "hide or parade" his views. But he was able to protect his children from capitalism, which he said meant ensuring that they had houses for themselves. He said that now it has been "made impossible for workers to buy houses," and that he had foreseen this eventuality. But his views on gender relations could be described as traditional. He said that he is in favor of only one member of the family working, that women should be educated, but can work only with additional help or after the kids have grown. He said that in the old days people would praise women by saying how clean they kept the house. He did not consider "house-keeping skills" to be much of a compliment.

The archives of the Canada-USSR Association are still held in private collection by Michael Lucas, and the Robert S. Kenny collection at the Thomas Fisher Rare Book Library in Toronto does not contain many documents related to the Society. However, Kenny and Lucas are mentioned in the VOKS collection at Georgian College: documents that originated with the Soviet organization, SSOD, which was the successor of VOKS. Robert Kenny died in 1993, but Michael Lucas remains active. He still heads up an organization called the International Council for Friendship and Solidarity with Soviet

${ }^{1193}$ Leslie Hunt, interview by author, 2 January 2007, Hanover, ON. 
People, which advocates the re-establishment of the Soviet Union, and publishes a journal called Northstar Compass. His wife, Helen Lucas, serves as financial secretary on the editorial board of the magazine.

Les Hunt claims that the Canada-USSR Association was practically defunct by the mid-1980s because the Gorbachev reforms made such an organization redundant, but Lucas says he took over in the 1960s when Hunt failed to keep a pro-Soviet demonstration in Toronto from becoming a target of "right-wing" groups. Lucas said, "After that I was asked by Bill Kashtan ${ }^{194}$ to come to a meeting and he said, 'Michael, you have to take over the Canada-USSR Association.' And they got rid of Leslie Hunt. I said, 'Why?' and they said, well, obviously this was not handled the right way, and me, being naïve, I took it over." 1195

Lucas was born in the Czechoslovak Republic in 1926. His name is listed as art director for Northern Neighbors in 1956, but at that time his name is spelled "Lukac" and pronounced "Lukach." Lucas said that he was related to General Lukac, head of the international brigade during the Spanish Civil War, but he changed his name in Canada because Canadians found it hard to pronounce. ${ }^{1196}$ Since they were from the Czech region of the Carpathian Mountains, Lucas said his family became associated with the Carpathian-Russian groups in Canada soon after their arrival in 1939. Lucas was an active member of the youth groups, and played music for concerts and dances organized by the 'progressive, ethnic' groups in Toronto. He became a graphic artist, and worked in the advertising business. Lucas worked for Southam Publications for years, but was

\footnotetext{
${ }^{1194}$ William Kashtan (1909-1993) succeeded Leslie Morris as general secretary of the Communist Party of Canada from 1965 to 1988.

${ }^{1195}$ Michael Lucas, interview by author, 27 July 2006, Toronto, ON.

1196 Ibid.
} 
asked to leave after his boss had been visited by RCMP officers, he said. From that time on, he ran his own advertising agency, specializing, he said, in subliminal ads. ${ }^{1197}$

He was a member of the Central Committee of the Communist Party of Canada at one time, but said he left the Party in 1970, when his "views were not accepted." Lucas thinks this is because he was in favour of pan-Slavic Communist groups in Canada, and wanted the groups to hold property in common -- for this he was called a "liquidationist" by the Party leadership. He maintained that the Ukrainian, Russian, Polish, Jewish, Carpatho-Russian and other groups should pool their resources and buy one big property which would include classes and performances from all Slavic cultures. This suggestion was rejected. The appeal of the Friendship Society for Lucas was its potential to unite all progressive-minded Canadians in one group. He praises Dr. A.J. Thut, whom Lucas says almost unilaterally funded Dyson Carter and his own Friendship Society activities in the interest of seeing a pan-Canadian, pro-Soviet, socialist Society. ${ }^{1198}$

Lucas is now head of the Russo-Carpathian Society, and it is in their premises that the Canada-USSR Association met from around 1981 until the demise of the Soviet Union. Lucas said that in 1991 there were 8000 members of the Canada-USSR Association. He admires Stalin, and thinks that Khrushchev's 1956 decision to distance the USSR from Stalin's legacy meant moving it away from true socialism. He thinks Gorbachev is a traitor for having allowed the USSR to crumble. The fact that this is also the official Russian Communist Party position today is appropriate, as Lucas maintains links with Communists in Russia. Predictably, Lucas is not a fan of current Russian Prime Minister, Vladimir Putin, and claims a caricature he once drew of Boris Yeltsin led

\footnotetext{
${ }^{1197}$ Ibid.

${ }^{1198}$ Ibid.
} 
to his being escorted from Russia by authorities. Since then Lucas has not been able to travel to Russia, as the Russian authorities refuse to grant him a visa. ${ }^{1199}$

Asked whether he and Helen Lucas raised their children differently than their neighbours because of their political beliefs, Lucas answered, "they were raised the same as my father raised me, that there is a much better world, that socialism is the only answer, because capitalism with all its hype and the things they've done- that's it... We raised [them] as a family that believes in the future of the world." He said that his daughter's teacher once called him and his wife in to the school to discuss the fact that his daughter had defended 'communism.' He praised his daughter for her courage, and claims that he never hid his political beliefs from others. On whether gender relations within their own marriage were different because of their involvement in the progressive movement, he said, "Well, basically, the people who came in as couples -- they thought the same way. Very few instances that a man and a wife, or a friend, would be in the opposite poles politically. So this is why it was always -- it was accepted, it was only natural, it was a family unit, that's right. The children would come... This is why, as I told you, I proposed that the progressive groups should join together. That's where people met and inter-married or whatever. It was natural. We met here at this organization, that was it."1200 Helen Lucas remains involved in the running of the current Soviet Friendship Society. As financial director, Helen Lucas made a passionate appeal for donations at the last International Council convention, and recently sent a special letter to the readership asking for donations to keep the Northstar Compass afloat.

\footnotetext{
1199 Ibid.

${ }^{1200}$ Ibid.
} 
From its earliest days the Soviet Friendship Society was intended to unite Canadians on the left in admiration of the USSR. It is not coincidental then, that the most prominent members were of Anglo-Celtic origin, or chose a less 'foreign'-sounding name. John Boyd, who was an active participant in CSFS events in the early 1950s, was born Boychuk, and explained that he was asked by the leadership of the Communist Party to change his name so that he would have greater influence in wider Canadian society. Boyd has argued that the Canadian Communist Party skillfully managed its supported organizations, like the Friendship Society and the Peace groups, to create the illusion of independent, non-partisan progressivism. Dyson Carter and his predecessors, Frank and Libbie Park, were amongst the best at this, Boyd says, because they were seen by outsiders to be suitably 'Canadian'. ${ }^{201}$ Although the cultural events offered by the CSFS attracted Canadians who had recently immigrated from Eastern Europe and who often had developed socialist ideals, ${ }^{1202}$ the leaders were invariably chosen for their clear, unaccented speech and Anglo-Celtic names. ${ }^{1203}$ The exception to this was the "Canada-

\footnotetext{
${ }^{1201}$ John Boyd, interview with author, 2 August 2006, Toronto, ON. The role of the Parks in the immediate post-war National Council for Canadian Soviet Friendship is discussed in the chapter on the pre-1949 Soviet friendship societies.

${ }^{1202}$ Since 1943, the RCMP had been remarking on the ethnic character of the Canadian-Soviet Friendship events, and in relation to a wartime rally, reported that " $80 \%$ audience foreign extraction." The Soviets, too, were unhappy with the fact that most of the LPP members were of Ukrainian-Canadian extraction, and officials in the Soviet Embassy in Ottawa were suggesting ways to reach out to more 'mainstream' Canadians. LAC, RG146, A200600124, RCMP Intelligence Branch, Toronto, 25 June 1943, "Re: RallyMaple Leaf Gardens, Toronto, Ont. June 22nd. 1943," p. 49; VOKS, 6:3:98:5-20, V. Loginov, Advisor, Soviet Embassy in Ottawa, "Short Report on the 5th Congress of the Labor Progressive Party of Canada and Its Post-Congress Work with the Masses", 19 March 1955. Loginov was expelled from Canada in 1961 for attempting to pay Canadians for information.(Department of External Affairs, Canadian Weekly Bulletin, 20 December 1961, p. 5.) John Boyd, an active LPP organizer until 1968, has also written about the LPP's inability to effectively reach Anglo-Saxon Canadians. "John Boyd, "A Noble Cause Betrayed... But Hope Lives On: Pages from a Political Life," originally published as Canadian Institute of Ukrainian Studies Report, no. 64, 1999; Socialist History Project, \{http://www.socialisthistory.ca/Remember/Reminiscences/Boyd/B1.htm\}, accessed 25 August 2007. ${ }^{1203}$ On how this was also attempted in the Housewives' Consumers Association, see Julie Guard, "Canadian Citizens or Dangerous Foreign Women? Canada's Radical Consumer Movement, 1947-1950" in Marlene Epp, Franca lacovetta, Frances Swyripa, Sisters or Strangers? Immigrant, Ethnic, and Racialized Women in Canadian History (Toronto, 2004), 161-189.
} 
URSS" Society founded in Quebec in the 1960s, while the Quebecois population was experiencing the Quiet Revolution. Early on, the President of this Society was Adelard Paquin, a francophone dentist from Montreal. ${ }^{1204}$

When in 1990, Carter expressed his disenchantment with the whole Soviet project, and his own writings, he wrote John Boyd: "I am not 'bitter' about it, but simply disgusted. I publicized so many Soviet 'achievements' that were total falsifications."1205 He said that he had been offered a contract to continue publishing Northern Neighbors in Russian and English from Moscow, as well as a "big book business" in Canada, but he wrote, "I couldn't accept, because of the work involved, but mainly because I want nothing to do with the ridiculous efforts to restore 'socialism' in USSR and other places." ${ }^{206}$ John Boyd too, has written about where Canadian Communists went wrong. In "A Noble Cause Betrayed" and in interviews Boyd has argued that the admiration of the Soviet Union by the Canadian left was a mistake. ${ }^{1207}$ Others, like Les Hunt and Michael Lucas, continue to maintain that the USSR under Josef Stalin was worth admiring. Lucas advocates the re-establishment of the Soviet Union as Chairman of the Toronto-based International Council for Friendship and Solidarity with the Soviet People. When asked about the way they raised their children, Soviet Friendship Society activists each noted that they tried to instill in their children a motivation to work towards

\footnotetext{
${ }^{1204}$ I have not been able to reach Adelard Paquin for an interview. He remains a convinced MarxistLeninist. He is the French language editor for the Northstar Compass, published by the International Council for Friendship and Solidarity with Soviet People in Toronto, and has recently referred to the "temporary collapse of the Soviet Union." (Dr. Adelard Paquin, "Editorial," Northstar Compass, vol. 16, no. 2, October 2007, p. 3.)

${ }^{1205}$ Letter from Dyson Carter to John Boyd, 28 February 1990, in John Boyd's private collection. ${ }^{1206}$ Ibid.

${ }^{1207}$ John Boyd, interview by author, 2 August 2006, Toronto, ON; John Boyd, "A Noble Cause Betrayed...But Hope Lives On: Pages from a Political Life," originally published as Canadian Institute of Ukrainian Studies Report, no. 64, 1999; Socialist History Project, $\{$ http://www.socialisthistory.ca/Remember/Reminiscences/Boyd/B1.htm $\}$, accessed 25 August 2007.
} 
a better, more just future society, but couched this in traditional terms. Association with the Society and other progressive groups was described as social and cultural, not only political. Based on their own experiences in youth and their adult activities, one might expect them to have spoken about the importance of Marxist lessons, books, and camps to their own children, ${ }^{1208}$ but instead this was minimized, and the interviewees spoke of the "normal" childhood they had offered their kids. Efforts were made to persuade me that the women were 'normal' mothers and wives. Still, the children of those involved with the Friendship Society all appear to have remained active in the progressive movement, whether or not today associated with the Communist Party of Canada. ${ }^{1209}$

Oral history interviews have allowed some of these individuals to "speak back" to the way Communists were portrayed by RCMP and newspaper sources. Each of the individuals interviewed for this project attempted to make his or her political engagement understandable in post-Cold War terms: referring variously to Christian or left-liberal values like gender, class and ethnic equalities. Some have attempted to put their ideas in the context of their times: growing up in the Depression years was considered to be a formative influence for many of them. But it is most particularly John Boyd who has spoken openly about revising the historical record. In commenting on parts of this

\footnotetext{
${ }^{1208}$ On growing up in radical homes in Canada and the United States, see Weisbord, The Strangest Dream (1983, 1994); Kim Chernin, In My Mother's House (1983, 1994); Paul C. Mishler, Raising Reds: The Young Pioneers, Radical Summer Camps, and Communist Political Culture in the United States (New York: Columbia University Press, 1999); Laxer, Red Diaper Baby (2004); Johnston, A Great Restlessness (2006); Julia L. Mickenberg, Learning from the Left: Children's Literature, the Cold War, and Radical Politics in the United States (New York: Oxford University Press, 2006).

${ }^{1209}$ Irene Kon was one of the most active members of the Communist Party of Canada in Montreal. Libbie Park's son, Raymond Boyer, served two years in prison for his role in passing information to the USSR, and his widow, Marguerite Taliffer, is active in the organization founded in Montreal by Stanley Ryerson, LPP theorist. Unfortunately it has been difficult to learn much about Breck Carter, but it is known that he met his wife, Bonita Carter, at a Labor picnic. Sally Nielsen is sympathetic to the left, although she does not maintain contact with the Communist Party of Canada. Ted Baxter's sons are members of the New Democratic Party. Michael Lucas says that his children are interested in his work, and associated with the Russo-Carpathian Society.
} 
project, he has pointed out that the VOKS contacts at the Soviet Embassy in Ottawa were also working for the $\mathrm{KGB}$, a fact that can be gleaned from the documents, but is nowhere printed in black-and-white. He has also spoken about the way the Communist Party of Canada backed more "mainstream" front organizations, and the reason they failed to make an impact: they were too obvious in their support, and too obliging in relation to the policy directives from the Soviet Union. His political activism, his acquaintance with those who, from within or on the margins of the CSFS, attempted to make the USSR more attractive to Canadians, and the subsequent tendency to reassess this activism, make John Boyd a study in "talking back" to Cold War historical narratives. For all of these reasons, it should no longer be possible to tell a Cold War tale without including an oral history component.

What does reading against the grain of "memoirs" and interview transcripts tell the historian that the police and organizational records do not say? These sources speak to motivation. They speak most importantly to individual attempts to make a limited difference in the world. But they also tell us that, for all their idealism, the CSFS leaders were people of their times. The leaders of the CSFS and its successor organization have been almost exclusively male, Anglo-Saxon and mostly working class intellectuals. Many of them came to the communist movement through church groups, and speak of the appeal of the Social Gospel. However, they turned to Marxism, and particularly the Soviet interpretation, as a more "scientific" conceptualization of the ideals they had found influential as children. While women often served as assistants, particularly for secretarial and accounting tasks, only Dorise Nielsen ever seriously rivaled a leader's charisma. This is not particularly surprising, as several participants pointed out that the 
CSFS leaders were appointed precisely because they could appeal to a larger Canadian public by virtue of their 'mainstream' identity, and for their service to the Party. Women were active in the CSFS in other ways. As has been noted in relation to the Communist Party of Canada more generally, they succeeded in carving out niches for themselves as speakers, delegates and feminist activists, as long as they did not challenge the leadership.

Using this approach we can get a sense for how CSFS activists themselves understood their participation, their idealism as projected onto the USSR, and the way this changed over the years. We can sense the pathos some of them feel today when they think about the Soviet "achievements" they helped publicize in Canada, and their disappointment that equality and social justice were neither attained in the USSR, nor fully in their own country. Even if admiration of the USSR proved to be woefully misplaced, and today we recognize that the CSFS' claims were false, we can also recognize that many members sincerely sought progressive, alternative living patterns, were concerned for the poor and underprivileged, and were hoping for equality and peace. We can also get a sense of the pride they felt and the courage they had in taking an active role, insisting that individuals could make change happen. And although their dream evaporated, they dared to believe that good relations with the USSR were possible at a time when many were doubtful. Their radicalism was a combination of ideology and circumstance, and their activism was important to the Canadian left and the Soviet authorities during the Cold War. 


\section{Appendix II \\ PHOTOGRAPHS AND ILLUSTRATIONS}

Image 1. Illustration from the Programme of the NC-CSF Congress,

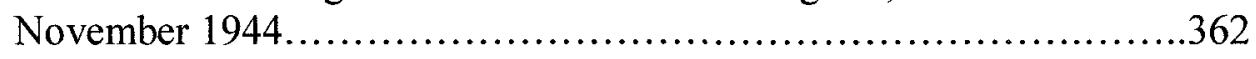

Image 2. List of Patrons of the NC-CSF Congress, 1944_..........................363

Image 3. National Executive of the wartime NC-CSF, $1944 \ldots \ldots \ldots \ldots \ldots \ldots \ldots \ldots . \ldots \ldots 4$

Image 4. Photographs of Dyson Carter and Dorise Nielsen...........................365

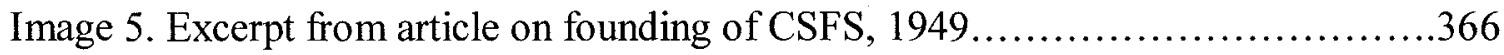

Image 6. Advertisement for Dorise Nielsen's CSFS publicity tour, 1950_...............367

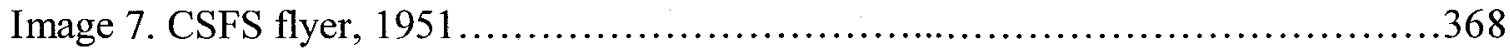

Image 8. Excerpt from article on Dorise Nielsen speaking tour, $1952 \ldots \ldots \ldots \ldots \ldots \ldots . . . . .369$

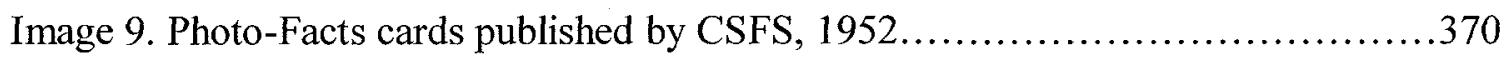

Image 10. Excerpt from article on Dyson and Charlotte Carter with photo, $1952 \ldots \ldots . . .371$

Image 11. Cover of CSFS booklet, Canadians Visit Our Northern Neighbours, 1953...372

Image 12. Photos clipped from newspapers on CSFS-sponsored exchanges, 1954_.....373

Image 13. Photo of guests at CSFS banquet in honour of D. Chuvakhin, 1954 _.........374

Image 14. Photo clipped from newspaper on CSFS speaking tour, $1955 \ldots \ldots \ldots \ldots \ldots . \ldots 375$

Image 15. Header of News-Facts and cover of first issue of Northern Neighbors........376

Image 16. Excerpts from Northern Neighbors, 1957................................377

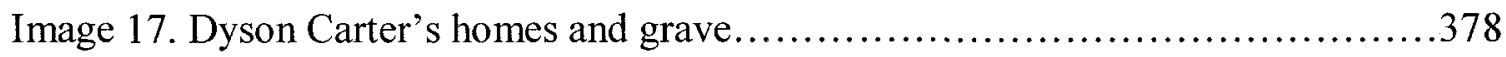




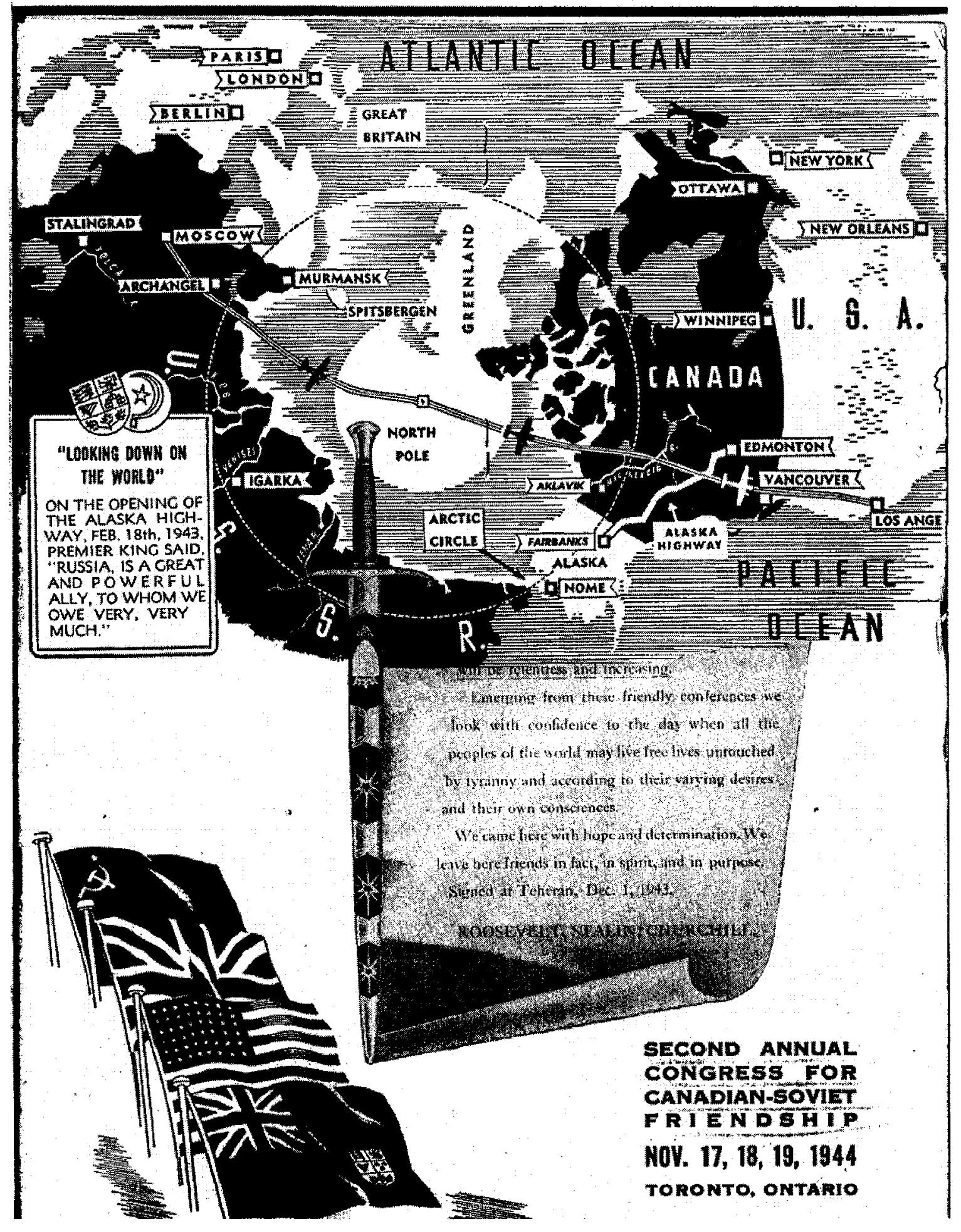

Source: LAC, RG146, A200600097, from the programme of NC-CSF Congress, November 1944, p. 190. 
List of Patrons attached to invitation to NC-CSF Congress, dated 27 October 1944. Source: LAC, RG146, A200600097, p. 147.

\section{P A T R O N S}

LTEUTENANT-COVERNORS:

Hon. Albert Matthews (Ontario) Major-Gen. Hon. Sir Eugene Fiset Lt,-Col Fon, Henry E. Kendall Lt.-Col. Hon; W. G. Clark (New Hon. F. F. McWilliams (Manitoba) Lt.-Col. Hon W. C. Woodward Fon Bradford w. LePage (Prince Hon. Archibald P. McNab (Sas-

Hon: John Campbell Bowen

Privie MINISTERs:

The Rjght fon W. I. Mackenzie Hon. George A. Drew (Ontario) Hon. A Stirling Maclumian (Nova Hon. J. B. MeNair (New Brunswick

Hon. Stuart S. Garson (Manitoba) Hon. Jolan fiart (British Columllon. William J. Patterson (Sas-

CHTEF JUSTICES:

The Ft. Hon. Sir Lyman Poore Hon. Severin Ietourneau (Quebec) Hon. Sir Joseph Andrew Chisholm

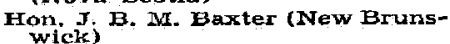
Fon James E. P. Prendergast Hom. David A. MacDonald (GritHon. Thane A. Campbell (Prince Fon. W. Melville Martin (SasHon. Horace Harvey (Alberta)

Water Abel

W. F. Angus Armstrong

J. E. Atkinson

John Basset

M. Banker. Bates

DeGaspe Beaubien

Perey Belmap Bengough

A. B. Bennett

Aoting Surgeon-Captain Charles $H$.

Andre Bieler

Prof. H. E. Blgelow

W. D. Bassey

John Boyd Dracken

Air-Marshal $L . S$. Breadner

Dr. Horace L. Brittain

John A Brockie

Sirsul Elizabeth Brown

John W. Bruce

Very. Rev. D. Pete

Staniey Burke

W. Ki. Burnel

John Burns

G. I. Burton

E. L. Bushnell

Morles Canlisie

Dyson Carter

Mine. Pierre E. Casgrafn

P. A, Cheste

Brooke Claxton, M.P.

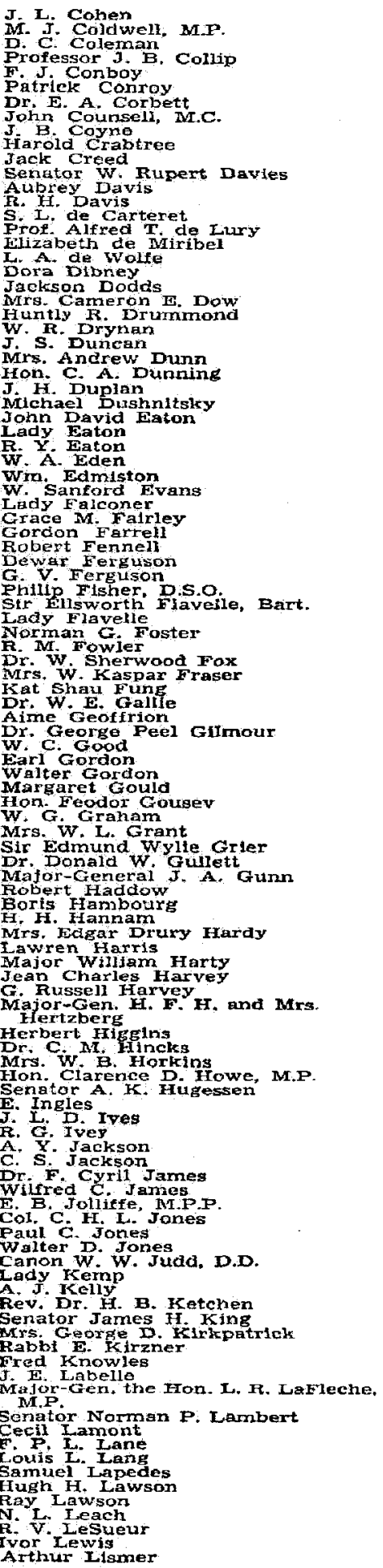




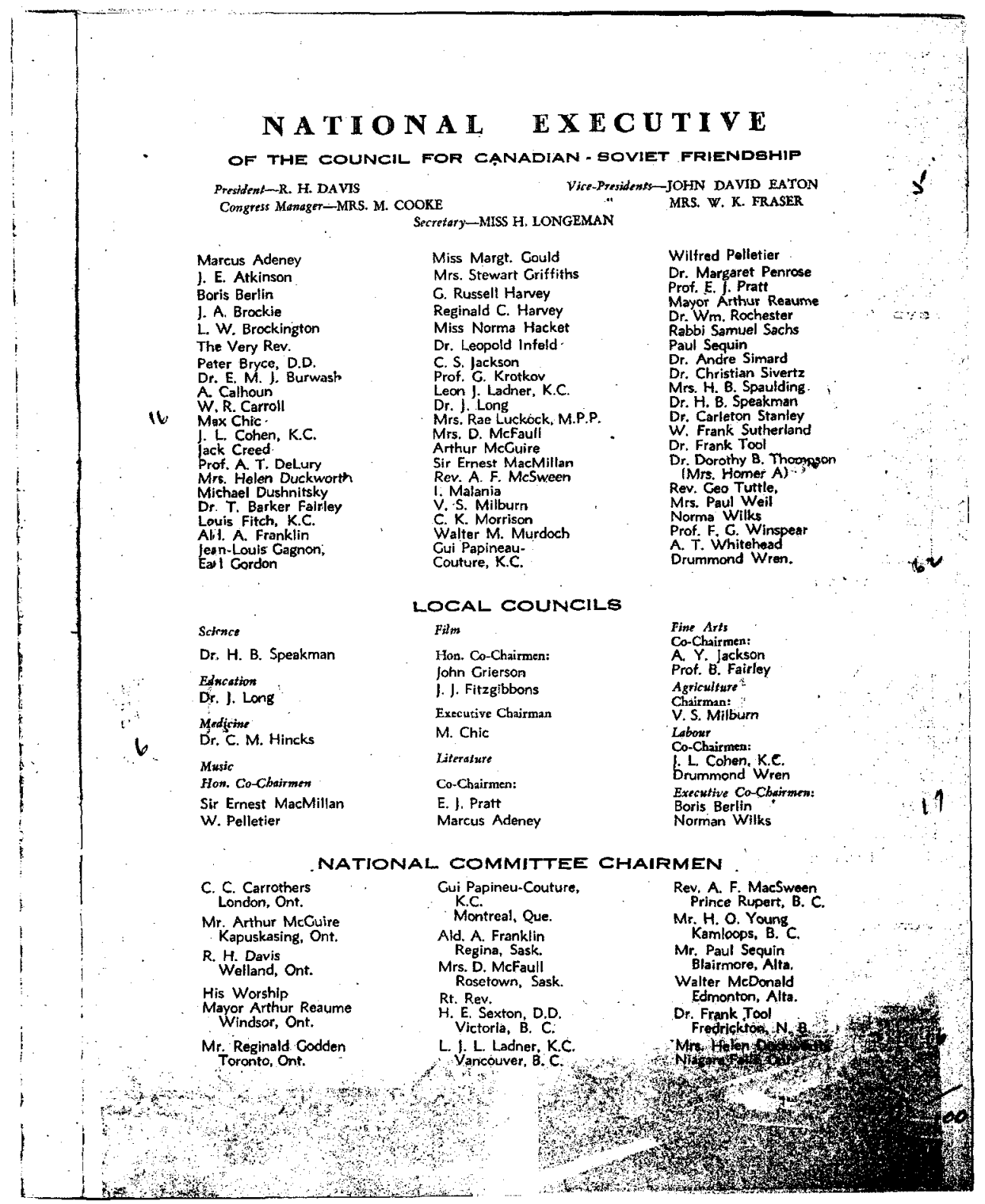

Source: Programme for the Second Annual Congress of Canadian, Soviet Friendship, November, 1944, LAC, RG146, A200600097, p. 202. 


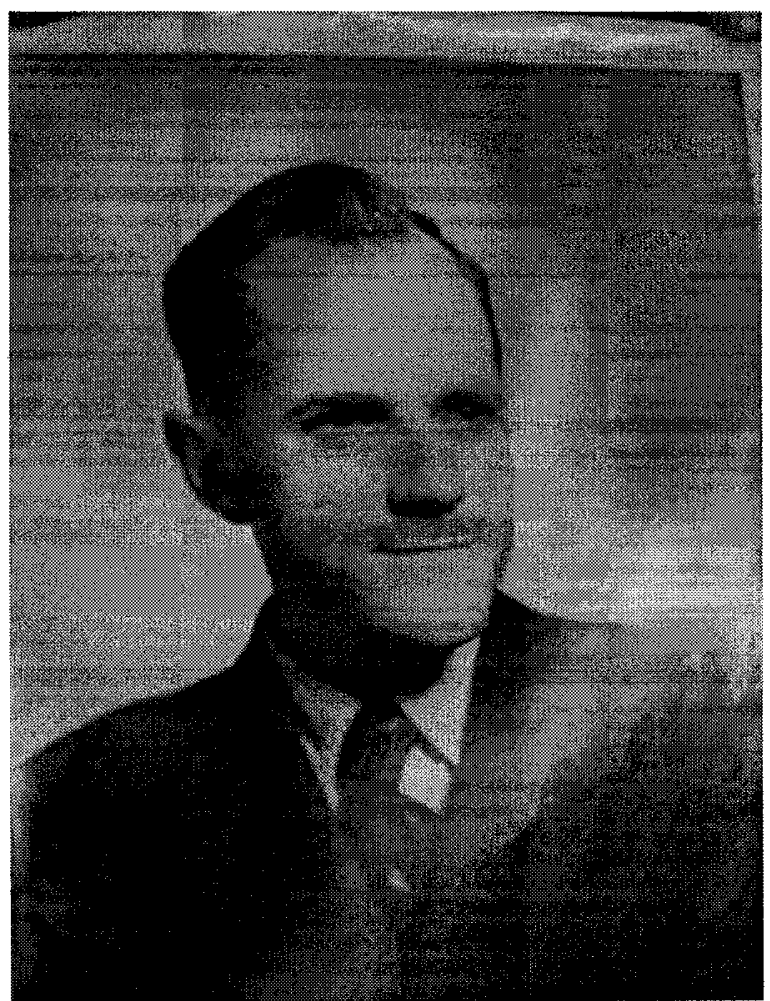

Dyson Carter, n.d.

Source: Robert. S. Kenny Collection, Thomas Fisher Rare Book Library, University of Toronto, MS Coll. 179, Box 63a.

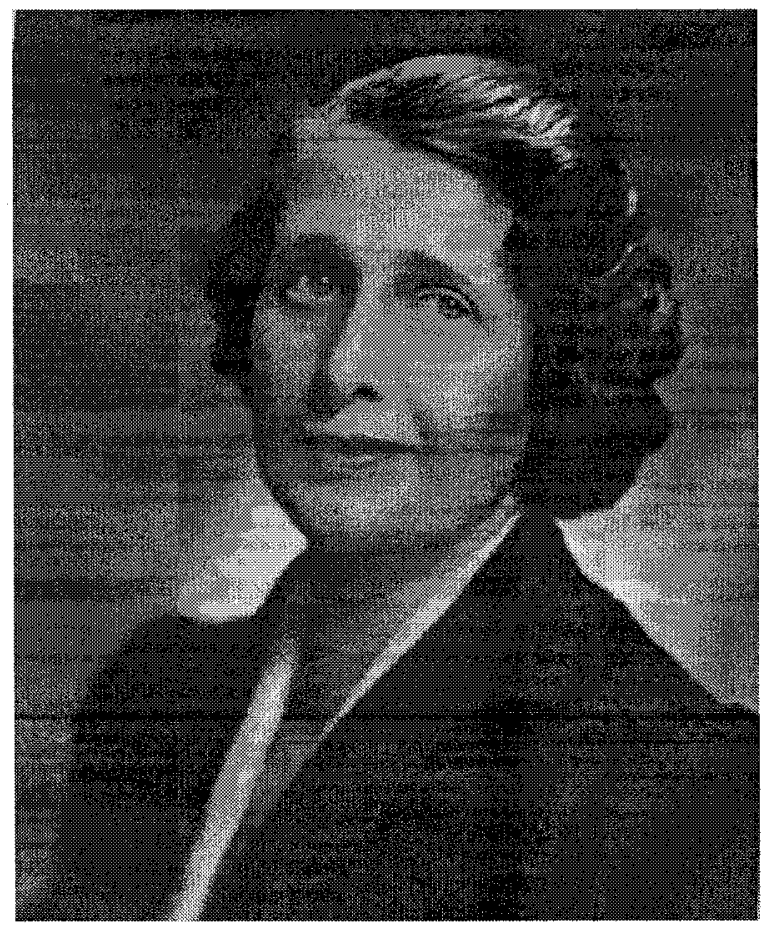

Dorise Nielsen, 1940

Photo by Yousuf Karsh, courtesy of the Canadian Museum of Civilization Corporation 


\section{$\operatorname{rin} 5 \quad 1949$ \\ CANADIAN TRIBUNE
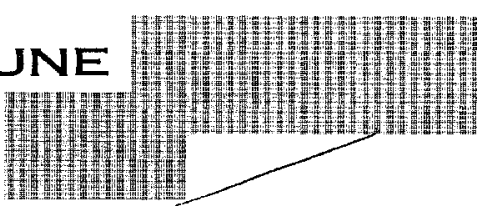

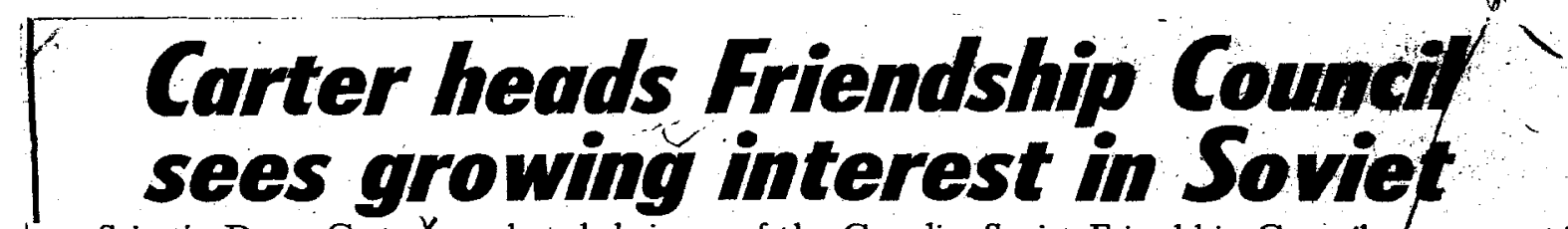

Scientist Dyson Carter fwas elected chairman of the Canadian-Soviet Friendship Council at an annual meeting which charted a fresh course of activity and heard Soviet representative Victor Bourdif $x$ tell mem. bers that the Soviet Union is using atomic power to correct "errors of nature."

"The day has gone when we have to think in terms of approaching people in high places who might lend their names to strengthen our cause," said Carter. He declared friendship would be built among those who have the most to gain, workers, farmers, youth, women, national groups, and pro-

fessional and business people.
He outlined sweeping changes in the world situation - upset of the U.S. atom bomb moniopoly, the Chinese vict ries and others-which underscored the importance of - Soviet

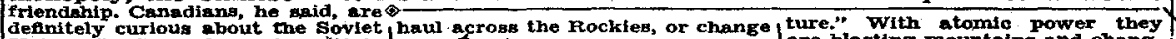

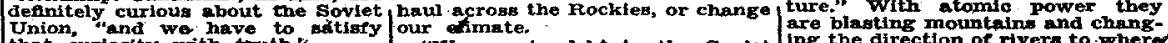
that euriosity with truth." "Wo are in debt to the Soviet ing the direction of rivern to where He satd we coutd jearn a great people for many Canadian pro- their waterz aro most needed For deal from the Sovlet Union on how

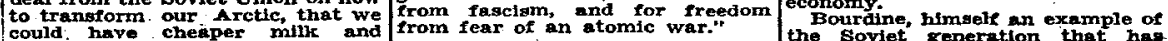
bread if our scientists were not Bourdine brought warm greet- grown up under zociallsm, gripped that we could learn practi-

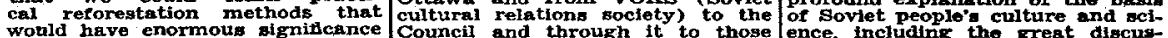
world have pulp industry, that we Canndians striving for peace and sions on formallim in music and could learn how to mave soid rer- Criendship. After outlining Soviet the Lysenkro theories. tiity and better tackle problems peace pollcy and economic achieve-

of mental health.

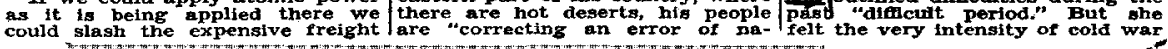
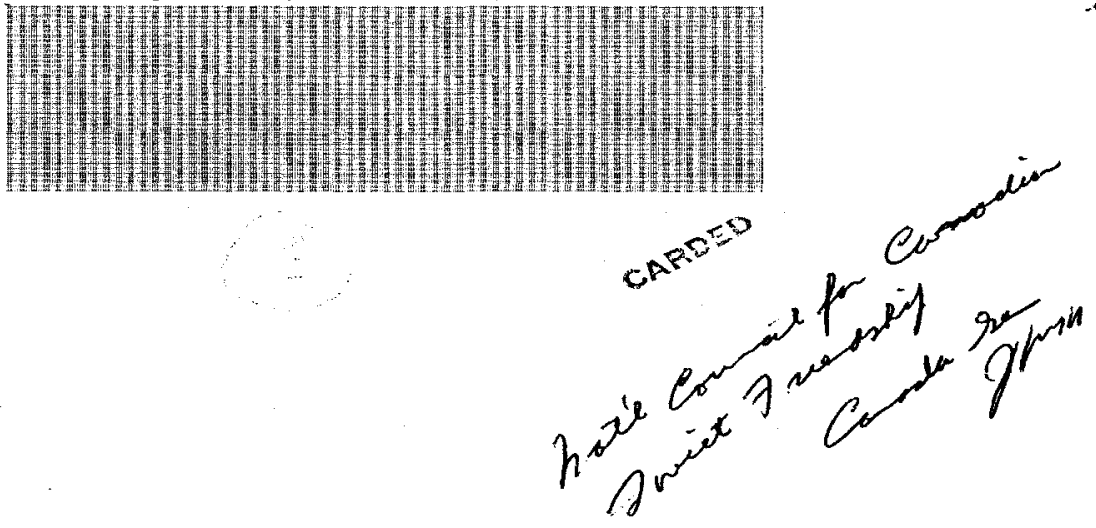

propaganda had created thespes plus the more revaris opened new evenueor
cil. New secretary the

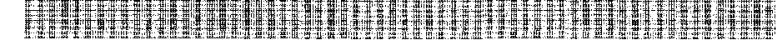

000053

Clipping from RCMP file on CSFS. Note an error in the article: Vladimir Burdin is referred to as "Victor."

Source: LAC, RG146, A200600096, p. 53. 
PEACE WUER

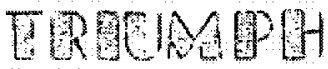

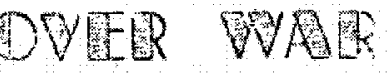

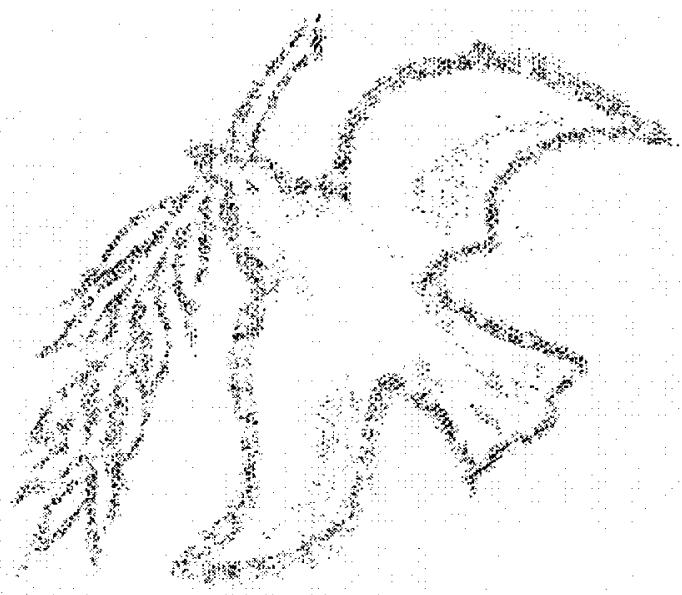

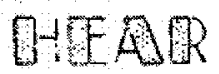

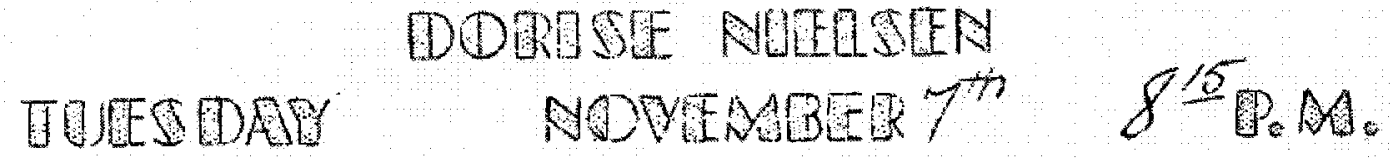

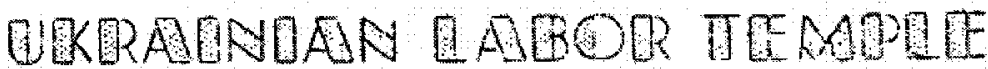

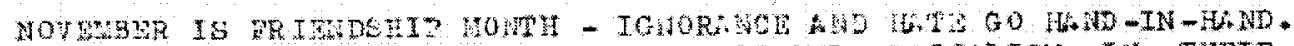

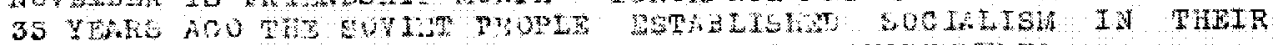

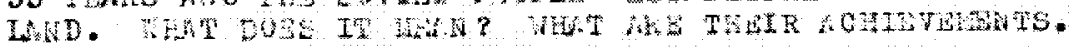

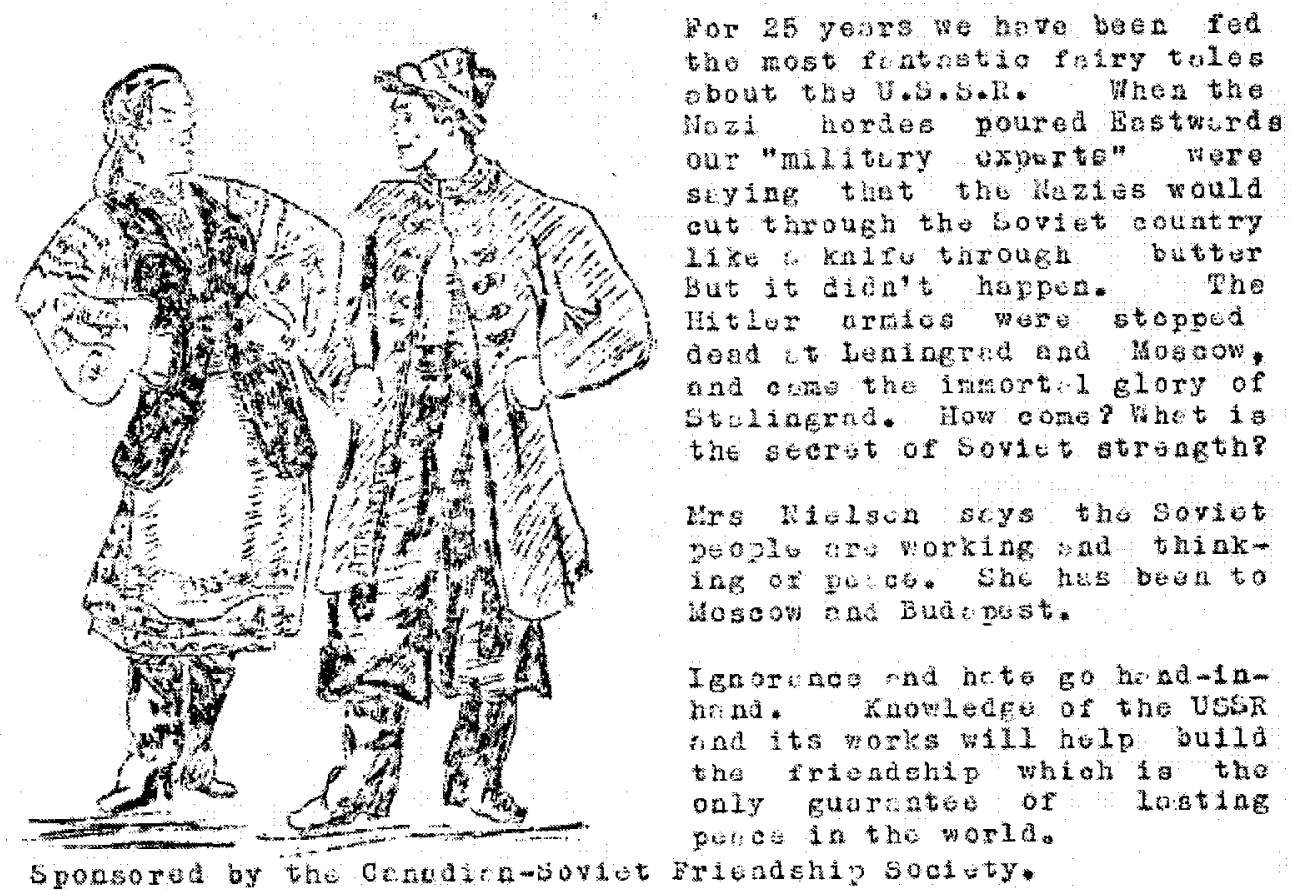

Advertisement from Dorise Nielsen's CSFS publicity tour of the Western provinces, 1950. Source: LAC, RG146, A200600097, p. 72 


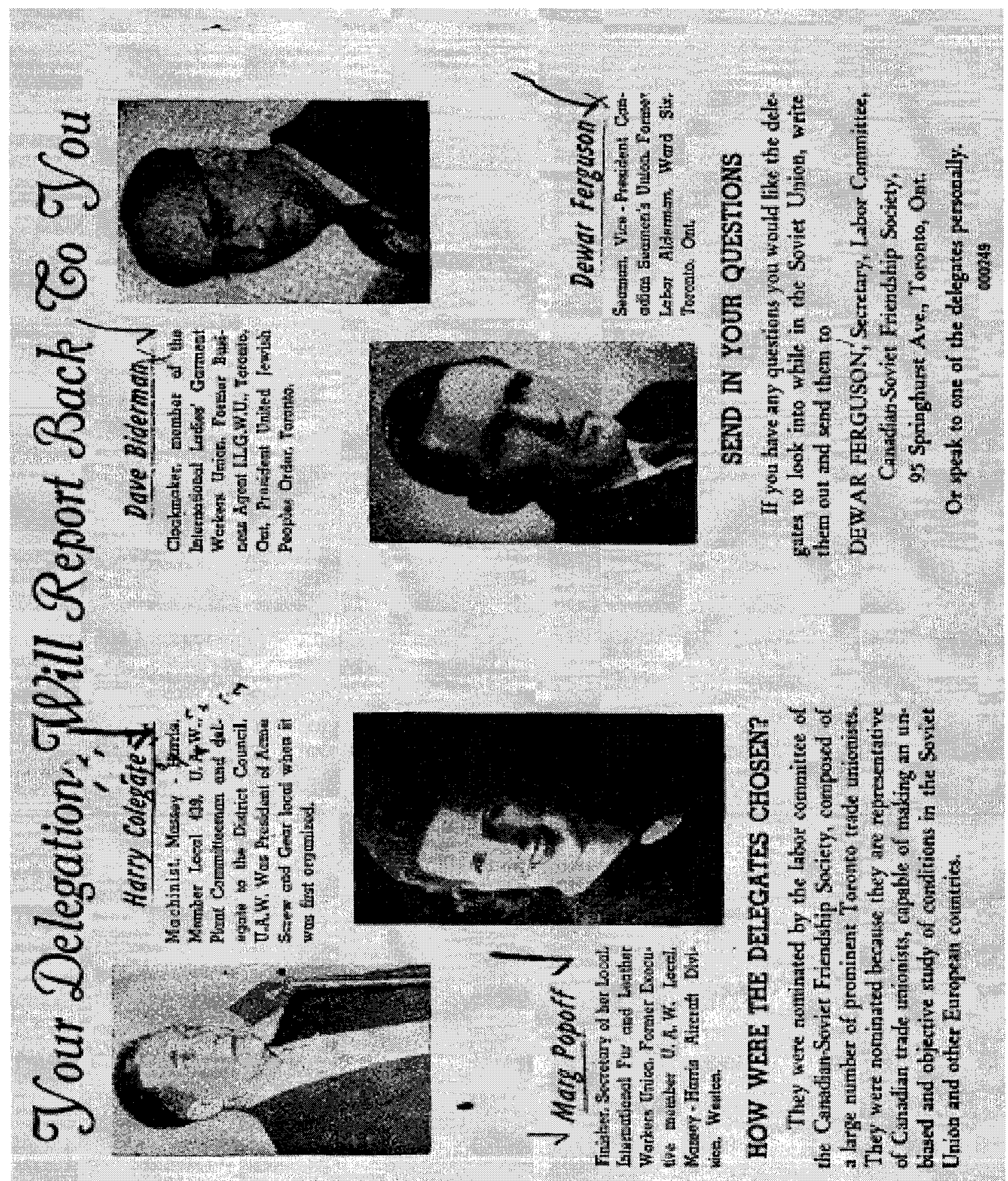

Source: From CSFS flyer, 1951, LAC, RG146, A200600097, p. 249. 


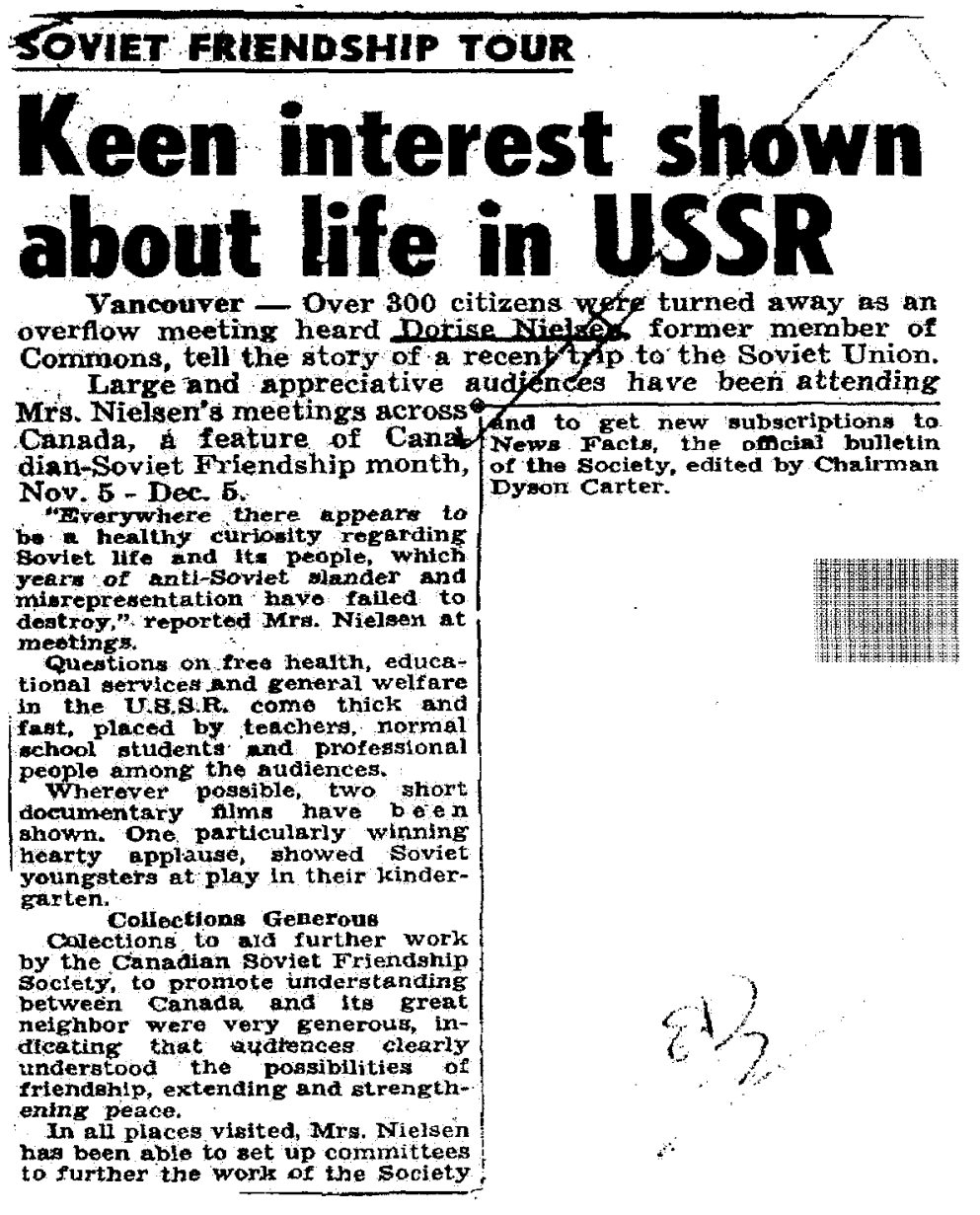

Source: Canadian Tribune, 1952, clipped on LAC, RG146, A200600105, p. 128. 


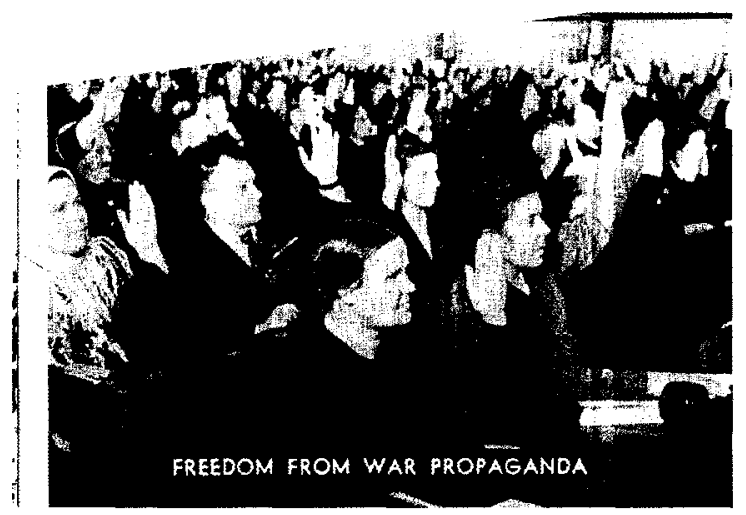

THE PAPERS SAY:

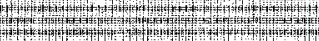

"Soyiot leaders fill their people with hotrod and wor propagands." THE Рното shows:

The Supreme Parliament of the Soriot Union passing a law eqainst war propaganda.

\section{THE FACTS ARE:}

The Soviot Union is ruled by a Parliamant made up of $]_{1} 316$ ordinary citizens olected by the whole dult population. On March 12. 1951 the Soviet Parliament passed a decree: "To bring to court persons guilty of war propoganda, and to try them as having committed. most gravo criminal offenco."

For the PROOF, the latest news about what's going on inside the Soviet Union, write for free sample copy of popular, easy-to-read paper: "NEWS-FACTS", 479 Queen West, Toronto 2B, Ontario
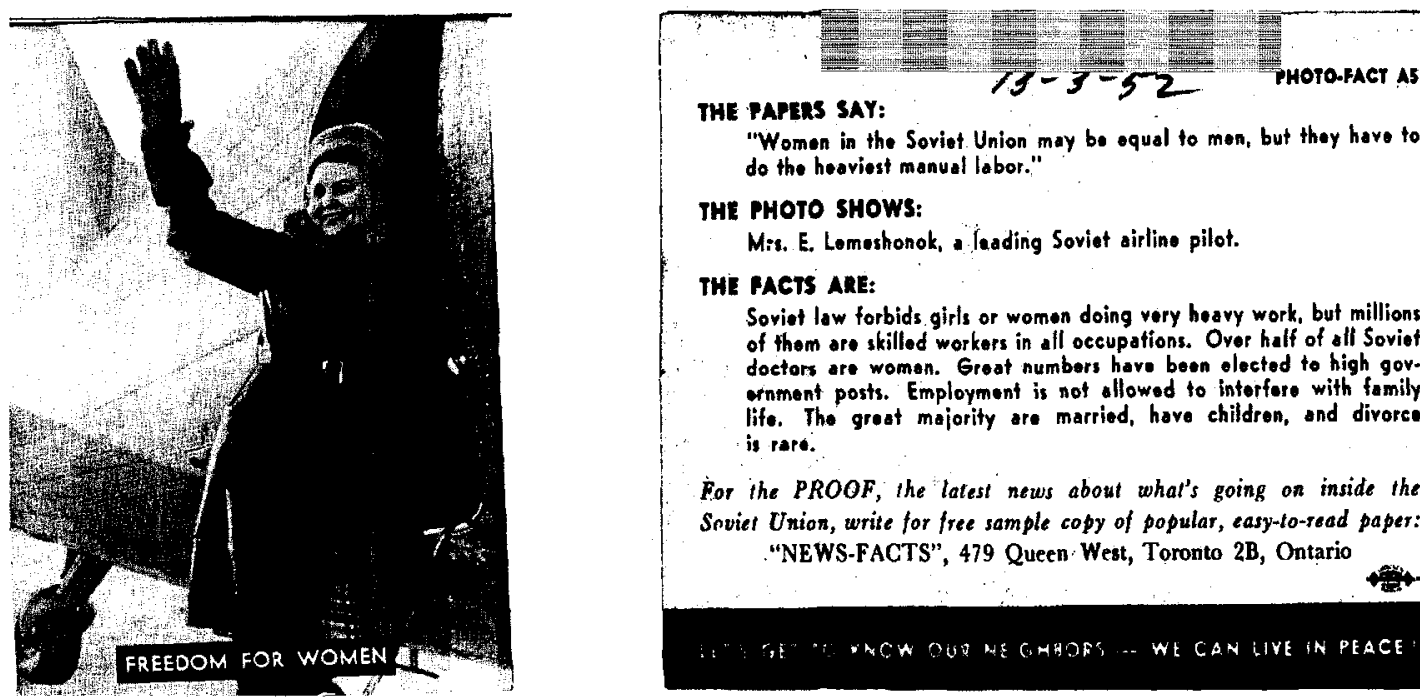

THE PAPERS SAY:

"Women in the Soriet. Union may be equal to men, but they have to do the heaviest manual labor."

THE PHOTO SHOWS:

Mis. E. Lemoshonok, a feading Soviet sirline pilot.

THE PACTS ARE:

Soviat law forbids girls or women doing very hoavy work, but millions of them are skilled workers in all occupations. Over half of all Soviet of them are skiled workers in all occupations. Oreler half of all Soviof doctors are women. Great numbers have been elected to high govlife. The great mejority are married, have children, and divorce is rate.

For the PROOF, the latest news about what's going on inside the Snviet Union, write for free sample copy of popular, easy-to-read paper: "NEWS-FACTS", 479 Queen-West, Toronto 2B, Ontario

$+$

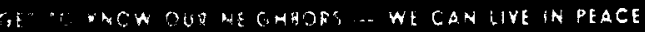

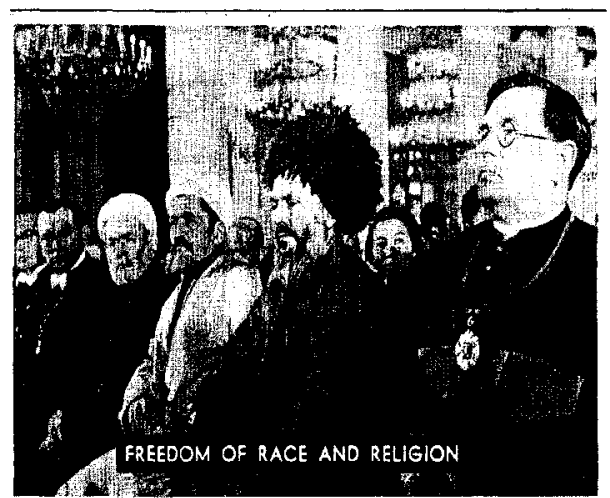

THE PAPERS SAY:

"The Soriet people don't know what roligious freedom is." THE PHOTO SHOWS:

Lesding Soviet clergy, of widely different religions and notionalities,

at a Peace Conference in Moscow.

THE FACTS ARE

The Soviot Union has great numbers of worshipping Orthodox and Roman Catholics. Moslems, Baptists, Jows, and smaller religious groups. Every raligien and nationelity is equal by Soviet law. There: tere no roligions sre laught in public schools, only in church or at home. In the Soviet Union it is a crime to discriminato against anyone, in any way, because of race or religion.

For the PROOF, the latest news about what's going on inside the Soviet Union, write for free sample copy of popular, easy-to-read paper: "NEWS-FACTS", 479 Queen West, Toronto 2B, Ontario

LET'S GET 10 KHOW OUR NEIGHBORS - WE CAN LIVE IN PEACE !

Photo-Facts Cards

Source: LAC, RG146, A200600100, p. 133-134, 141-142, 153-154. 


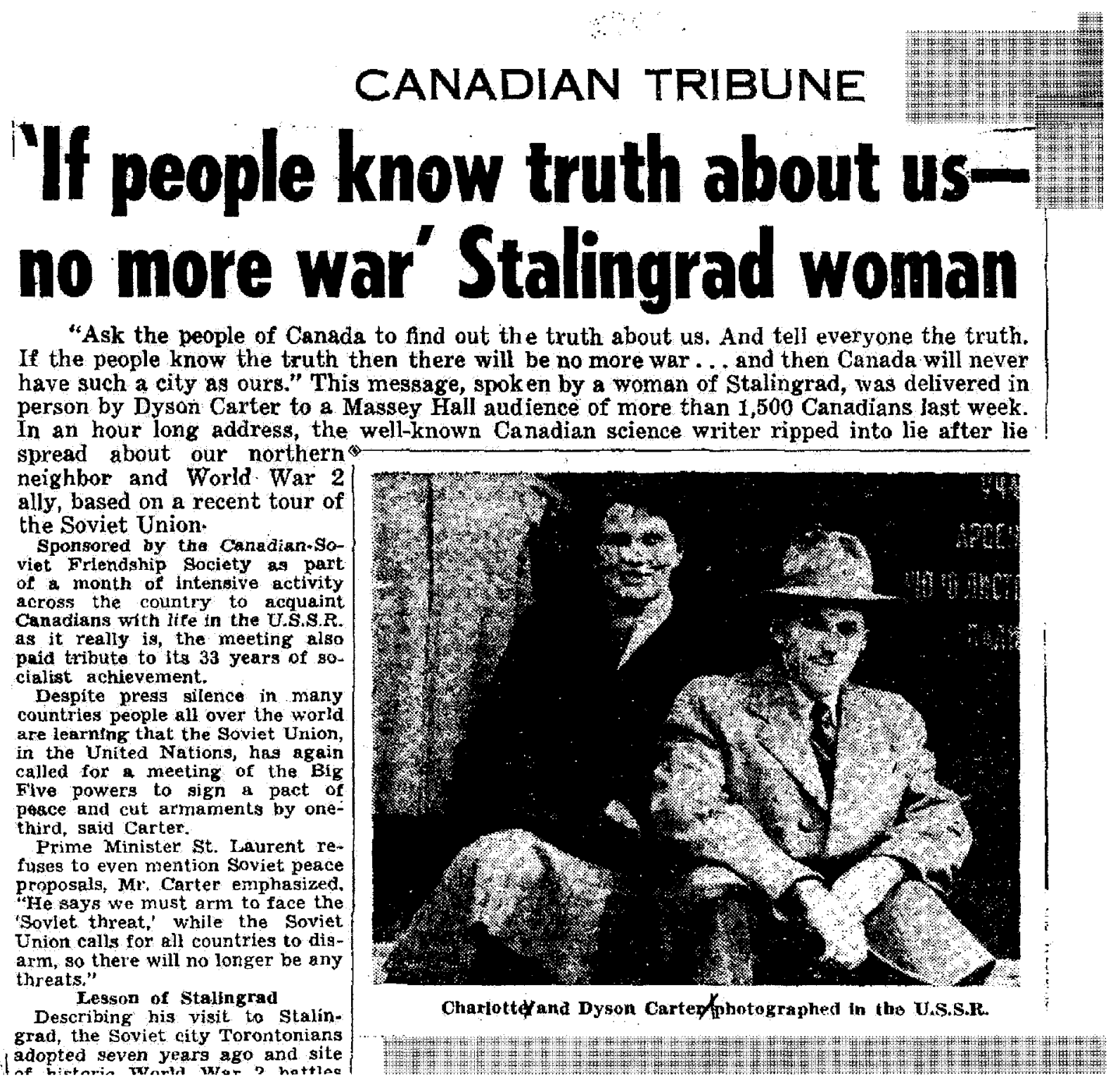

Source: The Canadian Tribune, 1952, clipped on LAC, RG146, A200600105, p. 129. 


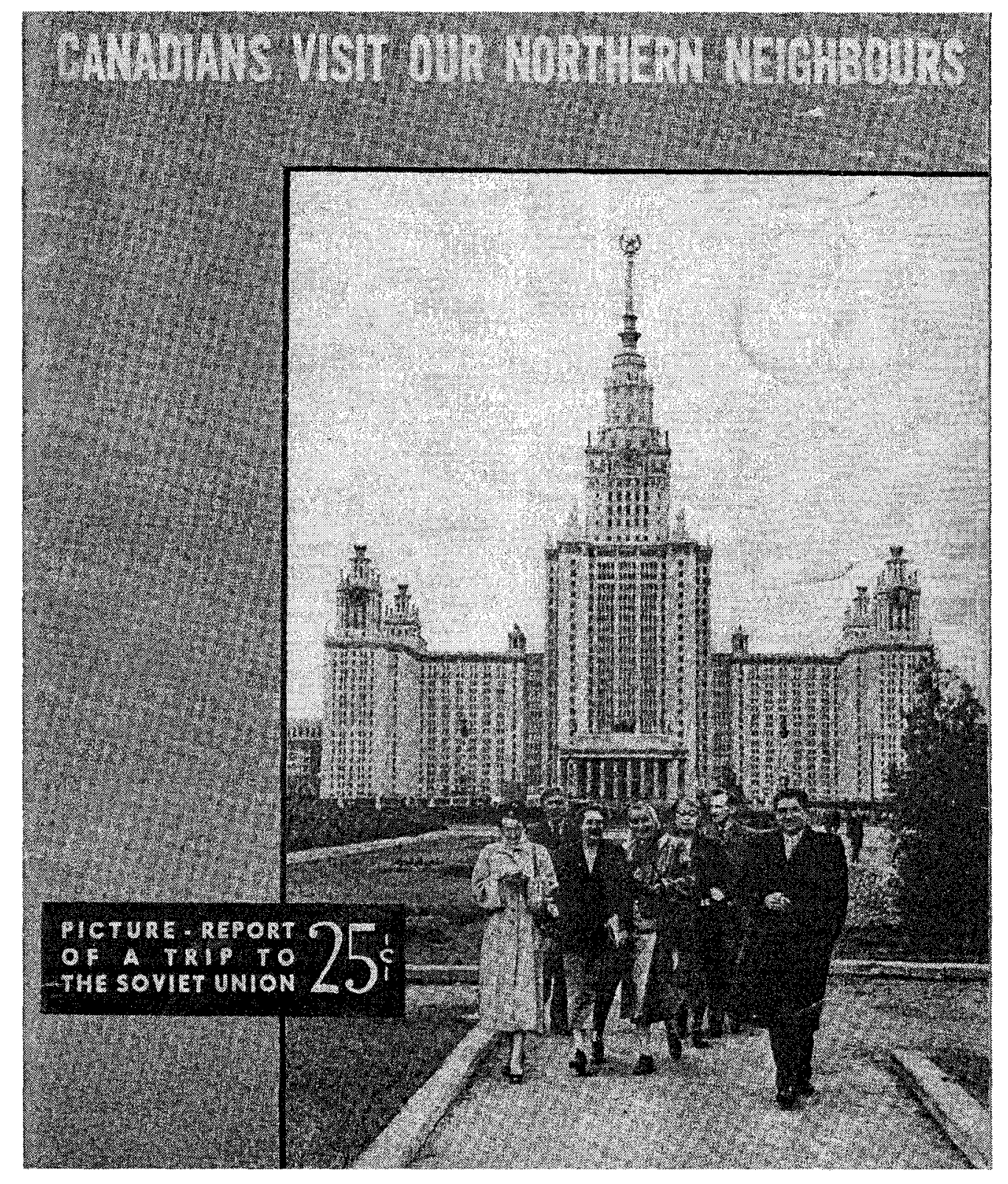

CSFS brochure distributed by News-Facts, containing the reports of the CSFS delegation to the USSR in 1953. The delegates here pictured are (L-R) Eleanor Ashworth, Major R.T. Lafond, Florence Dorland, Rosalind McCutcheon, Margaret Spaulding, Paul Pauk, and Leo Clavir. This copy was given to Jennifer Anderson by J.E. Baxter. 


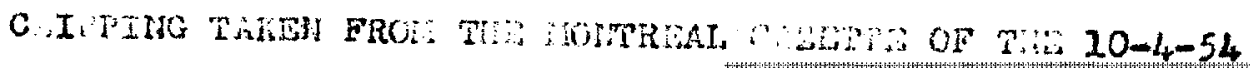
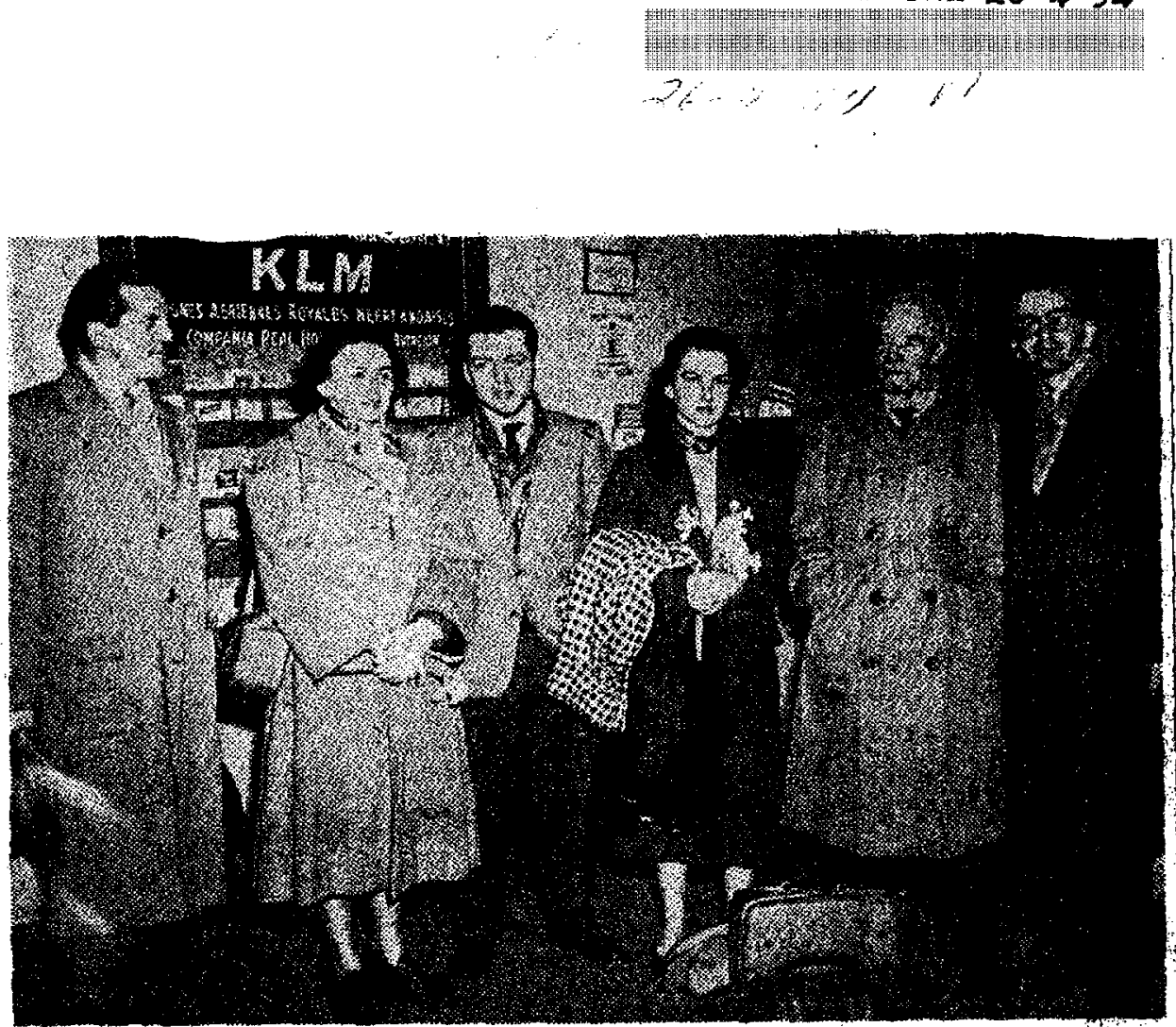

OFF To RUSSIA: Off to see "what's going on in the cultural tield" in the Soviet Union are Jemnine, Mrs. Madelelne Ssint-Germaln, Frede-

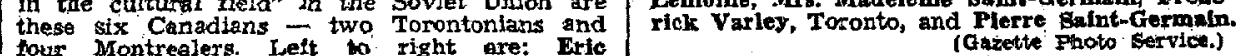

\section{Soviet Artists Thrill Audience}

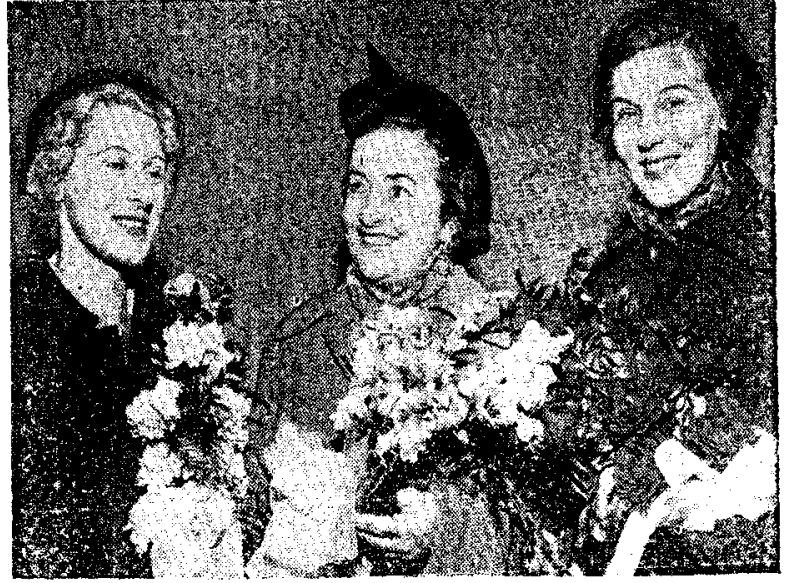

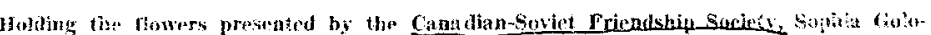

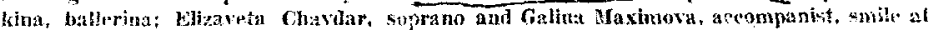

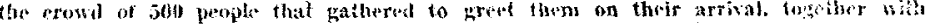
the otleer sousct artists, at the Cuion Station in Toromto.

Source: (top) Montreal Gazette, April 1954, clipped on LAC, RG146, A200600093, p. 23.

(Below) Source: Ukrainian Canadian, n.d., 1954, clipped on LAC, RG146,

A200600095, p. 66. 


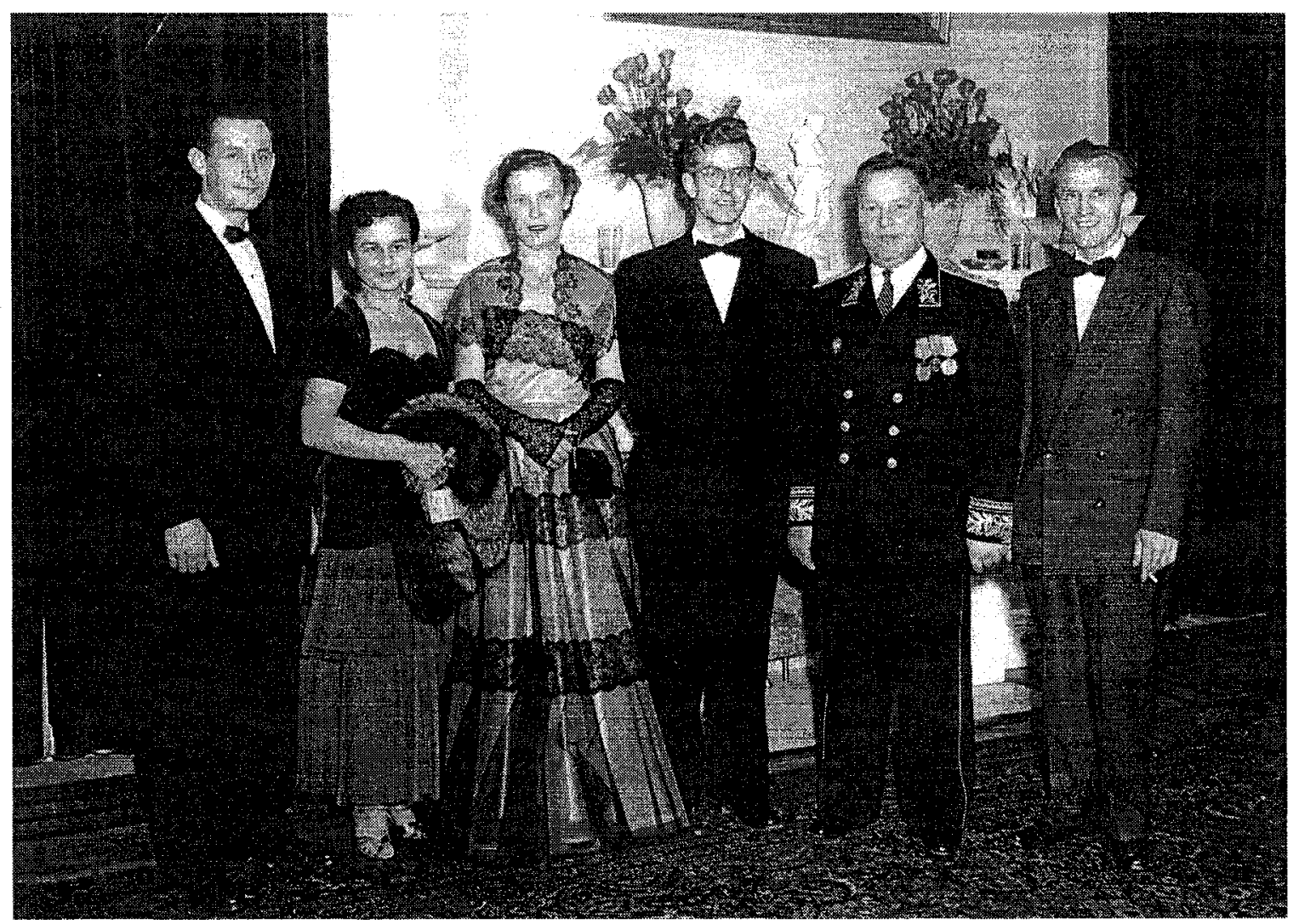

"This picture was taken in the Royal York Hotel in Toronto in 1954 on the occasion of a banquet given by the Canadian-Soviet Friendship Society in honour of His Excellency Dmitri Chuvakhin, the Soviet Ambassador to Canada. Pictured above are (1-r) Vladimir Burdin, Cultural Attaché at the Soviet Embassy; Mrs. Burdin; Mrs. Chuvakhin; Ted Baxter, National Secretary of the Canadian-Soviet Friendship Society; Mr. Chuvakhin; Paul Pauk, executive member of the Canadian-Soviet Friendship Society."

Source: Private Collection, J.E. Baxter. 

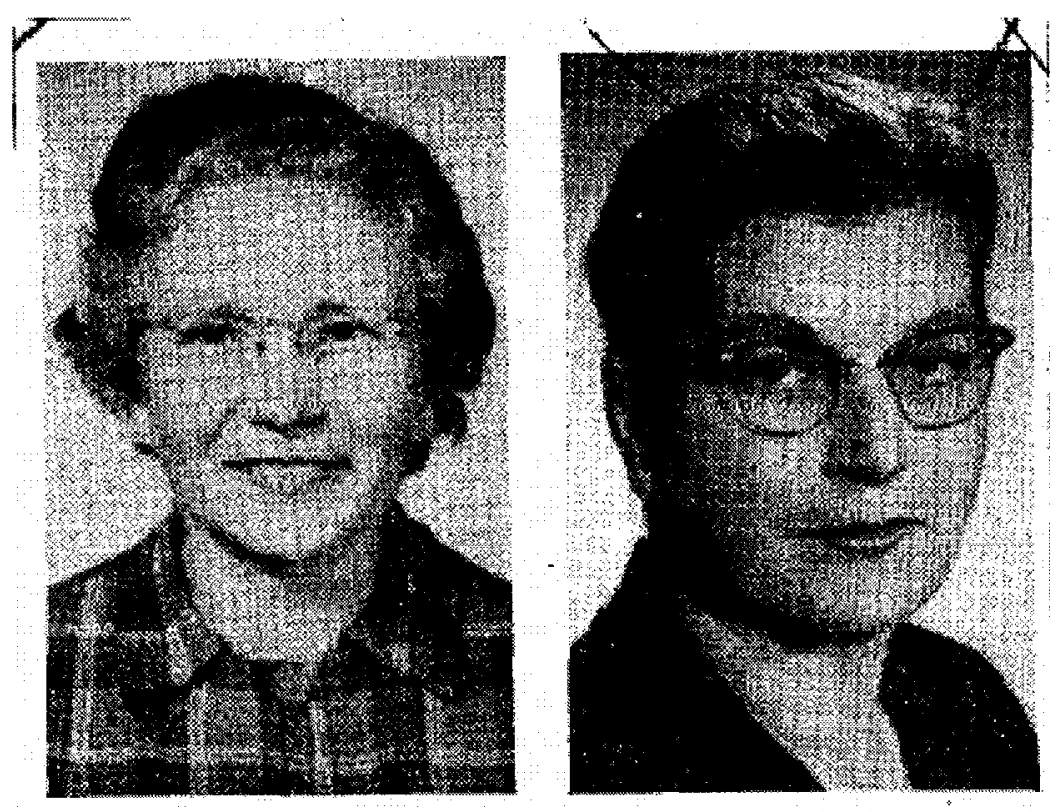

\section{City women to tour USSR}

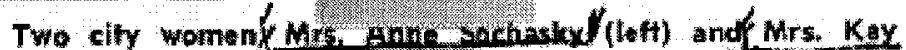

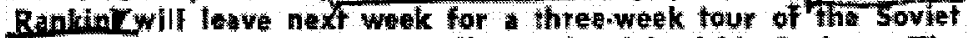
Union as delegates of the Canadian-Soviet Friendship Seciety. The soeicty is sponsoring a send-off gathering for them at the Russian People's Howe, 600 Campball Avenue, hare this coming Wednestay, Pebruary 2 , af 8 p.m.

Source: Clipping from the Pacific Tribune, January 1955, LAC, RG146, A200600092, p. 100 

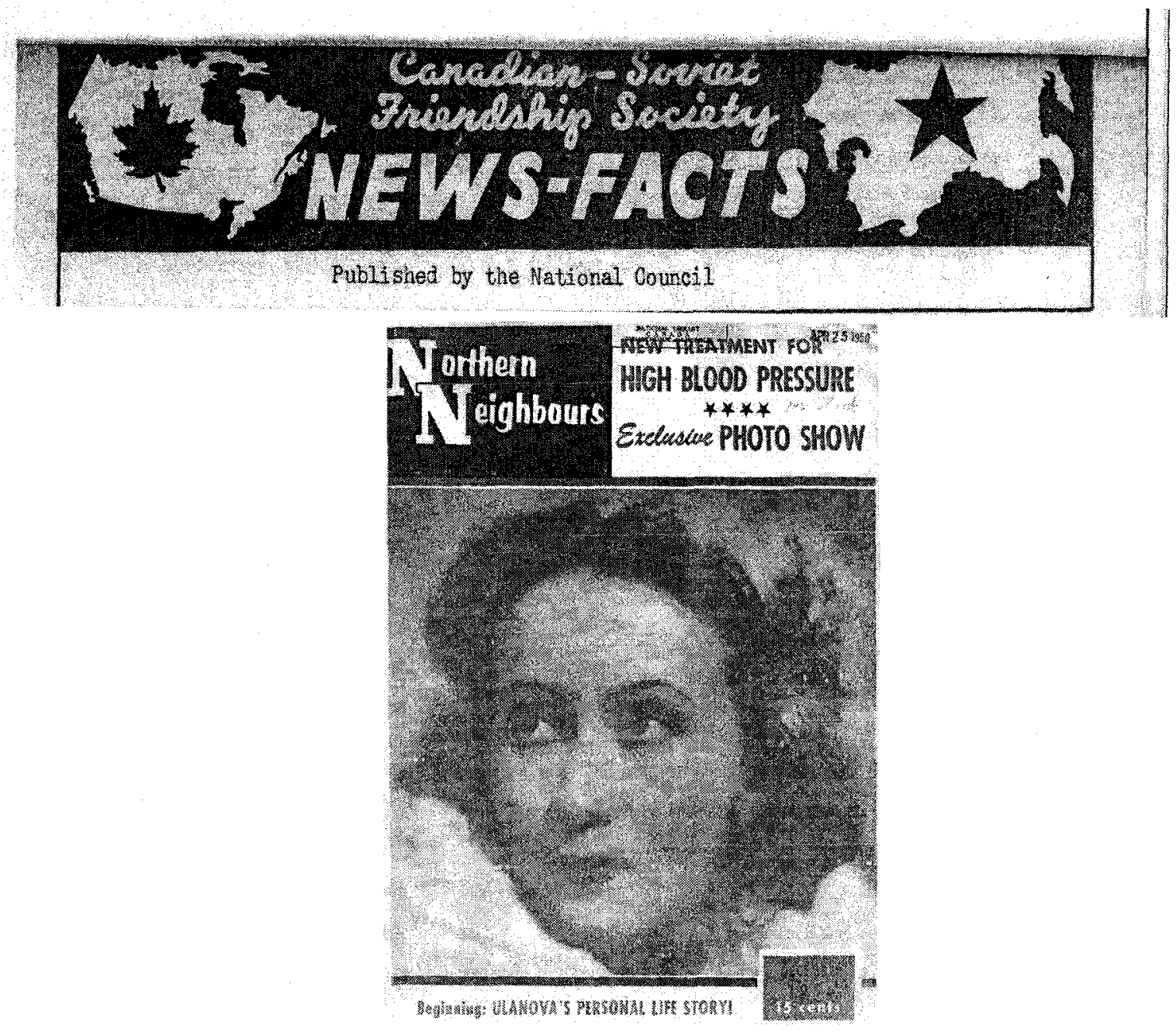

Header of CSFS publication News-Facts and first issue of Northern Neighbours, December 1956. 


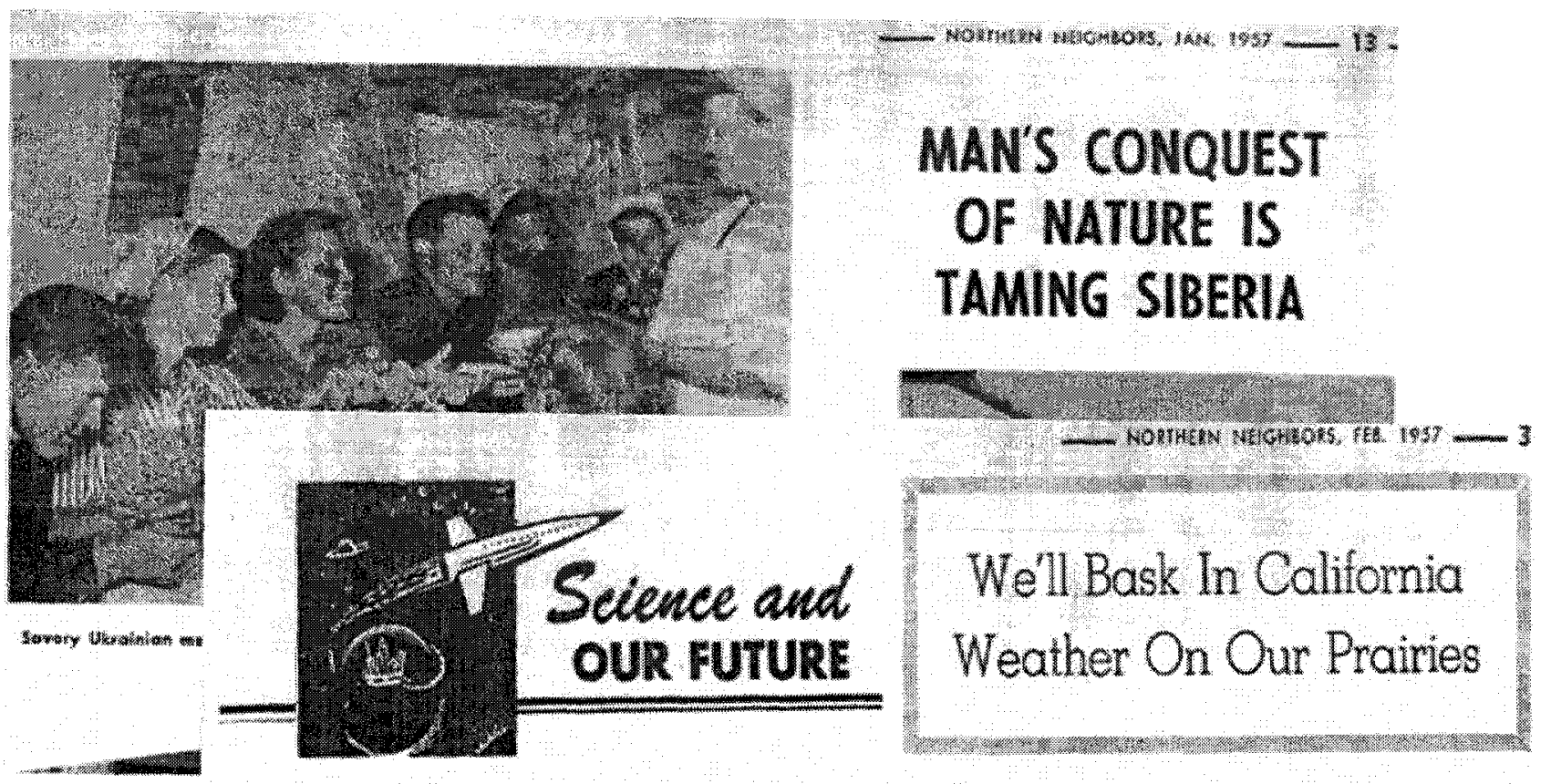

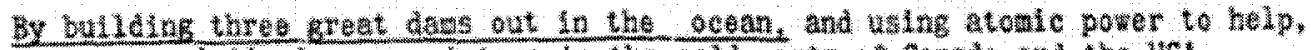

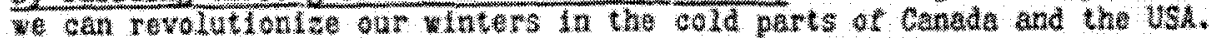

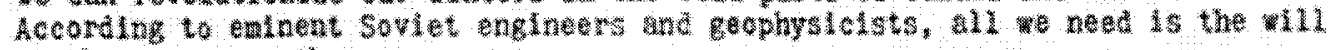

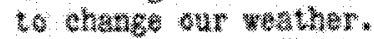

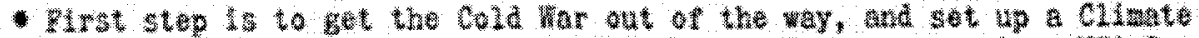
Aterat lon hutherlty of the thre norwem welghbor countries: Ush-canadaUSSR.

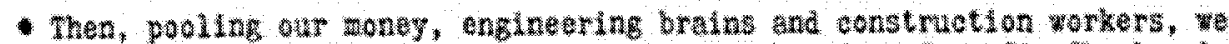

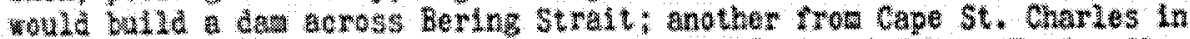

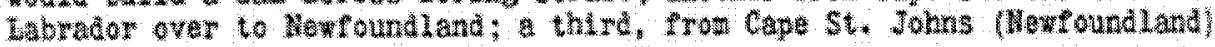
out int we Allawis.

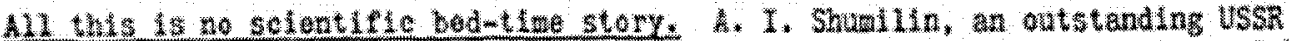

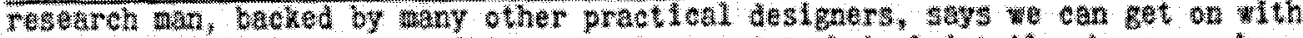

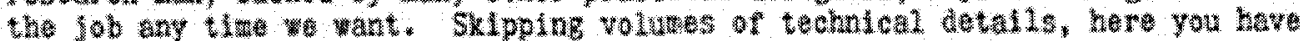

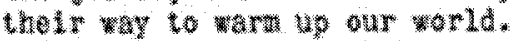

Excerpts from Northern Neighbors, 1957 


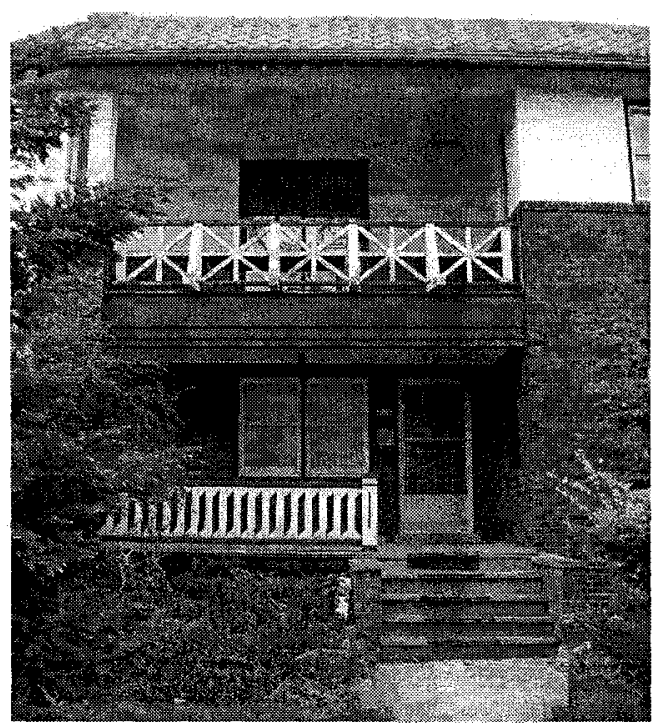

The Carter family's home, 1953-1957, 134 Colbeck St., Toronto Photo by J. Anderson

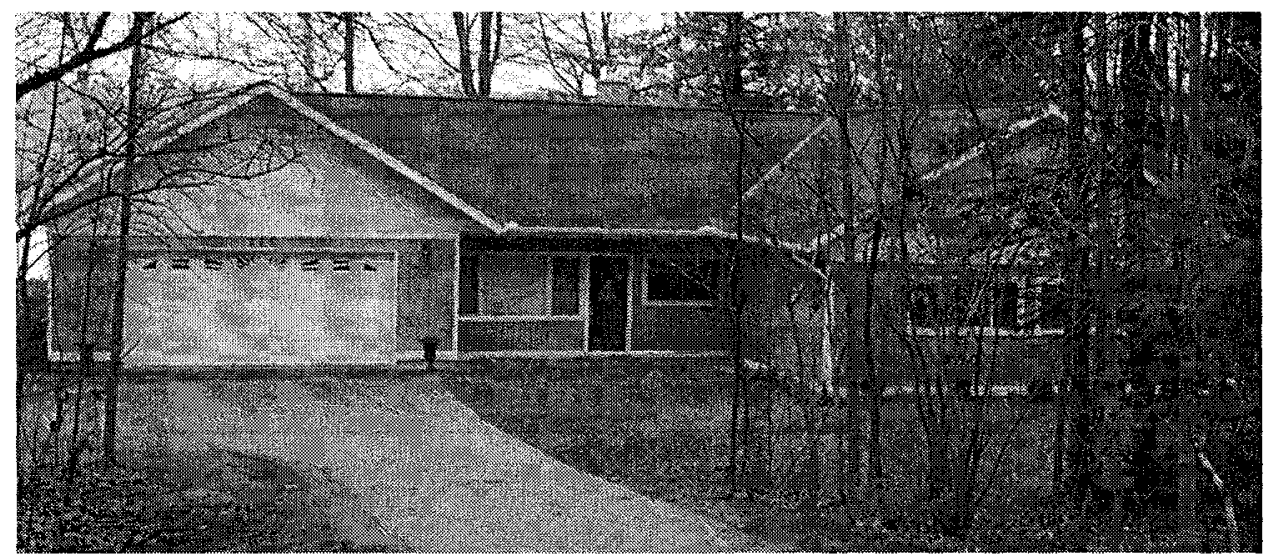

The Carter home until Dyson's death in 1996, Gravenhurst, ON Photo by J. Anderson

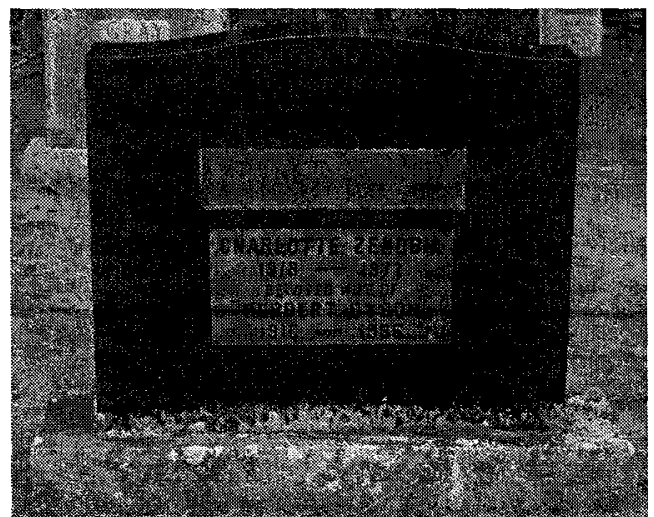

Dyson and Charlotte Carter's grave, Gravenhurst, ON Photo by J. Anderson 
Nhy 쿄

U N I VER S I T Y

Canada's Capital University
Office of Research Services

5th Floor, Tory Building

1125 Colonel By Drive

Ottawa, ON K1S 5B6 Canada

Tel: (613) 520-2516

Fax: (613) 520-2521

www.carleton.ca/ors

\section{Ethics Approval Form}

This is to certify that the Carleton University Research Ethics Committee has examined the application for ethical approval. The committee found the research project to meet appropriate ethical standards as outlined in the Tri-Council Policy Statement: Ethical Conduct for Research Involving Humans and, the Carleton University Policies and Procedures for the Ethical Conduct of Research.

$X$ New approval

$\square$ Renewal of original approval

\section{Original date of approval:}

Date of approval

Researcher

Status

Department

Supervisor

Title of project
18 July 2006 Jennifer Anderson

Ph.D. candidate

Department of History

Professor J. L. Black and Professor D. McDowall

Whose Truth? The Canadian-Soviet Friendship Society, 1949-1957

Co-investigators: $\mathbf{X}$ None

Ethics approval expires on: 18 July 2007

\section{All researchers are governed by the following conditions:}

Changes to the project: Should there be any changes to the project the researcher is required to advise the Carleton University Research Ethics Committee of the changes prior to the continuance of the research.

Adverse events: Should any participant suffer adversely from their participation in the project the researcher is required to report the matter to the Carleton University Research Ethics Committee.

Suspension or termination of approval: Failure to conduct the research in accordance with the principles of the Tri-Council Policy Statement: Ethical Conduct for Research Involving Humans and the Carleton University Policies and Procedures for the Ethical Conduct of Research may result in the suspension or termination of the research project.

Lëslie J. Mactonald-Hicks

Research Ethics Committee Coordinator

For the Chair of the Carleton University Research Ethics Committee

Prof. Antonio Gualtieri 
Carleton

UNIVERSITY

Canada's Capital University
Office of Research Services

5 th Floor, Tory Building

1125 Colonel By Drive

Ottawa, ON K1S 5B6 Canada

Tol: (613) 520-2516

Fax: (613) 520-2521

unw.carleton.ca/ors

\section{Ethics Approval Form}

This is to certify that the Carleton University Research Ethics Committee has examined the application for ethical approval. The committee found the research project to meet appropriate ethical standards as outlined in the Tri-Council Policy Statement: Ethical Conduct for Research Involving Humans and, the Carleton University Policies and Procedures for the Ethical Conduct of Research.

\section{$\square$ New approval}

X Renewal of original approval Original date of approval: 18 July 2006

Date of renewal

Researcher

Status

Department

Supervisor

Title of project
13 July 2007

Jennifer Anderson

Ph.D. candidate

Department of History

Professor J. L. Black and Professor D. McDowall

Whose Truth? The Canadian-Soviet Friendship Society, 1949-1957

Ethics approval expires on: 13 July 2008

\section{All researchers are governed by the following conditions:}

Annual Status Report: Ethics clearance is valid for one year from date of approval. You are required to submit an Annual Status Report to either renewal approval or close the file. Failure to submit the Annual Status Report will result in the immediate suspension of the project. Funded projects will have accounts suspended until the report is submitted and approved.

Changes to the project: Any changes to the project must be submitted to the Carleton University Research Ethics Committee for approval. All changes must be approved prior to the continuance of the research.

Adverse events: Should any participant suffer adversely from their participation in the project you are required to report the matter to the Carleton University Research Ethics Committee. You must submit a written record of the event and indicate what steps you have taken to resolve the situation.

Suspension or termination of approval: Failure to conduct the research in accordance with the principles of the Tri-Council Policy Statement: Ethical Conduct for Research Involving Humans and the Carleton University Policies and Procedures for the Ethical Conduct of Research may result in the suspension or termination of the research project.

Léslie J. Mactbonald-Hicks

Research Ethics Committee Coordinator

For the Chair of the Carleton University Research Ethics Committee

Prof. Antonio Gualtieri 


\section{BIBLIOGRAPHY}

\section{Note on Sources}

This dissertation benefits from unprecedented access to sources. The end of the Cold War made previously classified documents available to researchers. It also made it possible for former activists from within the Canadian Soviet Friendship Society and other leftist groups to participate in oral history interviews, speaking to their attempts to persuade fellow Canadians to see the Cold War from a different perspective. Documents copied from the State Archives of the Russian Federation (GARF), now held by the Centre for Research on Canadian-Russian Relations (CRCR) at the University Partnership Centre, Georgian College, show how the CSFS worked with the Soviet AllUnion Society for Cultural Relations with Foreign Countries (VOKS). Restricted documents from the collections of the Royal Canadian Mounted Police, and the Department of External Affairs, are now available. Voices from the oral history component at once support and counter the documentary evidence, complicating the narrative. Brief comment will be made here on the specific challenges these sources brought to the project.

The VOKS collection is remarkable as a source for the analysis of the Soviet internal perspective on the CSFS and Canadian public opinion. It is supplemented by documents from other Russian archives, also held at the CRCR. Among these are letters from the Soviet embassy in Ottawa to top Soviet officials such as Soviet Foreign Minister, Vyacheslav Molotov, assessing the impact of the Gouzenko Affair and the ability of the Communist Party of Canada (CPC) to counter anti-Soviet propaganda. But, like all documentary collections, there are some gaps. The collection runs from 1949 to 
1957 with few obvious gaps, but then does not pick up again until 1974. The crucial moment between 1958 and 1960 when VOKS and the CSFS were reorganized is not documented by the collection. The last document in the collection is dated 30 November 1979, and deals with the fourth conference of the Moscow-based USSR-Canada Society, which was affiliated with VOKS' successor, the Soviet Societies for Friendship and Cultural Relations with Foreign Countries (SSOD). Even when the gaps are not obvious, some documents may not have been copied, or may not have been preserved.

The documents in the archives of the Royal Canadian Mounted Police (RG146) to which this researcher gained access through Access to Information and Privacy (ATIP) were most helpful in filling in some of these gaps. Particularly useful was an RCMP report which I obtained through a second ATIP application, and which dealt specifically with the change from the CSFS to the Canada-USSR Association in 1960, together with the corresponding change in leadership. This information was backed up by oral interviews with the main participants. In some cases, the RCMP documents and the VOKS files mirrored one another, and in other instances, the collections gave very different perspectives on the same events. This complicated the narrative, and gave the researcher insight into the different purposes for which the documents were collected by the respective organizations.

Much has been made of the ATIP tendency to "black out" names, file numbers and other data. This project was not much affected by the removal of names partly because it was not a frequent issue, and partly because one could compare with other collections and oral interviews. The missing numbers at times made the use of the documents awkward, but eventually one got used to referring to them not by their volume 
and file numbers, but by the ATIP numbers assigned (ie. A200600101, etc.) What was more of an issue for this project were the entire pages sometimes removed by ATIP personnel. The researcher has no way of knowing what information was contained on these pages, and can only guess that at times at least, it must have dealt with the actions taken by the RCMP. This is problematic because although it is possible to judge that the RCMP surveillance of the CSFS was largely warranted, it has not proven possible to assess periodic CSFS claims to physical harassment by the RCMP.

In a letter to his friend John Boyd, Dyson Carter spoke sarcastically about the establishment at Library and Archives Canada of the "Dyson Carter fonds." $\mathrm{He}$ mentioned that it would be flattering to have such a collection in your name, if it was not for the fact that it contained so many false claims to Soviet superiority. The Carter fonds have proven important to this research in its assessment of the way Northern Neighbors was put together, and particularly in the way readers responded. Hundreds of readers' letters to Carter are in the collection, and these handwritten notes, often sent by elderly individuals who may not have used English as a first language are a moving testimony to Carter's appeal to the non-Party left. The letters show that many Canadians sincerely believed that the USSR represented a shining example of socialism in practice.

Access to other collections, including the Irene and Louis Kon Collection at McGill University, the Robert S. Kenny collection at the Thomas Fisher Rare Book Library (University of Toronto), the collection of the Association of United Ukrainian Canadians (AUUC), the Frank and Libbie Park fonds, the Frederick B. Taylor papers, and the June Callwood fonds (all at Library and Archives Canada), and the private papers of John Boyd and Larissa Stavroff have provided invaluable insight into the history of the 
radical left in Canada during the Cold War. The internal organizational files belonging to the Canada-USSR Association are still held privately, and are inaccessible. Seeking information on the Federation of Russian Canadians and the CSFS links to the CPC-LPP, the researcher also took a look at the Paraskeva Clark fonds and the collection of the Communist Party of Canada, both at Library and Archives Canada, but did not find material there relevant to the CSFS. In the case of Dyson Carter and the CPC-LPP, related documents may have been removed from the CPC collection before it was sent to Ottawa.

Access to documents from the Department of External Affairs (DEA), both via ATIP and on the permission of Greg Donaghy and Janice Cavell at Foreign Affairs Canada, has been beneficial in allowing a glimpse of DEA concerns with the CSFS, VOKS, and their successor organizations.

This project has also benefited from an oral history component, which was a challenging and rewarding aspect of the research. Comments are made in more depth on the value and the challenges of oral history in Chapter 3 (historiography) and Appendix I (methodology), so the researcher will here simply encourage other historians to consider it as an integral part of historical research. The value of the approach far outweighs the challenges, and can only enrich document-based research and narrative historical writing. 


\section{PRIMARY SOURCES}

\section{Oral Interviews Conducted}

Baxter, J.E., interviewed 8 December 2006

Boyd, John, interviewed 2 August 2006

Hunt, Les, interviewed 2 January 2007

Lucas, Michael, interviewed 27 July 2006

Nielsen, Sally (Thelma), interviewed 28 November 2006

Paul, Ira (with Irene Kuusela and Marie Rempel), interviewed 27 November 2006

Tarasoff, Koozma J., interviewed 27 September 2006

\section{Archival Collections Consulted}

\section{Library and Archives Canada:}

Association of United Ukrainian Canadian fonds (MG 28-V-154)

June Callwood fonds (MG31-K24)

Department of External Affairs fonds (RG25)

Dyson Carter fonds (MG31-D182)

Frank and Libbie Park fonds (MG31-K9)

RCMP fonds (RG146)

Frederick B. Taylor fonds (MG30-D360)

Centre for Research on Canadian-Russian Relations, Georgian College, Barrie: VOKS Collection

GARF [Gosudarstvennyi arkhiv Rossiiskoi Federatsii], fonds 5283

\section{Foreign Affairs Canada:}

Documents on Canadian External Relations (DCER)

McGill University, Montreal:

Irene and Louis Kon Collection

Thomas Fisher Rare Book Library, University of Toronto:

Robert S. Kenny Collection

\section{Private Collections}

John Boyd

Larissa Stavroff 
Memoirs and Other Primary Source Material

Andrew Christopher and Vasili Mitrokhin, The Mitrokhin Archive: The KGB in Europe and the West New York: Penguin Press, 1999.

Biderman, Morris. A Life on the Jewish Left: An Immigrant's Experience. Toronto: Onward Publishing, 2000.

Black, J.L., ed. Soviet Perception of Canada: An Annotated Bibliographic Guide. Ottawa: Carleton University, 1989.

Boyd, John. "A Noble Cause Betrayed...But Hope Lives On: Pages from a Political Life," originally published as Canadian Institute of Ukrainian Studies Report, no. 64, 1999; Socialist History Project, \{http://www.socialisthistory.ca/Remember/Reminiscences/Boyd/B1.htm\}, accessed 25 August 2007.

Chernin, Kim. In My Mother's House: A Daughter's Story. New York: HarperCollins, 1983, 1994.

Gouzenko, Igor. This Was My Choice: Gouzenko's Story. Toronto: J.M. Dent and Sons Ltd., 1948.

Irvine, William. Live or Die with Russia. Edmonton: s.n., 1958. Published in Russian as Zhit'vmeste s Rossiyei [Live with Russia] (transl. V.V. Isakovich). Moscow: Inostrannoi izdatel'stvo literature, 1958.

Krawchuk, Peter, ed. Reminiscences of Courage and Hope (Stories of Ukrainian Canadian Women Pioneers). Toronto: Kobzar Publishing Co., Ltd., 1991.

Laxer, James. Red Diaper Baby: A Boyhood in the Age of McCarthyism (Douglas and McIntyre, 2004).

R.C.M.P. security bulletins : the war series. Edited by Gregory S. Kealey and Reg Whitaker. St. John's, Nfld: Committee on Canadian Labour History, c1989c1993.

The Report of the Royal Commission to Investigate Disclosures of Secret and Confidential Information to Unauthorized Persons. Ottawa: Edmond Cloutier, 1946.

Volkov, Solomon, ed. Testimony: The Memoirs of Dmitri Shostakovich (trans. by Antonina W. Bouis). New York: Harper \& Row Publishers, 1979. 
Publications Written or Edited by Dyson Carter (and Charlotte Carter)

Sea of Destiny: the Story of Hudson Bay, Our Undefended Back Door. New York: Greenberg 1940.

Men, Machines and Microbes. Winnipeg: Contemporary Publishers, 1942.

Russia's Secret Weapon. New York: Contemporary Publishers, 1942.

Stalin's Life: At Last the True Story. Winnipeg: Contemporary Publishers, 1943.

Booze - the Saboteur. Winnipeg: Contemporary Publishers, 1943.

Atomic Dollars. Winnipeg: Frontier Books, 1946.

Atomic Future. Regina: King's Printer for Saskatchewan, 1946.

Sin and Science. New York: Heck-Cattell, 1946.

Tomorrow is With Us. Toronto: Progress Books, 1950.

We Saw Socialism. Toronto: Canadian-Soviet Friendship Society, 1951, 1952.

"How Not to be Afraid of your Heart," New Liberty, August 1952, p. 22-23, 62-63.

Fatherless Sons. Toronto: Progress Books, 1955.

Science of Health and Long Life in the U.S.S.R. Sydney, Australia: Current Book

Distributors, 1956.

Cancer, Smoking, Heart-Disease, Drinking in Our Two World Systems Today. Toronto:

Northern Book House, 1957.

The Big Brainwash. Toronto: Northern Book House, 1958.

Rising World. Toronto: Northern Book House, 1959.

Future of Freedom. Gravenhurst: Northern Book House, 1961.

Worker Power: Dare We Win? Gravenhurst: Northern Book House, 1970.

This Story Fierce and Tender. Gravenhurst: Northern Book House, 1986.

\section{SECONDARY SOURCES}

Periodicals

Canadian Jewish Weekly (Vochenblatt)

Canadian Tribune

Canadian Weekly Bulletin

Chempion

Das Yiddishe Wort

Drumheller Mail

Globe and Mail

Gravenhurst News

Great Soviet Encyclopedia

Financial Post

Izvestiia

Jedinstvo

Kanadai Magyar Munkas

Laudis Balsas (The People's Voice)

Literaturnaia Rossia

Ludove Zvesti

Montreal Gazette

Montréal Matin
Northern Neighbors

Northstar Compass

Nove Vreme

Ottawa Citizen

Ottawa Journal

Pacific Tribune

Pravda

The Standard

Soviet Monitor

Toronto Star

Toronto Telegram

Trud (Labour)

Ukrainian Canadian

Ukrainske slovo

Ukrainske zhyttia

Vestnik

Washington Post

Winnipeg Free Press 
News-Facts

New Times

New York Times
Winnipeg Tribune

Vancouver Daily Province

Monographs and Edited Collections

Abel, Kerry and Ken S. Coates, eds. Northern Visions: New Perspectives on the North in Canadian History. Peterborough, ON: Broadview Press, 2001.

Adams, Mary Louise. The Trouble with Normal: Postwar Youth and the Making of Heterosexuality. Toronto: University of Toronto Press, 1997.

Andrew, Christopher and Vasili Mitrokhin, The Mitrokhin Archive: The KGB in Europe and the West. New York: Penguin Press, 1999.

Angus, Ian. Canadian Bolsheviks: The Early Years of the Communist Party of Canada. Montreal: Vanguard Publications, 1981.

Avakumovic, Ivan. The Communist Party in Canada: A History. Toronto: McClelland and Stewart, Ltd., 1975.

Avery, Donald. Reluctant Host: Canada's Response to Immigrant Workers, 1896-1994. Toronto: McClelland and Stewart, 1995.

Beaumont, Joan. Comrades in Arms: British Aid to Russia, 1941-1945. London: DavisPoynter, 1980.

Bothwell, Robert and Granatstein, J.L., ed. The Gouzenko Transcripts. Ottawa: Deneau Publishers, 1982.

Bothwell, Robert. The Big Chill: Canada and the Cold War. Toronto: Canadian Institute of International Affairs, 1998.

Black, J.L. and Norman Hillmer, eds. Nearly Neighbours: Canada and the Soviet Union from Cold War to Détente and Beyond. Kingston: Ronald P. Frye and Company, 1989.

Black, J.L. and Martin Rudner, eds. The Gouzenko Affair: Canada and the Beginnings of Cold War Counter-Espionage (Manotick: Penumbra Press, 2006).

Black, J.L. Canada in the Soviet Mirror: Ideology and Perception in Soviet Foreign Affairs, 1997-1991 (Ottawa: Carleton University Press, 1998).

Breines, Wini. Young, White and Miserable: Growing Up Female in the Fifties. Chicago: University of Chicago Press, 1992. 
Caute, David. The Fellow Travellers: Intellectual Friends of Communism. Revised edition. New Haven and London: Yale University Press, 1988.

The Dancer Defects: The Struggle for Cultural Supremacy During the Cold War (Oxford: Oxford University Press, 2003).

Callwood, June. Emma. Toronto: Stoddart, 1984.

Cavell, Richard, ed. Love, Hate and Fear in Canada's Cold War. Toronto: University of Toronto Press, 2004.

Cohen, Lizabeth. A Consumer's Republic: The Politics of Mass Consumption in Postwar America. New York and Toronto: Knopf, 2003.

Corten, Irina H. Vocabulary of Soviet Society and Culture: A Selected Guide to Russian Words, Idioms and Expressions of the Post-Stalin Era, 1953-1991. Durham and London: Duke University Press, 1992.

Doyle, James. Progressive Heritage: The Evolution of a Politically Radical Literary Tradition in Canada. Waterloo: Wilfrid Laurier University Press, 2002.

Drakulic, Slavenka. How We Survived Communism and Even Laughed. New York: HarperCollins Publishers, 1993.

Endicott, Stephen. James G. Endicott: Rebel Out of China. Toronto: University of Toronto Press, 1980.

Falsifiers of History. [pamphlet] Moscow: Foreign Languages Publishing House, 1948.

Foreman, Joel, ed. The Other Fifties: Interrogating Midcentury American Icons. Urbana: University of Illinois Press, 1997.

Gaddis, John Lewis. We Now Know: Rethinking Cold War History. New York: Oxford University Press, 1997.

Golitsyn, Anatoliy. New Lies for Old: The Communist Strategy of Deception and Disinformation. New York: Dodd, Mead, 1984.

Gonick, Cy. A Very Red Life: The Story of Bill Walsh. St. John's, Nfld.: Canadian Committee on Labour History, 2001.

Granatstein, J.L. and Stafford, David. Spy Wars: Espionage and Canada from Gouzenko to Glasnost. Toronto: Key Porter Books, 1990.

Greig, Ian. The Assault on the West. Surrey, England: Foreign Affairs Publishing, 1968. 
Hahn, Werner G. Postwar Soviet Politics: The Fall of Zhdanov and the Defeat of Moderation, 1946-1947. Ithaca, N.Y.: Cornell University Press, 1982.

Hannant, Larry. The Infernal Machine: Investigating the Loyalty of Canada's Citizens. Toronto: University of Toronto Press, 1995.

Haynes, John Earl and Harvey Klehr. In Denial: Historians, Communism \& Espionage. San Francisco: Encounter Books, 2003.

Heaps, Leo. Hugh Hambleton, Spy: Thirty Years with the KGB. Toronto: Methuen, 1983.

Hewitt, Steve. Spying 101: The RCMP's Secret Activities at Canadian Universities, Toronto: University of Toronto Press, 2002.

Hunter, Peter. Which Side Are You On Boys...Canadian Life on the Left. Toronto: Lugus Productions, 1988.

Iacovetta, Franca. Gatekeepers: Reshaping Immigrant Lives in Cold War Canada. Toronto: Between the Lines, 2006.

Irr, Caren. The Suburb of Dissent: Cultural Politics in the United States and Canada during the 1930s. Durham and London: Duke University Press, 1998.

Johnston, Faith. A Great Restlessness: The Life and Politics of Dorise Nielsen. Winnipeg: University of Manitoba Press, 2006.

Kavchak, Andrew. Remembering Gouzenko: the Struggle to Honour a Cold War Hero. Toronto: The Mackenzie Institute, 2004.

Kealey, Linda. Enlisting Women for the Cause: Women, Labour, and the Left in Canada, 1890-1920. Toronto: University of Toronto Press, 1998.

Kinsman, Gary, K. Buse and Mercedes Steedman, eds. Whose National Security? Canadian State Surveillance and the Creation of Enemies. Toronto: Between the Lines, 2003.

Knight, Amy. How the Cold War Began: The Gouzenko Affair and the Hunt for Soviet Spies. Toronto: McClelland \& Stewart, 2005.

Kolasky, John. The Shattered Illusion: The History of the Ukrainian Pro-Communist Organizations in Canada. Toronto: Peter Martin Associates Ltd., 1979.

ed. Prophets and Proletarians: Documents on the History of the Rise and Decline of Ukrainian Communism in Canada. Edmonton: Canadian Institute of Ukrainian Studies Press, 1990. 
Korinek, Valerie Joyce. Roughing it in the Suburbs: Reading Chatelaine Magazine in the Fifties and Sixties. Toronto: University of Toronto Press, 2000.

Krawchuk, Peter. Our History: The Ukrainian Labour-Farmer Temple Movement in Canada, 1907-1991. Toronto: Lugus Publications, 1996.

Lévesque, Andrée. Red Travellers: Jeanne Corbin \& Her Comrades. Originally published as Scénes de la vie en rouge: l'époque de Jeanne Corbin, 1906-1944, transl. by Yvonne M. Klein. (Montreal \& Kingston: McGill-Queen's Press, 2006).

Lindstrom-Best, Varpu. The Finns in Canada. Ottawa: Canadian Historical Association, 1985.

Lindstrom, Varpu. Defiant Sisters: A Social History of Finnish Immigrant Women in Canada. Toronto: Multicultural History Society of Ontario, 1992.

Mann, Robert. The Petrov Affair: Politics and Espionage. Sydney and New York: Pergamon, 1987.

MacDowell, Laurel Sefton. Renegade Lawyer: The Life of J.L. Cohen. Toronto: University of Toronto Press, 2001.

MacLeod, Wendell, Libbie Park and Stanley Ryerson, eds., Bethune: the Montreal Years: An Informal Portrait. Toronto: James Lorimer \& Company Publishers, 1978.

Mastny, Vojtech. The Cold War and Soviet Insecurity: The Stalin Years. New York: Oxford University Press, 1996.

May, Elaine Tyler. Homeward Bound: American Families in the Cold War Era. New York: Basic Books, 1988.

Meyerowitz, Joanne, ed. Not June Cleaver: Women and Gender in Postwar America, 1945-1960. Philadelphia: Temple University Press, 1994.

Mickenberg, Julia L. Learning from the Left: Children's Literature, the Cold War, and Radical Politics in the United States. Oxford: Oxford University Press, 2006.

Mishler, Paul C. Raising Reds: The Young Pioneers, Radical Summer Camps, and Communist Political Culture in the United States. New York: Columbia University Press, 1999.

Nadel, Alan. Containment: American Narratives, Postmodernism, and the Atomic Age. Durham: Duke University Press, 1995. 
Okulevich, G. Russkie v Kanade: Istoriya Russkikh Raboche-Fermerskikh Klubov imeni M. Gorkovo (1930-1940) I Federatsii Russkikh Kanadtsev (1941-1952) (Toronto, 1952).

Palmer, Bryan D., ed. A Communist Life: Jack Scott and the Canadian Workers Movement, 1927-1985. St. John's, Nfld: Committee on Canadian Labour History, 1988.

Parr, Joy, ed. A Diversity of Women: Ontario, 1945-1980. Toronto: University of Toronto Press, 1995.

Pashuto, V.T. et al. Protiv fal'sifikatsii istorii nashei rodiny. Moscow: Znanie, 1961.

Penner, Norman. Canadian Communism: The Stalin Years and Beyond. Toronto: Methuen, 1988.

Ra'anan, Gavriel D. International Policy Formation in the USSR: Factional 'Debates' during the Zhdanovschina. Hamden, Connecticut: Archon Books, 1983.

Roberts, Glenna and Serge Cipko. One-Way Ticket: The Soviet Return-to-the-Homeland Campaign, 1955-1960. Manotick: Penumbra Press, 2008.

Rouillard, Jacques. Le syndicalisme québecois: Deux siècles d'histoire. Montréal: Editions Boréal, 2004.

Rush, Maurice. We Have a Glowing Dream: Recollections of working-class and people's struggles in B.C., 1935-1995. Vancouver: Centre for Socialist Education, 1996.

Sangster, Joan. Dreams of Equality: Women on the Canadian Left, 1920-1950. Toronto: McClelland and Stewart, 1989.

Sawatsky, John. Men in the Shadows: The RCMP Security Service. Toronto: Doubleday Canada, 1980.

Sawatsky, John. Gouzenko: The Untold Story. Toronto: Macmillan of Canada, 1984.

Scher, Len. The Un-Canadians: True Stories from the Blacklist Era. Toronto: Lester Publishing Ltd., 1992.

Schrecker, Ellen, ed. Cold War Triumphalism: The Misuse of History After the Fall of Communism. New York: The New Press, 2004.

Shtein, B.E. Burzhuaznye fal'sifikatory isatorii (1919-1939). Moscow: ANSSSR, 1951. 
Smith, Denis. Diplomacy of Fear: Canada and the Cold War, 1941-1948. Toronto: University of Toronto Press, 1988.

Swyripa, Frances. Wedded to the Cause: Ukrainian-Canadian Women and Ethnic Identity, 1891-1991. Toronto: University of Toronto Press, 1993.

Vance, Catherine. Not by Gods But By People: The Story of Bella Hall Gauld. Toronto: Progress Books, 1968.

Virtue, John. Fred Taylor: Brother in the Shadows. Montreal and Kingston: McGillQueen's University Press, 2008.

Watson, Louise. She Never Was Afraid: The Biography of Annie Buller. Toronto: Progress Books, 1976.

Weisbord, Merrily. The Strangest Dream: Canada's Communists, The Spy Trials and the Cold War. Montreal: Vehicule Press, 1994.

Whitaker, Reg. Double Standard: The Secret History of Canadian Immigration. Toronto: Lester and Orpen Dennys, 1987.

Whitaker, Reg and Gary Marcuse. Cold War Canada: the Making of a National Insecurity State, 1945-1957. Toronto: University of Toronto Press, 1994.

and Steve Hewitt. Canada and the Cold War. Toronto: James Lorimer \& Co., 2003.

Whitfield, Stephen J. The Culture of the Cold War. Baltimore: Johns Hopkins University Press, 1991.

Zubok, Vladislav and Constantine Pleshakov. Inside the Kremlin's Cold War: From Stalin to Khrushchev. Cambridge, Mass.: Harvard University Press, 1996.

Chapters, Articles, and Reviews

Aggeeva, I.A. "Kanada I nachalo kholodnoi voinyi: delo Gouzenko v sovetskokanadskikh otnosheniyakh" [Canada and the Start of the Cold War: The Gouzenko Affair in Soviet-Canadian Relations], Kholodnaya Voina 1945-1963 [Cold War, 1945-1963]. Moscow: Olma-Press, 2003.

Aleksandrov, G.F. "The Pattern of Soviet Democracy," (originally "O sovetskoy demokratii") speech delivered in 1946, translated by Leo Gruliow and published by Public Affairs Press. Washington: 1948.

Balawyder, A. "Canada and the Famine in Soviet Russia and the Ukraine (1921-23)," The New Review (December 1964), p. 1-10. 
Black, J.L. "Canada and the Soviet Union in 1945: The View from Moscow," in Greg Donaghy, ed., Uncertain Horizons: Canadians and Their World in 1945. Ottawa: Canadian Committee for the History of the Second World War, 1996.

Black, Joseph and J.L. Black. "Canada in the Soviet Mirror: English-language Canadian Literature in Soviet Translation," Journal of Canadian Studies, vol. 30, no. 2, Summer 1995.

Cavell, Janice. "The Second Frontier: The North in English-Canadian Historical Writing," Canadian Historical Review 83, no. 3 (September 2002), p. 364-389.

Fairley, Margaret. "Our Cultural Heritage," New Frontiers 1 (Winter 1952), p. 1-7.

Guard, Julie. "Canadian Citizens or Dangerous Foreign Women? Canada's Radical Consumer Movement, 1947-1950," in Marlene Epp, Franca Iacovetta, Frances Swyripa, eds., Sisters or Strangers? Immigrant, Ethnic and Racialized Women in Canadian History. Toronto: University of Toronto Press, 2004, p. 161-189.

Johnson, Gregory A. Review of Cold War Canada in the Canadian Historical Review vol. 78, no. 1 (March 1997), p. 139-141.

Kameneva, Olga Davidova. "Cultural Rapprochement: The U.S.S.R. Society for Cultural Relations with Foreign Countries," Pacific Affairs, vol. 1, no. 5 (October 1928), p. 6-8.

Kealey, Gregory S. "Presidential Address: The Empire Strikes Back: The NineteenthCentury Origins of the Canadian Secret Service," Journal of the Canadian Historical Association, vol. 10, 1999, p. 3-18.

Kramer, Mark. "The Role of the CPSU International Department in Soviet Foreign Relations and National Security Policy," Soviet Studies, vol. 42, no. 3 (July 1990), p. 429-446.

Kukushkin, Vadim. "Back in the USSR," Beaver, 86 (4), 2006, p. 33-36.

Leffler, Melvyn P. "The Cold War: What Do 'We Now Know'? in The American Historical Review vol. 104, no. 2, April 1999, p. 523.

MacDowell, Laurel Sefton. "Paul Robeson in Canada: A Border Story," Labour/Le Travail, no. 51, Spring 2003: 31 pars., accessed 2 June 2008, $<$ www.historycooperative.org/journals/11t/51/macdowell.html $>$.

McDowall, Duncan. "The Trials and Tribulations of Miss Agatha Chapman: Statistics in a Cold War Climate," Queen's Quarterly, 114/3 (Fall 2007), p. 357-369. 
Pechatnov, Vladimir O. "The Big Three After World War II: New Documents on Soviet Thinking about Post War Relations with the United States and Great Britain", Cold War International History Project, The Woodrow Wilson Centre (Working Paper no. 13, July 1995).

Piazzi, V. "The War of Documents: The Publication of the Nazi-Soviet Pact in 1948," in The History of International Relations in Central Europe and Eastern Europe: Study Traditions and Research Perspectives. Romania: Commission of History of International Relations, Babes-Bolyai University, 1995, p. 117-131.

Reiter, Ester. "Secular Yiddishkait: Left Politics, Culture, and Community," Labour/Le Travail, Spring 2002 $<$ http://www.historycooperative.org/journals/llt/49/05reiter.html > (10 Jun. 2008).

Roberts, Geoffrey. "Stalin the Pact with Nazi Germany, and the Origins of Postwar Soviet Diplomatic Historiography," Journal of Cold War History, vol. 4, no. 4 (Fall 2002), p. 93-103.

Roberts, Leslie. "McCarthyism - it's spreading n Canada - Now," New Liberty, vol. 31, May 1954, p. 15-17, 78-83.

Roberts, Peter and Serge Cipko. "Canada and the Khrushchev Government's 'Return to the Homeland' Campaign," Occasional Paper no. 8 (Centre for Research on Canadian-Russian Relations, Carleton University, November 2000).

Romerstein, Herbert. "History of the ID," in Foreign Service Institute, U.S. Department of State, Center for the Study of Foreign Affairs, The International Department of the CC CPSU Under Dobrynin. Washington, 1999, p. 111-138.

Wolters-Fredlund, Benita. "We Shall Go Forward with our Songs into the Fight for Better Life:' Identity and Musical Meaning in the History of the Toronto Jewish Folk Choir, 1925-1959" Toronto: University of Toronto, unpublished PhD thesis, 2005.

Selected Bibliography Related Specifically to Theoretical and Methodological Issues

Ankersmit, F.R. Narrative Logic: A Semantic Analysis of the Historian's Language. The Hague: Marinus Nijhoff Publishers, 1983.

-------------. "The Dilemma of Contemporary Anglo-Saxon Philosophy of History," History and Theory, vol. 25, no. 4, December 1986, p. 1-27.

Burton, Antoinette, ed. Archive Stories: Fact, Fictions and the Writing of History. Durham and London: Duke University Press, 2005.

Cruikshank, Julie. The Social Life of Stories: Narrative and Knowledge in the Yukon Territory. Vancouver: UBC Press, 1998. 
-.---_-.-. Life Lived Like a Story: Life Stories of Three Yukon Native Elders. Lincoln: University of Nebraska Press, 1990.

Iacovetta, Franca. "Post-Modern Ethnography, Historical Materialism, and Decentring the (Male) Authorial Voice: A Feminist Conversation," Histoire sociale/Social History 32.64 (November 1999), p. 85-101.

Kellner, Hans. Language and Historical Representation: Getting the Story Crooked. Madison, Wisconsin: University of Wisconsin Press, 1989.

McKay, Ian. Rebels, Reds, Radicals: Rethinking Canada's Left History. Toronto: Between the Lines, 2005.

Partner, Nancy F. "Making Up Lost Time: Writing on the Writing of History," Speculum, vol. 61, no. 1, January 1986, p. 90-117.

Portelli, Alessandro. "The Death of Luigi Trastulli: Memory and the Event," in The Death of Luigi Trastulli and Other Stories. Albany: SUNY Press, 1991.

Prins, Gwyn. "Oral History," in Peter Burke, ed., New Perspectives on Historical Writing. Pennsylvania: Pennsylvania University Press, 2004, p. 120-156.

Riordon, Michael. An Unauthorized Biography of the World: Oral History on the Front Lines. Toronto: Between the Lines, 2004.

Ritchie, Donald. Doing Oral History: A Practical Guide. New York: Oxford University Press, 2003.

Sangster, Joan. "Telling Our Stories: Feminist Debates and the Use of Oral History," Women's History Review 3.1 (March 1994), p. 5-28.

\section{Unpublished Theses}

Hinther, Rhonda L. “'Sincerest Revolutionary Greetings': Progressive Ukrainians in Canada, 1918-1991." Hamilton: McMaster University, unpublished $\mathrm{PhD}$ thesis, 2005.

Johnston, Faith. "Dorise Nielsen: The Life and Ideas of a Canadian Woman in Politics", Ottawa: Carleton University, unpublished M.A. Thesis, 1989.

Watson, Mary Eleanor Barber. "Study of Dyson Carter's Life and Works." Ottawa: Carleton University, Undergraduate paper, 1974.

Zembrzycki, Stacey. "Memory, Identity, and the Challenge of Community Among Ukrainians in the Sudbury Region, 1901-1939." Ottawa: Carleton University, unpublished $\mathrm{PhD}$ thesis, 2007. 


\section{$\underline{\text { Films }}$}

British Broadcasting Corporation, Mindbenders: Propaganda with Facts: Our Soviet Friends, director unknown, 1980.

National Film Board of Canada, The Un-Canadians, directed by Len Scher, 1996.

National Film Board of Canada, Letters from Karelia, directed by Kelly Saxberg, produced by Joe MacDonald, 2005. 